https://theses.gla.ac.uk/

Theses Digitisation:

https://www.gla.ac.uk/myglasgow/research/enlighten/theses/digitisation/

This is a digitised version of the original print thesis.

Copyright and moral rights for this work are retained by the author

A copy can be downloaded for personal non-commercial research or study, without prior permission or charge

This work cannot be reproduced or quoted extensively from without first obtaining permission in writing from the author

The content must not be changed in any way or sold commercially in any format or medium without the formal permission of the author

When referring to this work, full bibliographic details including the author, title, awarding institution and date of the thesis must be given

Enlighten: Theses

https://theses.gla.ac.uk/

research-enlighten@glasgow.ac.uk 


\title{
RESERVATIONS \\ TO THE ACCEPTANCE OF \\ THE COMPULSORY JURISDICTION OF \\ THE INTERNATIONAL COURT OF JUSTICE
}

\author{
A Thesis Submitted for the \\ Award of the Degree of Doctor of Philosophy \\ by \\ Khier GUECHI \\ LL.B., LL.M.
}

Faculty of Law

Glasgow University

November 88

(C) K. GUECHI 1988 
ProQuest Number: 10970869

All rights reserved

INFORMATION TO ALL USERS

The quality of this reproduction is dependent upon the quality of the copy submitted.

In the unlikely event that the author did not send a complete manuscript and there are missing pages, these will be noted. Also, if material had to be removed, a note will indicate the deletion.

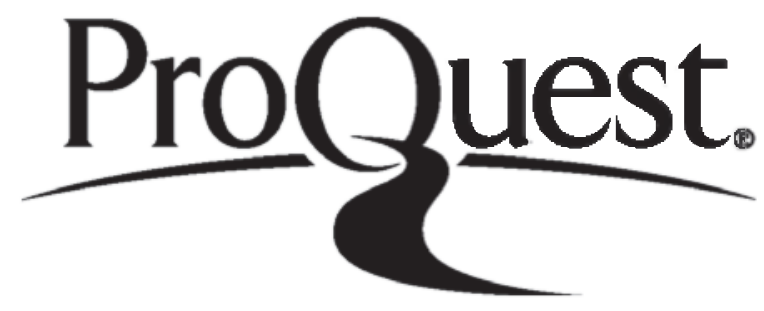

ProQuest 10970869

Published by ProQuest LLC (2018). Copyright of the Dissertation is held by the Author.

All rights reserved.

This work is protected against unauthorized copying under Title 17, United States Code Microform Edition @ ProQuest LLC.

ProQuest LLC.

789 East Eisenhower Parkway

P.O. Box 1346

Ann Arbor, Ml $48106-1346$ 


\section{ABSTRACT}

The thesis deals with one of the most important aspects of the optional compulsory jurisdiction system of the World Court which constitutes the last stage towards the achievement of an ideal, namely, the general and automatic jurisdiction over all legal disputes. In adhering to this system states have made different types of reservations and conditions. The analysis of all these reservations and conditions, their scope, RAISOH D'ETRE, effect on the Court's role in contributing to the development of compulsory jurisdiction and peaceful settlement of disputes, and whether they serve the interests of States making them and of the system of compulsory jurisdiction, is the purpose of the study. In short, the thesis attempts to evaluate to what extent, if any, the reservations have affected the Court's role in promoting the rule of law in international relations through the compulsory jurisdiction system.

Organizationally, the thesis is divided into six chapters: the first deals with the history of reservations before the advent of the P.C.I.J. Thus it follows the development of the theory of reservations to obligatory arbitrations since the end of the last century. Particular importance is given also to the examination of reservations during the drafting of the statutes of the P. C. I. J. and the I. C. J. and in the case-law of both courts. The remaining five chapters are devoted to the analysis of the different kinds of conditions and reservations to the acceptance of the court's compulsory jurisdiction. These conditions and reservations ar grouped under four categories: time limits and variation conditions (the second chapter); reservations PATIOHE TEMPORISE PEPSONAE (the third chapter), and nATEPIAE which, owing to their importance, are divided into three chapters: unnecessary reservations (the fourth chapter), objective reservations (the fifth chapter) and subjective reservations (the sixth chapter). Particular importance is given to the last type of reservations, not only 
because of their character, but also because they consist of a gauge of the freedom of making reservations

In the general conclusions, the thesis seeks to illustrate the existing situation of compulsory jurisdiction and the effect of reservations in practice. Many suggestions for improving the existing system are made and a model of a declaration of acceptance which might serve the interests of both the adhering parties and the compulsory jurisdiction, is recommended. 


\section{ACKNOWIEDGMENTS}

I am extremely grateful to Professor John P Grant, Dean of the Faculty of Law, University of Glasgow, for the help and guidance that I have received from him while engaged on this study. This research would not have been possible without his valuable suggestions and perceptive criticism.

I would also like to express my gratitude to the Registrar of the International Court of Justice for providing me with some basic documents which I could not find elsewhere.

My thanks are due also to the staff of Glasgow University Library, Mitchell Library and the National Library of Scotland for their valuable service.

Finally my special profuse and warm appreciation are due to my wife for her constant support and the time devoted to me in spite of her own studies, and to my father for his constant encouragement throughout the years.

K. GUECHI 
Acknowledgements

Table of Cases

$\begin{array}{llll}\text { CHAPTER (I) HISTORY OF RESERVATIONS } & \text { p } 5\end{array}$

SECTION (1) : RESERVATIONS TO OBLIGATORY AR- p 5 BITRATION BEFORE 1920

A - TYPES OF RESERVATIONS BEFORE $p \quad 6$ 1920

(I) Reservations Before the Second p 6 Hague Conference

(i) Reservations before the First p 6 Hague Conference

(ii) Reservations during the First p 11

Hague Conference

(iii) The Second International Con- p 14 ference of American States

(iv) The Anglo - French Treaty of p 16 1903

(v) Other Treaties p 17

(II) Reservations During the second p 18 Hague Conference

(III) Reservations During the Period p 26 Between the Second Hague Conference and 1920

B - SCOPE AND EFFECT OF RESERVA- p 28 TIONS

C - REASONS FOR MAKING RESERVATIONS · p 31 TO OBLIGATORY ARBITRATION

$\begin{array}{llllll}\text { SECTION (2) : RESERVATIONS TO THE COMPULSORY } & \text { p } 37\end{array}$ JURISDICTION OF THE P. C. I . J.

A - RESERVATIONS DURING THE DRAFT- p 38 ING OF ARTICLE 36 (2) OF THE STATUTE OF THE P. C. I. J. 
(I) The Advisory Committee of Jur- p 38 ists

(II) The Council and the Assembly of p 45 the League of Nations

B - THE ASSEMBLY'S INTERPRETATION p 50 OF ARTICLE $36 \quad(2 \& 3)$

C - RESERVATIONS IN THE DECLARA- p 51 TIONS MADE UNDER THE STATUTE OF THE P. C. I. J.

SECTION (3) : RESERVATIONS DURING THE DRAFT- p 56 ING OF THE STATUTE OF THE I. C. J.

DEFINITIONS and CLASSIFICATION p 77

CHAPTER (II) TIME-LIMITS AND VARIATION CON- $\quad$ p 84 DITIONS

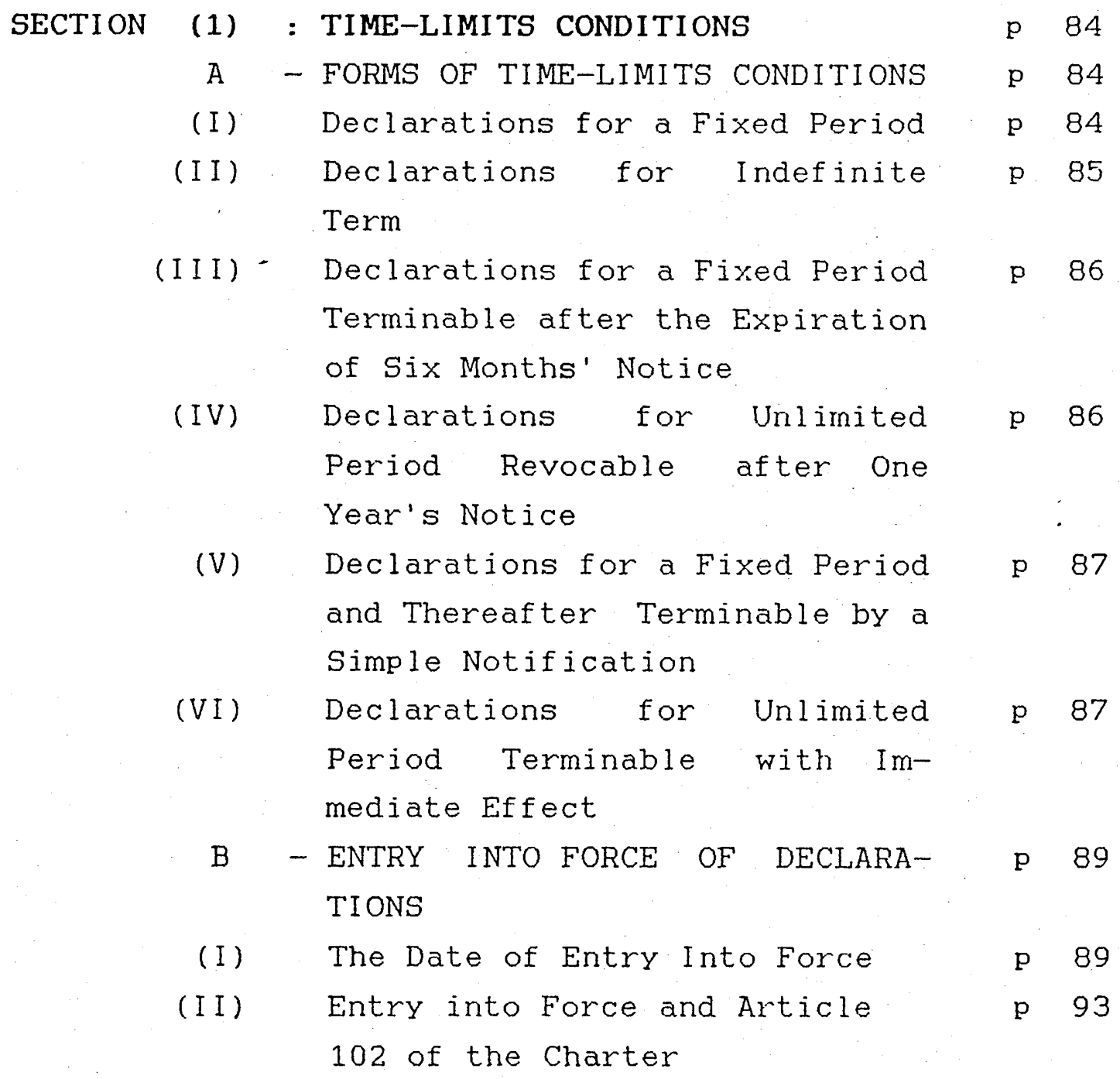




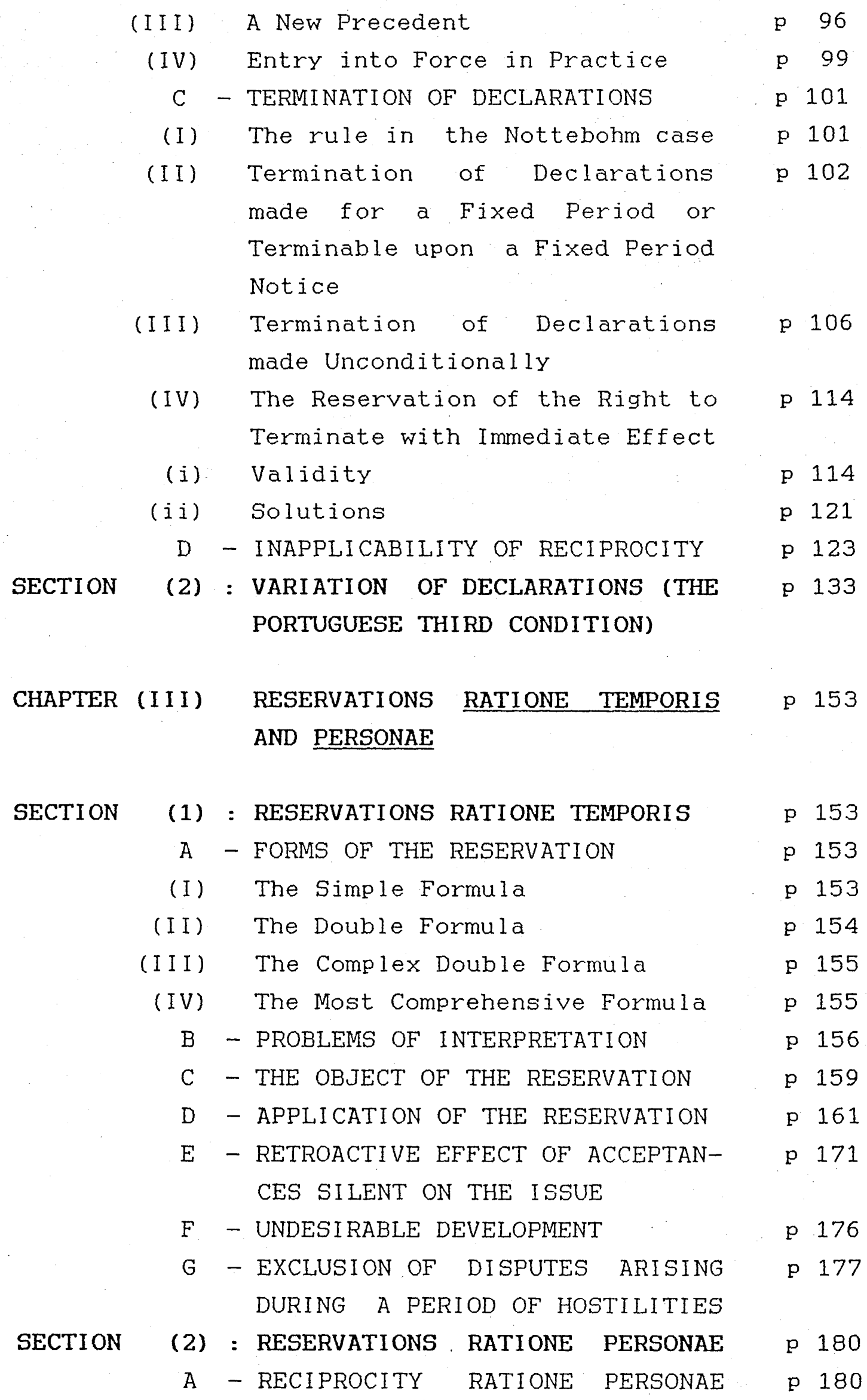




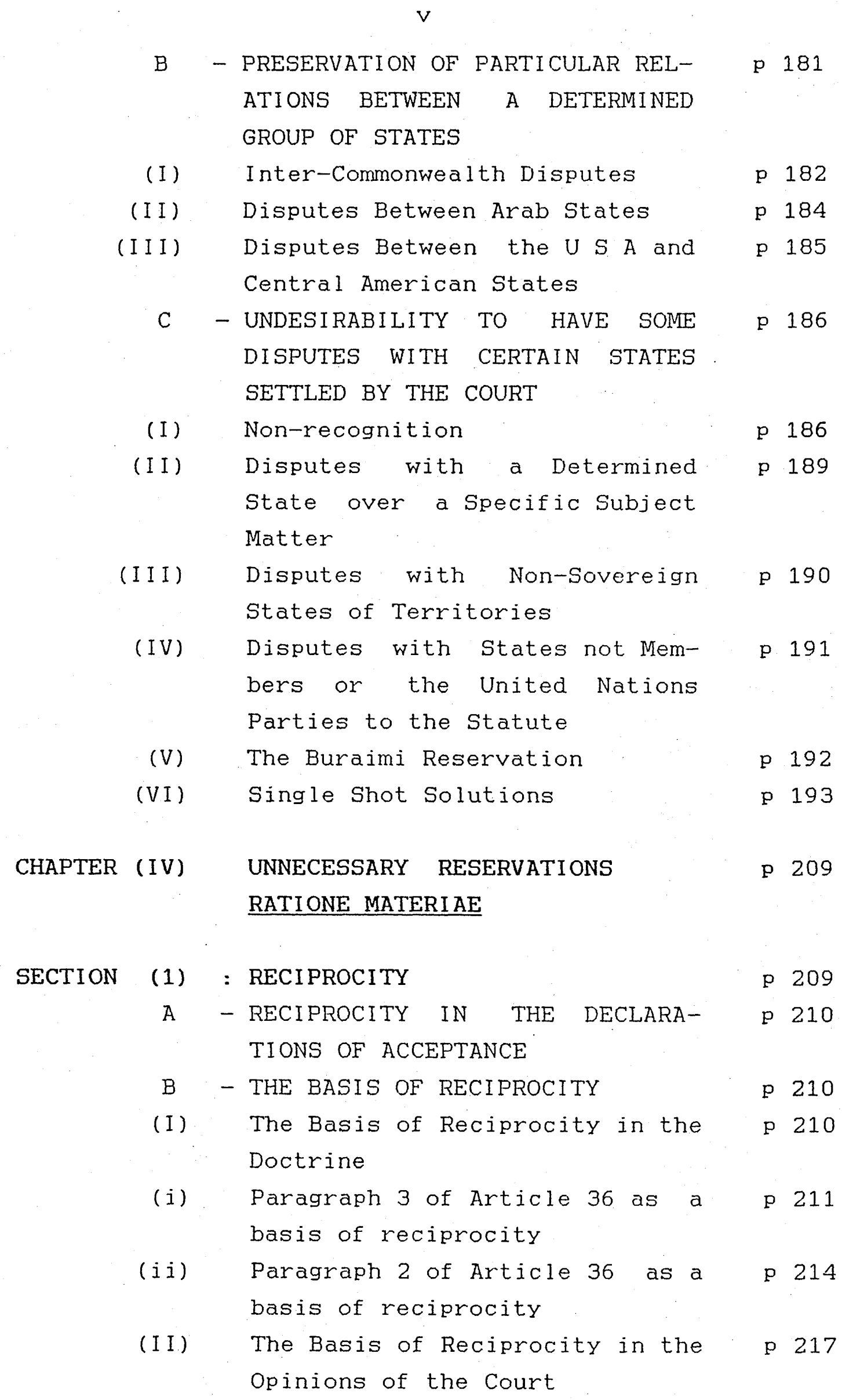


C - THE EFFECT OF THE OMISSION OF

p 219 RECIPROCITY FROM THE DECLARATIONS OF ACCEPTANCE

D - RECIPROCITY IN THE JURISPRUDE- p 226 NCE OF THE COURT

E - DELIMITATION OF RECIPROCITY p 233

(I) Reciprocity Operates with Res- p 233 pect to Reservations only

(II) Non-application of Reciprocity p 235 to the Pre-seisin Period

(III) Reciprocity Does Not Enable a p 236 State to Rely Upon a Rservation Not Included in the Oponent's Declaration

$F \quad$ - CONCLUSIONS

SECTION (2) : THE OBJECTIVE FORMULA OF DOMESp 240 TIC JURISDICTION RESERVATION

A - THE COVENANT FORMULA P 241

(I) The Scope of the Formula "Mat- p 242 ters Exclusively Within Domestic Jurisdiction According to International Law"

(II) The Effect of the Formula p 247

B - THE CHARTER FORMULA p 251

(I) The Relevance of Article 2 (7) p 252 of the Charter to the Compulsory Jurisdiction of the Court

(II) The Portee of the Formula "Matp 255 ters Essentially Within Domestic Jurisdiction"

(i) The omission of "International p 256 Law"

(ii) The omission of the reference p 258 to the body competent to decide whether a matter is or not within domestic jurisdiction

(iii) The substitution of "Esentialp 260 ly" for "Exclusively" 
vii

C - THE PRACTICE OF THE COURT IN p 265 REGARD TO THE RESERVATION

D - THE PLEA OF DOMESTIC JURISDIC- p 275 TION IN THE LIGHT OF THE NEW RULES

E - CONCLUSIONS p 278

SECTION (3) : THE RESERVATION OF LEGAL DIS- p 280 PUTES
A - "LEGAL DISPUTES" : A LIMITATION p 280 ON A LIMITED JURISDICTION?
(I) The Doctrine of "Legal" and p 282 "Non-legal" Disputes
(II) Article 36 as a Criterion p 287
B - "LEGAL DISPUTES" IN STATE PRAC- p 290 TICE
C - "LEgAL DISPUTES" IN THE JURIS- p 292 PRUDENCE OF THE COURT

\section{$\begin{array}{llll}\text { CHAPTER (V) OBJECTIVE RESERVATIONS RATIONE } & \text { P } 319\end{array}$ MATERIAE}

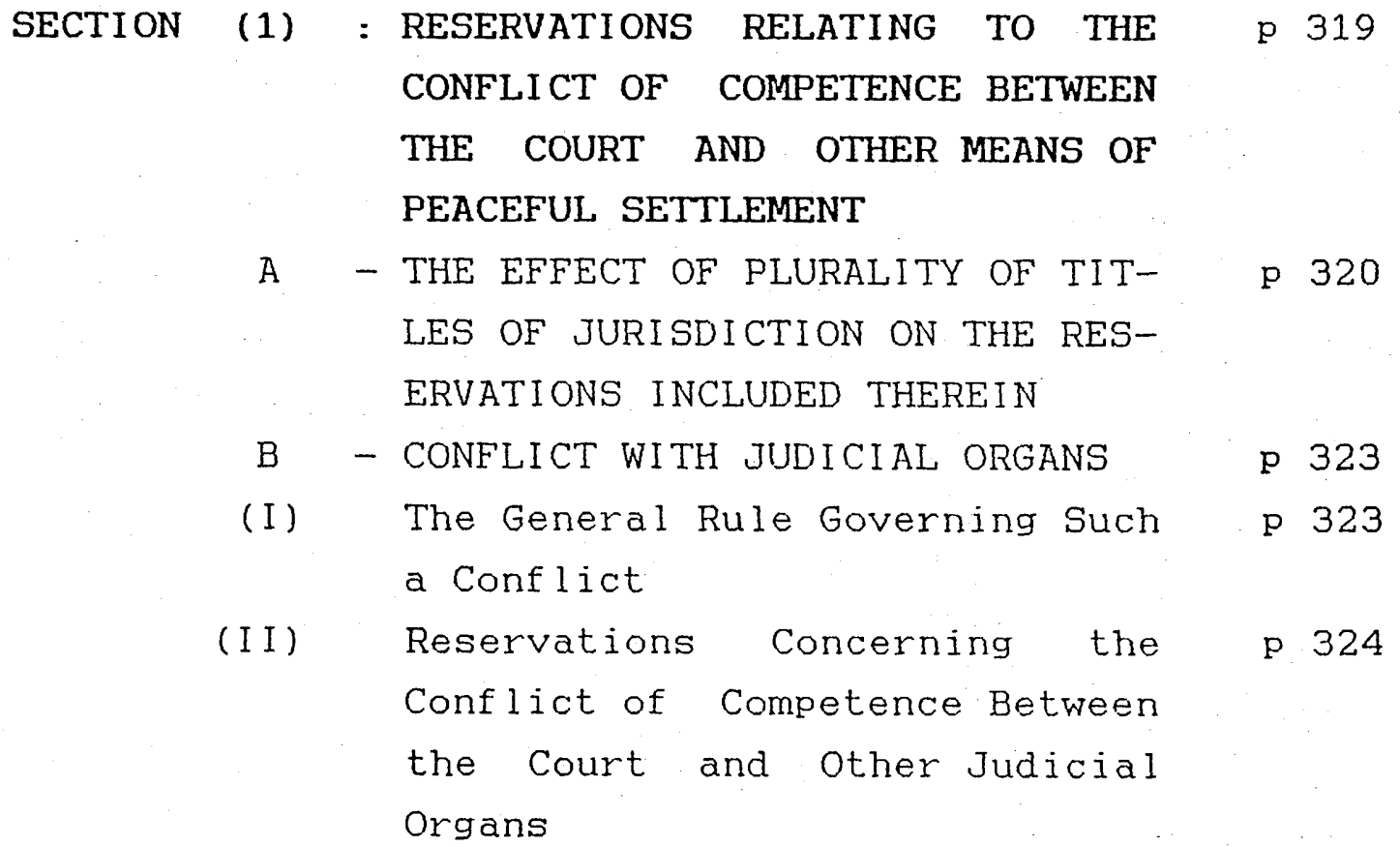


(i) Exclusion of disputes in regard

p 325

to which the parties have

agreed to recourse to arbitra-

tion or judicial settlement by

another body

(ii) Disputes excluded from judicial

p 236

settlement or compulsory ar-

bitration by virtue of previous

treaty or instrument

C - CONFLICT WITH NON-JUDICIAL ORGANS

(I) The Non-application of the p 239

Doctrine of Litispendence

Between the court and the

Political Organ

(II) The Suspension of Judicial

p 332

Proceedings by Bringing Disputes Before the Security

Council

(III) Disputes in Regard to which the

p 335

Parties Have Agreed to Have

Recourse to Other Means of

Peaceful Settlement

(i) The meaning of the expression

p 336

"other means of peaceful set-

tlement"

(ii) The significance of the res- p 339 ervation

(IV) Previous Recourse to Diplomatic p 340 Channels

(i) The reservation of disputes not p 340 satisfactorily adjusted by diplomacy

(ii) Priority of diplomatic negotiations

SECTION (2) : SUBJECT-MATTER RESERVATIONS

A - HOSTILITIES (RATIONE MATERIAE) p 349

(I) Forms of the Reservation p 349

(II) Evolution of the Reservation p 351 


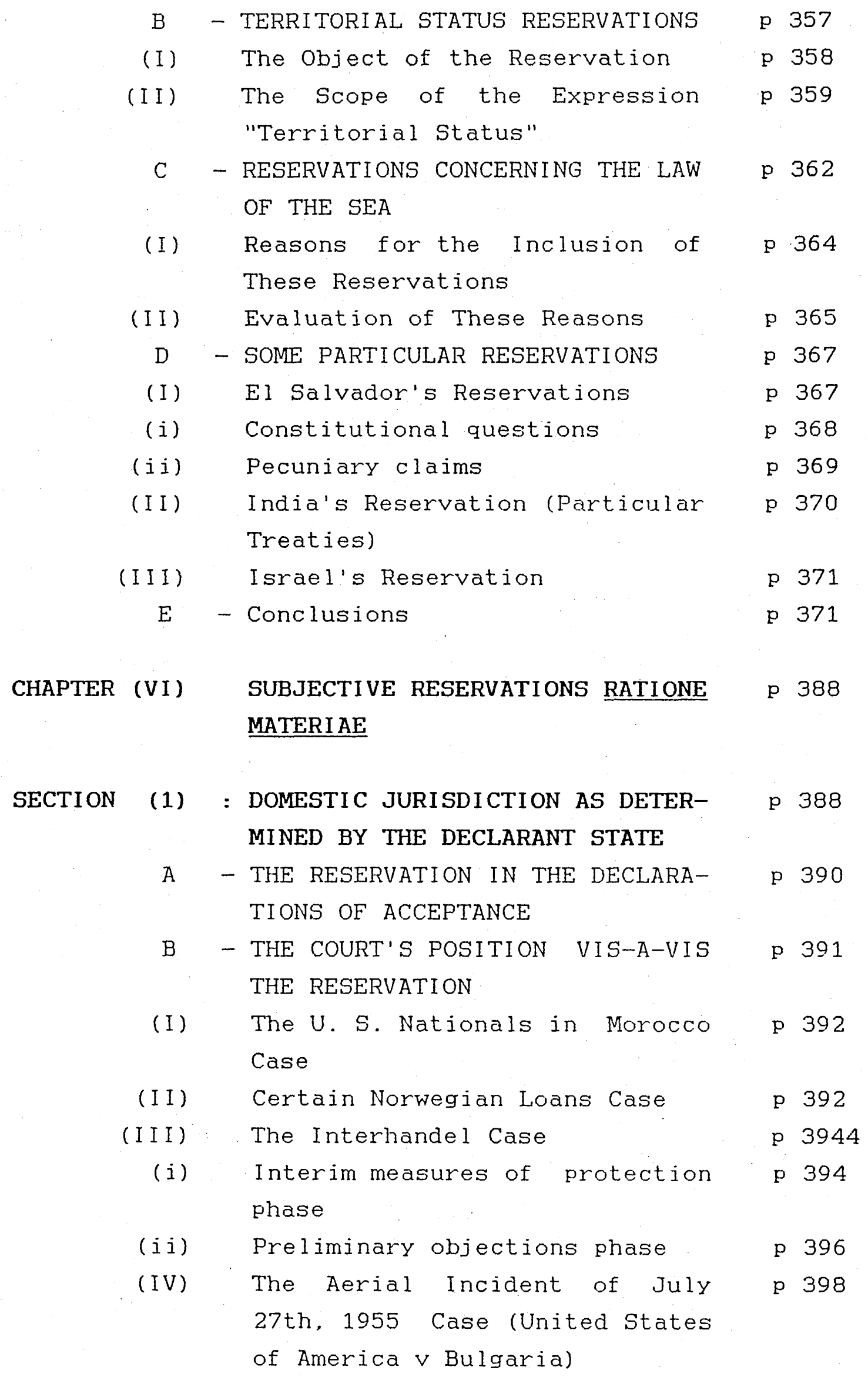


(V) Military and Paramilitary p 399 Activities in and Against

Nicaragua Case

C - VALIDITY OR NULLITY - DIFFERENT P 400 DOCTRINAL APPROACHES

(I) Invalid Reservation Nullifying p 401 the Entire Instrument of Acceptance

(i) Invalidity of the reservation p 401

(ii) Invalidity of the entire decla- p 405 ration

(II) Valid Acceptances Containing p 406 Invalid Reservations

(III) Reasonableness and Good Faith: p 408 "Amelioration by Interpretation"

(IV) Valid Reservation p 412

(i) Consistency with Article 36 (6) p 412 of the statute

(ii) Consistency with Article 36 (2) p 413

D - A LIMITED CHOICE p 417

(I) The First Approach is Rejected p 417 by the court

(II) The Fourth Approach - Insuffic- p 419 ient Grounds for Invalidity

(i) Inconsistency with Article 36 p 420 (6)

(ii) Inconsistency with Article 36 p 421 (2)

(iii) The invalidity of the reserva- p 423 tion according to the "applicable principles of law"

(iv) The "automatic declarations" as p 424 another way of access to the Court - approach

(III) Choice Between the Second and p 425 Third Approaches

E - CONCLUSIONS 


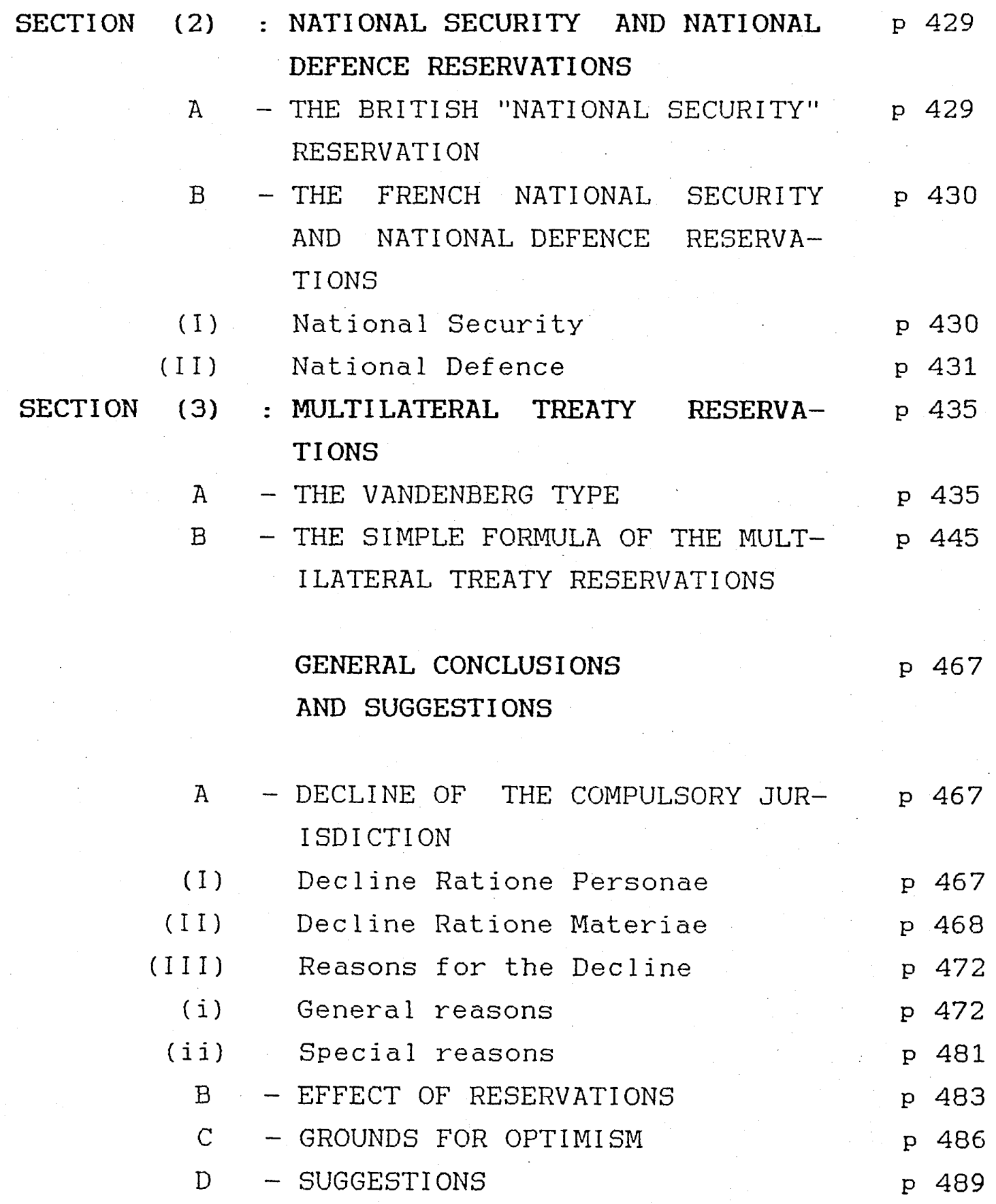




\section{Table of Cases}

Aegean Sea Continental Shelf : 265, 273, 300, 304, 347-348, 358, 359-361, $365,366,375,383,387$.

Aerial Incident of 27 July 1955 : (Israel v. Bulgaria) 99, 140, 144, 203, 204, 232, 254, 291, 303, 398-399, 452, 485.

Alabama Case: 403.

Ambatielos : 173, 204.

Anglo-Iranian Oil Co. : 75, 108-109, 112, 116, 131, 145, 146, 166, 202, $218,228-229,254,255,265,269,301,303,306,308,309,312,318$, $357,419,430,485$.

Application of the Convention of 1902 Goveming the Guardianship of Infants :485.

Arbitral Award Made by the King of Spain on 23 December $1906: 97,98,373$, 485.

Barcelona Traction: 143, 313.

Certain Expenses of the United Nations (Article 17, Paragraph 2, of the Charter) $: 281,314,318 b$.

Certain German Interests in Polish Upper Silesia : 201, 324, 346, 373.

Certain Norwegian Loans : 108, 146, 203, 218, 219, 224, 225, 229-230, 299, $301,303,396,397,400,401,410,411,418,419,430,449,450,451$, $453,454,455,456,457,458,459,461,485,490$.

Competence of the General Assembly for the Admission of a State to the United Nations : 409, 456.

Conditions of Admission of a State to the Membership in the United Nations (Article 4 of the Charter) : $318 \mathrm{~b}$.

Continental Shelf (Tunisia / Libyan Arab Jamahiria) : 384 (Libyan Arab Jamahiria / Malta) 374.

Corfu Channel : 366, 385.

Delimitation of the Maritime Boundary of the Golf of Maine Area : 384.

Denunciation of the Treaty of 2 November 1865 between China and Belgium :485.

Diversion of Water from the Meuse : 485.

Electricity Company of Sofia and Bulgaria : 108, 146, 158, 159, 161, 165-166, $169,171,199-200,218,224,225,227-228,233,249,265,268-269$, $291,301,303,318,321,322,327,373,377,485$.

Factory of Chorzów : 324, 374, 380.

Fisheries : 124, 215, 217, 366, 385, 386, 485.

Fisheries Jurisdiction : 290, 318, 366, 386.

Free Zones of Upper Savoy and the District of Gex : 379, 382, 402, 404, 405, 453.

Frontier Dispute : 384.

Gerliczy: 485.

Haya de la Torre : 282, 315. 
Interhandel : 154, 158, 159, 166-167, 172, 201, 202, 204, 205, 232, 236, $250,251,264,265,271-273,275,278,304,307,317,308,313,318 \mathrm{~b}$, $394-398,399,401,406-407,417,419,449,450,451,453,454,455$, $456,458,460$.

International Status of South West Africa : 282, 315.

Interpretation of Judgments No. 7 and 8 (Factory of Chozów) : 201, 373.

Interpretation of Peace Treaties with Bulgaria, Hungary and Romania : 201, 203, 262, 264, 266, 311, 312, 422, 459.

Interpretation of the Statute of the Momel Territory : 329, 374.

Land, Island and Maritime Frontier Dispute (EI Salvador / Honduras) : 384.

Legal Consequences for States of the Continued Presence of South Africa in Namibia (South West Africa) notwithstanding Security Council Resolution 276 (1970) : 485.

Legal Status of Eastem Greenland: 175, 485.

Legal Status of South-Eastem Greenland: 485.

Losinger : 249, 265, 268, 291, 307, 312, 485.

Mavrommatis Palestine Concessions : 169, 171-172, 173, 174, 201, 202, 203, 204, 342, 344, 379.

Military and Paramilitary Activities in and against Nicaragua : 75, 77, 92, 94, $95,96,102,104-106,109-112,119-120,127-128,130,140,143$, $147,148,185,197,204,219,232,234,235,236,276-277,291,293$, $296,301,302,304,313,315,323,329,331,348,352,353,355,373$, $377,378,399-400,411,418,425,437-441,442-444,446,447,452$, 459, 460, 462, 463, 465, 478, 480, 485, 487.

Nationality Decrees Issued in Tunis and Morocco : 242-243, 261, 265, 266-267, 269, 273, 274, 305.

North Atlantic Fisheries (U.S.A. /G.B.) : 68.

Northern Cameroons : 175, 201, 315, 476.

North Sea Continental Shelf : 366, 386, 478.

Nottebohm : 101-102, 114, 115, 117, 125, 136, 138, 144, 148, 403, 408, $421,454,455,485$.

Nuclear Tests : 75, 110, 111, 116, 120, 140, 147, 317, 318, 318b, 411, 432, $434,457,461,480,485$.

Pajzs, Csáky, Esterházy: 485.

Panevezys-Saldutiskis Raihway: 313, 485.

Phosphates in Morocco : 108, 131, 146, 160, 161-164, 169, 172, 200, 217 218, 226-227, 301, 303, 341, 344, 385.

Polish Postal Service in Danzig :409, 456.

Prince of von Pless Administration : 275.

Reservations to the Convention on the Prevention and Punishment of the Crime of Genocide: 61, 76.

Rights of Minorities in Upper Silesia (minority Schools) : 329, 374.

Rights of Nationals of the United States of America in Morocco : 392, 400, 451, 
485.

Right of Passage over Indian Territory : 76, 91, 94, 96, 100, 108-112, 116, $118,119,126-127,130,131,133-137,142,143,150,151,155,157$, $159,168-171,174,175,193-194,198,200,201,203,225,231,232$, $234,235,249,264,265,267,270,273,275,292,299,302,303,304$, $307,312,313,318 a, 331-332,374,375,380,408,409,419,424,426$, 455, 458, 476, 481.

South West Africa Cases : 207, 329, 343, 374, 375, 379, 476, 487, 496.

Status of Eastern Carelia, 281, 314.

Tempel of Preah Vihear: 143, 175, 373, 485.

Treatment of Polish Nationals and Other Persons of Polish Origin or Speech in the Danzig Territory : 26, 267, 312, 386.

Trial of Pakistani Prisoners of War: 116, 351, 370, 387.

United States Diplomatic and Consular Staff in Teheran : 293-295, 296, 297, 318, 318a, 329, 343, 347, 375, 378.

Voting Procedure on Questions Relating to Reports and Petitions Concerning the Territory of South West Africa : 402, 453, 


\section{Abbreviations.}

A.B.A.J.

A.F.D.I.

A.J.I.L.

A.R.

A.S.I.L.

Acta.S.J.G.

Ak.L.R.

Am.U.L.R.

An. A.

An.S.D.I.

An.U.S.F.D.

Annales U.M.C.S.

Annuaire I.D.I.

Arch.V.

B.C.I.C.L.R.

B.Y.B.I.L.

Can.B.R.

Can.Y.B.I.L.

ColumJ.I.L.

Colum.L.R.

Cor.I.L.J.

D.L.R.

Dahl.L.J.

F.L.R.U.T.

Fl.B.J.

For.I.L.J.

Ga.J.I.C.L.

Geogt.L.J.

G.L.R.

Georgt.L.J.

G.S.

Harv.I.L.J.

Houston J.I.L.
American Bar Association Journal.

Annuaire Francais de Droit International.

American Journal of International Law.

American Review.

Proceedings of the American Society of

International Law.

Acta Scandinavia Juris Gentuim.

Akron Law Review.

American University Law Review.

Annals Africains.

Annuaire Swiss de Droit International.

Annuaire de L'Université de Sofia, Faculté de Droit.

Annales Unversitatis Mariae Curie_Skolodownska.

Annuaire de L'Institut de Droit Internatioanal.

Archives des Völkerrechts.

Boston College International and Comparative Law

Review.

British Year-book of International Law.

Canadian Bar Review.

Canadian Year-book of International Law.

Colombia Journal of International Law.

Columbia Law Review.

Cornell International Law Journal.

Duke Law Journal.

Dalhouse Law Journal.

Faculty of Law Review, University of Toronto.

Florida Bar Journal.

Fordham International Law Journal.

Georgia Journal of International and Comparative

Law.

Georgtown Law Journal.

Georgia Law Review.

Georgetown Law Journal.

Grotius Society.

Harvard International Law Journal.

Houston Journal of International Law. 
Hito.J.I.L.P

Howard.L.J.

Hellinic.R.I.R.

I.A.

I.C.J.

I.C.J.Reports.

I.C.J.Y.B.

I.C.L.O.

Indian.J.I.L.

I.J.

I.L.

I.L.M.

Iowa.L.R.

Isr.L.R.

Inter'l.O.

Indian. $Q$.

Inter'l.Rel.

Indian.S.I.S.

Ita.Y.B.I.L.

Jap.A.I.L.

J.J.B.M.S.

J.P.C.

J.S.B.C.

K.J.I.L.

Ky.L.J.

L.N.

L.N.T.S.

L.Q.R.

Maryl.J.I.L.T.

Ned.T.I.R.

Northw.U.L.R.

Neth.Y.B.I.L.

N.Y.U.J.I.L.P.

O.R.G.A.
Hitosubashi Journal of International Law and Politics.

Howard Law Journal.

Hellinic Review of International Relations.

International Affairs.

International Court of Justice.

Reports of Judgments, Advisory Opinions and Order

of International Court of Justice.

International Court of Justice Year-book.

International and Comparative law Quarterly.

Indian Journal of International Law.

International Journal.

International Lawyer.

International Legal Materials.

Iowa Law Review.

Israel Law Review.

International Organisations.

Indian Quarterly.

International Relations.

Indian School of International Studies.

Italian Yearbook of International Law.

Japanese Annual of International Law.

the Journal of John Basset Moore Society.

Journal of Parliaments of Commonwealth.

Journal of State Bar of California.

Korian Journal of International Law.

Kentucky Law Journal.

League of Nations

League of Nations Treaty Series.

Law Quarterly Review.

Maryland Journal of International Law and Trade.

Nederlands Tidjschrift voor Internationaal Recht.

Northwestern University Law Review.

Netherlands Year-book of International Law.

New York University Journal of International Law and Politics.

Official Records of the General Assembly. 
ÖZ.ÖR

P.C.I.J.

Phil.L.J.

R.B.D.I.

R.C.A.D.I.

R.D.I.L.C.

R.G.D.I.P.

R.H.D.I.

R.P.P.

R.S.

S.C.L.Q.

Stanford L.R.

T.I.L.J.

U.D.L.R.

U.Kans.C.L.R.

U.N.

U.N.C.I.O.

U.N.T.S.

Virg.J.I.L.

Virg.L.R.

Wash.L.R.

Y.J.I.L

Y.J.L.

Z.A.Ö.R.V.
Österreichisches Zeitschrift für Öffentliches Retch.

Permanent Court of International Justice.

Philipinnes Law Journal.

Revue Belge de Droit International.

Recueil des Cours Academie de Droit International.

Revue de Droit International et de Législation

Comparée.

Revue Général de Droit General Public.

Revue Hellénique de Droit International.

Revue Politique et Parlementaire.

Revisita della Societa.

South Carolina Law Quarterly.

Stanford Law Review.

Texas International Law Journal.

University of Dayton Law Review.

University of Kansas City Law Review.

United Nations.

United Nations Conference on International

Organizations.

United Nations Treaty Series.

Virginia Journal of International Law.

Virginia Law Review.

Washington Law Review.

Yale Journal of International law.

Yale Law Journal.

Zeitschriff für Ausländisches öffenliches Recht und Völkerrecht. 


\section{NTRODUCTI ON}

It is well known that the jurisdiction of the International Court of Justice (I. C. J.) is based on the consent of States. One of the different ways of accepting that jurisdiction is the possibility of making a declaration under Article 36, paragraph 2, of the Statute of the court accepting as compulsory IPSO FACTO, and without special agreement, in relation to any other state accepting the same obligation, the jurisdiction of the Court. This system is known as the "Optional Clause", 1 or compulsory jurisdiction. It is in fact an "optional compulsory jurisdiction". It is in this sense that the term compulsory jurisdiction will be used and not in the sense that the jurisdiction is automatically applicable to all states parties to the statute as a result of that membership, nor in the sense that jurisdiction is compulsory only if it is not coupled with reservations which keep the last word as to their application to the state concerned.

The compulsory jurisdiction system occupies a special place in the problematic area of international adjudication. It is usually regarded as a gauge of the success or failure of the court. Thus at the San firancisco Conference in 1945, the Committee charged with drafting the statute of the Court predicted that the compulsory jurisdiction system would constitute a first step toward a general or automatic compulsory jurisdiction. Its hopes and expectations were formulated in the following terms:

\footnotetext{
"[The First Committee] ventures to foresee a significant role for the new Court in the international relations of the future. The judicial process will have a central place in the plans of the United Nations for the settlement of international disputes by peaceful means.. . It is confidently anticipated that the jurisdiction of this tribunal will be extended as time goes on, and past experience warrants the expectation that its exercise of this jurisdiction will recommend a general support".
} 
The Conference also adopted unanimously a recommendation asking the members of the United Nations "to make declarations recognising the obligatory jurisdiction of the International Court of Justice ..." 3

The statute of the court is almost silent on the question of reservations ${ }^{4}$ and conditions. The possibility that declarations of acceptance "mf be made unconditionally or on condition of reciprocity on the part of several or certain states or for a certain time" [Article 36 (2) ] is the only provision dealing with this subject. Yet in practice a considerable number of reservations and conditions have been appended by States to their declarations of acceptance.

This thesis seeks thus to evaluate to what extent, the expectations and hopes of the drafters of the statute have been realised. It seeks to find out whether the reservations and conditions embodied by states in their declarations of acceptance of the Court's jurisdiction under Article 36 (2) have affected the Court's role in contributing to the development of compulsory jurisdiction and the peaceful settlement of disputes and if so. to what extent? What is the scope of these reservations and conditions? Are there any limits to the freedom of making reservations and conditions? What are the reasons behind their inclusion? Is it desirable or practicable to eliminate the reservations altogether or only some of them? If only some are to be eliminated, what kind of reservations and conditions should be eliminated? Are any special steps desirable and practicable to ameliorate the others? It is proposed to deal with those questions while examining every reservation or condition.

For a complete picture on the question of reservations that might permit a more accurate picture of the situation it is deemed desirable to follow the development of the theory of reservation to obligatory arbitration throughout the period starting from the end of the 
last century until the advent of the P. C. I. J.

The prevalence of the desire of those who drafted the statute of the present Court to maintain the greatest possible continuity between this Court and its predecessor, the P. C. I. J., in order to preserve the progress already achieved, and the maintenance of Article 36 (2) of the statute, with a slight change, necessitates a concentration on the development of reservations and conditions during the period of the P. C. I. J., in both state practice and the jurisprudence of the Court.

It is in this spirit that the reservations and conditions to acceptances of the compulsory jurisdiction of the present Court will be dealt with. They will be examined under four main headings: Time limits and variation conditions; Reservations RATIONE TEHPORIS; PERSONAE, and, HATERTAE.

It is hoped that this thesis will dispel the myths concerning reservations and conditions, and suggest means whereby more States will adhere to the compulsory jurisdiction system and the adhering parties will amend reservations already made. 


\section{NOTES}

(1) Legally, the term "Optional Clause" is inaccurate because it was used originally as a description of a document which has disappeared. This document was a special protocol attached to the 1920 Protocol of Signature of the Statute of the P.C.I.J. which served as a form for declarations under Article 36 (2) of that Statute. See e.g. M.O. Hudson, the Permanent Court of International Justice 1920-1942. A Treatise, 1943 ; J.G. Merrills, "the Optional Clause Today", 50 B.Y.B.I.L. (1979), pp.87-116, at 88 ; D.J. Ende, Reaccepting the Compulsory Jurisdiction of the International Court of Justice : A Proposal for a New United States Declaration", 61 Wash.L.R. (1986), pp.1145-1183, at 1149 note26, and L. Gross, "Compulsory Jurisdiction Under the Optional Clause :History and Practice", in L.F. Damrosch (ed.), the International Court of Justice at a Crossroads, 1987, pp.19-57, at 19 note1. However, it it is still widely used by writers, States and the Court to refer to Article 36 (2). Thus it will used in this sense for convenience.

(2) U.N.C.I.O., vol.4, p.393(Doc. 913 IV/1/74(1), June 12, 1945).

(3) Ibid., pp.895,916, 919.

(4) It is to be noted that the word "reservations" in the title is used in its broadest sense including "conditions" though the latter will be dealt with separately. 


\section{HISTORY OF RESERVATIONS}

\section{SECTION (1) : RESERVATIONS TO OBLIGATORY ARBITRATION BEFORE 1920} (of idea on the development of the theory of reservations. Therefore it may help for a better understanding of either the forms in which the reservations included in the declarations of states accepting the jurisdictions of the International Court of Justice are framed, and the determination of whether the reasons for making reservations are still the same or have been changed, and if so. to what extent. For reservations to compulsory jurisdiction of the I. C. J. consists of the last stage in the development of that theory. In this context, and because of the similarities between the obligations assumes under general treaties of obligatory arbitration and the optional Clause, 1 this section deals only with these treaties as distinguished from compromissory clauses.

It is to be understood that the term "Obligatory" arbitration is used here in its broad meaning, i.e. as was called at that time. In other words, arbitration is obligatory when states agreed in advance to settle their future disputes by this means. Therefore, the difference between obligatory and voluntary arbitration was based mainly on the time at which the obligation to arbitrate was assumed, though it is generally agreed that that term had been misused, because from a legal point of view, the so called "Obligatory" arbitration was in fact a "Commitment to voluntary arbitration". 2 since, as a general rule, no actual procedures were provided for rendering the obligation theoretically undertaken as a reality. There was no obligatory arbitration in a sense that the obligation assumed in advance would insure the intervention of international tribunals or would not be paralysed subsequently or excluded. States deemed it necessary to conclude a special agreement (COMPROMIS) each time a par- 
ticular dispute arose, and as will be seen they kept for themselves the decision to determine the meaning of the broad reservations included. : Recourse to arbitration was, therefore, impossible by the initiation of one party only regardless of the consent of the other party to the dispute.

It is obvious that voluntary arbitration treaties are excluded here since there is no need to include reservations in these treaties. "The parties to a dispute know exactly the nature of the dispute and its applications. They do not accept being brought before a tribunal unless both have considered the question involved suitable for settlement by that means; agreed upon the constitution of the tribunal; the procedure to be followed; the rules to be applied; and defined the issues of the dispute.

For the purpose set above, the following points are to be discussed in this section: types of reservations made until the close of the First World War; their scope and effect, and finally reasons for making them.

\section{A - TYPES OF RESERVATIONS BEFORE 1920}

Having taken into consideration the important discussion devoted to reservations during The second Hague Conference, this period will be divided into three successive stages; before the Second Hague Conference, during that conference, and finally between 1907 and the end of the First World War.

\section{(I) Reservations Before the Second Hague Conference}

\section{(i) Reservations before the First Hague Conference:}

The contribution of Latin American States during the last century to the development of international arbitration has been recognised from voluntary arbitra- 
tion to compromissory clauses included mainly in treaties of commerce, alliance and peace relating to the interpretation and application of these treaties, to general treaties devoted only to arbitration. However as far as reservations clauses are concerned, neither those states nor the European ones included any reservations before 1890,7 except the reservation of previous recourse through diplomatic channels, which was inserted earlier. In fact, until 1890, there were only three satisfied general arbitration treaties between Latin American States. 9 In all of them, all future disputes and difficulties of any nature whatsoever were arbitrable if a solution had not been reached through diplomatic means. However they were not really obligatory because they did not contemplate a solution to the disagreement of these parties upon the nominations of subsequent arbitrators. The necessity of making a "special convention" (COHPRoHIS) each time a dispute arose was maintained.

The First Conference of American. States held in Washington from October 2, 1889 until April 19, 1890 is usually cited as the starting point in the history ${ }^{10}$ of reservations. The importance of the arbitration treaty concluded at that conference did not lie only in the fact that it contained the first reservation, but also in the method envisaged for the settlement of disputes between the parties. The plan of arbitration was a new diversion from the usual method resorted to by the Latin American States in the determination of arbitrable disputes. Though all dispute were arbitrable, as before, only controversies over limited subjects were arbitrable without condition. 11 The other disputes were, according to Article 3, arbitrable as far as they did not "in the judgment of any one of the nations involved in the controversy", imperil its independence.

The nature of the treaty as a multilateral one concluded between 18 states seems to be the main reason for making that reservation. This could be deduced from 
the fact that they had never inserted such a reservation before in their individual treaties. On the other hand, it was the first multilateral treaty devoted to international arbitration. Thus, in objecting to the signature of that treaty Chile and Mexico expressed the view that it was very broad and it should have included other reservations. In the opinion of the Chilean delegate the application of arbitration as a principle of international law, should have corresponded to its nature, otherwise it could not be considered by any means a guaranty of peace. Voluntary arbitration had thus been preferred to the making of such a treaty. Its conclusion was possible only, in this view, if the reservations of sovereignty, indignity and honour had been included along with the reservation of independence. He said:

\begin{abstract}
"A nation whose dignity has been wounded, or whose honour has been attacked, will never seek in the arbitration the remedy for the offence... The application of these principles has naturally to be left to the criterion and will of the nation which may be called upon to construe them, and which in a particular case will determine whether the case which has presented itself is, or is not included among them. Find it cannot be otherwise, because if the decision is to be given by a third party, the interested nation would sustain a detriment to its sovereignty, which cannot be allowed. Otherwise the evil produced thereby would be undoubtedly still worse than the evil which it was attempting to correct."
\end{abstract}

Mexico also preferred the addition of the reservations of national honour and dignity. 13 Thus they did not sign that treaty. Brazil and Argentine suggested in their resolutions presented to the conference the exclusion of questions which might affect the national sovereignty. The United States proposed the reservation of questions affecting territorial integrity. 14 However the delegation of Guatemala regarded these suggestions as attempts to weaken the treaty. It was thought that their inclusion would be erasure "with one hand [of] what the other hand had written. There is no question whatever which in some way or another does not affect the national honour and dignity, and to allow a recourse to war for 
these cases, could be tantamount to having accomplished nothing". However that treaty was without effect in practice. It was signed only by 11 states and ratified by one. 16

From that time, the Latin American States, influenced by their first, conference changed their attitude towards obligatory arbitration. They became more cautious, and started the inclusion of new reservations in their general arbitration treaties, as well as in compromissory clauses included mainly in treaties of peace and friendship made with European States. The reservation of sovereignty was included in two treaties between Spain and Columbia in 1894, 17 and Spain and Peru in 1897. 18

The reservation of independence was made twice; once in the treaty between Salvador and Guatemala, 19 and secondly in the treaty between The Netherlands and Portugal in 1894, but this time with the reservation of autonomy. 20 Another new reservation, i.e. the constitutional questions, was made in two treaties. The first was between Argentina and Uruguay in June 1899, 21 and the second between Argentine and Paraguay in November 1899. 22

The trend of inserting reservations in treaties also reached the parliaments of many states at that time. They were the main reason for rejecting the olneyPauncefote treaty of 1897 between the United States and Great Britain, and the Italian - Argentine treaty of 1898. The first as signed did not contain any express reservation. All disputes, as well as all questions of principle of grave general importance affecting national rights, were arbitrable in spite of the fact that the questions of honour and integrity had arisen before the signature of that treaty. 23 According to Lord Salisbury, neither government was willing "to accept arbitration upon issues in which national honour or integrity is involved". 24 The majority of the Senators were opposed to it on the grounds that it did not contain the reservations of honour, territorial integrity, foreign or domes- 
tic policy, or claims against a state of the United states." 25 The discussion of that treaty gave the Senators the opportunity of stressing the necessity of making a COMPROMIs each time a dispute arose, and of the Senate consenting to the COMPROHIS. This was the starting point to the policy to which the United States' Senate has clung since that time. 26

As to the second treaty, the Argentine Senate rejected it as it was signed because it deemed it necessary to amend the treaty as to the extent that questions should be excluded "which might affect the independence, the sovereignty and the fundamental principles on which the political organization of the two countries rest". It was thought that these reservations were inherent in the treaty, so that amendment was simply an explanation of what was undoubtedly in the minds of the negotiators. However the Italian government rejected the ratification of the treaty because of the amendment, which was described as introducing "a much too indefinite exception". Also "if reservations were to be included in the treaty, Argentine should explicitly name those questions which she desired to withdraw from the action of the treaty". 27

It is to be mentioned that this new trend of inserting reservations in arbitration treaties was not a step backwards in the progress of obligatory arbitration. On the contrary, it reflected the willingness of states to observe their obligations when they were more limited or when their nature corresponded to their application rather than making a general statement that all dispute, of whatever nature without reservations are arbitrable then offending it in practice as the Chilean delegation at the First American States Conference stated. ${ }^{28}$ Furthermore, it can hardly be said that arbitration treaties made at that time contained any real obligations because - as has been observed - they "were deprived of consequence", 29 or "were expressed aspirations of the statesmen rather than the working agreements". 30 


\section{(ii) Reservations during the First Hague Conference}

The idea of making a general arbitration treaty without reservations was not conceived during the First Hague Conference. This was maybe due to the fact that the Latin American States, which had been the greatest protagonists of obligatory arbitration, were not invited. Thus reservations were regarded as an essential element in making a universal obligatory arbitration treaty. The draft convention prepared by Russia, which called for the conference, showed the precautions taken as regard to such a treaty, by the inclusion of new reservations of a vaguer nature i.e. the reservations of "vital interests and national honour". 31 A request for the determination of these undefined words was made by Asser. As a response to that request, Marten recognised that "the text of Article 8 is in fact new, but he fears that it will not be possible to find a better". 32 The vague character of these clauses had perplexed the delegate of Switzerland. He wondered whether they included questions of national constitution or not. He stated that he was under instructions from his Government to request "an addition to the words 'vital. interests and national honour' with reference to the constitution of the country - but if it is understood that the words written into the draft of these articles comprehend, A ForTIop(y) the national constitution, he is able to declare himself as in accord with the proposed text". 3

The reservation of questions belonging to the past or "disputes and differences arising prior to the conclusion of a treaty" was another new one introduced by Roumania. 34 The United States suggested in her plan for a permanent Court that all disputes should be referred to that court, except those which involved States' "political independence" or territorial integrity.

On the other hand, the First Hague Conference had followed the First American States Conference in limiting 
the scope of arbitrable disputes. However the method followed by the former could be regarded as a development of the idea introduced by the latter, whereas the latter limited arbitrable disputes to those included in the list, although an attempt had been made during the First Hague conference to create a criterion for the determination of arbitrable and non-arbitrable disputes. This determination was based on legal questions as opposed to political ones. Therefore arbitrable disputes were only those, according to the Russian explanatory note, "which concern exclusively special points of $l a w$ and which do not touch upon the vital interests or national honour of States". So However no clear definition had been advanced for that purpose. Many formulae had been referred to. Among them it was conceived that the jurisdiction of arbitration extended to questions "of a legal nature and principally questions of the interpretation or application of treaties". However "differences where the opposing claims of the parties cannot be stated as legal propositions are thus, to some extent, by their very nature, outside the jurisdiction of an institution called upon to 'speak the law' ". Conflicting interests, differences of a political nature, do not belong, properly speaking to arbitration. S7 "Opposing interests" were also relied on for that determination. A treaty was of a political nature and therefore excluded from arbitration if the opposing interests were of a HATIMNAL CHAFACTER. However treaties of a HOFLDHIDE CHANACTER, which formed a system of "international relationship" - international unions - to serve interests which were also international, were arbitrable, because in those treaties interests of all states were "common and identical". The determination of the nature of the dispute in such cases seems to be left to states concerned, which would not permit their hands to be tied or to be reduced to a passive state when dealing with questions upon which their security in a large part depended, i.e., questions of which none but the sovereign power can be the judge. 
In the same vein it was stated before the Third Commission that:

\begin{abstract}
"States have never considered that arbitration is applicable indiscriminately to all the differences that may arise among them. There are controversies which seem to be exempt from arbitrable justice because the contentions of the parties cannot be formulated in a logical manner. Many political differences are of this character.
\end{abstract}

Even in the province of law, States - the majority of them at any rate - do not consider that arbitration is applicable forthwith to every dispute of a legal nature. There are disputes affecting rights of so superior an order that the powers do not consider themselves authorised to submit them to arbitral justice. The formula covering these excepted cases may vary "independence and autonomy" says the Dutch - Fortuguese declaration of July 5 1894; "vital interests and national honour' says the Russian project which was submitted to us." 39

It seems that according to the above formula a contention which could not be formulated in a legal manner did not mean necessarily that it was of a political nature. According to the formula introduced by Russia, two categories of disputes were arbitrable within certain limits. The first included disputes concerning the interpretation or application of 12 enumerated conventions as far as they did not involve the vital interests or national honour of the states in the controversy; and the second contained disputes concerning pecuniary claims with the same reservations. e.g. A dispute over unlawful injuries if it was concerning the bankruptcy of a state and within the limits where the principle of indemnity was recognised in practice. ${ }^{40}$ The failure of the conference to obtain an agreement upon arbitrable disputes was not due to this method. It had never been objected to PER SE, but the main problem was as to what categories of controversies should be included. 41 The United States delegates for example,"felt obliged to insist upon the omission from the Russian list ... international conventions relating to rivers, to interoceanic 
canals and to monetary matters". 42 Also Germany refused even the proposition to reduce the list to four cases in which she had agreed to obligatory arbitration. 43

To conclude, the delegates to the Conference did not conceive the application of obligatory arbitration beyond secondary classes of disputes. Even to those classes, it was not limited only to questions of a legal nature, or those which had no bearing on what were called "vital interests". "national honour" or "inalienable possessions", but states were willing to pledge themselves to accept arbitration in a manner that they could at the same time escape this obligation when they considered it necessary. Therefore the result was, in this respect, no more than the recognition of arbitration in questions of a legal nature and especially in the interpretation of or application of international conventions "as the most effective and at the same time the most equitable means of settling disputes which diplomacy has failed to settle". 44

\section{(iii) The Second International Conference of American States}

The Second International Conference of American States held at Mexico City from October 22, 1901, to January 31, 1902 followed the same procedure introduced by the First Conference in the determination of arbitrable disputes. Article $I$ of the treaty on compulsory arbitration provided for the arbitrability of all disputes "provided that in the exclusive judgment of any of the interested Nations the said controversies do not affect either the independence or national honour". Also the Second Article enumerated the controversies with regard to which these reservations could not be invoked. Disputes were to be submitted to The Permanent Court of Arbitration created by the First Hague Conference (Art.3), which was invested with the power to decide all questions relating to its own jurisdiction (Art.4). 
The idea of submitting all disputes to arbitration without reservations was endorsed by some States. Peru, for example, regarded the inclusion of such reservations as a:

"return to ideas and sentiments developed in the feudal
times. However in the modern State which is based on living
according to the law $\ldots$ the so-called superior or vital
interests could certainly not be an object for precise defini-
tion. Eut it is to be believed that there is not for any
nation any interest of greater importance than peace." 46

However other States regarded the reservations necessary for the conclusion of the treaty. The Mexican Government was in favour of making the reservation of national honour, and ascribed the failure of the first treaty to the absence of that reservation. It laid stress strongly upon its maintenance, in spite of its recognition of the impossibility of defining the scope of that reservation, for the reason that:

\footnotetext{
"The weakest nations - history is full of lessons on this point - prefer to succumb rather than to sacrifice their honour. And because this sentiment, worthy of respect, although sometimes exaggerated is irreducible, no nation can consent that a third party, be it whoever it may, should decide on the question, which may be called previous, whether the pending controversy with another Fower affects or does not affect, its independence or its honour."
}

Argentine preferred the clause of the right of sovereignty, as an ensemble of the essential condition to the existence of a nation, because it could embrace all other reservations. 47 The reservation of the constitutional principles became more popular between Latin American States. It was made in the same year i.e. 1902 in two treaties concluded by the Argentine with Bolivia and Chile. 
(iv) The Anglo - French Treaty of 1903

This treaty was very important in the history of the obligatory arbitration for two reasons. On the one hand it was among the early general arbitration treaties made by great powers which had been reluctant to enter into such treaties before. On the other hand it embraced all the widest reservations known at that time. It was influenced by the First Hague Conference in limiting its scope of application to disputes of a legal nature or relating to the interpretation of treaties existing between parties. These disputes were to be referred according to Article 1 to the Permanent Court of Arbitration if it had not been possible to settle them by diplomacy, provided that they did not affect "the vital interests, the independence, or the honour of the two contracting States and do not concern the interests of third parties." 49 By the inclusion of these reservations, the parties were disinclined to accept arbitration over disputes which they considered important, while at the same time they were willing to cope with the movement of obligatory arbitration. The consent of the two parties. was therefore, necessary for the submission of any dispute to the tribunal since the determination of whether the subject matter was affected by any reservations was left to them, otherwise the whole treaty could be set aside. 50 The conclusion of a special agreement in each individual case before appealing to the Permanent Court of Arbitration was necessary according to Article 2.

The form of this treaty was followed in almost identically the same terms by a large number of subsequent treaties before 1919. It was included in about 80 treaties throughout the period, half of them made by the United States and Brazil. 51 About 36 of these treaties were concluded during the period until the end of the first half of the year 1908. 52 


\section{(v) Other Treaties}

The International American Conference and the First Hague Conference had a great influence on the behaviour of Latin American States and the European ones respectively with regard to obligatory arbitration. The former States and Italy preferred the formula that all disputes were arbitrable except questions affecting the independence and honour of the contracting States. However these reservations could not be invoked with regard to questions listed in those treaties. The list was based mainly on the classes of matters included in the Second International Conference of American States with the addition or omission of other questions. 5.3 The European States relied on the formula discussed during the First Hague Conference in many treaties. These treaties were more limited in scope in comparison with the former, but contained more reservations such as the treaties concluded by Russia or Belgium with the European States which contained the reservations of independence, honour. vital interests and sovereignty.

Another reservation had been developed during that period concerning the exclusion from arbitration of any question which was within the jurisdiction of national courts. This reservation was made in many forms: some treaties provided for that disputes between citizens of one of the contracting states and the other state were exempted when the local courts were competent, 55 others made these disputes arbitrable only in case of denial of justice. ${ }^{56}$ or if questions of interpretation of treaties as well as denial of justice were involved, 57 and finally some treaties contained a suspensive condition according to which recourse to arbitration was not possible before there had been a definite decision by the municipal courts. 58

A new trend in the progress of obligatory arbitration had been marked by the inclusion of clauses accord- 
ing to which controversies upon the nature of the dispute were to be referred to tribunals. Thus the decision, which had an obligatory character, whether a dispute was arbitrable or not, was given to the tribunal itself. Those clauses were included in Article 18 of the Treaty of Commerce between Italy and Switzerland of July 13, 1904 and Article 15 of the treaty between Italy on the one hand, and Austria, Hungry and Germany on the other. 59 Moreover, Article I of the treaty between Italy and Peru dated April 18, 1905, which exempted questions concerning national independence and national honour provided that "in case there should be doubt regarding these two matters, the question shall also be settled by arbitral decision." 60 Article 2 of the treaty between Norway and Sweden of October 26, 1905, also empowered the tribunal to decide, in case of divergence, whether or not the dispute involved vital interests of one or the other of the parties. However there was no mention of the reservations of "independence" and "integrity" which were included in Article I beside the reservation of vital interests. $^{61}$ It seems that the parties considered the former reservations more important, and therefore they upheld them from the decision of the tribunal.

\section{(II) Reservations During the Second Hague Conference}

Unlike the First, the Second Hague Conference saw many propositions being made. This was due mainly to the fact that more states were represented, and States had been influenced by their practice in making Arbitration treaties during that period. ${ }^{62}$ Table 1 summarises the propositions presented to the conference. In fact the principle of obligatory arbitration was unanimously admitted in abstract, 67 but for the determination of which method would lead to its transformation to a reali$t y$, unsurmountable difficulties arose. The methods envisaged could be divided into four: arbitration of all disputes without reservations; the limitation of arbitration to enumerative subjects without reservation: its 


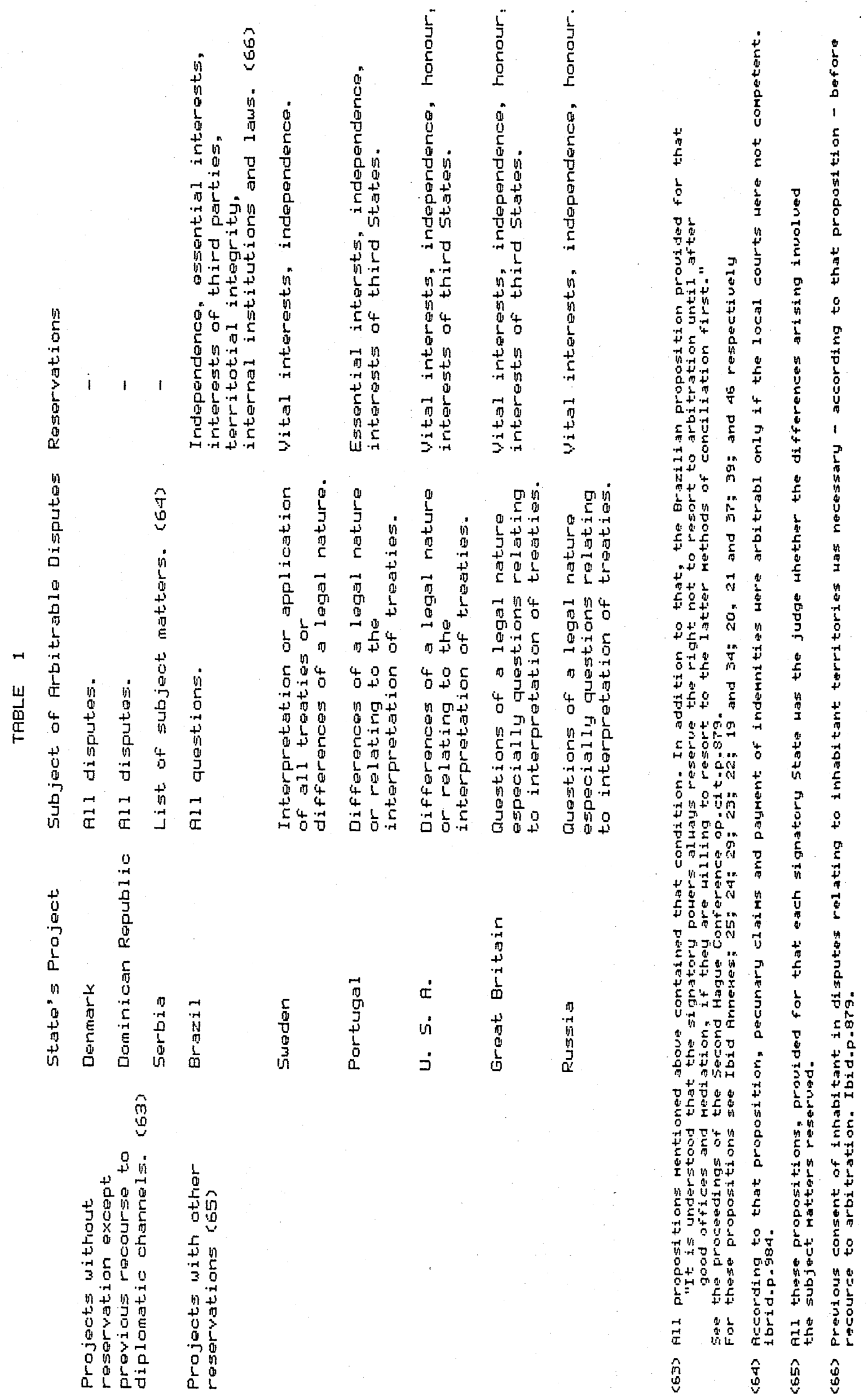


limitation to questions of a legal nature or to those relating to the interpretation or application of treaties with reservations: and finally to limit it as in the third formula with the addition of a listed subjects without reservations.

The first method included the proposals of the Dominican Republic and of the Danish Government. The former based its proposition on the recommendation of the Third International American Conference to the 19 States represented "to endeavour to collaborate in the making of a general convention of arbitration" at the Second Hague conference. 69 The latter relied on its obligatory arbitration treaties concluded between the two conferences especially those with the Netherlands. Italy and Portugal which were without reservations. However these proposals, as well as the Serbian one classified in the second category, did not obtain a long discussion because it was thought that the Conference would not accept such a proposal, in spite of the fact that many delegates criticised the inclusion of reservations - as will be seen. Thus, the president of the First Subcommission of the First Commission observed that:

\footnotetext{
"no member of the committee believes that any good would come from their discussing a proposition which would certainly be rejected by the conference; he declares that the committee does not accept the principle of general obligatory arbitration without reservation"
}

The most extensive discussion had been on the two last formulae. As to the third, two connected points arose: the determination of the nature of disputes, and which reservations should be included. Concerning the determination of legal and non-legal questions or justiciable and non-justiciable disputes ${ }^{71}$ the conference failed to create any criterion on which such a distinction should be made. Thus the delegates of Germany were in the lead in criticising this limitation. Marschall von Bieberstein asked : 
"What is the meaning of this word? (legal). It has been said that it may exclude "political matters". Now it is absolutely impossible, in a world treaty, to trace a line of demarcation between these two nations. A question may be legal in one country, and political in another one. There are even purely legal matters which become political at the time of a dispute. One of our most distinguished colleagues told us the other day, on another occasion, "that politics is the realm of international law'. Do we desist to distinguish "legal" questions from technical and economic questions? This would also be impossible. The result is that the word "legal" states everything and states nothing, and in matters of interpretation the result is just the same. It has been asked: "Who is to decide in the case of some dispute, whether a question is or whether it is not legal?" So far we have had no answer. Yet, this word "legal" is the nail on which we have hung the whole system of obligatory arbitration along with the list and with the table. If this nail is not solidly fastened, everything hung on it will fall to the ground." 72

The attempt to refute the difficulties mentioned by the German delegate was based on the fact that they were applicable also to individual treaties since Germany preferred these treaties and was against any attempt to making an universal obligatory arbitration treaty. 73 However it had been recognised that it was difficult, if not impossible, to determine either the questions of a juridical nature ${ }^{74}$ nor those of a political character. 75 A solution to the problem was suggested by the Italian delegate Guido Fusinato that the tribunal should decide upon this preliminary question, ${ }^{76}$ but it was rejected. Leon Bourgeois declared that:

"It is we who are here present who must state, who must decide whether or not a certain question is of a juridical nature." 77

Marschall von Bieberstein also opposed strongly to that idea. He thought that it was not possible "to leave to the arbitrator the decision of a matter so grave that in reality the future itself of the institution of arbitration is at stake". 78 As to which reservations should be included, it has never been conceived that a treaty could include all the reservations contained in 
the different proposals, to wit, the reservations of: vital interests, honour, independence, interests of third parties, territorial integrity. Local institutions or internal laws, in addition to the reservations concerning specific disputes made in the list such as pecuniary claims and payment of indemnities if the local courts were competent, otherwise such a treaty would have no sense at all. For the elimination of some of these reservations, the Brazilian proposition did not hold for a long time because it was regarded as too broad since it suggested the arbitration of political and legal questions on the one hand, and did contain more reservations, especially the reservation of Local institutions or internal laws and territorial integrity which were not made in the other propositions on the other hand. "79 The "arbitrariness" and "indecisiveness" of the former reservation, and the possibility offered by it for any state interested in escaping being sued before a tribunal by invoking its municipal law led to its elimination. ${ }^{80}$ As to the latter, it was criticised by Martens as being "so restrictive" that it excluded "most of the questions which have been the object of the fifty-five arbitral awards pronounced in the course of the nineteenth century". He even wondered if it was "easy to imagine cases to be submitted to arbitration which would touch neither the independence, nor the territorial integrity nor the institutions, nor the municipal laws of the states in controversy, especially if as stated in article 4 each State remains free to decide this matter in an exclusive manner". 81 Thus, Heinrich Lammasch pointed out that "one could not state whether it (the Brazilian proposition) is going too far, or whether it is going far enough". 82 For maintaining these reservations, the Brazilian delegate argued that they were included in the reservations made in the other propositions, especially vital interests and national honour.

The most attractive reservations were those of independence, vital interests, national honour and the 
interests of third States. However a divergence of opinion had arisen with regard to which reservations should be maintained. Some delegates were against the idea of making any reservations. Others regarded them all as indispensible. While others preferred only some of them. The most comprehensive attitude was taken by the Uruguayan delegate Juan P. Castro who preferred the arbitration treaty to be made on the early Latin American treaties style, i.e. without reservations. He was against the inclusion of the national honour clause. For any dispute that reached a "certain degree of acuteness" involved, he thought, the honour of both parties. He opposed also the reservation of vital interests because "every exception is a gate opening to war", he pointed out. As to the independence clause, Castro regarded it included tacitly in every treaty, for "no country worthy of being a country will ever submit its existence to the opinion of arbitrators". 84 Asser (the Netherland delegate) also proposed the inclusion of the reservation of vital interests and honour. In his opinion:

"This reservation seems indeed well calculated to disillusion the friends of arbitration. Ey means of it we are taking back with one hand that which we seem to be giving with the other. Since each State is free to decide that which in its judgment should be classed among the VITAL INTERSTS, doubt is permitted... In truth we do not see that for a dispute involving the vital interests of a state one should wish to exclude its settlement by means of arbitration, even if there should result from it the danger or the need of war; that one should prefer to the reasoned decision of a tribunal composed of respectable and impartial judges, rendered after a judicial discussion and a conscientious examination, a solution by arms, by blind force, by the good or evil chances on the battle-field.

The vital intersts concern the LIFE of the nations: war the DEATH of millions of brave citizens.

The vital interests in our day are generally the interests of an economic nature; War is the destruction by millions and billions of the national capital." 
The argument that the reservations were of no importance whatever in a world treaty was advanced by the German delegate Marschall von Bieberstein. He argued that the obligation asumed according to a treaty containing the clauses of independence, the honour and vital interests would be illusory, especially when each State would itself decide as to the exception which it had set forth. It is to be observed that Bieberstein was not in favour of making an arbitration treaty without reservations, but his argument was in fact a veil behind which he tried to hide the real intention of Germany to destroy the idea of making a world treaty of arbitration. 87 Among the advocates of a general treaty of arbitration was the Serbian delegate Milovan Milovanovitch who was against the exclusion of disputes of a political nature affecting the independence, the vital interests or the honour of states because disputes of such a character had been in the past and would be in future the direct causes of wars. 88

In spite of these arguments advanced by the artisans of obligatory arbitration, and the vagueness andelastic nature of the proposed reservations, the majority of the delegates considered them indispensible. It had been thought that between accepting a weak obligation to resort to arbitration and compromising the very principle of obligatory arbitration, the idea of reservations should prevail. 89 For the maintenance of that idea the following reasons were relied on: the impossibility of predicting the consequences of an unconditional world arbitration treaty or forming a judgment as to its scope; 90 "the absence of an international practice of a certain duration" as a means for the determination of the classes for which recourse to arbitration would be without reservations; 91 the absence of reservations would encourage States to seek other means to denounce the obligations assumed according to that treaty, 92 and finally these reservations had been included in treaties made before that conference especially on the Anglo - French model of 1903 and they had not led to ambiguous inter- 
pretations, and therefore no state would "invoke them without an absolute necessity". "93 Accordingly, the First Committee maintained the reservation of vital interests and independence by fourteen votes against four, and the whole Article 16 (a) which contained these reservations in addition to the clauses of honour and the interests of other States not involved in the disputes by thirty-five votes against five (Germany, Austria - Hungary, Greece, Roumania and Turkey), and four abstentions (Japan, Luxembourg, Montenegro and Switzerland). 94 with regard to the first reservation, the president of the First Committee observed that:

"with great force this clause of the reservation of vital interests is criticised, but it is so only because it has been found too elastic, and because arbitration is not then sufficiently obligatory. We but wish to follow, and it is through wisdom that we are not going further."

The fourth and the last method envisaged was that of enumerating subject matters in regard to which recourse to arbitration should be obligatory without reservations. The classes proposed by Portugal. Great Britain, the United States of America and Switzerland 96 were based mainly on those included in the Russian Proposition during the First Hague Conference. The general feature of those classes was that they were of secondary importance, and even for these cases it was impossible for the delegates to determine in advance a large number of specific cases upon which obligatory arbitration might bear 97 However it was thought that a limited list of a meager subject was better than nothing, because it could contribute to the establishment of peace, through the settlement of the little disputes arising in the daily life of nations, and would bring about the habit of resorting to arbitral justice. 98 In spite of the efforts made by the majority, the opposition of some states especially germany, Austria, Hungary, Belgium and Greece was the main obstacle to secure an absolute majority over a large number of cases. They based their refusal to the enumera- 
tive method on the changeable character of the cases i.e. a legal question might become a political one at the time of the dispute; "the innocent nature of almost all of the points", i.e. by their nature preclude any dispute; some of them called for the intervention of the legislative bodies, and the interpretation and application of certain of them came solely within the national jurisdiction. 99 Thus from 24 cases voted upon out of 32 , only 8 cases obtained an absolute majority before the First Sub-commission.

The previous pages show clearly the importance that had been given to the theory of reservations during the Second Hague Conference, in spite of the failure to conclude a general obligatory arbitration treaty, by the eminent jurists who were at the same time representatives off their governments and, therefore, instructed to advocate their governments' views. The most remarkable point is that what was considered at the First Hague Conference as "new reservations" i.e. honour, vital interests and independence became at the Second "wellknown reservations". 101

\section{I Reservations During the Period Between the Second Hague Conference and 1920}

The failure of the Second Hague Conference to reach an agreement upon obligatory arbitration left no alternative for States but to conclude individual treaties. In general all formulae used before the Second Hague Conference had been followed. i.e. The Anglo - French model, which was the most attractive especially between great powers: 102 the limitation of arbitration to legal questions especially those relating to the interpretation or application of the treaties and pecuniary claims with reservations, and the enumerated formula which differed from the previous in making recourse to arbitration as regard to listed cases without reservations. 103 The tendency towards making arbitration treaties without 
reservations became an exception. States, even the Latin American States, realised that their essential interests had to be protected. 104 The unratified Taft - Knox treaties of 1911, negotiated by the United States with Great Britain and France showed the reluctance of the great powers at that time, to conclude treaties without reservations. All differences "justiciable in their nature by reason of being susceptible of decision by the application of the principles of law or equity", except if it had been possible to settle them by diplomacy, were arbitrable without reservations. These treaties went farther in providing for that a joint commission composed of three nationals of each state, was to decide upon the nature of the dispute and whether or not it was justiciable. The failure in ratifying these treaties was due to the modification introduced by the senate concerning the omission of the clause relating to the determination of justiciable questions on the one hand, and the inclusion of some reservations such as the Monroe Doctrine, the integrity of the territory of the United States and of the different states, and questions of immigration on the other. ${ }^{105}$ Taft refused to ratify them, because, in his view, the adjudication of international arbitration courts should be abided by "in every issue which cannot be settled by negotiations no matter what it involves. whether honour, territory or money". 106

The number of treaties which empowered the tribunal to decide whether the previous questions were justiciable or whether a case touched upon one or more of the reserved subjects had been increased. Professor $N$ Politis has observed that up to 1914 there were 19 treaties. Italy was a party to 11 of them, which contained such provisions among 139 treaties in force. 107 However they consisted of an exception from the general rule that such decision was left to each state. Concerning the number of reservations, it had varied generally from one to five reservations ${ }^{108}$ without taking into consideration the stipulation of previous recourse to diplomatic means. The 
most desirable reservations were; honour, independence, vital interests and third parties interests. They were included in about $107,104,94$ and $87^{109}$ treaties respectively. The reservation of sovereignty was included in about 17 treaties; constitutional questions in about 16; nationality questions in 2 and past disputes in one treaty. 110

\section{B - SCOPE AND EFFECTS OF RESERVATIONS}

The broad terms in which reservations had been phrased throughout the period considered here raised the question of the necessity to qualify them. For this purpose no attempt succeeded. As has been seen, it was not possible to determine the meaning of reservations during the First Hague Conference, nor during the Second, and the suggestion of Asser to define the phrase "UITAL IHTERESTS OR NATIONAL HOHOUR" was rejected. 111 To illustrate the difficulties which arose during those conferences, the ignorance of the delegates to answer Odier's question of whether or not questions of national constitution were included in the reservations of vital interests and honour is worthy of mention. The view taken by Ruy Barbosa in advocating the Brazilian proposed reservations offers the best example. For retaining the reservations of territorial integrity and municipal institutions and laws, he argues that the former was implicitly contained in the terms of "ESSEHTIAL IHTERESTS" and almost always concerns the honour of the State. Explaining the vagueness of these terms Barbosa said: "let him who may state where ends the point of honour and where begins the juridical phase. Whatever may be said in connection with this matter, it is certain that if you admit the reservation of the questions affecting the honour of the peoples (and every one admits it), the Governments will not fail, if necessary, to include in it territorial integrity." The second was also connected with national honour since he considered the recognition of the denial of jus-tice hypothesis as a stain laid upon national judges. 
Other attempts to define "national honour" and "vital interests" were made before the Institute of International Law but they failed. It was proposed to use the general words "DROIT INALIENARLE" instead of those expressions. The difficulties of defining the word "independence" was also remarked on. 114 The impossibility of defining these reservations has been recognised by almost all writers on international law. They have been described as being "abstract", "vague" and general terms of an all"embarrassing elasticity". The loopholes in arbitration treaties were thus big enough to allow a signatory state to adopt a different interpretation whenever in its judgment the arbitral decision could be against it, claiming that its vital interests or national honour or independence would be imperilled. 115 This is why the nature of the objections assumed according to treaties which contained such clauses has been regarded as obligatory in name only, but in fact no obligation was assumed, or at least was undertaken on a voluntary basis. since the decision whether or not those reservations were involved was left to each party.

The confusion created by the inclusion of these abstract terms and the diverse combinations made in treaties, 116 such as the combination of independence and integrity of the territory; independence and autonomy, or independence, vital interests, national honour, sovereignty and interests of third states etc, led to different views as to the justiciability of matters covered by those reservations, 117 and to different approaches in order to reduce the number of reservations to an irrecusable minimum. For some writers the reservations of vital interests and national honour were large enough as to eliminate all other reservations, especially since they were usually not made alone, but along with other reservations. 119 However this view did not solve the problem as long as no clear definition was made to the term vital interests. Some considered the independence as 
the only acceptable reservation either because it could involve all other clauses if it is relied on by the state which was "hindered in doing or not doing anything that an independent state may do or abstain from doing", 119 or because reservation should not be invoked except when the existence of a state is at stake. ${ }^{120}$ Others sought a solution through the substitution of more precise terms for the general ones. Thus Sir Thomas Barclay suggested the substitution of the phrase "all difficulties which it has not been possible to settle by diplomatic methods, and affecting neither the independence nor territorial integrity nor the internal laws or institutions of any such $\mathrm{H}$. C. P.,nor matters involving prior arrangements of any H. C. P. with third parties." 121 for the words "vital interests".

This proposition is more qualified than that suggested by the Interparliamentary Union concerning the "national honour" clause because the latter contained the words "vital interest". According to it "national honour" was to cover disputes which;

"do not affect either their independence or vital interests, or the sovereign authority of the respective countries, or the interest of Third Powers" 122

It is clear that according to the last suggestion the reservation of national honour was considered larger in scope than that of vital interests.

These difficulties had not arisen in practice since, as it has been observed, ${ }^{123}$ reservations had not been relied on in the cases referred to International tribunals or the Permanent Court of Arbitration at the Hague. ${ }^{124}$ However the condition of previous recourse to diplomatic channels was relied on three times before the Central American Court in the case concerning the revolution which broke out in Honduras, ${ }^{125}$ and the two cases brought against Nicaragua by Costa Rica and El Salvador 
respectively in regard to its treaty of Bryan-Chamorro with the United States. In all these cases the court rejected the preliminary objection to its competence and held that these cases fell within its jurisdiction.

In spite of the fact that the court competence was unlimited, Nicaragua considered the clauses of independence and national honour as implied in the treaty which established it. Nicaragua claimed that the conclusion of that treaty was a sovereign act that could not be annulled, and that "no nation on earth would submit to the arbitrament of strangers its security and preservation." 126 It was observed that the refusal of Nicaragua to abide the court's decision in these cases was not due to the fact that its rights were affected, but because it was "in a very embarrassing position. It had to choose between offending the United States (as a powerful State) or its neighbours, and evidently its fear of the former was greater than the fear of the latter". 127 Whatever the reasons for that refusal, there is no doubt that these cases were the main cause for the downfall of that court as the only body before which a case could be brought unilaterally.

\section{C - REASONS FOR MAKING RESERVATIONS TO OBLIGATORY ARBITRATION}

The object of this study - as has been said - is to point out briefly the main reasons which were behind the inclusion of reservations during the period considered here, i.e. the period between the last decade of the nineteenth century and the establishment of the Permanent Court of International Justice in order to compare later whether those reasons are still the same for making reservations to the competence of the International Court of Justice.

In sticking to the theory of reservations many reasons had been relied on; some of them were of a gene- 
ral character or at least concerned a large group of States, and others were of a special character and concerned special treaties between limited States. Concerning the former, it is observed that the conception of absolute sovereignty was the main cause for the insertion of reservations. ${ }^{128}$ states were used to referring their disputes to arbitration on a voluntary basis. This method did not give rise to real problems for states accepting it since all the circumstances surrounding the dispute were known to the parties and therefore, they had the opportunity to decide whether or not it was suitable to resolve it by arbitration. According to this method national sovereignty was not diminished. However the unfamiliarity of States with the obligatory arbitration method as a new one, on the one hand, and the unforseen consequences in the future on the other, led them to think twice before accepting it. It was not easy for especially the great powers to accept being deprived of their "absolute rights" of choice of action. 12 ? The solution to the hesitation between accepting this new method and at the same time preserving those rights was therefore founded in the inclusion of escape clauses. For these reasons the only - Pauncefote Treaty, which provided for the arbitrability of territorial claims and questions of principle of grave general importance affecting the national rights, was rejected. ${ }^{130}$ The minority report of the Committee on Foreign Relations read:

\footnotetext{
"There are very few (treaties), if any, that relate to or declare certain fixed principles or policies or lines of action by which the nations surrender to each other any of their sovereign powers or permit one nation to participate in the control of the action of another in the future and unforseen events. Such agreements when they exist are made between netions that are not independent and those that exercise over them suzerainty or acknouledged right of control. In ell this mess of treaty engagements we have heard of none that resembles this treaty " 1 is
}

The theory of sovereignty was supported by other factors such as the colonial movement and the national 
industry which required new raw material and vast markets. ${ }^{132}$ The fear that arbitrators might neglect to take into considerations these factors increased States' clinging to the theory of reservations.

Taking into consideration the increasing size of armament, the absence of an organization to take the responsibility of collective security, and that recourse to war was not outlawed, States preferred using all their elements of strength and resistance, if other peaceful means failed, rather than appealing to arbitral tribuna1s. 135 In such circumstances appeal to arbitration was regarded sometimes as a sign of weakness, because - as the minority report cited above stated "without this unqualified right of appeal to arms no nation can be independent". This explains why great powers had been reluctant to accept obligatory arbitration without reservations whereas small States were more prepared to accept it. The history of the arbitration treaties concluded between Latin American States and the existence of the central American Court of Justice ${ }^{134}$ confirm this idea. In fact most of the treaties which contained reservations clauses, especially vital interests and national honour. were between great powers or at least one of them and a small State. Thus the existence of some reservations, such as independence, autonomy, territorial integrity and constitutional questions, in treaties between small States could be understood as an imitation of the model made in treaties concluded between great states on the one hand, and as an emphasis on the importance of these subjects for those states rather than being exclusions on the other. ${ }^{135}$ The fact that special relations between States circumscribed by a series of concrete and familiar factors, such as the geographical situation of the two countries, their financial and economic relations, and the historic tradition, which had grown up between them could not be observed in treaties between a large number of States, was another reason for making reservations. especially if it is noted that the conferences held at 
the end of the last century, i.e. the two Pan - American and the two Hague Conferences, helped in the creation, and the development of the theory of reservations.

States had been influenced also by the distinguished authors who thought that questions affecting vital interests, their honour, independence and territorial integrity were not arbitrable, and that arbitration should be confined to legal questions only. 136 The failure in finding a criterion for the distinction between legal and political or non-legal, or justiciable and non-justiciable disputes helped towards the inclusion of these reservations as a criterion in itself. 137 Thus arbitration had been limited generally to disputes of secondary importance, whereas diplomacy backed by force was regarded as the most desirable method for the settlement of important disputes.

The LACUNAE in international law or its uncertainty with regard to many points had been admitted by states as well as by many writers. $1 \$ 8$ This conception was due mainly to the domination of the positivist doctrine according to which a tribunal was to apply only the existing rules of positive law recognised by the disputant parties. Therefore international law that contained "so many gaps" 139 was considered "too weak to deal with questions involving the important interests of parties". 140 . The absence of a legislative body to lay down the law by which a tribunal could be guided was advanced as a support for that conception, 141 though States were not prepared to accept such a body even if it emanated from a conference. ${ }^{142}$ This reason reflected in fact the lack of confidence in the arbitrators which was the real obstacle in the path of obligatory arbitration. In his letter to the American delegates at the second Hague Conference the American Secretary of State, Elihu Root wrote: 
"There can be no doubt that the principal objection to arbitration rests, not upon the unwillingness of nations to submit their controversies to impartial arbitration, but upon an apprehension that the arbitrations to which they submit may not be impartial. It has been a very general practice for arbitrators to act, not as judges deciding questions of fact and $l$ aw upon the record before them under a sense of judicial responsibility, but as negotiators effecting settlements of the questions brought before them in accordance with the traditions and usages and subject to all the considerations and influences which affect diplomatic agents ... It very often happens that a nation which would be very willing to submit its differences to an impartial judicial determination is unwilling to subject them to this kind of diplomatic proces. " 143

For maintaining the idea that a "FOREIGNER" or "STRANGER" should not be trusted to solve questions of a great importance, the capacity of arbitrators to render ideal judgment and the ability to distinguish between vital and non-vital interests was doubted. Consequently, States were not expected to put their interests at the mercy of arbitrators. 144 As a support to that idea, the obligatory nature of the decisions of arbitral tribunals and the impossibility of appealing against them, even if they were unjust, had been advanced. These elements were pointed out in Salisbury's letter to Bayard. He wrote:

\begin{abstract}
"By whatever plan the tribunal selected, the end of it must be that issues in which the litigant states are most deeply interested will be decided by the vote of one man, and that man a foreigner. He has no jury to find his facts, he has no Court of Appeal to correct his law, and he is sure to be credited, justly or not, with a leaning to one litigant or the other. Nations cannot afford to run such risks in deciding controversies by which their national position may be affected or a number of their fellow - subjects transferred to a foreign rule." 145
\end{abstract}

The lack of confidence in arbitration caused also by the absence of a permanent court that could contribute to the development of international law through its jurisprudence, and hence obtain the confidence of states. 146 In fact the lack of confidence in the impartiality of tribunals - as it is observed - was not due to the non- 
eligibility of judges or arbitrators, but to the unwillingness of states to submit themselves to a body over which they had no control.

In addition to the above general reasons were also some specific ones. The most notable is the position taken by some parliaments, such as, the United States Senate's insistence upon the necessity of excluding questions relating to the Monroe Doctrine, immigration and the foreign policy of the United States, ${ }^{148}$ and that of the Argentine Senate as regard to constitutional questions, sovereignty and independence. ${ }^{149}$ There is no doubt that each state had in mind special reasons for making reservations, e.g. questions concerning international rivers and interoceanic canals for the United States during the First Hague Conference; 150 AlsaceLorraine for Germany; 151 the obligations undertaken and subsequently broken by Russia with respect to the Baltic Sea and the port of Batoum, 152 and Tacna in Africa for Chile at the First International American Conference. 153 It was hoped that states would define the subjects which they considered important as to be adjudicated instead of using vague and elastic formulae. This hope had been achieved mostly after 1919. The effects of the First World War, the creation of the League of Nations and the establishment of the Permanent court of International Justice (P. C. I. J.) helped the substitution of the old formulae by more definite ones. 


\section{SECTION (2) : RESERVATIONS TO THE COMPULSORY JURISDICTION OF THE PERMANENT COURT OF INTERNATIONAL JUSTICE}

Article 36, paragraphs 2 and 3 , of the Statute of the P. C. I. J. reads:

" (2) The Members of the League of Nations and the States mentioned in the Annex to the Covenant may, Either when signing or ratifying the protocol to which the present statute is adjoined, or at a later moment declare that they recognise as compulsory IPSO FACTO and without special agreement, in relation to any other Member or State accepting the same obligation, the jurisdiction of the court in all or any of the classes of legal dispute concerning:
(a) The interpretation of a treaty;
(b) any question of international law;
(c) The existence of any fact which, if established, would constitute a breach of an international obligation:
(d) The nature and extent of the reparation to be made for the breach of an international obligat- ion.

(3) The declarations referred to above may be made unconditionally on condition of reciprocity on the part of several or certain Members or State, or for a certain time."

According to the letter of this Article, States in accepting the Court's jurisdiction under the Optional Clause, could only limit their declarations to one or more of the classes enumerated in paragraph 2 , or to a certain time, or finally they could make them "on condition of reciprocity on the part of several or certain Members or States".

Taking into account that neither Article 14 of the Covenant according to which the Court was established, nor the Protocol of Signature or the optional Clause attached to it, did contain any mention toreservation clauses, this Article alone falls short of the explanation of reservations included in States' declarations throughout the period of that court, nor did it provide for any explanation to what sort of reservations are 
invalid, if any. Recourse to the history of the drafting of this Article and the actions taken subsequently, especially by the Assembly, seems therefore indispensible for answering these questions.

\section{A - RESERVATIONS DURING THE DRAFTING OF ARTICLE 36 (2) OF THE STATUTE OF THE P. C. I. J.}

This Article in its final form embodied in the Statute was the result of efforts made by three bodies; The Advisory Committee of Jurists; the Council of the League of Nations and the assembly.

\section{(I) The Advisory Committee of Jurists}

It was the duty of the Council to "formulate and submit to the Members of the League for adoption plans for the establishment of a Permanent Court of International Justice". 154 Accordingly the Council formulated on February 13, 1920 an Advisory Committee of 10 Jurists to draft a scheme for the court. This Committee, which was in session from June 16 to July 24, 1920 had before it almost all the previous schemes for a world court including the draft of 1907 for a court of Arbitral Justice, the Central American Court Convention, drafts of the Interparliamentary Union, the International Law Union, the collective draft of the Five Neutral Powers, in addition to the official plans submitted by other states.

As far as compulsory jurisdiction is concerned, the Covenant contained no reference more than the provision that "the Court shall be competent to hear and determine any dispute of an international character which the parties thereto submit to it". 156 Thus the question was raised in the Committee whether the Court's jurisdiction should be extended as to cover questions referred to it by unilateral application, or should be limited to cases presented by the consent of both parties. 
At the beginning, the odd conception of arbitral jurisdiction was raised with regard to both the jurisdiction of the court and reservation clauses. As to the former, it was suggested that the Court's jurisdiction should be limited to disputes referred to it by treaties in force or by future conventions. Therefore, the Court could be endowed with jurisdiction over cases referred by unilateral application only if these conventions provided for such jurisdiction, as did certain sections in the Peace Treaties, otherwise the consent of all parties involved was necessary.

157 The major obstacle in the way of adopting compulsory jurisdiction was due to the actual wording of Article 14 of the Covenant which seemed to some members of the committee to exclude that possibility. ${ }^{158}$ However the Committee found in Articles 12 and 13 of the Covenant a counterbalancing argument for overcoming this difficulty and the desire of modifying that Article. ${ }^{159}$ In rejecting the view that the Committee would go beyond its mandate by adopting compulsory jurisdiction, ${ }^{160}$ the majority of the Committee held that:

"not only is it obvious that the constituent statute of the court can confer upon it the degree of competence, which the states drawing up the statute, wish to give it, but also ... the grant of such powers, though perhaps not strictly in accordance with the letter of the Covenant, follows its spirit so exactly that it would seem a great pity, now that the court is being definitely organized, not to complete the progress made by this last provision" 161

Thus the jurists relied on Article 13 of the Covenant which, in their opinion, laid down cases in which States were bound to submit to arbitration though they recognised that the words "in their opinion" and "generally" seemed to weaken and diminish the force of the provision. In fact the Committee, in recommending a compulsory jurisdiction system according to which one party could summon the other party to the dispute even without its consent, did not dispense with the idea of previous consent totally, but it intended to eliminate the conception of making a compromIs each time a dispute 
might arise. Thus it made it clear that;

"There is no question of binding states to submit to arbitration without their consent. The competence of arbitral jurisdiction is dependent upon the existence of a convention. In this case the converition establishing compulsory arbitration is the constituent statute of the court." 162

Concerning reservation clauses, 16. it was proposed at one time to insert in the draft the old reservations in a new formula, i.e. "INALIENABLE RIGHTS" of States. Thus reservation, which was limited to one member of the Committee, was regarded as a term which appears to be more exact than that of "vital interests". 164 In arguing for the retention of this reservation Descamps declared that:

\footnotetext{
"There exist cases which can neither be stated nor decided legally, such as conflicts of interest and political disputes.
}

There exist cases even of legal character, in which the adoption of legal methods would imply, according to certain States" view, the abandonment of right considered rightly or wrongly inalienable.

The question therefore which arises in practice is to ascertain to what extent it is possible in a body of provisions providing for a general agreement on compulsory Jurisdiction to give such jurisdiction all the scope to which it is entitled, considering in an appropriate degree reserves which if they may not be made, may threaten to jeopardise a general International understanding."

Consequently he suggested that the four categories of a legal character enumerated in Article 36, paragraph 2. could be accepted with "A POSSIBLE RESERUATION", and a separate consideration could be given to controversies even of a legal character which involved inalienable rights. 160

Bearing in mind that the task of the Committee was not "to duplicate the Court of Arbitration", 167 but to make a step forward by establishing a Permanent court of 
Justice with a special character 168 as a necessary condition of any treaty which is to be compulsory in the true sense of the word, the jurists were able to overcome the difficulties encountered by the application of the so-called obligatory arbitration treaties, especially the necessity of an agreement upon the coHPRoMIs in each particular case, and the unlimited freedom of escaping the obligation undertook by means of including elastic reservations. There were many factors which helped in achieving that end. Above all it should not be forgotten that the jurists, unlike those in the Hague Peace Conferences, were not representing their governments but they acted in their individual capacity as independent jurists. 169 In other words they were trying to find the best way of extending the application of the rule of law in the life of nations and not what must be done in their governments' views. Thus, the President of the Committee stressed that "it must not be forgotten that the only instruction to the Committee is to find a best solution". 170 This factor, coupled with the factor of the fresh effects of the First World War, encouraged the jurists to concentrate on the positive results achieved during the past. Thus they emphasized upon the fact that the conference of the Hague or 1907 was unanimous "in admitting the principle of obligatory arbitration [and] in declaring that certain disputes ... be submitted to obligatory arbitration without restrictions", 171 though the Conference failed to agree upon the draft of the treaty of universal arbitration.

In this spirit the proposition of Descamps concerning "inalienable rights" was rejected: Ricci-Busatti considered it a delicate question. He thought that if 'the phrase 'inalienable rights' were considered ... this would give rise to the same objections and difficulties as such expressions as 'vital interests', 'honour' etc.. in the place of which the former was to be substituted". 172 Consequently Descamps abandoned that idea in order to make "an advance in the matter of international jurisdic- 
tion" and "to satisfy most of the members of the Committee". 173 Therefore, the new project, which he had worked out in conjunction with Lord Phillimore, contained two conditions only: exhaustion of "ALL diplomatic means" to settle the case before resorting to the Court and "provided that no agreement has been made to choose a Court of arbitration". 174

Even as regard to these reservations the jurists tried to limit their scope as far as possible and to secure the competence of the court when they invoked. The first question with respect to the exhaustion of diplomatic means of settlement was the determination of its necessity and limits. Loder doubted its necessity. In his view its existence in the project was an adaption of "a system of negative proof, a system which was always liable to cause difficulties". 175 However, this view was rejected on the ground that this condition was frequently used in international affairs, and that it had never given rise to any difficulties. ${ }^{176}$ The question was then raised as to the determination of its meaning. Root explained that "the eventuality referred to by this cause arises when one party requests the other party to state its views in writing and the other party refuses to do so". 177 However Altamira desired to have this clause covering "all peaceful means of obtaining a solution". and not limited to its narrow meaning, i.e. "to negotiations between diplomatic representatives". 178 The latter view seemed to the other member unacceptable for many reasons. Firstly, it was thought that "pacific means" might go so far as to include all violent means generally looked upon as compatible with a state of peace, which would hardly be admissible. Secondly it was too broad. It opens to a party acting in bad faith the possibility of creating difficulties by applying, for the settlement of a given conflict, to conciliation, to mediation etc.., and therefore render compulsory jurisdiction illusory. Final1y, it would create delays which might better be avoided."

Fernandes believed that these criticisms were also ap- 
plicable to the expression "all diplomatic means", and consequently asked for its modification. The Committee found that his arguments were well founded. Thus, the wording of the Hague Conference of 1907 and the Covenant. i.e. "International difference which it has not been possible to settle by diplomacy ..." 180 was adopted.

The second reservation concerning the previous agreement to choose another jurisdiction did not pose any difficulties. The only question was whether it should be for the court to decide whether a party had agreed to have recourse to a tribunal. The question was decided in the affirmative. 181

The result of the work of the committee was - as far as compulsory jurisdiction is concerned - the drafting of Articles 33 and $34 .^{182}$ The first laid down that the Court shall, first of all, decide whether the two conditions discussed above had been complied with; if so. it shall proceed to the next stage. i.e. "to hear and determine the dispute according to" Article 34, which established the real compulsory jurisdiction. According to the latter Article the court was to decide any dispute of a legal nature concerning the five points enumerated therein without any special convention or declaration giving it jurisdiction, since the previous consent was considered as established by the constituent statute of the court.

With reference to the last point it may be worth mentioning that the report of the Committee seem to contradict the proceedings of that committee with regard to the exhaustion of diplomatic means. As stated above the jurists agreed to confine this clause, in the words of Descamps, to "the ordinary sense of these words" 18. in order to close the door to the possibility of contesting the competence of the court by stating that the whole series of diplomatic means - negotiation, good offices, mediation, conciliation etc. - which as Fernandes ob- 
served "are not equally suitable to all disputes", 184 had not been exhausted. For this reason and the ones cited above the Committee agreed upon the proposition of Fernandes to eliminate the word "ALL" which he considered dangerous. 185 However the report of the Committee contained the expression "all means of friendly settlement". The existence of this word; in that report had thus, in the light of what has been said, probably no explanation but to be considered as an error.

In explaining Article 33 the report of the Committee stated after referring to the provisions of 1899 and 1907 which limited the international jurisdiction of arbitration to disputes which diplomacy had failed to settle:

\begin{abstract}
"This provision which is a dominating factor in the organization of Jurisdiction by Arbitration must also be the main factor in the organization of the Fermanent court of International Justice. It would not be wise that a state should be subject to an unforseen summons before the Fermanent Court of International Justice, even in virtue of a previous Convention of Arbitration. Such a proceeding would fail in the respect which states owe to each other. Appeal to the court should not be made until ALL means of friendly settlement have been tried. But the Committee did not intend to enable a party to avoid the jurisdiction of the court by alleging that there was still some, more hope of settlement by diplomatic means. In such case it is for the court to decide whether it has jurisdiction. On the other hand, supposing that the parties, though they have agreed to submit their case to an international jurisdiction, have in a previous convention selected another Court or any other jurisdiction of the nature of a tribunal of arbitration, it also falls to the defendant party to dispute the competence of the Court; in this case also it is for the court to decide whether the objection is to be upheld." 186
\end{abstract}

The conclusion that could be drawn from the proceedings of the Advisory Committee is that the jurists intended to eliminate reservation clauses except the exhaustion of diplomatic means and the agreement to choose another jurisdiction in the limits set above. 


\section{(II) The Council and the Assembly of the League of Nations}

- When the draft scheme of the Advisory Committee of Jurists was referred to the Council for approval, the latter opposed strongly to both Articles (33 and 34) concerning the Court's jurisdiction, not because they did not contemplate the possibility of making other reservations, but for other reasons. In fact adoption of the compulsory jurisdiction system was the major element in rejecting those Articles. It was pointed out from the beginning that the unilateral citation of one party to another before the court without its consent and the possibility of condemning it by default was unprecedented. Such a procedure would in practice only be tolerated by the smaller countries, it was pointed out. 187 However, the report represented by the French representative Leon Bourgeois and adopted by the Council at its meeting in Brussels on October 27, 1920, though it recognized that the draft of the jurists constituted a considerable advance in the administration of international justice and the development of the Court's authority. mentioned the following reasons for rejecting compulsory jurisdiction: the scheme ran against the Covenant and its adoption would constitute a modification of Article 12 of the Covenant; ${ }^{188}$ the Permanent Court was substituted for the Council decision whether or not diplomatic means of settlement were exhausted; it was also substituted for the free choice given to the parties by Article 12 of the Covenant to have recourse to another international tribunal or the Council; the refusal of several countries to admitting that the Court's competence would cover "any point of international law", and finally the objection of some States to the principle of "retrospective competence of the court". 189 The last point which has been developed later in States' declarations accepting the Council's jurisdiction, was explained by Leon Bourgeois as follows: 
"If we are to establish the principle of non-retrospection we should be obliged to introduce a distinction between Treaties concluded prior to the court and subsequently to this document, between events which occurred before or after its entry into force. We should be obliged to establish a criterion to determine whether any particular dispute was already pending or not at the moment in question. Neither the Convention nor the draft scheme of the Hague draws 5 uch a distinction nor do they establish such a criterion".

The reservation of disputes belonging to the past was proposed by Argentine ${ }^{191}$ in addition to the reservation of "questions which affect the political Constitution of the contesting states". 192 However the last reservation was not discussed.

The result was therefore the preference of voluntary jurisdiction based on individual treaties between States according to the two new Articles ${ }^{193}$ which were substituted for those proposed by the Advisory Committee of Jurists.

The draft was then referred to the Assembly at its first meeting, and sent to the Third Committee for discussion, then to the Sub-committee of the Third committee. Before the Sub-committee reservation clauses did not receive any consideration except the suggestion that general treaties which contained the reservations of "vital interests" and "honour" could not be brought before the Court unless a comprowIs had been made between the parties to the dispute. ${ }^{194}$ However, when the project was referred to the Third Committee, Lord Robert Cecil (South africa) stated that:

"he had always thought that the distinction between questions suitable for arbitration and other questions was to be drawn between questions which did and those which did not involve vital interests. But this distinction did not tally with that provided for in the Hague Scheme, according to which the court had to decide only whether a given question fell within the scope of Article 34 . It was, indeed, not certain that all questions covered by that frticle did not involve vital interest; he mentioned the interpretation of such treaties as that of Versailles. No Great Fower, he said, would be 
imposed to submit to the Court of Justice a dispute relating to this treaty." 195

Consequently he believed that the Court should decide only on matters which the parties had agreed to refer to such decisions, whereas questions involving vital interests should be left to the Council. However Lafontaine (Belgium) was against any mention of these reservations. In his opinion the opposition to the principle of compulsory jurisdiction as proposed by the Committee of Jurists "was due to the two fetishes of unanimity and sovereignty". He thought that "the only admissible sovereignty was that of justice", and that though the authors of the Covenant were inspired by the fetishes of vital interests and honour, their absence in the Covenant constituted an element of progress. 196

For the same purpose, i.e. the elimination of any possibility of making the reservation of vital interests. Costa (Portugal) suggested the suppression of the words "par ... Pacte" at the outset of the proposed paragraph dealing with the Court's jurisdiction as well as the words "TOUT OU PARTIE", which, in his opinion, opened the door to that reservation. For this reason his proposition was adopted. 197

Before that Committee Fernandes had the opportunity of insisting again upon a new paragraph concerning the condition of "reciprocity on the part of a certain number of Members, or of certain Members, or, again, of a number of Members including such and such specified Members". 198 For explaining this condition he stated "it was inadmissible for a state to accept the principle of compulsory jurisdiction without knowing exactly towards whom it accepted such obligation". 199 This addition seemed to create some confusion between the condition of reciprocity embodied in the words "vis-a-vis ... obligation" and the new condition proposed by Firmanders. 200 However the Drafting Committee took Huber's view in combining these two conditions: reciprocity RATIONE 
WATERIAE and reciprocity RATIONE PERSONAE. 201 The adoption of Fernandes' proposition combined with that proposed by Hagerup, concerning the possibility of accepting the Court's jurisdiction "for a certain time". 202 constituted paragraph 3 of Article 36. Thus, in its final report to the Assembly, the Third Committee did not refer to the question of reservations except the statement that:

"The effect of this provision is as follows: It give
power to choose compulsory jurisdiction either in all the questions enumerated in the Article or only in certain of these questions. Further, it makes it possible to specify the States (or Members of the League of Nations) in relation to which each Government is willing to agree to a more extended jurisdiction." 203

In the First Assembly, the debate on compulsory jurisdiction was again very heated. However in order to obtain unanimity. Article 36 was retained as proposed by the Third Committee. 204 In fact this Article was a compromise reached by the Third Committee between the views of the Committee of Jurists and those of the Council. 205 It was proposed by Fernandes as an alternative text. 206 With regard to reservations clauses the debate was limited to those of vital interests, honour and constitutional questions. Many of the delegates expressed themselves against the inclusion or even any mention of those reservations. Lafontaine, for example, declared that:

"I was astonished to hear those who once defended the principle of compulsory arbitration utter the words "vital interests". I heard proclaimed the absolute sovereignty of States. We were told that only the nations themselves were judges of their vital interests and that to recognise the right of a State to arraign another was a grave encroachment upon the sovereignty of states. This is not the moment to discuss these principles again. They are condemned by the general opinion of the world of jurists.

When I heard these arguments it seemed to me that a shadow haunted the room in which we sat, the shadow of a broad-shouldered cavalryman, of a tall Junker, who was the cause of our failure at the Hague in 1907 ... We must reply to 
those who spole of vital interests and absolute sovereignty. The voice of peoples tells you that there is only one vital interest, which is that all should bow before the sovereignty of justice. The nations entreat you and appeal to you that you may suffer justice to be done." 207

Blanco of Uruguay expressed himself in the same vein. He thought that reservations which could diminish the scope of the "principle of arbitration were inadmissible" and therefore, "neither the reservations regarding honour and vital interests nor those which concern constitution" were acceptable. "Arbitration must be free and unlimited". 108 In comparing the competence of the Court of Arbitration of 1899 , to which these reservations were admissible, to that of the P.C. I. J. Negulesco said:

\footnotetext{
"To day, even in the most serious conflicts, that is to say those that affect the honour and dignity of the state, they are obliged [States] to have recourse to peaceful means. They must choose between arbitration, the Fermanent court or the Council.
}

In the case of international treaties, we cannot speal: of the honour or of the vital interests of the states; in these affairs there is only one point of honour - that of keeping the engagement one has made." 209

It is now clear that all bodies which contributed to the framing of Article 36 intended to eliminate the broad reservations especially those concerning vital interests and honour. However neither the proceedings of the First Assembly nor those of the Third Comittee and its Sub-committee give any indication as to whether the two conditions included in Article 33 of the Committee of jurists (the exhaustion of diplomatic means and the exception of disputes in regard to which the parties have agreed or have recourse to another jurisdiction) were permissible. That Article was deleted without explanation. On the other hand, there is no room for doubt that they had not contemplated the inclusion of other reservations than those mentioned above. 


\section{B - THE ASSEMBLY'S INTERPRETATION OF ARTICLE 36 (2\& 3)}

The Assembly of the League of Nations had the occasion of interpreting paragraph 2 of Article 36 in 1924 while drafting the Protocol for Pacific Settlement of International Disputes. Having taken into consideration the fact that a small number of states were bound by the Optional Clause. ${ }^{210}$ the Assembly had taken a liberal view with respect to the meaning of that paragraph. Two questions were raised before the First Committee, which was entrusted with the study of the limits within which the terms of paragraph 2 could be clearly defined in order to facilitate the adherence to the Optional Clause. The first concerned who would decide which reservations were compatible with the statute, and the second was the extent of those reservations. As to the first question it was agreed. that according to Article 36 The Court was competent to decide upon its proper competence. concerning the second it was thought that in adhering to the Statute a state could make any reservations. This conclusion was based on the assumption that, since states were allowed to limit their declarations to certain categories of those enumerated in paragraph 2 , they could make any reservation. 211 Thus the resolution of the Assembly of October 2, 1924 regarded the terms of that paragraph as they were sufficiently wide to permit states to adhere to the Optional Clause "with the reservations which they regarded as indispensible". 212

This resolution had little affect on States position towards the Optional Clause. From 1924 until 1928 only six new declarations 213 were made. Three of which contained a new reservation limiting the Court's jurisdiction to "disputes arising after the ratification of the ... declaration with regard to situations and facts subsequent to (that) ratification". 214 Thus in 1928 the Ninth Assembly, which drafted the General Act for Pacific Settlement of Disputes, and for the same purpose, i.e. "to diminish the obstacles which prevent states from 
Committing Themselves", declared in its resolution of September 28, 1928 that States might accept the jurisdiction of the Court with "appropriate reservations limiting the extent of their commitment, both as regards duration and as regards scope". and that "the reservation conceivable may relate, either generally to certain aspects of any kind of disputes, or specially to certain classes or lists of disputes". 215

\section{C - RESERVATIONS IN THE DECLARATIONS MADE UNDER THE STATUTE OF THE P. C. I. J.}

Most of the declarations made during the period from 1920 to 1924 were without reservations. Three types of reservations were made during that period: Reciprocity RATIONE PERSONAE which was made only by Brazil; disputes in regard to which the parties had agreed to have recourse to other means of friendly settlement, and the limitation of the Court's jurisdiction to future disputes. 216 The first was in conformity with the letter and the spirit of paragraph 3 of Article 36. The second was in conformity with Article 33 of the Committee of Jurists which was deleted by the Third Committee. The last was not in conformity with both Articles, but it reflected the intention of some states before the Council of the League during its discussion - as has been said - 217 to except disputes belonging to the past.

However the views taken by the Assembly as regard to the interpretation of paragraph 2 of Article 36 had twofold effects. On the one hand, the number of declarations had increased noticeably. 19 states accepted the Court's jurisdiction in 1929 and 1930. 218 on the other hand, it caused a multiplication of the types of the reservations and rendered the forms of reservations more complicated.

The following reservations were made to the competence of the Permanent Court according to paragraph 2 
of Article 36:

1. Reciprocity RATIONE MATERIAE 219

2. Time Limits: 220

a. for a limited period.

b. without limit,

c. for as limited period "and thereafter until such time as notice may be given to terminate the acceptance".

3. Recourse to the Council of the League;

a. Suspension of the proceedings in the Court "in respect of any dispute which has been submitted to and is under consideration by the Council",

b. right to recourse to the Council before resorting to the court,

c. disputes not settled by the conciliation of the Council.

4. Disputes in regard to which the parties have agreed or shall agree to another method of friendly settlement. 221

5. Disputes for which a solution has been reached through diplomatic channels.

6. Domestic questions according to international law

7. Disputes with a specific group of States (British Commonwealth of Nations or Arab States).

8. Disputes in time of war or hostilities.

9. Reciprocity RATIONE PERSONAE: "as soon as (the jurisdiction of the court) has likewise been recognised as such by two at least of the Powers permanently represented on the Council of the League of Nations".

10. Right of Sovereignty.

11. Territorial status (including disputed right of sovereignty over islands, ports, waters and lines of communications).

12. Questions which belong to the constitutional regime. 222

13. Pecuniary ciaims. 
14. Disputes concerning a special treaty of peace.

15. Past disputes.

16. The limitation of the jurisdiction recognised to future disputes arising with regard to situations or facts subsequent to a given date.

17. Questions already settled.

18. Disputes with "States which refuse to establish or maintain normal diplomatic relations with" the declarant State.

Table 2 on pages 54 and 55 illustrates the number of reservations made by each state according to the above numeration of reservations.

This table shows the diversity of reservations made to compulsory jurisdiction of the P. C. I. J. It shows also that the majority of declarations regarded the condition of reciprocity as embodied in the words "in relation to any other state accepting the same obligation. It was, therefore, - as will be seen - 223 included in every declaration even in those which did not mention it or were made expressly without condition, since they were made according to paragraph 2 of Article 36. The most desirable reservations were those concerning questions in regard to which the parties had agreed to have recourse to another method of pacific settlement and the limitation of the Court's jurisdiction to future disputes arising with regard to situations or facts subsequent to the ratification or signature, or to a given date.

In spite of the fact that paragraph 2 allowed States to accept the jurisdiction of the Court in certain classes of legal disputes enumerated therein, they did not benefit from that provision, except Iran which limited its acceptance to disputes "with regard to situations or facts relating directly or indirectly to the application of treaties or conventions accepted by [Iran]". ${ }^{224}$ 


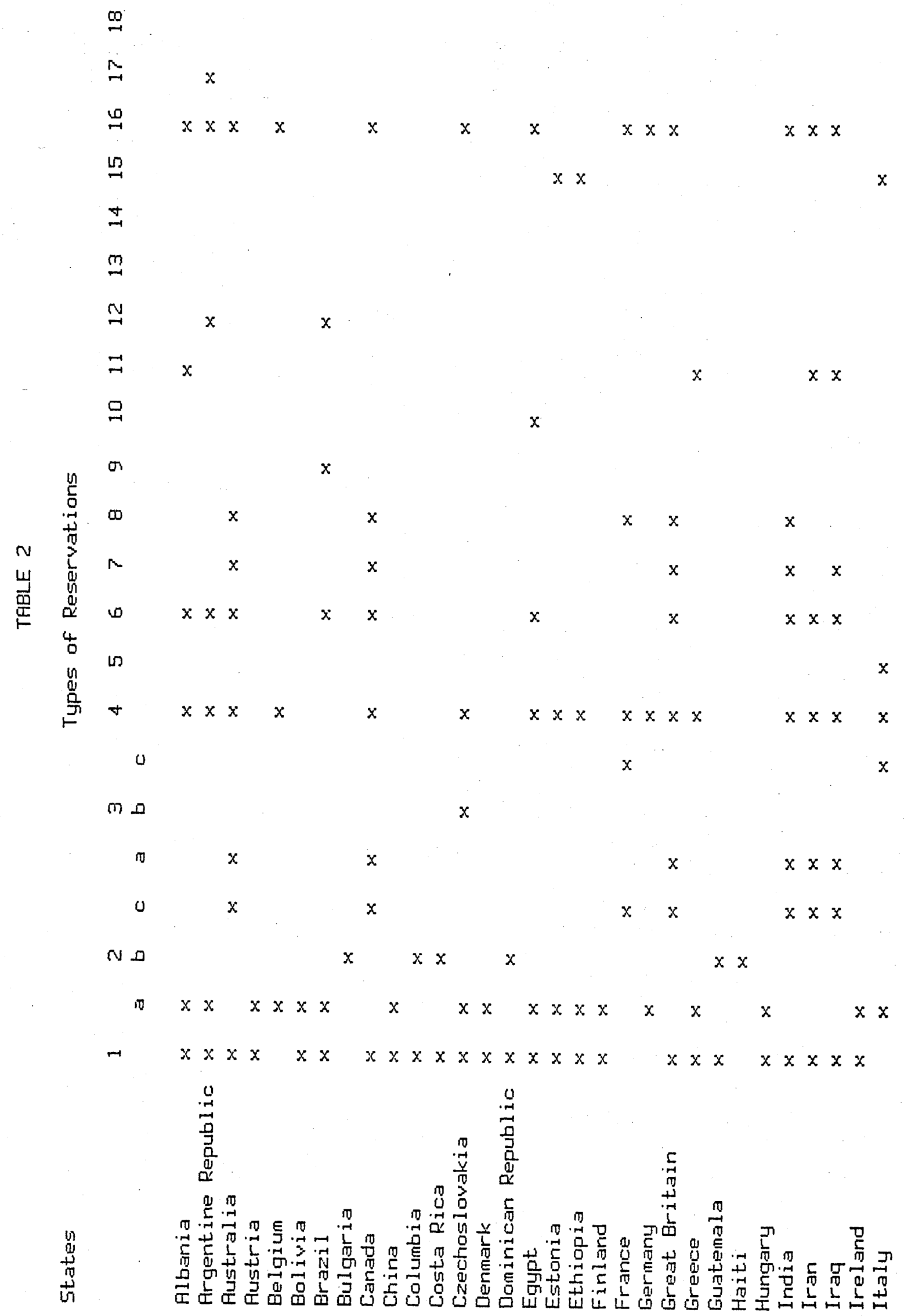




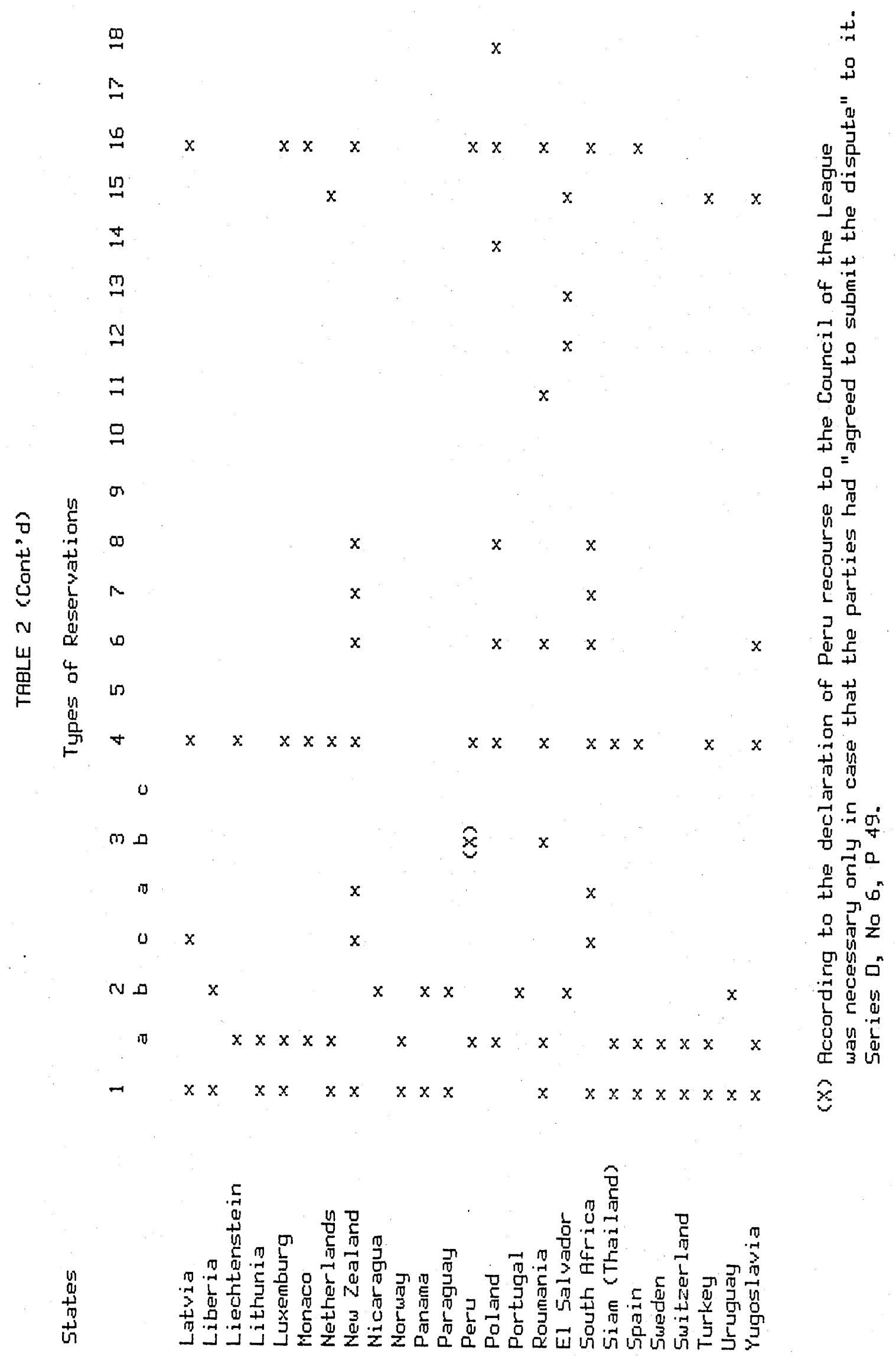


SECTION (3) : RESERVATIONS DURING THE DRAFTING OF THE STATUTE OF THE INTERNATIONAL COURT OF JUSTICE

The Dumbarton Oaks Proposals provided for that "there should be an International Court of Justice which should constitute the principal judicial organ of the Organization" and that its Statute "should be annexed to and be part of the Charter of the Organization". 225 Accordingly the United Nations delegated a Committee of Jurists which met in Washington from April 9, to 20, 1945 for the purpose of preparing and submitting to the San Francisco Conference a Draft Statute on the International Court of Justice.

The Committee of Jurists faced the same arguments and positions taken during the drafting of the statute of the P. C. I. J. with respect to which system should be adopted; compulsory or optional jurisdiction. ${ }^{226}$ At that stage the question of reservations did not obtain a lengthy discussion but it was raised occasionally. In spite of the fact that the majority of the delegates favoured compulsory jurisdiction, many of them favoured it with the possibility of making defined reservations. Gomez-Ruiz (Adviser of Venezuela) stated that compulsory jurisdiction should be "with the exception of cases which are in a process of settlement by other means". He thought that:

\footnotetext{
"In case all states were not in agreement as to the scope of compulsory jurisdiction ... reservations should be limited to two categories; first, cases which refer to events taking place prior to a certain date, and second, reservations as to States ngt regarded as submitting to the jurisdiction of the Court." 227
}

The idea that recourse to the Court's jurisdiction should be limited to disputes in regard to which the parties did not agree on another mode of settlement was shared by many States. ${ }^{228}$ The major importance of some declara- 
tions which excepted questions arising out of the Second World War was also pointed out. 229 Concerning domestic questions, the general opinion was that they were excluded from the Court's jurisdiction since they were excluded for the jurisdiction of the United Nations Organization according to Chapter VIII, Section A17 of Dumbarton Oaks Proposals. However it was emphasised that the Court should determine whether or not a dispute involved domestic matters.

As a solution to the sharp division between the majority who favoured Compulsory jurisdiction and those who preferred the return to the Optional Clause, Ramadan Pacha (Egypt) proposed the adoption of compulsory jurisdiction with the possibility of allowing the inclusion of reservations and thereafter withdrawing or waiving them. However his proposition was rejected by a vote of 10 against 4.231 Thus no solution was left before the Committee except to propose two alternative texts of Article 36. One leaving the acceptance of the Court's jurisdiction to the option of each state. The other text providing for the immediate acceptance of such compulsory jurisdiction by all parties to the statute. For that purpose two Sub-committees were created; the first was to draw up a draft on compulsory jurisdiction, and the second to draw up a draft of the optional clause. The final decision was left to the San Francisco Conference. The Committee decided also that that Conference would decide in the case of opting for compulsory jurisdiction, whether reservations would be required, though it was pointed out that paragraph 3 contained many gaps and the task of filling those gaps was of that Committee and not of the San Francisco Conference, 232 and that a further consideration should have been given to the subject of reservations.

At the San Francisco Conference the First Committee of the Fourth Commission (Judicial Organization) had been charged with the drafting of the statute of the Interna- 
tional Court of Justice. Its main task was to provide solutions to the problems that the Committee of Jurists was unable to resolve. Concerning the problem of reservations, two delegates expressed their desire to have the scope of reservations reduced as much as possible. The Australian delegate thought that "general reservations are likely to create confusion with respect to the jurisdiction of the Court". He referred to Article 39 of the General Act of 1928 allowing reservations in limited number of cases expressly stated, and proposed that that Article should be taken into consideration. 234 The Canadian delegate preferred also the New Zealand proposal of a standard schedule of reservations, 235 but he wanted reservations "to be more flexible" by adding to that proposal "the possibility of adding, withdrawing or modifying them". 236 The New Zealand delegate thought that allowing reservations "would produce substantially the same result as the Optional Clause". He pointed out. however, that he "would accept a formula of compulsory jurisdiction with reservations as a compromise" 237 between the two Washington texts.

The Sub-committee D was then created by Committee IV/1 to seek an acceptable formula between opposing views with respect to the competence of the Court. It rejected the New Zealand proposal by a vote of 7 against 5 , as a basis of its further discussion. In its report the Subcommittee observed:

\footnotetext{
"It was pointed out that the Optional Clause with reservations is not from a practical point of view, very different from the system of compulsory jurisdiction with reservations." 238
}

The conclusion reached by the Sub-committee was that "the system of optional jurisdiction at this time would be more likely to secure general agreement." However, it made two changes on Article 36 as proposed by the Committee of Jurists. The word "any" in the end of paragraph 2 (in all or any disputes) was deleted, and a new paragraph 
(5 now) was introduced concerning the continuity of declarations made under Article 36 of the Statute of the Permanent Court.

Concerning the explanation given to paragraph 2 , the report of the Sub-committee stated:

"The question of reservetion celle for an explanetion. AE is mell bnom the Article hes consictenty been interpreted in the past as al lowing States accepting the juriediction of the Court to subjet thetr declaretions to reservations. The Sub-comitime has consinered surh interpretetion es being henoforth established = It has therefore been considered unnecesesry to modify paregreph 3 in order to mele express reference to the right of states to mate such reservatione." 23

The New Zealand delegate stressed again before the Committee IV/1 that "all disputes would be subject to the jurisdiction of the Court and reservations would be specified in the statute" hoping that "the opponents of compulsory jurisdiction would accept any decision of the Committee, in the spirit of 'give and take' which had prevailed". 240 His proposition as well as the idea of compulsory jurisdiction were rejected by that Committee. In the report of the Raporteur [Nasrat Al - Farsy(Iraq)] it was observed:

"in an endeavour to reconcile the two pointe of view represented by the alternative texts propoes by the Commitee of Jurists, much support was given to the third dratt=. providing for immediate etceptance of compuleory jurisdiction subiet to stated reservations. Some of the deleqetes supporting optionel jurisdiction weres however whele to acrept this compromise other suggestione uere mede row anending the text of Article to in the optional form by incoporating pernited reservations. with or without piberty to add othere. These suggestione were al 150 rejected." 24

Then, the above mentioned statement of sub-committee $D$ was referred to in the report. When the report of Committee IV/1 was referred to Commission IV it was accepted without modification and no reference was made to the question of reservations either in the Commis- 
sion's discussion of that report or in its own report.

Thus another ground of legitimacy of the power of making reservations and conditions other than those mentioned in Article 36 (2 and 3 ) of the Statute was added to the liberal interpretation of this Article adopted by the Assembly of the League of Nations; the unbroken practice of states in inserting reservations in their declarations, and the recognition of that power by the P. C. I. J. by upholding - as will be seen - objections based on reservations and rejecting others as illfounded. Furthermore the validity of all types of reservations made under the statute of the P. C. I. J. is recognised explicitly by paragraph 5 of Article 36 of the present Statute. According to this paragraph, declarations made under the $P$. C. I. J. are deemed to be acceptances of the compulsory jurisdiction of the present Court "IN ACCORDANCE HITH THEIR TERMS". The power of attaching reservations and conditions to declarations of acceptance has also been admitted expressly by the present Court. In Military and Parliamentary Activities in and against Nicaragua the Court said:

"Declarations of acceptance of the compulsory jurisdiction of the Court are facultative, unilateral engagements, that States are absolutely free to make or not to make. IN MAKIHG THE DECLARATION A STATE IS EQUALLY FREE EITHER TO DO SO WHCOHDITIOHALLY AHD HITHOUT LIHIT OF TIHE FOR ITS DURATION, OR TO OUALIFY IT HITH CONDITIONS OR RESERUATIOHS".

It is not surprising thus that the discussion concerning the validity or reservations is now concentrated on the question whether or not the freedom of making reservations is limited instead of whether there exists such a freedom. 245 views are divided in regard to this question. Many publicists, including some judicial authorities, seem to take the view that Article 36 (2 and 3 ) permits the inclusion of conditions and reservations of "any kind". 246 However in the opinion of the majority that freedom is limited by the requirement that such 
reservations or conditions must be compatible with the Statute. ${ }^{247}$ This view had been taken also by some governments before the Court, even though the validity of their reservations or condition was challenged by the other party to the case. ${ }^{248}$ The rule laid down by the Court in the RESERUATIONS case, 249 that in order to be permissible a reservation must be "compatible with the object and purpose of the convention". is considered by some authors as another limitation. Accordingly a reservation frustrating the object of compulsory jurisdiction or contrary to its purpose is inadmissible. 250 However. States' freedom of inserting reservations will be examined in detail while examining the validity of the subjective reservation of domestic jurisdiction. 251

It is to be noted, finally, that from a purely legal point of view, the wording of paragraphs 2 and 3 of Article 36 of the Statute is not perfect. Firstly, it is doubtful whether the omission of the word "any" from paragraph 2 has had any effect at all since the possibility of limiting the Court's jurisdiction to one or more of the points seems to be maintained by the retention of declarations made under the statute of the P. C. I. J. such as the Iranian declaration, which was limited to the interpretation of treaties. 252 Secondly, the existence of a paragraph allowing the insertion of two conditions only while the validity of a large number of reservations is recognised seems to be unjustified. Thirdly, the fact that paragraph 3 of Article 36 did not give rise to problems of interpretation during the period of the P.C. I. J. does not mean necessarily that such problems are not likely to arise in the future, nor does it appear to be a reasonable justification for not ameliorating the wording of the paragraph. Therefore, it should have been provided for clearly in paragraph 3 that all reservations not incompatible with the statute are permissible, or that paragraph should have been omitted. 


\section{Notes}

(1) For the differences between arbitration and judicial settlement, see the report of E. Borel and N. Polits, "I' Extention de I Arbitrage Obligatoire et la Competence Obligatoire de la C.P.J.I. ", 33 (II) Annuaire I.D.I.(1927), pp.669_761, at 669 seq.

(2) R.R. Wilson, " Clauses Relating to Reference of disputes in Obligatory Arbitration Treaties", 25 A.J.I.L.(1931), suppt. pp.469-489, at 471.

(3) For the differences between Obligatory and voluntary arbitration see ibid., pp.470-471; E. Borel and Politis, supra note 1,pp. $762-763$ and the observations of A. Hobza and Le Fur, ibid ., pp.826-833, and 772-774 respectively ;E. Borel ,"I' Act Général de Genève ", 279 (II) R.C.A.D.I.(1929), pp.501-595, at 505-506; H.M. Cory, compulsory Arbitration of International Disputes, 1932, pp.IX-XIII; N. Politis, la justice Internationale , 1924, p. 193, and D. Schnidler, " les Progrés de l' Arbitrage Obligatoire Depuis la Creation de la Sociéte des Nations", 25(V)R.C.A.D.I.(1928), pp.237-361, at 238.

(4) The Central American Court was the only instance in which one party was able to bring a case before it by unilateral application without a previous conclusion of a special agreement (compromis)

(5) This does not apply to the condition of previous recourse to other means of peaceful settlement which had been included in most arbitration treaties whether obligatory or voluntary. See R.R.Wilson, International Agreements for Obligatory Arbitration,thesis, (1927), at 207 and "Reservations Clauses in Agreements for Obligatory Arbitration", 23 A.J.I.L. (1929), pp.68-93, at 75.

(6) Ibid.; E. Borel and N. Politis, supra note 1, pp. 672-673, and C.G. Fenwick, "National Security and International Arbitration ", 18 A.J.I.L. (1924), pp.777-781, at 777-778.

(7) See e.g.R.R. Wilson, Reservation..., supra 5, pp.75-79, and H. Kory, supra note 3, pp.3-11.

(8) See note 5 supra and the series of treaties concluded between Siam and some European countries : the treaty of Commerce and Navigation (may 1868), 69 British and Foreign State Paper,p. 1135; the treaty with Belgium (August 29, 1868), 59 ibid., p.413; with Austria (May 17 ,1869) 61 ibid.,1317, and with Italy (October 3,1868),60 ibid., p.779.

(9) These were between Colombia and Salvador (Dec. 24, 1880), Dominican Republic and Salvador (July 3, 1882), and Uruguay and Salvador (Feb. 7, 1883), W.R. Manning, Arbitration Treaties Among American Nations to the Close of the Year 1910, 1924, pp. 118-119, 128-129, $131-132$ respectively.

(10) See e.g. H. Cory, supra note 3, p.16 and R.R. Wilson's Thesis, supra note 5, $p, 208$. N.Politis observed that the first general treaty of arbitration was made in 1876 when Salvador concluded a treaty with Costa Rica , Guatemala Honduras Nicaragua, supra note 3,p.197. For the text of this treaty see W.R.Manning, supra note 9, pp.109-110. 
(11) These subjects were diplomatic and consular privileges;boundary of territories; indemnities; the right of navigation, and the validity,construction and enforcement of treaties. For the text the treaty see J.S. Scott, the international Conferences of American States, 1889-1928, 1931,pp. 40-43.

(12) H. Cory, supra note 3, p. 17.

(13) lbid., p.18.

(14) See R.R. Wilson's Thesis, supra note 5, p.209.

(15) H. Cory, supra note,3, p.18.

(16) Ibid., p.19, and J.B. Scott, the international Conferences..., supra note 11 p.41. It is to be observed that the fact that the first reservation was introduced in the First Pan American Conference does not mean that the view of inserting reservations had not been expressed by statesmen before. Thus Mr.Rolin favoured excluding questions affecting honour or the existence of a state from the scope of arbitration. See T. Barclay, "the Hague Court and Vital Interests ", 21 L.Q R.(1905), p. 109.

(17) Treaty of Commerce and Friendship, Fr. de Martens, Nouveaux Recueil Général des Traités, vol.33(II), p.575.

(18) Treaty of Peace, 89 British and Foreign States Paper (B.F.S.P.), p.598.

(19) Nov. 15, 1890, (Art.8), Martens, supra note 17, vol.17 (II), p.591.

(20) Treaty of Commerce (Art.7), ibid., vol.22, p.591. C. Cory observes that this treaty was the only one in force between two European states before the First Hague Conference, supra note 3,p.25.

(21) Traités Généraux d Arbitrage Communiques au bureau International de la Coure Permanente d 'Arbitrage, 1st. Series, p.1.

(22) 92 B.F.S.P. supra note 8, p.485.

(23) See H. Cory, supra note 3, pp.28-37 and T. Barclay, New Methods of Adjusting International Disputes and the Future, 1917, at 179-184.

(24) C. Cory, ibid., p.31.

(25) Ibid., p.35.

(26) R.R. Wilson's Thesis, supra note 5, p.215.

(27) H. Cory, supra note 3 , pp.38-39.

(28) lbid., pp.16-17.

(29) N. Politis, supra note 3; p.197, C.G. Fenwick, "the Elimination of Loopholes in Arbitration Treaties ", 21 A.J.I.L.(1927), pp.499-500, and H. Lauterpacht, "the Doctrine of Non -Justiciable Disputes in International Law", 8 Economica (1928), pp.277_317, at302.

(30) R.R. Wilson's Thesis,supra note 5, p.207.

(31) See Art. 7 of the "Outlines for the Preparation of a Draft Convention to be Concluded between the Powers Taking Part in the Hague Conference", in the Proceedings of the Hague Peace Conference of 1899 (Act and Documents), 1920, p.798.

(32) Ibid., pp.700-701.

(33) Ibid.

(34) Ibid., p.122.

(35) Ibid. 
(36) Ibid., p.123.

(37) Ibid., p.119.

(38) Ibid., 176.

(39) Ibid., p.596.

(40) For the list of the conventions enumerated therein see ibid., pp.124-125.

(41) See W.I. Hull, "Obligatory Arbitration and the Hague Conference ", 2 A.J.I.L.(1908), pp. 731-742, at 732 .

(42) See J.B. Scott, Instructions to the American Delegates to the Peace conferences and their Official Reports, 1916, p.24.

(43) The Proceedings..., supra note 31 p. 769.

(44) Art.16 of the Convention of the Pacific Settlement of International Disputes, ibid p.238.

(45) It contained the same classes of disputes which were introduced in the First Conference of American States, see note 11, below.

(46) H. Cory, supra note3, p.60.

(47) This convention,as the first, did not enter into force. It was signed by 9 states only. Ibid.

(48)See W.R. Manning, supra note 9, pp.316,329.

(49) See the texts in Traités Generaux..., 1st.series, supra note 21, p.33.

(50) R.R. Wilson's Thesis, supra note16, p.115.

(51)This number is based on $H$. Cory's survey, supra note 3, pp.52-57. The United States concluded during Dec.1904 and Jan.1905 a series of treaties on the same model with Great Britain, France, Germany, Spain, Portugal, Italy, Switzerland, Austria, Hungary, Sweden,Norway and Mexico. In 1905, the Senate advised and consented to the ratification of these treaties but with the substitution of the word "treaty" for the word "agreement" in order to necessitate the consent of the Senate before referring any dispute to arbitration. This amendment was the cause which prevented the ratification of these conventions. See J.B. Scott, Instructions..., supra note 42, p.79. For the list of treaties concluded by the United States see H. Cory supra note 3, pp. 55-57.

(52) See the treaties included under number (3) in "Treaties of Arbitration Since the First Hague Conference" , 2 A.J.I.L.(1908),pp. 823-830, at 824-827.

(53) According to H. Cory's list about, 16 treaties were modelled on the 1903 treaty, 10 of which were concluded by Italy, supra note 3, pp.63-64.

(54) For the list of treaties which contained this formula, see ibid., p.65.

(55) This clause was included in the treaty between Denmark and the Netherlands of Feb. 12, 1904.,Traités Generaux..., supra note 21, p.42. It was included in other treaties concluded by Russia, Belgium and Denmark. For their list see $\mathrm{H}$. Cory, supra note 3, p.66.

(56) Ibid. See also R.R. Wilson's Thesis supra note 5, p.213.

(57) The treaty between Italy and Denmark of Dec. 16, 1905, Traités Generaux..., 1st.Series, supra note 21, p.218, and that between Denmark and Portugal of March 20, 1907, ibid., p.67.

(58) See H. Cory, supra note 3, p.67.

(59) The Proceedings of the Hague Peace Conferences, the Conference of 1907, (Acts and Documents), vol. 2, p.436. 
(60) For the text of the treaty see ibid., Annex 66,pp967-970.

(61) Ibid., p.258. See also R.R. Wilson, Clauses ..., supra note 2, p.477.

(62) The President of the First Commission stated that 33 treaties of obligatory arbitration had been concluded during the interval between the two Hague Conferences, the Proceedings ..., supra note 59, p.88

(67) See J.B. Scott, Instructions ..., supra note 42 , p.129.

(68) W.I. Hull divided them into three categories : "universal"(all disputes without reservation), "inclusive"(list of subjects without reservations), and"exclusive" (all disputes with reservation), supra note 41, pp.731-741.

(69) See Annex 24, in the Proceedings of 1907, supra note 59, pp.879-880.

(70) Ibid ., pp.61, 406.

(71) For further details on legal and political or justiciable and non- justiciable disputes see Section 3, Chapter 4 infra.

(72) The Proceeding of (1907),vol. 2, p.50.

(73) See for example the response of the American delegate Mr. Choate ,ibid., p.815. See also N. P. Politis, supra note 3, pp.205-211.

(74) see the opinion of Clean Rizo Rangabé, ibid., p.72.

(75) Marshall von Bieberstein described the word "political" as"elastic". Ibid., p. 434, and Mr. Martens called attention to the danger lurking in vague formulae which could be interpreted in a contradictory sense, ibid., p.435.

(76)lbid., p. 433.

(77) Ibid., p. 435.

(78) Ibid., p. 434.

(79) See the view expressed by $H$. Lammasch with regard the differences between the Brazilian proposition and the other proposals, ibid., $\mathrm{p} .407$.

(80) See the opinion of M. Milovanovitch, ibid., p408.

(81) lbid., pp. 408-409.

(82)lbid., p.410.

(83) See the views expressed by Ruy Barboza, ibid., pp. 407, 409-410,430.

(84) Ibid., 267.

(85) Ibid., p. 233. Léon bourgeois was of the same opinion. He stated that questions of purely legal nature should be referred to the Permanent Court of arbitration without reservations of any kind. He agreed with $B$. Marschall in rejecting the so-called case of "the honour and vital interests". L.Bourgeois stated that "all jurists will agree in believing that these words introduce into the conventions a 'potestative condition' which deprives them of every shred of judicial necessity and makes the engagement of no value whatever. In those cases, where obligation is possible, it must be made a reality". Ibid., p.351.

(86) lbid.,p. 50.

(87) Mr. Kriege, a German delegate , regarded these conventions as indispensable .lbid., pp.418-419. The same view was expressed by Biebestein himself on a previous occasion.lbid., p.287.

(88) Ibid., p.79.

(89) See the statement of G. Streit, ibid., p.255.

(90) See the opinion expressed by Max Huber, ibid., p.66. 
(91) See the view expressed by G. Sreit, ibid., p.253.

(92) See the statement of C. Rizo Rangabi, ibid., p72.

(93) In his reply to the arguments advanced by Bieberstein with regard to the limitation of obligatory arbitration to disputes of a legal nature and the illusory obligation assumed according to Article (16a), which began with the expression "thou shalt". and finished with "if thou wilt",Louis Renault said: "we calculate to bind ourselves to the extent which our vital interests are not at stake. However the obligation seems to be reduced, it still exists, and a country will look twice before claiming that there is vital question where there there is none." Ibid., p. 68.

(94) Ibid., p. 88-89, 92.

(95) Views have been sharply divided with respect to which reservations should be maintained or omitted. Thus, M. Lange asked for the omission of the reservation of national honour, whereas it seemed to him "utopian to endeavor to eliminate" that of vital interests, ibid., p.257. Also the Belgium delegate stated that his government preferred certain reservations of "public nature ", ibid., p.61, and the delegate of Uruguay referred to the reservation of "internal affairs of any country ", ibid., p.415.

(96) For the subjects included in these propositions see the Annexes19, 27, 28, 31, 32,34 , and 37 , ibid., pp.875, 881, 882, 886, 887, 889, and 892-893 respectively.

(97) See for example the opinion expressed by L.M. Drago, p.54.

(98) See the view expressed by L. Renault, ibid., p.68.

(99) For further details see the view expressed by Bieberstein, ibid., pp.51-52.

(100) lbid., pp.566-567. It might be worth noting that Germany and AustriaHungary voted against every class, and Belgium and Greece voted against every one or abstained from voting, while only 5 states (France, Norway, Serbia, the Netherlands and Portugal) voted for these classes. See W.M.I. hull, supra note 41, p. 736. For further detail see A.P. Higgins, the Hague Peace Conferences, 1909; J.B. Scott, "the Work of the Second Hague Peace Conference", 2 A.J.I.L.(1908), p..1-28; A.S. Hershey, "Convention for the Peaceful Adjustment of international Differences ", ibid., pp.29-49; H. Lammasch, "Compulsory Arbitration at the Second Hague Conference", 4 ibid., (1910), pp .83-95, and T. Barclay, the Problems of International Practice and Diplomacy, 1907.

(101) the Proceedings ..., supra note 59, p.72

(102) See pp.16 above, and R.R. Wilson's Thesis supra note 5, pp.107-109, 112.

(102) The Proceedings ..., supra note 59, p.72.

(103) For a list of enumerative treaties see $\mathrm{H}$. Cory, supra note 3 pp.63-65.

(104) N. Politis has observed that up to the outbreak of the First Word War, 35 treaties were concluded, without counting the attempted experiences made by the Central American states, supra note 3 p.226.

(105) For the Taft-Knox Treaties see, ibid., pp. 224-225;C.G. Fenwick, the Elimination ..., supra note 29, p.500, R.R. Wilson's Thesis, supra note 5, pp. 217-219, and T. Barclay, New Methods ...,supra note 23, pp.193-197. 
(106) See his statement before the American Society for Judicial Settlement of International Disputes quoted by Sir Edward Grey in Parl. Debates, vol.22, Series 5, p.1988.

(107) N. Politis, supra note 3, p.228, and his report with M. Brown to the Institute of International Law, "la Classification des Conflits Comportant un Reglement Judiciaire ",29 Annuaire I.D.I. (1922), pp.23-59, at 37. The Institute proposed at its sessions in 1911 and 1912, to resort to an impartial agency (a joint commission) in case of a dispute between the parties as to whether national honour or vital interests were involved . 24 ibid., pp. 224-230, and 25 ibid., p. 411 .

(108) H.Wehberg, "Restrictive Clauses in International Arbitration Treaties", 7 A.J.I.L.(1913), pp.301-314, at 303-366, and A. Calvalcanty, "Restrictive Clauses in International Arbitration Treaties", 8 A.J.I.L. (1914), pp .723737, at 724-725. Note that the letter has taken into account the reservation of disputes of legal nature, and that his study is limited to treaties to which Brazil was a party.

(109) 8 of these treaties contained the reservation of third parties interests in different terms. They provided for that "differences which may arise with regard to the interpretation or application of a convention concluded or to be concluded between the High Contracting Parties and in which third powers have participated or to which they have adhered shall be excluded from settlement by arbitration ". See Treaties of Arbitration ..., supra note 52, p.827.

(110) These numbers are based mainly on the surveys contacted by $H$. Cory, supra note 3, pp. 12-68; H. Wehberg, supra note 108, pp.301-314; A Calvancanty, supra note 108, pp.723-737, and that of the A.J.I.L. ,supra note 52, pp.823830. It is to be noted that 5 treaties are repeated in the last survey : that between France, Norway and Sweden (July 9, 1904), p.825; that between Italy and Portugal (May 11, 1905), ibid., that between Portugal and Great Britain (Nov.16, 1904), p.826, that betwen Portugal and the Netherlands (Oct.1, 1904), ibid., and that between Portugal and Spain (May 31, 1904), ibid.

(111) The delegate of Germany gave to that phraseology a great importance. To his mind it had formed an essential guaranty, a sine qoa none of the adhesion of his government to the decisions of the Conference. On the other hand, Martens admitted that it was not possible to find better terms. See the Proceedings of 1899, supra note $31, \mathrm{pp} .407-410$.

(112) See p. 11 above.

(113) See the Proceedings of 1907, supra note 59, pp.407-410.

(114) For these attempts see 10 Annuaire I.D.I.(1903), pp.181 seq. and 14 ibid., (1911), pp.225 seq. See also T. Barclay, New Methods ..., supra note 23, p.59.

(115) See e.g. T. Barclay, ibid., p.61; H. Lauterpacht, the Function of Law in the International Community, 1933,pp.46-48 and the Doctrine of NonJusticiability ..., supra note 29, p. 302; J. Weslake, International Law, vol. i, 1904, p.339; H. Wehberg, supra note 108, p. 727 ; A. Cavalcanty, supra note 108, p.727, and J. Makowski, "l'Organisation Actuelle de l'Arbitrage International", 36 R.C.A.D.I.(1931), pp.267-380, at 355-367.

(116) $\mathrm{H}$. Wehberg observes that at least 15 combinations were made in arbitration 
treaties , ibid., p.306.

(117) A. Merignhac listed 16 authors who thought that questions touching upon sovereignty, honour, independence and integrity were not arbitrable, Traité Théorique et Pratique de l'Arbitrage International, 1895, p.184. See also J.L. Brierly, "Vital Interests and the Law", 11 B.Y.B.I.L.(1944), pp.51-57, and J.H. Ralston, "Some Suggestions as to the Permanent Court of Arbitration", 1 A.J.I.L. (1907), pp .321-329, at 329.

(118) See h. Wehberg, supra note 108, pp .306-314.

(119) J. Westlake, supra note 115, p. 339.

(120) See A. Cavalcanty, supra note 108, pp. 727 seq.

(121) New Methods ...,supra note 23, p.61. See also his book Problems ..., supra note 100, p.148.

(122) T. Barclay, New Methods ..., ibid.

(123) H. Cory, supra note 3, pp.99-104.

(124) In the North Atlantic Fisheries case between the U.S.A.and G.B. the question of sovereignty was involved but it was not invoked,though the treaty according to which the dispute was brought before the Court contained the reservations of vital interests, national honour and independence. See N. Politis, supra note 3, pp.101-103.

(125) See ibid., pp.142-144 ; and H. Cory, supra note 3, p.92.

(126) For these cases see ibid., pp.143-155 and 93-98 respectively, and "Judicial Decisions Involving Questions of International Law" 11 A.J.I.L. (1917), pp.181-229.

(127) H. Cory, supra note 3, p.97.

(128) See J.L. Brierly, supra note 117, p.52 ; R.R. Wilson's Thesis supra note 5, p.193, and H. Lauterpacht, the Doctrine ..., supra note 29, p.293. At the Second Hague Conference R. Barboza stated that "the submission to an inevitable court would imply, with sovereign nations, a flagrant abdication of sovereignty", the Proceedings of 1907, supra note 59 at 284.

(129) R.R. Wilson, ibid., and A. Mérignhac, supra note 117, p.186.

(130) See pp. 9-10 above.

(131) See H. Cory, supra note 3, pp.36-37.

(132) See C.G. Fenwick, National Security ...,supra note 6, p.780 and A. Cavalcanty, supra note 108, p.731

(133) See the declaration made by Chile in its opposition to the general arbitration treaty concluded at the First Pan-American Conference, see p. 8 above.

(134) For treaties concluded between the American states until the close of the year 1910 see W.R. Manning, supra note 9.

(135) For discussion on whether or not arbitration was in the benefit of small states see the Proceedings of 1907, supra note 59, pp.266-267, 421- 424.

(136) See pp.20-24 and 28-31 above.

(137) See pp.20-24 above ;H. Lauterpacht, the Function ...,supra note 115, p.19, and R.R. Wilson's thesis, supra note 5, p.71.

(138) See J. Makowski, supra note 115, p.355; H. Lauterpacht the Function ..., supra note 115 , pp.70-84. 
(139) See the Explanatory Note Concerning Article 10 of the Russian Draft, in the Proceedings of 1899 , supra note 31, p.173.

(140) H. Lauterpacht, the Doctrine ...,supra note 29, p.302.

(141) See the view expressed by Salisbury in 317 Hansard's Parliamentary Debates, p..1830-1834.

(142) H. Lauterpacht, the Doctrine ..., supra note 29, p.302.

(143) J.B. scott, Instructions ..., supra note 42, p.79.

In his letter to Mr. Bayard concerning the Olney- Pauncefote treaty, Lord Salisbury referred also to the question of arbitrators. He wrote : "It would be too indivious to specify the various forms of bias by which, in any important controversy between two Great Powers, the other members of the Commonwealth of nations are visibly affected. In the existing conditions of international sentiment, each Great Power could point to nations whose admission to any jury by whom its interests were to be bound to challenge, and in a litigation between two Great Powers the rival challenges would pretty well exhaust the catalogue of the nation from whom competent and suitable arbiters could be drawn. It would be easy but scarely decorous to illustrate this statement by examples. They will occur to anyone's mind who attempts to construct a panel of nations capable of providing competent arbitrators, and will consider how many of them would command equal confidence from any two litigating Poweres. This is the difficulty which stands in the way of unrestricted arbitration ...",see T. Barclay , New Methods ..., supra note 23, pp.56-58.

(144) See H. Wehberg, supra note 108, p.308, and T. Barclay, the Hague Court ...,supra note 16, p.113.

(145) See note 16 supra . The idea of the "stranger" was relied on by Nicaragua in rejecting the last two decisions of the Central Court, see p.31 above. the anxiety about the application of foreign rules was stressed upon by the American delegates to the Hague . they pointed out in their Report that "in view of the fact that a large majority of the members of the Court must necessarily be Europeans trained in the principles of the Roman Law, it has been deemed important from the first to secure all possible guaranties against practice or procedure which would put nations having the Common Law as the basis of their jurisprudence at a disadvantage. It is believed that this end has been successfully accomplished ." See J.B. Scott,Instructions ..., supra note 42, p.57.

(146) It is well known that the Permanent Court of Arbitration at the Hague was neither a court nor consisted of permanent judges. See e. g. A.P. Higgins, supra note 100, pp.510-511. in his instruction to the American delegates to the Hague E. Root ascribed the lack of confidence in judicial settlement to that reason. See J.B. Scott, Instruction ..., supra note 42, pp. 79-80.

(147) See H. lauterpacht, the doctrine ..., supra note 29, p.311.

(148) See p.9-10 above.

(149) Ibid.

(150) See J.B. Scott Instructions ..., supra note 42, p.733.

(151) See H. Cory, supra note 3, p.25.

(152) See H. Lauterpacht, the Doctrine ..., supra note 29, p.303. 
(153) See A. Calvancanty, supra note 108, p.737.

(154) Article 14 of the Covenant: "The Council shall formulate and submit to the Members of the league for adoption plans for the establishment of the Permanent Court of Justice. The Court shall be competent to hear and determine any dispute of an international character which the parties thereto submit to it. The Court may also give an advisory opinion upon any dispute or question referred to it by the Council or the Assembly."

(155) These plans were presented by Norway, Sweden, Denmark, the Netherlands, Switzerland, Italy, Germany, and Austria. For the documents presented to the Committee see P.C.I.J., Advisory Committee of Jurists-Documents Presented to the Committee Relating to the Existing Plans for the Establishment of the Permanent Court of International Justice.

(156) Art. 14 supra note 155.

(157) This was the opinion of Lord Philimore. See Permanent Court of International Justice, Committee of Jurists, Procès- Verbaux of the Proceedings of the Committee, June 16th-July 24th, 1920, pp.225-226.

(158) Ibid., pp.228, 231, 233 seq., 541-543. For an extensive discussion on this point see B.C.J. Loder, "the Permanent Court of International Justice and Compulsory Jurisdiction", 2 B.Y.B.I.L.(1921-22), pp.6-26 and P.J. Baker, "the Obligatory Jurisdiction of the Permanent Court of International Justice", 6 ibid., (1925), pp.68-102.

(159) For proposals to modify Art. 14, see the Proceedings of the Committee of Jurists ..., supra note 157,esp. pp.240-243, 286, 309, 619.

(160) This was the opinion of M. Adatci (Japan), ibid., pp.651,727.

(161) Ibid., p.729.

(162) Ibid., p.727. For further discussion on compulsory jurisdiction of the P.C.I.J. during the works of the Committee of Jurists see ibid., pp.219-281, 289 seq., 727-729 ;P.J. Baker, supra note 158 ; A. Giustini, "Compulsory Adjudication in International Law : the Past, the Present and prospects for the Future",9 For_l.L.J.(1986), pp. 213-256, at 217-235, and B.C.J. Loder, supra note158, L. Lloyd, "A springboard for the Future : A Historical Examination of Britain's Role in Shaping the Optional Clause of the Permanent Court of International Justice", 79 A.J.I.L.(1985), pp.28-51, at 28-34, and H. Cory, suprs note $3, \mathrm{pp} .120-123$.

(163) It is to be observed that the question of reservation clauses in the proceedings of the Committee of Jurists has been ignored in studies devoted reservations to the competence of the two Courts :the P.C.I.J.and the I.C.J.,except in B. Maus' study, les Réserves dans les Declarations d'Acceptation de la Juricditon Obligatoire de la Cour Internationale de Justice, who points out that this question had not been discussed by the Committee of Jurists!,thesis (Université de Genève, Faculté de Droit), p.12.

(164) the Proceedings of the Committee of Jurists, supra note 157, p.243. In fact, the substitution of the "inalienable rights" for reservations of vital interests and honour was proposed by D. Descamps himself before the Institute of International Law in 1904, 20 Annuaire I.D.I.(1904), pp.186-187.

(165) The Proceedings of the Committee of Jurists ..., ibid., pp.254-255. 
(166) Ibid., pp.243, 255.

(167) See B.C.J. Loder's opinion, supra note 158, 250.

(168) See the speech delivered by L. Bourgeois, the Proceedings of the Committee of Jurists, ..., supra note 157, p.8.

(169) The members of the Committee were :M. Adatci (Japan), R. Altamira (Spain), B. Descams (Belgium), F. Hegerup (Norway), A. De La Pradelle (France), Loder (the Netherlands), Lord Phillimore (U.K.), A. Ricci-Basatti (Italy), E. Root (U.S.A.), C. Bevilaqua (Brazil)who was replaced by his adviser R. Fernandes. lbid., p.IIl.

(170) Ibid., p.233.

(171) Ibid., 726-727. In this context the jurists studied other plans submitted to them without taking into consideration the reservations included in those plans. For example the Austrian plan contained the reservation of vital interests ; that of Switzerland contained, in addition to this reservation, the honour clause, and the draft of the Five Neutral Powers contained both these reservations in addition to that of independence (Art.22). Ibid., pp.83-84. M.O. Hudson observed that the experience of the Hague Peace Conferences did not justify large hopes of success in this direction, the Permanent Court of International Justice, 19201942. A Treatise, 1943, p.190.

(172) The Proceeding of the Committee of Jurists, supra note, 157, p.246.

(173) lbid., p.259.

(174) Ibid., p.272.

(175) Ibid., p.260.

(176) Ibid., p.263.

(177) lbid.

(178) Ibid.,p. 266.

(179) Ibid.

(180) Ibid., p.267. This clause was modified slightly in the text adopted in the first reading. It became as follows :"When, a dispute having arisen between states, and it has been found impossible to settle it by diplomatic means ...", (Art.33), ibid., p.665.

(181) Ibid., p.618.

(182) Article 33 :"When a dispute has arisen between states, and it has been found impossible to settle it by diplomatic means, and no agreement has been made to choose another jurisdiction, the party complaining may bring the case before the Court. The Court shall first of all, decide whether the proceeding conditions have been complied with; if so it shall hear and determine the dispute according to the terms and within the limits of the next Article.

Article 34 :"Between states which are Members of the League of Nation, the Court shall have jurisdiction (and this without any special convention giving it jurisdiction) to hear and determine cases of a legal nature, concerning:

a. the interpretation of a treaty ;

b. any question of international law ;

c. the existence of any fact which, if established, would constitute a breach of an international obligation ; 
d. the nature or extent of reparation to be made for the breach of an international obligation;

e. the interpretation of a sentence passed by the Court .

The Court shall also take cognizance of all disputes of any kind which may be submitted to it by a general or particular convention between the parties.

In the event of a dispute as to whether a certain case comes within any of the categories above mentioned, the matter shall be settled by the decision of the Court ". Ibid., pp.679-680

(183) lbid., p.263.

(184) Ibid., p.267.

(185) lbid., pp.267, 615.

(186) Ibid., p.726( emphasis added).

(187) League of Nations, Permanent Court of International Justice, Documents Concerning the Action Taken by the League of Nations under Article 14 of the Covenant and the Statute of the Permanent Court, 1921, p.20.

(188) In his note on the P.C.I.J. submitted to the Council, Belfour pointed out that Article 14 of the Covenant "clearly contemplates that the Court has only to deal with disputes which are voluntary submitted to it by the authorities concerned ... Evidently, the framers of the Article never intended that one Party to a dispute should compel another Party to go before the Tribunal; and this omission cannot have been a matter of choice, since the subject of compulsory arbitration has been before the legal authorities of the whole world now for many years. It has more than once been brought up for practical decision, and has always been before rejected". Ibid., p.38. For Discussion on this point see P.J. Baker, supra note 158.

(189) Documents Concerning the Action Taken by the Assembly ..., supra note 187, pp.47_48.

(190) Ibid., p.47.

(191) Ibid., p.64.

(192) Ibid. This reservation was made in the form of "questions which affect constitutional laws of the contesting States". Ibid., p.67.

(193) Article 33 :"The jurisdiction of the Court is defined by Articles 12, 13 and 14 of the Covenant'.

Article 34 :"Without prejudice to the right of the parties according to Article 12 of the Covenant to submit disputes between them either to judicial settlement or arbitration or to inquiry by the Council, the Court shall have jurisdiction (and this without any special agreement giving it jurisdiction) to hear and determine disputes, the settlement of which is by treaties in force entrusted to the tribunal instituted by the League of Nations." Ibid., p.47.

(194) Ibid., pp.133, 201-211. The proposition of Fernandes to include in the draft the condition of reciprocity ratione prsonae was abandoned by the SubCommittee. Ibid., p.566.

(195) Ibid., p.90.

(196) Ibid., p.94.

(197) Ibid., p.107. 
(198) Ibid., p.168.

(199) Ibid., p.107.

(200) When Fernandes proposed the addition of reciprocity ratione personae $M$.

Arias suggested the omission of the words "vis-a-vis ... obligation." Ibid

(201) Ibid.

(202) Ibid., p.317(Annex 14).

(203) Ibid., p.172.

(204) For the discussions of the First Assembly see ibid., pp.225-253.

(205) M.O. Hudson's Treatise,supra note 172, p.449.

(206) In the First Assembly, Haguerup declared that "the Committee has adopted the admirable proposal made by M. Fernandes ,the Brazilian delegate. This proposal is in conformity with the idea supported by M.Huber, the Swiss delegate, during the Hague Conference of 1907." See the Proceedings of the Committee ..., supra note 158, p.228.

(207) Ibid., p.233.

(208) Ibid.

(209) Ibid., p.237. See also the opinion of Fernandes at235.

(210) Only 16 of the 22 declarations, made in 1924 were effective. The other 8 declarations were subject to ratification but they had not been ratified. See P.C.I.J.,Series D, No.6, pp.33-54.

(211) See League of Nations Official Journal,supplement No. 21, Acts of the Fifth Assembly, 1924, pp.37-38.

The Protocol for the Pacific Settlement of International Disputes, which was attached to to an Annex to that resolution, reads:

The Signatory States undertake to recognize as compulsory lpso facto and without special agreement, the jurisdiction of the Permanent Court of International Justice in the cases covered by paragraph 2 of Article 36 of the Statute of the Court, but without prejudice to the right of any State ,when acceding to the special protocol provided for in the said Article and opened for signature on December 16th, to make reservations compatible with the said clause". Ibid., p.22(emphasis added).

(212) Ibid., p.21.

(213) Belgium, Ethiopia, Germany, Hungary, and Spain, P.C.I.J., Series D, No.6, pp.39-43.

(214) Belgium, Germany and Spain. Ibid.

(215) League of Nations Official Journal, Supplement No. 64, 1928, p.183.

(216) The Second was made by the Netherlands and Estonia, and the third was made by the Netherlands, P.C.I.J., Series D, No. 6, pp.37-38.

(217) See pp.45-46 above.

(218) This includes the declarations of France and El Salvador. The first was made in 1924 and the second in 1920 but they had not been ratified until 1929 and 1930 respectively. P.C.I.J., Series D, No.6, pp.45,34. The following States were parties to the Optional Clause in 1929 : Australia; Canada; Czechoslovakia; Great Britain; Greece; India; Ireland; Italy; New Zealand; Nicaragua; Peru; South Africa, and Siam(Thailand). The following States adhered to it in 1930 : Albania, 
Iran, Romania and Yugoslavia. Ibid., pp.33-54.

(219) The ratification of the Protocol of Signature which was deposited by El Salvador in August 29, 1930 provided for reciprocity in the following terms: "...it being further understood that Article 36 binds El Salvador only in regard to States which accept the arbitration in that form". Ibid., p.52.

(220) This is included for the purpose of illustrating the possibility of denouncing the acceptance by a simple notice. It is to be observed here that the declaration of Luxembourg was the only one which provided for that "unless is denounced six months before (its) expiration ..., it shall be considered as renewed for " same period. Ibid.

(221) the Italian declaration excepted disputes in regard to which other method of settlement provided by a special convention and Albania, greece and Turkey excepted disputes relating directly or indirectly to the application of treaties accepted by them and providing for another procedure. Ibid., pp.43, 44,52.

(222) El Salvador excluded "disputes or differences concerning points or questions which cannot be submitted to arbitration in accordance with the political constitution of this Republic." Ibid., p.52

(223) See Chapter 4 infra, at 214 seq and 219 seq.

(224) P.C.I.J., Series D, No.6, p. 53.

(225) For detailed discussions on this point see esp. A. Quadeer, "the International Court of Justice : A Proposal to amend its Statute", 5 Houston J.I.L.(1982), pp.35-52, at 35-46 ; H.J. Owen, "Compulsory Jurisdiction of the International Court of Justice", 3 Ga.L.R.(1969), pp.704-726, at704-713, and A. Giustini, supra note 163 , pp.228-235.

(226) U.N.C.I.O., vol. 14, p.455.

(227) Ibid., pp.153-154. See also the proposal submitted by Venezuela, ibid., pp.372_373, 434-435.

(228) Ibid., pp.153-154, 157, 161, 207,-208, 421, 427-428.

(229) lbid., pp.206-208.

(230) Ibid., pp.150, 205, 417, 420, 426, 432-433.

(231) Ibid., pp.208, 229.

(232) Ibid., p.155.

(233) Ibid., p.207. In its final report the Committee of Jurists stated :

"(It ), however,thought that the moment had not yet come to elaborate it(Art.36) further and see whether the compulsory jurisdiction thus established should be accompanied by some reservations such as one concerning differences belonging to the past, one concerning disputes which have been arisen in the present war, or others such as were authorised by the General Act of 1928. If the principle enunciated by this second text were accepted, it could serve as basis for working out provisions applying that principle with some modification as might be deemed opportune." Ibid., pp.841,668.

(234) U.N.C.I.O., supra note 227, vol. 13, p.225. Paragraph2 of Article 39 of the general Act of 1928 provides :

"These reservations may be such as to exclude from the procedure described in 
the present Act:

a) Disputes arising out of facts prior to the accession either of the party making the reservation or any other party with whom the said party may have a dispute.

b) Disputes concerning questions which by international law are solely within domestic jurisdiction of states.

c)Disputes concerning particular cases or already specified subject-matter, such as territorial status, or disputes falling within clearly defined categories. L.N.T.S.,vol. XCIII, 1929, p. 361.

(235) The New Zealand draft of article 36 provided in paragraph 3.-

"Such jurisdiction shall not( unless the parties to any particular dispute otherwise agree) include any of the following matters:

a) any disputes for the peaceful settlement of which the parties have agreed to adapt some other method and such method is in fact being adopted.

b) ...(and other matters as may be approved by the committee.) Ibid.,p.487, See also DOC. W.D.47, IV/1/49, ibid., p.561.

(236) Ibid., p.225.

(237) Ibid.

(238) lbid., p.558.

(239) Ibid., p.559.

(240) Ibid., 247.

(241) Compulsory jurisdiction was rejected by 31 votes against 14 , but many States voted in favour of the Optional Clause only to prevent stalemate. lbid.,pp250-251.

(242) Ibid., p.391.

(243) ibid., pp.53-64,90-101.

(244) Military and Paramilitary Activities in and against Nicaragua(Nicaragua v. United States of America), Jurisdiction and Admissibility, Judgment, I.C.J. Reports 1984, p.392, at 418, para. 59(emphasis added).

(245) It is to noted that Judge Levi Caneiro is the only judicial authority in the history of both Courts who thought that Article 36(2 and 3)"specifies the only condition which States may impose,viz, that of reciprocity on the part of one or more States, of a limitation in time". Anglo-Iranian Oil Co., Judgment, I.C.J. Reports 1952, p.93, at 154.

(246) See e.g. the Diss. Op. of Judge Castro in Nuclear Tests case (Australia v. France), Judgment , I.C.J. Reports 1974, p.253, at 383, and the Sep. Op. of Judge Ago in Military and Paramilitary Activities in and against Nicaragua case Nicaragua v. United States of America ), Merits, Judgment, I.C.J. Reports 1986, p.14, para. 5 .

(247) See e. g, the Diss. Op. of Judge Backwick in the Nuclear Tests cases ibid., p.417 and G.F. Jones, "Termination of Declarations Under the Optional Clause : Military and Paramilitary Activities in and against Nicaragua case ", 20 T.I.L.J.(1985), pp.557-581. See also the views of those who believe that the subjective reservation of domestic jurisdiction is invalid, Section 1, Chapter 6 below,p.401 seq. 
(248) See e. g. the Portuguese view in the Right of Passage over Indian Territory case, I.C.J. Pleadings, vol. 1, p.567 and vol. 4, p.135. See also the Indian view in the same case, ibid., vol. 1, p.195.

(249) Reservations to the Convention on the Prevention and Punishment of the Crime of genocide, Advisory Opinion, I.C.J. Reports 1951, p.15, at 26.

(250) See e.g. R.P. Anand, Compulsory Jurisdiction of the International Court of Justice, 1961,p.189 and S. Rosenne, the Law and Practice of the international Court, 2nd. revised ed., 1985, p.390.

(251) See Section 1, Chapter 6 below.

(252) The Iranian declaration was made on Oct. 2, 1930(P.C.I.J. Series D, No.6, p.53) and terminated on July 9, 1951(92 U.N.T.S.,p.432). 


\section{DEF I NI TI ONS \\ AND CIAASSIFICATION}

The permissibility of making reservations and conditions other than those provided for in paragraph 3 of Article 36 is now - as has been pointed out - an established question. States have attached different kinds. of reservations and conditions to their declarations accepting the Court's compulsory jurisdiction. Although the terms "reservations" and "conditions" are usually used interchangeably, yet they should not be confused. "Reservations" delineate the bounds of the area of disputes over which, subject to reciprocity, a state has accepted the Court's compulsory jurisdiction. Reservations, in this sense, relate to the scope and substance of the obligation assumed by a state under Article 36 (2) of the Statute. They may limit the time during which the court is vested with jurisdiction (reservations RATIONE TEHPORIS), the material scope of that jurisdiction (reservations RATIONE NATERIAE), or the States in regard to which the objection is assumed (reservations RATIONE PERSONAE). In contrast, conditions concern the legal force of the declaration itself as an instrument. They relate to the formal stipulations of its entry into force (whether, for example, it is subject to ratification), duration, variation and extinction. 1 This distinction is not theoretical but it has an important affect in so far as the principle of reciprocity applies only to the reservations. Thus in the HILITARY AND PARAHILITARY ACTIUITIES IN AND AGAINST NICARAGUA Case. the Court held that a state cannot rely upon a condition in its opponent's declaration. 2

Reservations in the above sense must also be distinguished from reservations to treaties. According to Articles 19 - 23 of the Vienna Convention on the Law of Treaties, reservations to treaties are intended to exclude or modify the legal effect of some provisions of the treaty in its application to that state. They assume 
therefore the existence of a prior agreement from which they derogate. Reservations to declarations of acceptance, on the other hand, constitute simply an integral part of the act which constitutes the agreement. In other words there is no prior agreement. 3 Furthermore, reservations to declarations cannot exclude or vary the legal effect of some existing provisions in relation to the declarant state. On the contrary, their function is to delineate - as has been said - the scope of the obligation assumed under Article 36 (2) of the Statute. The declarant state can accordingly lodge preliminary objections based on the reservations included in its declaration if it believes that the concrete case does not come within the scope of the obligation undertaken. 4 Another difference is that while reservations to treaties might only be made on accession otherwise they will be treated as denunciations, unless excepted by other states parties to the treaty, reservations to declarations might be made at any timeas will be seen - if the right to do so is reserved, or through terminating the declaration and making a new one with new reservations. These differences are of significance in so far as the general rules concerning treaty reservations are not applicable en bloc to reservations to declarations.

However, the different types of reservations and conditions which have been attached by states to their declarations of acceptance will be examined in five chapters according to the above classification, 7 viz, time limits and variation conditions; reservation RATIONE TEHPORIS and PERSONAE; and reservations RATIONE MATERIAE which, owing to their diversity and importance, will be divided into three chapters: unnecessary, objective and subjective reservations.

The following list and table indicate all kinds of reservations and conditions which have been inserted in the declarations of acceptance, including those made 
under the statute of the P. C. I. J. and deemed to be acceptances of the I. C. J.'s jurisdiction by virtue of paragraph 5 of Article 36 of the Statute.

1. Reciprocity (RATIONE HATERIAE).

2. Time-Limits Condition.

a) acceptance for a fixed period.

b) acceptance for a limited period and thereafter terminable by a simple notice,

c) for a limited period and thereafter terminable by notice of a determined period:

d) without time limits;

e) unlimited period terminable by a simple notification:

f) unlimited period revocable after notice of a determined period.

3. Ratification

4. Recourse to the Security Council.

5. Domestic jurisdiction according to international $1 \mathrm{aw}$.

6. Domestic jurisdiction as understood by the declarant state.

7. Disputes in regard to which states agreed to other means of settlement.

8. Disputes arising during or out of hostilities.

9. Territorial disputes.

10. Pecuniary disputes.

11. Disputes concerning constitutional regime.

12. Multilateral treaties.

13. The Portuguese Third Condition

14. National defence or national security.

15. RATIONE TEHPORIS reservations.

a) past disputes;

b) past disputes or arising out of facts or situations prior to a given date.

16. Legal disputes.

17. Israel reservations.

18. Disputes relating to any matter excluded from judicial settlement or compulsory arbitration by 
virtue of any treaty or convention.

19. Disputes concerning special treaties.

20. Reciprocity RATIONE PERSONAE (the Brazilian condition).

21. Disputes between a specified group of States.

22. Non-recognition.

23. Disputes with States which have not accepted the jurisdiction of the Court before a limited period.

24. Disputes with States which have not accepted jurisdiction when the dispute was referred to arbitration.

25. Disputes with a specific state over a specific subject.

26. Disputes with non-sovereign States or territories.

27. Disputes occurring during a determined period of time.

Table 3 on pages 81,82 and 83 indicates the number of reservations and conditions made by each state according to the above numeration. 


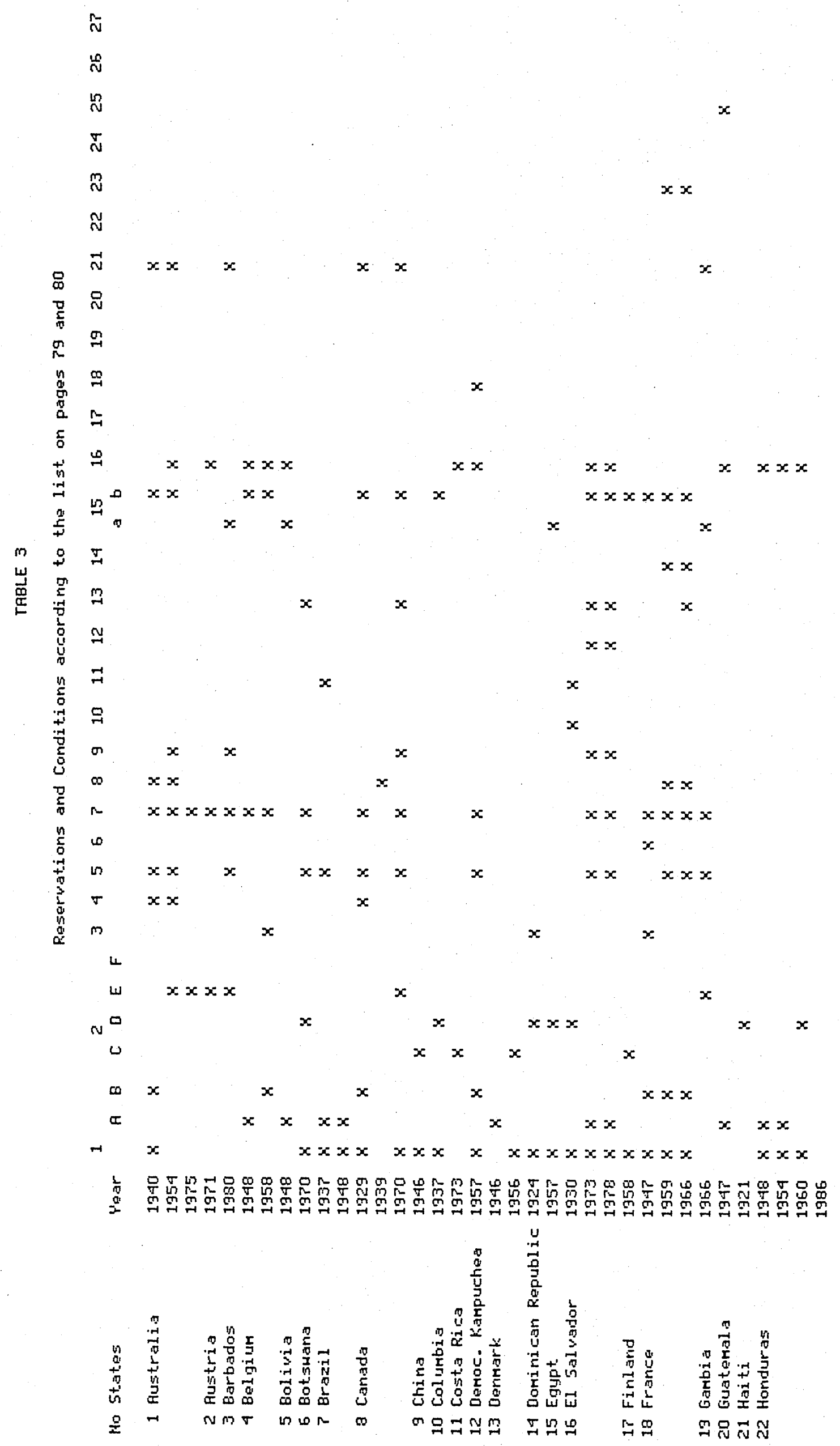




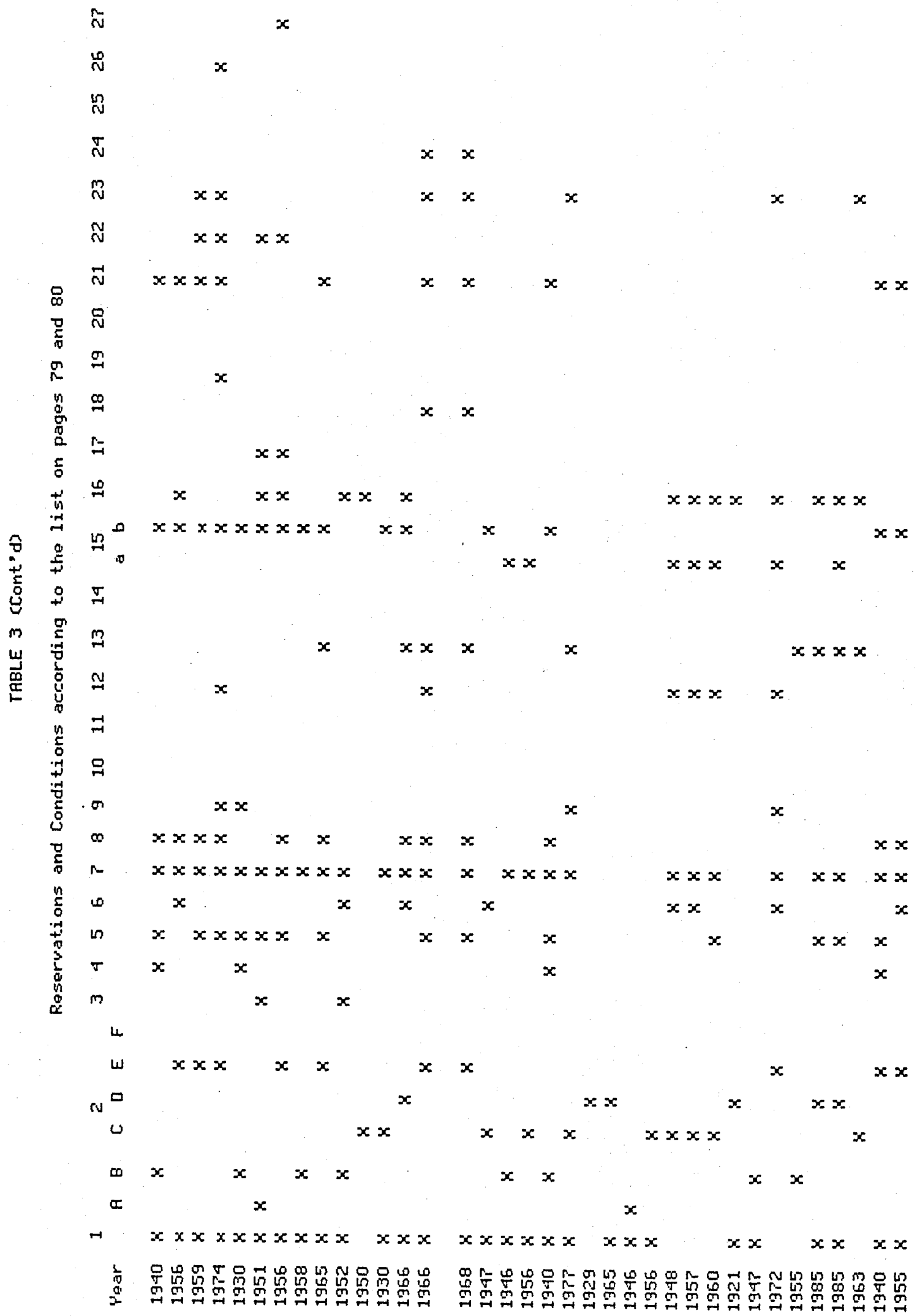

곧몸

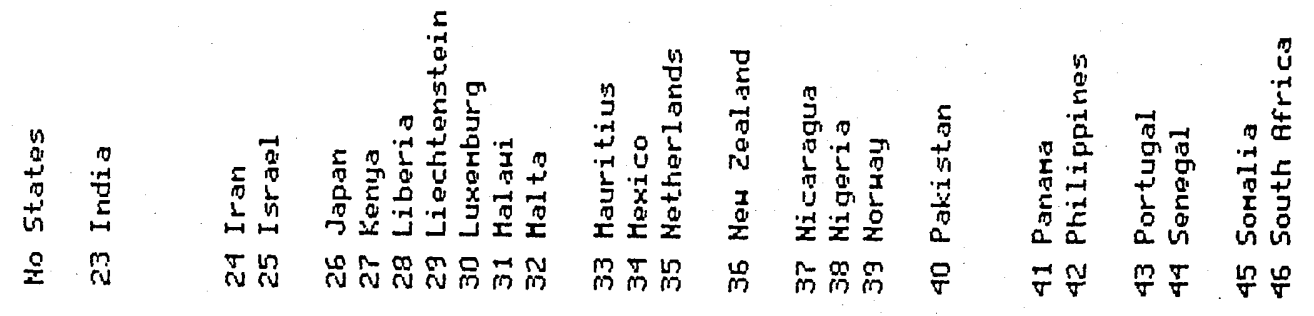




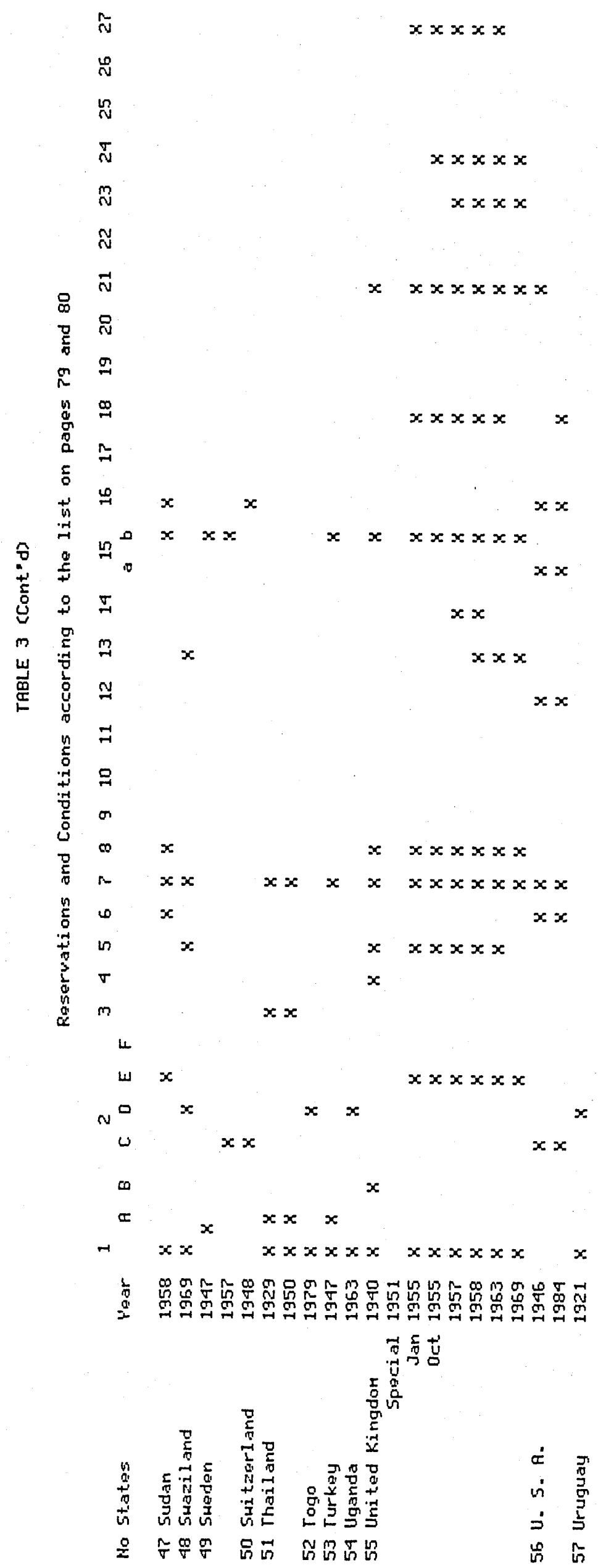




\section{CHAPTER I I \\ TIME-IIIMITS AND VARIATION \\ COND I II ONS}

States have interpreted in practice the provision that declarations may be made "for a fixed period" in different ways. Many time-limits formulae have been adopted. Some States have also reserved the right to vary their declaration whenever they wish. In fact, these conditions proved to be more harmful than reservations.

\section{SECTION 1 : TIME-LIMITS CONDITIONS}

Three major points concerning time-limits conditions have been given extensive consideration in the doctrine as well as in the Court's jurisprudence: the entry into force of the declarations of acceptance; their termination, and the applicability of reciprocity to these conditions. The discussion of these points seems to require a previous examination of the different forms in which these conditions are made.

\section{A - FORMS OF TIME-LIMITS CONDITIONS}

Paragraph 3 of Article 36 provides that declarations can be made "unconditionally" (in French PUREHENT ET SIMPLEHENT) or "for a certain time" (in French POUR UN DELAI DETERHINE). Until 1929. this provision had been understood as an indication that declarations should be made for a fixed period of time or for an indefinite term, but since then, this provision has been understood differently. Six forms of qualifications can be found in the declarations accepting the compulsory jurisdiction of the present court.

\section{(I) Declarations for a Fixed Period}

A comparison between the declarations accepting the jurisdiction, of the present court and those made during 
the period of its predecessor shows a drastic change in State practice. Whereas $33^{B}$ declarations out of 56 (i.e. $58 \%$ ) of the declarations made during the period of the $P$. C. I. J. were made for a fixed period, only $10^{9}$ declarations out of 57 (i.e. 17\%) made under the statute of the present Court had been at one time or another for a fixed period. In renewing their declarations, four states (Belgium, Denmark, Norway, Sweden) abandoned this form. The number was thus reduced to 6 states, (i.e. about 10\%). The situation is now worse. All the declarations currently in force, except that of El Salvador, are not for a fixed period. The declaration of El Salvador of November 26, 1978 was renewed for a period of ten years from that date. 10

\section{(II) Declarations for Indefinite Term}

Surprisingly, the number of declarations which do not mention any time limitation in their texts, has increased. Twelve declarations out of 46 currently in force are made for an indefinite term, (i.e. $21 \%$ of all declarations and $26 \%$ of declarations in force), six of which were made under the Optional Clause of the P. C. I. J. 11 The declarations of Bulgaria and Portugal lapsed on the date of the dissolution of the P. C. I. J. ${ }^{12}$ Three declarations (of Costa Rica, Guatemala and Liberia) did not enter into force because of lack of ratification. The declaration of Paraguay was terminated in 1938, and $\mathrm{El}$ Salvador modified its declaration in 1973. ${ }^{13}$ The other six declarations currently effective have been made since 1957. These are the declarations of Botswana (1970), 14 Egypt (1959), Malawi (1966), Nigeria (1965), Senegal (1985), Togo (1979), and Uganda (1963). The declaration of Togo is typical. It is made "for an unlimited period subject to the power of denunciation and modification attached to any obligation assumed by a sovereign state in its international relations". 15 


\section{(III) Declarations for a Fixed Period Terminable after the Expiration of Six Months' Notice}

Declarations in this category are either made for a fixed period, and thereafter are renewable for the same period unless denounced by a notice of not less than six months before the expiration of that period, or for a fixed period terminable after the expiration of six months' notice. It is obvious that the first formula is more favorable for the Court's jurisdiction and creates more stability between states accepting that jurisdiction. A state making such a declaration cannot terminate it except at the end of the period for which it was made, whereas this possibility is open, according to the second formula, at any time after the expiration of the initial period and, of course, on the condition that the proviso of notice is complied with.

Six declarations now in force include the first formula. It was made first in the declaration of Luxembourg of 1930 then followed by Denmark. Finland, Netherlands, Norway and Sweden. The declarations of Mexico and New Zealand contain the second formula. 16

\section{(IV) Declarations for Unlimited Period Revocable After One Year's Notice}

This form had never been used during the period of the P. C. I. J. It is limited to the declarations of Liechtenstein and Switzerland. However, there is no difference in practice between this form and the second of the third category above, except that the former gives the other declarants a more extended period to sue the State making it, in case it decides to terminate its declaration. 
(V) Declarations for a Fixed Period and Thereafter Terminable by a Simple Notification

The United Kingdom is the first responsible for introducing this form. ${ }^{17}$ It was made for the first time in its declaration deposited February 5, 1930, then it was copied by the Commonwealth countries (Australia, Canada, India, New Zealand, and South Africa), and by Iran, Iraq and Latvia. It is said that this formula appeared as an inadvertant result of drafting. 18 The ten years' period for which Great Britain and the Commonwealth countries accepted the Court's jurisdiction supports this view. In fact, if the principle of good faith is taken into consideration there would be no doubt that this form was more favorable for the Court's jurisdiction, because there was no need to renew it every time it expired. Thus, in 1930, Sir J F Williams said that "It must be supposed that no British Government after the end of 10 years would suddenly terminate its acceptance of the clause when threatened by unwelcome reference to the Court". 19 However state practice - as will be seen - has proved the fallacy of that prediction. None of the States mentioned above accepts the Court's compulsory jurisdiction in this form. ${ }^{20}$ They have generally abandoned it in favour of the next category.

Six of the declarations currently in force contain this formula. 21 The fixed period in all these declarations has expired and, therefore, they are terminable by a simple notification to the Secretary-General of the United Nations.

(VI) Declarations for Unlimited Period Terminable with Immediate Effect

The previous category opened the door for making declarations terminable immediately. When renewing its declaration, ratified April 7. 1930, South Africa made its declaration of April 7, 1940 "until such time as 
notice may be given to terminate the acceptance" ${ }^{22}$ of the Court's compulsory jurisdiction. This was the only precedent during the period of the P. C. I. J., but it had a draconic effect on state practice thereafter to such an extent that this formula has become the most attractive one. 15 of the 46 effective declarations (i.e. almost one third) are made in the same terms. By adding the seven of the previous category, the number of the declarations terminable at any time is now 22 (i.e. almost one half).

This unfortunate development raises the question whether this form and the previous one are in conformity with the statute. It is generally agreed that declarations made for a fixed period and thereafter terminable upon six or twelve months' notice do not violate the spirit of the statute, but although not strictly conforming to it, are therefore considered as valid. ${ }^{23}$ Can this view be generated to cover declarations that are made terminable immediately by a simple notice? This question will be dealt with later while discussing the termination of declarations made in this form.

It is to be noted, finally, that if the form and the period for which the Court's jurisdiction is accepted are considered as an indicator of the degree of confidence in the Court, the result would be, unfortunately, drastic in comparison with the situation during the era of the P. C. I. J. Seventeen declarations were made during that period for a period of 10 years, 24 one for 20 years (that of Ireland of 1930), one for 15 years (that of Belgium of 1925) and five declarations for 5 years. Also, whereas the period of eight declarations has risen from 5 years to 10 years, 25 the time-limits of five declarations only were diminished.

On the other hand, since 1945, only 8 declarations were made for 10 years, 27 two of which have expired [those of Brazil (1948) and Thailand (1950) respectively; 
one has become terminable at any time (that of Democratic Kampuchea of 1957) and the period of the others, except that of El Salvador, is reduced.

The drawback can be illustrated also by the abandoning by many states of the fixed period formula, for that of termination at any time. ${ }^{28}$ In contrast, the only apparent improvement is to be found in the declaration of New Zealand of 1977. which abandoned the immediate termination form for the fixed period (5 years), and thereafter until the expiration of six months after notice has been given to terminate the declaration. This is, of course, in addition to the Scandinavian declarations which have been modified in the same form as mentioned above.

\section{B - ENTRY INTO FORCE OF DECLARATIONS}

\section{(I) The Date of Entry Into Force}

The entry into force of a declaration has a legal importance in determining the date when the obligation accepting compulsory jurisdiction produces its effect 29 It may indicate also the "exclusion date" or the "critical date" 30 of the reservation RATIOHE TEHPORIS. This happens where the obligation is assumed only with regard to disputes subsequent to the entry into force of the declaration. Finally, it may determine, though not necessarily, the commencement date, and hence, the terminal date of the period for which the obligation is valid. 31

The Statute of the P. C. I. J. did not contain any indication as to the entry into force of a declaration. but the "Optional Clause" referred to the acceptance of jurisdiction "from this date" (French DES A PRESENT). For determining the date of entry into force, Hudson relied on this provision in addition to the French version of Article 36 (2) to reach the conclusion that "the declaration was intended to take effect at the time of signa- 
ture". 32 The P. C. I. J. had no opportunity to pronounce on this point, but declarations were deposited with the Secretary-General of the League of Nations. This action of states seems to have found its basis in the provision of the Protocol of Signature which stipulated that "each Power shall send its ratification of the Protocol to the Secretary-General of the League of Nations", who was to take the necessary action to notify such ratification to other signatory States. 33 Accordingly, the ratification of the Protocol of Signature was a necessary stage for the entry into force of a declaration, even if it was previously ratified and, even if the Protocol was signed.

A new improvement was introduced into the statute of the present Court by the addition of paragraph 4 to Article 36 at the San Francisco Conference by Committee IV/1. It provides: "such declarations shall be deposited with the Secretary-General of the United Nations, who shall transmit copies thereof to the parties to the Statute and to the Registrar of the Court". Since no explanation is recorded in the Committee's Report as to that addition, 34 the question arose as to whether this provision constitutes $A D$ UALIDITATEH for the entry into force of a declaration. Two views have been expressed before 1957. According to Hudson, the date of signature is the date of entry into force. Thus, he considered the insertion of the provision into the statute as a "detail of house keeping", though he admitted that it could be useful in the view of surrounding uncertainties. 55 Salo Engel took the same view. After examining in detail the four dates of the American declaration, namely the date of the Senate resolution according to which the declaration was made; the date of its signature by the President; the date of its deposit with the Secretary-General, and that of its registration by the secretariat, he reached the conclusion that it entered into force at the date of its signature, though he believed that the consideration of the date of deposit "would be in harmony with the general rule of International Law according to 
which mere ratification is not enough". "3t Hambro, on the other hand, considers the deposit as a "part of the legal act and the declaration is not complete without it". 37 This view is now largely accepted. 38

The I. C. J. confirmed Hambro's view in the RIGHT OF PASSAGE OUER INDIAN TERRITORY case. 39 Here, India contended that a state cannot validly file an application until the lapse of such brief period as in the normal course of events would enable the Secretary-General's communications of the Declarations to reach the states. In rejecting this contention the court declared that just by the deposit of its declaration with the SecretaryGeneral, "the accepting state becomes a party to the system of the Optional Clause in relation to the other declarant states, with all the rights and obligations deriving from Article 36. The contractual relation between the parties and the compulsory jurisdiction of the Court resulting therefrom are established 'IPsO FACTO' and without special agreement by the fact of the making of the declaration". 41

The Court observed that the Indian argument confused between two distinct provisions of paragraph 4: the requirement that declarations should be deposited with the Secretary-General, and the duty incumbent on the latter to communicate them to the other parties to the Statute. It declared:

".. However, it is only the first of these requirements that concerns the state maling the declaration. The latter is not concerned with the duty of the Secretary-General or the manner of its fulfillment. The legal effect of a declaration does not depend upon subsequent action or inaction of the Secretary-General. Horeover, unlike some other instruments, Article 36 provides for no additional requirement. for instance, that the information transmitted by the SecretaryGeneral must reach the parties to the statute, or that some period must elapse subsequent to the deposit of the declaration before it can become effective". 
Two judges expressed their disagreement with this holding. Judge Badawi relied on the theory of offer and acceptance, as the consensual bond formed between the declarant states, to $f$ ind that the procedure envisaged in paragraph 4 was merely intended "to take the place of direct negotiation", and therefore, speaking in a legal terminology, the system of declarations "constitutes a contract of correspondence between the declarant state and the other states through the agency of the SecretaryGeneral as an intermediary who, in these cases, constitutes a stage in the transmission". "Accordingly. since the application was filed against India before it received the declaration of Portugal, he thought that no contract had resulted and the position was the same as if the declaration had not been made.

Judge $A D$ HOC Chegla found it difficult "to understand if the first part of Article 36 (4) was mandatory, why the second part was not equally mandatory". He was not able also to accept the argument that the second part was purely administrative or procedural. Why should such an unimportant provision have found a place in so solemn a document as the statute of the court. "There must have been some reason why the framers of the statute inserted this provision in Article 36 (4) and the obvious reason was that some time should elapse between the making of the declaration and the filing of an application". "44 Yet both judges did not indicate how much time should elapse.

The court, however, confirmed its view in the MILITARY AND PARAHILITARY ACTIUITIES IN AND AGAINST NICARAGUA case (jurisdiction and admissibility). ${ }^{45}$ The date of entry into force of a declaration is therefore the date of its deposit with the Secretary-General, unless otherwise indicated (e.g. requiring the ratification of the declaration). Thus, the declarations are dated by the secretariat of the United Nations and the Registry of the Court according to the date of their deposit, regardless of the date of signature; the date 
from which a declaration is considered by the declarant to be binding, ${ }^{46}$ or that on which the declaratory condition was fulfilled.

\section{(II) Entry Into Force and Article 102 of the Charter}

Some commentators have found in Article 102 of the Charter of the United Nations an additional argument to support the view that the date of entry into force is that of the deposit with the Secretary-General. The second paragraph of that Article provides:

No party to any treaty or Internationel agreement which has not been registered in accordance with the provisions of paragraph i of this Article mey invole thet treaty or agreement before eny organ of the united lletiones.

Hambro argues that:

"It is clear that these declaretione fall within the term "treaty" in this Articles and thet the Internationel Court of Justice is an orgen of the United Hatione. It would then be neturel to say that these declaretions are valid from the moment wen they are deposted; and not before. It is believed that these declaretione, which are registered Ex orfaro by the Secreterist of the United Netions wil be registered at once so that there will be no discrepency between the dete of deposit and the date of registration. It is possible; however; that a declaretion mey be valid from the dete of deposit. although it canot be involed berore it has been regietered." 4 a

A $N$ Farmanfarma also believes that the date of deposit, as a date of entry into force, is substantiated by the above provision of Article 102. However the validity of declarations begins, in his view, from the date of their signature rather than from the date of deposit.

It seems that these arguments are erroneous, or at least paragraph (2) of Article 102 has no relevance whatsoever in determining the date of entry into force of a declaration for many reasons. Firstly, assuming that declarations fall within the term "treaty" - though they 
are not as will be seen 50 - the date of deposit of a declaration and the date of registration do not necessarily coincide, but in fact a long period of discrepancy might be observed. As an example the declaration of the United States was deposited with the Secretary-General on August 26,1946 - i.e. before Hambro's article was written

- but registered by the Secretariat on December 14, 1946. 51 Secondly, the I. C. J. made it clear in the RIGHT of PASSAGE case and MILITARY AND PARAMILITARY ACTIUITIES case - as has been seen - that the very essential date for the entry force is that of deposit, though it admitted in the former case that there may exist some element of uncertainty. "which is inherent in the operation of the system of the Optional Clause". during the interval between the date of notification to the Secretary-General and its receipt by the parties to the statute. 52 Consequently, the Court observed that:

"A State accepting the jurisdiction of the court must accept that an Application may be filed against it before the Court by a new declarant state on the same day on which that State deposits with the Secretary-General its declaration of acceptance. For it is on that very date that the consensual bond, which is the basis of the Dptional clause, comes into being between the States concerned." "s.

Thus Portugal in that case could have filed its application on December 19. 1955, the date of deposit, before it was registered EX OFFICIO on December 21,1955.

Thirdly, what does the open statement of Farmanfarma, that the validity of a declaration begins from the date of its deposit, mean? His consideration of declarations as "treaties", and his references to Article 102. and that the court is an organ of the United Nations. leave no doubt that he intends to make a comparison between the validity of declarations before their deposit and treaties before their registration. It is obvious that treaties can produce their effects between the parties from the date of signature according to Article 
12 of the Vienna Convention on the Law of Treaties. 54 In fact. Article 102 presupposes a legally valid instrument. The non-fulfillment of the obligation provided in that paragraph has no effect but to preclude the parties to a non-registered treaty from invoking it before any organ of the United Nations. What effect can a declaration have before being deposited? Can it be relied on by other States before the court? It is not possible, it is believed, since the deposit - as has been seen - is an essential element in the legal act. It may be argued that in the HILITARY AND PARAHILITARY ACTIUITIES (jurisdiction and admissibility) case the Court considered the declaration of Nicaragua made under the Optional Clause of the P. C. I. J. as a valid instrument, though, Nicaragua did not ratify the protocol of signature, 55 and therefore it was immune to be sued by other signatories. The issue here is not quite the same, because, at least all the requirements of making a declaration were fulfilled by Nicaragua in that case. According to Article 36 (2) of the P. C. I. J., a State member of the League of Nations or mentioned in the Annex to the Covenant could "either when signing or ratifying the Protocol [of Signature] ... or at a later moment" declare its acceptance of compulsory jurisdiction, i.e. a state could make a declaration though it had not ratified that Protocol, but only signed it. Although this condition was fulfilled by Nicaragua on September.24 1929, the Court observed that Nicaragua's declaration was "UALID FROH THE HOHENT IT HAS received by the Secretary-General of the League of Nations". "The fact of deposit of that declaration coupled with its special characteristics, namely, being made "unconditionally" or for unlimited period, gave it a "potential effect" 57 pending on the ratification of the Protocol Signature. In other words, its deposit transferred it into an international solemn obligation the effect of which was pending on the ratification of another distinct act, namely the Protocol Signature. 
Five judges 58 believed that the declaration of Nicaragua was not valid because of its failure to ratify the Protocol Signature. The qualification of that declaration as certainly valid, but not binding, seemed to judge Mosler "a misconstruction of a legal act which was subject to a suspensive condition. Moreover the use of this terminology may indicate that the 'certainly valid' declaration has an intrinsic validity which has only to be completed by ratification in order to become binding". 59 Judge Ago also observed that the signature of the Protocol of Signature "never took shape as an act producing legal effects at international level". Therefore, "the so-called potential effect could not, in any event, be binding in character". 60

However, they all agreed that Nicaragua had never become a party to the Protocol Signature and, hence never party to the statute or the Optional Clause 61

Nevertheless, it is clear that the circumstances in which Nicaragua's declaration was made do not apply to any other declaration made pursuant to Article 36 (2) of the I. C. J.. and therefore they are not valid before their deposit. 62

Lastly, if Hambro and Farmanfarma's views could be regarded as doctrinal arguments expressed before the RIGHT OF PASSAGE case (preliminary objections), the reference to Article 102 by some later commentators 63 as a further argument to support the Court's view in that case, seems to contradict that view, and may lead to the impression that unless declarations are REGISTERED by the Secretariat they cannot be invoked before the court.

\section{(II) A New Precedent}

In the HILITARY AHD PARAHILITARY ACTIUITIES IN AND AGAINST HICARAGUA case (jurisdiction and admissibility) 
the Court created a precedent, though limited to Nicaragua's declaration, as to the entry into force of a declaration made under the Optional Clause of the P. C. I. J. without ratifying the Protocol Signature. Here Nicaragua relied on its declaration of September 24, 1929, and Article XXIV (2) of the Treaty of Friendship. Commerce and Navigation of May 24, 1958 between itself and the United states for bringing the dispute before the Court. 64 It argued that its declaration was valid and binding acceptance of the compulsory jurisdiction of the Court by virtue of Article 36 (5). 65 Nicaragua contended that, though the ratification of the Protocol of Signature was not deposited, its declaration was included among declarations deemed to be acceptance of the Court's jurisdiction by virtue of the phrase "which are still in force" (the French version "POUR LINE DUREE QUI N"EST PAS ENCORE EXPIREE") because that phrase "was designed to exclude from the operation of the Article only declarations that have already expired, and has no bearing whatever on a declaration, like Nicaragua's" bo As a support for this argument, Nicaragua relied also on the Yearbooks of the International Court of Justice; the publications of the United Nations Secretariat, which included it amongst States "which have recognised the compulsory jurisdiction ... of the International Court of Justice or which are still bound by the acceptance of the Optional Clause of the Permanent Court of International Justice" or amongst States with regard to which there were "in force declarations", and on the attitude of the parties to that case and that of Honduras in the case of ARBITRAL AHARD HADE BY THE KING OF SPAIN ON DECEHBER 23, 1906. 67

The United States, on the other hand, argued that Nicaragua never became a party to the statute of the Permanent Court of International Justice and accordingly, it could not make an effective acceptance of the compulsory jurisdiction of the Permanent Court. The U.S. interpreted the expression "still in force" and its corresponding French version in a different manner. Both 
these expressions required, in its opinion, that a declaration must be "binding" to be deemed an acceptance of the jurisdiction of the present Court. 68

After observing the novelty of the issue involved in the case, the court rejected the American interpretation of the expression "still in force". The Court found that it had to interpret paragraph 5 of Article 36 on the basis of the actual terms used, which do not include the word binding. It said:

\begin{abstract}
"According to the TRAUAUX PREPARATORIES the word "binding" was never suggested; and if it had been suggested for the English text, there is no doutt that the drafters would never have let the French texts stand as finally worded. Furthermore, the court does not consider the French text to imply that $\angle A$ DUREE HON EXPIREE (the unexpired period) is that of a commitment of a binding character. It may be granted that, for a period to continue or expire, it is necessary for some legal effect to have come into existence. But this effect does not necessarily have to be of a binding nature. A declaration validly made under Article 36 of the statute of the Fermanent Court had a certain validity which could be preserved or destroyed, and it is perfectly possitgle to read the French text as implying on this validity".
\end{abstract}

The court found that the following facts confirm the above interpretation: the deliberate choice of the expression "POUR LNE DUREE QUI H"EST PAS ENCORE EXPIREE"; the intention to maintain the greatest possible continuity between it and its predecessor by those who drafted its statute, to maintain as far as possible the progress towards compulsory jurisdiction; 70 the particular weight that must be ascribed to certain official publications, namely, the I. C. J. and the United Nations Publications; 71 the silence of Nicaragua over the period since 1929; the conduct of the other states by not challenging the inclusion of Nicaragua among states bound by compulsory jurisdiction; the reliance of Honduras INTER ALIA on Nicaragua's declaration in the case of THE ARBITRAL AHARD MADE BY THE KING OF SPAIN ON DECEHBER 23 , 1906, and finally the United States letter of April 6. 
1984 which implied, in the Court's view, that the United States believed that Nicaragua was bound by the Court's jurisdiction. 72

Bearing in mind that Nicaragua was represented at the San Francisco Conference and duly signed and ratified the Charter of the United Nations, on the one hand, and the particular characteristics of its declaration being made for an unlimited period, on the other, the court ruled that Nicaragua's declaration "was valid at the moment when Nicaragua became a party to the statute of the new Court: it had contained its potential effect because Nicaragua, which could have limited the duration of that effect, had expressly refrained form doing so". 73 Therefore, the consent which had been given by Nicaragua in 1929 to the jurisdiction of the Permanent Court "had not become fully effective" in the absence of ratification of the Protocol of Signature. Yet, the ratification of the Charter of the United Nations, by a State represented at the San Francisco Conference presupposes that "the consent to transfer to the International Court of Justice a declaration accepting the jurisdiction of the Permanent Court may be regarded as effectively given", as the court ruled also in the AERIAL INCIDENT OF $\mathbb{H} L Y Z T$, 1955 (preliminary objections case).

\section{(IV) Entry Into Force in Practice}

A small number of declarations indicate the date of their entry into force. Among the 46 declarations currently effective, three declarations provide for that the date of deposit with the Secretary-General is the date of entry into force. 75 Although the statute does not require ratification, three declarations have been made subject to ratification. 76 . Therefore the date of the deposit of ratification is the date of their entry into force. Liechtenstein and Switzerland stipulated that their declarations "shall take effect from the date on which they became parties to the Statute". 77 Egypt and 
Mexico made their declarations effective from a specified date prior to the date of their deposit. This stipulation has no effect, as Briggs observes, on the date of entry into force, but it has the effect of diminishing the period for which the Mexican declaration was made, and rendering the Egyptian one, being made for unlimited period, expressly applicable to disputes arising prior to the date of entry into force. ${ }^{78}$ The other declarations are silent on the issue. Consequently the date of deposit is the determinant date.

Thus, the date of entry into force coincides with the "commencement" date where a declaration indicates only the former date, or where neither dates are indicated, or finally where only the latter is indicated and coincides with the date of deposit. On the other hand, it coincides with the "commencement date" and "exclusion date" RATIONE TENPORIS if a declaration specifies a single date for their operation, or where the declaration is made with regard to future disputes only.

If these three dates are borne in mind, it might be easier to interpret a declaration made in terms so ambiguous ${ }^{80}$ such as those of the Mexican declaration. 81 It confers jurisdiction over disputes "that may in future arise... out of events subsequent to the date of this declaration". The declaration which is dated October 23. 1947. was deposited with the Secretary-General on October 28, 1947, and by its terms "shall be binding as from 1 March 1947" 82 Accordingly, October 23, 1947 is the exclusion date; October 28, 1947 is the entry into force date; and March 1, 1947 is the commencement date of the period for which the declaration was made.

It is observed, finally that, although Article 36 (4) refers only to the deposit of declarations, it applies also to alterations, withdrawals and denunciations, as the Court observed in the RIGHT OF PASSAGE OUER INDIAN TERRITORY case (preliminary objections): 


\section{C - TERMINATION OF DECLARATIONS}

The question of the termination of the obligation assumed under Article 36 (2) was ignored by the drafters of the statute of the P. C. I. J. It might be fair to assume that they did not conceive that it would give rise to any problem in practice. It was also ignored by the framers of the present statute, though some new precedents emerged after 1929.

Normally, a declaration can be terminated according to its terms inasmuch as they are not inconsistent with the statute. Therefore, the expiration of the period for which a declaration is made, or the expiration of the period notice indicated in it, are the normal ways for its termination, in addition to the way to terminate an obligation assumed for indefinite term. However, the development brought about in practice had not left any method without contestation.

\section{(I) The rule in the Nottebohm case}

It is to be observed at the outset, that whatever the method provided for in a declaration, its termination in some circumstances is governed by the rule in the HOTTEBOHW case. In this case Guatemala's declaration was made for a period of five years from January 27,1947. Liechtenstein's declaration, on the other hand, was revocable on twelve months notice. On December 17, 1951 , i.e.. less than four weeks before Guatemala's declaration was due to expire, Liechtenstein filed an application against Guatemala. The latter, in a preliminary objection, contended that the Court was without jurisdiction, although it did not dispute that at the date when Liechtenstein's application was filed, the court became regularised by the jurisdiction over the case. It claimed that the court had no power to hear the case because its declaration must be understood as relating generally to the administration of justice by the court, not merely to 
the seizing of the Court with jurisdiction to administer justice.

The Court unanimously rejected that objection ruling that:

\begin{abstract}
"The seizing of the court is one thing, the edministration of justice is another. The letter is governed by the Statute, and by the fules which the court hes dram up by virtue of the powere conferred upon it by Article 30 of the Statute: Once the Court hed been regularly seised; the court must exercise its power; as these are defined in the Statute. After that, the expiry of the period fixed for one of the Declarations on which the Application was founded is an event which is unirelated to the exercise of the powers conferred on the Court by the statute, which the court exerciese whenever it has been regularly seised and whenever it has not been shown, on some other ground, that it lacks jurisdiction or that the clain! is inedmiseible: "84
\end{abstract}

This rule had been confirmed in the RIGHT OF PASSAGE case ${ }^{85}$ and MILITARY AHD PAPAMILITAPY ACTIUITIES case.

\title{
(II) Termination of Declarations made for a Fixed Period or Terminable upon a Fixed Period Notice
}

The lapse of the period for which declarations were made was the only method which was followed for the termination of declarations made according to the optional Clause of the P. C. I. J.. except the termination of the declarations of Paraguay and Brazil. 97 No protest whatsoever was made against that method of termination. But, can a declaration made for a fixed period or terminable upon a fixed period notice be abrogated or modified before the lapse of that period? This question has never been given any importance in the doctrine except by Waldock. In his discussion of the inequality between States making their declarations terminable immediately by a simple notice and states whose declarations are for a fixed period, he argued for the possibility of denouncing the declarations of the latter $U I S-A-4 I A$ the former on the basis of reciprocity. 88 However, attempts to 
modify declarations before the expiration of the period of their validity were made during the Second World War.

On September 7.1939, the United Kingdom, whose declaration was made for an initial period of ten years and then until notice would be given to terminate it. notified the Secretary-General of the League of Nations that it would not regard its "acceptance of the Optional Clause as governing disputes arising out of events occurring during the present hostilities". 89 The same action was taken by the Commonwealth Nations (New Zealand, the Union of South Africa, Australia, India and Canada). 90 Similarly France which on April 7, 1936 had made a declaration for a five years period, sent to the Secretary-General on September 10, 1939 a letter by which it regarded such disputes as excluded from the Court's jurisdiction. 91 The grounds on which they justified their actions appeared strongly to imply that they were invoking the CLAUSA REBUS/STANTIBUS. They alleged that the conditions which prevailed at the time of their acceptance of the Optional Clause ceased to exist. Their justification seems also to indicate that they "did not consider themselves to have the right unilaterally to modify or terminate their declarations except according to principles analogous to those governing the termination or modification of treaties".

Eleven neutral States made reservations in regard to the legal effect of the action taken by these states. It might be worth noting that Norway and Sweden drew attention to the fact that, by virtue of Article 36 of the statute and the declarations relating thereto, it rests with the Court itself to decide questions as to its own jurisdiction and, "should the case arise, to pronounce upon the validity and if necessary, the scope of the acts of denunciation referred to". 94 
The validity of these actions have been open to discussion, 95 and the court did not have an opportunity to consider the question until 1984 in the HILITARY AND PARAHILITARY ACTIUITIES IN AND AGAINST NICARAGUA CaSe (jurisdiction and admissibility). The United States deposited on April 6, 1984 with the Secretary-General a notification stating that:

"Not withstanding the terms of the aforesaid declaration, this proviso shall take effect immediately and shall remain in force for two years, so as to foster the continuing regional dispute settlement process which seeks a negotiated solution to the interrelated political, economic and security problems of Central America."

This was in spite of the fact that its declaration was made for a fixed period and thereafter until the expiration of the sixth months after notice having been given to terminate it.

Nicaragua contested the validity of this notification on the grounds that international law did not provide a basis for unilateral modification of a declaration made under Article 36 (2) of the statute unless the right to do so has been expressly reserved. 97

On the other hand the modification was regarded by the United States as suspending temporarily its consent to the adjudication of the claims of Nicaragua, and not a termination of its 1946 declaration, and therefore, the six months notice proviso was not applicable to the notification. It contended also that states have the sovereign extra-statutory right to modify at any time declarations made under Article 36 in a manner not inconsistent with the statute. For declarations are neither treaties nor governed by the law of treaties, but are $s U I$ GENERIS. Furthermore it was "inequitable and unjustified to hold the United States to its declaration made 38 years before and to ignore the fundamental change occurred in State practice under the Optional Clause, the 
United States argued. 98

Rebutting the United States arguments Nicaragua argued that the United States notification was without effect on the Court's jurisdiction to entertain the case. For that notification could have two interpretations: the first was to consider it as a modification of the 1946 declaration. In such a case the modification was contrary to the 1946 declaration which reserved the right to terminate and not to modify. Moreover, the six months' proviso was introduced to have "the effect of a renunciation of any intention to withdraw [the] obligation in the face of a threatened legal proceedings". 99 Accordingly the attempt to modify that declaration was nullified. The second was to consider that notification as a termination to the declaration, and it was in fact. Nicaragua argued. an attempt to terminate the acceptance UIS-A-UIS a certain number of identifiable states. In such an hypothesis the notification was likewise ineffective before the expiration of six months, i.e. before October 6, 1984. 100

The Court found that the arguments between the parties as to whether the negotiation should be considered as a modification or as a termination were without consequence for the purpose of its judgment. Yet the truth, in its view, was that the notification "intended to secure a partial and temporary termination, namely to exempt, with immediate effect, the United States from the obligation to subject itself to the Court's jurisdiction with regard to any application concerning disputes with American States". 101 However, as far as the validity of the United States' notification is concerned, the court said:

\footnotetext{
"The most important question relating to the effect of the 1984 notification is whether the United States was free to disregard the clause of six months" notice which, freely and by its own choice, it had appended to its 1946 Declaration. In so doing the United States entered into an obligation which is binding upon it vis-a-vis other states parties to the optional clause system. Although the United States retained the right
} 
to modify the contents of the 1946 Declaration or to terminate it: a power which is inherent in any unilateral act of a Stete, it has, nevertheless assumed an inescepeble obligetion touards other States accepting the optional oleuse; by stating formally and soleminly that any such chenge should tale effect only after six months have elapsed as from the date of notice." 102

The significance of this judgment is that states will, in future, be on notice that any self-imposed requirement relating to time-limits embodied in declarations must be observed as regards both modification and termination. 103

\section{(III) Termination of Declarations made Unconditionally}

On May 27, 1938, Paraguay sent the Secretary-general of the League of Nations the text of the decree withdrawing its declaration ratified on May 11, 1933 recognising the jurisdiction of the $P$. C. I. J. unconditionally. 104 Paraguay based its action, INTER ALIA on the fact that it ceased to be a member of the League of Nations and on the absence of any rule that could prevent it from withdrawing from the Optional Clause system. In fact the real cause for its action was to prevent Bolivia from referring its disputes with Paraguay over the frontiers to the Permanent Court. 105 Six States made reservations as to the legal effect of that withdrawal. 106 Czechoslovakia and the Netherlands observed that in the absence of any provision in the statute regarding the denunciation of declarations, the matter should be regulated by the general rules of international law concerning the termination of international undertakings. Brazil expressed the view that, unless a reservation to that effect was made, it could not accept such a withdrawal. The Swedish government thought that the decision as to the legal effect of that withdrawal should be left to the court. 107 However, Paraguay's declaration had been maintained in the list of operative declarations in the Yearbook of the International Court of Justice until 1959-60 with a note drawing attention to Paraguay's notice of cancellation and the reservations made by 
States mentioned above.

On November 1973, El Salvador also terminated its declaration of 1930, which did not contain any provision for its termination. As a justification for this act, El Salvador relied indirectly on the doctrine of REBUS SIC STANTIBUS. The preamble of the new declaration, which revoked and replaced the new one, referred to change in circumstances such as the promulgation of new political constitutions; the adoption of the Charter of the United Nations; the revision of the charter of the Organization of American States, and the changes brought about in the texts of the declarations of acceptance made by other States. 109 However in its response to Honduras' communication to the United Nations Secretariat challenging El Salvador's act of termination and considering it as "completely lacking in validity", 110 El Salvador relied heavily on the unilateral character of the declaration of acceptance as a "free act in which no other state can interfere". 111

These precedents have been the object of a long debate in the literature. Most of the writers, who have attempted to answer the question of the legitimacy of terminating a declaration made unconditionally connected it with another complicated point, $\forall I Z$, the nature of the declarations accepting the Court's compulsory jurisdiction. 112

It seems natural that views have been sharply divided with regard to the qualification of these declarations. It cannot be denied, on the one hand, that the making of a declaration belongs to the free discretion of the declarant as regards both the time of making it and its terms, as long as they are kept within the framework of the statute. On the other hand, declarations are made according to the statute, which is a multilateral treaty, and create reciprocal obligations between the declarants. 
The Court's guidance has offered another element which has contributed to the depth of that difference. In the PHOSPHATES IN HOROCCO (preliminary objections) case and the CERTAIN NORHEGIAN LOANS case declarations were referred to as an unilateral act. 115 In rejecting the British view in the ANGLO-IRANIAN OIL COMPANY case, that the Iranian declaration should be interpreted as to give meaning to all the words in the declaration, the court said:

\footnotetext{
"The text of the Iranian Declaration is not a treaty text resulting from negotiations between two or more states. It is the result of unilateral drafting by the Government of Iran $\therefore "$.
}

In the ELECTRICITY COMPANY OF SOFIA AND BULGARIA case the Court stated that as a result of the two declarations:

"an agreement came into existence between these two States accepting the compulsory jurisdiction of the court. ... This agreement, hereinafter referred to as the declarations, came into force on March 10th,1926, the date of the Eulgarian ratification." 115

Again in the RIGHT OF PASSAGE OUER INDIAN TERRITORY (preliminary objections) case the Court qualified the relations between the parties and compulsory jurisdiction as "contractual". It held that, at the date of deposit of declarations "the CONSENSUAL BOND, which is the basis of the Optional Clause, comes into being between the states concerned". 116 Furthermore, the Court had used technical terms taken from the Law of Treaties. such as "adherence" or "accession" to the Optional Clause. 117

Thus the determination of the nature of declarations depended very much on which element (i.e. the unilateral making of the declaration or the relations established by the combination of declarations) and case amongst the aforesaid cases have been taken into consideration. Some commentators have concentrated on the unilateral drafting of the declaration and on the ANGLO- 
IRANIAN OIL COHPANY case to reach the conclusion that declarations are unilateral acts and, therefore, they excluded the application of the general principles governing the interpretation of treaties. 118 Some have taken into consideration both elements: the unilateral character and the consensual and bilateral obligations established between States through their declarations. Accordingly declarations are SUI GENERIS 119 and the general rules governing the termination of treaties could be applied to them by analogy. ${ }^{120}$ others concentrate on the effect of joining declarations together. According to this view, declarations are unilateral in form, but contractual in substance. They are governed by the same rules applying to international treaties. ${ }^{121}$ Consequently, declarations made for indefinite term continue in force indefinitely, unless terminated by the consent of all other parties or according to the CLAUSA REBUS SIC STANTIBUS.

It has been pointed out that the question whether a declaration made unconditionally can be denounced "is never likely to arise" before the court. For. INTER ALIA, "once a State has denounced a title of jurisdiction, and especially a declaration accepting the compulsory jurisdiction, it is politically inconceivable that another State would seek to invoke the denounced instrument as the basis for the introduction of a new proceedings". The question is "therefore largely be relegated to the realm of theory". 122

Yet, the HILITARY AND PARAMILITARY ACTIUITIES IN AND AGAINST NICARAGUA case (jurisdiction and admissibility) showed the fallacy of this prediction. Here the court settled both questions, namely the qualification of the declarations, and the possibility of denouncing or withdrawing a declaration made indefinitely. The United States, it is to be recalled, argued that the declarations of acceptance "are SUI GENERIS, are not treaties and are not governed by the law of treaties", 125 and that Nicaragu- 
a's declaration, being indefinitely in duration "is subject to a right of immediate termination, without previous notice by Nicaragua". 124 Nicaragua on the other hand, denied that declarations of this kind are terminable by a simple notice. For, "the general view is said to be that" these declarations "continue in force indefinitely, in contractual terms; the question how far they may be terminable is governed by the principles of law of treaties applicable to consensual legal relations arising within the system of the Optional Clause". It concluded that "there can be no legal justification for the view that (its declaration) is subject to unilateral modification".

Concerning the arguments of the parties as regards the qualification of declarations the court emphasised, on the one hand, the fact that they are "facultative, unilateral engagements, that states are absolutely free to make or not to make". In making them, States are "equally free either to do so unconditionally and without limit of time for (their) duration, or to qualify them with conditions and reservations". Being of an unilateral character, declarations of acceptance of the Court's compulsory jurisdiction are, like other unilateral acts creating legal or factual situations, binding according to their terms, as the court observed in the NUCLEAR TESTS cases. 126 Thus, the court continued, "the unilateral nature of a declaration does not signify that the State making the declaration is free to amend the scope and the contents of its solemn commitments as it pleases". On the other hand the court drew the attention to the second element of the declarations. It said:

"... The declarations, even though they are unilateral acts, establish a series of bilateral engagements with other States accepting the same obligation of compulsory jurisdiction, in which the conditions, reservations and time-limit clauses are taken into consideration. In the establishment ofthe network of engagement, which constitutes the Dptional Clause system, the principle of good faith plays an important role". 
The court then reiterated its jurisprudence in the NUCLEAR TESTS cases that:

"... Just as the very rule of PACTA SUHT SERUANDA in the law of treaties is based on good faith, so also is the binding character of an international obligation assumed by unilateral declaration. Thus interested states may take cognisance of unilateral declarations and place confidence in them, and are entitled to require that the obligation thus created be respected."

It seems from the above statements that the court has followed Waldock's view that the consensual relation between the declarant states is SUI GENERIs. 128

The United States relied INTER ALIA on the precedents in which declarations were modified or withdrawn not in conformity with their terms, to support its claim that Nicaragua's declaration was terminable immediately without previous notice.

In fact, the declaration of El Salvador was the only instance in addition to Paraguay's termination and Columbia's correction mentioned above, in which a declaration for an indefinite term was revoked and replaced the previous one.

However the Court refused to take into consideration these instances, and therefore rejected the United States argument. It said:

".. The right of immediate termination of declarations with indefinite duration is far from established. It appears from the requirements of good faith that they should be treated $;$ by analogy, according to the law of treaties, which requires a reasonable time for withdrawal from or termination of treaties that contain no provision regarding the duration of their validity." 130

It seems thus that the court applied the customary international rule inserted in the Vienna Convention of the Law of Treaties [Article 56 (2)] which requires 12 
months' notice, though it did not say the 12 months would be the reasonable notice for the termination of a declaration of that kind. The court found it unnecessary to determine what reasonable period of notice would legally be required, since Nicaragua did not manifest any intention to withdraw its declaration. It said that "it need only be observed that from 6 to 9 April would not amount to a reasonable time". 131 This statement seems to suggest that that period should be determined according to the circumstances in each case. 132 Presumably a shorter period than 12 months would be sufficient, 135 if the object intended by the requirement of reasonable time is to disallow the state making such a declaration to escape being sued by the other declarant, or to give the latter the opportunity to file an application against that State.

However, the significance of this case in regard to the nature of the relations between the declarant states, being sUI GENERIS, lies in the fact that the court removed any doubt as "to the existence of any contradiction between either its own jurisprudence or that of its predecessor the P. C. I. J. ${ }^{134}$ The unilateral character of a declaration must be taken into account in some circumstances such as the interpretation of the words inserted in it, as the court ruled in the ANGLO IRANIAN OIL conPANY case. 135 . On the other hand, the "bilateral engagements" established within the optional Clause system may require in some instances, and in the absence of a provision to the contrary in the declarations, the application of the general principles governing international treaties. However it must be noted that these principles are not applicable as such, but by analogy as the court observed in this case.

Accordingly if the termination of the declarations of Paraguay and El Salvador had been tested, it would have been difficult not to consider them effective during a reasonable time, especially if the circumstances sur- 
rounding such terminations were taken into account. The former, as already mentioned, had been maintained amongst States accepting the Court's jurisdiction until 1960, and six states protested against its action. The latter relied on the customary international rule according to which treaties for indefinite duration could be terminated after a reasonable time.

Although the requirement of a reasonable time would create some stability between states parties to the Optional Clause, three judges expressed their disagreement with the Court's reasoning. They all gave much consideration to the instability created by declarations made terminable immediately by a simple notice, and relied on the instances of changes to these declarations to suggest that the declaration of Nicaragua should be considered terminable at any time. ${ }^{136}$ If the modification of these declarations creates some uncertainty between the declarant States - as will be seen shortlythe reference to Indonesia's withdrawal from the United Nations and hence from the statute by a notice of 24 hours, seems irrelevant here. 137 Furthermore the argument that how a state can withdraw from the Charter or the statute on 24 hours notice, and cannot do the same to withdraw from a declaration accepting the Court's compulsory jurisdiction, seems but to suggest that treaties are terminable immediately without a reasonable period of time.

It is to be observed finally that Honduras terminated its declaration of March 10, 1960 which was made expressly for an indefinite term by a new declaration deposited with the Secretary-General on May 22, 1986.138 Since it was terminated after the Court's judgment, it might be assumed that the reasonable time requirement is applicable to this termination. For this reason, perhaps, the new declaration does not stipulate that it produces its effects immediately. 


\section{(IV) The Reservation of the Right to Terminate with Immediate Effect}

\section{(i) Validity}

The inconsistency of declarations terminable by a mere notification to the Secretary-General of the United Nations with Article 36 (3) has been questioned in the literature. In fact, if the provision that declarations may be made "for a certain time" (POHP UN DELAI DETEPHINE) is interpreted to mean that declarations must be made for a "fixed" period as opposed to an undetermined period i.e. for a "non-fixed period" according to the French meaning of the term, 13 there would be no doubt that such declarations are not made for a "certain time" and therefore are not compatible with the statute. Thus, many commentators have not hesitated to consider it as not in conformity with the statute. 110 others, although they agree that it is not for a certain time, have found in the Rule in the HETTOPOHH case that once the court has been regularly seised the subsequent termination has no effect on the case referred to it, and in the possibility of invoking the HAXIH ID CEPTH EST AWOH CEPTUN PENELI POTEST by states making it to bring their declarations within paragraph 3 , possible reasons which prevent declarations in this form from being totally incompatible with the statute. 141 The validity of this form has not been contested on the basis of that express stipulation of Article 36 only, but also on other grounds.

Lauterpacht, for instance, expressed the view that:

\footnotetext{
"A wording which leaves the Etate at inerty to denounce an artitration treaty at any moment seriousy impeire its value, and although it can be found in a runber of embitretion conventions, there is little justificetion for it in a general treaty; except inedvertence in dretting":
} 
The third and most convincing ground which is relied on by almost all commentators is the glaring inequality created by such a form between States accepting the Court's compulsory jurisdiction system and its effect on the very purpose of that system.

In 1955 Waldock called attention to the fact that a declaration terminable by a mere notice can be used as an escape clause, since a state, whose declaration is for a fixed period or terminable after the expiration of a given period notice, engaged in dispute with a state whose declaration is terminable at any time and without any warning, may find that its opponent has withdrawn the dispute from the jurisdiction of the Court. Such a state has, thus, no means to sue its opponent, but, recourse to a premature filing of an application at the outset of the dispute. Accordingly, Waldock observed that "one objection to declarations immediately terminable by a mere notice to the Secretary-General is ... the pressure which they put on states to institute proceedings under the Optional Clause without first exhausting the possibilities of settlement out of the Court." 143 However, the fundamental objection to these declarations lies in the fact that "they tend to undermine the whole purpose of the Optional Clause. A state concerned can shape its course of action according to its position as a potential plaintiff or as a defendant". He continues:

"The Fight to terminate the declaration immediately by the mere giving of notice may be used HOT SO HUCH As A MEANS OF TERHIHATING THE GENERAL ORLIGATIOH OF THE STATE CONCERHED TO COHPULSORY IURISDICTIOH UNDER THE OPTIOHAL CLAUSE, BUT AS A MEANS OF HITHDRAHING FROM THE COURT'S COMPULSORY JURISDICTION A PARTICULAR DISPUTE AFTER IT HAS ARISEN." 144

For these reasons Waldock observed that this form of termination may be used to serve much the same purpose as the reservation of vital interests, national honour and independence, with the difference that, unlike these reservations, the rule in the NOTIEBOHN case is applica- 
ble to termination by a simple notice. 145

This one-sided privilege, the inequality and incertitude created by this reservation, and its use arbitrarily in practice have been insisted upon by the publicists as warning signs of its draconic effect on the compulsory jurisdiction system. ${ }^{146}$ This reservation has been used widely in practice, and sometimes in a short period subsequent to the making of a declaration. The United Kingdom, for example, used it six times between June 2 , 1955 and November 27, 1963. Recently Senegal made a declaration on December 2,1985, which replaces its declaration made eight months before (May 3,1985 ) in order to exclude disputes arising before the date of its last declaration. On November 21, 1985, Israel withdrew its declaration of 1956 which was subject to modification on February 1984. 147 Furthermore, the registration of the right to terminate has been used many times after the initiation of litigations before the court. This can be illustrated by many examples. In 1951. Iran terminated its declaration of 1932 after it had been sued by the United Kingdom in the ANGLO - IRANIAN OIL case. India terminated its declaration of 1940 following the application in the RIGHT of PASSAGE case. 148 France terminated its declaration of 1966 following the order of interim measures of protection in the NLCLEAP TESTS cases, ${ }^{149}$ and in the same year (i.e. 1974) India further narrowed the scope of its declaration by including a RATIONE TEHPORIS reservation, excluding disputes arising out of hostilities and including a new reservation designed to prevent an opponent from relying on the General Act of 1928, changes which followed the proceedings instituted by Pakistan in the PRISONERS of HAR case. 150 It has been observed that terminations of declarations following the institution of proceedings, such as those of India and Iran, were made in order to put the states concerned in a defensive posture against new applications in those disputes. 151 
If the termination of declarations in the above cases did not deprive the Court's of jurisdiction by the application of the rule in the NOTTEBOHH case, there are instances in which states were unable to resort to the Court because the opponents' declarations were terminated and replaced by new ones, excluding disputes between these states. In 1954, Australia, for example, made new reservations relating to the Law of the sea to frustrate a possible Japanese application concerning pearl fisheries, 152 and in 1955, the United Kingdom terminated its declaration made only five months previously, with the apparent aim of excluding its dispute with Saudi Arabia over Buraimi Oasis after the break-down of the attempted arbitration. 153 Again, in 1957, the United Kingdom introduced a new reservation concerning disputes which might affect national security in order to preclude any challenge to its nuclear weapons testing. 154 In 1970. Canada made a new reservation so as to exclude a possible American application regarding the Arctic Waters Pollution Prevention Act. 155 Another example is provided by the United States attempt to terminate or modify temporarily its declaration of 1946 UIs-A-UIS Central Amercan States. ${ }^{156}$ Following published reports that Nicaragua was planning to bring a complaint against the United States, the latter made on April 6, 1984, its new reservation with the aim of preventing Nicaragua from bringing the dispute before the Court. 157 Although this example may not be relevant here, its significance lies in the fact that the United States contended that its declaration could be modified at any time. If that contention had been accepted, the court would have been deprived of jurisdiction in that case.

Although the instances mentioned above are considered as terminations, Judge Jennings considered them as modifications to declarations which, though they reserved the right to terminate, did not expressly reserve the right to modify. ${ }^{158}$ However, the qualification of these changes as modifications or terminations seems 
to be theoretical, since those states could have notified the Secretary-General separately "of the intention to terminate the previous declarations or to include in the new declaration a clause to the effect that "this declaration revokes and replaces the previous declaration" as did India in its declaration of 1974.159

Having taken into account Waldock's view and State practice, some publicists have raised the question that, if the reservation of the right to terminate by a simple notice is invalid, will the whole declaration be invalid or is it valid despite the invalidity of the reservation?

Although the damaging effects of the immediate denunciation are now incontrovertible, there are, however, some grounds which may support its validity. Firstly, according to Article 36 (5) of the Statute, declarations made under the optional Clause of the P. C. I. J. are deemed acceptances of the compulsory jurisdiction of the present Court "in accordance" with their terms". Accordingly, the declaration of South Africa of 1940 made terminable by a simple notice was deemed as a valid acceptance of the compulsory jurisdiction of the present Court. It may be argued that the drafters of the present Statute had not much time to consider each reservation made before, and they did not have in mind that the effect of this reservation would be drastic. However, the broad statement made by the drafters as to the possibility of making reservations, ${ }^{161}$ coupled with the provision of Article 36 (5) leave no doubt as to the validity of the declaration of South Africa according to its terms. Secondly, the right to terminate with immediate effect has been widely used - as has been said - without any protest at least form states making their declarations for a fixed period or unconditionally. Thirdly, and this is the most important, the Court seems to have considered it as valid. In the RIGHT OF PASSAGE OUER INDIAN TERRITORY case (preliminary objections) the court refused to consider the Portuguese Third Condition, by 
which Portugal reserved the right to modify its declaration by excluding categories of disputes at any time, as being worse than the reservation in India's declaration, i.e. the right to terminate at any time, though India argued that the Third Condition was incompatible with the object and the purpose of the Optional $\mathrm{Clause}$ and hence invalid, and that it created such uncertainty as to the reciprocal rights and obligations of the declarants. 162

The Court held that the Third Condition was valid in spite of the fact that it admitted that "clauses such as the Third Condition bring about a degree of uncertainty as to the future action of the accepting Governments". It added that the uncertainty created by Portugal's condition was substantially the same as that created by certain States, including India, whose declaration was terminable immediately. There was "no essential difference, with regard to the degree of uncertainty", the Court Said. 165

Thus, the court rejected all the grounds on which the reservation of the right to denounce a declaration have been opposed. In fact, both conditions have the same effect. A State whose declaration contains a condition to modify at any time can escape being sued, as can the State whose declaration is terminable upon notice, before the court if the declaration was modified or terminated before the seisin.

As to the uncertainty, as a common factor to both conditions, the court held that it is "inherent in the operation of the system of the Optional Clause". 164 The Court thus let prevail the unilateral character of a declaration over the bilateral engagement established under the compulsory jurisdiction system.

In the MILITARY AND PARAMILITARY ACTIUITIES IN AND AGAINST NICARAGUA case (jurisdiction and admissibility) the Court seems also to have confirmed the validity of the right to terminate on notice. It did not maintain 
expressly that such a condition is valid, but it did not deny that right, though the United States argued - as has been seen - 165 that its declaration was terminable at any time and that a large number of declarations have been terminated by a mere notice. On the contrary the Court said that:

"... Since the United States purported to act on 6 April 1984 in such a way as to modify its 1946 Declaration with sufficiently immediate effect to bar an application filed on 9 April 1984, it would be necessary, if reciprocity is to be relied On, for the NICARAGUA DECLARATIOH TO BE TERHIHABLE HITH IHHEDIATE EFFECT".

The Court referred also to its statement in the NUCLEAR TESTS case that:

"When it is the intention of the state making the declaration that it should become BOUND ACCORDING TO ITS TERHs, that intention confers on the declaration the character of a legal undertaling, the State being henceforth legally required to follow a course of conduct consistent with the declaration." 167

Although this statement was made with regard to unilateral declarations in general, its quotation while considering the nature of declarations made under Article 36 (2) is, perhaps, of significance.

It is regrettable that the Court did not declare the invalidity of either the reservation of the right to terminate on notice and the Portuguese Third Condition, when the number of declarations containing them was comparatively small. It is regrettable also that the number of declarations containing the former has increased, though the majority of these declarations have never been terminated or modified, and some have not been subject to modification or termination for a long time. 168 In the light of the examples of termination mentioned above, and the possibility offered to other states to follow such actions, the pretence by which states purport 
to accept the compulsory jurisdiction of the Court while running very little risk in accepting it in any case in which they wish to avoid being made a respondent is. therefore, a throwback to the era before the League of Nations in which elastic reservations of vital interests and national honour, unilaterally determined, were inserted. 1 \%

\section{(ii) Solutions}

If the Court's statement that uncertainty is inherent in the optional Clause is accepted, and if the above interpretation that the reservation of the right to terminate on notice is valid according to the Court's jurisprudence is correct, there would seem to be no solution to the imbalance between states parties to the compulsory jurisdiction system, except either to modify Article 36 in such a way as to forbid this form completely, or to have declarations for fixed period or unconditionally modified.

Although the modification of the statute seems difficult in the prevailing circumstances and might not acquire the necessary votes owing not to the possible opposition of states making it, but mainly due to the opposition of states not parties to the compulsory jurisdiction system, a minor change requiring the suppression of this possibility might be adopted.

Concerning the modification of States' declarations, it may be suggested that declarations which are not terminable upon notice should be modified as to include a clause providing for that the Court's compulsory jurisdiction is accepted only in relation to states whose declarations are terminable after the expiration of a given period notice, say for example 12 month notice. However such a suggestion would turn out to be draconian in its effect, because it would exclude the majority of States accepting the Court's compulsory jurisdiction. 171 
It is also suggested to stipulate that "no notice of withdrawal will be effective if given sooner than six months after the occurrence of the events that give rise to the cause of action". 172 This suggestion seems also far from being a cure to the problem of "hit-and-run". Because, firstly it would create another reservation RATIONE TEHPORIS putting another burden on the Court for determining the critical date - as will be seen -, and secondly, if it would allow the respondent to sue the plaintiff states for another case, since the respondent can make a counterclaim against the plaintiff arising out of the litigation instituted by the latter, even if it has withdrawn its acceptance of jurisdiction, it may not achieve the same purpose in the relations between that State and the declarant. For, a dispute may take a long time before being brought to the knowledge of other States and hence they may know after the lapse of the period of six months.

It appears, therefore, as D'Amato points out, that the above solutions to the hit-and-run problem are cures worse than the disease. 173

A radical solution to the problem was proposed by the Institute of International Law in its resolution of 1959. 174 After a long discussion on time-limits conditions it was proposed at one time to require that the declarations must be made for an indefinite period. 175 The members of the Committee entrusted with making a report on obligatory jurisdiction did not agree upon that solution, but they agreed to eliminate totally the formula of termination on notice as a progressive step for the substitution of the principle of obligatory jurisdiction for the principle of voluntary jurisdiction. Owing to the belief that it was impossible to obtain the necessary votes required for the amendment of the statute, 176 and the desire to maintain the declarations made before it was agreed to draw the attention to the incompatibility of such a reservation with Article 36 (3). 177 The 
solution which was envisaged was that declarations should be for a fixed period of no less than five years renewable tacitly for the same period, unless notification of denunciation was given not less than 12 months before the expiration of any such period. 178

However, a solution based on the last requirement alone, i.e. a declaration for indefinite period subject to one year's notice of denunciation seems to be sufficient, if not better. For, while it would suppress the surprise element - or the "single shot" problem, it may encourage states not familiar with the system to adhere since they are not required to make their declarations for a long period.

A further solution has sometimes been envisaged in the application of reciprocity to time-limit conditions. Which is the subject of the next point.

\section{D - INAPPLICABILITY OF RECIPROCITY}

The application of reciprocity to time-limits as a solution to the imbalance created by the condition to denounce on notice, was suggested for the first time by Professor Waldock. In regard to the time factor, reciprocity does not mean only that the duration of the mutual obligations - the juridical bond - between any two states under the Optional Clause is limited to the joint period during which both declarations are in force, but

\footnotetext{
"there is . . another aspect of reciprocity in regard to time-limits ... Feciprocity would seem to demand thet in any given pairs of States each should have the same right as the other to terminate the juridical bond existing between them under the optional clause ... It is one thing to hold that a unilateral declaration made without time-limit binds a state concerned indefinitely toward other states which have made similar declarations. It is quite another thing to hold that such a unilateral declaration is binding indefinitely towards other states which have not undertaken the seme commitment. The inequality in the position of the two states under the optional Clause, if the principle of reciprocity is not ap-
} 
plied to time-limits, becomes absolutely inadmissible when a State $A^{*} 5$ declaration is without time-limit while that of State $B$ is immediately terminable on notice to the SecretaryGeneral. It would be intolerable that State E should al ways be able, merely by giving notice, to terminate at any moment its liability to compulsory jurisdiction vis-a-vis state $A$, whilst the latter remained perpetually bound to submit to the Court's jurisdiction at the suit of state $\mathrm{B} . "$

Accordingly, Norway was able to deprive the Court of jurisdiction in the ANGLO-NORHEGIAN FISHERIES case, if it had terminated its declaration which was made for a period of ten years, on the basis of reciprocity, since the declaration of the United Kingdom was terminable on notice, he observed. As to the question whether such termination would be vis-a-vis all states whose declarations are terminable on notice, or only vis-a-vis the State party to the dispute, he believed that it would be vis-a-vis the latter only because the relations established between States under Article 36 (2) are of a bilateral rather than multilateral character. ${ }^{180} \mathrm{He}$ carried the argument further, so as to apply reciprocity, even in the ordinary case between a state whose declaration is for a fixed period and the state whose declaration is without limit. Since the former may choose at the end of the period of its declaration whether to renew or terminate its obligations towards the state whose declaration is without limit, the latter "may reasonably contend that, it also is entitled at the end of the period to choose whether or not to continue its particular obligation towards" the former. He concluded that "the court must hold that under the Optional Clause each State, with respect to any other state, has the same right to terminate its acceptance of compulsory jurisdiction as is possessed by that other state". 181

Assuming that Waldock's view is correct, the question is how can it be applied in practice? Leaving aside for a while the application of reciprocity between states whose declarations are terminable on notice and the other states, and without entering into detail in regard to the 
complications that may be created by the application of reciprocity between the category of States $A$, whose declarations are for a fixed period, and that of states $B$, the declarations of which are without time-limit, in determining which state amongst the latter has relied on reciprocity and which has not (bearing in mind that Waldock did not explain whether the termination of the declaration of a State $B$ towards a State $A$ needs an express declaration or notification of termination, or that state can claim later before the court that its declaration was terminated at the time when the plaintiff renewed its declaration), it may be asked what is the purpose of applying reciprocity between those States? If State A terminates its declaration towards state $B$, the latter cannot be sued by the former any more before the Court. Moreover, there is no escape clause in that case. since state $B$ knew the exact date on which the declaration of State A was terminable, and it could, therefore, have shaped its course of action accordingly.

However, the question is settled by the Court - as already mentioned ${ }^{182}$ - by the application of the requirement of a reasonable time for the termination of declarations made unconditionally. In other words, such declarations are no longer indefinitely.

The application of reciprocity between States $A$ and $B$ on the one hand, and state $C$ whose declaration is terminable by a simple notice, on the other hand, seems to add to the complication of the compulsory jurisdiction system. It is to be observed firstly, that Waldock's view seems to contradict the rule in the NOTTEROHH case, that once the Court has been regularly seised in the subsequent termination of a declaration by notice or expiry is irrelevant on the case before the Court. ${ }^{183}$ What he was arguing for is the application of the other aspect of reciprocity - as he termed it - namely, before the seisin. To apply reciprocity before the seisin means simply to give state $A$ or $B$ the right to terminate their declar- 
ation towards state $C$ not only because state $C$ may terminate its declaration, but also because state $A$ or $B$ wants to avoid being brought before the court. It is, perhaps, clear now that the cure proposed against the disease of the "gross inequality" could turn out to be a cause for the wide spread of the disease. In other words, the application of reciprocity in this context could have the effect of destroying what has been left by the inclusion of the condition to terminate by a simple notice. and render the compulsory jurisdiction system a mere form according to which dispute can be brought before the Court except by the consent of both parties, i.e. nullifying the effect of paragraph 2, except in the relations between states $A$ and $B$, which have not escaped the complication of this view. 184

THE RIGHT OF PASSAGE OUER INDIAN TERRITORY case (preliminary objections) gave Waldock an opportunity to develop his view. In this case he argued on behalf of India that reciprocity should operate even prior to the deposit of an application before the court so as to establish an equivalence of reservations and conditions between any pair of states accepting the compulsory jurisdiction of the Court. Accordingly. India had the right to rely on the Portuguese Third Condition to modify its declaration at any time during its validity by a simple notification to the Secretary-General of the United Nations. Thus, he considered as unfounded the Portuguese argument that according to Article 36 (2) of the statute, reciprocity "is only concerned with the extent of the obligations of the two states at any time when the case is brought before the court". 185 "The condition of reciprocity provided in the statute "was clearly intended to be a general and continuing reciprocity governing the relations between the two states from the date of the establishment of the juridical bond between them until the date of its termination by the Declaration of one of them.", he argued. He rejected the Portuguese argument that by claiming to extend the scope 
of reciprocity to the measures that the states concerned might make before the institution of proceedings India distorted the system of compulsory jurisdiction. 186

As to these agreements the Court said:

"As Declarations, and their durations, made under Article 36 must be deposited with the Secretary-General, it followed that, HHEN A CASE is SURHITTED TO THE COURT, it is always possible to ascertain what are, AT THAT HOMEHT, the reciprocal obligations of the Farties in accordance with their respective Declarations".

For these reasons, perhaps, Waldock's view has not gained acceptance in the doctrine. ${ }^{188}$ The general view is that reciprocity does not operate as to time-limits.

However, the Court's judgment in the MILITARY AND PARAHILITARY ACTIUITIES IN AND AGAINST NICARAGUA case (jurisdiction and admissibility) is explicit on the point and clears the air. Here the United States contended, as summarised by the court, that:

"The principles of reciprocity, mutuality and equality of States before the Court permit the United States to exercise the right of termination with the immediate effect implicitly enjoyed by Nicaragua, regardless of the six months" notice proviso in the United States declaration." 190

In rejecting this argument the Court said:

"the notion of reciprocity is concerned with the scope and substance of the commitment entered into including reservations, and not with the formal conditions of their creation, duration or extinction." 191

Reaffirming its jurisprudence in the RIGHT of PASSAGE case, as cited above, that the critical date for the establishment of "the same obligation" is "the moment of the filing of the application", the court added: 
"The possibility that, prior to that moment, the one enjoyed a wider right to modify its obligation than did the other, is without incidence on the question." 192

In this case. Waldock's view was revived not only because the United States relied on it in its arguments, but also two judges 193 referred to it directly and one judge ${ }^{194}$ relied on it indirectly.

Judge Jennings pointed out that the idea of applying reciprocity before the seisin rather than after or at seisin is not free from difficulty and would be something of an innovation. For in ascertaining whether the court has jurisdiction, three factors must be taken into consideration: "the terms of the declarations of the two States concerned". and "the terms of the application" in the case.

\footnotetext{
"It is the latter which makes practicable the search for coincidence between the two declarations, and males it practicable because the necessary coincidence is limited to coincidence in respect of the subject matter of the application".
}

Therefore, he thought that "it is almost an implication of this dictum that it is not possible to make that ascertainment other than at the moment when a case is submitted to the Court". 195

Judge Oda's view is not clear on whether or not reciprocity would be applied to time-limits. After asking whether it was reasonable or equitable to allow a state as a respondent to escape at any time from the Court's compulsory jurisdiction and to take advantage as an applicant by imposing upon the other party the burden of inescapability, which it did not bear, he concluded that "the reciprocity of the obligation must exist at the date of the seised of the case, and acceptance of the Court's jurisdiction by the Applicant and the Respondent must be current at that date". Thus the United States was, in his view, fully exempted from the Court's jurisdiction in relation to Nicaragua on the date of Nicaragua's applica- 
tion, because the latter was not in a position to invoke the obligation which it did not bear and which the United States had borne.

He predicted that his interpretation may be criticised as an attempt nullify the original intention of the Optional Clause, but he found the answer to such a criticism in the development of state practice especially since 1945, namely, the compulsory jurisdiction has not been substituted for the Optional Clause as it was hoped for in 1945; the majority of States have not accepted the Court's compulsory jurisdiction, and amongst states accepting it only a small number impose upon themselves the obligation not to escape from the compulsory jurisdiction of the court in the face of being brought before the court. 196

Certainly no one can deny that these points are regrettable facts. Yet is it the condition of the right to terminate on notice that has been the cause for such a situation? Did any state amongst those which have imposed upon themselves the obligation not to escape, pretend before that case that its declaration was terminable by a simple notice? As has been said El Salvador is the only State which had modified its declaration before that judgment and according to the rule REBUS SIC STANTIBUS. Furthermore the declarations of these states are now terminable either by the expiry of the period notice set for in these declarations or after a reasonable time which in any event does not exceed 12 months, but they have not been terminated so far. The modification of Honduras' declaration is the only exception. Thus the view that "the Court should not close its eyes to practice and experience over the last 40 years" seems to be an exaggeration.

Judge Mosler found in the requirement of Article 36 (2) that the consensual bond exists only between states accepting the same obligation" a basis for applying 
reciprocity in regard to time-limits. It must, in his view, be applied to both types of qualifications which are permitted to be included in the declarations. He said that :

"Feservations restrict the substantive extent of the obligation, time-limits put an end to the obligation, whether made with or without substantive limitations, in its entirety. It is difficult to see how the "same obligation" within the meaning of Article 36, paragraph 2, can continue to exist longer for one state than for its potential counterpart whose declaration is limited by a shorter noticeperiod, or may be terminated by notification at any moment".

Judge Mosler, then, seems not to share the general view that the expression "the same obligation" does not require that declarations need not be identical. 199 It is true that according to the Court's ruling in the RIGHT OF PASSAGE case repeated in the HILITARY AND PARAHILITARY ACTIUITIES case that the expression the "same objection"

\footnotetext{
"means no more than that, as between states adhering to the Optional Clause, each and all of them are bound by such IDENTICAL OBLIGATIOHS as may exist at any time during which the acceptance is binding:"
}

However this statement was made with regard to reservations as distinguished from conditions. Also, it means no more than that however the declarations of the parties to the dispute before the Court differ in their scope by the inclusion of different reservations, the common ground or "identical obligations" are ascertainable at the time of the seisin. Moreover, how can it be denied that the declarations involved in that case, having been made according to the latter and spirit of Article 36 (3), did not meet the requirement of the same obligation?

In arguing for the application of reciprocity to time-limits Judge Schwebel advanced four reasons. Firstly, he relied on the mutuality and the sovereign equality of States before the law and the Court. This seems to be 
inspired from Waldock's view quoted by Schwebel in his fourth reason. These arguments have already been discussed above. As a second reason, he pointed out that "the Court has more than once entertained arguments about the application of reciprocity RATIONE TEMPORIS. It has never held that reciprocity does not apply to temporal conditions. ON THE CONTRARY both opposing States in these cases and the Court appear to ave assumed that it did or might". Then, he mentioned the PHOSPHATES IN HOROCCO, the ANGLO-IRANIAN OIL COHPANY and the RIGHT OF PASSAGE OUER INDIAN TERRITORY cases, in addition to Helmut steinberger's view. Finally he stated in the third argument that "the United States, in drafting its declaration of 14 August 1946, made it clear that it did not regard the safeguard of reciprocity as applying to temporal conditions". 201

It is to be observed that there is no indication whatsoever in any of the cases referred to from which it could be deduced that the court intended to extend the scope of reciprocity as to cover time-limits as distinguished from RATIONE TEHPORIS reservations. On the contrary the Court refused, as already mentioned, 202 in the RIGHT OF PASSAGE OUER INDIAN TERRITORY case to apply reciprocity to the PORTUGUESE THIRD CONDITIOH. Helmut Steinberger also does not say that reciprocity applies to time-limit conditions. In the passage quoted by Judge Schwebel himself, Steinberger says:

\footnotetext{
"The Court in several cases has confirmed the wide operational scope of the condition of reciprocity and stated the jurisdiction under the Optional clause is conferred on the Court "only to the extent to which the two declerations coincide in conferring it". THAT GOES FOR THE JURISDICTION RATIUTE TEHPORIS AS HELL AS FOR THE JURISDICTIOH RATIME HATERIA".
}

It appears thus, that Judge Schwebel overlooked the difference between reservations RATIONE TEMPOPIS and time-limit conditions. This is supported by his third reason. In fact, the United states did not regard the 
safeguard of reciprocity as to temporal conditions, but an example was given how reciprocity applies to RATIONE TEKPORIS RESERUATIONS. The passage quoted by Judge Schwebel himself from the Senate Report reads:

"Any limitation imposed by a State in its grant of jurisdiction therety also becomes available to any other state with which it might become involved in proceedings, even though the second state has not specifically imposed the limitation. Thus, for example, if the United states limited its grant of jurisdiction to cases "THEREAFTER ARISIHG" his country would be unable to institute proceedings regarding earlier disputes, even though the defendant State might not have interposed this reservation." 204

The conclusion to be drawn from what has been said is that reciprocity cannot be applied with regard to time-limits whether before or at the seisin, and the solution to the problem created by the condition to terminate at any time lies in the elimination of the condition according to the suggestion discussed above, if States are genuinely interested in promoting the rule of law in international relations through the compulsory jurisdiction of the International Court of Justice. 


\section{SECTION 2 : VARIATION, OF DECLARATIONS \\ (THE PORTUGUESE THIRD CONDITION)}

In 1955 Portugal accepted the compulsory jurisdiction of the court subject to three reservations and conditions the third of which constituted a complete innovation. By virtue of this condition Portugal reserved "the right to exclude from the scope of [its] declaration, at any time during its validity, any given category or categories of disputes, by notifying the SecretaryGeneral of the United Nations and with effect from the moment of such notification." 206 The Portuguese reliance on its declaration in the RIGHT OF PASSAGE OUER INDIAN TERRITORY case. 207 Three days after its deposit with the Secretary-General of the United Nations 208 gave the Court an opportunity to examine this condition from all angles. 209 This case was thus significant for many reasons. Firstly it was the first case in which the court made a distinction between reservations and conditions with the effect of limiting the application of reciprocity only to the former. Secondly, the meaning of the requirement of accepting "the same obligation" provided for in Article 36 . (2) of the Statute was explained for the first time in this case. Thirdly, it was the first case in which the validity of a condition or reservation inserted in a declaration of acceptance was invoked. The two first points are discussed elsewhere. 210 Reference to the third point has also been made. 211 However, the way in which the court handled the Indian challenge to the validity of this condition and its importance as a criterion for the permissibility of making reservations might require an extensive consideration.

In its first preliminary objection India argues that the Portuguese Third Condition was invalid and entailed the invalidity of the whole declaration because of its incompatibility with the object and purpose of the compulsory jurisdiction system. Therefore, Portugal did not accept at all the Court's jurisdiction under Article 
36 (2) of the Statute. ${ }^{212}$ Three reasons were invoked for such incompatibility.

Firstly, it was maintained that the Third Condition was open to the interpretation that Portugal reserved to itself the right to exclude from its declaration any dispute at any time, even a dispute in respect of which proceedings had already been instituted before the court. The retroactive effect of this condition ran against the principle and notion of compulsory jurisdiction. 213

Secondly, India argued that states party to the compulsory jurisdiction system were entitled to expect a reasonable degree of certainty in regard to the obligation imposed upon them by the declarations of other States. However the Portuguese Third Condition had introduced into the declaration of the interested state a degree of uncertainty as to the reciprocal rights and obligations under Article 36 (2). It, thus, put the parties to the compulsory jurisdiction system in a continuous state of uncertainty as to their rights and obligations which might change from day to day. This state of uncertainty rendered the declarant's acceptance of compulsory jurisdiction illusory. 214 Furthermore, there would be and inevitable time-lag between a modification to the obligation made pursuant to this condition and the receipt of other states of notice of that modification. During that interval the interested states would have a quite different understanding as to the categories of disputes accepted under Article 36 (2) of the statute. 215 It was erroneous to compare the reservation of the right to vary the scope of the declaration by giving notice and the right to terminate the whole declaration on immediate notice. India argued. For, in case of total termination the interested state can neither sue nor be sued. In contrast, in the case of the Third Condition it could protect itself against any inconvenient categories of disputes which might be brought by other States while at the same time it could maintain its claim 
to sue other States in respect of other categories of disputes. 216

The third reason advanced for the invalidity of the Portuguese Third Condition was that it offended against the basic principle of reciprocity underlying the compulsory jurisdiction system inasmuch as it conferred on Portugal a right which was denied to other States which did not make such a condition.

Portugal, on the other hand, denied that its Third Condition was intended to have such an effect. It maintained its view expressed in its communication to the Secretary-General of the United Nations after the Swedish challenge to the validity of its declaration because of the Third Condition, 218 that this condition was not capable of divesting the court of jurisdiction retrospectively. 219 It argued also that there was no uncertainty with regard to the reciprocal obligations of the parties at the time of submission of a case to the Court. Certainly the Third condition was capable of creating some uncertainty during the interval between a modification to the obligation and the receipt of other states of notice to that notification. However this uncertainty was similar to that created by the termination of a declaration by a simple notification without any obligatory period of notice. In the latter case the interested state could denounce its declaration and immediately make a fresh one excluding certain disputes. Legally such an act might be considered an operation of two parts. In contrast practically it was a simple act, because, the two parts could be made simultaneously by the same act of notification to the Secretary-General as did India when it terminated on February 7, 1956 its previous declaration and deposited a new one which was more restrictive. 220 Thus Portugal claimed that the power to terminate the entire declaration was a greater derogation from the compulsory jurisdiction system than a power merely to restrict its scope. Why should the lesser power have been inadmissible if the 
greater was permissible, it was asked? ${ }^{221}$

Portugal argued also that India misunderstood the operation of reciprocity. For it did not claim the benefit of any modification introduced under the Third Condition, but the right to modify its declaration even when Portugal did not exercise such a right. ${ }^{222}$ Thus, Portugal maintained that its Third Condition was valid since it did not violate any provision of the statute of the Court. Furthermore, it argued that even if its Third Condition were invalid, it did not follow automatically that its entire declaration was invalid. For, the nullity of a clause would nullify the entire act in which it was inserted only when that clause did constitute an essential element of the act, an element which cannot be isolated without prejudice to the will of the interested State. 223 India had, therefore, to prove that the Portuguese Third Condition did constitute an "impulsive and determinant clause" for the Portuguese decision to accept the Court's jurisdiction. ${ }^{224}$ Its Third Condition did not constitute an essential part of the declaration, Portugal maintained. The only consequence which could be drawn from the nullity of the Third Condition was therefore to consider that condition as unwritten. 225

The Court followed generally the Portuguese reasoning. It found that the validity of the Portuguese Third Condition and its effect on the entire declaration depended very much on the meaning of this condition which must be determined according to the "actual wording" of the condition and "applicable principles of law". 226 Consequently, relying on the ordinary sense of the words "with effect from the moment of such notification", the court held that these words meant simply that a notification under the Third Condition would apply only to a dispute referred to the Court after the date of the notification. No retroactive effect would properly be imputed to notification made under this condition. The Portuguese Third Condition did not, therefore, run against the NOTTEBOHH 
rule 227 which "must be deemed to apply both to total denunciation and to partial denunciation as contemplated in the Third Portuguese Condition", the Court said. 228 The court admitted that such a condition brought about a degree of uncertainty as to the future action of the accepting state especially during the interval between the date of a notification to the Secretary-General and its receipt by the parties to the statute. However this uncertainty did not differ in any way from that created by a total denunciation of a declaration immediately terminable by notice to the Secretary-General. The uncertainty created by both forms "is inherent in the operation of the system of the Optional Clause and does not affect the validity of the Third Condition contained in the Portuguese declaration".

As to the effect of the Third Condition on the basic principle of reciprocity, the court declined to share the view that this condition offended against that principle. For any new reservation introduced under this condition would operate automatically against the reserving state. Nor did the court accept the view that the Third Condition affected the requirement of accepting the same obligation because this expression meant no more than that the obligations of the parties to a dispute must be identical at any time during which the acceptance is mutually binding.

Having found that the Portuguese Third Condition was not inconsistent with the statute, the Court did not consider the effect of the invalidity of a reservation on the validity of a declaration as a whole. 231

As a consequence of this holding the Portuguese third Condition has been widely adopted. It figures now in fifteen other declarations ${ }^{232}$ two of which are limited to the special question of dispute settlement in the law of the sea. 235 of those fifteen declarations only those of El Salvador and Honduras do not expressly state 
that any future reservation is to have effect only from the date on which it is notified to the Secretary-General. 234 The declaration of $\mathrm{El}$ Salvador provides simply that El Salvador is "able at any time to modify, add, clarify, or derogate from the exceptions presented in it". 235 However, this declaration must be interpreted as to exclude any retrospective effect. For, any attempt to give a retrospective effect to new reservations introduced under this condition would violate the NaTTEBOHM rule and must be regarded as incompatible with the statute. 236

The question of the difference between the reservation of the right to denounce the whole declaration and the right to vary it has lost significance in most declarations since both rights are simultaneously reserved. The declaration of $\mathrm{El}$ Salvador is the only one, amongst those which contain this condition, which is made for a fixed period. 257 Two other declarations are now terminable on the expiration of six months after notice has been given of termination. ${ }^{258}$ The declarations of Botswana. Malawi and Senegal are with no provision on termination. 239 There is, however, a difference between a total termination of a declaration and a modification made pursuant to the condition in question. Whereas in the latter case the same declaration continues to produce its effect, the replacement of the previous declaration in the former case is to be considered as a new acceptance independent of the previous. This difference might be of critical importance for determining the consensual bond between a state which has modified or terminated its declaration and a state excluding disputes with any other State whose declaration was deposited or ratified less than twelve months previous to the filing of the application bringing the dispute before the court. 240 Thus. whereas a state which has modified its declaration continues to be a state accepting the same obligation vis-avis the State making the latter reservation; the total termination of a declaration and the deposit of a new one 
will prevent the interested state from suing that state and UICE UERSA before the expiration of 12 months after the entry into force of the new declaration. 241

In practice however, and in spite of its popularity, the Third condition was used only once. On December 2. 1985 Senegal modified its declaration which was made eight months previously for the purpose of adding a RATIONE TEHPORIS reservation. 242 However this should not undermine the possible draconic effect of the Third Condition on the compulsory jurisdiction system. It is in fact capable - as the Court observed 243 - of producing the same effect as the condition to terminate a declaration on immediate notice. It is therefore open to exactly the same objections put forward against the latter. 244 In an era "of instantaneous communication and elaborate intelligence - gathering networks, advanced knowledge of the preparation of an application", they are both capable of turning the compulsory jurisdiction system into one in which States decide on a case-by-case basis whether to subject themselves to the Court's jurisdiction. 245

However, the conclusion to be drawn from the Court's treatment to the Third condition is that the inconsistency of a condition or reservation with the statute of the court would lead to the invalidity of such a condition or reservation. 


\section{NOTES}

(1) See G.F. Jones, "Termination of Declarations Under the Optional Clause :Military and Paramilitary Activities in and against Nicaragua ", 20 T.L.I.J. (1985), pp.557-581, at 563 ; K. M. loannou, "Reservations to the Acceptance of Compulsory Jurisdiction of the I.C.J. _ A Tabular Analysis of their Procedural Treatment", Hellenic R.I.R.(1980), pp.415-437, at 415; J.P. Kelly, "the International Court of Justice : Crisis and reformation ", 12 Y.L.J.I.L. (1987), pp.342-374, at 351, and S. Rosenne, the Law and Practice of the International Court, 1985, p. 389.

(2) Military and Paramilitary Activities in and against Nicaragua (Nicaragua v. United States of America), Jurisdiction and Admissibility, I.C.J. Reports 1984, p.392, 419, para. 62.

(3) See Crawford, "the Legal Effect of Automatic Reservations to the Jurisdiction of the International Court of Justice" 50 B.Y.B.I.L.(1979), pp.63-86, at 77 and G.F. Jones, supra note 1, p.562.

(4) See S. Rosenne, the Law ..., supra note 1, pp.389-390.

(5) See the Diss. Op. of Judge Barwick in the Nuclear Tests case (Australia v. France), Judgment, I.C.J Reports, 1974, p.253, at 417-418.

(6) See e.g. the termination of declarations made for undefined period, pp.40-51 below.

(7) Although this classification is widely adopted as a traditional one, there is room for differences of opinion as to whether a particular reservation fits better into one class than the other. Comp. for example the classification adopted by $L$. Gross, "compulsory Jurisdiction Under the Optional Clause", in L.F. Damrosch (ed.), the International Court of Justice at a Crossroads, 1987, pp.19-57, at 24-26(tables 1, 2 and 3), and E.B. Weiss, "Reciprocity and the Optional Clause", ibid., pp.82-105, at 90-93.

(8) Albania, Argentina, Australia, Belgium, Bolivia, Brazil, China, Czechoslovakia, Denmark, Egypt, Ethiopia, Finland, France, Germany, Greece, Hungary, Ireland, Liechtenstein, Lithuania, Monaco, the Netherlands, Norway, Peru, Poland, Romania, Sweden Switzerland, Thailand, Turkey, and Yugoslavia. For the text of declarations made under the Optional Clause of the P.C.I.J. see P.C.I.J., Series D No.6, pp.33-54 and Series E, No. 15, pp.213-255, and M.O. Hudson, the Permanent Court of International Justice ,1920-1942. A Treatise, 1943, pp.683-705.

(9) Belgium, Bolivia, Brazil, Denmark, El Salvador, Guatemala, Norway, Sweden, Thailand and Turkey.

(10) I.C.J.Y.B. 1984-85, p.73.

(11) These are the declarations of Colombia, Dominican Republic, Haiti, Nicaragua,Panama, and Uruguay.

(12) Because they were not members of the United Nations and not parties to the Statute. the Bulgarian declaration was invoked by Israel in the Aerial Incident of July 1955 case[(Israel v. Bulgaria), Judgment, I.C.J. Reports 1959, p.127], but the Court held that the Bulgarian declaration was lapsed at the date of 
the dissolution of the P.C.I.J.

(13) See pp.106-107 and 111 below.

(14) Botswana and Senegal reserve the right to add, amend or withdraw any of the reservations included in their declarations, but not to modify or terminate the declarations themselves.

(15) Ibid., at 90 . Although the declaration of Honduras of 1960 provided expressly that it was made "for an undefined term " it was terminated by the declaration of May 22, 1986. See ibid., 1984-85, at 76 and 1985-86, at 71.

(16) The declarations of China and the United States were made in the same form . The declaration of the Costa Rica is simply made for a period of five years and shall be understood to be tacitly renewed for like periods unless denounced before the expiration of the said period. Ibid., 1986-87, p.64.

(17) C.H.M. Waldock, "Decline of the Optional Clause", 32 B.Y.B.I.L.(1955-56), pp.244-287, at 269.

(18) Ibid. See also H.Lauterpacht, "the British reservations to the Optional Clause", 10 Economica(1930), pp.137-172, at 144.

(19 "the Optional Clause ", (the British Signature and Reservations), 11 B.Y.B.I.L.(1930), pp.63-84, 75.

(20) It is to observed that the current declaration of New Zealand is terminable after the expiration of six months' notice (I.C.J.Y.B. 1985-86, at 81 ); those of Iran and Latvia were terminated and that of Iraq had never entered into force because of lack of ratification.

(21) The declarations of Austria, Belgium, Democratic Kampuchea, Japan, Liberia and Portugal. This form was also used France (declarations of 1947 and 1959), the Netherlands(1946), and the Philippines(1947).

(22) 200 L.N.T.S. ,p.493.

(23) See e.g. H.W. Briggs, "Reservations to the Acceptance of Compulsory Jurisdiction of the International Court of Justice", 93(II) R.C.A.D.I.(1958), pp.229-263, at 273-274 ; C.H.M.Waldock, supra note 17, at 266 ; B. Maus, les Resérves dans les Declarations d'Acceptation de la Juridiction Obligatoire de la Cour Internationale de Justice, 1959,thesis,(Université de Gènève, Faculté de Droit), pp.80-81 ;S. Prasasvinitchai, la Clause Facultative de Juridiction Obligatoire de la Cour Internationale de Justice, thesis(Université de Paris, Faculté de Droit et des Sciences Economiques), 1962, p.83-84 ; Ch. Debbasch, "la Compétence 'Ratione Temporis' de la Cour Internationale de Justice dans le Systeme de la Clause Facultative de Juridiction Obligatoire ", 31 R.G.D.I.P.(1960), pp.230 259, at 248, and M.Dubisson , la Cour Internationale de Justice, 1964, pp.173-174.

(24) The declarations of Argentina (1935), Austria (1927 and 1937), Bolivia (1936), Brazil (1921 and 1937), Czechoslovakia (1929), Luxembourg(1930), the Netherlands (1926 and 1936), Norway (1926 and 1936) Peru (1932), Poland (1931), Spain(1928), Sweden (1926 and 1936), Switzerland (1926 and 1936) and Thailand (1930 and 1940). See P.C.I.J., Series, D, No. 6, pp. 33-54 and Series E, No.15,pp.213-235. For the 
declarations which were made in 1940 see 200 L.N.T.S. , pp.488-496. For the declaration of the U.K. and the Commonwealth States see p.87 above.

(25) Austria, Denmark, Estonia, Finland, the Netherlands, Norway, Sweden, and Switzerland.

(26) The declaration of Ethiopia, U. K. , Australia, India, and New Zealand.

(27) Those are the declarations of El Salvador (1978), Democratic Kampuchea (1957), Brazil (1948), Denmark (1947), the Netherlands (1946), Norway (1946), the Philippines (1947) and Sweden (1947).

(28) The declarations of Israel (1956), France(1966), Pakistan (1960), and the Philippines (1971)

(29) H.W. Briggs, Reservations ..., supra note 23, p.269.

(30) L.F.E. Goldie, defines the critical date as "the point of time at the end of a period within which the material facts of a dispute are said to have occurred ... It is also the date after which the actions of the parties to a dispute can no longer affect the issue. It is exclusionary and it is terminal.", the Critical Date", 12 I.C.L.Q.(1963), pp.1251-1284 at 1251.

(31) E. Hambro, "some Observations on the Compulsory Jurisdiction of the International Court of Justice", 35 B.Y.B.I.L.(1948), pp.133-157, at 140.

(32) M.O. Hudson's Treatise, supra note 8, p.452.

(33) 6 L.N.T.S. ,p. 380.

(34) It was adopted on the proposals of Iran and France, U.N.C.I.O., vol.13, pp.276, 284,285. For further discussions see M.O. Hudson,"the Twenty -Forth Year of the World Court", 40 A.J.I.L.(1946), pp.1-52, at 34.

(35) Ibid.

(36) The Compulsory Jurisdiction of the International Court of Justice", 40 Georgt.L.J.(1951), pp.41-66.

(37) Supra Note 31, at 141.

(38) See e.g. H,W. Briggs, Reservations ..., supra note 23, p.269 ; Ch. Debbasch, supra note 23, at 242 ; M. Dubisson, supra note 23, p.168, and T. Meron, "Israel's Acceptance of Compulsory Jurisdiction of the International Court of Justice"4 Isr.L.R.(1969),pp.307-333, at 326.

(39) Right of Passage over Indian Territory, Preliminary Objections, Judgment, I.C.J. Reports 1957, p.125.

(40) See the next Section.

(41) Supra note 39 p. 146.

(42) Ibid.

(43)lbid., p..155-156.

(44) Ibid., p.170.

(45) Supra note 2, pp.403-404.

(46) For example the declaration of Mexico, which was signed on October 23, 1947, provides that it "shall be binding for a period of five years as from March 1947..." , but it is dated in the I.C.J.Y.B.(1985-86, at 80 ) October 28, 1947, the date of its deposit with the Secretary-General.

(47) For example the declaration of Liberia, which was made on March 3, 1952 subject to ratification, is dated in the I.C.J.Y.B. (1985-86, at 75) March 20, 1952, although its ratification (dated March 23,1953) was deposited on April 
17, 1953. See 163 U.N.T.S., p.117.

(48) Supra note 31 , at 141.

(49) The Declarations of the Members Accepting the Compulsory Jurisdiction of the International Court of Justice, thesis (Université de Genève, Faculté de Droit), 1952, pp.67-68.

(50) See p107 seq below.

(51) 1 U.N.T.S. , p.9.

(52) Supra note 39, p.143. S. Rosenne suggests that consideration should be given to introducing a short interval between the date of deposit and the date on which the deposit of the instrument produces its effect, the Law ..., supra note 1, at 381 .

(53) Right of Passage, ibid.,p.146.

(54) For the effect of signature see 1. Brownlie, Principles of Public International Law, 3rd. Ed. Revised ed.,1982, at 603.

(55) Cited supra note 2, p.409.

(56) Ibid., pp.403-404 (italics added).

(57) Ibid., at 404.

(58) Mosler, Oda, Ago, Jennings (Sep. Ops.), and Schwebel (Diss. Op.) ,ibid., pp.461-465;473-489;517-532;533-545, and 559, 562-600 respectively.

(59) Ibid., at 462 .

(60) Ibid., at 519,521. Judge Oda believed that by non-ratification of the Protocol of Signature, Nicaragua "had gone only half way toward recognition of the Statute", and that "from the viewpoint of legal activity, the half way stage reached by Nicaragua remained of no account.",ibid., 475 .

(61) Ibid., esp. pp.521-524, 567-568.

(62) It is to be noted that the Court has pointed out the only formality required for the making of a declaration is its deposit according to paragraph 4 of Article 36 of the Statute. See e.g. the Temple of Preah Vihear case, Preliminary Objections, Judgment, I.C.J. Reports 1961, p.17, at 31 ; Barcelona Traction, Light and Power Company, Limited, Preliminary Objections, Judgment, I.C.J. Reports 1964, p.6, at 30, and Military and Paramilitary Activities case, cited supra note 2, p.412.

(63) See e.g. R,P. Anand, Compulsory Jurisdiction of the International Court of Justice, 1961, at 152.

(64) Cited supra note 2, p.396.

(65) Ibid.

(66) Ibid., p.400.

(67) Ibid. For details on how the declaration of Nicaragua was treated in the publications of the P.C.I.J., the I.C.J. and the U.N. see ibid., pp.401-402.

(68) lbid., p.400.

(69) lbid., p.406.

(70) Ibid.,p.407.

(71) lbid., pp.408-409.

(72) Ibid., pp.410-411. 
(73) Ibid., p.404.

(74) Ibid., p.408. For the Aerial Incident Case, see I.C.J. Reports 1957(cited supra note 12), p.142.

(75) Democratic Kampuchea, Portugal and Togo, I.C.J.Y.B. 1985-86, pp.65, 86, and 90.

(76) The declarations of Belgium, Dominican Republic and Liberia, ibid., pp.63,66,75.

(77) lbid., pp.75 and 90.

(78) Supra note 23 , at 271.

(79) The declaration of Egypt was deposited on July 22, 1957. It provides that its effect has began from April 24, 1957. The Mexican declaration was deposited on October 28, 1947 for a period of five years as from March 1, 1947, I.C.J.Y.B. 1985-86, pp.67, 80

(80) It is Obvious that the commencement date and entry into force dates must coincide.

(81) H.W. Briggs, Reservations ..., supra note 23, p.280.

(82) I.C.J.Y.B. 1985-86, p.80.

(83) Cited supra note 39, p.143.

(84) Nottebohm, Preliminary Objections, Judgment, I.C.J. Reports 1953, p.111, at 122-123. For further details see C.H.M. Waldock, supra note 17, pp.261-263 and R.P. Anand, Compulsory ..., supra note 63, pp.173-176.

(85) Supra note 39, p.142.

(86) Supra note 2, p.416.

(87) For the declaration of Brazil see note 93 below, and for that of Paraguay see pp.106-107 below.

(88) Supra note 17, at 279.

(89) 197 L.N.T.S. , pp.285-287.

(90) Ibid., pp.288-292.

(91) Ibid., p.284.

(92) C.H.M. Waldock, supra note, 17, p.279.

(93) Belgium, Brazil, Denmark, Estonia, Haiti, the Netherlands Norway, Peru, Sweden, Switzerland and Thailand, P.C.I.J.,Series E, No. 16, p.333. It is to be noted that although Brazil had protested against those actions, it informed the Registrar of the P.C.I.J. by a letter dated August 3, 1944 of its decision to free itself "of all obligations towards the Permanent Court". A "memorandum" dated October, 1944 contained Brazil's justifications for its action. These justifications were based mainly on the fundamental changes in the circumstances in which its 1937 declaration was made. See S. Engel, supra note 36, at 63. However that declaration was deemed to be an acceptance of the I.C.J. 's jurisdiction pursuant to Art. 36 (5) until 1948 when Brazil made a new declaration. See I.C.J.Y.B. 1947-48,p. 130.

(94) P.C.I.J. Series E ,No. 16, p.333.

(95) Some authors consider the reliance on the doctrine of rebus sic stantibus for the termination of a declaration as well founded. See e. g. E. Hambro, supra note 31 p.142 ; S. Prasasvinitchai, supra note 23, p.48 ; J.G. Merrills, "the 
Optional Clause Today", 50 B.Y.B.I.L.(1979), pp.87-116, at 93. Comp. J.H.W. Verzijl, "the System of the Optional Clause ", 1 Intr. Rel.(1959), pp.585-610 , at 593, and S. Engel, supra note 36, p.62.

(96) I.C.J.Y.B. 1984--85, p.100.

(97) I.C.J. Reports 1984 (cited supra note 2), p.415.

(98) Ibid., pp.415-416. For further discussion see F. Hassan, "A legal Analysis of the United States's Attempted Withdrawal from Jurisdiction of the World Court in the Proceedings Initiated by Nicaragua ", 10 U.D.L.R.(1985), pp.295318, at 304- 309, and G.N. Barrie, "the United States 'Walkout at the I.C.J.", A.R.(1985),pp. 10-13.

(99) Ibid.

(100) Ibid. For a detailed examination of these arguments see C. Rucz, "l' Indication de Mesures Conservatoires par la Cour Internationale de Justice dans l'Affaire des Activities Militaires et Paramilitaires au Nicaragua et contre celui-ci", 89 R.G.D.I.P.(1985), pp. 83- 111, at 93-95.

(101) supra note 2,pp.417-418.

(102) Ibid.,p.419.

(103) T.M. Franck observes with regard to the United States attempt to modify or terminate its declaration that "it was a dodge that could not reasonably have been expected to appeal to a majority of the judges, particularly in view of the rather ostentatiously self- imposed 6 months notice requirement which sought to demonstrate U.S. resolve never to employ so unworthy an evasion.", "Icy Day at the I.C.J.", 79 A.J.I.L.(1985),pp.379-384, at 384.

(104) For the text of this decree, see P.C.I.J. ,Series E, No.14, p.57.

(105) For a detailed study of the reasons advanced by Paraguay see A.P. Fachiri, " repudiation of the Optional Clause ", 20 B.Y.B.I.L.(1939), pp.52-57; S. Engel, supra note 36, at 54-63; and A.N. Farmanfarma, supra note 49, pp.79-81.

(106) Bolivia, Belgium, Brazil, Sweden, Czechoslovakia,and the netherlands. P.C.I.J., Series E, No. 15, p.227 note 2.

(107) Ibid. The declaration of Colombia of 1932 was made Unconditionally but is was corrected on October 30, 1937 to apply only to disputes arising out of facts subsequent to January 6, 1932. By a letter dated August,27, 1936, the Secretary _ General of the League of nations, at the request of the Colombian Government, informed the members of the League of Nations that an error had occurred in the actual wording of Colombia's declaration. As an evidence, Colombia relied on its instrument of ratification, which contained an express mention of Colombia's law No. 38 of 1930 . This law provided for that conventions would relate solely to disputes that may arise out of events subsequent to the ratification. No protest was made by any State with regard to the addition of that reservation. P.C.I.J., Series E, No. 13, pp. 276-277.

(108) I.C.J.Y.B. 1960-1961, p. 209.

(109) Ibid., 1986-87, p.66.

(110) For the text of this communication see S. Rosenne, Documents on the International Court of Justice, 2nd. Ed. 1979, p. 361.

(111) 948 U.N.T.S., p.535, at 536-537.

(112) For the nature of declarations made under Art.36(2) see Esp. J.L.I. Buigues, 
"les Declarations d' Acceptation de la Juridiction Obligatoire de la Cour Internationale de Justice : leur Nature et leur Interpretation", 23 Ö.Z.Ö.R.(1972), pp.254-288 ; G. Rao, "the Nature of the Declarations Under the Optional Clause", Justitia(1962), pp.49-61 and E: Suy, les Actes Juridiques Unilateralux en Droit International Public, 1962, esp. p.142 seq.

(113) Phosphates in Morocco, Judgment, 1938, P.C.I.J., Series A/B, No. 74, p.10, at 23, and Certain Norwegian Loans, Judgment, I.C.J. Reports 1957, p.9, at 23.

(114) Anglo-Iranian Oil Co., Judgment, I.C.J. Reports 1952, p.93, at 105.

(115) Electricity Company of Sofia and Bulgaria, Judgment, 1939, P.C.I.J. , Series, A/B, No. 77, p.64, at 87.

(116) Cited supra note 39, p.146.

(117) Supra note 115, p.80.

(118) See e.g. G. Rao, supra note 112. Rao points out that "the widely held view that the relation established between States through their Declarations is either of a bilateral or multilateral character, is erroneous", p.59. He carries the argument a stage further so as to state that no direct judicial bond is created between States accepting the Court's jurisdiction. In his view the judicial bond "comes into existence only when a State brings a dispute before the Court... Till such time, the right to sue a State which had made a declaration is vague and undermined", p.60. Also J. Charpentier thinks that "(il) n'est pas niable que la declaration est un act unilateral, non seulement parce que, en la forme, elle émane d' un seul Etat, mais parce qu'elle produit, par elle meme, des effets juridiques; sans doute ces effets juridiques sont-ils ceux prévues par le Statut et la manifistation de volonté individuelle ne peut-elle les modeler que dans une mesure compatible avec le Statut, mais c'est le propre de tout act individuel d'etre determiné par des texts reglementaires.", "I'Arret de la C.I.J. dans l'Affaire de Barcelona Traction", 10 A.F.D.I.(1964), pp.327_352, at 343344.

(119) See C.H.M. Waldock, supra note 17, pp.250-254, and B. Maus, supra note, 23, pp.53-62,76. S Rosenne believes that the participation in the system of compulsory jurisdiction is a "sui generis" international engagement, but he follows a very different approach. However, he rejects the application "en bloc" of the general law of international treaties because,while the obligation assumed under the Optional Clause "may possess some affinities with the types of obligation regulated by the law of treaties, it is not on all fours with them.", the Law ..., supra note 1, at 414. Compare his view in the International Court of Justice, 1957, p.317. See also M. Dubisson, supra note 23, at 192-195, Ch. de Visscher, Problemes d'Interpretation Judiciaire en Droit International Public, 1963, p.199 and the Diss. Op. of Judge Alvarez in the Anglo-Iranian Oil Co., supra note 114, p.125.

(120) See e.g. C.H.M. Waldock, supra note 17, pp.264-265, and B. Maus, supra note 23 , pp.76-77.

(121) It is to be observed that the writers who take this view do not agree as to whether declarations of acceptance constitute of a multilateral treaty or they 
establish a series of bilateral treaties. According to R. Taoka they establish in effect "a multilateral arbitration treaty", Jap.A.I.L.(1959), pp. 1-11, at 6. J.R.Coquia observes that the parties' engagement is a "multilateral one but its content is ascertainable on the bilateral basis.", 52 Phil.L.J.(1977), pp.154164, at 161. See also T. Meron, supra note 38 , at 362 ; J.H.W. Verzijl, supra note 95 , at 586 ; J. Crawford, supra note 3, p.76 ; Sir G. Fitzmaurice, "the Law and Procedure of the International Court 1951-1954 : Treaty Interpretation and Other Treaty Points", 33 B.Y.B.I.L.(1957), pp. 1-70, at 23 , and K. holloway, les Reserves dans les Traités internationaux, 1958, pp.319-322. Comp. R.St.J. Macdonald, "the New Canadian Declaration of Acceptance of Compulsory Jurisdiction of the International Court of Justice", 8 Can.Y.B.I.L.(1970), pp. 3-38, at 6.

(122) S. Rosenne, the Law ..., supra note 1, p.417 and the Time Factor in the Jurisdiction of the International Court of Justice, 1960, p.27. See also R.St.J. Macdonald, supra note 121, pp.16-17.

(123) Cited supra note 2, p. 415.

(124) Ibid., p.416.

(125) Ibid., p.417.

(126)lbid., p.418. For the Nuclear Tests cases see I.C.J. Reports 1974, pp.267,472.

(127) I.C.J. Reports 1984, p.418. A.P. Rubin has observed that both paragraphs quoted by the Court in this case were concurred in only by six judges in the Nuclear Tests cases, while five of the other nine disagreed and four pointedly withheld their views, "the Legal Effects of Unilateral Declarations", 71 A.J.I.L.(1977), pp.1-30, at 1 note 3.

(128) Supra note 17, p.254. Judge Mosler understood this statement as a qualification of the declarations as sui generis, supra note 2, p.467. Comp. the Diss. Op. of Judge Schwebel, ibid., p.620.

(129) See pp.106 seq. above.

(130) Supra note 2, p.420.

(131) Ibid.

(132) See Judge Mosler Sep. Op., ibid., p.467.

(133) F.L. Kirgis,Jr, "Nicaragua v. United States as a Precedent", 79 A.J.I.L.(1985), pp.652-657, at 654 .

(134) Kirgis points out that "to treat Article 36(2) declarations as holding bilateral engagement is to go beyond anything the Court had held before, but some of its prior decisions certainly pointed in that direction."Ibid.

(135) See P.108 above.

(136) Judges Oda, Jennings and Schwebel, supra note 2, pp.506-510; 550-553, and 622-627 respectively. Judge Oda said that he was "astonished to find such an argument put forward by the Court. It seems that the Court is quite unaware of the development of the Optional Clause during the past decades.", ibid., at 510.

(137) See Judge Schwebel's Diss. Op. ,ibid., p.625.

A reference to Indonisia's withdrawal was also made in the "Observations on the International Court of Justice's November 26, 1984- Judgment on Jurisdiction 
and Admissibility in the Case of Nicaragua v. United States of America", released by the Department of State on January 18, 1985. It was argued that " by binding the United States to its 38-year old termination clause, the Court's holding ignores intervenence State practice and hence customary international law ... In particular, the Court ignores the fact that a number of States have modified their declarations with immediate effect in order to avoid jurisdiction and that states have been allowed to withdraw from the United Nations entirely on only 24 hours notice.", 79 A.J.I.L.(1985), pp.423-430, at 428.

(138) I.C.J.Y.B. 1985-86, pp.60 and 71.

(139) B. Maus, supra note 23, pp.78-81.

(140) Ibid., p.80 ; H.M. Briggs, Reservations ..., supra note 23, p.278 ; F. De Pauw, "la declaration Belge du 3 Avril 1958 Acceptant la Juridiction Obligatoire", 2 R.B.D.I.(1966), pp.94-124, N. Farmanfarma, supra note 49, pp.77-78, and Ch. Debbasch, supra note 23, p.250.

(141) See C.H.M. Waldock, supra note 17, pp.267-270 and S. Prasasvinitchai, supra note 23, p.85. For the rule in the Nottebohm case see p.101 above.

(142) The British Reservations ..., supra note 18, p.144. See also C. Volcan, "la Clause Facultative ", 18 Acta S.J.G.(1947-48), pp.30-55, at 41.

(143) Ibid., p.266.

(144) Ibid., p.267(emphasis added).

(145) Ibid.

(146) See e.g. J. Feydy, "la Nouvelle Declaration Française d'Acceptation de la Juridiction Obligatoire de la Cour Internationale de Justice", 12 A.F.D.I.(1966), p. 157 ; J.G. Merrills, supra note 95,pp.93-94 ; R St.J. Macdonald, supra note 121, pp.17-21, and M. Dubisson, supra note 23, pp.181-182. Comp. K. Weir, "the International Court of Justice : Is it Time for Change?", 8 Houston J.I.L.(1985), pp.175-191, at 178.

(147) See I.C.J.Y.B., 1985-86, p.60.

(148) See H.W. Briggs, Reservations ..., supra note, 23, p.275 and C.H.M. Waldock, supra note 17, p.268.

(149) 907 U.N.T.S., p.129.

(150) See J:G. Merrills, supra note 95, pp.93-94.

(151) See H. W. Briggs, supra note17, p.275.

(152) See R. Taoka, supra note 121, pp.8-9.

(153) See Judge Jennings' Sep. Op. in Military and Paramilitary Activities case , cited supra note 2, p.551.

(154) See J.G. Merrills, supra note 95, p.94.

(155) See R.St. J. Macdonald, supra note 121, p.23.

(156) See pp.104 seq. above.

(157) See E. MacWhinney, "Acceptance, and Withdrawal or Denial, of World Court Jurisdiction : Some Recent Trends as to Jurisdiction", 20 Isr.L.R.(1985), pp.148-166, 151.

(158) See note 140 above.

(159) I.C.J.Y.B., 1985-86,p.73.

(160) H.W. Briggs, supra note 23, pp.278-279. Briggs admits that it is most improbable that the Court would consider the reservation as invalid. The 
question, therefore, is theoretical, in his view, because if the right to denounce is used before the filing of an application, it would be difficult to sustain the basis that the Court had jurisdiction any way on the ground that the denunciation of a declaration in accordance with its terms was an illegal act. If, on the other hand, the notice of denunciation is not given, the Court will have to choose between the following hypothesizes: either it lacks jurisdiction despite the invalidity of the whole declaration, or it has jurisdiction despite the invalid escape clause which was not actually invoked. However, he excludes the possibility that the Court would have occasion to pronounce on the compatibility with the Statute of the right to terminate a declaration on notice. However the invalidity of the condition does not nullify the entire declaration in Debbasch's view, supra note 23, p.251.

(161) See Section 3, Chapter1 supra .

(162) I.C.J. Reports 1957 (cited supra note 39), pp.142-143. See also the next section.

(163) Ibid., p.143.

(164) Ibid.

(165) See pp.104-106, 109-111 above.

(166) I.C.J. Reports 1984 (supra note 2), pp.419-420 (emphasis added).

(167) Ibid., p.418.

(168) The declarations of the following States have not been subject to any changes : Barbados (1980), Belgium (1958), Costa Rica (1973), Democratic Kampuchea(1957), Kenya (1965), Japan (1958), Malta (1966), Sudan (1958), and Swaziland (1969).

(169) See H.W. Briggs, Reservations ..., supra note 18,p.279.

(170) It is to observed that during the discussion of the item "Review of the Role of International Court of Justice" in the Sixth Committee of the General Assembly many delegates,especially those of Socialist countries, expressed their opposition to proposals aimed at amending the Statute, but their opposition was against the attempt to introduce a system of automatic and general compulsory jurisdiction . See e.g. the view expressed by Mr. kolesnik, the Soviet delegate, 25 O.R.G.A., p.199, para.8 (U.N. Doc. A/C.6/SR.1212).

(171) A. D' Amato,"Modifying U.S. Acceptance of the Compulsory Jurisdiction of the World Court", 79 A.J.I.L.(1979), pp.385-405, at 389. He has considered the possibility of including such a clause in a proposed American declaration, but he has reached the same conclusion .

(172) Ibid., pp.391-392.

(173) Ibid., p.390.

(174) 48 (II) Annuaire I.D.I.(1959), at 360.

(175) 47 (l) ibid., (1957), esp. pp. 203-208.

(176) See the observations of Mr. Huber, ibid., pp.305-306.

(177) See the observations of Ch. de Visscher, ibid., p.319.

(178) lbid., 48 (II),(1959), p.360.

(179) Supra note 17, pp.278-279.

(180) Ibid., p.279. 
(181) Ibid.

(182) See pp.39-49 above.

(183) See p,101 above.

(184) H.W. Briggs believes that Wadock view is incorrect, supra note 23,p.276.

(185) I.C.J. Pleadings, Right of Passage over Indian Territory (potugal v. India), Vol. 4 p. 25 seq.

(186) lbid., p.36.

(187) Cited supra note 39, at 143 (emphasis added).

(188) R.P. Anand seems to take the same view, supra note 63, pp.185-186.

(189) See e.g. T. Minigawa, "Operation of Reciprocity Under the Optional Cause", Jap.A.I.L.(1960), pp.32-41, at 32-42 ; S. Rosenne, the Law ..., supra note 1, p.389 ; B. Maus, supra note 23, pp.101-102 ; Ch. Debbasch, supra note 23, pp.252-254 ; H.W. Briggs, Reservations ..., supra note 23,pp.268, 276-277 and "Nicaragua v. United States : Jurisdiction and Admissibility", 79 A.J.I.L.(1985), pp.373-378.

(190) I.C.J. Reports 1984(cited supra note 2), at 417.

(191) Ibid., p.419.

(192) Ibid., p.421.

(193) Judges Jennings and Schwebel, ibid., pp.449-450 and 626-627 respectively.

(194) Judge Oda, ibid., p.511.

(195) Ibid., p.549.

(196) Ibid., pp.511-513.

(197) See p.108 seq. above.

(198) I.C.J. Reports 1984, p.466.

(199) See Section 1, Chapter 4 infra ,p.215.

(200) I.C.J. Reports 1984, p.420.

(201) Ibid., pp.625-627 (emphasis added).

(202) See p.126 above and 133 seq. above.

(203) I.C.J. Reports 1984, p.626 (emphasis added).

(204) Ibid., p.618 (emphasis added).

(205) See p.62 above.

(206) 224 U.N.T.S., p.257.

(207) Cited supra note 39.

(208) The Declaration was deposited on December 19, 1955 and the application was filed by Portugal on December 22, 1955, i.e.,the day after full powers authorising the deposit were received.

(209) For this condition see Waldock, Decline of the Optional Clause, supra note 17, pp.275-276 ; J.G. Merrills, supra note 95, pp. 94-96, H.W. Briggs, Reservations ..., supra note 23 , pp. 256-266 ; R.P. Anand, Compulsory Jurisdiction ..., supra note 63, pp.240-243 ; B. Maus, supra note 23, pp.183187 ; S. Prasasvinitchai, supra note 23 , pp.147-148 ; M. Dubisson, supra note 23, pp.186-187, and R.St.J. Macdonald, supra note 121, pp.35-36.

(210) For the non-application of reciprocity to conditions see Section 1, Chapter 4 below, at 233-234 and p126 seq. above. For the meaning of the expression "the 
same obligation" see Section 1, Chapter 3,above,pp. 46-47.

(211) See pp.56-58 above.

(212) See I.C.J. Pleadings, case concerning Right of Passage over Indian Territory(portugal v. India), vol. I, pp.108-112, vol. IV, pp.25-33, 194199.

(213) Ibid., vol.1, pp.109-111, vol.IV, pp.25-27.

(214) Ibid., vol.I, pp.111-112, vol.IV, pp.27-32. Thus the then Professor Waldock doubted, as a Counsel for the Government of India, that "there is an international lawyer in the world who, when he first saw the Portuguese Third Condition, did not, as we say, 'raise his eyebrows'. It was a very strange introduction into the Optional Clause." Ibid., vol. IV, p.28.

(215) Ibid., vol.l, p.111.

(216) lbid., vol . I, p.111 and vol.IV, p.30.

(217) Ibid., vol.l, p.121, vol.IV,p.205.

(218) Sweden challenged the validity of the Portuguese Third Condition and hence the validity of the entire Portuguese declaration in a letter dated February 23, 1956 addressed to the Secretary-General of the U.N. The text of this letter is reprinted in vol.l, ibid., p.217. For the Portuguese reply see ibid., p.218.

(219) Ibid., vol.l, p.568 seq., vol.IV, pp.131-134, 197-199.

(220) Ibid., vol.I, p.571 seq., vol.IV, pp.135-140.

(221) Ibid.

(222) lbid., vol.l, pp.606-607.

(223) Ibid., vol.I, pp.566-567, vol.IV, pp.143-148.

(224) Ibid., vol.IV, p.147.

(225) lbid., vol.l, pp.566-567.

(226) I.C.J. Reports 1957 (cited supra note 39), p.142.

(227) See p.101 above.

(228) I.C.J. Reports 1957, p.142.

(229) Ibid., p.143.

(230) Ibid.,p.144.

(231) Ibid. It is to noted that the Court rejected India's first preliminary objection by a large majority ( 14 votes to 3 ). Ibid., p.152.

(232) The declarations of Austria, Botswana, Canada, El Salvador, Honduras, Kenya, Malawi, Malta, Mauritus, New Zealand, Norway, Senegal, Somalia, Swaziland and the United Kingdom.

It is worth noting that although India has made most of the reservations, it remained faithful to its argument in the Right of Passage case and therefore did not insert this condition in any of its declarations.

(233) The declaration of New Zealand and Norway. See I.C.J.Y.B., 1986$87, p p .80,82$.

(234) the declaration of Honduras explicitly excludes the retroactive effect of any modification to be made under this condition. It provides that "the Government of Honduras reserves the right at any time to supplement, modify or withdraw (its) declaration or the reservations therein by giving notice to the Secretary-General of the United Nations.", ibid., p.70.

(235) Ibid., p.68. 
(236) See J.G. Merrills, supra note 95, p.96.

(237) It is for a fixed ten-years period, see I.C.J.Y.B., 1986-87, p.66.

(238) The declaration of New Zealand and Norway, ibid., pp.80, 82.

(239) Ibid., pp.62, 76, and 85 respectively.

(240) For this reservation see Chapter 3, infra p. 193 seq.

(241) See B. Maus, supra note 23, p.186.

(242) See I.C.J.Y.B., 1985-86, p.86. The United Kingdom preferred termination to modification of its previous declarations. Thus in 1963 it terminated its 1958 declaration (482 U.N.T.S., p.382) and replaced it by the one which was terminated in 1969 (654 U.N.T.S., p.381) and replaced by the current declaration.

(243) See pp.136-137 above.

(244) See p.114 seq. above.

(245) J.P. Kelly, supra note 1, p.352. Thus, if the United States declaration had been terminable on notice or contained the Third Condition, the dispute concerning Military and Paramilitary Activities could certainly not have been brought before the Court. 


\section{CHAPTER I I I}

\section{RESERVATIONS RATIONE \\ IEMPORIS AND PERSONAE}

\section{SECTION 1 : RESERVATIONS RATIONE TEMPORIS}

The material scope of the jurisdiction conferred on the Court has been limited by the inclusion of RATIONE TEHPORIS reservations in the declarations of a large number of States subscribing to the compulsory jurisdiction. This reservation has been used in many forms and has given rise to complicated problems of interpretation.

\section{A - FORMS OF THE RESERVATION}

\section{(I) The Simple Formula}

The restriction of the obligation assumed under Article 36 (2) to disputes arising after a particular date was one of the first reservations to be incorporated in declarations made under this Article. It was made for the first time by the Netherlands in its declaration of 1921. This declaration was limited to future disputes.

The reservation was then copied by 4 other States during the period of the P.C. I. J. ${ }^{2}$ of the 46 declarations currently in force, 8 declarations contain this reservation. 3 These declarations vary a great deal as to the terms of the reservation. The declaration of the Netherlands covers disputes "arising or which arise after 5 August 1921 (the date of its first declaration); that of Pakistan is limited to "legal disputes arising after 24 June 1948, and that of Egypt is limited to disputes concerning the interpretation or applicability of the Constantinople Convention of 1888 arising after April 24. 1957. The exclusion date in Liberia's declaration is determinable according to an objective element, namely the date of the declaration (April 17, 1953). The other declarations are made in regard to disputes arising "in the future": 4 "hereafter", 5 "after the declaration is 
made", b or finally "after the present declaration". 7 The last category of declarations, except that of Senegal in which the date of signature coincides with the date of deposit with the Secretary-General, may give rise to a problem of interpretation concerning the determination of the exclusion date. Is it the date of signature of these declarations or the date of their entry into force? ${ }^{\mathrm{A}} \mathrm{A}$ literal interpretation may support the date of signature as the exclusive date since it was the only date in the declaration before its deposit. This interpretation may also prevail in case of dispute if the intention of the declarant is taken into consideration, as did the court in interpreting the reservation RATIOHE TEMPOPIS, as will be seen. In practice almost all states which maintained the date of the previous declaration referred to the date of deposit, as will be seen in the next forms, but the reference to a previous date or the date of signature has also been made. 9 In fact the short interval between the date of signature and the date of deposit ${ }^{10}$ makes it unlikely that any problem would arise in the determination of the exclusive date especially since most of the reservations were made a long time ago.

However, according to this form, the court is required only to determine the date of the dispute. Yet this is not as simple as it may seem. The problem encountered by the court in the INTERHANDEL case - as will be seen - bears witness to this.

\section{(II) The Double Formula}

Four declarations currently in force limit the Court's jurisdiction to disputes concerning situations or facts which may arise subsequent to the exclusion date, 12 one of which contains only the word "fact" instead of "facts and situations". "13 This form dates in time after the next form. 


\section{(III) The Complex Double Formula}

In accepting the jurisdiction of the P. C. I. J. in 1925 Belgium marked the starting point of this form. Its declaration excluded disputes arising after the ratification of the present declaration with regard to "situations or facts subsequent to the ratification". "14 Thus, if the previous form appears to stipulate that only the facts and the situations giving $r i s e$ to the dispute must be subsequent to the exclusion date, this form stipulates clearly that both the dispute and the facts or situations giving rise to it must be subsequent to the exclusion date. In practice, however, there is no difference between these forms. 15 For it is difficult to imagine that a dispute would arise prior to the exclusion date whereas the facts and situation from which it arose would be subsequent to that date. Furthermore the jurisprudence of the court concerning the reservation RATIONE TEHPORIS shows - as will be seen - that the Court has always divided the reservation into two parts: the determination of the date on which the dispute arose, and the date of the facts and situation which gave rise to it. 16

However, this form can be found in the declarations of Belgium, Canada, Japan, Kenya, Luxembourg, Mexico, 17 Sudan and the United Kingdom.

\section{(IV) The Most Comprehensive Formula}

In its declaration of November 26, 1973, El Salvador introduced an entirely new form. It excluded:

"pre-existing disputes, it being understood that this includes any disputes the foundations, reasons, facts, causes, origine, definitions, ellegations or bases of which existed prior to this date, even if they are submitted or brought to the knowledge of the court hereafter".

Keeping in mind its failure to deprive the Court of jurisdiction in the RIGHT OF PASSAGE case, India did not 
hesitate to copy this form literally in its declaration of 1974, with the exception that the words "disputes prior to the date of this declaration" are substituted for the words "pre-existing disputes". Although the interpretation of this form - as Merrills observes ${ }^{18}$ is a matter of speculation in the absence of any pronouncement from the court, it may be said that this formula could have the effect of excluding a large number of disputes, if there are still some not excluded.

In determining the exclusion date in the last three forms a large variety of terms have been used. Seven declarations indicate clearly the exclusion date. ${ }^{19}$ In four declarations the exclusion date is that of their entry into force, or the entry into force or the deposit of a previous declaration. ${ }^{20}$ The date of independence is the exclusion date in the declarations of Kenya and Sudan, and the end of the Second World War is the exclusion date in that of the United Kingdom. The date of signature is the exclusion date in the declaration of Luxembourg (September 15, 1930). The declarations of India and Mexico provide that disputes prior to the date of "this declaration" are excluded. Whatever the intention of the last two states, the interval of 3 days between the date of signature and the deposit in the former, and 5 days in the latter exclude the possibility that any problem of interpretation would arise. The declarations of El Salvador and Japan use almost the same language with the difference that their date of signature and deposit are the same.

\section{B - PROBLEMS OF INTERPRETATION}

According to the last three formulae, the Court is not required only to ascertain the date on which the dispute arose and its relation to the exclusion date embodied in the declaration, but it has also to face the chronological development of events and causal relationship between them, and the conflict of view expressed by 
the parties to the dispute, along with the ascertainment of the link between these facts and situations and the exclusion date. 21 Thus, Lautherpacht, in his discussion of the complex double formula in the British declaration of 1929 termed it as an "elastic and comprehensive reservation". For it is clear that the phrase "of situations and facts prior to the ratification" is vague and admitting of a variety of interpretations. An event given rise to a dispute may happen on a given date, but the essential facts relevant to and forming the background of the dispute may have happened many decades before, he observed. ${ }^{22}$ Furthermore, he drew attention to the difficulties inherent in the reservation. To illustrate them he asked:

\begin{abstract}
"Does the restriction to situations and facts prior to the ratification include the interpretation of treaties concluded before the ratified acceptance of the optional Clause? ". When does a dispute arise? Does the verb refer to the time at which the injurious event occurs? or to the time when the claim is first put forward through the appropriate channels? or thien the claim has been rejected and the parties have finally disagreed? or raise another query, what does a situation prior to ratification mean? If legislation injuriously affecting aliens and elleged to be contrary to international law has been passed prior to ratification, would the continued application of such legislation fall under the terms of the reservation? one can easily multiply these questions. "23
\end{abstract}

Some of these questions are still valid. The Court, for example. has not defined the notions "facts" and "situations". It observed in the first case in which the reservation RATIONE TEMPORIS was invoked before it that the determination of the existence of these notions depends on the specific circumstances of each case. 24 It might be true that they are "incapable of definition in abstract legal terms", 25 but what was sometimes termed by the Court as a "situation" has been challenged. In the RIGHT OF PASSAGE case (Merits), for example, the court determined the "situation" as that of the "Portuguese enclaves within the territory of India which gave rise to the need for the Right of Passage for Portugal and its 
claim to such a right." 26 This qualification seemed to judge Badawi erroneous. He thought that the court arbitrarily ascribed to the notion situation a purely geographical meaning, whereas that was only a factor in the situation. 27 . Nor did the Court interpret terms embodied in declarations, such as "relating" to or "with regard to" or "arising out" of subsequent facts and situations. In the ELECTRICITY COMPANY OF SOFIA AND $B U L G A R I A$ case judge $A D$ HOC Papazoff did not concur with the Court reasoning in determining the critical date. He pointed out that the words "with regard to" were broader in scope than the words "arising out of". Consequently. he said that according to the former, "the essential point is that the past must not be called in question in any way". Thus, although the dispute arose after the exclusion date, the situation from which it arose existed prior to that date in his view. 28

Moreover, the determination of the date of the dispute and its relation to the critical date requires that the general phrase "a disagreement on point of law or facts, a conflict of views of interests between two persons" 29 as a classical definition of the dispute, be transferred into concrete terms. To go further, for determining these dates the court must interpret the dispute itself. This task is not as easy as it might seem. The practice of the court, as in the INTERHANDEL case, shows that the dispute could be looked at from different angles. As Rosenne explains in his exhaustive study of the problems to which the concept of dispute could give rise with regard to RATIONE TEHPORIS reservations, that in order to reach a correct interpretation of the dispute "the judges found themselves confronted with three issues. The first was to establish the relevant facts; the second to postulate the mutual relations of all the relevant factors of the dispute. The solution of these items itself constituted the preliminary to the third and final phase". 50 
In connection with the interpretation of the dispute, two complicated problems should be settled: the determination of the subject of the dispute, and the distinction between it, the subject of the claim and the relief sought. This could be a very complicated task. The ELECTRICITY COMPANY OF SOFIA AND BULGARIA, the IHTERHANDEL and the RIGHT OF PASSAGE cases show how the opinion of the judges can be divided. In the first, judge Erich thought that the subject of the dispute was the acts of the Bulgarian authorities and not the formula established by the Mixed Arbitral Tribunal. 31 In the second, judge Basdevant, though he concurred with the decision that the application was inadmissible, followed a different approach. He stated that he should direct his attention to the subject of the dispute and not to any particular claim put forward. 32 Four other judges disagreed with the Court's determination of the subject of the dispute. They believed that the core of the dispute was the character of enemy or non-enemy status of the Interhandel and its assets. 3 In the third case judge Chagla stated that the real dispute was "with regard to the obligation of India, not with regard to her violation of that obligation".

Whatever the difficulties raised by this reservation, it is objectively stated. Certainly it has the effect of complicating the task of the court, but the latter has kept it within bounds and limited its scope in many cases as will be seen after the discussion of the object of reservation.

\section{C - THE OBJECT OF THE RESERVATION}

There is no doubt that the reservation RATIONE TEHPORIS was inserted to counteract the retroactivity of the Court's compulsory jurisdiction. It has been made with a view to achieving distinct objectives. The first is to exclude specific disputes with which the declarant State was concerned when it accepted the jurisdiction. 35 
Thus, the insertion of the complex double formula for the first time in the Belgium declaration of 1925 was designed mainly to exclude its dispute with the Netherlands concerning the sovereignty over wielingen. 36 . The second is to exclude a large number of categories of state disputes. Thus, it is said that the British declaration of 1930 was made with the intention of excluding "territorial disputes and claims arising out of the operations of the British fleet and the application of Prize Law of Great Britain during the (First) World War". 37 This object was explained by the P. C. I. J. in the PHOSPHATES IN HOROCCO case. It said that the reservation was :

\begin{abstract}
"inserted with the object of depriving the acceptance of the compulsory jurisdiction of any retroactive effects, in order to avoid, in general a revival of the old disputes, and to preclude the possibility of the submission of the court, by means of an application, of situations or facts dating from a period when the State whose action was impugned was not in a position to foresee the legal proceedings to which these acts and situation give rise."
\end{abstract}

The third objective is to preclude the possibility of the submission to the Court of disputes arising from a particular period of national history. This can be illustrated by the choice of the date of independence as the exclusion date in some declarations such as those of Kenya, Sudan and Malawi. 39 . It is clear that these states intended to keep the complicated disputes concerning the colonial period out of the Court's compulsory jurisdiction.

There is little doubt that the reservation. especially in its three double exclusion formulae, is capable of achieving all these objectives, but the question is whether these objectives require such a broad reservation. As Lauterpecht pointed out, instead of referring $E O$ NOHINE to the specific dispute or even to the categories of disputes, the draftsmen preferred the "more general GEHUS PROXIMUM which necessarily goes beyond the object 
of the limitations as originally intended." 40 "Thus he described it, correctly, as "one on the face of it arbitrary, and it saddles future governments with a duty which the government stipulating the reservation is not willing to accept in respect of the acts of its predecessors". 41 Brierly expressed the same view. In commenting on the reservation made by the British government in adhering to the German Act of 1928, he said:

"Why we propose to lay on. our successors in respect of disputes which we are bequeath to them, a procedure which we are unwilling to apply to the disputes which have been bequeathed to us? Can the thought behind the reservation be that our predecessors have done certain questionable things which we should not care to defend, whereas, our own conduct is so exemplary that our successors have nothing to fear from arbitration? The explanation seems to be too cynical to be accepted; but is there any other?" 42

\section{D - APPLICATION OF THE RESERVATION}

Although the simple exclusion formula is historically the older, both the P. C. I. J. and the present Court faced jurisdictional objections relying on the double formulas (including the complex one). It was invoked before the P. C. I. J. in two cases: ${ }^{43}$ The PHOSPHATES IN MOROCCO case and the ELECTRICITY COHPANY OF SOFIA AND BULGARIA case. In dealing with the reservation, the $P$. C. I. J. regarded its task as constituting of a determination of two consecutive dates: the date on which the dispute arose and the date of the facts or situations which gave rise to it. In the first case, the court proceeded directly to the determination of the date of the facts and situation from which the dispute arose, because both parties agreed that the dispute arose after the crucial date, $U I Z$, the date of the French acceptance (April 25, 1931). Italy, the plaintiff argued that the monopolization of the Moroccan phosphates instituted by the DAHIRS of 1920 has established a monopoly contrary to 
international obligations. The regime, being still in operation, constituted, in its view, a situation subsequent to the crucial date, and that situation fell, therefore within the Court's jurisdiction. Furthermore, it invoked the notes of the Ministry of Foreign Affairs of 1933 and 1934 in which it was pointed out that there was no appeal from the decision of the Mines Department of January 8, 1925, and accordingly no satisfaction was made.

Thus the Italian government contended that the dispute arose from facts subsequent to France's acceptance of the Court's compulsory jurisdiction for three reasons: firstly, certain acts were accomplished after the crucial date; secondly, these acts taken in conjunction with earlier acts "constitute as a whole a single. continuing and progressive illegal act which was not fully accomplished until after the crucial date", and thirdly, that act, having taken place prior to that date, "gave rise to a permanent situation inconsistent with international law which has continued to exist after the said date". 45

The Court relied on the terms included in the French declaration for determining the criterion of which facts and situations should be taken into account. It found that these terms were "PERFECTLY CLEAR". It said:

\footnotetext{
"The only situation or facts falling under compulsory jurisdiction, are those which are subsequent to the ratification and with regard to which the dispute aroses that is to SaY, THOSE HHICH HUST BE CONSIDERED AS BEIHG THE SOURCE OF THE DISPUTE." 46
}

In interpreting the two terms "facts" and "situations" the court refused to resort to a restrictive interpretation as a means of enhancing the scope of its jurisdiction. Such an interpretation, it observed, may exceed the intention of the states making the reservation. For, they were inserted with the object of depriv- 
ing the acceptance of any retroactive effect and "to embrace in the most comprehensive expression possible, all the different factors capable of giving rise to a dispute". It continued that the facts, or situations:

\footnotetext{
"are placed in conjunction with one another, so that the limitation RATIONE TEHPORIS is common to them both, and that the employment of one term on the other could ngt have the effect of excluding the compulsory jurisdiction".
}

This interpretation may be of significance because Columbia's declaration applies only to disputes arising out of "facts" subsequent to January 6, 1932 and the Mexican declaration is limited to disputes arising out of "EVENTS" subsequent to the date of the declaration. 48 Although the latter includes a different term, the above comprehensive interpretation seems to cover it.

By the application of the above criterion the Court found that the DAHIRS of 1920 and the decision of the Mines Department of 1925 were the essential facts which really gave rise to the dispute. Consequently, it found it impossible to admit that factors subsequent to the exclusion date were sufficient to found jurisdiction if they merely presumed the existence of, or confirmed or developed, prior situations or facts which constituted "the real cause of the dispute". 49

The Court rejected also the Italian argument concerning the continuing and progressive unlawful action, which has only been completed by certain acts subsequent to the exclusion date, as well as the contention that the prior acts gave $r$ ise to the permanent situation inconsistent with international law. The court found that the ascertainment whether there was a denial of justice or not was not possible without calling in question the decision of 1925, as a fact prior to the exclusion date. 50

By this ruling the Court, thus answered Lauterpecht's question whether a continued application of the 
legislation alleged to be contrary to international law falls under the terms of the reservation.

In his dissenting opinion, judge Van Eysinga observed that the "continuity and performance of unlawful acts certainly constitutes a situation". The Court was not, in his opinion, required to find "the causal facts of the dispute". A dispute "which arises with regard to situations subsequent to a given date" is something different from a dispute the causal facts of which are subsequent to that date, or from a dispute which arises from a situation subsequent to that date", he said. "52 He observed also that the dispute meant by the French declaration was a dispute between states and not for instance between Italian claimants and the Moroccan authorities. Consequently judge Eysinga thought that the dispute between Italy and France did not arise until the latter took up the case of its nationals, i.e. June 16, 1933. 53

Judge Cheng also was in favour of a restrictive interpretation of the terms "situations and facts". Firstly, he relied on the idea of continuity or progressivity of the wrongful. In his view the monopoly was still existing, although it was instituted by the 1920 DAHIRS. He said:

"It is an existing fact or situation. It is wrongful. It is wrongful not merely in its creating, but in its continuance to the prejudice of those whose treaty rights are alleged to have been fringed, and this prejudice does not merely continue for an ald existence but assumes a new existence every date". 54

Secondly, he looked at the phrase "situations or facts subsequent to this ratification" from a different angle. He thought that it did not mean quite the same thing as "situations or facts CREATED after the ratification. Consequently a situation or fact existing after the crucial date is no less a situation or fact subsequent. although it may have existed also before that date." 55 
In the ELECTRICITY COMPANY OF SOFIA AND BULGARIA case - Bulgaria, (the respondent), whose declaration was without reservation RATIONE TEMPORIS, relied on the reservation embodied in the Bulgarian declaration ratified on March 10, 1926. In this case also the Court was not obliged to determine the date on which the dispute arose, because the parties agreed that the dispute arose on June 14, 1937, i.e. after the exclusion date. Different facts were regarded by the parties as the source of the dispute. Whereas according to Bulgaria's view the dispute arose with regard to the situation created by the awards of the Mixed Tribunal of July 15, 1923 and May 27.1925 fixing the price per kilowatt hour of power distributed, 56 Belgium argued that the decision of the State of Mines of November 24, 1934 and the judgment of the Bulgarian Courts of 1936 and 1937 constituted the facts from which the dispute arose.

The Court rejected the Bulgarian view observing that a distinction must be made between the source of the right of the claimant company and the source of the dispute. The awards of the Mixed Tribunals, as the source of the right claimed, "did not give rise to the dispute, since the parties agree as to their binding character and their application gave rise to no difficulty", "58 the court said.

The Court's judgment in this case seems to narrow the scope of the criterion established in the previous case. After reaffirming the previous statement that the only situations or facts which must be taken into account are those which must be considered as being the source of the dispute, the court observed:

"It is true that a dispute may presuppose the existence of some prior situation or fact, but it does not follow that the dispute arises with regard to that situation or fact. A situation or fact in regard to which a dispute is said to have arisen must be THE REAL CAllSE of the dispute". 
This dictum seems to substitute the criterion of the real cause for that of the source of the dispute. 60 By its distinction between the source of right and the situations or facts as a source of the dispute, the Court answered Lauterpecht's question whether the reservation covers the interpretation of treaties concluded prior to the exclusion date.

The reservation RATIONE TEHPORIS arose in a completely different form before the I. C. J. in the ANGLaIRANIAN OIL COMPANY case. Here the court found itself obliged to interpret the phrase "disputes arising after the ratification of the present declaration with regard to situations or facts relating directly, or indirectly to the application of treaties or conventions accepted by Persia and subsequent to this declaration" 62 included in the Iranian declaration. The issue turned on whether the words "subsequent to the ratification" referred to treaties or "facts and situations". The United Kingdom argued that the meaning of this phrase would become clear if it was regarded merely as a variant of the Belgian formula. In such a case the reservation would not apply to the date of conclusion of treaties.

Relying on the Iranian intention, the Court rejected the British arguments holding that Iran intended to limit its acceptance of compulsory jurisdiction to disputes relating to the application of treaties accepted by Iran after the ratification of the declaration. 64

The I. C. J. had the occasion to discuss the simple exclusive formula in the INTERHANDEL case. 65 The jurisdiction of the Court was founded in this case on the Swiss and American declarations. The former was without reservation RATIONE TEHPORIS and the latter, which was deposited on August 26, 1946, was applicable only in regard to disputes "hereafter arising". Thus the crucial date was August 26, 1946. 
In its First Preliminary Objection the United States asked the Court to judge and decide:

\footnotetext{
"That there is no jurisdiction in the court to hear or determine the matter raised by the Swiss Application and Memorial, for the reason that the dispute arose before August 26. 1946, the date on which the acceptance of the courts compulsory jurisdiction by this country became effective".
}

The United States contended that the dispute went back at least to the middle of the year 1945, and that divergent opinions as to the character of the Interhandel were exchanged between the American and the Swiss authorities on a number of occasions before August 26, 1946. 67

The Court connected the determination of the critical date with the subject of the dispute. Since the latter was regarded as the return to the Interhandel of the assets vested in the United States, the Court considered the date of the negative reply (July 26,1948$)$, which was described by the Department of state as its final and considered view, as the crucial date. For, it was at that point that the "divergence of views of the two Governments were concerned with a clearly defined legal question. 68 Thus the court refused to adopt the view that the dispute had arisen during 1945, 1946 and 1947 because the discussions between the Swiss authorities, on the one hand, and the allied and the American authorities, on the other, related to the research for the blocking and liquidation of German property and interests in Switzerland, i.e. the exchange of views related to the character of the Interhandel as enemy or non-enemy. Since these discussions were without any final conclusion, the court could not see in them a dispute between Governments which had already arisen with regard to the restitution of the assets claimed by the Interhandel in the United States. The facts and situations which have led to the dispute must not be confused with the dispute itself. 69 The court therefore, rejected, by 10 votes to 5 the first Preliminary objection. 
THE RIGHT IF PASSAGE DUER INDIAN TERRITORY case (preliminary objections) shows the difficulties to which the double exclusion formula is capable of giving rise. 7 It was the first case in which the agreements of the parties were sharply divided as regard both the date of the dispute and the facts or situations from which the dispute arose. Portugal, the applicant, contended that the dispute arose after 1953, when India adopted certain measures relating to the passage over its territory, and that the question of the existence or non-existence of the legal right of passage was not, prior to February 5 . 1930 (the exclusion date indicated in the Indian declaration of 1940) in controversy between the parties to the dispute.

India on the other hand, challenged the court's jurisdiction in its sixth preliminary objection by invoking its complex double exclusion formula. ${ }^{72}$ It argued that the dispute itself arose - partly or wholly - before 1930, and that it was the whole concatenation of events from 1779 onwards, if anything, which established the right of passage.

The court found itself unable to determine at that stage either the date on which the dispute arose, or the situations or facts which gave rise to it. It stated that a pronouncement of those questions necessitated "an examination and clarification of often COHPLICATED. questions of facts bearing on the practice pursued by the Authorities concerned for a period of very considerable duration and stretching back to 1818, or even 1779". 74 The objection was, therefore joined to the merits.

In the second phase, the court believed that it had to consider what was the subject of the dispute in order to form a judgment as to its jurisdiction. For this purpose it did not confine itself to the subject cited in the Portuguese application as being "the conflict of views between the two States when, in 1954, India opposed 
the exercise of Portugal's "right of passage", but it held that the dispute had a threefold subject:

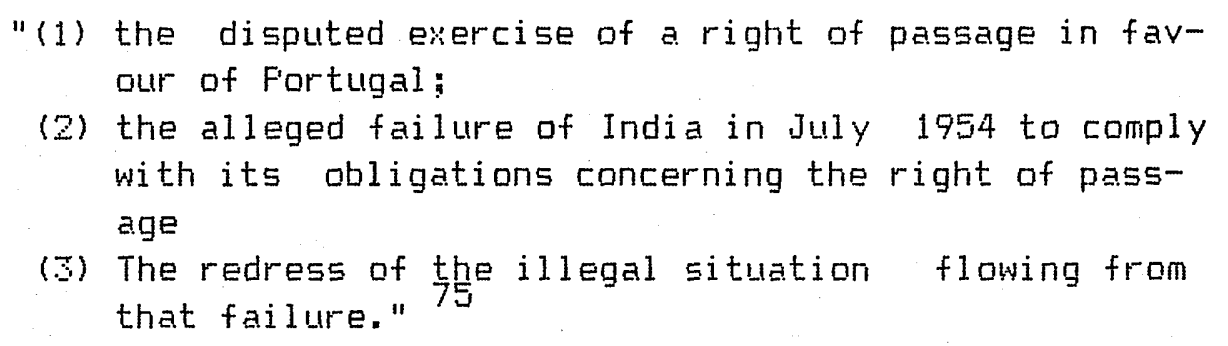

The Court proceeded then to the definition of the dispute in order to determine the date on which it arose. In the light of the P. C. I. J.'s definition in the MAUROHAATIS case that the dispute is a "conflict of legal views", 76 the Court found that the dispute with all its consistent elements had not come into existence before 1954, since before that time passage had been effected in a way recognised as acceptable to both sides. It refused to take into consideration certain incidents which had occurred before 1954, because they did not lead the parties to adopt clearly defined legal positions as against each other. ${ }^{77}$ Concerning the second part of the reservation, the court preferred the criterion in the ELECTRICITY COMPANY OF SOFIA AND BLLGARIA case, namely the "real cause", then that in the PHOSPHATES case (the source of the dispute). Pointing out that in the former case a distinction had been drawn between the source of the rights claimed and the source of the dispute, the Court confirmed that "only the latter are to be taken into account for the purpose of applying the Declaration accepting the jurisdiction of the court." 78

In determining the "situation" and "facts" which gave rise to the dispute, the court found the former in the situation of the Portuguese enclaves within the territory of India, which gave rise to the need for a right of passage for Portugal and its claim to such a right, and the latter in those of 1954 which Portugal advanced as showing the failure of India to comply with 
its obligations, and infringement of that right.

The most significant point in this judgment is the Court's approach in interpreting the reservation RATIONE TEHPORIS. It was interpreted in a positive manner as indicating the disputes which were covered by a declaration accepting the compulsory jurisdiction rather than proceeding on the principle of excluding from that acceptance any given dispute. ${ }^{80}$ This interpretation combined with the preference of the "real cause" constitute a major element in enhancing the scope of the Court's compulsory jurisdiction. The result of this approach was that the Court considered what it termed as "minor incidents" which occurred before 1954 as irrelevant, and treated the situation of those territories as a "whole whatever may have been the earlier origin of one of its parts". 81 This whole was regarded as having come into existence only after the critical date embodied in the Indian declaration. It said:

\footnotetext{
"the fact that a treaty of a greater or lesser antiquity, that a rule of international law, established for a greater or lesser period, are involed, is not the yardsticl: for the jurisdiction of the Court according to the Indian Declaration. That Declaration is limited to the requirement that the dispute shall concern a situation or facts subsequent to February 1950: the present dispute satisfies that requirement."
}

Three judges did not concur with the Court's reasoning. Judge Kojevnicon declared that he could not concur with the Court without giving his reasons. 83 Judge Badawi pointed out that, according to a positive interpretation of the reservation RATIONE TEHPOPIS, the intention of India was disregarded. For, it was not possible, for the purpose of the interpretation of the Indian declaration, to join the facts to the dispute. Accordingly he concluded that "not only the situation which gave rise to the dispute, but also the very subject of the dispute ... come within the period proceeding the crucial date of the Indian Declaration". 84 Judge Chagla believed that Portugal's argument that the facts and situations prior to 
1930 dealt with the source of its right was false. "If there is a divergence between the Parties as to the very sources of the right claimed, then it is clear that this divergence or difference constitutes the dispute". $85 \mathrm{He}$ regarded also the portuguese contention that, a wide construction of the reservation RATIONE TEMPORIS would deprive the court of jurisdiction in most cases, as false. This was so, because in most cases the legal titles were not disputed, as in the ELECTRICITY COMPANY OF SOFIA AND BULGARIA case. 86

The lesson to be learned from these cases is that, although the Court has managed to keep the reservation within bounds, the application of the vague criteria of the "source of dispute" or "real cause" did not lessen the difficulties imposed upon it by the inclusion of this reservation.

\section{E - RETROACTIVE EFFECT OF ACCEPTANCES SILENT ON THE ISSUE}

Portugal is the only state that has accepted the compulsory jurisdiction expressly with a retroactive effect. Its declaration of 1955 covers disputes "arising of events both prior and subsequent to the declaration of the 'Optional Clause' which Portugal made in December 15. 1920, as a party to the Statute of the Permanent Court of international Justice". 87 Twenty three ${ }^{88}$ declarations out of 46 are made without any reference to RATIONE TENPORIS reservation. The question that might be raised, therefore, is whether the scope of the obligation accepting the Court's compulsory jurisdiction has a retroactive effect or is it limited to disputes arising after that acceptance and therefore, at least the simple formula of the reservation, is inserted ARUNDANTE CAUTELA?

This question was dealt with by the P. C. I. J. in the HAUROHHATIS case (Jurisdiction). Here the jurisdiction of the Court was founded on Article 26 of the Mandate for Palestine. Dealing with its jurisdiction RATIONE 
TEMPORIS the Court said:

"The court is of the opinion that, in case of doubt, jurisdiction based on international agreement embraces all disputes referred to it after its establishment ... The reservation made in many arbitration treaties regarding disputes arising out of events previous to the conclusion of the treaty seems to prove the necessity of an explicit limitation of the jurisdiction and, consequently, the correctness of the rule of interpretation enunciated above, The fact of a dispute having arisen at a given moment between two states is a sufficient basis for determining whether, as regards tests of time, jurisdiction exists, whereas any definition of the events leading up to a dispute is in many cases inextricably bound up with the actual merits of the dispute".

Relying on the first part of this dictum. Farmanfarma observes that "It must not be forgotten that when a declaration is not expressly made unconditionally and has made no reference to time limitation, the principle to be applied is that jurisdiction extends to disputes arising after the declaration has been made." 70 This opinion constitutes an exception from the general view that by this dictum, though concerned with a compromissory clause, the Court laid down the principle that if no express limitation is made the acceptance of the compulsory jurisdiction would have a retroactive effect. 91

The retroactivity of the obligation assumed under Article 36 (2) can be deduced also from the Court's judgment in the PHOSPHATES IN HOROCCO case. Since reservations RATIONE TEHPORIS are made in order to deprive the acceptance of any retroactive effects and to avoid and preclude a revival of old disputes according to that judgment, 92 declarations which do not contain such a reservation could not achieve that purpose. Furthermore the INTERHANDEL case removed any doubt as to the retroactivity. In that case, the declaration of Switzerland, the applicant, was without reservation RATIONE TEHPORIS, and the United States declaration, in which the exclusion date was August 26, 1946, was made in regard to disputes "hereafter arising", as already mentioned. 93 The United 
States argued in its Second Preliminary Objection that the dispute, even if it was subsequent to its declaration, arose before July 28, 1948 (the date of the deposit of the Swiss declaration and on which Switzerland became party to the statute), and therefore the Court was deprived of jurisdiction by the application of the principle of reciprocity, otherwise, retroactive effect would be given to the compulsory jurisdiction of the court. 94

Switzerland, on the other hand, argued that in the absence of an analogue reservation in its declaration. the jurisdiction was accepted in regard to disputes prior to 1948, and, therefore, there was no critical date as far as its declaration was concerned. For supporting its argument Switzerland invoked the doctrine of the P. C. I. $J$. in the HAUROMHATIS case, and the general view adopted by publicists. 95

In rejecting that objection the court noted the false conception which was attributed to the principle of reciprocity by the United States. 96 Although the Court did not discuss the retroactive effect of declarations. it had in fact decided that the retroactivity is the rule. This is established by the fact that the court found that it had jurisdiction to entertain the dispute though it arose, as has been seen, before July 28, 1948.

In the light of this decision the other question that may be raised is whether in case of successive declarations, the later declaration would have a retroactive effect, if the previous was made with regard to future disputes only. Where the later declarations maintain such a reservation it seems that the rule discussed above, and that laid down by the Court in the AmBATIELas case is applicable. In this case the court refused to give a retroactive effect to a later treaty contrary to its own provisions. 97 However if the reservation is omitted in the later, it seems reasonable to infer the retroactivity, unless it is proved that the declarant 
intended to renew its previous declaration as it was. In such a case the critical date of the previous might be maintained.

The third question is whether there exists a temporal limit as to the retroactive effect of the acceptance of the Court's compulsory jurisdiction. In other words, is the jurisdiction of the Court limited to disputes arising after the establishment of the P.C. I J. taking into consideration the continuity between the present Court and its predecessor, 98 or does it cover disputes arising out of facts and situations prior to that establishment? J G Sauveplanne believes that according to the general view that a general clause of jurisdiction implies a limitation of its application in future disputes, the potential competence pre-established by the insertion of the general clause into the statute is limited to disputes arising after the establishment of the P. C. I. J. ${ }^{99}$ The statement of the P. C. I. J. in the MAUROHMATIS case cited above, seems to lay down the general proposition that in the absence of a reservation RATIONE TEMPORIS, the jurisdiction of the court would cover disputes arising before its establishment. This view is supported by the fact that in the RIGHT of PASSAGE case the Court reached its decision on the basis of an examination of events which occurred before 1920.100

But does the retroactivity in this sense apply visa-vis new States? In other words does the Court's compulsory jurisdiction cover disputes arising out of events occurring before the date of independence, if the reservation RATIONE TEMPORIS had not been made? This question is of significance since the following states, which achieved their independence after the Second World War. have not inserted the reservation in their declarations. Those are: Botswana, Democratic Kampuchea, Mauritius, Nigeria, Somalia, Swaziland, Togo and Uganda. The jurisprudence of the court seems to indicate that its jurisdiction, in the absence of an express reservation, extends 
as to cover disputes arising before the independence. In the RIGHT OF PASSAGE OUER INDIAN TERRITORY case, the Court - as has been seen - was obliged to examine events stretching back to 1818 or even 1779. 101 The decisions of the Court in other cases such as the EASTERN GREENLAND, TEHPLE OF PEAH UIHEAR and NORTHERN CAMEROON, was based on an examination of events which occurred before one or both parties existed. 102 Rosenne finds in what he termed as a "strongly marked element of continuity in policy and personnel" (i.e. the former movement which becomes the new state and the people remain the same) an element supporting the idea of extending the Court's jurisdiction to the period prior to the date of independence. However he believes that "as a matter of general principle the Court ought not to be quick in exercising jurisdiction over disputes originating before the existence of the State". This principle cannot, in his view, be effected by the exceptional character of the cases mentioned above. $10 \mathrm{~s}$ In fact, as he observes, the court in the RIGHT of PASSAGE case, for instance, had not been asked to make any finding whatsoever with regard to the past, but to pronounce on the existence of the right claimed by Portugal in 1954. Furthermore there is a major element which refutes the idea of retroactivity, namely, the connection between international responsibility and international personality. How can the retroactivity be applied in a period during which the international personality as an essential factor was missing? 104 Undoubtedly, this view, if taken, would create more stability in international relations.

Bearing in mind the uncertainty as to whether an unqualified acceptance would have a retroactive effect, Kenya, Pakistan and Sudan find it reasonable to protect themselves expressly against such retroactivity by the exclusion of disputes arising prior to their independence, while others exclude either disputes prior to the date of the declaration (Barbados, Gambia, Philippines and Senegal) or disputes arising out of facts and situa- 
tions prior to that date (Malawi). However, the reservation RATIONE TEHPORIS has been regarded as a reasonable clause to be inserted in the declarations of newly independent states as long as its scope does not exceed the date of independence.

\section{F - UNDESIRABLE DEVELOPMENT}

The different problems discussed above and the difficulties encountered by the court in dealing with the reservation RATIONE TENPORIS might justify its criticism and the strong appeal to eliminate it, 106 except where it is intended to exclude disputes which occurred before the independence. That criticism has been considered only by Australia, New Zealand and the Netherlands. The two former states omitted the double exclusion formula from their previous declarations, and their effective declarations are without reservation RATIOHE TEHPORIS. The Netherlands changed the exclusion date of the simple formula from August 6, 1946, in its declaration made the same date, to August 5, 1921 (the date of its first declaration) in its current declaration. Certainly the effect of the reservation diminishes with time. 107 Thus the declaration of the Netherlands is more than 65 years old; those of Luxembourg and Columbia are more than 55; the declarations of Mexico, Sweden, the United Kingdom, Belgium and Pakistan are about 30 years old. However, the recent developments indicate the undesirability of the reservation. The declaration of the Philippines of 1947 was without this reservation, but its current declaration includes the simple exclusion formula. El Salvador's declaration of 1973 substituted the new complicated formula of the sweeping effect for the simple exclusion formula. Furthermore, by maintaining the new reservation in the declaration of 1978. El Salvador reduced the period subject to the Court's jurisdiction by 57 years. The same can be said with regard to India's declaration of 1974, with the difference that the latter substituted the new exclusion formula for the double (complex) for- 
mula, and reduced the period by 15 years. By using the date of the declaration as the exclusion date, Canada's declaration of 1985 reduced that period by 15 years. This period was reduced by the previous declaration of 1970 by 40 years.

On December 2, 1985, Senegal modified its declaration made just eight months before only for the purpose of including the reservation RATIONE TEHPOPIS. Bearing in mind the implications which the new formula is capable of giving rise to, and the application of reciprocity 108 to the RESERUATION RATIONE TEHPORIS, those declarations are capable of reviving the effect of the old declarations and introducing it in those made without it. Moreover, what is the significance of excluding by a new declaration a period during which the court's jurisdiction had been accepted? If these reservations are not to be eliminated in spite of the fact that they have gone beyond their object, it is greatly hoped that at least those examples will not be followed. 109

\section{G - EXCLUSION OF DISPUTES ARISING DURING A PERIOD OF HOSTILITIES}

In some declarations there is to be found a war or hostilities exclusion clause connected with the reservations RATIONE TEMPOPIS. In September 1939, as already mentioned, France, the United Kingdom and five Commonwealth States (Australia, Canada. India. New Zealand and South Africa). sought to amend their declarations to exclude disputes arising during the Second World War. 110 When the declarations of the United Kingdom and the Commonwealth States, except Canada, terminated in 1940. the exclusion of "disputes arising out of events occurring at a time when (these states) were involved in hostilities" 111 were included in the new declarations made in the same year. Thus, the determination whether a dispute is included or not is based mainly on the criterion of time during which the dispute arose. If it has 
arisen during a period of hostilities it would be excluded whatever its origins and even if there was no connection between it and the hostilities. 112 This reservation became a reservation RATIONE MATERIA in the United Kingdom's subsequent declarations. For the criteria - as will be seen ${ }^{113}$ - transferred from the period during which the dispute arose to the "causal facts" of the dispute. In other words the relation between the hostilities and the dispute must be a relation between cause and effect for the exclusion of the dispute from the Court's jurisdiction.

Disputes which occurred during the Second World War were excluded from the United Kingdom acceptance of June 2, 1955 by another reservation, namely, the exclusion of "disputes arising out of events occurring between the 3rd of September 1939 and the 2nd of September 1945". This reservation, being updated, has been criticised as "unnecessary". 115 It set an example which was followed by Israel. The latter excluded from the scope of its 1956 declaration "disputes arising out of events occurring between 15 May 1948 and 20 July 1949". The broad war exclusion clause included in that declaration excepted:

"disputes arising out of, or having reference to any hostilities, war, state of war, breach of peace, breach of armistice agreement or belligerent or military accupation (whether such war shall have been declared or not, and whether any state of belligerency shall have been recognised or not) in which the Government of Israel are or have been or may be involved at any time".

and was capable of excluding disputes occurring during the specified period covered by that reservation. Furthermore, the declaration of Israel, unlike that of the United Kingdom of June 2, 1955, excluded disputes concerning situations or facts prior to October 25, 1951. The reservation of hostilities seems, therefore - as Merills observes - to be inserted EX ARUNDANTE CAUTELA. 117 However, the reservation of disputes occurring during a 
determined period have disappeared. The United Kingdom abandoned it for a reservation RATIONE TEMPORIS excluding disputes prior to October 24, 1945 and Israel's declaration of 1956 was terminated on November 21, 1985. Sudan's declaration, thus, is the only one which includes a RATIONE TEMPORIS hostilities clause. According to the terms of its declaration "disputes arising out of events occurring during any period in which the Republic of Sudan is engaged in hostilities as belligerent" 118 are excluded. This reservation seems to be worse than those of the United Kingdom and Israel since it is not limited to a specific period but operates in any period of hostilities in the future on the condition that sudan would be belligerent. 


\section{SECTION 2 : RESERVATIONS RATIONE PERSONAE}

The provision of Article 36 (3) that declarations can be made "on condition of reciprocity on the part of several or certain states" and the existence of some special considerations at the time of making declarations have led certain states either to exclude from the operation of the Court's compulsory jurisdiction disputes with certain States or to delay the entry into effect of their declarations. The exclusion of disputes with certain states has been made mainly with the object of preserving the special relations existing between a determined group of States, or on the contrary excluding States with which the relations are hostile, ${ }^{119}$ or as an escape clause, or on the contrary for the purpose of depriving other states of the possibility of using the compulsory jurisdiction system only as a beneficial means UIS-A-UIS the declarant States. No protest whatsoever has been made against the insertion of reservations RATIOHE PERSONAE, and they have been considered in the doctrine as not inconsistent with the system of compulsory jurisdiction 120

\section{A - RECIPROCITY RATIONE PERSONAE}

The provision of Article 36 (3) mentioned above was inserted in the statute of the P. C. I. J. in 1920 to satisfy the preoccupation of the Brazilian delegate $M$ Fernandez. His original proposition was as follows:

\footnotetext{
"[States] may adhere unconditionally or conditionally to the Article providing for compulsory jurisdiction, a possible condition being on the part of a certain number of Members or: again, of a number of Nembers including such and such specified lembers." 121
}

In order to adopt this proposition, he argued before the Sub-committee of the Third Committee of the First Assembly that "It was inadmissible for a state to accept the principle of compulsory jurisdiction without 
knowing exactly toward whom it accepted such obligation".

This view reflected Brazil's desire not to be the only important State to accept the Optional Clause. That desire was expressed in its instrument of ratification of the Optional Clause deposited November 4, 1921 which recognised as compulsory the jurisdiction of the Permanent Court "on condition of reciprocity and as soon as it has likewise been recognised as such by two at least of the Powers permanently represented on the Council of the League of Nations". 123 This condition was met on February 5, 1930, 124 the date of entry into force of the declaration of the United Kingdom as the second permanent member of the Council of the League of Nations to accept the Optional Clause after Germany. This - as Waldock observed 125 - is not really a "condition of reciprocity" but rather a suspensive condition. It simply authorises States to delay the entry into force of their declaration until a certain number of states or certain named states accept the compulsory jurisdiction of the Court. However, in spite of maintaining that provision of the present Statute, no State, except Brazil, has ever benefited from it.

\section{B - PRESERVATION OF PARTICULAR RELATIONS BETWEEN}

\section{A DETERMINED GROUP OF STATES}

Some states without affecting the normal operation of the compulsory jurisdiction system vis-a-vis other declarant States, included in their declarations, clauses of quite different nature from that provided for in Article 36 (3), excluding disputes with certain specified States with which particular relations exist. These relations are either the outcome of the Colonial period or of the common factors existing between a group of states belonging to one region. Three different types of reservation have been inserted at one time or another. The first and the largest excludes disputes between the members of the Commonwealth of Nations, the second excluded disputes between Arab States and the last excluded 
disputes between the United States and any Central American state.

\section{(I) Inter-Commonwealth Disputes}

When the United Kingdom accepted the jurisdiction of the P.C. I. J. in 1929, it excluded "disputes with the Government of the British Commonwealth of Nations. all of which disputes shall be settled in such a manner as the parties have agreed or shall agree". 126 The same reservation was included in the declarations of all the other members ${ }^{127}$ except Ireland. The reason for inserting this reservation was explained by the government of the United Kingdom as follows:

"Disputes with other members of the Eritish Commonwelth of Nations are excluded because the members of the Commonwealth, though international units individualiy in the fullest sense of the terms are united by their common allegiance to the Crown".

If Sir Cecil Hurst's view expressed during the discussion of the statute of the P. C. I. J., that Article 14 of the Covenant excluded "disputes between two of the units composing the British Empire, because the relations between them were different from the relations between two foreign states, and for this reason the relations between them were not international". 127 is taken into consideration, it would seem that the above explanation did not contradict the British Government view in 1928 that the signature of the Optional Clause must be general and not discriminating against any state.

As a second reason for excluding INTER SE disputes, it was expected that the Judicial Committee of the Privy Council would constitute an alternative, purely Commonwealth institution for the settlement of these disputes. However it operated that that body was regarded so closely associated with the United Kingdom rule, 131 and therefore not likely to be an acceptable tribunal between 
'newly independent members. As Mackay said "It smacks of the pre-Commonwealth days, when inferiority not equality of States was the rule". ${ }^{132}$ An attempt to fill that gap was made by the Imperial Conference in 1930. It was suggested to follow the experience of the Permanent Court of Arbitration, namely, to constitute an $A D$ HOC tribunal of five members selected from the panel. 13

Taking into consideration the insufficiency of either reasons to maintain this reservation at the present time, the general view is that it should be abandoned. 134 This is because the first reason seems to ignore the fact that the members of the Commonwealth cling to their independence. They are "often more closely associated with non-Commonwealth than with the Commonwealth states, are unwilling to accept loyalties associated with a colonial past". 155 Secondly, no tribunal for the settlement of INTER $S E$ disputes has been constituted and there is no prospect that it would be realised. 136

In these circumstances it appears that, instead of strengthening relations between Commonwealth states, the reservation favoured the settlement between them and the so called "foreign States". This was made very clear by Ali Khan as a Prime Minister of Pakistan. Urging India to refer the Canal Water Dispute to the International Court of Justice, he said:

"Under the optional clause the Government of India have agreed to accept the jurisdiction of the International court on the application of countries which are not members of the Commonwealth. The exception doubtless contemplated that there would be Commonweal th machinery equally suited to the judicial settlement of disputes. While such commonwealth machinery is lacking it would be anomalous to deny to a sister member of the British Commonwealth the friendly means of judicial settlement that is affected by India to countries outside the Commonweal th". 
It is, perhaps, this reason which led to the omission of this reservation from Pakistan's declaration of 1948 and the following declarations. However, the use of the reservation has decreased in comparison to the number of Commonwealth countries accepting the Court's compulsory jurisdiction. Whereas in 1955 the declarations of the seven Commonwealth parties to the compulsory jurisdiction system all contained such reservations, only eight declarations 138 out of 15 contain it at the present time. By the application of reciprocity only disputes between States which have not inserted it 139 can be referred to the court. Also disputes between India and Pakistan or any other Country which might leave the Commonwealth are excluded. For. India's declaration excludes disputes with "any state which is or has been a Member of the Commonwealth of Nations." It is to be observed that Kenya's declaration is the only one excluding future members expressly.

\section{(II) Disputes Between Arab States}

The common factors existing between Arab countries appear to be the main cause for copying the Commonwealth reservation in Iraq's declaration of September 22, 1938. The reservation excluded "disputes with the government of any Arab State, all of which disputes shall be settled in a manner as the Parties have agreed or shall agree. 141 However the reservation was without effect not merely because that declaration had not been ratified, but also because Egypt, whose declaration had also never been ratified, was the only Arab State which accepted the Optional Clause of the P. C. I. J.

No such reservation is made in the declaration of Sudan and the special one of Egypt as the only Arab States accepting the compulsory jurisdiction of the present Court. Taking into account the absence of any machinery suitable for the settlement between Arab Countries, it might be advisable not to make such a 
reservation, should they ever accept the Court's jurisdiction. The fallacy of the psychological conception that recourse to the court is not a friendly means of settling disputes between what might be called the "Arab family" should not be a bar to the Court's compulsory jurisdiction. On the contrary the complicated disputes existing between these states require the submission of these disputes to the court, ${ }^{142}$ especially in the light of the fact that they have not been able, and there is no prospect of so doing, to create their projected Arab Court of Justice.

\section{(III) Disputes Between the United States and Central American States}

On April 6, 1984, it is to be recalled, the United States deposited with the Secretary-General of the United Nations a notification excluding "disputes with any Central American State or arising out of events in Central America, any which disputes shall be settled in such a manner as the parties to them may agree". 144 The reservation on the face of it appears to suggest the preservation of the particular relations between the States. This was made clear in the second paragraph of the modification, which justified the exclusion of those disputes by the desire "to foster the continuing regional dispute settlement process which seeks a negotiated solution of the inter-related political, economic and security problems of Central America". However in factas already mentioned 145 - it was inserted for the purpose of depriving the court of jurisdiction to entertain the dispute between Nicaragua and the United States. It was invoked by the United states in the MILITARY AND PARAHILITARY ACTIUITIES IN AND AGAINST HICARAGUA case. 146 The Court neither discussed its scope nor its validity since the issue turned on whether the stipulation provided for in the notification that "it shall take effect immediately", was valid or not, i.e. whether a declaration made for fixed period and thereafter 
terminable after the expiration of six months' notice could be terminated or modified at any time. However, the reservation, which was made for two years only, disappeared when the United States withdrew its declaration on October 8, 1985. The arguments cited above as to the desirability of making this kind of reservation applies here especially if it is - as here - used as an escape clause.

\section{C - UNDESIRABILITY TO HAVE SOME DISPUTES WITH CERTAIN STATES SETTLED BY THE COURT}

\section{(I) Non-recognition}

Special political reasons affecting the relations between a declarant state and certain other states have led the former to exclude disputes with the latter. Thus, in 1930. Rumania and Yugoslavia accepted the jurisdiction of the P. C. I. J. in relation to any other state the government of which was recognised by them. ${ }^{147}$ Poland also excluded in its declaration of 1931, which had never entered into force, disputes arising between it "and States which refuse to establish or maintain normal diplomatic relations with" 148 it. This reservation was inserted with the object of depriving Liechtenstein of the possibility of bringing a dispute before the court by unilateral application because the relations between the two states were very tense at the time.

These examples have been copied in two declarations accepting the jurisdiction of the present Court. Israel's declaration of 1956 included the Polish formula but with more qualifications. Its declaration excluded:

"Any dispute between the state of Israel and any other State .. which does not recognise Israel or which refuses to establish or maintain normal diplomatic relations uith Israel and the absence or breach of normal relations precedes the dispute and exists independently of that dispute." 150 
This reservation was designed mainly to exclude Arab. Moslem and other States which refuse to recognise the existence of Israel or refuse to establish normal diplomatic relations with it. This formula consisted of an amelioration of the old reservation included in the previous declaration made in 1950. The latter excluded "any dispute between the state of Israel and another State which refuses to establish or maintain NoRHAL RELATIONS with it. 151 This formula was open to criticism in two respects. According to Meron, it was pointed out in diplomatic correspondence with Israel that the use of the phrase "normal relations" rather than "normal diplomatic relations":

\begin{abstract}
"Could conceivably have the result negativing the entire effect of the acceptance by the Israel Government of the compulsory jurisdiction of the Court, since the very fact of serious dispute might allow it to be maintained that relations had ceased to be normal, and that there was thus no obligation upon the Israel Government to accept the jurisdiction of the Court." 152
\end{abstract}

Secondly the attention was drawn to the meaning of the word "maintain". It was pointed out that the reservation "was susceptible of at least two interpretations; one of which was probably not in conformity with the Court Statute, which, in Article 36, paragraph 6, reserved to the court the COHPETENCE DE LA COMPETENCE" 15.

Israel clarified the point in the instrument of ratification of the declaration which contained the following interpretation:

"It being understood that reservation (C) is intended in principle to apply in cases where the absence of relations existed prior to and independently of the dispute, it shall not normally be involed in cases where relations are broten after or as a result of the dispute. Nevertheless, any difference of views which may arise in a given case will come under the jurisdiction of the Court in accordance with Article 36. paragraph b, of its statute. Taking into account this provision of the Statute, the Government of Israel cannot commit itself or its successors to abide strictly by this 
interpretation should a difference arise as to the competence of the court under this declaration and, should such a dispute arise, full freedom of action is hereby reserved as to the wey in which the jurisdiction of the court may be involed".

The clarification itself gave rise to another complication. The phrase "this interpretation", which referred to the interpretation contained in the instrument of ratification. 155 was understood by the United Nations Secretariat as a statement by which Israel could not commit itself "to conform strictly to the Court's interpretation in a case where the Court's competence would be questioned". 156 Although the United Nations corrected its press release. Hudson believed that the clarification "seems to be designed to open the door for a challenge of the application of the provision of Article 36, paragraph 6", and that "a general tolerance of such an inroad on a most important provision of the Statute would be a regrettable retrogression". 157 However the reservation had never been invoked before the Court, and if it had, problems of interpretation of the words "in principle" or "shall normally be invoked" could have been raised. Nevertheless, the modification of the reservation in the declaration of 1956 clarified the issue, though the words "normal relations" were inserted after the phrase "normal diplomatic relations".

Non-recognition reservation is now limited to India's declaration of 1974. The reservation covers:

"Disputes with the Government of any State uith which, on the date of an application to bring a dispute before the Court. the government of India has no diplomatic relations gr which hes not been recognised by the Government of India".

Although this reservation avoids the criticism made against Israel's declaration and, therefore, it cannot be said to be inconsistent with Article 36 (6), it is much broader 159 in scope. Whereas the Israeli reservation could not have been invoked except where the applicant refuses to establish or maintain normal diplomatic rela- 
tions with Israel and the breaking off of relations had no connection with the dispute brought before the Court. India's reservation can be invoked even where India itself breaks off those relations whatever the connection between the breaking of relations and the dispute. Therefore, it can be used as an escape clause if the breaking off precedes the filing of the application. Thus the formula has been regarded as an overdraft, and if it was not, it must be regarded as a thoroughly retrograde step. Certainly a state has the entire right to exclude disputes with those who refuse to establish diplomatic relations with it, but to exclude from the Court's jurisdiction disputes for no better reason than that relations have become politically tense is to deny that the court can contribute to the settlement of the contentious issues and to undermine its authority and jurisdiction.

It is hoped, therefore, that India, if it considers that the reservation must be maintained, will modify it as to insert the conditions made in Israel's declaration of 1956 .

\section{(II) Disputes with a Determined State Over a Specific Subject Matter}

In its declaration of January 27, 1947, Guatemala excluded from the Court's compulsory jurisdiction "the dispute between England and Guatemala concerning the restoration of the territory of Belize. ${ }^{162}$ This reservation is both RATIONE PERSONAE (applying only to England) and RATIONE HATERIA (applying only to the dispute concerning Belize). Guatemala preferred - as pointed out in the declaration - to have the dispute settled by the Court EX AEQLO ET BOHO in accordance with Article 38 (2) of the Statute.

The validity of this reservation cannot be contested. On the contrary, it is believed that it established a perfect example to be followed by any state which really intends to promote the Court's compulsory juris- 
diction. Instead of making a general reservation, the declaration specified the state and the dispute excluded. and at the same time contained an offer to settle the dispute by the court in another manner, without any other reservation.

\section{(III) Disputes with Non-Sovereign States or Territories}

Surprisingly, the current declaration of India contains an entirely new reservation covering "disputes with non-sovereign States or Territories". Such a reservation has never been made, even by Great Powers during the colonial period, either in arbitration treaties before the establishment of the P. C. I. J. or later. Since the reasons for making it are not clear, its examination would be a matter of speculation. However, at first glance it seems that it is inserted EX ABUNDANTE CAUTELA since the membership to the statute is limited to STATES members of the United Nations or STATES nonmembers of the United Nations, parties to the Statute according to Article 93, paragraph 2, of the Charter of the United Nations within the conditions laid down by the General Assembly upon the recommendation of the Security council, in 1946, 164 or finally to other STATES in accordance with Article 35, paragraph 2, of the Statute. It is true that the organs of the United Nations including the court do not question the statehood of political units whose admission to the statute has been decided upon by the General Assembly on the recommendation of the Security Council. They are considered as states from the point of view of the Statute, regardless of whether they will be so regarded by the General international law. Thus when Liechtenstein applied to be a party to the statute it was argued that it was not an independent state, and San Marino's application was opposed to on the ground that the Country was a diminutive State. 165 However if India intended to exclude those states only, it might have made its declaration UIS-A-UIS States member of the United Nations 
as has been done by some states. It is also very well known that the general declarations of the third category of States made in accordance with Article 35 and the resolution adopted by the Security Council on October 15. 1946, cannot "be relied upon UIS-A-UIS states parties to the Statute which have made the declaration in conformity with Article 36, paragraph 2, of the Statute". 166

It may be argued that the reservation intended to exclude the possibility of referring disputes in the regions concerning some territories, in which there exist movements of independence, belonging to neighbouring States in which India has been involved, or to close the door for the possibility of referring disputes concerning non-sovereign states or Territories by other States as did Ethiopia and Liberia in the South West Africa cases.

It might be said also that the reservation reflects India's fear of independence of one of its internal States, though in such a case the non-recognition of the reservation is capable alone if excluding such disputes from the Court's jurisdiction. However, the effect of this reservation on compulsory jurisdiction cannot be weighed as long as its meaning is unclear.

\section{(IV) Disputes with States not Members of the United Nations Parties to the statute}

The Court's jurisdiction has sometimes been accepted in relation to States member of the United Nations. This reservation is limited at present to the declaration of Democratic Kampuchea of 1959. 168 It was copied in the French declaration of 1959. The view has sometimes been advanced that the latter was a drafting error. 169 Yet its retention in the french declaration of 1966 rebutted that view. Thus Prasasvinitchai believes that it was inserted with the desire not to establish any judicial link except with a state whose admission to the International community is subjected to its decisive control. 170 It is obvious that this view cannot be 
applied to the declaration of Democratic Kampuchea. Thus the reservation in the declaration of the latter might be considered as a drafting error.

However the effect of the reservation is limited to the exclusion of Liechtenstein, San Marino and Switzerland as the only States not member to the United Nations, members to the statute.

\section{(V) The Buraimi Reservation}

In October 1955 the United Kingdom terminated its declaration made only five months previously and issued another one including a new reservation excluding:

\footnotetext{
"Disputes in respect of which arbitral or judicial proceedings are taking, or have taken, place with any state which, at the date of the commencement of the proceedings, had not itself accepted the compulsory jurisdiction of the International Court of Justice".
}

The formulation of the reservation followed the breakdown of the Buraimi Arbitration with Saudi Arabia because of the charges of bribery of potential witnesses by the government of the latter. 171 Although it was made specifically to preclude Saudi Arabia from referring that dispute to the Court, it was capable of depriving the Court of potential jurisdiction to decide disputes which had not been settled by arbitration. For this reason and the possibility of preventing potential appeals, arbitral or judicial, to the International Court of Justice, Briggs could not see the advantages of introducing the reservation. 172 However Merrills regards this view as "too harsh a judgment". For the reservation requires that the dispute must first have been submitted to arbitration, and therefore recourse to the court be with the desire to reopen the case. ${ }^{175}$ This would have been true if the reservation was confined to the Baraimi dispute especially if the special circumstances surrounding it are taken into consideration, but why should the 
fear of reopening the dispute be a bar to the Court's jurisdiction if a tribunal had not been able for one reason or another to settle other disputes with other States? In such a case the dispute has not been closed at all.

This reservation is copied literally by some Commonwealth states in their current declarations. 174

\section{(VI) Single Shot Solutions}

The filing of an application by Portugal against India in the RIGHT OF PASSAGE OUER INDIAN TERRITORY case. three days only after the deposit of its declaration, gave professor Waldock the opportunity to draw attention to what he called a "glaring inequality in the position of a State which does and a state which does not make a declaration under the Optional Clause". 175 The latter can use the Optional Clause for a tactical opportunity by making a declaration just before instituting the suit against the former which is continuously liable to be brought before the Court and then remain immune simply by withholding an "open-ended" 176 acceptance of general compulsory jurisdiction. As a solution to the problem Waldock proposed the inclusion of a reservation including:

"all disputes with a State which at the date of the ratification of the declaration has not been accepted the Optional clause, except disputes which arise after the acceptance of the Qptional clause by the state with regard to situations or facts subsequent to the said acceptance"

Two other elements appear to have encouraged some States to adopt Waldock's view, though in different formulae. The statement of the court in the RIGHT OF PASSAGE OUER INDIAN TERRITORY case that "a State accepting the jurisdiction of the court must expect that an application may be filed against it before the court by a new declarant state on the same day on which that state 
deposits with the Secretary-General its declaration of acceptance". 178 and the deposit of the Egyptian declaration of July 22, 1957 concerning its declaration of April 24. 1957 on Suez Canal and the arrangements for its operation.

Thus the United Kingdom withdrew its declaration of April 18, 1957, which contained the following reservation excluding from the Court's compulsory jurisdiction:

"(Viii) disputes in respect of which any other party to the dispute has accepted compulsory jurisdiction of the International Court of Justice only in relation to, or for the purposes of the dispute; or where the acceptance of the court's compulsory jurisdiction on behalf of any other Farty to the dispute was deposited or ratified less than twelve months prior to the filing of the application bringing the dispute before the Court".

The first part of the reservation seems to be designed to exclude declarations such as the Egyptian one, i.e. limited to specific disputes. It might be regrettable that such a reservation was made for the first time by a state which was itself the first one to introduce in 1946 a declaration limited to "disputes concerning the interpretation, application or validity of any treaty relating to the boundaries of British Honduras". 179 Moreover, although, it is questionable whether these declarations can be qualified as acceptances under Article 36 (2), 180 they should not be disregarded. The Egyptian declaration, for example, cannot be devoid of any importance. It concerns subjectmatter of vital interest for the world. Therefore, why should a step like it be defeated? Such a declaration should - as professor D'Amato observed be welcomed at least as a partial step along the road to general acceptance. 181

If the first part of the British reservation has undoubtedly the effect of excluding subject-matter declarations, it is not so easy to have the same effect with 
regard to general acceptance. For the phrase "only in relation to or for the purpose of the dispute", may give rise to difficulties and may meet with unsympathetic interpretation by the Court. ${ }^{182}$ For example, it would be somewhat difficult to prove that the Portuguese acceptance of the Court's jurisdiction in 1955 was - as professor Briggs points out - made only in relation to or for the purpose of the Right of Passage dispute with India. for the following reasons: firstly, it is to be recalled that the Portuguese declaration is the only one which has been made expressly to cover disputes arising out of events both prior and subsequent to the date of the declaration. Therefore, if it was made for the purpose of that dispute, it might not have given the other declarants the opportunity to sue it for any dispute whenever one arose. Secondly. Portugal became a member of the United Nations, and hence party to the statute on December 14, 1955, 184 i.e. 5 days only before the deposit of its declaration. Thirdly, the declaration of India as respondent, was terminable immediately by a simple notice to the Secretary-General. Consequently if India had known that the declaration was deposited, it might have terminated its declaration on the same day, or at least introduced a reservation depriving the court of jurisdiction to entertain the case. Lastly. Portugal's declaration is amongst the few declarations which have not been subject to modification though it was made for one year.

However, there is no doubt that the lesson learned from that case is the possibility offered to states outside the system, of using it as a means of opportunism. The second part of the reservation aims at depriving those states of such opportunism, and providing some protection against surprise application. Thus the modification of the declaration fo Israel on February 24, 1984 by introducing a similar reservation seems intended to deprive Egypt of the possibility of referring the dispute with Israel over Taba by modifying its declaration of 1957 or making a new declaration. 
It is obvious that the principle of reciprocity suspends the effect of a new declaration containing such a reservation for one year UIS-A-UIS other states, i.e. this state cannot be sued by the other declarants during that period.

Certainly the inclusion of the second part of the reservation is necessary for the establishment of equality between states 186 in and outside the compulsory jurisdiction system, but it is believed that it is not a perfect solution. for it might be used against its aim. The clause of twelve months may give a state making the reservation the opportunity to sue the new declarant just after the expiry of that period then terminate its declaration or modify it in away to exclude a potential dispute with that state. The problem has, thus, a strong connection with the termination of declarations at any time. Thus it is regrettable that when the United Kingdom introduced the reservation, its declaration was terminable on notice. Any complete solution for the single shot problem has to take into consideration the hit-andrun problem. Thus it seems that neither of the following proposals constitute a general solution for these two problems: the first, which was made by professor Waldock, requires the addition at the end of Article 36 the proviso:

\footnotetext{
"Frovided that for a period of two years after the date when any such declaration comes into force it shall not have effect with respect to a dispute concerning matters which were the subject of differences between the Farties during two years immediately preceding that date".
}

and the second is that made by professor L Gross requiring the following addition to paragraph 4 of Article 36 : declarations "shall not enter into force until a month or so after the deposit". 188 It is obvious that the effect of both these proposals is limited to the "single shot" problem. They constitute thus a partial solution to the problem as a whole, as long as they leave states parties 
to the compulsory jurisdiction system free to hit each other and run. Since both these proposals require amendment of the statute, the simple and perhaps, complete solution can be achieved by adding to that Article the proviso:

"Frovided that the declaration shall have effect as long as it has not been revoled subject to one year"s notice".

A worse solution than the British one was made by France in its declaration of 1959 which excluded:

\footnotetext{
"Disputes with any State which, at the date of reference of facts and situation giving rise to the dispute, has not accepted the compulsory jurisdiction of the International Court of Justice for a period at least equal to that specified in this declaration".
}

This reservation was capable of giving rise to complicated problems. The determination of the date of the facts and situation giving rise to the dispute is not easy, as already mentioned. 189 It could have the effect of excluding disputes with states which had accepted the jurisdiction for along time before the declaration was made. Furthermore, France could have had difficulties for determining - according to the terms of its own declaration - which States were excluded and which engagements were superior or inferior to the French engagement. 190 For example, was it possible to invoke it against states whose declarations were made unconditionally especially in the light of the rule in the HILITARY AND PARAMILITARY ACTIUITIES IN AND AGAINST NICARAGUA case that they are terminable after a reasonable time? 191 Could it cover declarations terminable immediately or if the notice of termination required was less than 3 years (the period for which the French declaration was made)? The application of reciprocity could have complicated these problems, 192 and might have had the effect of depriving france from resorting to the court at least vis-a-vis states the declarations of which were for a period more than 3 years. 195 
In 1966. France modified its declaration of 1959. By omitting the initial period for which that declaration was made, the final phrase of the reservation was omitted. The reservation is, fortunately, no longer a feature of current practice. It disappeared following the French termination of the declaration of 1966, in 1974. On the other hand, the British reservation appeared to some States as acceptable formula. It has been incorporated in seven declarations. India was, naturally, the second State to make it in 1959 following the Court's judgment in the RIGHT OF PASSAGE OUER INDIAN TERPITORY case. With the termination of Israel's declaration, the reservation is to be found in the declarations of Malta. Mauritius, New Zealand, Philippines, Somalia and the United Kingdom. 


\section{Notes}

(1) P.C.I.J. , Series D, No.6, p.37.

(2) El Salvaor (1930), Italy (1929), Turkey (1936) and Yugoslavia (1930), Ibid., pp.34,43, and 51. for the text of the declaration of Turkey see ibid., Series E, No.15, p.336.

(3) the declarations of Barbados, Egypt, Gambia Liberia, the Netherlands, Pakistan, the Philippines and Senegal. See I.C.J.Y.B., 1986-87, pp.59-91.

(4) Gambia's declaration .

(5) The philippines' declaration.

(6) Barbados' declaration.

(7) Senegal's declaration.

(8) Most publicists admit the difficulty of determining that date. See e.g. H.W. Briggs, "Reservations to the Acceptance of Compulsory Jurisdiction of the International Court of Justice", 93 R.C.A.D.I.(1958), pp.229-363, at 280 an B. Maus, les Reserves dans les Declarations d'Acceptation de la Juridiction Obligatoire de la Cour Internationale de Justice, thesis (Universite de Geneve, Faculté de Droit), 1959, p.135. However S. Prasasvinitchai observes that the intention of the declarant State should be determined according to the terms of the declaration, or to the circumstances in which it was made, and in case of absence of any provision the date of entry into force may serve as the exclusion date. , la Clause Facultative de Juridiction Obligatoire de la Cour Internationale de Justice, thesis (Université de Paris, Faculté de Droit et des Sciences Economiques), 1962, p.89.

(9) Pakistan's declaration,for example, refers to June 24, 1948 as the exclusion date though the first declaration was signed on June 22, 1948 and deposited on July 9, 1948.

(10) The longest period between the date of signature and the date of deposit is to be found in the Philippines declaration, which was signed on December 231971 and deposited on January18, 1972. This interval does not exceed one week in the other concerned declarations.

(11) See J.G. Merrills, "the Optional Clause Today", 50 B.Y.B.I.L.(1979), pp.87-116. See also pp.161-171 below.

(12) The declarations of Finland, Colombia, Malawi and Sudan.

(13) The declaration of Colombia.

(14) P.C.I.J., Series D, No.6, p.39.

(15) R.St.J. Macdonald admits that there is little practical difference between the two double formulae, "the New Canadian Declaration of Acceptance of Compulsory Jurisdiction of the International Court of Justice", 8 Can.Y.B.I.L.(1970), pp.338, at 22. See also S. Rosenne, the Law and Practice of the International Court, 2nd. Revised ed., 1985, p.494.

(16) In his Separate Opinion in the Electricity Company of Sofia and Bulgaria case Judge Erich Observed that there little difference between these three forms (i.e., including the simple formula). He said that"the reservation ratione Temporis inserted in many international undertakings appears in different form 
... fundamentally there is little difference between the intentions of the contracting States. Any dispute caused by facts or measures of a legal character prior to to certain decisive and critical date are excluded from the application of the rule. Such formulae may be criticised as inexact and likely to cause confusion, but they must be given the meaning which the contracting parties had in mind.",Electricity Company of Sofia and Bulgaria,Judgment, 1939, P.C.I.J., Series A/B, No.77, p.64,at142.

(17) The declaration of Mexico substitutes the word "events" for the words "facts and situations", I.C.J.Y.B.,1986-87, p.79.

(18) Supra note 11, p.100.

(19) The declarations of Belgium, Colombia, Finland, Sudan, Sweden and the United Kingdom.

(20) Belgium (the date of ratification of the previous declaration i.e. July 13, 1948), Sweden (the date of the deposit of the previous declaration,i.e, April 6, 1947), Colombia (the date of the signature and entry into force,i.e., January 6 , 1932) and Finland (the date signature and deposit i.e., June 25, 1958).

(21 ) See I.F.I. Shihata, the Power of the International Court to Determine its Own Jurisdiction : Competence de la Competence, 1965, .216.

(22) H. Lauterpacht, "the British Signature and Reservations", 11 B.Y.B.I.L. (1930), pp.137-172, at 141-142. A.N. Farmanfarma believes that the reservation, if taken literally, is capable of excluding all disputes from the Court's jurisdiction, the Declarations of the Members Accepting the Copulsory Jurisdiction of the International Court of Justice, thesis (Université de Genéve, Faculté de Droit), 1952, p.74.

(23) Ibid., p.143. These difficulties have been observed in almost all subsequent literature on this point. See e.g. E. Hambro, "Some Observations on the Compulsory Jurisdiction of the International Court of Justice", 35 B.Y.B.I.L.(1948), pp.133-157, at $143 ;$ C.H. Vignes, "Observations sur la Nouvelle Declaration Française d' Acceptation de la Juridiction Obligatoire de la Cour Internationale de Justice",31 R.G.D.I.P.(1960), pp.52-74, at 54 ; H.W. Briggs, Reservations ..., supra note 8, p.290 ; F. De Pauw, "la Declaration Belge du 3 Avril 1958 Acceptant la Juridiction Obligatoire", 2 R.B.D.I.(1966), pp.94-124, at 23-26, and "la Belgique et la Compétence Obligatoire de la Cour International", 1 ibid., (1965), pp.49-87, at 76-77 ; J.H.W. Verzijl, "the System of the Optional Clause", 1 Int'l. Rel.(1959), pp.585-610, at 594595, and"the Competence of the International Court of Justice", ibid., (1954), pp.39-49, at 45-46 ; Sir J.F. Williams, "the Optional Clause", 11B.Y.B.I.L.(1930), pp.63-84, at 74 ; J.L. Brierly, "British Reservations to the General Act", 12 ibid., (1931), pp.132-135, at 133 , and R.P. Anand, Compulsory Jurisdiction of the International Court of Justice, 1961, p.74.

(24) Phosphates in Morocco, Judgment, 1938, P.C.I.J., Series A/B, No.74, p.10, at 143-148.

(25) S. Rosenne, the Law ..., supra note 15, p.491.

(26) Right of Passage over Indian Territoty, Merits, Judgment, I.C.J. Reports 1960, p.6, at 35. 
(27) Ibid., p.73.

(28) Cited supra note 16, pp.148-149.

(29) Mavrommatis Palestine Concessions, Judgment No.2, 1924, P.C.I.J., Series

A, No.2, p.11. A similar definition is to found in many other cases . See e.g. Certain German Interests in Polish Upper Silesia, Jurisdiction, Judgment No.6, 1925, P.C.I.J., Series A, No. 6, p.14 ; Interpretation of Judgments Nos.7 and 8(Factory at Chorzow), Judgment No.11, 1927, P.C.I.J., Series A, No.13, at 10-11 ; Interhandel, Judgment, I.C.J. Reports 1959, p.6, at 22 ; Right of Passage (Merits), cited supra note26, at 33 ; Interpretation of Peace Treaties with Bulgaria, Hungary and Romania, First Phase, Advisory Opinion, I.C.J. Reports 1950), p.65, at 328, 343, and Northern Cameroons, Judgment, I.C.J. Reports 1963, p.15. For the definition of dispute see Sir P. Spender's opinion in the Interhandel case, ibid., p.60 ; Ch. Debbasch, "la Compétence 'Ratione Temporis' de la Cour International de Justice dans le Systeme de la Clause Facultative de Juridiction Obligatoire", 31R.G.D.I.P. (1960), pp.230-259, at 237 ; J.G. Sauveplanne, "les Limitations Ratione Temporis dans L'aaplication de la Clause Facultative", Neth.Y.B.I.L.(1956), pp.342-354, at 293-296 ; J.G. Merrills, "Sir Gerald Fitzmaurice's Contribution to the Jurisprudence of the International Court of Justice", 48 B.Y.B.I.L.(1976-77), pp.183-240, at 204, and G. Gorden, " 'Legal Disputes' Under Article 36 (2) of the Statute", in L.F. Damrosch (ed.), the International Court of Justice at Crossroads, 1987, pp.183-222, at 198-202.

(30) The Law ..., supra note 15, p.294.

(31) Sep. OP. , supra note 16, at 143.

(32) Supra note 29, p.30.

(33) Judges Hackworth, Willington Koo, Sir P. Spender and Zafrulla Khan, ibid., pp.33, 53, 73 and 23 respectively.

(34) Cited Supra note 26, p.116.

(35) S. Rosenne, the Law,... supra note 15, p.490.

(36) For further details concerning this dispute see F. De Pauw, la Declaration Belge ..., supra note 23, pp.108 seq.

(37) H. Lauterpacht, supra note 22 , at 140-141.

(38) Cited supra note 26, p.24.

(39) J.G. Merrills, the Optional ..., supra note 11, pp.96-97. P. Quéneudec observes that Kenya inteded, perhaps, to exclude the dispute with Somalia concerning "the Northern Frontier District", "les Etats Africains et la Competence de la C.I.J.", An. A. (1967), pp.323-358, at 44 note 115.

(40) Supra note 22, pp.141-142.

(41) Ibid., p.140.

(42) Supra note 23, p.133. However the reservation was both necessary and desirable according to Sir J.F. Willams, supra note 23, p.75. K. Yokota describes it as 'natural', Compulsory Jurisdiction of the International Court of Justice", in International Law Association, Reports of the 51st. Conference, Tokyo, 1964, pp.8-18, at 11.

(43) The reservation ratione temporis was invoked before the P.C.I.J. in the Mavrommatis case but with regard to a compromissory clause in a treaty, supra 
note 29, p.6.

(44) Supra note 26, p.12.

(45) Ibid., p.23.

(46) Ibid., p.24(emphasis added).

(47) Ibid.

(48) I.C.J.Y.B., 1985-86, pp.65,80.

(49) P.C.I.J., Series A/B, No.74, at 24.

(50) Ibid. The idea of continued and progressive unlawful action was fully developed by Mr. Montagna and Professor Ago,see P.C.I.J., Series C, No. 84, at $488-498,847,855,1233,1237$ seq. For counter arguments see the pleadings of Professor Basdevant and Mr. Lémonon, ibid., pp.720, 723, 1023, 1026, 1043, 1060. See also J. Soubeyrol, "Validity dans le Temps de la Declaration d' Acceptation de la juridiction Obligatoire", 5 A.F.D.I.(1959), pp.232-257, at 234-240.

(51) See p.157 above .

(52) Supra note 26 , at 35.

(53) lbid., p.34.

(54) Ibid., p.36.

(55) lbid., p.37.

(56) Cited supra note 16, p.81.

(57) Ibid., pp.65, 82.

(58) Ibid.

(59) Ibid (emphasis added).

(60) This new restriction seemed to Judge Erich inacceptable. He warned in his Separate Opinion that, if taken in a very limited sense, the reservation ratione temporis might become almost void of substance. For, the alleged damage suffered before the exclusion date could be resuscitated by a claim submitted to some national judicial or administrative authority subsequent to that date. The final dismissal of the Claim could then be alleged as an unlawful act and as the element giving birth to the dispute, ibid., p.143. See also the opinion of Judge Papazoff, ibid., pp.148-149.

(61) See p.157 above. In fact, H. Lauterpacht doubted that the reservation would have that effect. Rof discussion on this point see B. Maus, supra note 8, p.141. It may be added that the non-exclusion of disputes concerning treaties concluded before the exclusion date is supported by the existence of reservations excluding disputes concerning treaties,such as the multilateral treaty reservation. See Section 3, Chapter 6 below.

(62) Anglo- Iranian Oil Co., Judgement; I.C.J. Reports 1952, p.93, at 103.

(63) I.C.J. Pleadings, Anglo-Iranian Oil Co., p.164 seq.

(64) Supra note 62, pp.105-107. Professor H.W. Briggs observes that the Court "appear to have applied a restrictive interpretation to the declaration as a grant of jurisdiction, while refusing to construe restrictively the reservation ratione temporis which was the source of the ambiguity", supra note 8, p.288.

(65) Cited supra note 29.

(66) Ibid., pp.10-11. For discussion of this objection see I.C.J. Pleadings, 
Interhandel case (Switzerland v. United States of America), pp.308-310, 389-395, 476-485, 523-534, 595, 601-608, 623-627. See also H.W. Briggs, "Interhandel: the Court's Judgment of March21, 1959, on the Preliminary Objections of the United States", 53 A.J.I.L.(1959), pp.547-563.

(67) Ibid., p.20.

(68) Ibid. This Statement was regarded by Professor J.H.W. Verzijl as deviation from judicial precedents in the Mavrommats and Peace Treaties cases, the System ..., supra note 23, p.594.

(69) Ibid., p.22.

(70)Five Judges dissented on this point (Hackworth, Cordova, Wellington Koo, Sir P. Spender and Zafrallah Khan, who declared that he was in agreement with Hackworth's Separate Opinion). They all thought that the dispute arose before August 26, 1946 and they had concentrated on the enemy or non-enemy character of the Interhandel. Ibid., pp.33-40;41-44;48-53;59-73, and 32 respectively. See also H.W. Briggs, supra note 66, at 547-563, and S. Rosenne, the Law ..., supra note 15, pp.492-493 and the International Court of Justice, 1957, pp.410 seq.

(71) Right of Passsge over Indian Territory, Preliminary Objections, Judgment, I.C.J. Reports 1957, p.125. It is to be observed that the this formula was invoked by France in Certain Norwegian Loans case (Judgment, 1957, p.9 at 21-22) and by Bulgaria in the Aerial Incident of 27 July 1955 case [(Israel v. Bulgaria), Judgment, I.C.J. Reports 1959, p.127, at 133], but the Court lacked jurisdiction on another ground and therefore the reservation had not been discussed.

(72) Ibid., p.151.

(73) I.C.J. Pleadings, Right of Passage case, p.218.

(74) I.C.J. Reports 1957, Cited supra note 71, p.152. In his Dissenting Opinion, Judge Badawi pointed out that priority should have bee given to the date of the situation and not to the date of the dispute, because the declaration did not say "concerning prior disputes", but "prior situations or facts". However, the language of the Indian declaration was different. Ibid., p.161. Judge Chagla preferred the formula in the Phosphates in Morocco case, which meant, in his view, that "a situation would include within its connotation not merely facts but also legal consequences resulting from a given set of facts." Thus he observed that Portugal's argument that the dispute arose in 1954 was false. He concluded that the was no answer to India's sixth preliminary objection and the Court had no jurisdiction to entertain the dispute. Ibid., pp. 179-180.

(75) Cited supra note 26, pp. 33-34.

(76) See p.158 above.

(77) I.C.J. Reports 1960, Cited supra note 26, p.34.

(78) lbid., p.35.

(79) Ibid.

(80) Ibid.

(81) Ibid. S. Rosenne Observes that the treatment of the dispute as a whole seems to contradict the experience of the previous year in the Interhandel case, the 
Law ..., supra note 15, p.497.

(82) Ibid., p.36.

(83) Ibid.,p.52.

(84) Ibid., pp.69-75.

(85) Ibid., p.117.

(86) Ibid., p.118.

(87) I.C.J.Y.B. , 1985-86, p.86.

(88) The declarations of Austria, Botswana, Costa Rica, Democratic Kampuchea, Denmark, Dominican Republic, Haiti, Honduras, Liechtenstein, Malta, Mauritius, New Zealand, Nicaragua, Nigeria, Norway, Panama, Somalia, Swaziland, Switzerland, Togo, Uganda and Uruguay.

Mavrommatis Palestine Concessions, Judgement No.2, 1924, P.C.I.J.,Series A, No.2, at 35.

(90) Supra note 20, p.71.

(91) See e.g. E. Hambro, Some Observations ..., supra note 23, p.145 ; B. Maus, supra note 8, p.135; J.G. Sauveplanne, supra note 29, pp.345-346 ; Ch. Debbasch, supra note 29, pp.243-247; M.O. Hudson, the Permanent Court of International Justice, 1920-1942. A Treatise, 1943, p.35 ; H.W. Briggs, Reservations ..., supra note 8,283 , and $S$. Rosenne, the Law ..., supra note 15,pp.484-485.

(92) Cited supra note 24, at 24. See also p.11 above.

(93) See pp.166-167 above.

(94) Cited supra note 29, at 23.

(95) I.C.J. Pleadings, Interhandel case, pp.396-401.

(96) I.C.J. Reports 1959, cited supra note 29, at 23. See also Section 1, Chapter 4 below, p.236.

(97) Ambatielos, Preliminary Objections, Judgment, I.C.J. Reports 1952, p.28, at 40 seq.

(98) For the idea of continuity between the two Courts see the Aerial Incident case (Israel v. Bulgaria), cited supra note 71, p.145 and Military and Paramilitary Activities in and against Nicaragua case (Nicaragua v. United States of America), Jurisdiction and Admissibility, Judgment, I.C.J. Reports 1984, p.392, at 407 seq.

(99) Supra note 29, pp.347-348. But Comp. S. Rosenne, the Law ..., supra note 15, pp.483-489.

(100) See pp.166-169 above.

(101) Ibid.

(102) S. Rosenne, the Law ..., supra note 15,p.488.

(103) Ibid., p.489.

(104) Ibid. For the problems connected with the idea of continuity and the distinction between it and state concession, see 1. Brownlie, Principles of Public International Law, 3rd.ed.1983, pp. 84-88.

(105) R. Rosenne, the law supra note 15, p. 489; R. P. Anand, Studies in International Adjudication, 1969, p. 42, and J. G. Merrills, the optimal clause ..., supra note 11, p.97. 
(106) See pp. 158-159 and 161-162 above.

(107) See R.St. J. Macdonald, supra note 15, p.26 and Merrills, supra note 11, p.97.

(108) After asking whether a state can rely on reciprocity for modifying the exclusion date included in its declaration, Maus finds that if the critical date is indicated in an objective manner, i.e by indicating a determined date, the fixed cannot be modified by the application of reciprocity, but if the date is determined by a subjective event such as signature or ratification, reciprocity can have the effect of modifying the critical date. Supra note 8, pp.137-138. The reason for making this distinction is not apparent. Moreover, Maus seems to confuse between the invocation of the critical date included in the declaration of the respondent, State and its attempt to to rely upon the principle of reciprocity in order to make the date of the declaration of the applicant, which does not include such a reservation, as a critical date, i.e. as did the United States in the Interhandel case. However, the Court refused in this case to give reciprocity such an effect. See I.C.J. Reports 1959 (cited supra note 29), pp.22-23. See also Section 1, Chapter 4 Below at 233-234.

(109) See J.G. Merrills, supra note 11, p.97.

(110) See Section 1, Chapter 2 above ,p.103.

(111) 197 L.N.T.S. , pp.285-287.

(112) See B. Maus, supra note 8, p.144 and S. Prasasvinitchai, supra note 8 , pp.133-134.

(113) See Section 2, Chapter 5 below, at 349.

(114) See B. Maus, supra note 8, p.144 and S.Prasasvinichai, supra note 8 , pp.133-134.

(115) J.G. Merrills, supra note 11, p.97.

(116) I.C.J.Y.B., 1984-85, p.79.

(117) J.G. Merrills, supra note 11, p.79. For further detail see T. Meron, "Israel's Acceptance of Compulsory Jurisdiction of the International Court of Justice", 4 Isr.L.R.(1969), pp.307-333, at 327-328.

(1.18) I.C.J.Y.B., 1985-86, p.88.

(119) See B.Maus, supra note 8, p.146, and S. Prasavinitchai, supra note 8 , pp.138-139.

(120) Ibid. See also J.H.W. Verzijl, the System ..., supra note 23, p.596; H. Lauterpacht, the British Reservations ..., supra note 22, at 147 ; S. Rosenne, the Law ..., supra note 8, pp.403-405, and H.W Briggs, supra note 8, p.303.

(121) Records of the First Assembly, Committee 1, 1920, p.553.

(122) League of Nations, P.C.I.J., Documents Concerning the Action Taken by the Council of the League of Nations under Article 14 of the Covenant and the Adoption of the Assembly of the Statute of the P.C.I.J.,p.107.

(123) P.C.I.J., Series E, No.15, p.218.

(124) See M.O. Hudson's Treatise, supra note 91, p.684. 
(125) C.H.M. Waldock, "Decline of the Optional Clause", 32 B.Y.B.I.L.(1955-56), pp.244-287, at 255. for further detail see Section 1, Chapter 4 below, p.210 seq.

(126) P.C.I.J., Series D, No.6, p.45.

(127) Austria, Canada, India, New Zealand and South Africa.

(128) "Memorandum on the Signature of his Majesty's Government in the United Kingdom of the Optional Clause of the Statute of the Permanent Court of International Justice", 1929, Cmd.3452, p.6.

(129) P.C.I.J., Advisory Committee of Jurists, Proces-Verbaux of the Proceedings of the Committee, June 16-July 12, 1920, pp.71-72.

(130) H. Lauterpacht, the British reservations ..., supra note 22, at 148.

(131) R.Y. Jennings,"the Commonwealth and International Law", 30 B.Y.B.I.L.(1953), pp.326-330, at 327 .

(132) Quoted by R.W. Jennings, ibid., p.327.

(133) See E.J. Coory, " A Commonwealth Court", 43 J.P.C.(1962), pp.347-353.

(134) See e.g. R.Y. Jennings, supra note 131, pp.326-330 ; J.G. Merrills, supra note 11, pp.103-104 ; R.St.J. Macdonald, supra note 15, pp.30-32, and R.P. Anand, Compulsory ..., supra note 23, pp.238-240 and Studies ..., supra note 105, pp.43-45. But comp. J.F. Williams, supra note 23, p.75.

(135) R.St.J. Macdonald, supra note 15, p.131.

(136) Ibid. See also J.E.S. Fawcett, the British Commonwealth in International Law, 1963, pp.144 seq., 202-209.

(137) Quoted by R.P. Anand, Compulsory ..., supra note 23, p.239.

(138) The declarations of Barbados, Canada, Gambia, India, Kenya, Malta, Mauritius and the United Kingdom.

(139) Those which do not contain it are the declarations of australia, Botswana, Malawi, New Zealand, Nigeria, Swaziland and Uganda.

(140) Its declaration excludes disputes "with the Government of any State Which , on the date of this declaration is a member of the Commonwealth of Nations or may be so become subsequently.", I.C.J.Y.B., 1985-86, p.74.

(141) P.C.I.J., Series E, No. 15, p.215.

(142) As an Example, if the dispute concerning the Western Sahara had bee brought before the Court by unilateral application according to Art: 36 (2), it might have been settled since long time.

(143) For the projected Arab Court see E. Foda, the Projected Arab Court of Justice, 1957.

(144) I.C.J.Y.B., 1984-85, p.100.

(145) See pp.36-40 above.

(146) I.C.J. Reports 1984 (Cited supra note 98), at 415-421. It is to be noted that $F$. Hassan has challenged the validity of this reservation. He argues that this reservation "is invalid per se as partially negativing the general jurisdiction $a b$ initio conferred on the Court by the submission of a declaration under Article 36.", "A Legal Analysis of the United States's Attempted withdrawal from the 
jurisdiction of the World Court in the Proceedings Initiated by Nicaragua", 10 U.D.L.R.(1985), pp.295-318, at 308.

(147) P.C.I.J., Series, D, No.6, pp.53 and 51 respectively.

(148) Ibid., p.54.

(149) T. Meron, supra note 117, p.321.

(150) I.C.J.Y.B., 1984-85, p.79. For the Israeli reservation see T. Meron, supra note 117, pp.320-324 ; B. Maus, supra note 8, p.149 ; J.G. Merrills, supra note 1,pp.104-105 ; S. Prasasvinitchai, supra note 8, pp.142-143 ; R.P. Anand, Compulsory ..., supra note 23, p. 244 and Studies ..., supra note 105, p.295 and I.F.I. Shihata, supra note 21, p.274.

(151) I.C.J.Y.B.,1950-51,p.19 (italics added).

(152) Supra note 117, p.322.

(153) Ibid.

(154) I.C.J.Y.B., 1950-51, p.193.

(155) S. Rosenne, the International Court ..., supra note 70, p.342.

(156) T. Meron, supra note 117, pp.323-324.

(157) "The Thirtieth Year of the World Court", 46 A.J.I.L.(1952), pp.1_39, at 35.

(158) I.C.J.Y.B. 1985-86, p.72.

(159) J.G. Merrills, the Optional Clause ..., supra note 11, p.105.

(160) Ibid.

(161) Ibid.

(162) 1 U.N.T.S., p.49.

(163) For the different types of reservations made before 1920, see Section1, Chapter 1 above.

(164) Only Liechtenstein, San Marino and Switzerland are parties to the Statute according to that Article. See I.C.J.Y.B., 1985-86,p.46.

(165) S, Rosenne, the Law ..., supra note 15, pp.271-274.

(166) For the Whole Text of the reservation see I.C.J.Y.B., 1985-86, p.47.

(167) South West Africa, Preliminary Objections, Judgment, I.C.J. Reports 1962 , p.319.

(168) I.C.J.Y.B., 1985-86, p.65. Some States have accepted the Court's jurisdiction expressly in relation to members and non-members of the U.N. See e.g. the declarations of Israel of 1950 and 1959, and that of Panama.

(169) See B. Maus, supra note 8, p.148.

(170) Supra note 8, p.141.

(171) C.H.M. Wadock, supra note 125, at 268 and "the Thirty-Forth Year of the World Court", 50 A.J.I.L.(1956), pp.1-19, at 15.

(172) Supra note 8, p.301.

(173) Supra note 11, p:103.

(174) The declarations of Malta and Mauritius.

(175) Supra note 125, p.280 and see Chapter 2 above ,pp.123-132. 
(176) A. D' Amato, "the United States Should Accept by a New Declaration, the General Compulsory Jurisdiction of the World Court", 80 A.J.I.L.(1986), pp.331-336, at 333 .

(177) Supra note 125, at 282.

(178) Cited supra note 71, p.146.

(179) 1 U.N.T.S., p.3. The declaration was renewed for 5 years as from Feb. 12, 1951, 80 U.N.T.S., p.304

(180) J.G. Merrills, supra note 11, p.102 ; T. Meron, supra note 117, p.310 ; T. Taoka, "Japan and the Optional Clause", Jap.A.I.L. (1959), pp.1-11, at 3, and S. Rosenne, the Law ..., supra note 8, p.370.

(181) "Modifying U.S. Acceptance of the Compulsory Jurisdiction of the World Court", 79.A.J.I.L.(1985), pp.385-405, at 388 .

(182) Ibid. See also J.G. Merrills, supra note 11, p.102.

(183) Reservations ..., supra note 8, p.302.

(184) I.C.J.Y.B., 1985-86, p.44.

(185) The reservation excluded "any dispute with respect of which any other party thereto has accepted, or amended, a previous acceptance of the compulsory jurisdiction of the International Court of Justice, only in relation to or for the purpose of the dispute; or where the acceptance or the amendment of a previous acceptance of the Court's compulsory jurisdiction, on behalf of any other party to the dispute, was deposited or ratified less than 12 months prior to the filing of the application bringing the dispute before the Court". Ibid., p.80.

(186) See J.G. Merrills, supra note 11, pp. 101-102; R.P. Anand, Compulsory ..., supra note 23 , pp. 244-248 ; A. D'Amato, the United States Should ..., supra note 176, p.333 and Modifying ..., supra note 181, pp.387-389, and B. Maus, supra note 8, pp.147-148. Comp. H.W. Briggs, Reservations ..., supra note 8, p.302. (187) Supra note 125, p.286.

(188) L. Gross, "the International Court of Justice : Consideration for Requirements for Enhancing its Role in the International Legal Order", in L. Gross (ed.), the Future of the International Court of Justice, vol. 1, 1976, pp.22-104, at 79 [reprinted from 65 A.J.I.L.(1971), pp.253-326].

(189) See p. 156 seq. above.

(190) See Section 1 supra.

(191) See Chapter 2 above pp. 111-112.

(192) J. Feydi, " la Nouvelle Declaration Française d' Acceptation de la Juridiction Obligatoire de la Cour Internationale de Justice", 12 A.F.D.I.(1966), pp.155161.

(193) C.H. Vignes, supra note 23, pp.71-73. 


\section{UNNECESSARY RESERVATIONS RAIIONE MATERI AE}

Many States excluded from the scope of their acceptances of the Court's compulsory jurisdiction disputes which are already excluded from that jurisdiction by virtue of the Court's Statute. Thus, the reservations limiting the Court's jurisdiction to legal disputes only. or excluding disputes concerning matters which by international law fall within the jurisdiction of the declarant, appear in may declarations. Also the emphasis that the acceptance of the Court's jurisdiction is made on the condition of reciprocity can be found in a large number of declarations. This condition and the above reservations will be dealt with in the following sections.

\section{SECTION 1 : RECIPROCITY}

Reciprocity plays a major role in the determination of whether the Court has jurisdiction over a concrete dispute before it, through the determination of the common will of the parties to the dispute, or the extent to which their declarations coincide in conferring jurisdiction upon the Court. ${ }^{1}$ Reciprocity has thus two aspects to it. First, it means that in a dispute between two States, the narrower title of jurisdiction becomes the common denomination for both States. It means also that a State can invoke a reservation in its opponent's declaration even though it is not included in its own declaration. 2 In other words "what is sauce for the goose is sauce for the gander"' 3 Reciprocity in this sense has been treated as a "condition" or "principle". " and even sometimes as a "reservation".

The determination of the place of reciprocity in the system of compulsory jurisdiction raised some questions, which have been described as "the most difficult and important" " $q$ questions with regard to the declara- 
tions under Article 36 (2) of the Statute. Views are divided with regard to the basis of reciprocity, its effect and application. This is due mainly to the phraseology fof Article 36 (2-3) and, to some extent, the position taken by the court with respect to reciprocity. These points will be examined after considering the principle of reciprocity in the declarations accepting the Court's jurisdiction.

\section{A - RECIPROCITY IN THE DECLARATIONS OF ACCEPTANCE}

Different formulae have been adopted by States in regard to reciprocity. 13 of the 46 declarations currently in force stipulate expressly that the Court's jurisdiction is accepted subject to "the condition of reciprocity". " 13 other declarations include what might be termed as the "double formula of reciprocity". They accept the Court's jurisdiction "in relation to any other State ACCEPTING THE SAHE OBLIGATION, that is to say, on condition of reciprocity". "The same formula appears in the 5 other declarations with he sole difference that the words "that is to say" are omitted. " The other declarations do not contain any reference to the word "reciprocity", but 12 of them are made expressly "in relation to any other state accepting the same obligation", 10 one is made "conditionally"; 11 one simply recognises the Court's compulsory jurisdiction "as compulsory"; 12 and one recognises that jurisdiction "as provided for in paragraph 2 of the statute". 13

\section{B - THE BASIS OF RECIPROCITY}

\section{(I) The Basis of Reciprocity in the Doctrine}

Article 36, paragraph 2, of the statute of the International Court of Justice provides that "the states parties to the present statute may at any time declare that they recognise as compulsory IPSO FACTO and without special agreement, in relation to any other state ACCEPT- 
ING THE SAME ORLIGATION the jurisdiction of the Court in all legal disputes" concerning four listed categories. Paragraph 3 of the same Article adds:

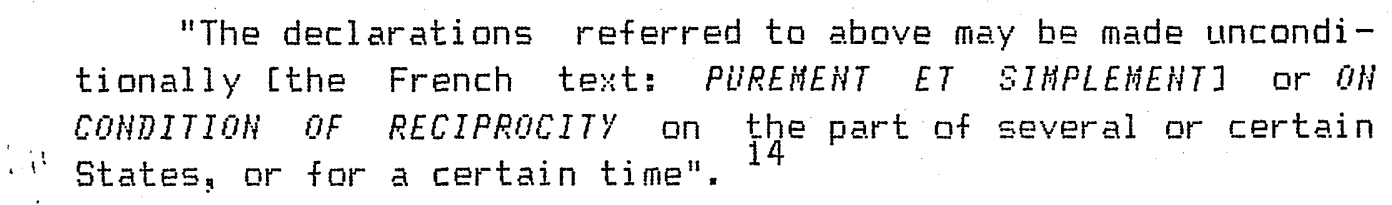

"The declarations referred to above may be made unconditionally [the French text: PUREMENT ET SIHPLEHENT] or of ConDITION of RECIPROCITy on the part of several or certain " i States or for a certain time".

This Article has been interpreted in two different ways in order to determine the basis of reciprocity: the interpretation of the said Article as it stands and its interpretation by reference to the preparatory works especially the proceedings of the Advisory Committee of Jurists of 1920 .

\section{(i) Paragraph 3 of Article 36 as a basis of reciprocity}

In the view of those who follow the first approach, the interpretation of paragraph 2 of Article 36 has to take into consideration the provision in paragraph 3 that the Court's jurisdiction might be accepted "unconditionally or on condition of reciprocity". In other words, paragraph 3 alone has never been considered as a basis of reciprocity, but in connection with paragraph 2 . 15

Professor G Enriques explains the connection between these two paragraphs as follows:

\footnotetext{
"Si l'on met ces régles en présence l'une de l'autre et si on les apprecie dans leur coexistence en tenant compte de la référence faite par la première a la second, il semble que l:on doive conclure que la reciprocity est etablie pour ce qui concerne la déclaration d'acceptation de la jurisdiction obligatoire, tell qu"elle est prevue par le 2. alinia".
}

There is no doubt, in his view, that there exists a distinction between the acceptance of the Court's compulsory jurisdiction with and without reciprocity. ${ }^{17}$ In supporting this view professor Enriques advanced the following arguments: firstly, the very existence of 
paragraph 3 implies that there exists a distinction between accepting the Court's jurisdiction with and without reciprocity. The only way of affirming the nonexistence of the distinction provided in paragraph 3 would be to demonstrate that this paragraph is deprived of any significance. Secondly, the declarations accepting the Court's jurisdiction at that time proved, in his opinion, the existence of such a distinction. This was so because all states, except two, 18 included in their declarations explicitly or implicitly the condition of reciprocity. Accordingly, Enriques has reached the conclusion that paragraph 2 Article 36 should be read as if the words "in relation to any other state accepting the same obligation", were not there. "19 Furthermore, the idea that paragraph 3 of Article 36 is a suspensive condition, and that reciprocity is inherent in the optional Clause system, is not applicable, in Enriques' view, not only because this interpretation is erroneous, but :

"plus exactement, l interpretation de la réciprocité,
tell qu"elle a été supposé plus haute, ne peut pas etre
admise, primo, parce que ce n"est pas sur la base de lavolo-
nté des Etats signataires du statut qu"il faut determiner le
sens de l'obligation de soumettre a l'arbitrage at celui de la
reciprocite y relative; secondo, par ce que la volonté qui a
reellement etabli la convention d"arbitage at la réciprocité
est celle qui est manifasteg par la declaration d"acceptation
de la juridiction obligatoire, valonté qui attribue a la
reciprocité un sens different de celui qui est expose plus
haut".

Although professor Hambro believes that reciprocity is an absolute condition according to paragraph 2 of Article 36, he points out that paragraph 3 seems to support the possibility of making declarations without reciprocity. However such an unconditional acceptance cannot be presumed. 21

Professor J H W Verzijl also rejects the idea that reciprocity is an absolute requirement according to 
Article 36 (2). "It is, in the contrary, so little a principle CONSACRE (principle embodied) by Article 36. (2) that paragraph 3 of the same Article explicitly permits on a footing of equality declarations on condition of reciprocity and unconditional declarations." 22

The aforementioned opinions seem to have confused the two types of reciprocity: reciprocity RATIONE HATERIAE according to paragraph 2 of Article 36 in the sense set out in the beginning of this section, and reciprocity RATIONE PERSONAE, or as a suspensive condition, according to paragraph 3. A reference to the drafting of paragraph 3 by the Advisory Committee of Jurists in 1920 shows clearly that it was inserted as a result of a proposition made by Mr Fernandez, the Brazilian delegate, who intended to make it possible for a State to pick and choose its partner in the compulsory jurisdiction relationship. Fernandez insisted that the states, in accepting the Court's jurisdiction, can condition their acceptance on the acceptance of that jurisdiction by a particular number of States or by certain specified states. 23 In his proposal Fernandez pointed out that states "may adhere unconditionally or conditionally to the Article providing for compulsory jurisdiction, a possible condition being reciprocity on the part of a certain number of Members, or, of a number of Members including such and such specified Members." 24 To clarify this proposal, Fernendez stated before the Third Committee of the First Assembly that "he considered that it was inadmissible for a State to accept the principle of compulsory jurisdiction without knowing exactly towards whom it accepted such obligation." 25 At the same meeting Mr Hube (Switzerland) explained more precisely the meaning of Fernandez's proposal. Hube stated that "the draft of the Subcommittee provided for reciprocity 'RATIONE MATERIAE' whereas Fernandez wished a stipulation establishing reciprocity 'RATIONE PERSONAE'; both things could without difficulty be combined." 26 
The intention of the Brazilian delegate was expressed in the Brazilian declaration of November 1, 1921. which was made "on condition of reciprocity and as soon as it has likewise been recognised as such by two at least of the powers permanently represented on the council of the League of Nations". 27

Thus the attempt to interpret paragraph 2 of Article 36 in connection with paragraph 3 without reference to the preparatory works had led to a misunderstanding of the meaning of reciprocity according to that paragraph. It seems also that the misuse of the word "reciprocity" in paragraph 3 is the main factor which has contributed to this confusion. However, the preparatory works of paragraph 3 show that this paragraph has its reason d'etre and that it is not an interpretation of the words "in relation to any other state accepting the same obligation". Nor can paragraph 2 be read as though those words were not there, as it has been suggested.

\section{(ii) Paragraph 2 of Article 36 as a basis of reciprocity}

Leaving aside the above mentioned views for a while, it is generally agreed that reciprocity finds its basis in the words "in relation to any other state accepting the same obligation". These words appeared to the late judge Hudson to suggest that every declaration made under Article 36 (2) has this characteristic impressed upon it. Thus, reciprocity " is not a reservation made by the declarant; it is a limitation in the very nature of the declaration which operates under, or is made ' in conformity with' paragraph 2 of Article 36". 28 He went on to state that, form a legal point of view, the insertion of the condition of reciprocity into the declarations of acceptance "seems to serve no purpose; all of the declarations contain the limitation IPSO FACTO, and this is true even though they are said to be without condition". 29 
The same view is shared by the late judge professor Waldock. The above phrases of paragraph 2 were inserted, he observes, "in the earliest declarations EX ABUNDANTI CAUTELA when jurisdiction under the Optional Clause was still untried, and the general opinion is that they are otiose ... Reciprocity, in short is a basic constitutional provision of the statute applying to every declaration even to a declaration like that of Nicaragua expressed to be made 'unconditionally'." 30 These views are widely adopted. 31

However, it is to be observed that the words "in relation to any other state accepting the same obligation" do not mean that the declarant state is bound only UIS-A-UIS other states which have made exactly, or even broadly, the same declarations, reservations and conditions. 32 Taking into account the number of declarations and the unilateral determination of the conditions on which states are willing to accept the Court's jurisdiction. such an interpretation would lead to the nullification of the compulsory jurisdiction system. These words seem thus to have been inserted in Article 36 "simply for the purpose of limiting a state's liability to accept the Court's jurisdiction at the suit of another state to CASES HHEN THE DISPUTE FALLS HITHIN A CATEGORY OF DISPUTES COUERED BY BOTH THETR DECLAFATIONS". IS Thus, having regard to the unilateral drafting of declarations. reciprocity is the means by which the common will of the parties, as a basis for the Court's jurisdiction, and the common element in different texts can be determined in any case before the court.

Reciprocity in this context finds its roots in the Second Hague Peace Conference of 1907. Since States were generally prepared to accept some enumerated categories of matters without reservation, a protocol indicating which States had agreed to submit different categories of dispute was envisaged. Accordingly, a state would be under an obligation to resort to obligatory arbitration 
without reservation in relation to any other state for these categories of dispute with regard to which both States had accepted that obligation. This was explained in the protocol proposed by the British delegation as follows:

"each power signatory to the present protocol accepts arbitration without reserve in such of the cases 1 isted in the table hereto annexed as are indicated by the letter $A$ in the column bearing its name. It declares that it makes this engagement with each of the other signatory powers whose reciprocity in this respect is indicated in the seme manner in the table":

The idea of applying reciprocity to reservations had also been contemplated in that conference. It was expressed clearly by Mr Georgios Streit in his proposition that:

\footnotetext{
"every restriction or reservation which any one of the signatory Fowers may add with respect to matters regarding which it declares itself willing to accept arbitration; may be involed against that Fower, even if the latter has not made any reservation or restrictign with respect to the said matters in its notification."
}

However, the words "in relation to any other state accepting the same obligation" were inserted by the draftsmen of the statute as an indication that a dispute could not be referred to the court unless it fell under a category of the four enumerated in paragraph 2 of Article 36 over which both parties had accepted the Court's jurisdiction. Hence, these words were intended to be a criterion for determining the obligations of the parties as regard the category into which the actual dispute fell and not as a requirement for the reciprocal operation of reservations, since the insertion of the latter was never contemplated by the draftsmen in 1920, as already explained. It However, the interpretation of Article 36 (2 - 3) as allowing states to make their declarations subject to different reservations has given the principle of reciprocity a great importance. 
The view that reciprocity RATIONE MATERIAE finds its basis in paragraph 2, and not in paragraph 3 of Article 36 is supported also by State practice. There is no mention at all of reciprocity "according to paragraph 3 either in States' declarations accepting the Court's compulsory jurisdiction, or in their pleadings before the Court". On the contrary, 13 declarations state clearly that the words "in relation to any other state accepting the same obligation" are equivalent to the word "reciprocity" (RATIONE MATERIAE). 37 states had also referred to reciprocity, as provided for in paragraph 2 , in their pleadings before the court.

From what has been said, it might be argued that reciprocity finds its basis not only in the words "in relation to any other state accepting the same obligation", but in the system of compulsory jurisdiction itself. This might be so since it is generally agreed, as stated above, that reciprocity is applicable even to declarations made unconditionally. In other words, reciprocity as an element of jurisdiction, is inherent in the compulsory jurisdiction system and could be applied even if the above mentioned words had not been provided for in Article 36 (2). It could be regarded as a general principle applicable to any act conferring jurisdiction upon an International court or tribunal. 39 Thus, the application of this principle was contemplated in the Hague Peace Conference of 1907, embodied in Article 39 (3) of the General Act of 1928, and is applicable even between States which accept the Court's jurisdiction under Article 36, paragraph 1.

\section{(II) The Basis of Reciprocity in the Opinions of the Court}

The P. C. I. J. had been consistent in regarding reciprocity as embodied in Article 36 (2) of the Statute. Thus, in the PHOSPHATES IH HOROCCO case it stated that "as a consequence of reciprocity stipulated in PARAGPAPH 2 of $A R T I C L E$ 36 of the statute of the court, it is recog- 
nised that [the] limitation holds good as between the parties". ${ }^{40}$ In the ELECTRICITY COMPANY OF SOFIA AND BULGARIA case, the P. C. I. J. also referred to the "condition of reciprocity" as "laid down in PARAGRAPH 2 OF ARTICLE 36 of the Court's statute..." 41

The I. C. J. followed this view in the first case in which it had an occasion to comment on the principle of reciprocity, namely, the ANGLO IRANIAN OIL COMPANY case. ${ }^{42}$ However it referred to reciprocity as provided for in paragraph 36 (3) in the NORHEGIAN LOANS case. After declaring that it was following the jurisprudence of its predecessor the P. C. I. J. and its own jurisprudence in the ANGLO IRANIAN OIL COMPANY case, the I. C. J. stated that:

\footnotetext{
"In accordance with the condition of reciprocity to which acceptance of the compulsory jurisdiction is made subject in both declarations and which is provided for IH ARTICLE $36_{\text {s }}$ PARAGRAPI 3 of the statute..." 43
}

This statement raises the question why this reference to paragraph 3 instead of paragraph 2? It is, perhaps, difficult to consider this statement as indicating a deviation from the previous jurisprudence. The reference by the court to the jurisprudence of the P. C. I. J. and its own judgment in the ANGLO IPANIAN OIL COMPANy case may support this view. The assumption that the Court's statement was an explanation of reciprocity RATIONE PERSONAE seems to be without support. For, firstIy, the Court was considering reciprocity as a condition according to which "Norway, equally with France, is entitled to except from the compulsory jurisdiction of the Court disputes understood by Norway to be essentially within its national jurisdiction". 44 Secondly, Norway referred in its preliminary objections to reciprocity as a principle embodied in Article 36, paragraph 2. 45 Furthermore, the absolute character of reciprocity as a jurisdictional requirement clearly appears from the court's opinions, even in this case. ${ }^{46}$ Thus the reference to 
paragraph 3 was "probably, an error". 47

In the HILITARY AND PARAHILITARY ACTIUITIES IH AND AGAINST NICARAGUA case the Court referred also to reciprocity according to paragraph 3 of Article 36 . In rejecting the contention of the U S A that Nicaragua's declaration was terminable by a simple notice and therefore the U S A had the right, according to the principle of reciprocity, to terminate its declaration with immediate effect, the Court declared that:

"the United States argument attributes to the concept of reciprocity, as embodied in PARAGRAPHS $z$ AHD 3 a meaning that goes beyond the way in which it has been interpreted by the Court according to its consistent jurisprudence."

The Court's reference to reciprocity in this case is, thus, based on both paragraphs 2 and 3 . Hence this statement could be understood as a reference to reciprocity in its two types: reciprocity RATIONE HATERIAE according to paragraph 2, and reciprocity RATIONE PERSONAE according to paragraph 3. The Court's mention of its "consistent jurisprudence" might support this view because - as already mentioned - the court referred to paragraph 3 in the NOPHEGIAN LOANS case only.

Whatever the intention of the Court, the drafting of paragraph 3 of Article 36 as explained above seems to leave no doubt that the "condition of reciprocity" provided for in paragraph 3, refers to another type of reciprocity different from that embodied in paragraph 2. Fortunately, the Court's reference to paragraph 3 is without practical effect, since reciprocity RATIONE HATEPIAE had been applied - as will be seen - in the same manner in all cases in which it was relied on.

\section{C - THE EFFECT OF THE OMISSION OF RECIPROCITY FROM THE DECLARATIONS OF ACCEPTANCE}

Although the weight of Scholarly opinion regards, 
as pointed out above, the mention of reciprocity in the declarations of acceptance as otiose. 49 some commentators take another view, especially when the declaration is made unconditionally. It might be, therefore, appropriate to consider the arguments advanced in support of this view in order to remove any doubt on this point. although there is only one declaration which is made "unconditionally". 50

The main argument which is usually cited by the writers who reject the idea that the rights and obligations of the parties under Article 36 (2) of the statute are necessarily reciprocal, is that states are free, according to the express terms of paragraph 3 of the said Article, to accept the Court's jurisdiction "unconditionally" or on condition of reciprocity. 51 This argument appears to be ill-founded, for, firstly, the history of paragraph 3 shows - as has been seen 52 - that it has another meaning; secondly, there is no declaration providing that it is made "without reciprocity"; and thirdly, it is believed that to assume that unconditional acceptance is an acceptance "without reciprocity" is to impose more obligations upon the state concerned and hence such interpretation is contrary to the general rules which requires a restrictive interpretation in such a case.

It has also been suggested that it should be permissible for a state to make a declaration broader than Article 36 (2), by dispensing with the requirement of reciprocity, as it is permissible for it to adopt the narrowest interpretation of the Article, by inserting reservations. Yet it is emphasised that a mere assertion that the acceptance is made unconditionally would not be enough; the provision would have to be drafted in the clearest terms. 5 S However it might be asked whether it is likely that a state would be prepared to make such a declaration? 54 
Professor Hambro criticises Hudson's view that the formula "without condition" seems to serve no purpose, as going too far. This is, in spite of his recognition that reciprocity is an "absolute condition". In addition to the freedom of making unconditional acceptance according to paragraph 3, professor Hambro argues that:

"If a State wished to make its acceptance of the compulsory jurisdiction not subject to any condition, why should it not be able to do so? Is there any rule of internationel law preventing states from accepting far-reaching unilateral obligations? They may thereby put themselves in a position of inequality as regard other states. They may give up a fraction of their sovereignty. They may consider it l audable for states to give up some of their sovereignty in order to increase the scope of the compulsory juriediction of the International Court of Justice".

There is maybe no rule of international law preventing states from accepting far-reaching unilateral obligation, and there is no doubt that the invocation of reservations by reliance on the principle of reciprocity may weaken the jurisdiction of the court, but this is the meaning which has been given to reciprocity by both the Court - as will be seen - and States. They have never challenged the right of a state to rely upon a reservation included in the other party's declaration. On the contrary, it was argued that reciprocity should be applied in a broader manner so as to cover conditions in addition to reservations and to be applied even before the filing of an application before the Court. 56

On the other hand, it is difficult to imagine States giving up a fraction of their sovereignty and putting themselves in a position of inequality in order to increase the scope of compulsory jurisdiction. If they wished really to increase it, they would have accepted it without reservations, a hypothesis in which there is no need at all to apply reciprocity. However, having taken into consideration the fact that the overwhelming majority of declarations contain reservations, some of which 
have a sweeping effect, it would not seem desirable to regard a unique "unconditional" declaration among the 46 currently in force as a means of improving the Court's compulsory jurisdiction, and, therefore, deprive that State of the right to avail itself of the reservations included in the other declarations. The main reason behind the existence of reciprocity in the compulsory jurisdiction system is the establishment of equality between the members of the system. 57 Accordingly it might not be possible to deprive a state of the right to benefit from such a principle without strong reasons. 58

Professor Enriques adopted a wider criterion than that adopted by professor Hambro for the determination of whether a State had accepted the P. C. I. J.'s jurisdiction with or without reciprocity. In professor Enriques' view a state was accepting the compulsory jurisdiction of that Court without reciprocity not only in case of making its declaration explicitly "unconditionally" but also in case of making it without mention of the "condition of reciprocity" or the words "in relation to any other state accepting the same obligation". 59

After about 30 pages, Enriques reached the conclusion that the difference between accepting the Court's jurisdiction with or without reciprocity is that in the former case states undertook the obligation UIS-A-UIS States which accepted the Optional Clause only, whereas their obligation in the latter was assumed in relation to all other states which had ratified the statute of the $P$. C. I. J. regardless of whether or not they made declarations under the Optional clause. ${ }^{60}$ The legal relationship between states which accepted the jurisdiction without reciprocity and states which ratified the statute of the P. C. I. J. without accepting its jurisdiction was based, in his view, on what he called "ACCOPD APBITRAL TIPIQUE", 61 which allowed the latter to sue the former, but not UICE UEPSA. 62 
This view seems to be inadmissible on more than one ground. It is obvious that a declaration accepting the Court's compulsory jurisdiction is made under Article 36 (2) of the statute. There is no need, therefore, to reiterate the terms of that Article. Consequently, how can it be possible to deduce from the omission of the words "in relation to any other state accepting the same obligation" that the declaration is made without reciprocity. Furthermore, it was not possible for a state which had ratified the statute of the P. C. I. J. without accepting the jurisdiction of that Court to sue a state party to the optional Clause for the following reasons: firstly, there is no doubt that, according to the additional Protocol of December 16, 1920 (the Optional Clause) and Article 36 (2) of the Statute of the P. C. I. J.. a state could not be brought before the court without making a declaration accepting the jurisdiction of that Court. In other words, the ratification of the Protocol of Signature had to be followed by the declaration, if it was not made before. $63 \mathrm{~A}$ state which had ratified the Protocol of Signature without accepting the compulsory jurisdiction of the P. C. I. J. was in the same position as any State which is now a member of the United Nations but does not accept the Court's compulsory jurisdiction. It is obvious that the latter state cannot sue another party to the system of compulsory jurisdiction. Secondly, if Enriques' viewpoint was to be accepted, the principle of equality between states accepting the compulsory jurisdiction would have been jeopardised. Thirdly, Enriques" "accord" finds no basis in practice. No state opting-out of the system has ever sued a state opting-in before the court on the basis of Article 36 (2). The I. C. J. has been clear in stating that Article 36 (2) requires the making of a declaration of acceptance and its deposit with the Secretary-General, otherwise no case can be brought before it on that basis. 64

D W Greig appears also to differentiate between the existence and non-existence of an express mention of the 
condition of reciprocity in the declarations of acceptance. This view is based on the difference between reciprocity as a "condition" and as a "principle". He points out that the first is incorporated in most declarations of acceptance whereas the second is inherent in Article 36 (2) of the Statute, which refers to "any other State accepting the same obligation". "65 In his opinion. the Court has clarified correctly the difference between them in the NORHEGIAN LOANS case, since the Court allowed Norway to rely upon the french reservation of domestic jurisdiction. Greig observes that:

$"$ ". the two reservations placed side by side only excluded matters within the national jurisdiction as understood by the French Government, so that it was not possible for Article 36 (2) to operate at 311 , certainly not to the extent of enabling the Norwegian Government to exclude the subject matter of the dispute from the Court's jurisdiction on the grounds that it fell within Norway's nationel jurisdiction.

How, then, was the court able to reach the conclusion that Norway, could rely on the French reservation to the extent of enabling it to classify the dispute as being within Norwegian domestic jurisdiction? The Court"s explanation was. that both declarations included a condition of reciprocity."

It seems that Greig's reliance on the Court's reference to reciprocity as embodied in the declarations of the parties to the dispute to reach this conclusion, contradicts what he says in the same page about the ELECTRICITY COHPANY OF SOFIA AND BULGARIA case. He points out that Bulgaria was able to invoke the Belgian reservation RATIONE TEMPORIS because "it was accepted by both parties, and by the Court that Bulgaria could rely upon the terms of the Bulgarian reservation." 67 For this reason and the fact that the Bulgarian declaration was made unconditionally, "it is clear that whether the matter was approached as a condition, or as a principle of reciprocity, the conclusion would have been the same. The area common to both declarations was restricted by the Belgium time limitation, so that from either point of view, Bulgaria was in effect relying upon it." 68 
It may be difficult to find such a difference concerning reciprocity in these two cases. There is no indication that the P. C. I. J. took into consideration the agreement of the parties in regard to the invocation of the Belgian reservation, or the opinion of the Court would have been different if there had not been such an agreement. Also, the P. C. I. J. referred in the ELECTRICITY COLPANY OF SOFIA AND BULGARIA case - as in the NORHEGIAN LOANS case - to the declaration of Bulgaria as containing the condition of reciprocity. The court said that "... the condition of reciprocity laid down in paragraph 2 of Article $36 \ldots$ and repeated in the Bulgarian declaration, is applicable as between the parties". 69 Moreover, did the French government challenge the possibility of relying upon its reservation of domestic jurisdiction? What is the obstacle that could prevent Norway from relying in that case on the french reservation to the extent of enabling it to exclude the subject matter of the dispute from the Court's jurisdiction? Finally, what is the effect of the difference between the "PRINCIPLE" of reciprocity and the "CONDITION" of reciprocity since the former "will normally enable one party to rely upon the reservation contained in the other party's declaration"? - as Greig himself concedes.

Almost the same argument was put by professor Waldock, as a counsel for the Indian government in the RIGHT OF PASEAGE OUER INDIAN TERRITORY case. He referred to "the condition of reciprocity which is inherent in the Optional Clause" and "the condition of reciprocity expressly made in the Indian declaration...". 71 Professor Waldock stressed the difference between making a declaration with or without the express condition of reciprocity. Reciprocity "applies, perhaps A FORTIORI when there is such an express condition in the defendant state's declaration. For - and the point seemed obvious to usthe sole purpose of such an express condition is to make clear that the Court's compulsory jurisdiction is accepted only on the basis of a complete equality of rights 
and obligations between the declarant State and any other State adhering to the Optional Clause", ${ }^{72}$ he argued. As a response to the Portuguese contention that the express condition of reciprocity adds nothing to a declaration, professor Waldock pointed out that "very possibly an express condition of reciprocity adds little or nothing to the legal effect of the declaration." 73

However, this view was rejected by the court in that case. ${ }^{74}$ In fact the court did not make any difference between the "condition" of reciprocity and the "principle" of reciprocity - as Greig himself admits 75 or between the existence or non-existence of an express mention of reciprocity, as will be seen shortly. Consequently, reciprocity produces its effect IPSA LEGE since it is inherent in the compulsory jurisdiction system, 76 and the words "on condition of reciprocity" in the declarations of acceptance are "unnecessary and presumably inserted EX ARUNDANTI CALTELA". 77 However this is not to say that states cannot renounce the right to invoke the principle of reciprocity, or that the court has to apply it PROPRIO hOTU if the respondent state did not invoke it. 78

\section{D - RECIPROCITY IN THE JURISPRUDENCE OF. THE COURT}

The P. C. I. J. had the first opportunity to discuss the application of reciprocity in the PHOSPHATES IH morocco case ${ }^{79}$ between Italy and France. The French declaration contained the reservation of "disputes which may arise after the ratification of the ... declaration with regard to situations or facts subsequent to such ratification". "90 The Italian declaration did not contain such a reservation, but was made subject to previous recourse to diplomatic channels. In its preliminary objection, France invoked the principle of reciprocity claiming the benefit of the Italian reservation in addition to its own reservation. The court sustained the preliminary objection based on the French reservation. It said: 
"This declaration [the Italian] does not contain the limitation that appears in the French declaration concerning the situations or facts with regard to which the dispute arose; nevertheless as a consequence of the condition of reciprocity stipulated in paragraph 2 of Article 36 of the Statute of the court, it is recogniged that this limitation holds good as between the parties".

The importance of this case, as far as reciprocity is concerned, lies in France's reliance on the words "in relation to any other state accepting the same obligation" as equivalent to the condition of reciprocity, a view which was confirmed by the court's reference to Article 36 (2) of the Statute. Yet the Court's reference to reciprocity in regard to the invocation of a reservation contained in the defendant's own declaration seems - as professor Waldock observed - to be a misuse of that term. "The true ground would seem to be the fundamental rule that a state can never be brought before the court except on the conditions on which it has consented to jurisdiction." 82

In the ELECTRICITY COHPANY OF SOFIA AHD BULGARIA case reciprocity was directly in issue. Here, the court had also to examine the application of reciprocity to the reservation RATIONE TEHPORIS, which had been included in the applicant's (Belgium) declaration. Although the Bulgarian government accepted the Court's jurisdiction "unconditionally", it relied upon the Belgian reservation in its objection to the Court's jurisdiction. In accepting the Bulgarian objection the Court said:

\footnotetext{
"The Eelgian Government relies on the limitation RATIOHE TEHPORIS embodied in the Belgian declaration concerning the situations and facts with regard to which the dispute has arisen: in order to dispute the jurisdiction of the court. Although this limitation does not appear in the Eulgarian Government's own declaration, it is common ground that, in consequence of the condition of reciprocity laid down in paragraph 2 of Article 3 of the Court's Statute and repeated in the Eulgarian declaration, it is applicable as betueen the parties." QS
} 
Several judges had confirmed in their separate and dissenting opinions in this case the Court's holding that the respondent state can rely on any reservation to a declaration of acceptance which the applicant state has expressed in its declaration. 84

The significance of this case is that neither did the court refer to the UNCONDITIONAL acceptance of its jurisdiction, nor did Belgium contend that Bulgaria had, accordingly, no right to rely on the principle of reciprocity. On the contrary, the court considered reciprocity as embodied in the Bulgarian declaration. Thus, there should still be no doubt that the words "in relation to any other State accepting the same obligation" refer to reciprocity.

The I. C. J. has endorsed this view. Thus in the ANGLO - IRANIAN OIL COHPANY case, Iran, the respondent State, objected to the Court's jurisdiction on the ground that the Court had jurisdiction only in so far as jurisdiction is conferred on it by the declarations of the parties. ${ }^{85}$ Accordingly. Iran relied on the terms of its declaration, which was limited to disputes relating directly or indirectly to the application of treaties accepted by Iran and subsequent to the ratification of the declaration, provided that these disputes did not concern, INTER ALIA, questions which, by international law, fell exclusively within its domestic jurisdiction. Although there was no need for the invocation of reciprocity when a state relied on its own reservation, according to the rule mentioned above, the court made a brief statement with respect to reciprocity. After stating that its jurisdiction depended on the declarations made by the parties under Article 36 (2) on condition of reciprocity, the Court elucidated the function of reciprocity as a necessary element for the determination of the scope of its jurisdiction through the determination of the mutual obligations covered by the declarations of the parties to the dispute before it. The court said: 
"By these declarations, jurisdiction is conferred on the Court only to the extent to which the two declarations coincide in conferring it. As the Iranian Declaration is more limited in scope than the United Kingdom Declaration, it is the Iranian Declaration on which the Court must base itself. This is the common ground between the Farties." 87

The NORHEGIAN LOANS 88 case provided the Court with another occasion to develop and examine in more detail the principle of reciprocity. France, the applicant State, had appended to its declaration a reservation excluding "differences relating to matters which are essentially within the national jurisdiction as understood by the Government of the French Republic." 89 The Norwegian declaration did not contain this reservation, but was made "on condition of reciprocity". Four preliminary objections were filed by Norway. The first objection consisted of two parts. In the first part, it was claimed that, since the dispute was about the payment in gold of the bonds held by French nationals, it did not fall within any of the categories enumerated in Article 36 (2) relating to international law, but within the domestic jurisdiction of Norway. In the second part. Norway considered itself "fully entitled" to rely on the French reservation mentioned above. 90 It agreed that there could be no possible doubt that the dispute fell within its jurisdiction:

"If however; there should still be some doubt, the Norwegian Government would rely upon the reservations made by the French Government in its Declaration of March 1st, 1949, by virtue of the principle of reciprocity, which is embodied in Article 3t, paragraph 2, of the Statute of the Court and which has been clearly expressed in the Norwegian Declaration of November 16th; 1946, the Norwegian Government cannot be bound; UIS-A-UIS the French Government, by undertakings which are either broader or stricter than those given by the latter Government."

The Norwegian Government stated clearly in its preliminary objection that although it did not insert any such reservation in its own declaration it had the right to rely upon the reservation placed by France upon its own 
undertakings .

92

In the second objection, Norway relied upon the French reservation RATIONE TEMPORIS limiting the Court's jurisdiction to disputes which may arise in respect of facts or situations subsequent to the ratification of its declaration.

The Court having sustained the second part of the first preliminary objection, did not examine the first part of that objection. However, it ruled that:

"The Court notes in the first place that the present case has been brought before it on the basis of Article 36, paragraph 2, of the Statute and of the corresponding Declarations of Acceptance of compulsory jurisdiction: that in the present case the jurisdiction of the Court depends upon the declarations made by the parties in accordance with Article 36 , paragraph 2, of the statute on condition of reciprocity; and that, since two unilateral declarations are involved, such jurisdiction is conferred upon the Court only to the extent to which the two Declarations coincide in conferring it. A comparison between the two declarations shows that the French declaration accepts the Court's jurisdiction within narrower limits than the Norwegian Declaration: consequently, the common will of the Farties, which is the basis of the Court? 5 jurisdiction, exists within these narrower limits indicated by the French reservation.

Then the court continued:

"In accordance with the condition of reciprocity to which acceptance of the compulsory jurisdiction is made subject in both Declarations and which is provided for in Article 36 , paragraph 3 , of the Statute, Norway, equaliy with France, is entitled to except from the compulsory jurisdiction of the Court disputes understood by Norway to be essentially within its national jurisdiction." 95

It is to be noted that this pronouncement of the Court would have been necessary only if the court had examined the first part of the first Norwegian objection and found that the object of the dispute was covered by international law. 
The question whether or not the principle of reciprocity applies to the Portuguese Third Condition ${ }^{96}$ had been given extensive importance in the RIGHT OF PASSAGE OUER INDIAN TERRITARY case. 97 The Indian Government relied on the principle of reciprocity in three preliminary objections: the first, second and fourth. It challenged the Court's jurisdiction on the grounds that the Portuguese declaration was invalid, inasmuch as it gave Portugal a right which was denied to other signatories; the premature filing of the Portuguese application "violated equality, mutuality and reciprocity to which India was entitled under the Optional Clause under the express condition of reciprocity contained in her declaration. and finally the filing of the said application had violated the reciprocal right conferred upon India by the Optional Clause to invoke the third condition in the Portuguese declaration. ${ }^{98}$

The grounds on which the Court rejected these objections have already been examined. 99 However, it might be worth recalling that the significance of this case lies in the Court's statement that "the notions of reciprocity and equality are not abstract conceptions. They must be related to some provisions of the statute or of the Declarations," 100 and the Court's explanation, for the first time, of the expression "the same obligation" incorporated in Article 36 (2) of the Statute. In explaining it the Court said:

"It is not necessary that the "same obligation" should be irrevocably defined at the time of the deposit of the Declarations of Acceptance for the entire periad of its duration. That expression means no more than that - as between states adhering to the Dptional CIause each and all of them are bound by such identical obligations as may exist at any time during which the acceptance is mutually binding".

By this statement the Court affirmed its jurisprudence that the declarations of States need not be "identical" in a sense that they must include the same reserva- 
tions or conditions. It is clear form the cases examined above that the court considered the declarations as containing the same obligations though they were different in their contents. Therefore, the expression "identical obligations" should be considered to bear the meaning that the parties to a dispute before the Court must have undertaken the obligation of accepting the Court's compulsory jurisdiction, and that the scope of this obligation is to be determined by the exclusion of reservations appended to both declarations at the time of the filing of the application.

Reciprocity was one among other grounds on which Bulgaria objected to the court's jurisdiction in the AERIAL INCIDENT OF JULY $27 t h, 1955$ (Israel v Bulgaria). 102 In its second preliminary objection Bulgaria contended that since Israel excluded disputes prior to the date of its submission to the Court's jurisdiction, the Government of Bulgaria, could not, pursuant to the principle of reciprocity, "be regarded as having accepted the compulsory jurisdiction of the International Court of Justice in respect to the facts prior to December 14th, 1955". 103 Bulgaria relied also on the principle of reciprocity in its fourth preliminary objection that the dispute was essentially within its domestic jurisdiction and, therefore, excluded from the Court's jurisdiction according to Israel's declaration. 104 The Court lacked jurisdiction on the ground that the Bulgarian declaration, which formed part of the Protocol signature of the P. C. I. J.. ceased to be in force. Accordingly, it found it necessary to proceed to the consideration of these objections. 105

As in the RIGHT of PASSAGE case, the Court considered the reliance on reciprocity as an inappropriate use of this term, and hence rejected the claim to benefit from its application, in two other cases; the INTERHANDEL case and the HILITARY AND PARAMILITARY ACTIUITIES IN AND AGAINST NICARAGUA 107 case in respect to RATIONE TEHPORIS reservations and time-limits conditions respectively. 


\section{E - DELIMITATION OF RECIPROCITY}

The fact that reciprocity forms an integral part of the system of compulsory jurisdiction does not mean that its application is absolute with respect to any reservation or condition incorporated in the declarations of acceptance. The following limitations on its operation can be inferred from the Court's jurisprudence.

\section{(I) Reciprocity Operates with Respect to Reservations Only}

The idea of the "absolute reciprocity" in a sense that it applies to any limitation or condition contained in the opponent's declaration has been adopted by the late judge professor Waldock in his article "Decline of the Optional Clause". 108 He relies on the Court's statement in the ELECTRICITY COMPAHY OF SOFIA AND BULGARIA case that the Bulgarian reservation RATIONE TEHPORIS was applicable between the parties, and on the treatment of several judges in their dissenting opinions in the same case, of the limitations, conditions and reservation in the declaration of one party as automatically read into that of the other party, as a basis for his statement that "it could be regarded as settled that, in virtue of the principle of reciprocity laid down in the optional Clause, a defendant state can always rely upon a limitation, condition or reservation in its opponent's declaration". 109 It is true that some judges referred in their discussion of the application of reciprocity to "LIHITATIONS" and "CONDITIONS". However it seems difficult to deduce from their opinions that they had considered reciprocity as applicable to conpITIONs as distinguished from reservations. ${ }^{110}$ Firstly, the terms reservations, limitations and conditions are - as already mentioned 111 - usually used interchangeably. This is supported by the reference of judge Eysinga and judge $A D$ HoC Papazoff in the same case, to the reservations of previous recourse to other methods of pacific settlement, and ratione temporis as a "COHDITION" and "LIHITATIOH" respectively. 
Secondly, the judges opinions addressed mainly the reservation RATIONE TEHPORIS which undoubtedly falls within the scope of the operation of reciprocity. Finally, a general statement like that of judge Anzilotti that "as a result of ... declarations, an agreement came into existence between the two states accepting the compulsory jurisdiction of the Court, in conformity with Article 36 of the statute and subject to the limitations and conditions resulting from the declarations" 113 is still true in a sense that disputes covered by RESERUATIONS might be excluded by the application of reciprocity, but the application of conditions is due to the terms of the declarations themselves and the general rule that states cannot be brought before the court except within the conditions set forth in their declarations. However professor Waldock's argument concerns the application of reciprocity as to time limits conditions. 114 He repeated the same view on behalf of India in the RIGHT OF PASSAGE OUER INDIAN TERRITORY case while advocating the application of reciprocity to the Portuguese Third Condition. Professor Waldock argued in this case that " the Optional Clause does give such a reciprocal right to invoke AHY condition, reservation or limitation in the other Party's Declaration". 115

The question has, however, been settled by the Court, as already mentioned in the RIGHT OF PASSAGE OUER INDIAN TERRITORY case, and the HILITARY AND PARAHILITARY ACTIUITIES IN AND AGAINST NICARAGUA case. In the former. the Court rejected the claim to benefit from the Portuguese. Third Condition, and in the latter stated without any ambiguity that:

\footnotetext{
"the notion of reciprocity is concerned with the scope and substance of the commitments entered into including reservations, and not with the formal condition of their creation, duration or extinction." 116
} 


\section{(II) Non-application of Reciprocity to the Pre-seisin Period}

In addition to the above view professor waldock argued also in the same case, UIZ, the fIGHT OF PASSAGE, that reciprocity should operate from the date of the deposit of a declaration and not only from the date of filing of an application. This was because reciprocity "was clearly intended to be a general and continuing reciprocity governing the relations between the two States from the establishment of the judicial bond between them until the date of its termination by the expiry of the declaration of one of them."117 This view was, however, rejected by the court. After reiterating its jurisprudence concerning the application of reciprocity, the Court indicated the difference between the date of the deposit of a declaration and the date of the filing of an application. The contractual relations between the parties and the compulsory jurisdiction of the court are to be established at the former date, the court observed. "For it is on that very date that the consensual bond, which is the basis of the Optional Clause, come into being between the states concerned". 118 on the other hand the "identical obligation" that exists between the parties is to be determined at the date of the seisin because:

"when a case is submitted to the Court; it is al weys possible to ascertain what are at that moment; the reciprocal obligations of the Farties in accordance with their respective
Declarations". 119 .

This view has been confirmed by the court in the HILITARY AND PARAHILITARY ACTIUITIES IN AND AGAINGT NICARAGUA case by rejecting the United States argument that reciprocity should be applied before the date of the filing of an application. 120 


\section{(II) Reciprocity Does Not Enable a State to Rely Upon a Reservation Not Included in the Opponent's Declar- ation}

The manner in which the United States invoked the principle of reciprocity in the INTERHANDEL case obliged the Court to examine this limitation. The United States declaration contained a reservation restricting the Court's jurisdiction to disputes "hereafter arising", i.e., after August 26, 1946. The declaration of Switzerland, the respondent, did not include such a reservation, but was effective on July 28, 1948. The United States contended that, in virtue of reciprocity the Court's jurisdiction was limited to disputes arising after July 28. 1948. The Court rejected this objection unanimously on the grounds that:

"Feciprocity in the case of Declarations accepting the compulsory jurisdiction of the Court enables a Farty to invole a reservation to that acceptance which it has not expresesed in its own declaration but which the other Farty hes expressed in its Declaration. For example, Switzerland, which has not expressed in its Declaration any reservation RATIOHE TEMPORIS, while the United States has accepted the compulsory jurisdiction of the court only in respect of disputes subsequent to August 26, 1946, might, if in the position of the Fespondent; invole by virtue of reciprocity against the United States the American Feservation if the United States attempted to refer to the court a dispute with switzerland which has arisen before August 26, 1946. This is the effect of reciprocity in this connection. Fieciprocity enables the State which had made the wider acceptance of the jurisdiction of the court to rely upon the reservations to the acceptance laid down by the other Farty. There the effect of reciprocity ends. It cannot justify a State : in relying upon a restriction which the other Farty . . had not included in its own Declaration." 121

On the same ground the Court overruled the United States objection to its JURISDICTIOH IH MILITARY AND PARAHILITARY ACTIUITIES case that it could disregard the clause of six months notice inserted in its declaration UIS-A-UIS Nicaragua. The Court said "it appears clearly that reciprocity cannot be invoked in order to exclude 
departure from the terms of a State's own declaration, whatever its scope, limitations or conditions". 122

\section{F - CONCLUSIONS}

The following conclusions might be drawn from what has been said above:

Reciprocity forms an integral part of the Optional Clause. It is an essential element in the determination of the Court's jurisdiction, through the determination of the common will of the parties to a concrete case before the court. It is, therefore of a great importance since the declarations of acceptance are drafted unilaterally and consequently include different reservations.

Reciprocity in this context finds the basis in the requirement of the establishment of equality between States party to any treaty which permits the making of reservations. Thus, it has been applied to obligatory arbitration treaties and become a general rule of arbitral law. However as far as the Optional Clause is concerned, it finds its basis in the words "in relation to any other state accepting the same obligation" set forth in Article 36, paragraph 2. This view is supported by the practice of states, both in their declarations of acceptance, though many formulae have been used, and in their pleadings before the court. They have never referred to reciprocity according to paragraph 3 . The court's jurisprudence also supports this view, though it referred to paragraph 3 twice.

The TRAUALX PREPARATOIRES of the Committee of Jurists of 1920 shows that the words " ... or on condition of reciprocity on the part of several or certain States" refer to reciprocity RATIONE PERSOMAE i.e. the possibility of making a declaration on condition that, until the acceptance of the court's jurisdiction by certain determined states, it cannot be regarded as an 
effective declaration.

It follows that, since all the declarations are made according to Article 36 (2), reciprocity is applicable to every declaration regardless of whether it is made without this condition, or "unconditionally". Its insertion is, thus, unnecessary.

The requirement of the parties' acceptance of the "same obligation" does not mean that the declaration must contain the same reservations or conditions. It means no more than both declarations must involve within their scope the subject matter of the dispute, and that each party is entitled to rely upon any reservation incorporated in the opponent's declaration. In other words, jurisdiction is conferred on the court only within the narrower limits.

The fact that a state has the right to invoke any reservation in its opponent's declaration means neither. that the Court has to apply reciprocity "PROPRIO MOTU" in case that the interested party did not invoke it, nor that the exercise of such right is without limits. On the contrary, reciprocity should not be regarded as an abstract conception, but states in invoking it must take into consideration that reciprocity operates only in regard to reservations as distinguished from conditions; that the crucial date in the application of reciprocity is the date of the seisin, and finally, that they are not entitled in the name of reciprocity, to rely upon a reservation which the opponent's declaration does not contain.

Since every state has an absolute right to invoke the conditions included in its declaration as a bar to the Court's jurisdiction, reliance on the principle of reciprocity would be a miss-use of that term. The appropriate rule, in such a case, is that jurisdiction is conferred on the court only within the conditions set forth in the declaration of acceptance. 
239

Within the limits mentioned above, there is a complete reciprocity in the relations between states party to any dispute before the court. 


\section{SECTION (2) : THE OBJECTIVE FORMULA OF DOMESTIC JURISDICTION RESERVATION}

As has been seen in the first chapter, the general feature of arbitration treaties concluded in the era before the establishment of the League of Nations was the insertion of clauses excluding from the competence of tribunals disputes concerning vital interests, national honour and independence. By retaining the power of interpreting these vague terms, there was no need for states to speak of the reservation of domestic jurisdiction. For the first term alone was broad enough to cover matters falling within the reserved domain. $122 \mathrm{~b}$ In those circumstances the principle of absolute sovereignty had been fully preserved. However the conflict between the desire to protect the independence of states and the requirements of an organised international Society, 123 led to exclusion form the conciliation function of the Council (or the Assembly) disputes arising out "of matter which by international law is solely within domestic jurisdiction of" States. 124 This provision, which has been described as "one of the last refuges of sovereignty", 125 has been maintained, but with a totally different version, in Article 2 (7) of the Charter of the United Nations. The latter provides:

\footnotetext{
"Nothing in the present Charter shall authorise the United Nations to intervene in matters which are essentially within the domestic jurisdiction of any state or shall require the Nembers to submit such matters to settlement under the present Chapter".
}

It is not intended here by the reference to these two Articles, to discuss all the problems to which they have given rise. Such a discussion is beyond the object of this study. Their relevance is limited, firstly to the fact that they have provided for two formulae. 126 which have been used in the declarations accepting the Court's jurisdiction, and, secondly to the question whether Article 2 (7) is applicable as such to the Court, being 
the main judicial organ of the United Nations.

Thus the determination of the scope of the reservation of domestic jurisdiction and its significance, it is believed, might better be discussed separately according to these two forms before the consideration of whether or not the reservation proved to be a useful means in practice for contesting the jurisdiction of the court.

\section{A - THE COVENANT FORMULA}

The insertion of the reservation of domestic jurisdiction in Article 15 (8) ${ }^{127}$ of the Covenant did not as such lead directly to the inclusion of the reservation in the declarations made under Article 36 (2) of the statute of the P. C. I. J. The jurisdiction of the court having been regulated by an independent instrument and derived from declarations made under the Optional Clause, was not affected in any way by the provision of Article 15 (8). In fact, the provision did not affect even the general obligation undertaken under Articles 12 - 14 of the Covenant to settle by arbitration or judicial settlement disputes recognised to be suitable for such forms of settlement. ${ }^{128}$ However it served as a model copied in Article 39 of the Geneva General Act of 1928 as one of the reservations which could be made by states adhering to the Act. From this Article (i.e. 39) the reservation of domestic jurisdiction seems to have found its way into the declarations made under the Optional Clause. 127 Thus, it was made for the first time by the United Kingdom and the members of the Commonwealth (Australia. Canada, India, New Zealand and South Africa) in their declaration deposited in 1929. The declarations excluded:

\footnotetext{
"di sputes with regard to questions which by international law.fall exclusively within [their] jurisdiction".
}

In the following year, the reservation appeared in the declarations deposited by Albania. Iran and Rumania. 
then by Poland in 1931; Brazil in 1937. Iraq in 1938 and Egypt in 1939.131 It is asserted that the insertion of this reservation into the United Kingdom and the dominions declarations was due mainly to the apprehension of certain Dominions that their immigration laws might be encroached upon by the P. C. I. J. 132 This was made abundantiy clear in the despatch sent in 1925 by the Government of New Zealand to the Home Government on the subject of the compulsory jurisdiction.

The reservation of domestic jurisdiction in this form can be found now in the declarations of Barbados. Canada, Democratic Kampuchea, El Salvador, Gambia, Honduras, Kenya, Malta, Mauritius, Pakistan, Senegal and Switzerland. 134

\section{(I) The Scope of the Formula "Matters Exclusively Within Domestic Jurisdiction According to International Law"}

The concept of domestic jurisdiction was dealt with by the P. C. I. J. in its Advisory Opinion on the NATIONALITY DECREES IN TUHIS AND MOROCCO. 135 Although the question at issue was the determination whether the Council of the League of Nations was competent or not under Article 15 (8) of the Covenant to deal with the dispute which arose out of the Nationality decrees issued by France, the opinion of the court is of a critical importance with respect to the scope of the reservation of domestic jurisdiction. For, firstly, it is still the most extensive and most influential opinion that has so far been given on the question. Secondly, it concentrated on terms identical to those which are embodied in the declarations of acceptance of the Court's jurisdiction. namely, matters solely or exclusively within the domestic jurisdiction of states according to international law.

The Court pointed out, first, that its task was limited to the determination of the nature of the matters in dispute, and not whether the parties were or not 
competent in law to take or refrain from taking a particular action. Such determination appeared to depend to a large extent on the meaning of the phrase "solely within the domestic jurisdiction". This phrase seemed to the Court "to contemplate certain matters which, though they may very closely concern the interests of more than one state, are not, in principle regulated by international law". 136

The Court then proceeded to the determination of the nature of the boundaries between domestic and international jurisdiction and the criterion to be applied for determining whether a matter belongs to the one of the other sphere. Qualifying the above definition, the court said:

"The question whether a certain matter is or is not solely within the jurisdiction of a State is an essentially relative question: it depends upon the development of international relations. Thus in the present state of international law, questions of nationality are, in the opinion of the court, in principle, within this reserved domain.

For the purpose of the present opinion, it is enough to observe that it may well happen that a matter which. like that of nationality, is not, in principle, regulated by international law, the right of a state to use its discretion is nevertheless restricted by obligations which it may have undertaken towards other states, In such a case, jurisdiction which, in principle, belongs solely to the State, is limited by rules of international law. Article 15 (8) then ceases to apply as regards those states which are entitled to invole such rules, and the dispute as to the question whether a State has or has not the right to take certain measures becomes in these circumstances a dispute of an international character and falls outside the scope of the exception contained in this paragraph ..."

This dictum of the Court has many significance:

1. The test for determining whether a matter falls within domestic or international jurisdiction is international law. This test received its impetus from the terms of the reservation itself 
[both in Article 15 (8) or in the declaration] which refer to international law. Thus by referring to "the development of international relations", the Court meant "the development of international law ...". This is so because the court continued "Thus in the present state of international law ...". Furthermore the phrase "regulated by international law" in the Court's definition of the concept of domestic jurisdiction supports this view.

2. The question whether a certain matter is within or outside domestic jurisdiction turns simply on whether the matter involved is or is not the subject of international obligations stemming from the sources of international law as indicated in Article 38 of the statute of the International Court of Justice.

3. There are no matters which by their intrinsic character fall within the reserved domain. A matter is either regulated by international law - general or particular - and therefore belongs to the sphere of international jurisdiction, or left by international law for regulation by States 140 Thus the INSTITUT DE DROIT INTERHATIONAL rejected by a large majority ( 63 votes to 5 ) a proposition that there are certain matters which fall by their nature within the domestic jurisdiction of States. 141

4. In determining the scope of Domestic Jurisdiction the dynamic character of international law must not be overlooked. The state of international law - general and particular - is, thus of a critical importance. Consequently, the moving boundaries between domestic and international jurisdiction may have the following implications: 
Firstly, the reserved domain may decrease. In fact this is a natural consequence of the gradual development of general international law and the process of treaty making. The effect of the diminution of the sphere of domestic jurisdiction differs, therefore, according to the reasons by which a matter has become a subject of international obligations. If this was due to a rule of general international law, the matter ceases universally to be within domestic jurisdiction, but if it was due to the assumption of a treaty obligations, the matter ceases to be a matter of domestic jurisdiction only between the parties to the treaty. 142

Secondly, the sphere of domestic jurisdiction may increase. This is a result of the first implication. For inasmuch as the new accepted obligations remove a matter from the reserved domain, the theory implies that a matter principally of domestic jurisdiction, but transferred to the international jurisdiction, can be transferred back to the sphere of domestic jurisdiction. this can be accomplished either by terminating certain treaties or concluding new treaties according to which the states free themselves from the obligation that has removed the matter from their reserved domain.

Thus the scope of the reserved domain differs according to the content of general international law at any given moment on the one hand, and according to the international obligations assumed by the states in their relations with each other on the other hand. For a matter that has been transferred to international jurisdiction in the relations between states $A$ and $B$ may still fall within the reserved domain in the relations between States $A$ and $C$ or $B$ and $C$. 
The Court also explained what would and what would not suffice to remove a matter from domestic to international jurisdiction. Firstly, it said that it was certain that the mere fact that a state brought a dispute before an international organization (The League of Nations) would not suffice to give a dispute an international character. Nor would it suffice that the complainant should rely on engagement of an international character. "i.e. merely dress up its complaint in the guise of one founded on alleged international obligations of the defendant". 144 The matter would enter the sphere of international jurisdiction when the legal grounds relied on are of judicial importance for the settlement of the dispute.

In the light of this background, both the P. C. I. $J$. and the International Court of Justice have dealt with the reservation of domestic jurisdiction as will be seen. The Institut de Droit International followed the general lines of the above opinion. This can be illustrated by the definition adopted by the Institut in 1954:

" "The reserved domain" is the domain of state activities where the jurisdiction of the state is not bound by international law.

"The extent of this domain depends on international law and varies according to its development". " 14

This definition was considered as a correct statement of the general concept of the reserved domain of domestic jurisdiction, in spite of the radical changesat least of wording - brought about by Article 2 (7) of the Charter of the United Nations.

The above definition has been widely adopted by writers as the correct $\angle E G A L$ definition of the term domestic jurisdiction. For, this test, being based on whether the matter is or is not one regulated by international law, or that based on "whether in the particular 
case there exists a concrete rule of international law limiting the State's freedom of action", 147 and that based on "whether the matters involved are or are not the subject of international obligations, whether arising under treaty or international agreement, or under rule of general customary international law", 149 lead to a similar practical result as long as it can be considered that the first two tests include treaty obligations. 149 Consequently, if the reservation of matters of domestic jurisdiction is included in the declarations with the aim of objecting to the Court's jurisdiction to examine such a matter at all, it is almost always closely bound up with the obligations and rights of the parties on these merits. In other words, the concept of domestic jurisdiction has a "dual character ... concerned both with the boundaries between international and states jurisdiction and with the substantive rights and obligations of states under international law." 150 This will be explained in more detail when discussing the reservation of domestic jurisdiction in the practice of the court.

\section{(II) The Effect of the Formula}

Having taken into consideration the fact that the Court's jurisdiction is limited to the four legal categories of disputes enumerated in Article 36 (2) of the Statute and that the Court must, by virtue of Article 38 of its statute, decide the case brought before it in accordance with international law, the question that arose, shortly after the introduction of the reservation of matters of domestic jurisdiction in the declaration of the United Kingdom in 1929, was what could be accomplished by such a reservation. In the light of these facts, the reservation seemed to $H$ Lauterpacht "meaningless" unless it was intended to have another effect. 151 For. the limitation of the Court's power to decide legal disputes in accordance with international law leads necessarily to the exclusion of disputes with regard to matters which by virtue of international law are within 
the exclusive jurisdiction of a state. The court must declare such matters to be within the exclusive jurisdiction of that state and must reject any claim contrary to that exclusive right. In order to avoid this interpretation depriving the reservation of any meaning Lauterpacht drew attention to the possibility that it might have been inserted by states with the intention of substituting themselves for the Court in determining the nature of the matter in question. This appeared to him to be supported by what he called "the studied determination" to refrain from indicating who was competent to decide whether a question was or was not within domestic jurisdiction, and by the canon of interpretation that provisions of a treaty should be interpreted as to yield a meaning. 152 This was so in spite of the provision of Article 36 (4) of the statute of the P. C. I. J. which provided expressly that "in the event of a dispute as to whether the Court has jurisdiction, the matter shall be settled by the decision of the Court", and in spite of the clear statement in the British official memorandum on the Optional Clause that the reservation was "merely an explicit recognition of a limitation on the jurisdiction of the Permanent Court which results form international law itself". 153

The jurisprudence of both the P. C. I. J. and the I. C. J. appear "to lay at rest such a fear". 154 In fact, no state had ever contended before the P. C. I. J. that disputes as to jurisdiction were outside the provision of Article 36 (4). Nor did any State in inserting a reservation of domestic jurisdiction in a declaration under Article 36 (2) attempt to substitute itself for the Court in interpreting or applying the reservation. 155 The same is true with regard to declarations made under Article 36 (2) of the statute of the I. C. J. containing the reservation of domestic jurisdiction in the covenant formula. The existence of the subjective formula of the reservation of domestic jurisdiction, keeping the interpretation and application of the reservation within the 
hands of the declarant confirms, regardless of its validity, the view that the Court's power to decide on its own jurisdiction cannot be affected without the most express and unambiguous language to that effect. 156 Thus in all cases in which the reservation of domestic jurisdiction in this form was raised the Court - as will be seen - has decided the question as to the nature of the matter in dispute.

The view that the reservation is implied in the Statute of the Court has also been confirmed by the court in many cases. In the LOSIHGER AND conPANY case Yugoslavia relied on Article 36 (2) of the statute as excluding matters of domestic jurisdiction, and not on the terms of its declaration excluding such matters. 157 In the ELECTRICITY COMPANY OF SOFIA AND BULGARIA case, 158 neither the applicant nor the respondent declarations contained a reservation of domestic jurisdiction. However Bulgaria filed a preliminary objection in which it contended that the dispute did not fall within any of the categories of dispute enumerated in Article 36 (2) of the Statute. The court, though it did not pronounce on the accuracy of this contention, recognised that this was in effect a contention that matters of domestic jurisdiction were excluded from its competence by virtue of Article 36 (2). 159

The same argument had also been advanced before the I. C. J. In the RIGHT OF PASSAGE OUER INDIAN TERRITORY case, ${ }^{160}$ India argued, in the fifth of its six preliminary objections that the dispute concerned a question which by international law fell exclusively within its domestic jurisdiction and, therefore, was excluded from the Court's jurisdiction both by virtue of the reservation inserted in its declaration and by virtue of Article 36 (2) of the statute. 161 
The INTERHANDEL case 162 provides the clearest example on the effect of including or not the reservation of domestic jurisdiction in the declarations of acceptance of the Court's jurisdiction. Although neither the United States nor the Swiss declarations contained the objective formula of the reservation of domestic jurisdiction, the United States contended in part (6) of its fourth preliminary objection that there was no jurisdiction in the court to hear and determine any issue concerning the seizure and detention of the vested shares of the G. A. F. on the grounds that such seizure and retention were, according to international law, matters within the domestic jurisdiction of the United States. 165 It is noteworthy that Switzerland did not contest the United States reliance on the principle of domestic jurisdiction according to international law. On the contrary, it admitted expressly that part (6) of the Fourth Preliminary objection was based on a general rule recognised by international law. 164

The Court's treatment of this objection as an objection to its jurisdiction in spite of the absence of any reservation in either of the declarations in question, confirms, by implication, the view that the reservation of domestic jurisdiction is inherent in the statute of the court, 165 and can always be raised both as a preliminary objection or as a defence on their merits. Thus the general view is that the inclusion of the reservation in a declaration cannot offer any additional protection other than that already provided by the statute itself, and therefore, it is "otiose and too cautious".

It is to be observed that, in supporting this view some commentators have relied on Article 2 (7) of the Charter of the United Nations as a further limitation upon the court not to intervene in matters of domestic jurisdiction. 167 The relevance of this Article to the Court's jurisdiction will be discussed shortly. 
However, some writers believe that there is a difference between the existence and the absence of the reservation of domestic jurisdiction in a declaration. A State making the reservation can rely on it both as a bar to the Court's jurisdiction and as a defence on the merits, whereas in the absence of a reservation the plea of domestic jurisdiction can only be advanced as a defence on the merits. 168 This view seems to be affected by Waldock's view advanced in 1954, though he considered the reservation as implied in Article 36 (2) of the Statute and therefore it can always be raised also as a preliminary objection. 169 However, the INTERHANDEL case - as has been said - appears to eliminate such a distinction.

\section{B - THE CHARTER FORMULA}

As a result of the adoption of the new formula of domestic jurisdiction in Article 2 (7) 170 of the Charter, some states have modified the reservation of domestic jurisdiction modelled upon Article 15 (8) of the Covenant, or made a new declaration bringing the language of that reservation in line with that of Article 2 (7). This formula was introduced for the first time by the United states in its declaration made in 1946. It is now included in the declarations of India, Botswana, Liberia, Malawi, Mexico, the Philippines and Sudan. These declarations do not recognise the jurisdiction of the court over disputes "in regard to matters which are ESSEHTIALLY within the domestic jurisdiction" of these states. 171 However it is to be observed that only the declarations of India and Botswana ${ }^{172}$ are relevant here. For in all the other declarations the reservation of domestic jurisdiction is used in its subjective form - namely, the State alone is entitled to decide whether the matter is or is not within its domestic jurisdiction. 17 s

The Charter formula has given rise to two important questions: the first is whether Article 2 (7) of the Charter is applicable IPso JURE to the contentious juris- 
diction of the Court and the second is, in what sense does the reservation purport to restrict the jurisdiction of the court?

\section{(I) The Relevance of Article 2 (7) of the Charter to the Compulsory Jurisdiction of the Court}

The view that Article 2 (7) of the Charter is applicable IPSO JUPE to the compulsory jurisdiction of the Court was advanced by Iran in the ANGLO-IRANIAN OIL ComPANY case. Iran contended that the words "Nothing in the present Charter" in Article 2 (7) should be read in conjunction with Articles 7 and 92 of the charter. Also since the former expressly makes the Court one of the principal organs of the United nations and the latter refers to the statute of the Court as "annexed" to the Charter and expressly provides that it "forms an integral part of the present Charter", Article 2 (7) would form a constitutional limitation upon the Court's jurisdiction in all contentious cases. 174 These arguments were advanced by Iran to support its claim that the subsequent adoption of article 2 (7) had the effect of substituting the formula "matters essentially within" for that of "matters which according to international law, are within domestic jurisdiction".

Regardless of the substance of those arguments. that claim did not carry conviction as far as the jurisdiction of the Court under Article 36 (2) of the Statute is concerned. for Article 36 (5) of the Statute is clear on this point. It expressly states that declarations under the oid statute are to be deemed acceptances of the compulsory jurisdiction of the new Court "in accordance with the terms". 175

The United Kingdom, on the other hand, opposed the Iranian interpretation of Article 2 (7) with great force. It argued that the prohibition in Article 2 (7) concerned only organs whose authority is derived from the Charter. 
not directly, as in the case of the Court, from the consent of the parties. Secondly, even if Article 2 (7) was applicable to the Court, it would have no effect whatsoever on the Court's contentious jurisdiction. For all matters of domestic jurisdiction are by definition beyond the scope of international law. Moreover, any dispute concerning any of the four points enumerated in Article 36 (2) of the Statute fell necessarily outside the scope of domestic jurisdiction. ${ }^{17 t}$ As the Court upheld the second preliminary objection concerning the reservation RATIONE TEMPORIS, the opportunity to pronounce on this point was lost. Thus, the question is still one on which divergent opinions have been expressed.

On the one hand, some writers have relied on one or more of the Iranian arguments to prove the applicability of Article 2 (7) of the Charter as such to the Court's contentious jurisdiction. 177 Thus, Rosenne, for instance, believes that by virtue of the provision of Article 92 of the Charter, that the statute forms "an integral part" of the Charter, the statute and the Charter are to be read as one instrument. Accordingly, the general provisions of the Charter (other than those in Chapter XIV concerning the Court directly) are applicable also to the Court. However there is no subordinate status in the statute in relation to the charter. This is so in spite of the fact that the court is governed by the Statute and not by the Charter. ${ }^{178}$ Also the provision of the same Article (i.e. 92), that the Court is the principal judicial organ of the United Nations, seemed to $C$ Vulcan sufficient for the application of Article 2 (7) to the work of the Court. 179 other authors state simply that Article 2 (7) is applicable to the Court without explaining on what argument this view is based. 180

On the other hand, the theory of the non-applicability of Article 2 (7) to the Court has found many advocates. Professor Waldock has been, perhaps, the leading authority on this point. Firstly, he reiterated the 
argument advanced by the United Kingdom in the AngloIranian ail company case, that the court derives the jurisdiction neither from the Charter nor from the statute, but from the consent of states given in one of the methods enumerated in Article 36 of the statute. In fact this was confirmed by the court in the AERIAL INCIDENT OF 27 IULY 1955 case. Here the Court said: "... Article 36 , contrary to the desire of a member of delegations at San Francisco, does not make compulsory jurisdiction an immediate and direct consequence of being a party to the Statute." 181 Then Waldock advanced a more convincing argument. He observed that the words "the present Charter" in Articles 2 (7) and 92 of the Charter were used in the narrow sense exclusive of the statute of the court. The internal evidence of the Charter and Statute - such as Articles 93 and 108 of the Charter - supports this view. Moreover, even if the words "the present Charter" were interpreted in the wide sense inclusive of the Statute, it would not follow that the Court's jurisdiction is limited by the reservation of "matters essentially within domestic jurisdiction". For "there is nothing in the words of Article 2 (7) to preclude the Court ... from intervening in matters essentially within domestic jurisdiction. If IT HAS BEEN AUTHORISED TO DO SO BY STATES CONCERNED in an INSTRUHENT DEHORS THE CHARTER".

Consequently he reached the conclusion that "It may be said with confidence that Article 2 (7) of the Charter does not, as such, touch the Court's jurisdiction in contentious cases". 183

Be that as it may, the question whether Article 2 (7) consists, as such, of a limitation upon the compulsory jurisdiction of the Court remains, however, a doctrinal question, as far as the reservation of domestic jurisdiction is concerned unless it is proved that the scope of the formula "matters which are essentially within domestic jurisdiction" is wider than that of "questions which by international law fall exclusively 
within domestic jurisdiction".

\section{(II) The Portee of the Formula "Matters Essentially Within Domestic Jurisdiction}

As is well known Article 2 (7) of the Charter has introduced considerable changes in the formula of domestic jurisdiction as embodied in Article 15 (8) of the Covenant. It is not proposed here to embark on a general examination of these changes, 184 nor is it intended to consider in detail the meaning of the formula "matters ... essentially within the domestic jurisdiction" as embodied in Article 2 (7). Such examination is outside the scope of this thesis. This formula is relevant only to the extent that it is copied in some declarations and within the limits set for in these declarations. Consequently, since the declarations exclude "disputes in regard to matters which are essentially within the domestic jurisdiction" 185 of the state concerned, the main question is whether the scope of domestic jurisdiction before is altered by this new formula. The answer will be limited to the effect of the omission of the reference to international law as the standard for determining domestic jurisdiction; the omission of any indication as to who should decide whether a matter is or is not within domestic jurisdiction, and finally, the substitution of the word "essentially" for the word "exclusively" or "solely".

Before examining these points it might be observed that there is no reference to the word "intervene", which has given rise to a sharp controversy as to its meaning with regard to political organs, 186 in the reservation of domestic jurisdiction as embodied in the declarations. This might be explained by the conviction of states that the judicial decision could never be the equivalent of an intervention in the customary accepted sense of the word, as the United Kingdom argued in the AllGLO-IRANIAN OIL confany case. 187 
(i) The omission of "international law"

The TRAUEAUX PREPARATOIRES of the San Francisco Conference are confused and throw an uncertain light on the deletion of the words "by international law" from Article 2 (7) of the Charter. 188 Whereas the delegate of the United States Mr Dulles defended the omission on the ground that "international law was subject to constant change." 189 "undefined and inadequate" 190 on this subject Dr Evatt, the delegate of Australia, did not see any need for including the words "according to international law" in Article 2 (7) on the ground that "there was any other possible criterion that could be used". 191

However, it seems certain that the omission was intentional. This might be inferred from the failure of the Belgium proposal to add the words "according to international law" to obtain the required two thirds majority. It was defeated by 18 votes to 14.192

The above explanation of Mr Dulles has been widely criticised on many grounds even by the political organs of the United Nations. It is asserted that that explanation completely overlooked the opinion of the P. C. I. J. on the nationality Decrees which laid down the criterion of international obligations. ${ }^{193}$ Furthermore, the flexibility of international law was the very reason for the existence of the reservation of domestic jurisdiction and referring to international law as a yardstick. For if the boundaries between domestic and international jurisdiction were rigid, there would have been no reason for the existence of the reservation. 194

Whatever was the reason for omitting "international law", the question that might be raised is whether there exists another criterion for determining whether a matter is or is not within domestic jurisdiction. 
According to one interpretation, the result of the intentional omission of international law is that the political organs of the United Nations are free to apply a political or extra judicial criterion.

According to another interpretation the omission should be interpreted in favour of the United Nations organs. For the sphere of state activities free from international legal obligations is further eroded by the criterion of international concern or repercussions. This interpretation is said to be not only in conformity with Article 2 (7), but also with the intention of the framers of that Article, who intended to establish an effective political organization for the maintenance of international peace and security. It would, therefore, be absurd to limit the competence of the political organization to deal with legal disputes. 196

None of these interpretations is regarded as a correct one for the concept of domestic jurisdictioneven vis-a-vis the political organs. For, it is asserted that the question of jurisdiction is a legal one and the concept of international concern is a political one. Also since it is fairly "obvious that no legal term can be explained except by reference to the law of which it is part", the only relevant criterion is that of international law. ${ }^{197}$ Secondly, the criterion of international concern fails to afford any reasonably ascertainable test, since the determination of what is of an international concern is itself a matter of opinion. Bearing in mind the fact that "under the present day condition very little that a country does fails to have some repercussion outside its border". this criterion could "unduly restrict the field, if it would not virtually destroy the whole concept of international jurisdiction". 198 Third1y, the concept of international concern was expressly rejected by the $P . C$. I. J. in its opinion on the Nationality Decrees. It said that as regards matters which "though they may UERY CLOSELY CONCERN THE INTERESTS OF 
HORE THAN ONE STATE", "EACH state IS Solle JUDGE". 199 Finally, the concept of domestic jurisdiction appeared to some members of the INETITUT DE DROIT INTERHATIONAL to require the elimination of any connection between the extent of domestic jurisdiction and "the development of international RELATIONS". Thus this phrase, which was inserted in the draft resolution was omitted from the final resolution adopted by the Institut. 200 The final resolution connected the scope of domestic jurisdiction with the development of international law as the only criterion. Consequently the repercussion or international concern are not relevant except where the legal rights of another state or the international community are involved. 201 The omission of the words "according to international law" seemed thus to the majority of the writers to "imply somewhat gratuitous disparagement of international law and to have no effect whatsoever". 202

This conclusion is undoubtedly accurate with regard to the omission of the words "international law" from the reservation of domestic jurisdiction in some declarations accepting the Court's jurisdiction. This is so not only because of the above reasons but mainly because the court cannot, by its very nature as a judicial organ and by virtue of the express provisions of its statute (Article 38), but apply the rules of international law. 205

\section{(ii) The omission of the reference to the body competent to decide whether a matter is or not within domestic jurisdiction}

This omission is not, in fact, peculiar to the reservation modelled on Article 2 (7) of the Charter, but even the declarations made prior to the establishment of the United Nations did not mention the body competent to decide on the nature of the matter. This was - as explained before 204 - due to the express provision of Article 36 of the statute of the P. C. I. J. which empowered the court to decide on its own jurisdiction. It 
may be asked, therefore, whether the adoption of the charter formula has affected Article 36 (6) of the Statute of the I. C. J.

Professor Kelsen found in the intentional omission 205 of a reference to the organ competent to decide an indication that the decision upon the nature of a matter was kept in the hands of states concerned. He went further, saying that this was so with regard to declarations accepting the Court's jurisdiction under Article 36 (2) of the statute. He said:

\footnotetext{
"The only question is whether, in case the other party contradicts this view, paragraph $b$ of Article $3 b$ applies providing that the Court shall settle the metter. Even if the answer is in the affirmative, the Court is bound by Article 2, paragraph 7, of the Charter and consequently has to recognise a matter to be essentially within the domestic jurisdiction of the state which, under this provision of the Charter, declares the matter to be essentially within its domestic jurisdiction. That means that Article 2, paragraph 7, of the Charter may deprive a declaration made under Article 36, paragraph 2, of the Statute of almost all its value." 206
}

This view does not appear to carry conviction. It seems, firstly, to disregard the fact that the court, though established by the Charter, functions according to its statute (Article 1 of the Statute). That view, thus, attempts to extend the effect of Article 2 (7) of the Charter to the work of the Court, a question which is doubtful, as has been said, and to make devoid of any significance a clear text, i.e. Article 36 (6) of the statute. Secondly, it might be asked what is the significance of the compulsory jurisdiction if the court is deprived from the decision to decide on its own jurisdiction? Or can the jurisdiction of the Court under Article 36 (2) in such a case, be described as compulsory? There is no doubt that paragraph 6 of Article 36 is an essential part, not only of that Article but of every scheme of truly obligatory jurisdiction. 207 Thirdly, is it fair to assume that the framers of paragraph 6 intended to 
waste the time of the Court and to cause the parties much expense for the purpose of obtaining a declaratory judgment holding the view of the defendant? Also, this view seems to disregard the general rule of international law that international tribunals are entitled to determine questions of their jurisdiction arising under the instrument from which they derive their jurisdiction. 208 Thus, in all the cases in which the objective reservation of domestic jurisdiction was invoked, the Court - as will be seen - applied paragraph 6 of Article 36 as it stands. Certainly in almost all these cases the reservation was modelled on the Covenant formula, but this does not alter the fact that even according to the latter formula, there is no reference to the organ competent to decide.

Finally, since the issue concerns international obligations of a State valid in international law, it is submitted that if a decision is kept within the hands of States concerned, the obligation would cease to be an obligation of international law although it might be an obligation of international morality. 209 Moreover the existence of the subjective form of the reservation of domestic jurisdiction indicates that the objective reservation of domestic jurisdiction is governed by Article 36 (6).

Thus, it is generally recognised that the omission of a reference to the organ competent to decide in Article 2 (7) of the Charter does not mean necessarily that the decision is left for States concerned. 210 Also as regards the declarations made under Article 36 (2) of the Statute, paragraph 6 of that Article is regarded, as decisive on this point, even by those who believe that Article 2 (7) is applicable to the Court. 211

(iii) The substitution of "essentially" for "exclusively"

At the San Francisco conference the Belgium proposal concerning the substitution of the words "exclusive- 
ly" or "solely" for "essentially" was defeated by a large majority ( 28 to 2 votes). ${ }^{212}$ The preference of the word "essentially" was due - as explained by Dulles and Dr Evatt - to the desire to broaden the scope of domestic jurisdiction and correspondingly to restrict the sphere of the activity of the United Nations especially that of the Social and Economic council to deal with Economic and Social problems. 215 The substitution disclosed, thus, the great desire for a flexible and wider interpretation which would ensure that certain matters would fall "EsSENTIALCY" within the domestic sphere, even though by reason of their international repercussion, or the existence of relevant international legal obligation, they might no longer be comprised "SoLELy" within that sphere.

Since international repercussion is not relevant to the Court - as has been said - it might be asked whether international law contains any criterion determining matters which are in ESSENCE matters of domestic jurisdiction. Although the P. C. I. J. had refuted in its advisory opinion on the HATIONALITY DECREES, the view that a matter of a treaty obligation can be of domestic jurisdiction regardless of the subject matter of the treaty obligation, that view has found some proponents. Robin, for instance, considering only the first part of the P. C. I. J. definition of the concept of domestic jurisdiction, in that case, pointed out that the word "essentially" was synonymous with "principally". consequently, if a matter was principally within domestic jurisdiction it must be treated as a whole within that sphere even if it was practically within the international sphere. He admitted that treaty obligations affect the limits of domestic jurisdiction, but this was so only to the extent that there existed a clear indication in that direction. A treaty of an exceptional nature made in special circumstances could not affect the limits of domestic jurisdiction. Otherwise how can the states be blamed if they reserved for themselves the decision whether a matter was or was not within domestic jurisdic- 
tion. 216

This view was refuted by the Court in its Advisory Opinion on the INTERPRETATION OF PEACE TREATIES. Here Bulgaria, Hungary, Rumania and several other governments considered the request for an advisory opinion as "an action ULTRA UIRES on the part of the General Assembly". This contention was based on the conception that in dealing with the question of observance of human rights and fundamental freedom in the states concerned, the general Assembly disregarded the provision of Article 2 (7) of the Charter and was "interfering" or "intervening" in matters essentially within the domestic jurisdiction of States. 217

The Court dismissed the objection on the ground that it was not called upon to deal with either the alleged violations of the provisions of the treaties concerning human rights and fundamental freedom, or the interpretation of the Articles concerning those matters. The object of the request was much more limited, the Court observed. It was "directed" solely to obtaining from the Court certain clarifications of a legal nature regarding the applicability of the procedure of the settlement of disputes by the "commission provided for in the express terms" of the relevant Articles of the treaties concerned. The court said:

\footnotetext{
"The interpretation of the terms of a treaty for this purpose could not be considered as a question essentially within the domestic jurisdiction of a state. It is a question of international law which by its very nature, lies within the competence of the court.
}

These consideration also suffice to dispose of the obiection based on the principle of domestic jurisdiction and directed specifically against the competence of the court. namely, that the court as an organ of the United Nations, is bound to observe the grovisions of the charter, including Article 2, paragraph 7." 218 
Although this statement does not provide a basis for the application or non-application of Article 2 (7) to the Court's jurisdiction, it confirms the jurisprudence of the P. C. I. J. that there are only two spheres. A matter is subject to international legal obligations, and hence within international jurisdiction or not subject to these obligations and therefore belongs to the domestic sphere regardless whether it is described as "exclusively" or "solely" or "essentially".

It might be argued that since the Peace Treaties case is the only instance in which the objection was based on Article 2 (7) of the Charter, the finding of the Court in that case cannot be cited to prove that the Court is favourably inclined towards extending the interpretation peculiar to the Covenant formula to that of the Charter. Such a view would neglect the fact that a state cannot impose its view on other states with respect to treaty obligations. 219 It should also be borne in mind that the rule PACTA SUHTA SERUANDA cannot be regarded as merely treaty $l a w$ but as the most elementary principle of international legal order. 220

It follows that the substitution of the word "essentially" for "exclusively" or "solely" has no legal significance whatsoever. Or as Pollux said "the change has merely an ideological significance and nothing more". To have the effect of excluding treaty obligations the reservation must be unambiguous. ${ }^{222}$ The Charter formula cannot as such have that effect.

The conclusion to be drawn from what has been said is that the balance of argument seems to be in favour of the non-applicability of Article 2 (7) of the Charter to the jurisdiction of the Court under Article 36 (2) of the Statute. However, if there is still some doubt in the light of an absence of a clear decision from the court. the question seems to be without practical importance. This is so, inasmuch as the idea that the Charter formula 
is broader than that of the Covenant, is refuted by the practice of the Court, of the United Nations organs 223 and of States themselves. This can be illustrated by the position taken by the United States, which played a considerable role in introducing Article 2 (7) into the charter, and the United Kingdom before the court in the PEACE TREATIES case. They emphasised that the only criterion for determining whether a matter is or is not within domestic jurisdiction is that of international law as consistently maintained by the P. C. I. J. It was argued also that "in the event of dispute, the issue whether a matter was or was not essentially of domestic jurisdiction would be subject to settlement by Treaty Commissions". As to the significance of the word "essentially" it was maintained that:

"Certainly as between the parties" matters expressly covered by treaties cannot $22 \overline{4}$ considered matters essentially of domestic jurisdiction." 224

In the RIGHT OF PASSAGE OUER INDIAN TERRITORY case. India appears to have been convinced of the weakness of the idea that the reservation of domestic jurisdiction modelled on Article 2 (7) is broader than that modelled on Article 15 (8) of the covenant. Although a reference was made to that idea by Soskice (council for India), he stressed that "it is for the court rather to know and lay down the precise limits of the reserved domain." $225 \mathrm{He}$ recognised also that the assumption of treaty obligation shifts a matter from domestic to international jurisdiction. 226

The position of Switzerland in the Interhandel case was also in the same direction. Although the declarations of both parties were without the objective reservation of domestic jurisdiction. Switzerland - as has been said 227 - relied on Article 36 (2) of the statute and not on Article 2 (7). That means, by implication, that Switzerland was coincided either of the non-applicability of 
Article 2 (7). to the Court or that that Article was of the same significance as the reservation inherent in Article 36 (2) of the Statute. 228

Perhaps the most important fact in this respect is states practice in their declarations. As observed before, all States - with the exception of Israel 229 and India - which favoured the inclusion of the objective reservation of domestic jurisdiction since 1945, have excluded from their declarations "disputes with regard to questions which, by international law, fall exclusively within the jurisdiction of the state concerned" or, as in the declaration of Botswana "disputes relating to matters which, by international law, are essentially within [its] domestic jurisdiction". This practice seems to suggest that the reservation of matters essentially within domestic jurisdiction have left the scope of the reserved domain very much where it was under the declarations made under Article 36 (2) of the P. C. I. J. and within the limits determined by that court in the HATIONALITY DECREES OPINION. Otherwise the new formula could have widely spread in the declarations made under Article 36 (2) of the new court.

\section{C - THE PRACTICE OF THE COURT IN REGARD TO THE RESERVATION}

The Chief characteristic of the concept of domestic jurisdiction in relation to the practice of the court in contentious cases has been its lack of specific relevance. The reservation was invoked in one case only (the LOSINGER case) before the P. C. I. J. However it was lodged as a plea to the jurisdiction of the same court in the ELECTRICITY CONFANY OF SOFIA AND BULGARIA case in spite of the absence of any express reservation in the declarations of both parties. The reservation has been invoked before the International Court of Justice in four cases: the ANGLO-IRANIAN OIL COMPAHY, the RIGHT OF PASSAGE OUER INDIAN TERRITORY, the IHTERHAHDEL and the AEGEAN SEA CONTINENTAL SHELF. In addition to these cases 
the question of domestic jurisdiction has been examined by the Court in there Advisory Opinions: TUHIS AHD HOROCCO NATIONALITY DECREES, the TREATHENT OF POLISH NATIONALS IN DANZIG and INTERPRETATION OF PEACE TREATIES. 230

1. The ADUISORY OPINIOH ON THE NATIONALITY DECPEES IN TUNIS AND MOPOCCO has an important relevance here not only for the reasons discussed before, 231 but also because of the way the plea of domestic jurisdiction had been disposed of by the P. C. I . $J$. In the light of the fact that the objection was made to the Council and not to the jurisdiction of the court itself, the court had no choice but to uphold the French objection or reject it as ill founded. Having taken into consideration the intimate connections between the plea of domestic jurisdiction and the merits of the case and the requirement to dispose of the objection without prejudging the rights of the parties as they might emerge from a full investigation of the merits, the Court applied what is now well known as the "provisional view" theory. 232 According to this theory the relevant issue in determining whether the matter in dispute is or is not within domestic jurisdiction is not the substantive rights of the parties under international law but the PRIHA FACIE status of the matter itself, namely whether it discloses agreeable points of international $1 \mathrm{aw}$. In other words it is sufficient, for that purpose, to make a summary examination of the merits without deciding on the substantive rights of the parties. "When once it appears that the legal grounds (titres) relied on are such as to justify the provisional conclusion that they are of judicial importance for the dispute" $2 \mathrm{~S}$ concerned, the Court would reject the plea of domestic jurisdiction. It goes without saying that a decision based on this theory rejecting the objection cannot be "interpreted as indicating a preference on the part of the court in 
favour of any particular solution as regards the whole or any individual point of the actual dispute". 254

The provisional view principle has influenced the future jurisprudence of the Court as will be seen.

2. In its Advisory Opinion of february 4, 1932 on the TREATHENT OF POLISH NATIONALS IN DANIIG the P. C. I. J. reaffirmed its previous opinion with regard to the relativity of the concept of domestic jurisdiction and the Chief element which has to be taken into consideration in determining the scope of that concept. As regards the latter, the court pointed out that the plea of domestic jurisdiction cannot be advanced where an international obligation has been assumed and conversely a matter remains within the sphere of domestic jurisdiction as long as international obligations are absent. Thus, rejecting the Polish argument that, though the application of a constitution is in principle a matter of domestic jurisdiction, the Danzig constitution, being under the guarantee of the League of Nations and intimately connected with certain treaty provisions, eliminated "the ordinary legal distinction between matters of domestic and international character", the Court said:

"It should be observed that, while on the one hand according to generally accepted principles, a State cannot rely, as against another state, on the pro- visions of the latter's Constitution, but only on international law and international obligations duly accepted, on the other hand and conversely, a State cannot adduce as against its own constitution with a view to avoiding obligations incumbent upon it $2 \mathrm{yng}_{\mathrm{s}}$ international law or treaties in force." 235 
3. The P. C. I. J. had the first opportunity to consider the concept of domestic jurisdiction in a contentious case in the LOSINGER AND COMPANY case. Here the respondent (Yugoslavia) filed a preliminary objection to the Court's jurisdiction on the ground that the dispute did not concern a question of international law. It contended also that there existed no international obligation accepted by Yugoslavia. 256 Although the Yugoslav declaration excluded disputes with regard to questions which by international law fell exclusively within the jurisdiction of Yugoslavia, the latter did not rely on the terms of its reservation but relied directly on Article 36 (2) of the Statute.

The Court found that that objection was intimately connected with the Swiss submissions on the merits. Consequently it observed that deciding the objection at that stage involved the danger "of passing upon questions which appertain to the merits of the case, or prejudging their solution". 237 The objection was therefore joined to the merits. 238

4. The jurisdiction of the P. C. I. J. was also objected to on the ground that the dispute fell within domestic jurisdiction in the ELECTRICITY COMPANY OF SOFIA AND RULGARIA case. 239 However the difference here was that the declarations of both parties (Belgium and Bulgaria) did not contain the reservation of domestic jurisdiction. Thus, here again the objection was based on Article 36 (2) of the statute. Bulgaria argued that the dispute did not fall within any of the four categories of legal disputes provided for in Article 36 (2). Since the argument intended to deprive the legal relation created between the Belgian Company and the Bulgarian authorities by the awards of the Mixed Arbitral Tribunals of any international element, the court considered that argument as amounting 
"not only to encroaching on the merits, but to coming to a decision in regard to one of the fundamental factors of the case." The plea was, therefore, dismissed on the ground that it did not possess "the character of a preliminary objection within the meaning of Article 62 of the Rules." 240

5. The reservation of domestic jurisdiction was invoked for the first time before the International Court of Justice in the ANGLO-IRANIAN OIL COHPANY case. 241 The Court, as previously mentioned, 242 lacked jurisdiction on another ground and made no pronouncement on the issue of domestic jurisdiction. Nevertheless, the case has some significance for two reasons. The first is that it might be inferred from the brief statement made by the court at a previous hearing, when it considered the United Kingdom's request for an indication of interim measures of protection, that the Court had followed the 'provisional view' principle adopted by its predecessor in the NATIONALITY DECREES oPINION, In its order of JUly 5, 1951 the Court said:

\footnotetext{
"Whereas the complaint made in the application is one of an alleged violation of international 1 aw by the breach of the agreement for a concession of April 29, 19S3, and by $a$ denial of justice which, according to the Government of the United kingdom, would follow from the refusal of the Iranian Government to accept artitration in accordance with that agreement, and whereas it cannot be accepted a priory that a claim based on such a complaint falls completely outgide the scope of international jurisdiction ..."."
}

Secondly, the same order seems to indicate that when once it appears on a summary view that the applicant state raises arguable questions of international law, the plea of domestic jurisdiction would be insufficient to stop the indica- 
tion of interim measures of protection pending a final judgment on the jurisdiction to examine the merits 244

6. The RIGHT OF PASSAGE was the second case in which the reservation of domestic jurisdiction was relied on before the International Court. In its fifth preliminary objection India argued that the dispute concerned a question which by international law fell within its domestic jurisdiction and, therefore, was excluded from the Court's jurisdiction both by its declaration and by virtue of Article 36 (2) of the statute, which limits the Court's jurisdiction to the four categories of questions of an international legal nature. ${ }^{245}$ It is noteworthy that India relied on the provisional view theory. 246 It contended that a summary view of the relevant facts and applicable law showed that none of the legal grounds, namely; treaty, custom and general principles of law, invoked by the applicant justified "the provisional conclusion that they are of real importance judicially for determining the legal position of the Parties with respect to the passage of Portuguese persons and goods between Daman and the enclaves." 247 Nor could it be possible to regard those grounds as reasonably arguable under international $1 \mathrm{aw}$.

Since those facts were disputed by Portugal. the court held that the fifth objection invoked an elucidation of those facts and their legal consequences, which required an examination of the actual practice of the British, Indian and Portuguese authorities with respect to the right of passage; the legal significance of the practice followed by the British and Portuguese authorities, and the legal effect and the circumstances surrounding the application of Article 17 of the treaty of 1779 and the Mahratha Decrees issued in 
pursuance thereof. All these questions appeared to the Court to be so intimately tied up with the merits that it was not possible to pronounce upon this objection without prejudging the merits. Accordingly, the objection was joined to the merits. 248

Judge Chagla (ad hoc) pointed out in his dissenting opinion that the Court had been inclined to join the objection to the merits because of the feeling that it was impossible to pronounce on the issue without investigating the merits. "But this is not always so. Otherwise it could never be open to a state to take a preliminary objection on that ground." 24 ?

In the second phase (Merits) the Court rejected India's fifth preliminary objection. It observed that a treaty, international custom and principles of international law were relied upon as establishing a right of passage as against India. To claim that such an obligation is binding upon India, to invoke, whether rightly or wrongly, such a principle, is to place oneself on the plane of international law. The court added:

\footnotetext{
"Indeed, in the course of proceedings both Parties took their stand upon that ground and on occasion expressly said so. To decide upon the validity of those principles, upon the existence of such right ot fortugal, and upon the alleged failure to fulfil that obligation, does not $f^{11}$
}

7. The INTERHAHDEL case set another example of the possibility of invoking the plea of domestic jurisdiction as a bar to the Court's compulsory jurisdiction even in the absence of any express reservation to that effect in the declarations accepting that jurisdiction. It is true that the United States declaration contained the subjective 
reservation of domestic jurisdiction. However the objection that there was no jurisdiction in the Court to consider the seizure and detention of the vested shares of General Amiline and Film Corporation because they were, ACCORDING TO INTERNATIONAL $L A H$, matters within the domestic jurisdiction of the United States, was of "different character and of unequal scope", 251 as the court said, to the objection based on the subjective reservation of domestic jurisdiction. Here, Switzerland invoked Articles 4 and 6 of the Washington Accord of May 25. 1946. By virtue of the former, the United States had assumed the obligation to unblock Swiss assets in the United States, and by virtue of the later, the parties had undertaken the obligation to refer disputes concerning the application or interpretation of the Accord to arbitration in case of failure of other means of settlement. The obligation to recourse to arbitration or conciliation had also been undertaken by the parties by virtue of Article 1 of the Treaty of Arbitration and Conciliation of February 16, 1931.

In order to avoid an examination of the merits, the Court confined itself to considering whether the grounds invoked by Switzerland "are such as to justify the provisional conclusion that they may be of relevance in this case and, if so, whether questions relating to the validity and interpretation of those grounds are questions of international law". 253 The interpretation of the relevant provisions of the Washington Accord, the enemy or neutral character of the property of the assets of Interhandel, and the interpretation and application of the provision relating to arbitration or conciliation were considered sufficient grounds which justified the provisional conclusion that they invoked questions of international law relevant to the case. Accordingly the objection was rejected. 254 
The Court had, thus followed the view enunciated by the P. C. I. J. in the NATIONALITY DECREES opinion. A view that refused to follow in the previous case (the RIGHT of PASSAGE) though both parties preferred it. However, the significance of this case is that the Court made it clear that the provisional view theory is not limited to advisory opinion but it is also a convenient way for disposing of the objection based on the reservation of domestic jurisdiction in contentious cases. 255

8. The AEGEAN SEA CONTINENTAL SHELF 256 is the last case in which the reservation of domestic jurisdiction was examined by the court, but was considered this time from an unusual angle. Since the dispute concerned the delimitation of the continental shelf, the Greek Government tried to diminish the scope of its reservation to the General Act of 1928 excluding from the Court's jurisdiction:

\footnotetext{
"Disputes concerning questions which by international law are solely within the domestic jurisdiction of States, and in particular disputes relating to the territorial status of Greece, including disputes relating to its rights of sovereignty over its ports and lines of communication." 25 t
}

Relying on a grammatical interpretation, Greece argued that when making the reservation it did not intend by the reference to "disputes relating to the territorial status of Greece" to designate this category of disputes as an autonomous category additional to that concerning matters solely within domestic jurisdiction. 258 The court refused to give the reservation such an effect. For in reservations to treaties or in declarations accepting the Court's compulsory jurisdiction and in Article 39 (2) of the General Act of 1928, disputes concerning matters of "domestic jurisdiction" and 
disputes relating to "territorial Status" have been kept quite separate and distant. Furthermore, the Court observed that if the Greek interpretation was accepted, the reservation of disputes relating to territorial status would have been deprived of any significance especially in the light of the relativity of the concept of domestic jurisdiction as explained by the P. C. I. J. In MATIOHALITY DECREES opinion 259

The Court has, therefore, reaffirmed its predecessor's view concerning the scope of domestic jurisdiction. Explaining that view the Court said:

\footnotetext{
"a matter which is not in principle regulated by international $l$ aw and is thus a matter within the State"s domestic jurisdiction, will cease to be such if the state has undertelen obligations towards other states with respect to that matter". 260
}

From the above practice it is clear that the reservation of domestic jurisdiction did not achieve its purpose if it is intended to bar the jurisdiction of the Court IN LININE. Nor did the court uphold an obligation to its jurisdiction based on the concept of domestic jurisdiction. This seems to be logical in the light of the Court's jurisprudence. It is so, as long as the court would reject the preliminary objection to its jurisdiction unless, when on a summary examination, the plaintiff's case would not disclose any arguable matters of international obligation relevant to the issue. Such a hypothesis is "in the nature of things likely to be rare". For it is unlikely that a case may arise in which the plaintiff's case would not disclose grounds of international law relevant to the issue. Therefore, the provisional examination test "reduces to the bare minimum the practical effect envisaged by the reservation in question." 262 The Court seems also to have taken into consideration what has been called the "Chief danger of the 'provisional view' theory" 263 for the plaintiff state. 
For a decision upholding a preliminary objection to jurisdiction prevents the plaintiff State from any further presentation of its case. In other words by losing the preliminary objection the plaintiff state becomes IPSO FACTO a loser of the merits.

\section{D - THE PLEA OF DOMESTIC JURISDICTION IN THE LIGHT OF THE NEW RULES}

Under the Rules of 1936 and 1946, the Court had three options to dispose of a preliminary objection. It could uphold, reject - as in the IHTERHANDEL case, or join it to the merits as did the Court in the LOSIGEP and RIGHT OF PASSAGE cases. In fact the P. C. I. J. first joined an objection to the merits (in the PRINCE VON PLESS case) before there was any rule to that effect. 265 The joinder had been considered a suitable way of disposing of a preliminary objection "whenever the interests of good administration of justice require it" and especially where the decision on the objection "would run the risk of adjudicating on questions which appertain to the merits of the case". 2tb However the experience of the BARCELOHA TRACTIOH LIGHT AND POHEP CONPANY case, 267 which showed that after a prolongation of an expensive and time consuming procedure the decision could be in favour of the preliminary objection, was regarded in many quarters as a reason for amending the Rules of the Court. Consequently the 1972 Rules maintained in 1978, have introduced two important amendments. The first is the elimination of the procedure of joinder. Article 79 (7) of the 1978 Rules provides that the Court "shall either uphold the objection, reject it, or declare that the objection does not possess, in the circumstances of the case, an exclusively preliminary character". The second amendment concerns the determination of the Court's jurisdiction at a Preliminary stage of the case. Paragraph 6 of the said Article reads: 
"In order to enable the Court to determine its jurisdiction at the preliminary stage of the proceedings, the court. whenever necessary, may request the parties to argue all questions of 1 aw and fact, and to adduce all evidence, which bear on the issue".

Bearing in mind the fact that the preliminary objection based on the reservation of domestic jurisdiction is directed against the judicial competence of the Court, it should be asked whether the Court's choices of disposing of this objection will be limited, by virtue of Article 79 (6) of the Rules, only to upholding or rejecting the objection at the preliminary stage of the proceedings, or it can declare that the objection does not possess, in the circumstances of the case, an exclusively preliminary character. The answer will, of course, depend on how the Court will apply paragraphs 6 and 7 of article 79 to a preliminary objection of domestic jurisdiction.

The Court has availed itself of the new choice provided for in paragraph 7 only in the MILITARY AND PARAMILITARY ACTIUITIES IN AND AGAINST HICARAGUA case. As the point of issue involved an objection based on the multilateral treaty reservation, not much assistance can be derived from the case. However, in the first phase of the case (jurisdiction and admissibility) 269 the court seems to have taken the view that the new Rules require that the jurisdictional aspect ought to be decided at the preliminary stage, either by upholding or rejecting the objection based on the multilateral treaty reservation. This could be inferred from the Court's emphasis that the question at issue, i.e. what States were "effected" by the decision on the merits, was not in itself a "JURISDICTIONAL PROBLEH". 270 The Court availed itself of the new procedural technique after noting that the multilateral treaty reservation "could not bar its adjudication of all Nicaragua's claims" 271 and therefore did not "constitute an obstacle for the court to entertain the proceedings instituted by Nicaragua under the Application of 9 April 1984". 272 The issue did not, therefore, concern a jurisdictional aspect, but matters of substance 
relating to the merits of the case. For, as the court said, it was not possible to identify the states "affected" before the general lines of the judgment became clear. 273

In the second phase of the case 274 the Court took the opportunity to comment briefly on the rational of the third choice offered by Article 79 (7) of the Rules. Here, again, the court pointed out that the question whether the court has jurisdiction is among the questions which "do not NORMALLy require an analysis of the merits of the case." 275 Then it said:

\footnotetext{
"while the variety of issue raised by preliminary objections cannot possibly be foreseen, practice had shown that there are certain linds of preliminary objections which can be disposed of by the Court at an early stage without exanination of the merits. ABOUE IT IS CLEAP THAT A OUESTIOH OF TURISBICTIOH IS OHE HHICH REGUIRES DECISIOH AT THE FRELIHIHARY STAGE OF THE PROCEEDIHGS".
}

However this statement is qualified by the limitation of the immediate decision upon preliminary objections only to those which are of an exclusively preliminary character. An objection is not of that character when it contains "both preliminary aspects and other aspects relating to the merits.

This qualification, in conjunction with the word NOPHALLY mentioned above seems to suggest that the court might declare that the preliminary objection of domestic jurisdiction, being, usually, as the practice has shown, bound up with the merits, does not possess, in the circumstances of the case, an exclusively preliminary character and thus will have to be dealt with at the stage of the merits.

The preliminary objection of domestic jurisdiction might thus be disposed of according to one of the following methods. It could be upheld either on a summary view, 
as did the court in the INTERHANDEL case, or according to Article 79 (7) of the Rules by asking the parties to argue at the preliminary stage questions of 1 aw and $f a c t$. even those touching upon the merits, which bear on the jurisdictional issue. The third option is to declare that the objection does not possess an exclusively preliminary character if the objection "is so intertwined with elements pertaining to the merits that a bearing of the issue would syphon of into the preliminary stage the whole of the case." 279

\section{E - CONCLUSIONS}

The conclusions to be drawn from the foregoing considerations may be summarised as follows.

The concept of domestic jurisdiction refers to matters which are not regulated by international law general or practical. Its scope differs according to the content of that law at any given time. The practical significance of the reservation of domestic jurisdiction is almost similar to the reservation limiting the Court's compulsory jurisdiction to legal disputes. ${ }^{280}$ For the ascertainment whether a matter is within domestic jurisdiction is tantamount to asking whether it is subject to international legal objections.

The inclusion of the reservation in declarations accepting the Court's compulsory jurisdiction is unnecessary. For it cannot - as the practice of the court has shown - offer any additional protection other than that already provided by international $\mathrm{l}$ aw and the statute of the Court. A state can always advance the plea of domestic jurisdiction either as a preliminary objection or as a defence on the merits. This is so regardless whether the reservation is modelled on the covenant formula or that of the Charter of the United Nations. This conclusion is supported by the fact that the reservation in both its formulae (i.e. of the covenant and the Charter) 
is inserted only in 14 out of 46 declarations currently in force. 281 Furthermore, of the original parties 3 States (Australia, New Zealand and the United Kingdom) have abandoned the reservation. In this context the reservation is not harmful to the Court's compulsory jurisdiction.

The retention of the reservation in spite of the foregoing considerations reflects the strong connection which exists between the concept of domestic jurisdiction and the notion of sovereignty. Thus, it has been argued that the reservation was adopted at the San Francisco Conference to have "above all the psychological effect of reassuring some states that their sovereignty would thereby be preserved". 282 It is not surprising, therefore, to find the reservation almost limited to the declarations of newly independent States. In fact, with the exception of Canada, the reservation is included only in the declarations of developing states.

Whatever the reason for inserting the reservation it proved to be a fragile instrument to bar the jurisdiction of the court IN LIHINE LITIS.

In order to discourage the unnecessary prolongation of proceedings at the jurisdictional stage a new approach is adopted by the 1972 and 1978 Rules. The Court may now request the parties to argue at the preliminary stage all questions of law and fact even those touching upon the merits, which bear upon the jurisdictional issue, or declare that the objection does not possess, in the circumstances of the case, an exclusively preliminary character. 


\section{SECTION (3) : THE RESERVATION OF "LEGAL DISPUTES}

\section{A - "LEGAL DISPUTES" : A LIMITATION ON A LIMITED JURISDICTION?}

While the majority of states have accepted the Court's compulsory jurisdiction in "all disputes" other than those expressly reserved without qualifying the term "disputes" but with the mention that the acceptance is made "in conformity with", 284 or in accordance with, 285 or "pursuant to", 286 or "as provided for" 287 in Article 36 (2) of the statute, 16 states, 289 i.e. almost one third, stipulated that their acceptance is to cover "LEGAL DISPUTES" other than those excluded. This is in spite of the fact that the declarations of the latter states use the same terms as those of the former, i.e. "in conformity with" ... etc or "under Article 36, paragraph 2, of the statute". These latter declarations can be classified into two groups: either they simply accept the Court's jurisdiction in "all legal disputes", or in "all legal disputes concerning" the four points set forth in Article 36 (2) of the Statute. This classification seems however without significance since these declarations are made in conformity with Article 36 (2).

It may thus be asked whether states, by making this reservation, are only reiterating the term "legal disputes" as used in Article 36 (2) or they wished to emphasis that they have excluded some disputes even though these may fall within one of the four categories of disputes enumerated in Article 36 (2).

States must be aware of the fact that the court's compulsory jurisdiction is limited by statutory provisions to "legal disputes". Thus Article 36 (2) of the Statute provides for that the Court's compulsory jurisdiction may be accepted "in all legal disputes concerning : 
a) the interpretation of a treaty;

b) any question of international law;

c) the existence of any fact which, if established, would constitute a breach of an international obligation:

d) the nature or extent of the reparation to be made for the breach of an international obligation.

Besides, this paragraph should be read in conjunction with Article 38 (1) of the Statute, which requires the court "to decide in accordance with international law". The jurisprudence of the Court also confirms this limitation. It was confirmed by the P. C. I. J. shortly after its establishment. It said in the STATUS of EASTERN CARELIA case that "The Court, being a Court of justice. cannot, even in giving advisory opinions, depart from the essential rules guiding their activity as a Court." 289

In the Advisory Opinion of 20 July 1962 on CERTAIN EXPENSES OF THE UNITED NATIONS the I. C. J. pointed out that it had always been guided by the above principle articulated by its predecessor. After reiterating the above statement the court continued that "if a question is not a legal one, the Court has no discretion in the matter; it must decline to give the opinion requested". 290

One year later the Court said in the Northern Cameroon case that:

\footnotetext{
$\therefore$ "The function of the Court is to state the lawn but it may pronounce judgment only in connection with concrete cases where there exists at the time of the adjudication an actual controversy involving a conflict of legal interests between the parties. The court's judgment must have some practical consequence in the sense that it can arfect existing legal rights or obligations of the parties, thus removing uncertainty from their legal relations." 291
}

If the reservation of "legal disputes" is aimed at excluding from the scope of the compulsory jurisdiction 
"political disputes" it seems also without significance at least in the light of some pronouncements of the Court. Thus, being unable to deduce any legal obligation from the general considerations of the case, the court stated in its Advisory Opinion on the International STATUS OF SOUTH-HEST AFRICA that "it is not for the court to pronounce on the political or moral duties". 292

This principle was confirmed in the following year in the HAYA DE LA TORRE case. The Court made it clear that it is not part of its judicial function to make a choice which "could not be based on legal considerations, but only on considerations of practicability or political expediency." 293 Consequently if the limitation of "legal disputes" is to have any significance it must be intended either to have the effect of keeping the determination of the character of the dispute in the hands of the interested State, or excluding certain disputes, despite being encompassed within one of the four categories of disputes enumerated in paragraph 2 of Article 36, from the Court's compulsory jurisdiction.

The first supposition cannot stand. As has been seen in the previous section 294 a reservation keeping the power of the determination of the character of a matter cannot - regardless of its validity - be presumed without an express mention to that effect inasmuch as the Statute confers clearly on the court the decision to decide its competence, [Article 36 (6)]

As to the second hypothesis, it seems desirable to be preceded by a brief examination of the distinction between legal and non-legal disputes.

\section{(I) The Doctrine of "Legal" and "Non-legal" Disputes}

In 1930 - shortly after the British acceptance of the compulsory jurisdiction of the P. C. I. J. Lauterpacht asked to what disputes did the expression "legal 
disputes" or "justiciable disputes", which appeared in the official Memorandum, refer?

"Does it refer to disputes which are capable of a solution by the application of an existing rule of international law? or to disputes of minor importance as distinguished from political disputes involving grave issues? or to disputes in which the plaintiff State puts forward its demand in the term of a legal proposition? or does it refer to disputes in which the application of legal rules is likely to yield results compatible with justice and the progress of international relations?"

In this passage Lauterpacht summarised the four clear classical - although not mutually exclusive - tests for the distinction between "legal" and "non-legal" or "justiciable" and "non-justiciable" disputes.

The diversity of these tests illustrates how the distinction between those terms baffled international lawyers. However, in its simplest and earliest form, the distinction was based on the conception that certain disputes were inherently of a legal character and hence capable of settlement judicially and others were political and hence outside the scope of such settlement. The basic idea behind such conception was that arbitral or judicial settlement should be limited to disputes of minor importance while the solution of important disputes should be left to other means of peaceful settlement. Thus the Hague Conventions for the Pacific Settlement of International Disputes in 1899 and 1907, to which the first formal use of the distinction between legal and political disputes is usually attributed, arbitration or judicial settlement was regarded as the most effective and the most equitable means of settling disputes "of a legal nature and especially ... the interpretation or application of international conventions", 276 provided that the honour, vital interests, independence of the parties and the interests of the other states were not involved. Unsuccessful attempts have also been made to limit arbitral or judicial settlement to enumerated 
questions of an extremely technical character without the above reservations.

297

According to this test, and that limiting arbitral or judicial settlement to disputes "which are justiciable in their nature by reason of being susceptible of decision by the application of the principles of law", 298 or its variant that "rights" are justiciable, while "interests" are not, 299 the distinction between legal and nonlegal disputes is based on the nature of the subject matter to which the disputes refer.

Such a theory was criticised in the inter - war years on many grounds. Some intrinsic gaps in those criteria were patent to most scholars in that period. The subjective reaction to an event in determining the importance of a dispute or whether the dispute touched upon the honour or vital interests was observed. 300 It was also thought that some of these criteria were based on the conception that there are many gaps in international law, and on the limited role of international judges. 301 Furthermore, it was noted that owing to the nature of the parties entitled to appear before the International Court or International Tribunal, being political institutions, every dispute is of a mixed character. Every dispute between states is legal and economic or political. "A conflict is economic or political with respect to the interests which are involved, it is legal (or non-legal) with respect to the normative order controlling these interests." 302 The apparent contradictory practice of States by submitting disputes of high political importance to judicial settlement and withholding disputes obviously capable of decision on strictly legal line from that procedure, had its effect on abandoning those objective tests. 305

Thus the characteristic feature of most. post war tests, is that they substitute both the attitude of States for the nature of the dispute and the theory of 
"justiciability" 304 or "non-justiciability" for "legal" or "non-legal" or "political". 305 they constitute what is called the "subjective theory of justiciability". 306

To say that the most recent tests are based on the attitude of States i.e. whether they are demanding the application of the existing rules or they are basing their claims on other than legal considerations, does not mean that the objective theory of justiciability has disappeared. H J Morgenthau, for instance, believes that disputes concerning "the overall distribution of power" cannot be submitted to a court of Law. They cannot be formulated in legal terms. At the bottom of these disputes lies a "tension between the desire to preserve the existing distribution of power and the desire to overthrow it". 307 Morgenthau classifies international disputes according to their relation to tension into three types: "pure disputes". "disputes with the substance of tension" and "disputes representing tension". Justiciability is limited, in his view, to the first type of disputes. 300

Although it is generally recognised each of the guides which have been proposed for the identification of "legal" and "non-legal" is unsatisfactory, 309 the most widespread guide seems to be that proposed by $\mathrm{H}$ Kelsen. The distinction between legal and political dispute should, in his view, be based not on the nature of the subject matter to which the dispute refers but on the norms to be applied for the resolution of the dispute. "A dispute is a legal dispute if it is to be settled by the application of legal norms, that is to say, by the application of existing law. It is a political-not a legal - dispute if it is to be settled by the application of other norms - such as principles of equity, justice, and the like." 310 As to the effect of the attitude of the parties on the character of a dispute. Kelsen believes that "legal disputes are disputes in which both parties base their respective claims and their rejection 
of the other party's on positive international law, whereas political disputes are disputes in which at least one party bases its claim or its defence, not on positive international law, but on other principles or on no principles at all." 311

This test has been widely adopted - as such or with a little variation both individually $\$ 12$ and collective$1 y$. 313

Another aspect of the problem concerning the justiciability of international disputes is determination of the extent of justiciability. Taking into consideration the mixed character of almost every dispute, the question is raised as to whether every conceivable international dispute is justiciable, or are there inherent limitations on the theory of justiciability? This question has been approached in different ways, even by scholars who subscribe to the subjective theory of justiciability, according to - INTER ALIA, the different conception on the State of international law - whether it is complete or incomplete - and the degree of belief in the usefulness and efficiency of international adjudication. thus Lauterpacht observed in his seminal study of the question of justiciability that virtually all international disputes can be formulated and resolved in legal terms. States invoke justiciability, in his view, because of the desire to have the dispute resolved politically, and not because the dispute is inherently insusceptible to judicial or arbitral resolution. 314 Lauterpacht denied the theory of non-justiciability of any logic or substantive validity. characterising it as "a well meant attempt to lend the authority of a legal principle to an attitude of states inimical to any real recognition of the sovereignty of law." 315 Variations on his views were later articulated by - among others Kelsen, 316 R Higgins, 317 Jenks, 318 Hambro, 319 Brownlie $\$ 20$ and Rosenne. $\$ 21$ 
On the other hand there are many scholars who consider the above view as an idealistic view. They believe that there are some valid reasons for States' refusal to accept compulsory adjudication. The common ground between these scholars, who are sometimes lumped together as "realists" $\$ 22$ in spite of diverse opinions. is that some disputes are not amenable to judicial settlement for one reason or another. The non-justiciability is attributed sometimes to the existence of certain relations between the dispute and the tension, 325 and sometimes to the efficiency of the solution offered by the judgment. 324 Thus it is thought that judicial settlement should be limited to disputes which involve a limited number of questions "THAT ARE DISPOSITIUE of the dispute, which are complete in themselves, and which can be posed in terms of two clear alternatives." 325 Also sometimes the non-justiciability is attributed to the importance of political or economic interests involved. 326

The foregoing consideration demonstrate the complicated problems which are associated with the expression "legal disputes". The question is whether Article 36 (2) of the statute has facilitated the task of the court in dealing with that term.

\section{(II) Article 36 (2) as a Criterion}

The Court seems - as the above statements suggests 327 - to consider the limitation of "legal disputes" as an inherent limitation on its function as a Court of Law. Thus it must first of all, be satisfied that the dispute before it is a "legal dispute". The role of the court is, therefore intimately linked with the scope of that expression. The growth of its role depends on the expansion or construction of that concept. However, how can the Court satisfy itself that the dispute is not "non-legal"?

Article 36 (2) appears, it is believed, to facilitate the task of the court for determining the character 
of the dispute. For inasmuch as the Court's compulsory jurisdiction is limited to the four categories set forth in Article 36 (2), the Court is not required to determine whether the dispute is of a political or other non-legal character. The court is not equipped to measure the political impact of the dispute. 328 It is required only to satisfy itself that the dispute falls within one of those categories. In other words the expression "legal disputes" in Article 36 (2) is equivalent to saying that the dispute must be "justiciable" being encompassed by one of the four categories enumerated therein. 329 Nonlegal disputes do not fall within these categories. This is the result of an enquiry made by the most eminent authorities 330 on the court on whether the adjective "legal" is descriptive or limitive of these categories of dispute. In other words whether it requires that the dispute which falls into one of the four categories must be also a "legal dispute"? After an exhaustive examination of the drafting of Article 13 of the Covenant of the League of Nations, from which those categories were taken, and Article 36 (2) of the Statute of the P. C. I. $J$. by the Committee of Jurists in 1920, they reached the conclusion that the term "legal" is "merely a descriptive word, employed with reference to disputes which satisfy the requirements of one of the four categories". 331 It is far from being in the nature of a limitation and far from qualifying and limiting the scope of the four classes of disputes. Furthermore, it is believed that it would not be possible to consider the term "legal disputes" as a limitation unless it is estimated that categories ( $c$ ) and (d) can encompass non-legal disputes. In such a case they are not legal disputes and hence they lose their REASON $D^{*} E T R E$.

Consequently, regardless of whether the enumeration of the four categories of disputes in Article 36 (2) does constitute the provision of criticism for the distinction between "LEGAL" and "HON-LEGAL" disputes or merely indicates those classes of disputes in respect to which 
the obligation of compulsory jurisdiction is undertaken, and leaving aside the question of whether the Court's compulsory jurisdiction encompasses any international legal dispute, especially in conformity with point (6) [any question of international law], 35 it is submitted that those categories constitute a criterion - and may be the only criterion which guides the court in determining the "NUSTICIABILITY" of a dispute referred to it under Article 36 (2) $\quad 354$

Keeping in mind these considerations and the compulsory nature of the Court's jurisdiction under Article 36 (2), the generally accepted criterion of justiciability based on the attitude of states 355 seems, so far as the compulsory jurisdiction is concerned, to require a re-examination. To make a dispute non-justiciable because one party has relied exclusively on other than legal considerations - say political, economic or military. considerations - means that that party has a discretionary power to rid itself of its obligation to adjudicate inasmuch as the Court's compulsory jurisdiction is limited to legal disputes. 35 There is no doubt that the justiciability depends completely on the attitude of States in the sense that the Court's compulsory jurisdiction depends totally on the previous consent of states. However the importance of States' attitude is limited to the time at which the compulsory jurisdiction is accepted. At that time a state may limit the scope of justiciability by excluding certain disputes, which it thinks are not justiciable in relation ot other states for one reason or another, from the Court's compulsory jurisdiction. However once the jurisdiction is accepted the criterion of justiciability becomes objectively ascertainable according to both the statutory provisions relating the Court's jurisdiction and the terms of the parties' declarations. In other words the court must satisfy itself that the subject matter of the dispute falls within both the scope of Article 36 (2) read in conjunction with Article 38 (1) of the statute and the 
scope of the declarations of the parties. Another limitation on the attitude of states is that the decision upon the character of the dispute - being judiciable or notis within the Court's hand pursuant to Article 386 (6) of the statute. To say otherwise, i.e. to give States which choose not to benefit from the opportunity of making a category of dispute non-justiciable by means of a reservation a second choice to do so "is tantamount to allowing the requirement of consent to degenerate into a requirement of double consent, in the form of confirmation of consent previously given." $\$ 37$

From the aforesaid considerations it appears that the reservation of "legal disputes" is without significance. For it cannot have any effect other than that produced by the expression "legal disputes" in Article 36 (2). This conclusion is supported by states' attitude with regard to such a limitation before the court and the jurisprudence of the latter.

\section{B - "LEGAL DISPUTES" IN STATE PRACTICE}

It is not surprising, perhaps in the light of what has been said, to find that no state has ever ralied on "legal disputes" as a reservation embodied in its declaration accepting the Court's compulsory jurisdiction.

States, however, have sometimes referred to one or another of the tests discussed above in their attempts to attribute a non-legal character on the dispute. Thus in the FISHERIES MURISDICTION case Iceland challenged the Court's jurisdiction on the ground INTEP ALIA, that its UITAL IHTERESTS were involved. $3 B$ Non-justiciability in the sense that there was no legal obligation imposed by international law in regard to atmospheric tests was the feature of the Nuclear Tests Cases. 387 In its note of february 7. 1973 to the Australian Prime Minister and Foreign Minister. France alleged that its nuclear tests did not constitute a violation of any existing rule of 
international law. 340

A combination of some of the test of justiciability was made by Canada as a reason for modifying its declaration in 1970 in order to exclude the dispute concerning Arctic. It pointed out that it was not prepared to litigate "on vital issues concerning which the law is either inadequate, non-existent, irrelevant... [or] does not provide a firm basis for decision". $\$ 41$

Nevertheless, States have generally approached the question whether a concrete dispute is legal or not by means of one of the following arguments: either that the dispute is not one which falls within one of the four categories set out in Article 36 (2) of the Statute, or that the dispute is not one which can be decided by the application of international law pursuant to Article 38 (1) of the statute. 342 The first argument was advanced in the LOSINGER AND COMPANY; ELECTRICITY COMPANY OF SOFIA AND BULGARIAF AERIAL INCIDENT OF 27 JULY 1955 and HILITARY AND PARAHILITARY ACTIUATES IN AND AGAINST NICARAGUA cases. In the first the objection was joined to the merit. In the second it was regarded as not possessing the character of a preliminary objection. 345 in the third the court declined jurisdiction on other grounds.

In all these cases the argument that the dispute did not fall within the scope of paragraph 2, of Article 36 had been merged with the argument that the dispute fell within the domestic jurisdiction of the respondent.

In the HILITARY AND PARAHILITARY ACTIUITIES case professor Louis Sohn argued for the United States that it "was not the United States purpose to argue that the application must be dismissed because it presents a 'political' question, as opposed to a legal question". The United States' purpose was to demonstrate that ongoing use of unlawful force did not come within the scope of Article 36 (2). 345 However, this statement was contradicted later by the United States when it resorted to 
the 'political issue' argument. In the statement issued by the Department of State on October 7. 1985 it was pointed out that "the conflict in Central America is not a narrow legal dispute, it is an IHHEREHTLY PQLITICAL problem that is not appropriate for judicial resolution".

This argument that the dispute cannot be decided by the application of international law in accordance with Article 38 (1) was made in the RIGHT of PASSAGE OUER INDIAN TERRITORY case. It was presented in a form of a contention that there had been no arguable case for decision in accordance with Article 38 (1) of the Statute. Here also the argument had been merged with the contention that the dispute fell within domestic jurisdiction. The court found that it was not possible to pronounce upon the objection without prejudging the merits. 347 The objection was dismissed in the second phase on the ground that the existence of delicate questions of application was not sufficient for holding that the right was not amenable to judicial determination according to Article 38 (1).

The above cases show not only that states have never invoked the RESEPUATION of "legal disputes", but also they have never relied on the expression "legal disputes" of Article 36 (2) alone. They have invoked the latter together with the objection of domestic jurisdiction and with other objections. This fact has led Rosenne to the observation that states seem to adapt themselves to the tendency of the court considering the objection as a defence to the merits rather than a plea in bar. 349

\section{C - "LEGAL DISPUTES" IN THE JURISPRUDENCE OF THE COURT}

It is very fortunate that the Court has had some occasions recently in which it took a position on the most complicated point in the theory of justiciability namely, the mixed character of disputes. This character has been the main element behind the divergent views on 
justiciability. Whereas it appeared to some as a reason for the restriction of the scope of the judiciability, 350 it seemed to others a reason for broadening that scope. 35

The Court seems, however, to have taken the second view in the UHITED STATES DIPLOHATIC AHD COHSULAR STAFF IN TEHERAN and HILTARY AND PARAHILITARY ACTIUITIES IH AND AGATHST NICARAGUA cases.

In the former, the Iranian Government, which did not participate in the proceedings, contested the Court's cognisance of the case in its letters to the court of December 9. 1979 and March 16, 1980 on the ground that the dispute was non-justiciable. It was so because it only represented "a marginal and secondary aspect of an overall problem". It was not possible. Iran argued, to study the case divorced from other elements concerning. INTEP ALIA, more than 25 years of continual interference by the United States in the internal affairs of Iran, the shameless exploitation of [Iran], and numerous crimes perpetrated against the Iranian people, contrary to and in conflict with all international and humanitarian norms". 352

Iran seems thus to have taken the view that the question of hostages was inherently political or at least, evaluated in its relation to the "tension" between the two parties, it represented, according to Morganthau's theory of justiciability, only the tip of the iceberg. 55 This question involved in the conflict was not, in Iran's view, a legal one concerning the interpretation or application of treaties, but resulted from "an overall situation containing much more fundamental and more complex elements". Consequently, Iran continued:

\footnotetext{
"The Court cannot examine the American application divorced from its proper context, namely the whole political dossier of the relations betueen Iran and the United states over the last 25 years. This dossier includes. IHIER ALIA, all the crimes perpetrated in Iran by the American Government, in
} 
particular the ColP D:ETAT of 1953 stirred up and carried out by the $C$ I $A$, the overthrow of the lewful national government of Dr Mossadegh, the restoration of the Shah and of its regime which was under the control of the American interests and all the social, economic, cultural and political consequences of the direct interventions in our internal affeirs, as well as grave, flagrant and continuous violations of all international norms, committed by the United States in Iran. " $\$ 4$

Although the Court agreed with Iran that there was no doubt that the Islamic revolution of Iran was a matter "essentially and directly within the national sovereignty of Iran". 555 it rejected the Iranian arguments. Having regard to the importance of the legal principle involved, namely the interpretation or application of multilateral conventions codifying international law governing diplomatic and consular relations, the court was not able to share the view that the case of hostages would be regarded as "secondary" or "marginal" and thus outside of the Court's jurisdiction. On the contrary it was one which by its very nature fell within international jurisdiction. 356

The Court rejected also the basic idea underlying the Iranian arguments, namely that the court cannot take cognisance of the case because of the mixed character of the dispute. The court did not find any provision of the Statute or Rules which "contemplates that the court should decline to take cognisance of one aspect of a dispute namely because that dispute has other aspects. however important. 357 Accordingly the Court ordered some interim measure of protection.

In the second stage of the proceedings (the merits) the court, after noting the absence of any explanation by Iran of the reasons why the American application could not be examined separately from the "overall problem", observed that any contention intending to deprive the Court of jurisdiction only on the ground that the dispute is of a mixed character would overlook not only the nature of the relations between states; the provisions governing the Court's jurisdiction; the jurisprudence of 
the Court, but the more fundamental element namely the object for which the court is created. It said:

\begin{abstract}
"[L]egal disputes between sovereign states by their very nature are likely to occur in political contexts, and often form only one element in a wider and long-standing political dispute between the states concerned. Yet never has the view been put forward before that, because a legal dispute submitted to the Court is only one aspect of a political dispute: the Court should decline to resolve for the parties the legal questions at issue between them. Nor can any basis for such a view of the Court"s functions or jurisdiction be found in the Charter of the statute of the court; if the Court weres contrary to its settled jurisprudence, to adopt such a view, it would impose a far-reaching and unwarranted restriction upon the role of the court in the peaceful solution of international disputes." 358
\end{abstract}

This dictum, which was adopted unanimously, seems to have many implications. The first and the most obvious is the rejection of the idea that the legal aspects in a dispute of a mixed character cannot be separated from other aspects, especially the political aspects - as submitted to adjudication. 359 The second is that this dictum read in conjunction with the above mentioned statement in the Court's Order of December 15, 1979, seems to suggest that the crucial point of justiciability is the ascertainment that the dispute has fallen within the Court's jurisdiction. Once the Court finds that the dispute is within its jurisdiction it would take cognisance of the case regardless of the other aspects of the dispute and regardless of their weight. Accordingly the theoretical argument as to whether there is more law in every international dispute or more politics, seems meaningless. The court is to decide only legal elements. The third is that the dictum appears to imply that all disputes brought before the court are to be presumed justiciable. For it is unlikely that a state would not formulate its claim on legal terms whatever the implications of other non-legal elements involved in the dispute. The fourth is that the court seems to have refused to give much importance to the attitude of states - the 
respondent in the case - as a criterion for justiciability. i.e. once a party has relied on non-legal grounds the dispute would be "political" 360 For there is no doubt that the "deep rootedness and the essential character of the Islamic revolution of Iran, a revolution of a whole oppressed nation against its oppressors and their master$s^{\prime \prime} . \quad 3 \leqslant 1$ and the other aforesaid arguments advanced by Iran cannot be considered as legal grounds.

It is said that such an approach by the Court, i.e. considering only the legal elements in a dispute of a mixed character. may have the effect that the dispute will have been judicially DECIDED but not judicially SETTLED. 362 However the Court expressly pointed out that its task as the principle judicial organ of the United Nations " is to resolve any legal question that may be in issue between the parties to a dispute; and the resolution of such legal questions by the court may be an important, and sometimes decisive factor in promoting the peaceful settlement of the dispute." 363 "By this interpretation the court seems to have taken the view adopted by some treaties that the combination of more than one 364 procedure is sometimes the best method for the settlement of certain disputes. 365

In the HILITARY AHD PARANILITARY ACTIUITIES IH AND AGAINST NICARAGUA case the United States did not - as has been said 360 - argue that Nicaragua's application should hàve been dismissed because it involved a 'political' rather than 'legal' question. It argued that an allegation of an ongoing use of unlawful armed force was never contemplated by the framers of the Charter to be encompassed by Article 36 (2) of the Statute. $\$ 67$ Nevertheless, the Court reaffirmed its view expressed in the UNITED STATES DIPLOHATIC AHD COHSULAR STAFF IN TEHERAH case while examining the fifth ground of inadmissibility advanced by the United States - namely Nicaragua's failure to exhaust the regional process (the Contadora process) for the resolution of conflicts occurring in Central America. 368 
Here again the Court found UNANIHousLy that Nicaragua's application was admissible. 367 However in the second phase (merits) judge Oda observed that the Court should have declared the non-justiciability of Nicaragua's application because it did not fall within the categories of legal disputes within the meaning of Article 36 (2). He stated that even if his argument was ill founded, "it would ... have been prudent for the court, in the light of the merits of the present case, to find it a matter of judicial propriety not to proceed with a case so highly charged with issues central to the sensitive political relations of many states". 370 The determination of the appropriate procedure for settling disputes of a mixed character depends, in his view, on which elements in the dispute are prevailing. A dispute of an "overwhelmingly political character" is better to be settled by a conciliation procedure. $\$ 71$

Two points might be inferred from this case. The first is that the United States seems to have been convinced that the Court's compulsory jurisdiction cannot be barred by the mere qualification of a dispute as apolitical character. The second is that between the warning that the tendency to submit "essentially political conflicts, to adjudication ... would undermine the very foundation of jurisdiction" $\$ 72$ and bolstering up its role in the peaceful settlement by narrowing the scope of non-legal disputes, the court has chosen the latter approach. Therefore the Court's statements cited in the beginning of this section, limiting the Court's jurisdiction to "legal disputes". should be understood in the light of the cases concerning the UNITED STATES DIPLOMATIC AHD CONSULAR STAFF IN TEHERAN and HILITARY AND PARAHILITARY ACTIUITIES IN AND AGAIHST NICARAGUA:

To sum up, the reservation of "legal disputes" in some declaration cannot, if intended to, have the effect of excluding "HON-PURE LEGAL DISPUTES", for the simple reason there are no purely legal disputes in the rela- 
tions between states. Nor can it have an effect more than that of the same expression in Article 36 (2) of the statute. The attitude of states, having never invoked it as a reservation but as an inherent limitation on the Court's jurisdiction, indicates that it is an UNNECESSARY reiteration of the same term embodied in paragraph 2 of Article 36 instead of declaring simply that the jurisdiction is accepted pursuant to that paragraph. For these reasons, and having never been able to bar the court's jurisdiction, even as a statutory limitation, the reservation of "legal disputes" is harmless. 


\section{Notes}

(1) See Certain Norwegian Loans, judgment, I.C.J . Reports 1957 p.9, at 23.

(2) See E.B . Weiss, " Reciprocity and the optimal Clause ", in L.F Damrosh (ed), The International Court of Justice at a Crossroads, 1987, pp.82_105, at 84 85.

(3) See H.W.A Thirlway, " Reciprocity in the Jurisdiction of the International Court ", 15 Neth. Y.B.I.L (1984), pp.97_138, at 98.

(4) The Court has treated it under both terms, see e.g. Certain Norwegian Loans case, cited supra note 1, I.C.J Reports 1957, pp 23_24, and Right of Passage over Indian Territory Case , Preliminary objections, Judgment, I.J.C .Reports 1957, p 125, at 144_147. Writers have also used these terms interchangeably. See e.g. M.O. Hudson, The Permanent Court of International Justice 1920_1942 A Treatise, 1943, p.465, R.P.Anand, Compulsory Jurisdiction of the International of justice , 1961, pp. 159_164, T.Meron, " Israel's Acceptance of the Compulsory Jurisdiction of the International Court of Justice ", 4 Isr. L.R. (1969), pp. 307-332 at 307-318 ; R.St. Macdonald, "the New Canadian Declaration of Acceptance of the Compulsory Jurisdiction of the International Court of Justice", 8 Can.Y.B.I.L (1970), pp.3_8, at 10_15, and S. Rosenne, the Law and Practice of the International Court,2 nd. revised ed., 1985, pp. 384_88, and 304_307. But Comp. D.W.Greig, International Law , 2 nd.ed., 1976,. pp 684_50.

(5) See e.g E.Hambro, " The Jurisdiction of the International Court of Justice ", 76(I) R.C.A.D.I. (1950) , pp. 123_215 at 184_185 " Some Observations on the Compulsory Jurisdiction of the International Court ", 25 B.Y.B.I.L. (1948), pp.133_157, at 136_137, and H.Lauterpacht, " The British Reservations to the Optimal CLause", Economica, 1930, pp137_172, at 139.

(6) E.Hambro, Some Observations.....lbid., p.136.

(7) These are the declarations of Barbados, Botswana, Canada, Egypt, India, Kenya, Malta, Mauritius, New Zealand, Somalia, Sudan, Switzerland, and the United Kingdom. See I.C.J.Y.B. 1986_1987, pp.59_91.

(8) The Declarations of Democratic Kampuchea, Denmark, Finland, Liberia, Luxembourg, Mexico, The Netherlands, Nigeria, Norway, Togo, Dominican Republic, Panama, and Uruguay (emphasis added).

(9) These are the declarations of Colombia, Malawi, Japan, Senegal, and Uganda.

(10) These are the declarations Australia, Austria, Belgium, Costa Rica, El

Salvador, Gambia, Honduras, Liechtenstein, Pakistan, Philippines, Sweden, and Switzerland.

(11) The declaration of Nicaragua

(12) The declaration of Haiti.

(13) The Portuguese declaration.

(14) Emphasis added.

(15) See e.g.G. Enriques, " L' Acceptation sans Réciprocité de La Juridiction Obligatoire de la Cour Internationale de Justice, " 13 R.D.I.L.C, (1932), pp.834_60; E.Hambro, Some Observations ..., Supra note 5, pp.136_137, and 
J.H.W Verzil, " Cour Internationale de Justice_ L' Affaire relative a Certain Emputs Norwegeans ", 4 Ned.T.I.R. (1957), pp 373_406, at 381, and " the System of the Optimal Clause ", 1 Inter'L Rel., (1959), pp.585_610, at $587 \_89$.

(16) Ibid; pp.837_838

(17) Ibid; p.835

(18) Haiti and Lithuania, ibid.

(19) Ibid; p.858. A.Bramson seems to share the same view. He thinks that the inclusion of reciprocity in the declarations of acceptance does not provide any other guaranties than those derived from paragraph 2 of Art. 36. It is, therefore, superfluous" que la mise en relief de la condition de réciprocité dans l'Article 36 (3) du Statut." , Problémes de competence dans le Statut et la Jurisprudence de la Cour Internationale de Justice ", 8 Annales U.M.C.S.L. (1961),pp 101_136, at 110.

(20) Supra note 15, pp.839_840.

(21) Some Observations ..., supra note 5.pp.136_137, and the jurisdiction ..., supra note 5, pp.184_185.

(22) C.I.J. ..., supra note 15, p. 381 . In his interpretation or the relation between paragraphs 2 and 3 of the Article 36, Verzijl observes : "The fact alone that no such reference to reciprocity occurs in the declaration would not seem to be conclusive in the light of the text of paragraph 2 which assumes reciprocity as a natural condition, but on the other hand, there is no cogent reason for considering the condition of reciprocity as mandatory. And when such an unconditional acceptance has once been intended, no further denial of its true meaning should be permitted. What one might say, however, is that in case of contestation by a declarant state as the respondant Party, renouncement of reciprocity must not be presumed, but established by conclusive evidence", The system ..., supra note 15, p.589.

(23) See the Records of the First Assembly (1920), Committee 1, p.553. See also, C.H.M. Waldock, " Decline of the Optional Clause ", 32 B.Y.B.I.L. 1955_56, pp. 244_287, at 254_61; H.W.A. Thirlway, supra note 3, pp.103_108; J.G.Merrills, " the Optional Clause Today ", 50 B.Y.B.I.L. (1979), pp87_116, at 88_89, and the Separate opinion of Judge Jiménez De Aréchaga in Continental Shelf case ( Lybian Arab Jamahiria/Malta), Application for the Permission to intervene, Judgment, I.C.J Reports 1984, p.3 at 61_62.

(24) See C.H.M . Waldock. Ibid., p.255.

(25) League of Nations, P.C.I.J., Document Concerning the Actions Taken by the Council of the League of Nations under Article 14 of the Covenant and the Adoption by the Assembly of the Statute of the P.C.I.J. p. 107.

(26) Ibid.

(27) P.C.I.J. Series D, No.6, p.37.

(28) Supra note4, p.465.

(29) Ibid.

(30) Supra note 23, pp. 255-255.

(31) See.e.g. H.W.Briggs, "Reservations to the Acceptance of Compulsory 
Jurisdiction of the International Court of Justice ", 93(I) R.D.A.D.I (1958), pp.229_263, 267; T.Minagawa, "Operation of reciprocity Under the Optional Clause ", Jap. A.I.L (1960), pp.32_41, at 36; R.P. Anand, supra note 4, p.159; C.Vulcan, " La Clause Facultative ", 18 Acts S.J.G (1947_1948), pp.30_55, at 39_40; B.Maus, Les Réserves dans les Declarations d'acceptation de la juridiction Obligatoire de la Cour Internationale de Justice", Thesis (Université de Genève, Faculté de Droit), 1959 at 97_101; and P.Higgins, "British Acceptance of Compulsory Arbitration under the Optional Clause, and its Implication.", , 1929, p.6. But comp.H. Kelsen, " The Law of the United Nations ", 1950, pp.526_527.

(32) See H.Briggs, Ibid., p.242_243, C.H.M. Waldock, supra note 23, pp.255_256; R.P Anand, supra note 4, p.161, and R.St.J.Macdonald, supra note 4, p.12.

(33) C.H.M. Waldock, supra note 23, p.256 (emphasis original)

(34) See J.B.Scott (ed.), Proceedings of the Hague Peace Conferences, Acts and Documents, the Conference of 1907, 1920, Vol.2, p.136 seg.,898_901. See also C.H.M Waldock, supra note 23, p.257, and E.B.Weiss, supra note 2, p.83.

(35) Acts and documents, Ibid., p.551_52.

(36) See section 2 of Chapter 1 Supra. See also H.A.Thirlway, Supra note 2, pp. 104_107, C.H.M. Waldock, supra note 23, p.257 and E.B.Weiss, supra note 2 p.83.

(37) See the declarations of States Listed in note 8 supra.

(38) See e.g. Certain Norwegian Loans case , Judgment, I.C.J Reports 1957, p. 9 at 144 .

(39) See B.Maus, supra note 31, p.97, and T.Meron, supra note 4, p.318. C.G.Tenekides argues that the application of reciprocity as provided for in Article.39 (3) of the general Act of 1928 could be generalized as a general rule of arbitration Law, " Les Actes Compromissoires Concurents." 17 R.D.I.L.C. 1936, pp. 719_740, at 722.

(40) Phosphates in Morocco, Judgment, 1938, P.C.I.J., SEries A/B, No.74,p.10, at 22.( emphasis added).

(41) Electricity Company of Sofia and Bulgaria, Judgment, 1939, P.C.I.J, Series A/B , No77, p.64, at 81. (emphasis added).

(42) Anglo Iranian Oil Co., Judgement, I.C.J Reports 1952, p.93, at 103

(43) Certain Norwegian Loans, Judgement, I.C.j Reports, 1957, p.9, at 24 (emphasis added)

(44) Ibid.

(45) Ibid., p.23.

(46) H.W. Briggs, supra note 31, pp.255-256.

(47) Ibid., p.256. In his Dissenting Opinion in this case Judge Basdevant referred to reciprocity as embodied in paragraph 3 . This reference has been interpreted a taken unintentionally from the judgement.

(48) Military and Paramilitary Activities in and against Nicaragua case (Nicaragua V. United States of America), Jurisdiction and Admissibility Judgement, I.C.J. Reports 1984, p.392, at 420.( emphasis added).

(49) see pp.214-215 and 217 above. 
(50) The declaration of Nicaragua I.C.J.Y.B. 1986-87, p.81.

(51) see G. Enriques, Supra note 15,p.835; E.Hambro, The Jurisdiction ..., supra note 5, p.184_185 and Some Observations ..., supra note 15, pp.136_137, and J.H.W.Verzijl, C.I.J ..., supra note 15, p.381.

(52) See 213 seq.above.

(53) I.F.I.Shihata, The Power of the International Court to Determine its own Jurisdiction - Competence, 1965, p.150.

(54) See R.St.J.Macdonald, supra note 3, p.14.

(55) Some observations ..., supra note 5, p.136.

(56) See pp.233 seq above.

(57) See S. Rosenne, supra note 4, p.304.

(58) See B.Maus, supra note 31, p.98.

(59) Supra note 15, p.842. S.Glichitch seems to go further as to consider a declaration providing for that it is made " According to the terms of Article 36 (2)" as made without reciprocity. Consequently, he thinks that the declarations of Liechtenstien of 1939 and that of Monaco of 1937 were without reciprocity, la Jurisdiction Obligatoire de la Cour Premanente de Justice Internationale ", 1940, pp.85_86.

(60) Ibid., pp.840 Seg.

(61) lbid.,p.857.

(62) Ibid., pp.852_54, 857. For Comments on Enriques' view see H.W.A.Thirlway, supra note3, pp.107_108, E.Decaux, " La Réciprocité en Droit International ", 1980, pp.81_83, and H.W.Briggs, supra note 31 , pp.240_241.

(63) See M.O.Hudson, supra note 4, p.451.

(64) See e.g. The Right of Passage over Indian Territory case ( Preliminary Objections), cited supra note 4, p.145, Military and Paramilitary Activities in and against Nicaragua case (Jurisdiction and Admissibility) cited supra note 47, p.404.

(65) Supra note 4, pp.648_50.

(66) Ibid., p.649. (emphasis original).

(67) Ibid.

(68) Ibid.

(69) P.C.I.J. Series A/B. No.77, p.81.

(70) Supra note 4, pp.648_649.

(71) I.C.J.Pleadings, Right of Passage over Indian Territory, Vol.IV, 1960, p.23.

(72) Ibid., p.40.

(73) Ibid. But comp. his article cited supra note 23, p.255.

(74) Right of Passage over Indian Territory, (Preliminary objections), cited supra note 4, pp.144_147.

(75) Supra note 4, p.650.

(76) See.T.Meron, supra note4, p.318.

(77) See A.P. Fachiri, The Premanent Court of International Justice 2nd, ed, 1932, pp. 96_97; R.P.Anand, supra note 4, p.158; H. W.Briggs, supra note 31, pp.256, 266_267, and S.Rosenne, "The International Court of Justice" , 
1957, p.316.

(78) See S.Rosenne, the Law ..., supra note 4, p.387.

(79) Phosphates in Morocco,Judgment, 1938, P.C.I.J, series A/B, No 74, p.10.

(80) P.C.I.J. series D, No. 6, p.45.

(81) P.C.I.J. series A/B. No. 74., p.22.

(82) C.H.M.Waldock, supra note 23, p.259. see also, H.W. Briggs, supra note 31 , p.250.

(83) Electricity Company of Sofia and Bulgaria, Judgment, 1939, P.C.I.J, series A/B, No77,p. 64, at 81 .

(84) See the opinion of Judges Anzilotty; Urrutia; Van Eysinga; and Judge ad Hoc Papazoff ibid., pp.87_89; 103; 109, and 146.

(85) Anglo_Iranian Oil Co, Judgment, I.C.J. Reports 1952, p.93 at 98.

(86) See 104 .U.N.I.T.S. p.492.

(87) Supra note 85, p.98. The President of the Court, Sir Arnold McNair, expressed the opinion that "... It should be noted that the machinery provided by that paragraph [2 of Art. 36] is that of 'contracting_in' not of 'contracting_out'. A State being free either to make a declaration or not, is entitled, if it decides to make one, to limit the scope of its declaration in any way it chooses, subject always to reciprocity. Another State seeking to find the jurisdiction of the court upon it must show that the declaration of both States concur in comprising the dispute in question within their scope.",Ibid., 116.

(88) Cited supra note1.

(89) Ibid, p.23.

(90) Ibid.

(91) Ibid.

(92) Ibid.

(93) Ibid., pp.21, 22.

(94) Ibid., p.23.

(95) Ibid., p.24.

(96) That is, the reservation of the right to exclude from the scope of the declaration, at any time, during its validity, any given category or categories of disputes, by notifying the Secretary_General of the United Nations see section 2 of chapter 2 supra.

(97) See the parties arguments in this case I.C.J Pleadings, the Right of Passage over Indian Territory ( Portugal v. India ), vol. IV, pp23, 40_43, 102_104, 162_165, 202_211, and the Court's Judgment in this case (Preliminary Objections), cited supra note 4, pp.143_148.

(98) I.C.J. Pleadings, ibid., pp.102 _103.

(99) See Chapter 2 supra pp.118-119 and 133 seq.

(100) I.C.J. Reports 1957, supra note 4, p.145.

(101) Ibid., p.144.

(102) Aerial Incident of 27 July 1955 (Israel v. Bulgaria), Judgment, I.C.J

Reports 1959, p.127.

(103) Ibid., p.133.

(104) Ibid. 
(105) lbid., p.146.

(106) See p 236 seq below. For extensive discussion on reciprocity in the juriprudence of the Court see esp. E.Decaux, supra note 62, 89_109 and. H.W.A.Thirlaway supra note 3, 108_133.

It is to be noted that reciprocity was applied by the Court also in the Aegean Sea Continental Shelf case, which was based on the 1928 General Act for the Pacific Settlement of International Disputes. The Court dismissed the case on the ground that the dispute was excluded from its jurisdiction because of the Greek reservation of territorial disputes, Aegean Sea Continental Shelf, Judgment, I.C.J. Reports 1978, p.3. For further details see H.W.A.Thirlway, ibid, pp.130_133.

(107) See section I, Chapter II supra, p. 127 seq.

(108) Cited supra note 23.

(109) Ibid., p.260.

(110) See the opinions of Judges Anzilotti; Urrutia; Van Eysinga, and Judge ad hoc Papazoff, P.C.I.J., series A/B, No.77, pp.87, 89; 103; 109; and 146 respectively.

(111) See chapter 2 supra pp.77-78.

(112) P.C.I.J Series A/B, No.77, pp.99 and 146 respectively.

(113) Ibid., p.87.

(114) Supra note 23, pp.278_279.

(115) I.C.J. Pleadings, supra note 97, vol.4, p.42.

(116) Military and Paramilitary Activities in and Against Nicaragua ( jurisdiction and Admissibility), cited supra note 47, p.419. For further details see section1, chapter II supra, p.127. See also E.B.Weiss, supra note 2, pp. 86_97.

(117) I.C.J. Pleadings, supra note 97. vol.4, p.47, see also the argument of Mr.Stevald, ibid.,p.204.

(118) Rights of Passage ( Preliminary objections ), cited supra note 4, p.146.

(119) ibid., p.143.

(120) See section 1, chapter II supra, p.127. See also E.B.Weiss, supra note 2, pp.93_94.

(121) Interhandel, Judgment, I.C.J.Reports 1959, p.6, at 23.

(122) Military and Paramilitary Activities ..., ( jurisdiction and Admissibility), cited supra note 47, p.419.

(122b) See C.H.M.Wakldock, " The Plea of Domestic Jurisdiction before the International Legal Tribunals ", 31 B.Y.B.I.L. (1954), pp.96_142, at 100, 104. L.Preuss, "Article 2, Paragraph 7, of the Charter of the United Nations and Matters of Domestic Jurisdiction ", 74 (I) R.C.A.D.I. (1949), 553_653, at 558_559, and A.Verdross, " La Compétence Nationale ' dans le Cadre de l'Organisation des Nations Unies et L'Independence des Etats", 36 R.G.D.I.P.(1968), pp.314_315. 
(123) See L. Preuss, ibid., at 559-560. This was explained by the P.C.I.J. in its Advisory Opinion on the Nationality Decrees Issued in Tunis and Morocco as follows : " the reservations generally made in arbitration treaties are not to be found in this Article[ Art. 15 of the Covenant]. Having regard to this very wide competence processed by the League of Nations, the Covenant contains an express reservation protecting the independence of States; this reservation is to be found in paragraph 8 of Article 15", Advisory Opinion, 1923, P.C.I.J., Series B, No. 4, at 24.

(124) Article 15 (8) of the covenant: " If the dispute between the parties is claimed by one of them, and is found by the council, to arise out of a matter which by international law is is solely within the domestic jurisdiction of the party, and the council shall so report and shall make no recommendations to its settlement".

(125) Pollux, " Domestic jurisdiction.", 17 Acta S.T.J.G. (1946), pp.13_35, at 13.

(126) For the third formula, i.e, the subjective formula of domestic jurisdiction see section1 chapter 6 intra.

(127) For a discussion of Article 15 (8) and how it was drafted see especially J.L.Brierly, "matters of Domestic Jurisdiction ", 6 B.Y.B.I.L(1925) pp 8_19, J.M.Howell, " Domestic jurisdiction ", in R.R.Wilson (ed.), International Law Standard and Commonwealth Developments, 1966, pp.138_146, and L.Preuss, supra note 122 , at 562 _568.

(128) Waldock observed that " There is no indication in the travaux preparatoires of the Covenant that the question of a reserved domain was ever discussed in connexion with arbitration or judicial settlement under Articles12_14, The plea ..., supra note 122, at 104. See also L.Gross, " The Charter of the united Nations and the Lodge Reservations,", 41 A.J.I.L (1947), pp.531_554, at 538.

(129) M.O.Hudson's Treatise, supra note 4, p.470; R.P.Anand, Compulsory ..., supra note 4, p.190, and B.Maus, supra note 31, pp.111_112.

(130) P.C.I.J, series D, No.6, pp.45, 54, 50, 48, 47, and 46 respectively.

(131) Ibid, pp.52, 53, 53, 54, and Series E, No.13, p.277, Series E.No.15, p.215, and 216 respectively.

(132) H.Lauterpacht, The British Reservations ..., supra note 5, p.150.

(133) Cmd 2458, No.8. The relevant passage is quoted by Lauterpacht, ibid., p.150_151.

(134) I.C.J.Y.B., 1985_1986, pp.60_92.

(135) P.C.I.J., Series B, No.4, pp.7 seg.

(136) Ibid., pp.23_24.

(137) lbid., P.24.

(138) Q.Wright observes that the phrase "the development of international relations " should be understood as " as the development of legal relations of states through treaties or otherwise, not the factual relations of states in political, economic, cultural, or other aspects." " Domestic Jurisdiction as a 
limit on international and supra national action." 56 Northw, U.L.R.(1961), pp.11_40 at 16. But Comp.J.M.Howell." the Commonwealth and the Concept of Domestic Jurisdiction," 5.Can Y.B.I.L.(1967), pp.14_44, at 24_25.

(139) See Sir Gerald Fitzmaurice, " the Law and the Procedure of the International Court of Justice, 1954_1959 : General Principles and Sources of International law, 35.B.Y.B.I.L (1959), pp.183_231, at 197.

(140) Thus three_zone theory, that there are : 1_matters absolutely governed by international law, 2_matters essentially within domestic jurisdiction by the intrinsic nature, and 3 an intermediate zone of matters, is generally rejected in the doctrine. H.W.Briggs, for example, describes it as a "well known, but unconvincing", Reservations ..., supra note 31, at 319. This theory was Strongly Criticized before the Institut de Droit International in 1954, see 45 (II) Annuaire I.D.I.(1954), pp.140. 143_144. As it is well known, the theory has been advocated by H.Rolin, (Ibid., pp.138_140; " the International Court of Justice and Domestic Jurisdiction ", 8 Inter'l .0.(1954), pp.36_44, and see his argument before the I.C.J as an advocate for the Iranian Government in the Anglo_Iranian Oil Co. case, I.C.J Pleadings _ ( United Kingdom V Iran ), pp.469_70, 619_21); A.Verdross, " The Plea of Domestic Jurisdiction before International Tribunals and Political Organs of the United Nations", 28 Z.A.Ö.R.(1968), pp.33_40, La Competence ..., supra note 122, at 323, and his observations in 44 (I) Annuaire I.D.I.(1952), pp.176_180.

(141) 45 (II) Annuaire I.D.I (1954), pp.149_150.

(142) See Sir G.Fitzmaurice, " The Law and Procedure of the International Court of Justice : International Organisations and Tribunals, " 29 B.Y.B.I.L (1952), pp.1_62, at 36, and A.N.Farmanfarma, The Declarations of the Members Accepting The Compulsory Jurisdiction of the International Court of Justice, Thesis (Université de Genéve, Faculté de Droit ), 1952, pp.112_113.

(143) A.N.Farmanfarma, Ibid.,p.113.

(144) C.H.M.Waldock, the Plea ..., supra note 122, at 112, at 109.

(145) P.C.I.J., Series B, No.4, p.26.

(146) 45 (II) Annaire I.D.I (1954) pp.150, 299.

(147) H.Lauterpacht, the British Reservations ..., supra note 5, at 153 note 33.

(148) Sir G.Fitzmaurice, General Principles ..., supra note 139, p.197.

(149) Ibid., pp.197_198. Most of the legal definitions are based generally on one of these tests. See .e.g. C.H.M.Waldock, the Plea ..., supra note 122 at 96_97; J.S.Woo, " the World Court and Domestic Jurisdiction ", 10 K.J.I.L (1965), pp.49_64 , at 56_57; T.Minagawa, " the Principle of Domestic Jurisdiction and the International Court of Justice ", 8, Hito.J.I.L.P.(1979), pp.9_27, at 9; E.Grisel, Les Exceptions d'Incompetence et d'Irrecevabilité dans la procedure de la cour internationale de justice, 1968, p.99; L.Preuss, Article 2 ..., supra note 122, at p.568; I.Brownlie, Principles of Public International Law, 3 rd.ed, 1982, p.291_292, and Q.Wright, supra note 138, pp.15, 18, 24, 37. When the political elements of the concept of domestic jurisdiction have been taken into consideration the legal definition appeared to some commentators as 
insufficient. See, especially M.S.Rajan, " The Question of Defining ' Domestic Jurisdiction', 1 Indian J.I.S (1960), pp.248_279; A.Verdross, the Plea of Domestic Jurisdiction, supra note 140 , at 33 , and J.M.Howell, the Commonwealth and the Concept of Domestic Jurisdiction, supra note 138, pp.15_16.

(150) C.H.M.Waldock, the Plea ..., Supra note 122, p.98.

(151) H.Lauterpacht, the British Reservations ..., supra note 5, pp.148_149.

(152) Ibid., pp.148_155.

(153) Memorandum on the Signature by His Majesty's Government in the United Kingdom of the Optimal Clause of the Statute of the Permanent Court of International Justice." Misc.n.12 (1929) Cmd.3452, p.12.

(154) H.W.Briggs, Reservations ..., supra note 31, pp.327_328.

(155) See C.H.M.Waldock, the Plea ..., supra note 122, at 107, and M.O.Hudson's Treatise supra note 4, pp.681_703.

(156) See Waldock, Ibid.,p.131.

(157) Losinger, order of 27 June 1936, P.C.I.J, Series A/B, No.67,p.15, at 15, and P.C.I.J. Series C, No78, The Lisinger\&Co case, p.124 .

(158) Cited supra note 41.

(159) Ibid., pp.82_83. See H.W.Briggs, Reservations ..., supra note 31, at 316_317, and J.S.Woo, supra note 149, at 64 .

(160) Cited supra note 4.

(161) Ibid., p.133, In his oral argument Sir Frank Soskice (Council for India) referred to Hudson's view that the insertion of the reservation make no difference to the effect of the declaration. I.C.J. Pleadings, case concerning Right of Passage over Indian Territory (Portugal V India), Vol.IV,p.66. He also stressed that it was " for the Court rather to Know and lay down the precise limits of the reserved domain.", Ibid., p.67.

(162) Cited supra note 120.

(163) Ibid., p.11.

(164) See Switzerland's Observations (20.IX.1958), I.C.J.Pleadings, Interhandel case (Switzerland V United States of America) 1959, p.413.

(165) In his dissenting opinion in the Interhandel case Judge Lauterpacht observed that what could be inferred form the court's examination of part (b) of the United States Fourth objection was that the court considered a reservation of this kind as inherent in every declaration. I.C.J Reports 1959, p.122, Commenting on this opinion, Briggs would have preferred the conclusion that "It is implicit in the Statute." " Interhandel : The Court's Judgment of March 21, 1959, on the Preliminary Objections of the United States." 53 A.J.I.L. (159), pp.547_563, at 556 .

(166) T.Minagawa, the Principle ..., note 120 at 16_17; J.S.Bains believes that the reservation is inserted abundanti cautela and hence legally superfluous and redundant: " Domestic Jurisdiction of the World Court.", 5.Indian J.I.L (1965) pp.464_492, at 484. In his seventh edition of Oppenheim, H.Lauterpacht 
characterized the reservation as " Scientifically unsound and unnecessary inasmuch as the position of the defendant State in these matters is fully safeguarded by international law ", L.F.Oppenheim, International Law, 7th. ed.(1952), Vol.2, p.62. This view is shared by J.H.W.Verzijl, "The Competence of the International Court of Justice", 2 Int'l.Rel.(1954), pp.39-49, at 47, and the system ..., supra note 15 , at 596 . For views considering the reservation as unnecessary see e.g. Ch.Rousseau, Droit International Public, Vol.5, 1983, p.456; S.Rosenne, the law..., supra note 4, p.394; A.N.Farmanfarma, supra note 142 , at $93 ; \mathrm{K}$. Yokota, "the Compulsory Jurisdiction of the International Court of Justice", International Law Association, Reports of the 51 st Conference, Tokyo, 1964, pp.8_19, J.G.Merrills, "the Optional Clause Today " 50 B.Y.I.L. (1979), pp.87_116, and R.P.Anand, Compulsory ..., supra note 4, p.190.

(167) See R.St.J.Macdonald, supra note 4, p.32. Comp. J.S.Bains supra note 166, 484_485 and S.Prasasvinitchai, La Clause Facultative de Juridiction Obligatoire de la Cour Internationale de Justice, Thesis (Université de Paris, Faculté de Droit et des Sciences Economiques,1962, at 99_100.

(168) J.H.W.Vezijl, The system ..., supra note 15, p.596 and sir G.Fitzmaurice, General Principles ..., supra note 139, p.200. Bearing in mind this distinction, Judge H.Lauterpacht observed in his dissenting opinion in the Interhandel case that part (b) of the fourth preliminary objection of the U.S.A. " must properly be regarded as defense on the merits, as being a substantive plea in the sense that there is no rule of Internatioanl Law limiting the freedom of action of the United States on the subject." I.C.J.Reports 1959, p.122.

(169) The plea ..., supra note 122, p.115.

(170) Article 2, paragraph 7, provides : " Nothing in the present character shall authorise the United Nations to intervene in matters which are essentially within the domestic jurisdiction of any state or shall require the Members to submit such matters to settlement under the present charter."

(171) I.C.J.Y.B., 1985_86,pp.61_92. It is to be noted that the declaration of Mexico does not contain the world "essentially". It excludes matters which, in its opinion, are within its domestic jurisdiction, ibid., 80.

(172) The declaration of Botswana is relevant only to the extent that it uses the term essentially, otherwise it is identical to the covenant model. The declaration excludes " matters, which, by international law, are essentially within the domestic jurisdiction of the Republic of Botswana." Ibid.,p.63.

(173) For the subjective form see section 1, chapter 6 infra.

(174) I.C.J. Pleading, Anglo-Iranian Oil Co.case (United Kingdom v.Iran ),pp.292 $-293,465$ sep. , 621 seq.

(175) See C.H.M. Wadock, the plea ...supra note 122, p.125.

(176) I.C.J. pleadings, Anglo -Iranian Oil Co.case, pp.156-163, 327-331, 350 $-357,375-379,561-581,654-564$.

(177) These arguments were put forward by $\mathrm{H}$. Rolin in the Anglo-Iranian Oil Co 
case as an advocate for Iran, and he developed them later in his article "The international court of Justice and domestic jurisdiction ",supra note 140,pp. 36 -44 .

(178) The Law ... supra note 4, pp.65-68.

(179) Supra note 31,p.49.

(180) See A. Bramson, supra note 19, p.112; C.H. Vignes,"Observations sur la nouvelle Declaration Francaise D'acceptation de la juridiction Obligatoire de la cour internationale de justice", 31 R.G.D.I.P.(1960), pp. $52-74$, at $66 ; H$. Kelsen, "Limitation $s$ on the functions of the United nations "55 Y.L.J. (194546),pp. 997-1015, at 1000; Q.Wright , supra note 138, p. 31; A.W.Rudzinski,"Domestic Jurisdiction in the United Nations Practice", 9 India Q.(1953), pp.313-352, at 329-330, and A.A.C. Trindade,"The Domestic Jurisdiction of States in the Practice of the United Nations and Regional Organizations ", 25 I.C.L.Q. (1976), pp.715,-765 , 750.

(181) Cited supra note 102 , p. 145 .

(182) The plea ... supra note 122 , pp.122 -123.

(183) lbid ,pp. $123-124$. Waldock's view has been adopted by many writers . See e.g. T. Mjnagawa ,the principle ... supra note 150, pp.13 -14 ;I.F.l. Shihata , supra note 53 , pp.231 -232 ; H.W. Briggs ,Reservations ... Supra note 31 , pp. $320-321$, and J.S. Woo, supra note 149 pp.59, 64.

(184) For the differences between articles 15(8)and 2(7) See J.S.Woo, Ibid . pp.59-60; H.Rolin, supra note 140 ,p.40 ; A.W.Rudzinski, supra note 18, pp.314-315, and L. Gross, supra note 128 pp. $539-542$.

(185) The declaration of India ,I.C.J.Y.B.1985-86, p. 72. Comp.The declaration of Israel of 1956 ,Ibid.,1984 -85 , p. 79.

(186) For the meaning of the term "intervention" see A.W. Rudzinski ,supra note 180 ,pp.330-332 ; A .Verdross , La compétence ... șupra note 122 , p.323 ; Q.Wright , supra note 138,pp. $29-31$; Pollux , supra note 125 , pp. $26-29$; L.Preuss , Article 2 ... , supra note 122 ,pp.579 -587, and H.Louterpatcht ,"The International Protection of Human Rights " ,70(II) R.C.A. D.I.(1947), pp. 18 23.

(187) I.C.J. Pleading, Anglo-Iranian Oil Co case , p. 572 . Comp.L.Gross , supra note 128, p.542;H.Rolin supra note 140,p. 39 and B .Maus , supra note 31 ,p.46.

(188) L.Preuss attributes this omission to an anti legal sentiment which was prevalent among certain leading delegations at that conference, supra note 122 , p598.

(189) U.N.C.I.O. Doc .1019 1/1/42, June 16,1945, vol. 6 ,p.508.

(190) Charter of the United Nations : Report of the president on the results of the San Francisco conference by the chairman of the United States Delegation, the Secretary of the State, June 26,1945 ,Department of State Publication 2349,conference series 71, 1945,pp.44-45.

(191) U.N.C.I.O., Vol 6 , p.511. 
(192) Ibid .,512.

(193) C.H.M. Waldock, the plea ... supra note 122 ,p.127 and L.Gross , supra note 140 ,p.540.

(194) A.N. Farmanfarma supra note 142 ,p.116 .For criticism of dulles 'explanation see esp. H. Lauterpatch ; International protection ... supra note 186 ,p. 22 and Pollux, supra note 125, pp.25 -26.

(195) See S.Prasasvinitachai, supra note 167, pp.89-90 and B Maus, supra note 31, p.47.

(196) For discussion on this view see T.Minagawa, The Principle ... supra note ,142, p.10.

(197) Pollux ,supra note 125, p.25.

(198) Sir G.Fitzmaurice , general principles ... supra note 139, pp.36-37. See also L.Preuss, article 2 ..., supra note 122, p.627. For the theory of international concern or repercussions, see L.Preuss , Ibid ., pp.627 -30, $636-42$; Q.Wright , supra note 138, pp., $20,21,36$; J.M.Howell ,the commonwealth ... supra note 138, p.17, and Domistic Jurisdiction ... supra note 127 , pp.151-157; 164 ; N.Benwich ,"The limits of the Domistic Jurisdiction of the State", A.S.I.L.(1945), pp.59-89, at 61 , and J.S.Watson,"Autointerpretations,competence and the continuing Validity of article 2(7) of the charter ",71 A.J.I.L. (1977), pp.60-83, at 78.

(199) Cited supra note 123, p. 23.

(200) See the Observations of M. Spiropoulos, 45(II) Annaire I.D.I. (1954), p.126 and the final resolution, lbid. , p.299.

(201) See Q.Wright, supra note 138 ,p.36 and C.H.M. Waldock, the plea ... supra note 122, p.127.

(202) Pollux, supra note, 125, p.26. See also C.H.M. Waldock, ibid., p.129; sir G.Fitzmaurice, general principles ..., supra note 139, p. 198 and International Organization ..., supra note 42, pp.36_37, and L.Preuss, Article 2 ..., supra note 122, p.627.

(203) See B.Mauss, supra note 31, p.47; C.Vulcan, supra note 31, pp.49_50; S.Prasasvinitchai, supra note 167, p.98_99, and A.N.Farmanfarma, supra note 142, p.117.

(204) See p.247 above.

(205) The Belgium proposition to add the words " in the judgment of the organisation " was defeated by 27 votes to 7 U.N.C.I.O. Doc.1019, I/I/42, Vol.6.p.512.

(206) Limitations ..., note 180, p.1000 note 5.

(207) H.Lauterpacht, the British Reservations ..., supra note 5, p.154.

(208) See C.H.M.Waldock, the Plea .., supra note 122, pp.106_107.

(209) Q.Wright, supra 138, pp.16_17, and H.Lauterpacht, the British Reservations ..., supra note $5, \mathrm{p} .145$.

(210) The Practice of the political organs is relied on in support of that view. In 
fact it cannot be denied that the U.N organs have interpreted Article 2(7) as vesting them with the power to decide on the nature of the matter. However this practice seemed to some ultra vires on the part of these organs. See esp.J.S.Watson, supra note 198, pp..60_83, and L.Gross, supra note 128, pp.540_542.

(211) See e.g.C.Vulcan, supra note 31, p.49_50 and L.Gross, Ibid., p.542.

(212) U.N.C.I.O. Doc.109, I/I/42, Vol.6,512 .

(213) Ibid., pp.507_508, 511_512. See also H. Lauterpacht, the International protection ..., supra note 186, pp.24_25, 27_28; L. Press, Article 2 ..., supra note 122, pp.575-579,599-604; A.W.Rudzinski, supra note 180, pp.333_341; Pollux, supra note 125, pp.21_25, and " A Commentary on the charter of the United Nations signed at San Fransisco Conference on the 26th June, 1945, British Parliamentary Paper, Misc. No.9 (1945), Cmd: 6666, p.6.

(214) L.Preuss, and A.W.Rudzinski, ibid., 602, and 333 respectively.

(215) See.e.g H. Kelsen, Limitations ..., supra note 180, p.999 and Principles of International Law, 2nd ed, Revised and edited by R.W.Tucker, 1966, p.299; L.Gross, supra note 128, p.540; H.Rolin, supra note 140,pp.42_43, and Judge Krylon's Diss. Op in Peace Treaties with Bulgaria, Hungaria, and Romania, First Phase, Advisory Opinion, I.C.J. reports 1950, p.65, at 112.

(216) H.Rolin, Ibid.

(217) Supra note 215, p.70.

(218) Ibid., pp.70_71.

(219) See T.Minagawa, The Principles of Domestic ..., supra note 150, p.18.

(220) Ibid., p.19. See also C.H.M.Waldock, the plea ..., supra note 122, p.130.

(221) Supra note 125, p.24. This is in fact the widely held view. See e.g. C.H.M.Waldock, the Plea ..., supra note 122, p.31; Sir G. Fitzmaurice, General Principles ...,supra note 139, pp.198_200 and International Organisations ..., supra note 142, pp.35_36; T.Miningawa, The Principles of Domestic ..., supra note 150, p.19; D.J.L. Davies, " Domestic Jurisdiction : A Limitation on International Law ", 32 G.S.(1947),pp.60_67, and M.Dubisson, La Cour Interationale de Justice, 1964, p.183.

(222) It might be asked whether the Kenyan declaration intended to have that effect, because it excludes " disputes with regard to matters which by general rules of International Law fall exclusively within " its jurisdiction. I.C.J.Y.B. 1985_1986, p.74 (emphasis added)

(223) For the Practice of the U.N organs see J.S.Watson, supra note 198,pp.71_76; A.A.C.Trindade, supra note 180, pp.722_738; J.M.Howell, Domestic Jurisdiction, supra note 127, pp.148_157, H.Lauterpacht , International Protection ..., 186, pp.38_43, and L.Preuss, Article 2 ..., supra note 122, pp.605_619. L.Preuss observes that the elasticity of the terminology of Art. 2(7) has led to opposite results in the practice of the U.N Organs to that intended for by its framers, ibid., p.649. See also, I.Brownlie, supra note 150, p.294. 
(224) I.C.J.Peadings, Interpretation of peace Treaties with Bulgaria, Hungaria, and Romania, p.278.

(225) I.C.J.Pleadings, case concerning Right of passage over Indian Territory (Portugal V India), Vol.4,p.67

(226) lbid., p.76.

(227) See 250 above.

(228) I.C.J.Pleadings, Interhandel case (Switzerland V United States of America), 1959, pp.413_417.

(229) The Declaration of Israel was withdrawn on Nov.2, 1985, I.C.J.Y.B. 1985_86, p.60.

(230) For the Last opinion see pp.262-263 above

(231) See p135 above. On this case see A.P.Fachiri, supra note 77, pp.144_156.

(232) See C.H.M.Waldock, the Plea ..., supra note 22, pp.107_114; H.W.Briggs, Reservations ..., supra note 31, pp.312_313; T.Mingawa, the Principle of Domestic ..., supra note 150, pp.25_26, and Sir G.Fitzmaurice, General Principles ..., supra note 139, pp.200_207.

(233) P.C.I.J. ,Series B.,No. 4 (cited supra note 123) , p.25_26.

(234) H.Lauterpacht queried this conclusion, see the British Reservation ..., supra note 5, p.153 note 33. For Criticism of this view see C.H.M.Waldock, the Plea ..., note 122, pp.111_114.

(235) Treatment of Polish Nationals and Other Persons of Polish Origin or Speech

in the Danzig Territory, Advisory Opinion, 1932, P.C.I.J, Series A/B, No.44, p.4, at 24 .

(236) Losinger, P.C.I.J, Series C, No78, p.124.

(237) Cited supra note 157, p.23.

(238) Ibid., p.25.

(239) Cited supra note 41, p.64.

(240) Ibid., pp.82_83.

(241) Cited supra note 85, p.93.

(242) See p.252 above.

(243) Anglo_Iranian Oil Co.Interim Protection, Order of 5 July 1951, I.C.J.Reports 1951, p.89. See also C.H.M.Walodock, the Plea ..., supra note 122 , pp.137_138.

(244) Ibid., See also H.W.Briggs, Reservations ..., supra note 31, p.318 and J.S.Woo, supra note 149, p.62.

(245) Right of Passage ..., cited supra note 4, pp.131, 133.

(246) Portugal favoured a provisional conclusion rejecting the Indian objection I.C.J.Pleadings, case concerning the Right of Passage over Indian Territory (Portugal V India), Vol.I, pp.613_614.

(247) I.C.J.Reports, 1957, p.131.

(248) Ibid., pp.149_150. In his dissenting opinion Judge Kleastad preffered the rejection of the objection on the ground of a provisional view to the joinder. He 
thought that the interpretation of treaties and the general custom as well as the general principles of the law, which were invoked by Portugal, were questions of international law perhaps of judicial importance for the dispute. The provisional examination could, in his view, be limited to the nature of the dispute, and therefore, could not in any way prejudge the merits. Ibid., pp.164_165. Judge Chagla also favoured a provision conclusion, but upholding the objection. Ibid., pp.173_178.

(249) lbid., p.174_175.

(250) Right of Passage over Indian Territory, Merits, judgment, I.C.J.Reports 1960, p.6 at 33.

(251) Interhandel, cited supra note 120, p.11.

(252) Ibid., pp.24_25.

(253) Ibid.,p.24.

(254) lbid., p.25.

(255) Comp. I. Brownlie, supra note 150, p. 296.

(256) Cited supra note 106.

(257) lbid., p.21.

(258) Ibid.

(259) Ibid., pp.22, 24_25.

(260) lbid, p.25.

(261) C.H.M.Waldock, the Plea ..., note 122, p.114.

(262) Diss.Op.of Judge H.Lauterpacht in the Interhandel case, I.C.J.Reports, 1959, p.

(263) C.H.M.Waldock, the Plea ..., supra note 122, p.113. This danger was explained also by Portugal in the Right of Passage case, I.C.J.Pleadings, Vol.1 pp.613_614.

(264) Ibid., See also Sir G.Fitzmaurice, General Principles supra note 139, p.205 and E.Grisel, supra note 150 pp.114_116.

(265) See S.Rosenne, the Law ..., supra note 4, p.464.

(266) Panevezys_Saldutiskis Railway, order of 30 June 1938, P.C.I.J.; Series A/B, No75, p.53, at 56.

(267) Barcelona Traction, Light and Power Company, Limited, second Phase, Judgment, I.C.J.Reports 1970, p.3.

(268) Military and Paramilitary Activities in and against Nicaragua (Nicaragua $V$ United States of America), Merits, I.C.J.Reports 1986, p.14, at 30. on the new Rules, see E. Jiménez de Aréchaga, "The Amendments to the Rules of Procedure of the International Court of Justice", 67 A.J.I.L. (1973), pp.1_22 (esp.11_21); E.Hambro, "Will the Revised Rules Lead to Greater Willingness on the Part of Prospective Client?", in L. Gross (ed.) The Future of the International Court of Justice, vol. 1, 1976, pp. 365-376, at $370-372$; S. Rosenne, the Procedure of the International Court of Justice, A Commentary on the 1978 Rules of the International Court of Justice, 1983, pp. 164-167, and M. Lachs, "the Revised Procedure of the International Court of Justice", in F. Kalshoven, P. 
J. Kuyper and J. G. Lammers (eds.), Essays on the Development of the International Legal Order, 1980, pp. 21-52, at 31-32.

(269) Cited supra note 47.

(270) lbid., p.425.

(271) lbid., p. 424.

(272) Ibid., p.425-426.

(273) lbid., p. 425.

(274) Cited supra note 268.

(275) Ibid., p. 30 (emphasis added).

(276) Ibid. (emphasis added).

(277) Ibid., p. 31.

(278) T. Minagawa, (the Principle of Domestic ..., supra note 150, p. 26), E Hambro, (Will the Revised ..., supra note 268, p. 370) and Judge $E$ Jiménez De Aréchaga (supra note 268, p. 17) are of the same view.

(279) E. Jiménez De Aréchaga, ibid., p.17. See also T. Minagawa, the Principle of Domestic ..., ibid ., p. 17.

(280) See e.g. S. Rosenne, the Law ..., supra note 4, pp. 393-395, and T. Minagawa, Ibid., pp. 15-17.

(281) See pp. 242 and 251 above. 24 States have never made this reservation. These are : Australia, Belgium, Colombia, Costa Rica, Denmark, Finland, Domenican Republic, Haiti, Japan, Liechtenstein, Luxembourg, the Netherlands, Nicaragua, Nigeria, Norway, Panama, Portugal, Somalia, Sweden, Switzerland, Togo, Uganda, Egypt, and Uruguay.

(282) A. A. C. Trinidad, supra note 180, p. 762.

(283) See Q.F Natchaba, les Etats Africains et la Cour Internationale de Justice, thesis (Université de Poitiers , Faculty de Droit et des Sciences Sociales), 1979, p.54 and G. M. Abi- Saab, the Newly independent States and the Scope of Domestic Jurisdiction", 54 A.S.I.L. (1960), pp. 84-90.

(284) See the declarations of Australia, Barbados, Canada, India, Japan, Kenya, Luxembourg, Malta, Mauritius, New Zealand, Nicaragua, Norway and the United Kingdom.

(285) Botswana, Colombia, Mexico, Swaziland, Sweden, Finland, Gambia and the Netherlands.

(286) Denmark and Togo.

(287) Portugal.

(288) Austria, Belgium, Costa Rica, Democratic of Kampuchea, Egypt, El Salvador, Honduras, Liberia, Liechtenstein, Malawi, Pakistan, the Philippines, Senegal, Sudan and Switzerland.

(289) Status of Easter Carelia, Advisory Opinion, 1923, P.C.I.J., Series B, No. 5, at 29.

(290) Certain Expenses of the United Nations (Article 17, paragraph 2, of the Charter), Advisory Opinion, I.C.J. Reports 1962, p. 151, at 155. 
(291) Northen Cameroons, Judgment, I.C.J. Reports 1963, p.15, at 33-34.

(292) International Status of South West Africa, Advisory Opinion, I.C.J. Reports 1950 , p. 128 , at 140.

(293) Haya de la Torre, Judgment, I.C.J. Reports 1951, p. 71, 79.

(294) See p. 258 seq. above.

(295) The British Reservations ..., supra note 5, p. 163. For an extensive discussion on these tests see his book the Function of Law in The International Community, 1933, pp. 6-48, 52 seq., 139 seq., 245 seq.

(296) Article 16 of the 1899 convention and 38 of that of 1907. See Section 1, Chapter 1, above pp.14, 18 seq and $H$. Laterpacht, the Function ..., ibid., p. 27 seq. ; R. Higgins , "Policy Considerations, the International Judicial Process", 17 I.C. L.Q. (1968), pp. 58-84 at 36 ; N.N. Atkinson, Jr, "Justiciability and the Statute of the International Court of Justice", 15 Howard L.J. (1969), pp. 518-589, at 529, and the Diss. Op. of Judge Oda in the Military and Paramilitary Activities case, Merits, supra note 268, pp. 221-224.

(297) See Section 1, Chapter 1, pp.25-26 and H. Lauterpacht, the Function ..., supra note $295, \mathrm{pp} .550-553$.

(298) This Definition of Justiciability was made in the 1911 Treaty of General Arbitration Treaty between the United States , France and Great Britain but with the addition of the words "or equity" after the phrase "the principle of law ". See 5 A.J.I.L.(1911), at 253, 249. This definition appeared also in a large number of treaties concluded between the United States on the one hand and some Latin American States on the other, during the period 1928 and 1930 with the omission of the words " or equity" in some of these treaties. See the Diss. Op. of Judge Oda in Military and Paramilitary Activities case, Merits, Cited supra note 268, at 232.

(299) See P.N. Notron, "the Nicaragua case : Political Questions before the International Court of Justice", 27 Virg. J.I.L. (1987), pp. 459-526, at 494-495. The Locarno Treaties of 1925 defined justiciable disputes as those "with regard to which the parties are in conflict as to their respective rights." For Criticism of Locarno criterion see $\mathrm{H}$. Kelsen, "Compulsory Adjudication of International Disputes", 37 A.J.I.L. (1943) , suppt. , pp. 397-406 and Principles of International Law, 2 nd. ed. Revised and edited by R. W. Tucker, 1966, pp. 526-527.

(300) See e.g. H. G. Darwin, "General Introduction", in C. H. M. Waldock (ed.), International Disputes : the Legal Aspects, 1972, pp.57-76, at 60 ; T.M. Franck, the Structure of Impartiality, 1968, p.178, and N. N. Atkinson, supra note 296, pp. 545-548.

(301) See H. G. Darwin, Ibid., p. 59 and R. Higgins, supra note 296, pp. 67-70.

(302) H. Kelsen, Compulsory Adjudication ..., supra note, 299, p. 401. The mixed character of almost every international dispute is generally admitted. See e.g. T. M. Franck, the Structure of Impartiality, supra note 300 , pp. 173-174; $\mathrm{H}$. Lauterpacht, the Function ..., supra note 296, p. 153 ; F. Vallat, "Forward" in C. 
H. M. Waldock (ed.), supra note 300, p. XV and "the Function of International Court of Justice in the World Community", 2 Ga. J.I.C.L. (1972), pp. 55-58, at 56 ; the Report of the Study Groupe in C.H.M. Waldock (ed.), ibid., p. $8 ; \mathrm{H}$. Mosler, "Political and Justiciable Legal Disputes : Revival of an Old Controversy? ", in B. Cheng and E. D. Brown(eds.), Contemporary Problems of International Law : Essays in Honour of George Schwarzenberger on his Eightieth Birthday, 1988, pp.216-229, at 221-222 ; E. Gorden, " Discretion to Decline to Exercise Jurisdiction ", 81 A.J.I.L. (1987), pp. 129-135, at 133, and A. W. Rovine, "the National Interest and the World Court ", in L. Gross(ed.), the Future of the International Court of Justice, vol. 1, 1976, pp. 313-335, at 318-319.

(303) See H. Lauterpacht, the Function ..., ibid., pp. 153-165. For these and other tests see R. Higgins, supra note 300 , at 59-60, L. Gross, "Underutilization of the International Court of Justice", 27 Harv. I.L.J. (1986), pp. 571-597, at 581-584, and E. Gorden, "Legal Disputes Under Article 36 (2) of the Statute", In L. F. Damrosch (ed.), the International Court of Justice at a Crossroads, 1987, pp. 183-223.

(304) For the meaning of the word "justiciability" see E. Gorden, Legal Disputes ..., ibid., p. 190 ; N. P. Norton, supra note 299, at 493-494 ; H. Lauterpacht, the Function ..., supra note 186, pp. 19-20, and A. N. Atkinson, supra note 296, pp. 520-523.

(305) The qualification "legal" or "political" disputes has been generally dismissed as untenable. See P. N. Norton, supra note 299 , at 489 note 106 . T. M. Franck describes the expression "political disputes " as meaningless, the Structure of Impartiality, supra note 300, p. 177 . See also L. Sohn, "exclusion of Political Disputes from Judicial Settlement", 38 A.J.I.L. (1944), suppt. , pp. 694-700, at 698.

(306) See A. N. Atkinson, supra note 296, pp. 523-563.

(307) Politics Among Nations , 1961, p. 428.

(308) Ibid., pp. 428-431. For criticism of this view, see H. Kelsen, Principles ..., supra note 299 , at $528-529$.

(309) See e.g. R. Higgins, supra note 296, pp.74, $83 ; H$. Lauterpacht, the Function ..., supra note 186, p. 5 ; H. G. Darwin, supra note 300, p. 62 , and A. W. Rovine, supra note 302 , at 181.

(310) Principles ..., supra note 299, p. 526.

(311) Compulsory Adjudication ..., supra note 299, p. 403.

(312) See e.g. E.Hambro, Some Observations ..., supra note 5, p. 137, and the Jurisdiction ..., supra note 5, p. 171 ; S Prasasvinichai, supra note 167, pp. 29-30 ; B. Maus, supra note 31, p.38, and R. Higgins, supra note 296, p. 74.

(313) See e.g. the view adopted by the Study Group of David Davies Memorial Institute of International Law, in C. H. M. Waldock (ed.) supra note 300, pp. 6-8 and the Joint Diss. Op. of Judges Onyeama, Dillard, Jiménés De Aréchaga and Sir 
H. Waldock in the Nuclear Tests case ( Australia v. France), Judgment, I.C.J. Reports 1974, p.253, at 364-367. Note that Sir H. Waldock was the Chairman of the Study Group.

(314) The Function ..., supra note 186, pp. 163-165.

(315) Ibid., p. 5.

(316) Principles ..., supra note 299, pp. 527-530.

(317) Supra note 296, p.172.

(318) The Prospects of International Adjudication, 1964, pp.15-16.

(319) The Jurisdiction ..., supra note 5, p.171.

(320) "The Justiciability of Disputes and Issues in International Law", 42 B.Y.B.I.L. (1969), pp. 123-143, at 124. However, Brownlie contradicts the basis of Lauterpacht theory by arguing that some disputes are withheld by States from adjudication by one means or another.

(321) The Law supra note 4, p. 94. Among other scholars who share Lauterpacht view are P. Chapel, I' Arbitrabilite des Différends Internationaux, 1967, p.59, R. Lavalle, " the Notion of International Legal Disputes and the assumption of Jurisdictions by the International Court of Justice in the Hostage case ", 35-36 R.H.D.I. (1982-83), pp. 97-110, at 109 and W. Friedman, " the International Court of Justice and the Evolution of Law", 14 Archiv V. (1969-70), pp. 305-320, at 308 .

(322) For further details on these reasons see I. Brownlie, Justiciability ..., supra note 318 and J. G. Merrills, "the Justiciability of International Disputes", 47 Can. B.R. (1969), pp. 241-269. Although T. M. Franck believes that all disputes are justiciable, he criticizes very strongly the realistists. Realism must be redefined in his view. "It is only in the very most recent years that we are beginning to emerge from this bringe of realism", he points out. "To characterize all important disputes as political is merely to say that we are captives of our animal nature, that we have no choice to live by law. This is mischievous, and it is not real.", the Structure of Impartiality, supra note 300 , pp. 174-175.

(323) See H. J. Morgenthau, supra note 307, pp. $62-63$ and $C h$. de Visscher, Theory and Reality in Public International Law, revised ed. , 1968, p. 79.

(324) See H. Hohmann snd P.J.I.M. De Waart, " Compulsory Jurisdiction and the Use of Force as a Legal issue : the Epoch-Making Judgment of the International Court of Justice in Nicaragua v. United States of America", 34 Neth.I.L.R. (1987), pp. 162-191, at 169. L. Sohn seems to share this view, supra note 305, p.695.

(325) T. M. Franck, the Structure of Impartiality, supra note 300, p. 190 (emphasis original).

(326) See P.N. Norton, supra note 299, p.499-500.

(327) See pp.107-109 above.

(328) See E. Gorden, Discretion ..., supra note 302, p, 133 and S. Rosenne, the Law ..., supra note 4, p. 91. 
(329) See B. Maus, supra note 31 , pp.38-40.

(330) See e.g. S. Rosenne, the Law ..., supra note 4, p. 374 ; H. Lauterpacht, the British Reservations ..., supra note 5, pp. 161-162 and the Function ..., supra note 296, pp. 35-36; M.O. Hudson's Treatise, supra note 4, pp.454-459; H. W. Briggs, Reservations ..., supra note 31, p. 235 ; R.P. Anand, Compulsory ..., supra note 4, pp. 165-168, and A. P. Fachiri, supra note 77, p. 109.

(331) M.O. Hudson's Treatise , supra note 4, p. 456. See also E. Gorden, Discretion ..., supra note 302, p.131. But comp. S. Prasasvinitchai. supra note 167, p. 31 and $\mathrm{H}$. Kelsen, the Law of the United Nations, supra note 31, p. 527. Note also the hesitation of J. F. Williams, " the Optional Clause : the British Signature and Reservations ", 11 B.Y.B.I.L. (1930), pp. 63-84, at 68.

(332) B. Maus, supra note 31, p. 38.

(333) It is generally agreed that the four categories set out in Article 36(2) constitute of a " schematic compendium of ... all legal disputes." M. O. Hudson's Treatise supra note 4, p. 459. See also H. W. Briggs, Reservations ..., supra note 31 , p.225, M. Dubisson, supra note 221p. 162, and s. Rosenne, the Law ..., supra note 4, p. 376. But Comp. J. F. Williams, supra note 331, p. 68.

(334) See R. Higgings, supra note 296, pp. 64-65 esp. note 20 ; B. Maus, supra note 31 , pp. 38-40, and A. Chayes, "Nicaragua, the United States and the World Court", 85 Colum.L.R. (1985), pp. 1445-1482, at 1476.

It is to be observed that in the Electricity Company of Sofia and Bulgaria case the P.C.I.J. considered the four points enumerated in Article 36(2) as a " general provision which enumerates the legal disputes for which the Court is competent." P.C.I.J. Series A/B, No. 77 (cited supra note 41), p.82.

(335) See pp. 285-286 above.

(336) Kelsen himself, as one of the founders of that theory, observed that the criterion based on States' attitude could lead to such a result . See Compulsory adjudication ..., supra note 299, p. 403. See also Schwebel's argument as a Deputy Agent and Counsel of the United States in the United States Diplomatic and Consular Staff in Teheran case, I.C.J. Pleadings, p.279. Comp. R. Lavalle, supra note 320, p. 108.

(337) E. Gorden , Discretion ..., supra note 302, pp. 133-134.

(338) Fisheries Jurisdiction (United Kingdom v. Iceland), Jurisdiction of the Court, Judgment, I.C.J. Reports 1973, p.3, at 7.

(339) Nuclear Tests (Australia V. France), Judgment, I.C.J. Reports 1974, p. 253, and (New Zealand v. France), ibid., p. 457.

(340) I.C.J. Pleadings, Nuclear Tests, (Aust. v. Fr. ), vol. 2, Annex 10, p. 28. For further details on the justiciability of these cases see the Sep. Op. of Judges Gros, Pétren and Igncio-Pinto, and the Joint Diss. Op. of Judges Onyeama, Dillard, Jiménéz de Aréchaga and Sir H. Waldock, I.C.J. Reports 1974, pp. 296297 ; 303; 308-309, and 364-367 respectively. See also L. Gross, Underutilization ..., supra note 303 , at $585-586$. 
(341) Quoted in Dillard, " the World Court : Reflections of a Professor Turned Judge", 27 Am.U.L.R. (1978), pp. 205-250, at 230.

(342) See S. Rosenne, the Law ..., supra note 4, pp. 375-376.

(343) See p.268 above.

(344) For Further detail on these cases see S. Rosenne, ibid., pp. 375-376.

(345) See "Summary of Arguments by Professor Louis Sohn, Verbatim Record, Public Setting held on October 16, 1984, I.C.J. Doc. CR. 84/18, p.67. T. M. Franck summarizes this argument as one intended to invite the Court to dismiss the case not because it was "political" but because it was a "clash of political forces." , Judging the World Court, 1986, p. 62.

(346) See" Statement on the United States Withdrawal from the Proceedings Initiated by Nicaragua in the International Court of Justice (January 8, 1985)", 24 I.L.M. (1985), p. 246.

(347) See pp. 270-271 above.

(348) Right of Passage, Merits, cited supra note 250, pp. 36-37.

(349) S. Rosenne, the Law ..., supra note 4, p. 375.

(350) See e.g. A. W. Rovine, supra note 302, p. 318.

(351) See p. 286-287 above.

(352) United States Diplomatic and Consular Staff in Teheran, Provisional Measures, Order of 15 December 1979, I.C.J. Reports 1979, p. 7, at 11.

(353) Supra note 307, pp. 429-430. See also L. Gross, Underutilization ..., supra note 303 , pp. 587-588.

(354) I.C.J. Reports 1979, p. 11.

(355) Ibid., p. 16.

(356) Ibid., pp. 15-16.

(357) Ibid., p. 15.

(358) United States Diplomatic and Consular Staff in Teheran, Judgment, I.C.J.

Reports 1980, p. 3, at 20.

(359) See A. W. Rovine, supra note 302, p. 318.

(360) See pp. 113-114, 118-120 above.

(361) See the Iranian letter of March 16, 1980, I.C.J. Reports 1980, p. 8.

(362) See R. Lavalle, supra note 320, p. 109 ; L. Sohn, supra note 305, p. 695, and T. M. Franck, the Structure of Impartiality, supra note 300, pp. 170-171. T. M. Franck thinks that a correct Judicial Decision answering the legal elements in the dispute might make matters a good deal worse. It is a correct answer to a wrong question, he points out. Ibid.

(363) I.C.J. Reports 1980 (cited supra note 358), p. 21.

(364) It goes without saying that the question whether or not the parties will comply with the judgment is outside the Court's preview. The Security Council is the organ vested with the power to consider such a question pursuant to Article 94 of the Charter. For further detail on this point, see A. Chayes, supra note 334, pp.1477-1478.

(365) For example Article 18 of the European Convention on the Settlement of 
Disputes. See H. G. Darwin, supra note 300, pp. 61-62.

(366) See p. 291 above.

(367) I.C.J. Reports 1984 (cited supra note 47), p. 436.

(368) Ibid., p. 439.

(369) Ibid., p. 442. On the the Justiciability of this case see P. N. Norton, supra note 299 ; T. M. Franck, Judging the World Court, supra note 345, pp. 39-42 ; H. Hohmann and P. J. I. M. De Waart, supra note 324, pp. 165-169 ; E. Gorden, Discretion ..., note 302, pp. 133-134; A. Chayes, supra note 334, pp. 14451482, and H. H. Almond, Jr, " the Military Case : New Perspectives on the International Court of Justice and Global Public Order", 21 I.L (1987), pp. 195-208.

(370) I.C.J. Reports 1986 (cited supra note 268), p. 220.

(371) Ibid., pp. 238-246. The prevalence of political aspects has sometimes been relied upon by some judges as a reason for non-justiciability. Thus Judge Gros referred in the Nuclear Tests case (Aust. v. Fr. ) to what he termed as the "essentially political conflicts", I.C.J. Reports 1974, cited supra note 313, p. 297. Judge Igncio-Pinto found the subject matter of the dispute in the same case as one which had an "all too markedly political character", ibid., p. 308. In Certain Expenses of the United Nations case (cited supra note 290, p. 254) Judge Korestsky thought that "the political issue prevailed over judicial considerations". In the Conditions of Admission of a State to Membership in the United Nations (Article 4 of the Charter) case Judge Alvarez said that " in reality this question is both legal and political, but the legal elements predominate." I.C.J. Reports, 1947-48, p. 57, at 70.

(372) See the Sep. Op. of Judge Gros in the Nuclear Tests case (Aust. v. Fr. ), cited supra note 313 , p. 297. 


\section{CHAPTER V}

\section{OBJECTIVE RESERVATI ONS RATIONE MA IFR I A}

The general characteristic feature of this group of reservations is that their scope can be determined objectively. They intend either to adjust the competence between the Court and other means of pacific settlement of disputes or to exclude, disputes relating to some specific subject matters. Therefore, they do not generally contravene either the statute of the court or the spirit of the compulsory jurisdiction.

\section{SECTION (1) : RESERVATIONS RELATING TO THE CONFLICT OF COMPETENCE BETWEEN THE COURT AND OTHER MEANS OF PEACEFUL SETTLEMENT}

Almost all States accepting the Court's compulsory jurisdiction under Article 36 (2) of the Statute have also accepted that competence under Article 36 (1) of the Statute by the insertion of clauses in multilateral or bilateral treaties conferring jurisdiction on the court over any dispute which may arise between the parties or disputes relating to the interpretation and application of that treaty. ${ }^{2}$ These Treaties often contemplate other procedures for the pacific settlement in addition to the judicial settlement of the court. Furthermore, pursuant to the Charter of the United Nations. States have undertaken the obligation to settle their disputes peacefully. Thus Article 33 (1) of the Charter reads:

\footnotetext{
"The parties to any dispute, the continuation of which is likely to endanger the maintenance of international peace and security, shall, first of all, seek a solution by negotiation, enquiry, mediation, conciliation, arbitration, judicial sett]enent, resort to regional agencies or arrengements, or other peaceful means of their oun choice."
}

The political organs of the United Nations, especially the Security Council and the General Assembly are given a wide authority for the maintenance of international peace and security. The Court's jurisdiction may thus concur 
with either other judicial or non-judicial means of peaceful settlement. Some states deemed it necessary to regulate such "conflict" in their declarations of acceptance.

Before examining these two forms of conflict it might be desirable to discuss briefly the effect of plurality of titles of jurisdiction on the reservations included in these titles.

\section{A - THE EFFECT OF PLURALITY OF TITLES OF JURISDICTION ON THE RESERVATIONS INCLUDED THEREIN}

As has just been pointed out a state may confer jurisdiction on the court by virtue of both a declaration of acceptance and another instrument. How will the different reservations included in these titles be applied? Do they operate cumulatively of exclusively?

The resolution of a conflict between the different titles of jurisdiction appeared to many writers not very difficult. It has been suggested that the general principles of law applicable to conflicting or incompatible international agreements between the same parties such as LEX POSTERIOR DEROGAT LEGI PRIORI, LEX SPECIALIS DEROGATE LEGI GENERALI, and LEX SPECIALIS PRIORI DEROGAT LEGI GENERALI POSTERIORI should be relied on for determining which title is to prevail. 3 Some went even a stage further in suggesting that the question of which title is to prevail must be decided by the Court even if it is not raised by the respondent and even if both parties to the dispute agree that both instruments are in force so long as there is no agreement between them as to the competence or incompetence of the Court to entertain the dispute. Otherwise the existence of different reservations in each instrument would lead to the situation where recourse to the court is permitted by a treaty but not by the declarations or UICE UERSA. This, it is argued, would mean that, in the same legal system, there 
can at the same time exist two rules relating to the same facts and attributing to these facts contradictory consequences. 4

This approach appeared to others non convincing for two reasons: firstly it is difficult to be certain that one title is LEX GENERALIS and the other is LEX SPECIALIS; secondly all instruments conferring jurisdiction on the Court "have so much in common that it cannot be presumed that two or more such documents are either conflicting or incompatible with one another, so as to bring either of these two very general and divergent principles into play". 5 Therefore it is deemed more reasonable to consider the plurality of titles of jurisdiction as an indication of the parties' intention to have them applied cumulatively.

The principle was first applied by the P. C. I.J. in the ELECTPICITY COHPANY OF SOFIA AHD RULGAPIA case where the applicant, Belgium, relied on its own declaration and that of Bulgaria in addition to the Treaty of Conciliation. Arbitration and Judicial settlement of. June 23. 1931, which came into force in February 4, 1933.7

The Court took a liberal view warmly welcomed by whoever feels that the judicial settlement of disputes may greatly contribute to easing international tension. " ${ }^{B}$ Relying on the intention of the parties, having not contested the validity of both titles, the court decided that the multiplicity of concurring titles of jurisdiction must be interpreted in a way that the parties intended to extend compulsory jurisdiction rather than to restrict it. It said :

\footnotetext{
"In its opinion, the multiplicity of agreenents concluded accepting the compulsory jurisdiction is evidence that the contracting Farties intended to open up new ways of access to the Court rather than to close old ways or to allow them to cancel each other out with the ultimate result that no iurisdiction would remain.
} 
In concluding the Treaty of Conciliation, Artitration, and Judicial Settiement, the object of Belgium and Eulgaria was to institute a very complete system of mutual obligations with a view to the pacific settlement of any disputes which might arise between them. There is, however, no justification for holding that in so doing they intended to weaken the obligations which they had previously entered into with a similar purpose, and especially where such obligations were more extensive than those ensuing from the Treaty.

It follows that if, in a particular case, a dispute could only be submitted to the court under the Treaty whereas it might be submitted to it under the declarations of Belgium and Bulgaria accepting as compulsory the jurisdiction of the court ... the Treaty cannot be adduced to prevent those declarations from exercising their effects and disputes from being thus submitted to the Court."

Then the Court explained how it would tackle objections to its jurisdictions under both titles. It may not examine the objections raised under the second title unless objections under the first title prove well-founded. "Only if both these sets of objectives are alike held to be well-founded will the court decline to entertain the case." 10

Reciprocal declarations and compromissory clause had been relied on together in many cases before the International Court of Justice. 11 In none of them the question of which title should prevail was raised either by the parties concerned or by the court. The principle set down in the ELECTRICITY OF SOFIA AHD BULGARIA case had been applied in the subsequent cases. Thus the reservations in each title operate separately. In other words the Court will consider its jurisdiction under each title separately. If it found that it is deprived of jurisdiction by virtue of a reservation in the parties' declarations it will consider the second title (the treaty) and will take cognisance of the case unless it upholds an objection based on a reservation included therein. In this sense the multiplicity of titles of jurisdiction operate cumulatively, namely, an application will not fail because the subject mater is not covered by one 
title, if it is encompassed by the other title.

This being the case, it does not follow that the multiplicity of titles of jurisdiction cannot operate exclusively. This may occur not only pursuant to a special reservation in one title (the declaration) maintaining -as will be seen 13 - the reservations in other titles, but also by virtue of a general reservation in the former. This can be illustrated by the titles invoked in HILITARY AND PARLIAHENTARY ACTIUITIES case namely, the reciprocal declarations of Nicaragua and the United States and the Treaty of Friendship, Commerce and Navigation concluded between them in 1956. If that treaty had been a multilateral one, the court would have eliminated the possibility of founding its jurisdiction on the 1956 Treaty pursuant to the multilateral treaty reservation included in the declaration. of the United States. 14 The Court would have had no choice but to decide its competence on the basis of the reciprocal declarations alone. Thus the court in that case, deemed it appropriate to ascertain under the 1956 Treaty after pointing out that the multilateral treaty reservations "abuIouscy" did not affect its jurisdiction under that Treaty.

\section{B - CONFLICT WITH JUDICIAL ORGANS}

\section{(I) The General Rule Governing Such a Conflict}

The conclusion of different treaties providing for recourse to other judicial or arbitral bodies for the settlement of disputes either before or after the acceptance of the Court's compulsory jurisdiction by a declaration under Article 36 (2) may lead to a conflict of jurisdiction between the court and another judicial or arbitral body. Such a conflict may take a positive or negative form. It is negative where neither organ considers itself competent and positive where both estimate that they are competent. How are such conflicts to be settled? 
The answer was given by the P. C. I. J. in the cHorzoH FACTORY case. 16 In fact the argument that the Court should step aside because another tribunal was competent was advanced in an earlier stage of the dispute, namely, in the GERHAN INTERESTS IN POLISH UPPER SILESIA case. However the Court managed to escape the question whether the doctrine of litispendence was applicable or not, by refusing to consider the claim brought before it and that referred to the tribunal as identical. 17 Yet it was not possible to follow that approach in the CHORZOH FACTORY case, because there were two arbitral tribunals before which the same case could have been brought. The court was, therefore, obliged to answer how the conflict with other judicial organs could be settled. It said:

"When it has to define its juriadiction in relating to that of another tribunal, [it] cannot al low its own competence to give away unless confronted with a cleuse which it considers sufficiently clear to prevent the possibility of negative conflict gf jurisdiction involving the danger of a denial of justicen" 18

The Court thus, facing the argument that another tribunal was competent, did not hesitate to determine not only its own jurisdiction but also at least on a PPIMA FACIE basis, the jurisdiction of the other tribunal involved and preferred to exercise its jurisdiction to the exclusion of that of the other tribunal. 1 ?

\section{(II) Reservations Concerning the Conflict of Competence Between the Court and Other Judicial Organs}

Can the Court follow the same approach. i.e. prefer its own jurisdiction in spite of the existence of a clear reservation in the relevant jurisdictional instrument limiting the resort to the court to cases where no other means of judicial settlement are provided? The adjustment of this conflict by giving priority to other judicial bodies than the International Court of Justice is the 
object of these reservations which have taken different forms.

\section{(i) Exclusion of disputes in regard to which the parties have agreed to recourse to arbitration or judicial settlement by another body}

The declarations of Liberia and Pakistan excluded from the Compulsory jurisdiction of the Court disputes "in regard to which the parties have agreed or may agree to bring before other tribunals as a result of agreements already existing or which may be made in the future". 20 This formula is even narrower in the declarations of Austria and Japan. They exclude "disputes which the parties thereto have agreed or shall agree to refer for final and binding decision to arbitration or judicial settlement". 21

This reservation is amongst the few reservations which are expressly permitted. It is consistent with Article 95 of the Charter which reads:

"Nothing in the present Charter shall prevent Hembers of the United Natione from entrusting the solution of their differences to other tribunals by virtue of arguments elready in existence or which may te concluded in the future "

The reservation indicates the intention of the declarant not to revoke or endanger in any degree whatsoever the agreements with other states to settle their disputes by arbitration. 22 However the application of the reservation depends on the existence of a competent concurring tribunal or other court for the settlement of the dispute referred to the court. This condition must clearly be fulfilled in order to deprive the International Court of Justice of jurisdiction. It seems that the reservation cannot have such effect - at least in so far as the reservation of Japan and Austria are concernedexcept where there exists a real obligation to arbitrate that dispute. Consequently, the reservation cannot depr- 
ive the I.. C. J. of jurisdiction even where the treaty compromissory clause contains such obligation but with a reservation for example RATIONE TEHPOPIS excluding that dispute because it has arisen out of events which occurred before the crucial date. The same can be said where the concurring title provides for a facultative recourse to arbitration. 23 It is obvious that the decision upon the fulfillment of these conditions is for the I. C. J. according to Article 36 (6) of its Statute.

\section{(ii) Disputes excluded from judicial settlement or compulsory arbitration by virtue of a previous Treaty of Instrument}

In 1955, the United Kingdom introduced in its declaration made on June the 2 nd, a new reservation excluding "disputes relating to any matter excluded from compulsory adjudication or arbitration under any treaty. convention or other international agreement or instrument to which the United Kingdom is a party". 24 This reservation had been maintained in all the British subsequent declarations except that of 1969 which is now in force. It has been copied textually in the declarations of Democratic Kampuchea, Malta and Mauritius. 25

It has been said that this reservation is a reiteration of the reservation excluding from the Court's compulsory jurisdiction disputes in regard to which the parties to the dispute have agreed to have recourse to other means of peaceful settlement included in the same declarations. 26 Maus carries the argument a stage further. It is obvious, he believes, that if a question is excluded from arbitration, it cannot be submitted to the International Court of Justice pursuant to Article 36 (2) of the statute because the special rule prevails over the general rule and the will of the parties is always the basis of jurisdiction even as regards an act so important as the Optional Clause. It is a general rule of international law that does not require a special reservation 
and hence the reservation is useless in his view.

This argument does not seem to carry conviction. This is not only because it contradicts the rule applied by the Court in the ELECTRICITY COMPANY OF SOFIA AND EULGARIA case and others to concurrent titles of jurisdiction, 29 but also because it disregards the very terms of the reservation. In fact the simultaneous existence of those two reservations in the same instrument - especially in that of the United Kingdom - a country which is very careful in drafting its declarations - implies that they are of a different scope. However, the terms of the reservation seem to indicate that it was intended to operate against the presumption of the cumulative effect of concurring titles of jurisdiction. 29 Thus, a state making the reservation may deprive the Court of jurisdiction to entertain a dispute brought before it not because the dispute is excluded expressly in either of the declarations, but because that dispute was excluded at some time - even in the last century - by any act of whatsoever character whether TREATY or COHUEHTION Or IHTERNATIONAL AGREENEHT Or INSTRUHENT regardless whether multilateral or bilateral and regardless of its object and the character of the obligation undertaken, be it obligatory or facultative. Moreover, the general terms of the reservation appear to have the effect of maintaining old treaties of arbitration containing the famous reservations of vital interests, honour and independence... etc. although the decision whether those reservations are involved or not cannot be left to the state concerned because the question concerns the Court's jurisdiction. which is to be determined by the court itself pursuant to Article 36 (6) of the statute. It goes without saying that the principle of reciprocity will complicate those difficulties. A state making the reservation, or a state intending to sue the former, has to consider any instrument to which its opponent is a party, contemplating recourse to judicial or arbitral procedure for the settlement of their dispute. 
The foregoing considerations indicate clearly the uncertainty created by this form of reservation. This uncertainty may exceed any degree of uncertainty created by other reservations. For however the relations between States accepting compulsory jurisdiction under Article 36 (2) are complicated, the scope of the obligations between two or more states can be determined at any time by a simple comparison between the declarations of those States. 30 . In contrast the determination of the common will of a state making such a reservation and the other States requires a deep study of all treaties and instruments concluded between those states relating to judicial or arbitral settlement of disputes. In these conditions it may be asked what kind of disputes has a Country accepted, and not what kind of disputes it has excluded, like the United Kingdom, for example, which has concluded throughout the period since the end of the last century a long series of arbitration treaties.

In the light of these considerations, and although the Court appears to have considered the uncertainty as insufficient ground for the invalidity of a reservation. the reservations seems to run against the conception of the compulsory jurisdiction system. In this sense it seems also subjective unlike the other reservations in this chapter, and it is included here only for the sake of classification. Thus, it is strongly hoped that Democratic Kampuchea, Malta and Mauritius will follow the British action by eliminating this reservation as they followed the United Kingdom before by copying the reservation from its previous declarations, or they will reconsider its terms if they are intending to exclude some defined disputes.

\section{C - CONFLICT WITH NON-JUDICIAL ORGANS}

As has been explained in the beginning of this section, that the different titles conferring jurisdiction on the Court not infrequently contemplate recourse 
to other means for peaceful settlement of disputes, and the mutual relations of the court and other principle organs of the United Nations 32 may lead to the submission of the same dispute to different organs. Different kinds of reservations have been made in the declarations of acceptance with a view to adjusting the jurisdictional conflict between the different means of settlement. These reservations concern either the suspension of the proceedings before the Court when a dispute is put on the active agenda of the Security Council or excludes disputes which are not settled by other methods of settlement or disputes in regard to which the parties have agreed to have recourse to other means of peaceful settlement. It might be appropriate to precede the discussion of those reservations by a brief discussion on how the Court has treated objections to its exercising jurisdiction, in the absence of such reservations, based on the simultaneous consideration of the same dispute by another political organ.

\section{(I) The Non-application of the Doctrine of Litispendence Between the Court and the Political Organs $32 \mathrm{~B}$}

In the absence of a clear reservation preventing the Court from exercising, or requiring it to suspend, its jurisdiction another organ is considering the dispute, the Court did not hesitate to take cognisance of the case. The earlier practice on the issue is summed up in the SOUTH HEST AFPICA CASES 35 where the court had followed the general lines marked out by its predecessor in MIHORITY SCHOOLS 34 and the IHTERPPETATION OF THE STATUTE OF THE MONEL TERPITORY 35 cases and therefore went forward in spite of the fact that the dispute has been continuously on the agenda of the General Assembly. 36 However the WNITED STATES DIPLOHATIC and COHSULAR STAFF IH TEHERAN 37 and HILITARY AHD PARAMILITARY ACTIUITIES IN AND AGAINST NICARAGUA cases $3 \mathrm{~B}$ have raised the issue in its most extreme form. 
In the former case the same dispute had been under the consideration of many organs. It was first referred by the United States to the Security Council on November 9. 1979. Four days later the dispute was submitted to the Court, which held its jurisdiction unanimously on December 15. 1979 to entertain the United States request for indication of provisional measures of protection in spite of the fact that not only the Security Council was "actively seised of the matter" but also the Secretary-General was under an express mandate from the Security Council to use his good offices. 39 Nor was the Court prevented from going into the merits of the case in a later stage because of the establishment of a comMIssion by the Security Council "to undertake a fact-finding mission to Iran to hear Iran grievances and to allow for an early solution of the crisis between Iran and the United States." 40

The Court seems to have considered the simultaneous exercise of jurisdiction over the same matter by both the Security Council and itself as a Nopmal thing for two reasons. First, the absence of any provision in either the Charter or the statute which prohibit the Court from exercising its jurisdiction over a matter in respect of which the Security Council is exercising its jurisdiction. If such a prohibition were contemplated it would have been made expressly in either of those instruments as it is the case in Article 12 of the Charter which expressly forbids the General Assembly to make any recommendation with respect to. "disputes or situations under the consideration of the Security Council". Second, the Court, as a principle Judicial organ of the United Nations, is vested with the power to solve $A N Y$ YEGAL questions that may be at issue between the parties. On the other hand the Security Council is under an obligation to take into consideration the important and decisive role of the Court in promoting peaceful settlement of disputes. Thus Article 36 (3) of the Charter provides: 
"In making recommendations under this Article, the Security Council should also take into consideration that legal disputes should as a general rule be referred by the parties to the International Court of Justice, in accordance with the provisions of the Statute of the Court.".

Accordingly the court observed that it did not "seem to have occurred to any member of the Council that there was or could be anything irregular in the simultaneous exercise of their respective functions by the Court and the Security Council. Nor IS THERE IN THIS HAY ANY CAUSE FOR SURPRISE".

The character of the other concurring organs appears thus of a critical importance for determining whether the Court should proceed with the examination of the case or step aside. The court will declare itself incompetent only where the function of the other organ is identical to that of the court, i.e. empowered to decide matters of fact and law in the dispute. Since such requirement was not complied with by the existence of a commission as an instrument for mediation, conciliation or negotiation, the court decided the case.

In the MILITARY AND PARAMILITARY ACTIUTTIES IN AND AGAINST NICARAGUA case the Court refused to depart from its consistent jurisprudence on the issue because of the al legations that the case concerned matter over which the Security Council is given a "primary responsibility" 45 or that the Court's admission of the claim would amount to exercising a function, which does not $f$ ind a basis in the United Nations system, namely, a judicial "review" of the Security Council actions. For the failure of the Security Council to adopt a resolution condemning the United States actions owing to the negative vote of the United states amounted, it was agreed, to a security Council decision to take no action. "44 In rejecting this ground of inadmissibility, by a vote of sixteen to zero, the Court was more explicit that in the previous case. It observed that the fact that the Security Council and itself constitute two organs of a different character 
entrusted with functions of a different nature must not be overlooked. "The Council has functions of a political nature assigned to it, whereas the court exercises purely a judicial function. Both organs can therefore perform their separate but complementary function with respect to the same events". 45

As to the argument that the judicial proceedings constituted an appeal to the Court from an adverse decision of the Security Council, the court pointed out that it was not asked to examine the action taken by the Security Council, but to perform its duty as principle judicial organ of the United Nations namely to pass a judgment on some legal aspects of a situation which had also been considered by the Security Council.

The conclusion to be drawn from what has been said is that owing to the existence of different bodies entrusted with the function of maintaining international peace and security, and to States' freedom to confer on one or more of those bodies the jurisdiction to settle the dispute, the simultaneous exercise of jurisdiction by judicial and political organs will happen not infrequently. This parallel exercise of jurisdiction by organs of different nature appeared to the Court as not only normal but sometimes desirable in promoting the peaceful settlement of disputes. Thus neither did the Security Council dis-seise the Court from a case pending before it - as has been suggested ${ }^{47}$ - nor did the Court, as had been predicted, follow "the most cautious attitude" 48 by differentiating the issue before it from that before the Council or adjourning the case until the Council takes action.

\section{(II) The Suspension of Judicial Proceedings by Bringing Disputes Before the Security Council}

This reservation seems to have found its origins in the statement made by the Third Committee of the Fifth 
Assembly of the League of Nations in which attention was drawn to the possibility of reserving from the Court's compulsory jurisdiction "the right of laying disputes before the Council of the League of Nations with a view to conciliation in accordance with paragraphs $1-3$ of Article 15 of the Covenant with the proviso that another party might, during the proceedings before the council, take proceedings against the other in the court". 49 Inspired by this statement the unratified French declaration of 1924 reserved the possibility of appeal to the Council of the League in accordance with paragraph 3 of Article 15 of the Covenant. 50 It was then introduced by the British Declaration of 1929 and subsequently adopted by several other states. 51

The reservation was made in two forms. Whereas the declaration of Great Britain and the Commonwealth states set forth some conditions for the application of the reservation, the other states reserved for themselves the right to suspend unilaterally and at any time the judicial proceedings by bringing the dispute before the Council. The former accepted the jurisdiction of the $P$. C. I. J. with:

\begin{abstract}
"The condition that [the Government of the declarant Statel reserve the right to require that proceedings in the Court shall be suspended in respect of any dispute which has been submitted to and is under consideration by the Council of the League of Nations, provided that notice to suspend is given after the dispute has been submitted to the council and is given within ten days of the notification of the intention of the proceedings in the Court, and provided also that such suspension shall be limited to a period of twelve months or such longer period as may be agreed by the parties to the dispute or determined by a decision of all the members of the Council other than the parties of the dispute." 52
\end{abstract}

The object of this reservation was explained in the declaration of signature made by the Government of the United Kingdom, partly, by the necessity to exclude "disputes which are really political in character though judicial in appearance. Disputes of this kind can be 
deals with more satisfactorily by the Council." 5 This explanation was criticised strongly by $\mathrm{H}$ Lauterpacht 54 and John F Williams 55 as long ago as 1930. It was considered as "essentially retrogressive" and involving "a nervous quest for the security from law" as if the political decision of a legal question provided greater safety. 56

By virtue of Article 36 (5) of the Statute of the I. C. J. the reservation has been maintained for some time in the declarations of Great Britain and the Commonwealth States. The Australian Declaration of 1954 was the only declaration made under Article 36 (2) of the Statute of the I. C. J., which maintained the suspensive reservation with almost the same conditions with the substitution of the Security Council of the United Nations for the Council of the League of Nations. 57 However, the reservation was dropped from the new declarations of Canada, Australia and New Zealand made in 1970, 1975 and 1977 respectively and therefore, it has now disappeared.

The elimination of the reservation might be due to the limited practical value of the reservation and the strong criticism levelled at it. The possibility that a party can convince the other party to accept something less acceptable than his rights or change his view in less than 12 months, which is a very short period in international relations, has been questioned. ${ }^{58} \mathrm{~A}$ decision from the Council to examine the dispute was also a necessary condition for the operation of the reservation. Moreover, the jurisdiction of the Security Council is limited by virtue of Chapters VI and VII of the Charter to certain kinds of disputes described therein and even with regard to these disputes the council is under an obligation to take into consideration that legal disputes should be referred to the Court ${ }^{59}$ (Article 36 (3) of the Charter). On the other hand some weighty objections have been raised against the inclusion of the reservation. It is observed that such a reservation does not allow only 
either party to a dispute to suspend the judicial proceedings but any member of the United Nations since under Article 35 of the Charter any member state may bring a dispute to the attention of the security Council. 60 Furthermore, it is believed that the way in which disputes are handled by the Security Council does not justify the substitution of that body for the court in the settlement of legal disputes. On the contrary the Council's composition; namely, being composed of representatives of various states, the resort to "walking outs". delays and adjournments are elements that can magnify and complicate the dispute instead of resolving it. 61

To sum up, the suspensive reservation is undesirable, as long as it is intended to harmonize arrangement for peaceful settlement, because, as $R$ St J Macdonald observes, "at best it will accomplish a delay [and] at worst it will be invoked against the declarant ... not only in matters which are 'really political in character' " 62

\section{(III) Disputes in Regard to which the Parties Have Agreed to Have Recourse to Other Means of Peaceful Settlement}

The Netherlands declaration of 1921 was the first to introduce this reservation. It was made in respect of "any future dispute in regard to which the parties have not agreed to have recourse to some other means of friendly settlement." 65 The use of the reservation soon became quite common. In fact it has been the most popular reservation since 1921. It appeared in 25 out of 56 Declarations made under the Optional Clause of the P. C. I. J. ${ }^{64}$ and it is now included in 22 out of the 45 declarations in force. ${ }^{65}$ It has been used in two forms. Whilst some declarations exclude disputes in respect of which the parties have agreed before their acceptance of the compulsory jurisdiction under Article 36 (2) to have recourse to other means of settlement, bo the majority 
have extended the scope of their reservations to cover even subsequent agreements. They excluded disputes in respect of which the parties "HAVE AGREED or SHALL AGREE" to have recourse to other means of peaceful settlement. Being framed in general terms, the reservations have given rise to many difficulties of interpretation, especially as to the meaning of the expression "other means of settlement".

\section{(i) The meaning of the expression "other means of peaceful settlement"}

Different views have been propounded on the meaning of this expression. Those views can be grouped into 3 main groups. Some authors believe that according to both the classical terminology and the terms of Article 33 of the Charter of the United Nations the expression encompasses all the peaceful methods of settlement, whether judicial or political. 67 The absence of any qualifications in the reservation except the requirement that the other means must be peaceful is advanced as another argument. The other means must not, therefore, be judicial, or arbitral, or binding or final. The reservation is in line, it is argued, with the flexibility that characterizes the charter provisions on the peaceful settlement of disputes. It "serves to encourage the development of a definite procedure for peaceful settlement by determining in advance a rough order of priorit$y^{\prime \prime}$. 68 In the same direction some go further as to include within that expression even the political organs of the United Nations. 69

According to the second view the reservation, being copied from treaties of arbitration and conciliation, is inserted in part to preserve special arbitral procedures envisaged in early treaties and in part to safeguard the procedure of conciliation. 70 
Finally, some authors observe that the expression "other means of peaceful settlement" is limited to judicial and arbitral means. For the expression "peaceful SETTLEHENT" implies that the "other method" is one leading to a final result. 71

However, in the absence of a clear pronouncement by the Court, ${ }^{72}$ the meaning ot that expression depends to a large extent on the intention of the parties to the dispute brought before the court. Yet there are some indications that the political procedures are excluded from the scope of that expression or at least limited. The existence of a reservation designed to suspend proceedings before the court when the dispute is under the consideration of the Security Council, seems to exclude the political organs of the United Nations. 73 . If States intended to extend the scope of other means of peaceful settlement so as to cover the political organs of the United Nations, they would not have made the suspensive reservation. However such a reservation appeared in all declarations along with the reservation of other peaceful means of settlement. State practice also seems to indicate that the meaning of that expression is limited to peaceful means leading to a final settlement for the following reasons. Firstly, some states - as has been seen $^{74}$ - have qualified the expression in that direction. Secondly, when states intended to extend the scope of that expression, they have not hesitated either to enumerate these methods or to use other terms. Thus, the French declaration of 1929 limited the Court's compulsory jurisdiction to disputes which had not been settled by COHCILIATION or the COUHCIL Or by OTHER HETHOD OF SETTLENENT BY ARBITRATION 75 and the Italian declaration, made in the same year, recognized the jurisdiction of the $P$. C. I. J. "subject to any other method of settlement provided by a special convention, and in any case where a solution through the diplomatic channels or further by the action of the Council of the League of Nations could not be reached". 76 on the other hand, India and Kenya 
have expressed their intention not to limit the scope of the expression "other peaceful means of settlement" to those leading to a final settlement. Their declarations exclude "disputes in regard to which the parties to the dispute have agreed or shall agree to have recourse to some other METHOD or HETHODS of settlement. ${ }^{77}$ The declaration of Gambia may also be interpreted in the same way. It excludes "disputes in regard to which the parties have agreed to a settlement OTHER THAN BY RECOUPSE TO THE INTERNATIONAL COURT OF JUSTICE. 78

Thirdly, the British explanation, though special, of the effect of the reservation seems to support the above interpretation. It was said that:

\footnotetext{
"Commercial treaties and conventions dealing with special subjects such as reparations, or other technical matters, such as copyright, very often contain provisions setting up SPECIAL TRIEUHALS to deal with disputes which may arise as to the meaning or application of their terms. When that is the case, the dispute will be dealt with as provided in the egreement and will not be submitted to the Court at the Hague."
}

Finally the limitation of the meaning of the expression "other means of peaceful settlement" to means leading to a final settlement seems to be in line with the object of accepting the compulsory jurisdiction. It may be doubted whether in accepting a settlement by a binding decision states intended to resort to other means which do not lead to a final solution. 80

The determination of the meaning of that expression is an important element in the determination of the effect of the reservation. Thus if the above interpretation is correct, there would be no need to enquire whether the reservation has a suspensive effect, or would a mere recourse to another means of peaceful settlement exclude altogether recourse to the court. The existence of the reservation renders the exhaustion of the agreed upon process a pre-condition for the Court to take cog- 
nizance of the case. If the parties reach a final settlement by the agreed upon process, there should be no need at all to have recourse to the Court. Otherwise their failure to reach such a settlement, for one reason or another, cannot deprive the court of jurisdiction. However the wording of the reservation would not warrant an answer if the expression "other means" is extended to cover non-judicial as well as judicial means. 81 In such a case the intention of the parties must be considered in every case. 82

\section{(ii) The significance of the reservation}

According to the terms of the reservation a real agreement between the parties to the dispute is a necessary condition for the application of the reservation. It is obvious that if the parties to a dispute agree to settle it by other means than the Court they will not bring it before the court. If their agreement to resort to another means is reached after the seising of the Court they can discontinue the judicial proceedings at any time pursuant to Article 88 of the Rules of the Court. Thus the reservation seems to have been made only with the object of excluding proceedings instituted in violation of an agreement to resort to other means for the settlement of that dispute. The necessity of the reservation is questioned also even with regard to the last hypothesis. For the court, it is submitted, might "well decline to adjudicate in such a situation on grounds of judicial priority". 83 However, in the absence of a clear pronouncement by the court on the scope of the reservation its significance is unclear. Nevertheless, the Court's handing of a case referred to several other political organs simultaneously, the real risk of overlapping between universal, regional and other systems, and differences involved in those systems of possibilities, procedures and norms to be applied, appeared to some authors sufficient reasons for retaining the reservations as one that "facilitates adjustments between systems of 
dispute settlement and allows states maximum flexibilit$y^{\prime \prime}$. 84 However the Court's jurisprudence that the parallel exercise of jurisdiction by judicial and non-judicial means over the same dispute can constitute an important and decisive factor in promoting the peaceful settlement of a dispute, ${ }^{85}$ seems to indicate that those reasons may not justify the exclusion of the judicial settlement if the parties are really willing to settle their disputes.

The conclusion to be drawn from the foregoing considerations is that the reservation of disputes in regard to which the parties have agreed to have recourse to some other method of peaceful settlement has not been relied on in practice in spite of being widely adopted. Nevertheless the expression "other means of peaceful settlement" is vague. It needs to be clarified if it is to be maintained. There are two ways for such improvement; either to adopt the formula in the declaration of Australia, namely, disputes "in respect of which the parties thereto have agreed or shall agree to have recourse to OTHER HEANS OF PEACEFUL SETTLEHEHT FOP ITS FINAL AND BINDING DECISIONS", 86 or to adopt the formula used in some treaties providing that if no definite and obligatory solution is arrived at by recourse to other means of pacific settlement the Court will be competent.

\section{(IV) Previous Recourse to Diplomatic Channels}

\section{(i) The reservation of disputes not satisfactorily adjusted by diplomacy}

The reservation that recourse to judicial settlement should be limited only to disputes "not satisfactorily adjusted by diplomacy" is - as the court observed - very common in bilateral treaties of amity and of establishment. 88 An attempt to include a similar condition in the statute of the P. C. I. J. was made - it is to be recalled - by the Committee of Jurists, which drafted that statute in 1920. However the condition was 
deleted later from Article 33 of the drafted Statute when it was referred to the Assembly and the Council of the League of Nations. 89 This reservation reflects States preference of diplomatic means for the settlement of their disputes. In fact, the settlement of disputes by the Court is today, for various reasons, less popular in international society than, the other means of dispute settlement, especially the diplomatic ones. 70 Yet it is beyond the scope of this thesis to discuss all those means separately in order to find out the advantages which have encouraged states to reserve the right to solve their disputes by those means rather than by the Court. 91 It may suffice to note here that the fear of loss of control over the case is regarded generally the main reason behind states reluctance to refer their disputes to judicial settlement as a "win - or -lose. zero - sum game". 92 This reason is best summarised by the late judge Sir Fitsmaurice. Drawing upon his long experience as juris consult, he ascribes the preference of almost all governments to settle their disputes by "means of political acts they understand, rather than judicial ones they do not and tend to distrust" to the fear of :

"Loss of all freedom of manoeuver once the dispute is fairly in the hands of a Court or arbitral tribunal. No longer then - whatever may be achievable through the forensic artscan the processes of propaganda, persuasion, bargaining: lobbying and the manipulation of votes. It is the feeling of Lose of ConTPoL over the future of the case when it becomes SUB-7UDTCE, and goes as it were into cold storage for perhaps two or three years before the final decision is given; as compared with the ability to retain such control whenever the matter is dealt with on a political basis or in a political forum, which, even if only subconscicusly, qus case governments to shy away from the arbitrator or judge".

However, the reservation of previous recourse to diplomatic channels has never appeared EXPPEssly in a declaration of acceptance except in the Italian Declaration of 1920. 94 It was relied on by France in PHOSPHATES IN Horocco case. 95 However the Court, having upheld 
another objection, did not feel called upon to adjudicate on the objection based on that reservation. 76

Among the declarations currently in. force, the Japanese declaration is perhaps the only one that can be interpreted as to require a previous recourse to diplomatic channels. It excludes disputes "which are not settled by other means or peaceful settlement". "97 This reservation must not be confused with the reservation of disputes with regard to which the parties have agreed to have recourse to some other method of settlement. Whereas the latter intends - as has been said ${ }^{98}$ - to safeguard the competence of other organs as the parties have agreed, the former is designed to impose an obligation on the other party to show evidence of effort to settle the dispute by diplomatic means before resorting to the Court, 99 even if the parties to the dispute have not agreed to resort first to diplomatic means of settlement. The court must, thus, ascertain whether recourse negotiations had taken place before the filing of the application instituting proceedings before it, and it will uphold an objection to its jurisdiction based on the reservation if such a condition is not complied with. This is what can be inferred. from the Court's practice, under Article 36 (1) of the Statute, concerning this reservation. Although the court has not upheld such an objection, it has always made it clear that that condition must be complied with before the filing of the application instituting the proceedings before it. 100

The rejection of the objection based on the reservation of previous recourse to diplomatic channels might be due to the permissive approach that has been followed in the ascertaining of the exhaustion of diplomatic negotiations. This approach was followed by the P. C. I . $J$. in the MAUROMHATIS PALESTINE CONCESSIONS case where it said: 
"Negotiations do not of necessity al hays presuppose a more or less lengthy series of notes and dispatchess it may suffice that a discussion should have been commenced, and this discussion may have been very short: this will be the case if a deadloct: is reached, or if finally a point is reached at which one of the Farties definitely declares himself unable; or refuses to give way, and there can be therefore no doubt that the dispute cannot be settled by diplomatic regotiation." 101

While maintaining the same approach, 102 the I. C. S. has taken a more permissive outlook towards the requirment of diplomatic negotiations provided for in the jurisdictional title. Thus in the souTH-HEST AFRICA case the Court, after recalling its predecessor's view that "it is not so much the form of negotiation that matters as the attitude and views of the parties on the substantive issues of the question involved", 105 interpreted a reservation limiting the jurisdiction to disputes that cannot be settled by negotiation as not requiring a direct negotiation between the parties to the dispute before it. It considered the extensive debate in the United Nations Organization over the subject matter of the dispute sufficient. The court held that the collective negotiation in the United Nations had reached an impasse and therefore it was evident that "there can be no doubt ... that the dispute cannot be settled by diplomatic negotiation". 104

In the UNITED STATES DIPLOHATIS AND COHSULAR STAFF IN TEHERAN case the Court has given another example on how a deadlock can be reached. It said that the refusal of a party to enter into any discussion of matter would dispose of the requirement of previous recourse to diplomacy.

This being the case when the reservation is included in a declaration, can it be said that the situation is the same even in the absence of as express reservation because such a condition is inherent in the Statute or in declarations silent on this point? 


\section{(ii) Priority of diplomatic negotiations}

The question whether there exists an obligation to recourse to diplomatic negotiations before referring a dispute to the court had been considered before the INSTITUT de DROIT International in 1956 when a proposition was made to introduce a reservation to that effect in the "clause - modele" for the compulsory jurisdiction of the court. That proposition was rejected by a large majority (40 votes to 15 ). 106 The refusal to adopt such a reservation was due mainly to the convincing arguments advanced by Jessup and Waldock. Jessup regarded it as a survival of the period during which governments were hesitating to submit their disputes to the court. He thought that the insertion of such a reservation would mean that judicial settlement by the court is regrettable. Whereas states should consider such method as a normal means for the settlement of their disputes. 107 In addition to this argument, Waldock drew attention to the danger of retaining that "traditional clause". He relied on the cases on which the reservation was invoked (HAUROHHATIS and PHOSPHATES IN MOROCCO) to show how it can incite states to use it as a "dilatory manoeuvres".

Yet many authors still believe that the court cannot take cognizance of a case unless it is satisfied that diplomatic channels have failed to settle the dispute. This is because the obligation to resort to diplomatic negotiations is, it is argued, either a customary rule of International $1 \mathrm{aw}^{109}$ or a general principle of international law that cannot be ignored by the court 110 in support of these views, reliance has been made on State practice in inserting the reservation of previous recourse to diplomatic channels in a large number of compromissory clauses; the jurisprudence of the court, and on the fact that negotiations are made on the top of peaceful means of settlement of disputes listed in Article 33 of the Charter of the United Nations. 
It is true that in practice it will rarely happen that disputes will be referred to the Court without there having been some diplomatic negotiations beforehand. However to argue that the previous recourse to diplomatic negotiations is a customary rule or general principle of international law, the argument seems to fall of its own weight. Firstly, the failure to adopt such a condition in the Declaration on Principles of International Law Concerning Friendly Relations and Co-operation Among States in accordance with the Charter of the United Nations 112 in spite of the insistence of some states, in addition to the refusal of the Institut de Droit International to do so, might refute such an argument. 113 secondly, state practice in including the reservation in compromissory clauses seems to support the non-existence of a rule or principle requiring the exhaustion of diplomatic means more than the existence of such a rule or principle. The inclusion of the reservation in some compromissory clause and its absence in the statute and declarations of acceptance seems to indicate that. States somETIHEs and not always, require that judicial settlement should be preceded by diplomatic negotiations. 114

Thirdly, it is true that some of the Court's statements appear at first glance to suggest that recourse to the Court should be limited to disputes that cannot be settled by diplomatic means. Thus the following statements are usually cited:

1. "The Court realises to the full the importance of the rule laying down that only disputes which cannot be settled by negotiation should be brought before it." 116

2. "It would no doubt be desirable that a State should not proceed to take as serious a step as summoning another state to appear before the court without having previously, within reasonable limits, endeavoured to male it quite clear that a difference of views is in question which has not been capable of being otherwise overcome." 117

3. "Whereas the judicial settlement of international disputes, with a view to which the court has been es- 
tablished; is simply an alternative to the direct and friendly settlement of such disputes betueen the Farties? as consequently it is for the Court to facilitete; so far as it is compatible with its Statute such direct and friendly settlement."

However these statements should be read in their proper context and not isolated form what precedes and follows. Thus the interpretation of the first statement requires that two things must be borne in mind: firstly, the Court was faced with a clear reservation in the title of Jurisdiction limiting its jurisdiction to disputes which "cannot be settled by diplomacy", 117 and secondly, what follows that statement. The court qualified its statement by the following phrase:

"It recognises, in fact, that before e dispute can be made the subject of an action of 1 ang its subject matter should haye been clearly defined by means of diplomatic negotiation." 120

The real intention of the court was, therefore, to indicate the role of diplomatic negotiation in the definition of the subject matter of the dispute. It is clear that such a role is different from the requirement that diplomatic negotiation must first be exhausted.

The same can be said in regard to the second statement. For it is preceded by the following passage:

\footnotetext{
"In so far as concerns the word "dispute", the court otserves that $\ldots$ the manifestation of the existence of the dispute in a specific manner, as for instance by diflometic negotiations is not required."
}

Moreover, the Court referred to its previous holding in the GERHAN IHTERESTS IN POLISH UPPEP SILESIA case that so long as the title of jurisdiction does not stipulate that diplomatic negotiations must first of all be tried, recourse may be had to the Court "as soon as one of the parties considers that a difference of opinion" has arisen. 
As to the third statement, it should be remembered that the Court's competence was based on the canproMIs according to which the parties themselves had asked the Court to help them to negotiate during the process of the judicial procedure. 124

Finally, the reference to diplomatic negotiation first in Article 33 of the Charter does not necessarily mean that it must be resorted to before other means. These are not in fact listed in order of priority. 125 The jurisprudence of the court in recent cases is clear, not only on this point but on the whole conception of the inherent priority of diplomatic means. In rejecting such a conception the court said in the UNITED STATES DIPLOHATIC case that "negotiation, enquiry, mediation, conciliation, arbitration and judicial settlement are EHUHERATED TOGETHER in Article 33 of the Charter as means for the peaceful settlement of disputes", and that negotiation and recourse to judicial settlement by the court had, in many cases, pursued PARI PASSU. ${ }^{126}$ The Court was clearer on the issue in the AEGEAN SEA CONTINENTAL SHELF case. Facing the question whether the existence of continuing and active negotiations between the party would constitute an impediment to the Court's exercise of jurisdiction, it did not hesitate to give a negative answer. Without even examining whether the parties had began negotiations on the subjective issue or whether they were meaningful or not, as the letter of the Ambassador of Turkey to the Netherlands of April 24, 1978 seems to require, the court said:

"[It] is unable to share this view. Negotiations and judicial settlement are enumerated together in Article 30 of the Charter of the United Nations as means for the peaceful settlement of disputes. The jurisprudence of the Court provides various examples of cases in uhich nenotiations and recourse to judicial settlement have been fursued PARI PABSU. Several cases, the most recent being that concerning the Trial of Falistani Frisoners of War . . show that judicial proceedings may te discontinued when such negotiations result in the settlement of the dispute. Consequently, the fact that negotiations are being actively fursued during the present proceed- 
ings is not, legally, any obstacle to the exercise by the Court of its judicial function".

This dictum has been relied on by the Court in the HILITARY AND PAPANILITARY ACTIUITIES IN AND AGAINST NICARAGUA case in rejecting the firth ground of inadmissability put forward by the United States, 128 namely, the exhaustion of the regional negotiation (through the Contatodora process) "is laid down in the Charter as a precondition to the reference of a dispute to the Security Council only, in view of its primary responsibility in this domain, but such a limitation must A FORTIORI apply with even greater force with respect to the court". The Court observed that neither the Security Council nor itself should be prevented from exercising their separate functions under the charter and the statute because of the existence of active negotiations in which both parties may be involved. 130

It is clear from these cases that there is no principle or rule of international law which requires the judicial settlement to be preceded by diplomatic negotiations, 131 and that the priority of diplomatic negotiations requires an express reservation in the declaration of acceptance.

To conclude, States, contrary to their practice with respect to compromissory clauses, have not generally included an express reservation requiring the previous exhaustion of diplomatic means before the institution of proceedings. Such an attitude might be justified by the fact that in practice it will rarely occur that a case will be submitted to the court without there having been some diplomatic negotiations beforehand as well as by the permissive attitude of the court in interpreting the reservation. For these reasons also the reservation proved to be a weak means for depriving the Court of jurisdiction. 


\section{SECTION (2) - SUBJECT-MATTER RESERVATIONS}

For a long time States have been urged to include, if necessary, reservations excluding disputes concerning particular cases as clearly specified subject matters. Although such reservations create "holes" in the scope of the Court's compulsory jurisdiction, they may, it is submitted, constitute a stage for more general acceptance rather than for eroding that jurisdiction. 135 Thus reservations concerning belligerency, territorial status, some areas of the law of the sea, and other reservations peculiar to certain States have been made.

\section{A - HOSTILITIES (RATIONE MATERIAE)}

\section{(I) Forms of the Reservation}

While some states have - as explained before 134 based their reservations relating to hostilities on the time during. which the dispute arose, and therefore excluded disputes occurring during a period of hostilities, others have relied on the relation between the hostilities and the dispute. This relation must be a relation of cause and effect for the exclusion of the dispute from the Courts jurisdiction.

Again the United Kingdom is the first country to introduce the reservation of hostilities RATIOHE HATER$I A E$. In its declaration of June 2, 1955 the United Kingdom excluded "disputes arising out of or having reference to any hostilities, war, state of war, or belligerent or military occupation in which the Government of the United Kingdom have been involved". "156 The reservation had been maintained in the British subsequent declarations except that of 1969 which is still in force. In due course this reservation has been incorporated in other declarations though in different forms. Aiming at excluding the events relating to the Algerian War of Independence, ${ }^{137}$ France had made a similar reservation but in broader terms. 
Whereas the application of the British reservation was subject to the involvement of the U. K. in the Hostilities, the French reservation excluded simply "disputes arising out of any war or international hostilities". 138 Thus the question of whether the reservation could have been invoked, even when France was not involved in the war or international hostilities had been left open. This may be illustrated by the following example: suppose that there was a war between State $X$ and state $Y$ and France wanted to protect its nationals against state $Y$. Could the latter have relied on the French reservation? The terms of the reservation seems not to warrant a confident answer. 139 The same can be said with respect to the reservation of Malawi excluding "disputes concerning any question relating to or arising out of belligerent or military occupation".

Three other declarations 141 are similar with an important addition of a provision excluding disputes over peace keeping activities. This provision adds disputes concerning "the discharge of any functions pursuant to any recommendation or decision of any organ of the United Nations in accordance with which the Government ... have accepted obligations". This formula was introduced by India in its declaration of 1959. $142 \mathrm{~A}$ It is said that the reservation was made in the Indian declaration with the object of excluding from the Court's jurisdiction disputes relating to India's roles in such places as Korea and the Gaza Strip, where India undertook certain obligations on behalf of the United Nations, in addition to the exclusion of the Kashmir dispute, though the latter was excluded by other reservations.

A more restrictive form is to be found in the declaration of Honduras of 1986. It exempts from the Court's jurisdiction disputes "relating to facts or situations originating in armed conflicts or acts of a similar nature which may affect the territory of the Republic of Honduras, and in which it may find itself 
involved directly or indirectly".

The final and the most comprehensive form of the reservation is that introduced by the declaration of $E 1$ Salvador of 1973 and copied literally by India in its declaration of 1974 . They cover:

\begin{abstract}
"disputes related to or connected with facts or situations of hostilities, armed conflicts, individual or collective actions taken in self-defence, resistance to aggression, fulfillment of obligations imposed by international bodies? and other similar or related acts, measures or situations in which [the declarant] is, has been or may in future be invol ved" " 144
\end{abstract}

The state hostilities that characterizes the relations between the Central American States, which almost all accept the Court's compulsory jurisdiction, seems to have been the main reason behind the introduction of this formula by El Salvador. Such a formula appeared to India more protective especially in the light of the claim brought by Pakistan in the PRISONERS OF HAP case. 145

\title{
(I I) Evaluation of the Reservation
}

A comparison between the declarations accepting the compulsory jurisdiction of the I. C. J. and its predecessor, the P. C. I. J. shows clearly that the reservations relating to hostilities constitute a depressing development. ${ }^{14 b}$ No comparable reservation is to be found in any declaration made under the Optional Clause of the P. C. I. J. Furthermore, the different forms of the reservation disclose a disquieting trend away from the exclusion of disputes arising out of hostilities, belligerent or military occupation, towards the use of force for the United Nations purposes and in the recent form almost any use of force by the belligerent state. 147

However can it be said that the reservation itself in its different formulae is no more than a reflection of the actual legal pattern provided for the settlement of 
disputes arising out of international institutions, since the settlement of such disputes, being conferred by virtue of Chapters VI and VII of the Charter on the political organs - especially the Security Council - is outside the scope of the Court's jurisdiction?

The HILITARY AND PARAHILITARY ACTIUITIES IN AND AGAINST NICARAGUA case 148 provided the Court with an opportunity to consider this question. Here the United States maintained that inadmissibility of disputes involving armed hostilities is an implied limitation on the Court's jurisdiction. It argued that an ongoing use of unlawful armed force was never intended by the drafters of the Charter of the United Nations to be encompassed by Article 36 (2) of the statute of the Court. 149 The "primary" responsibility for the maintenance of international peace and security was, it was asserted, conferred on the Security Council and complementary responsibilities were conferred on the General Assembly and regional organizations, but not upon the court. Furthermore, there were no words in the Charter or the Statute which suggest a role for the court with respect to actions under Chapter VII of the Charter. On the contrary, the United States argued, the drafters intended to confine on the Security Council the entire responsibility over disputes falling within the scope of that Chapter. 150

The Court, however, found by a vote of 16 to 0 that the ongoing armed conflict in Nicaragua was no barrier to judicial resolution of the legal aspects of that conflict. 151

Examining the above arguments advanced by the United States, judge Schwebel found himself unable to agree that the drafters of the charter and the statute intended to exclude the court from adjudicating disputes falling within the scope of Chapter VII of the Charter. Nor could he agree that the practice of states in interpreting the Charter and statute confirmed such intention. 
These arguments appeared to him insufficient because of the absence of a text excluding disputes involving the continuing use of armed force from the Court's compulsory jurisdiction. On the contrary Article 36 of the Statute is cast in comprehensive terms, he observed. Paragraph 1 of that Article confers on the Court jurisdiction over "all cases" which the parties refer to it and "all matters specially provided for in the Charter of the United Nations or in the treaties and conventions in force", and paragraph 2 provides that the states may recognise the compulsory jurisdiction "in all legal disputes". The exclusion of disputes over the continuing use of force required an express reservation to that effect in the declaration of acceptance, he pointed out. 158

By upholding its jurisdiction to entertain Nicaragua's claims, the court also rejected the notion held by many jurists and commentators that "force cases" are not justiciable or that the court is ineffective in adjudicating such cases. 154

However, the HILITARY AND PARAMILITARY ACTIUITIES case has offered a precedent in the light of which some American lawyers have made some suggestions with respect to the reservation of hostilities. Having predicted that the United States, having withdrawn from the Court's compulsory jurisdiction as a result of that case, would not rejoin on terms that would permit lawsuits similar to Nicaragua's, Professor A D'Amato suggests the retention of the reservation of hostilities either in a modified form or as it exists in the declaration of other states.

He proposes the insertion of the following proviso in a future United States declaration:

"PROUIDED FURTHER, that with respect to disputes relating to, or pleadings of any contesting Farty that allege or refer to, ongoing armed hostilities or the threat or use of military force, the Court may only declare the righte and duties of the Farties under international 1 aw, and may not issue any order or enforceable judgment." 
He finds in the possibility that the Security Council might be caught between enforcing its primary mission - namely, maintaining international peace and securityand enforcing a judgment of the Court, a principled argument for his proposal. Such a possibility may occur, in his view, when a state does not comply with the judgment and the Security Council finds that the enforcement measures against that State might endanger international peace and security. Thus he proposes the inclusion of the above proviso as a remedy for that dilemma, on the one hand, and as an alternative to the over broad reservation of all cases of ongoing armed hostilities, on the other hand. As a further precaution, he suggested that the above proviso may provide also that "it is to be automatically amended to exclude cases involving ongoing armed hostilities entirely from the Court's jurisdiction". 157

Such a proposal seems to run against the object for which it is made regardless of whether it is compatible with the United Nations Charter and the Court's Statute or not. ${ }^{158}$ Firstly, it has never occurred in practice that the Security Council faced such a dilemma and it seems unlikely to happen. The enforcement of a judgment means enforcement of international peace and security as the primary mission of the Council since legally the later is obliged - as noted before 159 - by virtue of Article 36 (3) of the Charter to take into consideration that legal disputes should be referred to the court. Secondly, assuming that such a dilemma was likely to happen, it would not be limited to the enforcement of a judgment concerning armed conflicts, but to the enforcement of other judgments as well so long as the interested State is refusing to comply with the judgment. The proposed proviso can thus constitute a new device, which if generalised with respect to other disputes, may further erode the system of compulsory jurisdiction instead of mitigating the effect of the reservation concerning ongoing armed hostilities. Finally, it seems wiser to oblige a state, which has accepted voluntarily the com- 
pulsory jurisdiction system, to respect its obligation under Article 94 of the Charter to comply with the decision of the court rather than to try to prove the compatibility of the declaratory judgments with the Charter and statute. Such an attempt would not only nullify the effect of an Article (94) embodied in the Charter, but also weaken the whole system of adjudication provided in the statute.

In fact the above proposal might be considered as an over-caution on the part of professor D'Amato, as one of the foremost advocates of the judicial settlement by the court, in trying to find an acceptable way which could encourage states to adhere to the compulsory jurisdiction system and at the same time does not weaken that system. Thus he asks whether cases such as the MILITARY AND PARAMILITARY ACTIUITIES are not an ideal occasion for settling conflicts in court instead of the battlefield. $\mathrm{He}$ also considers the inclusion of the reservations relating to hostilities by states as a sign of falling prey to "a strange psychology", 150 criticising the reservation in the United Kingdom declaration of 1944 excluding cases originating in events of the Second World War he says:

\footnotetext{
"One wonders with bombs. dropping on London, what made lawyers and government officials in their underground shelters so frightened by the prospect of a ruling on the legality of a war-related case by a court of law sitting at the Hague." 161
}

Furthermore in his editorial comments published in the preceding year i.e. 1985, 162 he criticises very strongly the reservation excluding disputes involving armed hostilities. He observed that such a reservation would disable the reserving state from resorting to the Court in many cases that may arise in the future, such as disputes arising out of terrorist acts especially those supported by a State. ${ }^{163}$ More significantly, the reservation may encourage the reserving state to escalate disputes that have began peacefully into armed hostilit- 
ies so as to avoid the Court's jurisdiction. Thus, warning shots by a military vessel sent to a self-proclaimed "exclusive economic zone" might escalate a dispute over fishing rights in that area into a dispute involving armed hostilities. Also "a military action that has ceased, and thus becomes subject to a lawsuit for damages, might be revived by intermittent military actions". 164 These examples indicate how the reservation can cut a "hole" in the jurisdiction of the Court. 165

Nonetheless, it would be better to have the reservation of hostilities included in the declaration of acceptance, especially where it is made alone and not in the broadest and the most objectionable form, if the acceptance of the compulsory jurisdiction is subordinated to the insertion of such a reservation. 166

It is to be observed, finally, that the reservations relating to hostilities might, at first glance, give the impression that they are made by great powers as an indication of their intention to protect their interests by reliance on their own power rather than by submission to a system which they cannot control. In fact those reservations are to be found only in the declarations of developing countries. This is not perhaps surprising since most of the hostilities exist between those countries. With the exception of $E l$ Salvador those reservations are made by some states, members of the Commonwealth (India, Kenya, Malawi, Malta and Mauritius). Since the declaration of these states, except that of India, were made at a time when a similar reservation was made by Great Britain, it is hoped that these states will also drop those reservations. They deal with an area of international law of fundamental importance and thus constitutes a "pernicious erosion of the Court's jurisdiction". 167 


\section{B - TERRITORIAL STATUS RESERVATION}

Although territorial disputes have, sometimes, been one of the major reasons behind the insertion of some broad reservations, 168 the territorial status reservations as such have only appeared after 1924. 167 However. as far as the declarations of acceptance are concerned. the reservation appeared for the first time in the Greek declaration of 1929. 170 The reference in Article 39 the Geneva General Act of 1928 to a possible reservation excluding "disputes concerning particular cases or clearly specified subject-matters, such as territorial status" must have led to the inserting of the reservation in the Greek declaration. 171 It was then copied by several States some of which repeated the statement in the Greek declaration that disputes relating to sovereignty of ports and ways of communication were included in those concerning territorial status 172 and others excluded simply disputes relating to territorial status of the reserving state ${ }^{173}$ or relating to its "right of sovereignty". 174

The Iranian declaration of 1930 had, for some time, been the only one that contained such a reservation among the declarations made under Article 36 (2) of the I. C. $J$. By the termination of that declaration in 1951 after the institution of proceedings in the AHGLO IPANIAN OIL COMPANY case the reservation disappeared.However since 1972 it has reappeared in some declarations in connection with the reservations concerning the law of the sea. It was reintroduced by the Philippines in its declaration of 1972. which excluded disputes "arising out of or concerning jurisdiction or rights claimed or exercised by the Philippines ... in respect of [its] territory ... including its territorial sea and inland waters". 175 El Salvador and India except disputes "concerning or relating to ... the status of [their] territory or the modification or delimitation of [their] frontiers or any other mater concerning boundaries". 176 In 1983 Malta modified 
its declaration of 1966 in order to add new reservations excluding - INTER ALIA - disputes concerning "its territory, including the territorial sea, and the states thereof". ${ }^{177}$ Finally, the declaration of Honduras excepts, in addition to disputes concerning facts and situations originating in armed conflicts or similar acts which may affect its territory, disputes relating to "territorial questions with regard to sovereignty or islands, shoals and keys, internal waters, bays, the territorial sea and the legal status and limits thereof".

However, two questions may be raised with respect to territorial status reservations: what is the object of the reservation and its scope?

\section{(I) The Object of the Reservation}

It has been maintained that the insertion of territorial status reservations in numerous bilateral treaties of pacific settlement of the inter-war period was GENERALLY due to a prevailing apprehension of attempts to modify the post-war arrangements. 179 However, the inclusion of such reservation in both those treaties and in declarations of acceptance reflects the reserving state's intention to exclude specific disputes. Thus the reservation was made by Greece in both the declaration which accompanied its instrument of accession to the General Act of 1928 and its declaration of acceptance of the $P$. C. I. J.'s jurisdiction of 1929, as the Court pointed out in the AEGEAH SEA CONTIHENTAL SHELF case, in order "to guard against the revival of Bulgarian aspirations to cover direct access to the Aegean Sea". 180 The dispute over the Rock of Quitastueno and Swan Islands between Honduras, on the one hand, and Columbia and the United States, on the other hand, 181 and the dispute between Honduras and El Salvador concerning Land, Island and Maritime Frontier 182 seems to have led both Honduras and El Salvador to insert into their declarations the aforesaid reservations. 


\section{(II) The Scope of the Expression "Territorial Status"}

The AEGEAN SEA CONTINEHTAL SHELF case has provided an opportunity for the Court to determine the scope of the expression "territorial status" and to pronounce on an important point of interpretation applicable to any reservation, namely, the effect of the subsequent evolution of international law on the terms of a reservation intended to exclude some determined disputes.

It was maintained by the applicant (Greece) that the expression "territorial status." and other equivalent terms such as "territorial integrity", "territorial situation" and "maintenance of frontiers" were included in order to exclude "disputes which were likely to arise out of territorial claims by neighbors dissatisfied with existing solutions". 183 Such expressions constituted, it was argued, of no more than "a 'code-word' for intangibility of the frontiers and territorial statuses established by the international instruments in force". 184

The Court recognised that the motive which led States to include the reservation of territorial status was. IN GENERAL to protect themselves against possible attempts to modify territorial arrangenents established by peace treaties. However, it observed that it did not follow that states intended to have the scope of the reservation confined to questions connected with the revision of such arrangements. The historical evidence adduced by Greece did not suffice, in the opinion of the Court, to establish that the expression "territorial status" was used in that restricted sense. On the contrary, the evidence seemed to confirm that the expression:

\footnotetext{
"is to be understood as a generic term denoting any matters properly to be considered as comprised within the concept of territorial status under general internetionel law and therefore includes not only the particular legel regime but the territorial integrity and the boundaries of a state".
} 
Nor did the Court accept the argument that the reservation was not applicable because it concerned the subjectmatter (the Continental Shelf) which was wholly unknown when the reservation was made. Such a reservation was "intended to have a fixed content regardless of the subsequent evolution of international law", the court observed. Furthermore, having observed the close and necessary link that always exists between a jurisdictional clause and reservations to it, the court found it difficult to accept the idea that the meaning of such a clause, but not of the reservation, should follow the evolution of the law. ${ }^{186}$ Consequently a reservation must be interpreted in accordance with the rules of international law as they exist when the application is considered by the Court, and not as they existed when the reservation-was made, the court concluded. 187

In the light of this interpretation, the court refused to accept the contention that the reservation of territorial status was not applicable to Greece's submissions because firstly the dispute concerned the DELIHITAIIoN of the Continental Shelf boundary, a question which was "entirely extraneous to the notion of territorial status", and secondly, disputes concerning rights over the Continental Shelf could not be considered as encompassed by reservations since the Continental Shelf was not part of the territory of the Coastal state under applicable rules of international law.

In rejecting the first argument the Court observed that, quite apart from the fact that the dispute was not simply one relating to delimitation, it would be difficult to consider such delimitation as entirely extraneous to the notion of territorial status. For "any disputed delimitation of a boundary entails some determination of entitlement to the areas to be determined". 189 Additionally, the historical evidence proved that in treaty practice the notion "frontier" had been considered as closely associated with the notions "territorial 
integrity" and "territorial status".

As to the second argument, the Court observed that it was asked to decide whether the dispute referred to it was one "relating to the territorial status" of the applicant and not whether the rights in dispute were legally to be considered as territorial rights. However, "a dispute regarding entitlement to and delimitation of areas of Continental Shelf tends by its very nature to be one relating to territorial status". This was so because, the Court continued, "legally a coastal state's rights over the Continental Shelf are both appurtenant to and directly derived from the State's sovereignty over the territory abutting on that Continental shelf". 191

The above case shows clearly that a reservation excluding a specified dispute is not only to the benefit of the compulsory jurisdiction of the Court, but could also be to the benefit of the reserving states. This lesson should be learned better not only by states which extended the scope of their reservations to disputes concerning "the airspace superjacent to [their] land and maritime territory 192 but especially by those extending it so as to cover disputes referring to airspace over the territories, waters, the contiguous zone and the exclusive economic zone. ${ }^{173}$ If the exclusion of territorial disputes might have some justification, being both related to a constitutive element of the existence of a state and made by developing countries most of which have gained their independence recently, 194 the above extension seems unjustified. However, the reappearance of the reservation especially in its broadest form is to be deplored. Such a development seems to disregard the efficiency of the Court in the settlement of territorial disputes, particularly those concerning the delimitation of both land and maritime territories. 195 Thus the declaration of Guatemala of 1947 provided the best example to be followed, if states are really interested in promoting the compulsory jurisdiction of the Court. It 
recognised the jurisdiction of the Court in all legal disputes except "the disputes between England and Guatemala concerning the restoration of the territory of Belize", unless it were decided EX AEQLO ET BONO in accordance with Article 38 (2) of the Statute. 196

\section{C - RESERVATIONS CONCERNING THE LAW OF THE SEA}

In addition to the previous reservation concerning territorial status, some states excluded another category of disputes concerning some areas of the sea. The latter reservation has been connected with the development of international law rules concerning those areas, and thus it has appeared recently in the declarations of acceptance. The Australian declaration of 1954 was the first one to contain such a reservation. It excluded from the Court's jurisdiction:

"disputes arising out of or concerning jurisdiction or rights claimed or exercised by Australia

(a) in respect of the continental shelf of Austrelia and the Territories under the authority of Australia, as that continental shelf is described or delimited in The Australian Froclamations of 10 September $195 \mathrm{~s}$ or in or under the Australian Fearl Fisheries Acts;

(b) in respect of the natural resources of the sea-bed and subsoil of that continental shelf, including the products of sedentary fisheries; or

(c) in respect of Australian waters, within the meaning of the Australian Fearl Fisheries Acts, being jurisdiction or rights claimed or exercised in respect of those waters by or under those Acts,

except a dispute in relation ot which the parties have first agreed upon a mobus UIYEHDI pending the final decision of the Court in the dispute.".

The Australian reservation had not been copied by any state until the beginning of the seventies. However since 1970 different reservations with different scope have emerged. This new era was inaugurated by the Canad- 
ian declaration of 1970, which contained two subjectmatter reservations: one on the living resources excluding disputes arising out of or concerning jurisdiction or rights claimed or exercised by Canada in respect of those resources, and the other - the first of its kind in the history of Article 36 (2) - on pollution. It excepted disputes "in respect of the prevention or control of pollution or contamination of the maritime environment in marine areas adjacent to the coast of Canada". 198 These reservations have been copied literally by Barbados. 179 While those declarations do not cover disputes relating to territorial limits and non-living resources of the sea, other declarations exclude both the latter disputes and those excluded by the Canadian declaration. Thus the declaration of Malta for instance, excludes besides disputes concerning its territory, including the territorial sea and the status thereof - as already mentioned 200 - the following categories of disputes concerning :

"(b) the continental shelf or any other zone of maritime jurisdiction, and the resources thereof,

(c) the determination of any of the above,

(d) the prevention or control of pollution or contamination of the marine environment in marine areas adjacent to the coast of Malta." 201

However the most comprehensive reservation is that included in the Indian declaration. Although it was - again - inspired by the declaration of El Salvador of 1973, the Indian declaration goes further in covering:

"disputes with India cancerning or releting to:

(b) the territorial seas the continental shelf and the margins, the exclusive fishery zone, the exclusive economic zone, and zones of national maritime jurisdiction including for the regulation and control of marine pollution and the conduct of scientific research by foreign vessels; 
(c) the condition and status of its islands, bays and gulfs and that of the bays and gulfs that for historic reasons belong to it:

(d) the airspace superjacent to its land and maritime territory: and

(e) the determination and delimitation of its maritime boundaries." 202

This is in addition to the aforesaid reservation of territorial status and boundaries. 203

\section{(I) Reasons for the Inclusion of These Reservations}

Two reasons seem to have led States to include the above reservations. The first is the desire to exclude one or more determined disputes. Thus, following the Japanese proposal, in October 1953, to refer the dispute over pearl fisheries in the Arafuga Sea to the Court, the Australian government withdrew its declaration of 1940 and included the aforementioned reservation. Australia agreed to submit the dispute to the court on the condition that the two states reach an agreement on a provisional regime. 204 Also the reservation of Canada was - as already mentioned 205 - designed to cover disputes over the Canadian Arctic Waters Pollution Prevention Act of 1970. 206

Apprehensions as to the results of the Third United Nations Conference on the Law of the Sea seem to have been the second reason for the inclusion of the above reservations. This is best illustrated by the Norwegian reservation, in the declaration of 1976 of "the right at any time to amend the scope of this declaration in the light of results of [the Conference] in respect of the settlement of disputes". 207 Canada was more explicit on this issue. As already mentioned, 208 it justified the insertion of its reservations on the grounds that applicable international law was undeveloped. This was because it failed "to keep place with technology, to 
adapt itself to special situation, and in particular to recognize the right of a coastal state to protect itself against the dangers of marine pollution". 209

\section{(II) Evaluation of These Reasons}

The above reasons appear to consist of insufficient grounds to justify the insertion of reservations couched in such broad terms as that of India, which is almost equivalent to one excluding the whole subject of the law of the sea. 210 It is clear that the application of the principle of reciprocity expands the scope of the reservation as was the case in the AEGEAN SEA CONTINENTAL SHELF case, 211 in spite of the fact that this principle can only be relied on by states in the region around the reserving state.

This kind of reservation is also criticised on the ground that the development of customary international law concerning the reserves matter will proceed irrespective of these reservations. Thus, the Court, in a case involving the maritime environment of Europe or Africa could define customary law in a way that would have a great impact upon claims concerning the maritime area around a reserving state in America. "The net effect of the reservation might therefore be to disable the reserving state] from participating in a case that could determine the content of customary law". 212

On the other hand the conclusion of the new treaty on the law of the sea must have eliminated any uncertainties on the new trend on the law, if they were actually a cause for inserting those reservations, which characterised the previous decade. The reserving states should, therefore, have followed the Canadian example by dropping those reservations from their declarations of acceptance.

Moreover, and most importantly, the above reservations undermine the Court's contribution to the modern 
Law of the sea. If these reservations, being limited to developing countries ${ }^{214}$ which played a major role in the development of the modern law of the sea, are intended to reflect apprehensions that the court might be very conservative on this issue, they disregard the fact that the Court has, on the contrary, been progressive, without, of course, departing from its judicial character. 215 Thus the regime of straights and the innocent passage of warships, is regarded as the outcome of the judgment of the CORFU CHANNEL case. ${ }^{216}$ The contribution of the court 's judgment in the FISHERIES case of $1951^{217}$ to modern law of the sea has been considerable. It established the system of strait baseline applied for indented and island-fringed coasts, a system which was explicitly provided for, for the first time, in the 1958 Geneva Convention on the Territorial sea and Contiguous Zone. Also the Court's judgment in this case helped to open the way to special treatment of archipelagic waters. 218

\section{In the NORTH SEA CONTINENTAL SHELF case 217 the}

Court held that the equidistance principle did not reflect the rule of customary law and could therefore be displaced by the equitable adjustment required by the special circumstances of the coastal configuration of the parties. 220 The concept of the continental shelf as the natural prolongation of the coastal state's land territory into and under the sea was initiated by the court in this case. 221 In the FISHERIES JURISDICTION case 222 the Court recognised the recent developments in the law of the sea indicating that the LAISSEZ-FAIRE treatment of the living resources of the high seas have been substituted by a system in which regard must be paid to the rights of the other states and the needs of conservation for the benefit for all. 223 Finally, in the $A E G E A H$ SEA CONTINENTAL SHELF case - as already mentioned 224 - the Court held that the coastal state's rights over the continental shelf are both appurtenant to and directly derived from the State's sovereignty over the adjoining land, and that the territorial status of the coastal 
State comprises, IPSO JURE the rights of exploration and exploitation of the continental shelf to what it is entitled under international law.

By this contribution to the modern law of the sea, its long tradition of judicial proceedings and its position as the principal judicial organ of the United $\mathrm{Na}-$ tions, the court has proved to be peculiarly equipped to play a major part in the settlement of international disputes concerning the law of the sea. ${ }^{225}$ This explains why the reference of such disputes to the court has become more popular in recent years. 226

From these considerations it is hoped that states making reservations excluding disputes concerning the law of the sea, especially those which expressed at one time or another their willingness to resort to the court for the settlement of such disputes, ${ }^{227}$ will follow the example set by Australia and Canada, and deposit an unqualified declaration. Or it is hoped they will couch their reservations in restricted terms, if the exclusion of a particular dispute is deemed indispensible. 228

\section{D - SOME PARTICULAR RESERVATIONS}

For special reasons peculiar to certain states other reservations have been appended to the declarations of those states.

\section{(I) El Salvador's Reservations}

When ratifying the Protocol of Signature on August 29. 1930, El Salvador formulated the following reservations:

\footnotetext{
"The provision of this statute do not apply to any disputes or differences concerning points or questions which cannot be submitted to arbitration in accordance with the political constitution of this Fepublic.
} 
"The provisions of this statute al $=0$ do got apply to $=$ pecuniary claims made against the nation $:$ :

By virtue of Article 36 (5), these reservations continued to produce their effect until 1973 when El Salvador revoked its previous declaration and replaced it by a new one omitting those reservations. 230 Nevertheless, the possibility that such reservations be inserted by any State may require a short comment on those reservations.

\section{(i) Constitutional questions}

El Salvador's reservation excluding constitutional questions from adjudication was not the first precedent. As has already been mentioned, such a reservation appeared no less than 16 times in arbitration treaties concluded before 1920, most of which were concluded between Latin American countries. 231. A similar reservation had even been inserted in some declarations made under the Optional Clause of the P. C. I. J. 232

This reservation was inserted in the declaration of El Salvador as a result of the limitations imposed by the Constitution of El Salvador in 1886 on the treaties that might be concluded or ratified by $\mathrm{El}$ Salvador. 23

However, the reservation has been subjected to criticism on more than one ground. Its validity has been contested on the ground that "it has been commonly agreed upon by international lawyers that an international tribunal is not bound by national constitution". 234 In fact that principle was recognised by the court. It said that "a state cannot adduce as against another state its own constitution with a view to evading obligations incumbent upon it under international law or treaties in force". 255 Thus, without this reservation the court would have rejected an argument that a treaty imposing certain obligations on $E l$ Salvador had been entered into or ratified in violation of El Salvador's constitution. 
However it is submitted that El Salvador's reservation was intended to exclude the possibility that the court would render a judgment against the constitution. 286

However, the reservation cannot escape another objection. There is no doubt that the scope of a declaration containing such a reservation is not limited, but varies according to the modification to which the constitution is subjected. Thus, at least theoretically, the reserving state could prevent the submission of certain disputes to the Court by amending its constitution. 237

\section{(ii) Pecuniary claims}

This reservation seems to have been made with the object of excluding the application of the provisions of clause (d) in Article 36 (2) of the statute of the P. C. I. J. ${ }^{258}$ That clause authorised the Court to decide "the nature or extent of reparations to be made for the breach of international obligations". However according to the terms of the reservation, not all disputes covered by the clause (d) were excluded. A dispute could have been excluded only if it concerned a pecuniary claim. Reparations of non-pecuniary nature such as restitution and compensation, could, thus, have been decided by the Court. 259 Also El Salvador or another State could have asked the court for a declaratory judgment determining the responsibilities, without fixing the reparations to be made, or asked to $\mathrm{fix}$ the non-pecuniary reparations where it was possible. 240

The validity of this reservation had never been contested. For under Article 36 of the Statute of the P. C. I. J. States were authorised expressly to exclude "any of the classes of legal disputes" encountered therein. 241 Although these words have been omitted from Article 36 (2) of the statute of the I. C. J. such a reservation is, no doubt valid. This is because subject matter reservations that do not run against the provisions of the 
Statute or the object of compulsory jurisdiction are - as have been mentioned ${ }^{242}$ - deemed valid.

\section{(II) India's Reservation (Particular Treaties)}

The current Indian declaration contains a new reservation excepting:

"disputes where the jurisdiction of the court is or may be found on the basis of a treaty concluded under the auspices of the League of Nations, unless the Government of India specially agree to jurisdiction in each case".

There is a strong indication that the reservation is intended to eliminate any possibility that a case would be referred to the Court on the basis of the General Act of 26 September 1928 for the Pacific Settlement of International Disputes. 244 The reservation was made after the TRIAL OF PAKISTAN PRISONERS OF HAR case, 245 which was based - INTER ALIA - on that Act. In this case India contested the Court's jurisdiction on the ground that the General Act "is either not in force or, in any case, its efficacy is impaired by the fact that the organs of the League of Nations and the Permanent Court of International Justice to which it refers have now disappeared". Furthermore, on september 15, 1974, i.e. 3 days only before the deposit of the Indian declaration, India notified the Secretary General of the United Nations that it had never regarded itself as bound by the General Act since its independence, whether by succession or otherwise. 247

Accordingly, India has, by this reservation, partly nullified the effect of Article $37^{248}$ of the Statute of the Court not only in relation to states accepting the Court's jurisdiction under Article 36 (2), but also VIZ$A-U I Z$ any other state accepting that jurisdiction under Article $36 \cdot(1)$. 
The reservation has, thus, provided another example on how states prefer to couch their declarations in general terms instead of excluding the particular disputes that have led to the insertion of the reservation. However, there is a price to be paid for such a reservation because of the application of the principle of reciprocity. India can therefore expect to have this reservation automatically turned against it in any case in which India appear as applicant. It is perhaps wiser that when making a reservation, regard must also be paid to the possibility of being applicant not only against States accepting the Court's compulsory jurisdiction under Article 36 (2), but also against those accepting it under Article 36 (1).

\section{(III) Israel's Reservation}

In order to exclude from the Court's compulsory jurisdiction disputes arising out of the activities of the government of Mandatory Palestine; the Jewish Agency, or any similar bodies before its establishment, Israel excluded from its declaration of 1950 - ratified in 1951 - disputes which did not "involve a legal title created or conferred by a Government or authority other than the Government of the State of Israel or an authority under the jurisdiction of that Government". 247 "In a substantially similar form the reservation was incorporated in Israel's declaration of 1956 . $^{250}$ The reservation disappeared when Israel terminated its acceptance of the Court's jurisdiction on November 21, 1985. 251 However. the very nature of the reservation renders it impossible to be initiated and thus it does not require further discussion. 252

\section{E - CONCLUSIONS}

From the aforesaid considerations the following conclusions may be drawn. All the reservations included in this section are made by developing countries. Either 
they have been originated by those states or copied from declarations of developed countries - as the reservations concerning hostilities - and then modified by expanding their scope. This is not surprising as most of the disputes reserved, such as those concerning territorial status or hostilities, exist between developing countries.

No doubt, it is true, that a subject-mater reservation may constitute a preliminary stage for a more general acceptance of the Court's compulsory jurisdiction and hence a declaration containing such "reservation is better than a refusal to accept that jurisdiction". However it is not the case with most of the reservations discussed here. For, on the one hand, they are couched in the broadest terms, which carves out of the Court's jurisdiction a large portion of disputes in some areas of international law which are of primary importance. On the other hand, they are made alongside several other reservations most of which are framed in the same manner.

Since most of those reservation have been made with the object of excluding particular disputes, a reservation couched in terms excluding those specific disputes is most desirable for the compulsory jurisdiction system. and could be so for the reserving state by limiting the scope of the operation of reciprocity.

Nevertheless, there is no doubt that subject-mater reservations are valid and that they are still better than the general reservations such as RATIOHE TEHPOPIS reservations. 


\section{Notes}

(1) But see pp.327-328 below

(2) For the List of instruments other than the declarations of acceptance conferring jurisdiction on the court, see I.C.J.Y.B. 1985-86, pp.93_109

(3) See e.g S.Prasasvinitchai, la Clause Facultative de Juridiction Obligatoire de la Court International de Justice, Thesis ( Université de Paris, Faculté de Droit et des Sciences Economiques ), 1962, pp 115_117; B.Maus, les Réserves dans les Declarations d' Acceptation de la Juridiction Obligatoire de la Court International de Jusitice, , Thesis (Université de Genève, Faculté de Droit), 1959, pp.117_119; R.P.Anand, Compulsory Jurisdiction of the International Court of Justice, 1961, p.234; F.De Paw, " La Declaration Belge du 3 Avril 1958 Acceptant La Juridiction Obligatoire de la Cour Internationale de Justice ", R.B.D.I (1966), pp.94_124, at 117, E.Hambro," Some Observations on the Compulsory Jurisdiction of the International Court of Justice ", 25 B.Y.B.I.L (1948), pp.133_157, , at 147, and C.G.Tenekides, " Les Actes Compromissoires Concurrents ", 17 R.D.I.L.C. (1936), pp.719_740.

(4) See the Dis.Op.of Judge Anzillotti in the Electricity Company of Sofia and Bulgaria case, Judgment, 1939, P.C.I.J, Series A/B, No.77, p.64, at 88_91.This view was shared by three other Judges (Urrutia, Jonkneer van Eysinga and Hudson). They all reached the conclusion that the 1931 Treaty between Belgium and Bulgaria prevailed over the reciprocal declarations of the parties according to the general principles referred to above. Ibid, pp.103,111 and 132 respectively.

(5) S.Rosenne, the Law and Practice of the International Court, 2nd. revised ed, 1985, p.475.

(6) Ibid.

(7) Electricity company, cited supra note 4, p.75.

(8) J.H.W. Verzijl, " the System of the Optional Clause ", 1 Int. Rel. (1959), pp.585_610, at 608 .

(9) Cited supra note 4, p.76.

(10) Ibid.

(11) The Temple of Preah Vihear case, Preliminary Objections, I.C.J. Reports 1961, p.35; Arbitral Award Made by the King of Spain on 23 december 1906, Judgement, I.C.J. Reports 1960, p.192, and Military and Paramilitary Activities in and against Nicaragua (Nicaragua V. United states of America), Jurisdiction and Admissibility, Judgement, I.c.j. Reports 1984, p.392.

(12) See S. Rosenne, the law and Practice..., supra note 7, p.475.

(13) See pp.326-328 below.

(14) For this reservation see chapter 6 section 3 below.

(15) Military and Paramilitary Activities case, supra note 11,p.426, para.77.

(16) Interpretation of Judgement Nos. 7 and 8(Factory of Chorzow), Judgement, No.11, 1927, P.C.I.J., Series A, No.13.

(17) Certain German Interest in Polish Upper Silesia, Jurisdiction, Judgement No.6, 1925, P.C.I.J., Series A, No.6,pp.19-21. 
(18) Factory at Chorzow, Jurisdiction, Judgement No.8, 1927, P.C.I.J., Series A, No.9, p.30.

(19) See B. Maus, Supra note 3, pp.16-17, S.Prasasvinitchai, supra note 3, pp.119-120, and I.F.I. Shihata, the Power of the International Court to Determine its Own Jurisdiction. Competence de la Competence, 1965, pp.258261.

(20) The Liberian reservation, I.C.J.Y.B. 1985-86,p.75. Comp. the text of the reservation of Pakistan, Ibid., p.83. A similar reservation was made in the U.S. declaration of 1946, 1 U.N.T.S., p.9. It was also made in the declarations of the following States, which were made under the Optional Clause of the P.C.I.J.: France, Italy and Peru, P.C.I.J. Series D, No.6, pp.45,43 and 49 respectively.

(21) The text of the reservation of Japan, I.C.J.Y.B. 1985-86, p.74. Comp. the text of the reservation of Austria. Ibid., p.61.

(22) For this reservation see S. Prasasvinitchai, supra note 3, pp.119-120, B. Maus, supra note 3, pp.122-123; R.P. Anand, Compulsory Jurisdiction..., supra note 3, p.232; J.G. Merrills, " the Optional Clause Today", 50 B.Y.B.I.L. (1979), pp.87-116, at 105-106, and R. Taoka, "Japan and the Optional Clause", 3 Jap. A.I.L. (1959), pp.1-11, at 10.

(23) See B. Maus, supra note 3, pp.122-123.

(24) See S. Rosenne, Documents on the International Court of Justice, 1974, p.308.

(25) I.C.J.Y.B., 1985-86, pp.65, 77 and 79 respectively.

(26) See B.Maus, supra note 3, pp.125-126. Comp. Prasasvinitchai, supra note 3, pp.117-118.

(27) Ibid.

(28) see pp.321-323 above.

(29) Comp. Prasasvinitchai, supra note 3, pp.117-118.

(30) For the determination of the common will of the parties to a dispute before the Court see section 1, Chapter 4 supra, p.214 seq.

(31) This observation was made by the Court in regard to the Third Portuguese Condition in the Right of Passage over India Territory case. See section 2, chapter 2 supra, p.135

(32) See S. Rosenne, the law and practice..., supra note 7, p.68 Seq.

(32B) For a detailed study on the Litispendence Between the Court and the organs of the U.N. see D. Giobanu, "Litispendence Between the International Court of justice and the Political Organs of the United Nations", in L. Gross(ed), the Future of the International Court of justice, Vol.1, 1976,pp.209-275.

(33) South West Africa, Preliminary Objections, Judgement, I.C.J. Reports 1962, p.319.

(34) Rights of Minorities in Upper Silesia (Minority Schools), Judgement No.12, 1928, P.C.I.J, Series A, No.15,p.4.

(35) Interpretation of the Statute of the Momel Territory, Preliminary Objection, Judgement, 1932, P.C.I.J, Series A/B, No.47, p.243.

(36) See S. Rosenne, the Law and practice ..., supra note 7,pp.83-87.

(37) United States Diplomatic and Consular Staff in Teheran, Judgement, I.C.J. 
Reports 1980, p.3.

(38) Cited Supra note 11. In the Aegean Sea Continental Shelf case, Greece appealed to the court and the Security Council on the same day (August 10, 1976) seeking simultaneously both Legal and Political settlement. The court, having into consideration the fact that the Security Council had already recommended steps " to prevent the aggravation or extension of the dispute", declined to indicate the measures of protection requested by Greece. I.C.J. Reports 1976, p.13.

(39) I.C.J. Reports 1980, p.21, paras. 39-40.

(40) Ibid., pp.20-21, para.39.

(41) lbid., p.22, para. 40 (emphasis added).

(42) Ibid., p.23, para. 43. For more details see L. Gross,"Underutilization of the International Court of Justice", 27 Harv.I.L.J. (1986). pp.571-597 at 594596.

(43) I.C.J. Reports 1984,pp.431-432, para.89. The Court upheld Nicaragua's argument that "primary" did not mean "exclusively". Ibid., pp.431-432, 434, para.89-90, 95.

(44) Ibid., pp.432-433, para.91.

(45) Ibid., p.435, para.95. A. Chayes observes that the United States argument falls of its own weight partly because the failure to adopt a resolution owing to a veto by the permanent member concerned cannot be considered as a decision of the Council against the aggrieved State . It is a nonaction, he says."Nicaragua, the United States, and the World Court", 85(II) Colum.L.R.(1985), pp.14451482, at 1470. On this point see also A. D'Amato,"Modifying U.S. Acceptance of the Compulsory Jurisdiction of the World Court", 79 A.J.I.L.(1985), pp.385405 , at $399-400$.

(46) B. Maus thinks that the simultaneous exercise of jurisdiction by the Court and the Security Council is unlikely under chapter VI of the Charter because of the priority given to the Court, see supra not 3, p.130. For criticism of this differentiation between Chapters VI and VII of the Charter see I.F.I. Shihata, supra note 12, p.261.

(47) L. Delbez, Les Principes Généraux du Contentieux International,1962,p. 42.

(48) I.F.I. Shahata, supra note 12, p.261.

(49) League of Nations, Records of the Fifth Assembly, Third Committee, p.199. See also M.o. Hudson, the Permanent Court of International Justice, 1920-1942. A Treatise, 1943, p.470.

(50) See P.C.I.J. Series D, No.6, p.45.

(51) It was made by Australia, Canada, Czechoslovakia, France, Great Britain, India, Iran, Iraq, Italy, New Zealand, Romania, South Africa and Peru. See Hudson's Treatise, supra note 49, p.470; H.W. Briggs, "Reservations to acceptance of Compulsory Jurisdiction of the International court of Justice", 93 R.C.A.D.I.(1958), pp.230-363 at 298-300, and R.P. Anand, Compulsory Jurisdiction ..., supra note 3,pp.235-238.

(52) For example the declaration of Great Britain, P.C.I.J. Series D, No.6, p.45.

(53) "Memorandum on the Signature by His Majesty's Government in the United kingdom of the Optional Clause of the statute of the Permanent Court of International Justice", Miscellaneous No.12 (1929), Cmd. 3452, p.6. 
(54) "The British Reservations to the Optional Clause", 10 Economica (1930), pp.137-172, at 155-160.

(55) "the Optional Clause" (the British Signature and Reservations), 11B.Y.B.I.L. (1930), pp.63-84, at 76-80.

(56) H. Lauterpacht, the british Reservations ..., supra note 54, p.159.

(57) See S. Rosenne, Documents ..., supra note 24, p.258.

(58) J.F. Williams, supra note 55, pp.79-80.

(59) See R.St.J.Macdonald, "the new canadian Declaration of Acceptance of the Compulsory Jurisdiction of the International Court of Justice", 8 Can.Y.B.I.L.(1970), pp.3-38, p.29;H.W. Briggs, Reservations ..., supra note 51,p.299; E.Hambro, "the jurisdiction of the International Court of Justice", 76 R.C.A.D.I.(1950), pp.125-215, at 189-190, and R.P. Anand, Compulsory Jurisdiction ..., supra note $3, \mathrm{pp} .235-238$.

(60) A. D'Amato, Modifying U.S. Acceptance ..., supra note 45, p.399.

(61) See H. Lauterpacht, the British Reservations ..., supra note 54, p.157 and A.N. Farmanfarma, the Declarations of the Members Accepting the Compulsory Jurisdiction of the International Court of Justice, thesis (Universite de Genève, Faculté de droit ), 1952, p.136. Arguing for the undesirability of the reservation Professor D'Amato point out that "We know too much now about the political nature of voting in the United Nations to be as complacent about giving those political organs preemptive jurisdictional powers as were the old members of the league of nations", Modifying U.S. Acceptance ..., supra note 45, p.400.

(62) Supra note 59, p.29.

(63) P.C.I.J, Series D, No.6, p.37. In the subsequent declaration s of the Netherlands the reservation was limited to agreements made after the entry into force of the statute of the P.C.I.J. See the declaration of 1926, Ibid., p.40 and that of 1936 , ibid., Series E, No.13, p.276.

(64) These are the declarations of: Australia, Argentina, Czechoslovakia, Egypt, estonia, Ethiopia, Germany, Great Britain, India, Iran, Iraq, Latvia, Luxembourg, the Netherlands, New Zealand, Poland, Romania, South Africa, Spain, Thailand, Yugoslavia, Liechtenstein and Monaco. This is without counting those of Albania, Greece and Turkey which excluded disputes relating directly or indirectly to the interpretation of a treaty accepted by the declarant State and providing for another method of settlement. For the text of all those declarations see Hudson's Treatise, supra note 49, pp.681-705.

(65) These are the declarations of Australia, Barbados, Botswana, Belgium, Canada, Democratic Kampuchea, El Salvador, Gambia, Honduras, india, Kenya, Luxembourg, Malawi, Malta, Mauritius, the Netherlands, New Zealand, the Philippines, Senegal, Sudan, Swaziland and the United Kingdom. I.C.J.Y.B. 1985-86, pp.61-92.

(66) The declarations of Gambia, the Netherlands and senegal, ibid., pp.79, 81 and 86.

(67) See e.g. B. Maus, supra note 3, pp.123-124.

(68) R.St.J. Macdonald, supra note 59, pp.27-28.

(69) See e.g. S. Deryfus, "les Declarations Souscrites par la France aux Termes de 
I'Article 36 du Statut de la Cour Internationale de la Haye ", 5 A.F.D.I. (1959), pp.258-275, at 265 and S. Prasasvinitchai, supra note 3, p.123.

(70) See H. Lauterpacht, supra note 54, p.145-147; H.W. Briggs, Reservations ..., supra note 51, p.296; A.N. Farmanfarma, supra note 61, pp.137-138, and F. De Pauw, supra note 3, p.14.

(71) J.F. williams, supra note 55, p.75(emphasis original).

(72) In the Electricity Company of Sofia and Bulgaria case Judges Eysinga and Hudson, dissenting, thought that the Belgium reservation deprived the Court of Jurisdiction. P.C.I.J., Series A/B, No.77, cited supra note 4, pp.111, 132.

(73) see b. Maus, supra note 3, p.127.

(74) See p.325 above.

(75) P.C.I.J, Series D, No.6, p.45(emphasis added).

(76) Ibid., p.43.

(77) I.C.J.Y.B. 1985-86, pp.72, 74(emphasis added).

(78) Ibid., p.70.

(79) Memorandum ..., supra note 53, p.6.

(80) See F. De Pauw, supra note 3, p.115-116.

(81) See H. Lauterpacht, supra note 54, p.147 and Hudson's Treatise, supra note 49, p.470.

(82) See B. Maus, supra note 3, p.124. the scope of the expression "other peaceful means of settlement" have lead to divergence of Opinion even as to the validity of the reservation. While most authors do not question its validity Q.F. Natchaba thinks that it is not compatible with Article 36(2) of the Statute because it limits, and even hinder, the extension of the court's compulsory jurisdiction, les Etats Africains et la Cour Internationale de justice,thesis (Université de Poitiers, Faculté de Droit et des Sciences Sociales), 1978, p.41. Comp. A.N. Farmanfarma, supra note 61, p.139; R.P. Anand, Compulsory Jurisdiction..., supra note 3, p.232, and M. Dubissan, la Cour Internationale de Justice, 1964, p.182.

(83) See J.G. Merrills, supra note 22, p.106; H.W. Briggs, Reservations ..., supra note 51, p.298; S. Prasasvinitchai supra note 3, pp.129-130, and D.J. Ende, "Reaccepting the Compulsory Jurisdiction of the International Court of Justice: A proposal for New Unite States Declaration", 61 Wash. L.R. (1986), pp. 11451183, at 1164-1165.

(84) R.St.J. Macdonald, supra note 59, p.28 and J.G. Merrills, supra note 22, p.106. D.E. Ende considers the reservation " as a safety valve against judicial impropriety ". Ibid.

(85) See Military and Paramilitary Activities case (1984), cited supra note 11, p.434, par.93. for examples on how the combination of those two different methods have led to a successful settlement of some disputes see L.Gross, Underutilization ..., supra note 42, p.583 seq. and "the International Court of Justice : Consideration of Requirements for Enhancing its Role in the International Legal Order", in his book Essays on International Law and Organization , 1984, pp.931-1006, at 941. See also M. Lachs,"La Cour Internationale de Justice dans le monde d'Aujourd'hui"; 11 R.B.D.I., (1975), 
pp.548-561, at 554 and C.F. Murphy, "the World Court and the Peaceful Settlement of Disputes", 7 Ga.J.I.C.L.(1977), pp.551-578, at 551.

(86) I.C.J.Y.B. 1985-86, p.61.

(87) For examples on these treaties see F. De Pauw, La declaration Belge ..., supra note 3, p.116.

(88) Military and Paramilitary Activities case, cited supra note 11, p.427, para. 81, and United States diplomatic and Consular Staff in Teheran case, cited supra note 37, p.27, para. 52 . For examples on treaties containing such a reservation see Hudson's Treatise, supra note 49, p.469; G. Geamanu, "Theorie et Pratique des Negociations en Droit International", 166 R.C.A.D.I.(1980), pp. 373-448, at 419 and " Les negociations Moyen Principal du Reglement Pacifique des Differends Internationaux", in J. Makarczyk(ed.), Essays In International Law in Honour of Judge Manfred Lachs,1984, pp.375-388, at 382-83; J. Soubeyrol, " La Negociation Diplomatique Element du Contentieux International", 35 R.G.D.I.P. (1964), pp.319-49, at 324-25, and N. Kaasik, " La Clause des Negociations Diplomatiques dans le Droit International Positive et dans La Jurisprudence de la Cour Permanente de justice Internationale", 14 R.D.I.L.C. (1933), pp.62-95, at 65.

(89) See Section 2, chapter 1 supra, pp.45-48, 50-51. Comp. N. Kaasik, Ibid., pp. 66-69.

(90) See e.g. L. Gross, " the International Court of justice and the United Nations", in his book Essays on International Law and Organization,supra note 85, pp.845930, at 929( Reprinted from 121 R.C.A.D.I. (1967); pp.319-439; C.W. Jenks, the Prospects of International Adjudication, 1964, p.107; H. Mosler, "the International Court of Justice at its Present Stage of Development", 5, Dalh. L.J. (1979), pp.545-67, at 545; C.M. Dalfen, "The World Court in Idle Splender: the Basis of States' Attitudes", 13 I.J.(1967-68), pp.124-139, at 124, and F. Honig, " the Diminishing Role of the World Court", 34 I.A.(1958),pp. 184-194.

(91) For a comparison between the advantages and disadvantages of adjudication and diplomatic means of dispute settlement see G. Geamanu, supra note 88, p. 418, 424; J. Soubeyrol, supra note 88, pp. 320-23, H.G. Darwin, "Negotiation", in C.H.M. Waldock(ed.), International Disputes: the Legal Aspects, 1971, pp.7782, at 77, 80-82; L. Gross, "On the Justiciability of International Disputes", in his book Essays on International Law and Organization, supra note 85, pp.10471059, at 1053-54; the I.C.J. and U.N., supra note 90, p.929, and Underutilisation ...,supra note 42, at 591-96; M. Sørensen, "the International Court of Justice: Its role in Contemporary International Relations", 14 Int'L.O.(1960), pp.260-276 at 274-75; T.M. Frank,Judging the World Court,1986, pp.54-56; R.B. Bilder, "Some Limitations of Adjudication as an International Legal Dispute Settlement technique", 23 Virg. J.I.L. (1982), pp.1-12, at 4-5, and "International Dispute Settlement and the Role of Adjudication", in L.F. Damrosch(ed.), the International Court of Justice at a Crossroads, 1987, pp.155-182.

(92) R.B. Bilder, some Limitations .., ibid., p.4 and T.M. Frank, Judging the World court, supra note 91, p.55. 
(93) "Enlargement of the Contentious Jurisdiction of the Court ", in L. Gross(ed.), the Future of the International Court of justice, Vol.2, supra note 32B, pp.461-498, at 463. For further detail see his special report entitled "the Future of Public International Law in the International Legal System in the Circumstances of Today", in Institut de Droit international, Livre Centennaire 1873-1973, 1973, pp. 275 seq.

(94) For the text of the reservation see p337 above.

(95) Cited supra note 95, p.17.

(96) Ibid., p.29.

(97) I.C.J.Y.B. 1985-86, p.73.

(98) see pp335-339 above.

(99) See Hudson'Treatise, supra note 49, p.469.

(100) See e.g. The Mavrommatis Palestine Concessions, Judgment No. 2, P.C.I.J., Series A, p.6, and South West Africa cases( Preliminary Objections), supra note 33, p.319.

(101) lbid., p.13.

(102) See South West Africa cases. (preliminary Objections), cited supra note 33, p.346.

(103) Ibid.

(104) Ibid.

(105) Cited supra note 37, p.27, para. 52.

(106) 46 Annuaire I.D.I. (1956) p.217.

(107) Ibid., pp.199-200.

(108) Ibid., pp.204-206.

(109) M.M. Ahi,Les Negociations Diplomatiques Prealable a la soumission d'un differend a une Instance Internationale, 1957, pp.36-37. G. Geamanu believes that if it is difficult to prove that there is a customary international law to that effect, there is no doubt that an international rule requiring the previous recourse to diplomatic means have existed since the beginning of the 19th century, Theorie et Pratique des Negociations ..., supra note 88, p.419.

(110) see N. Kaasik, supra note 88, pp.68-69.

(111) see e.g. Ibid., and g. Geamanu Theorie et Pratique des Negociations ..., supra note 88, p.419.

(112) see S. Rosenne, documents, supra note 24, p.251.

(113) see g. Geamanu Les Negociations ..., supra note 88, pp.381-82.

(114) see j. Soubeyrol, supra note 88, p.326.

(115) M.M. Ahi, supra note 109, pp.36-37 and G. Geamanu, Les Negociations ..., supra note 88, p.383.

(116)Mavrommatis Palestine Concessions case, (Jurisdiction), cited supra note 100, p.15.

(117) Chorzow Factory case, (interpretation), cited supra note 16, pp.10-11.

(118) Free Zones of upper Savoy and district of Gex, Order of August 19, 1929, P.C.I.J. Series A, No.22, at 13.

(119) Article 26 of the Mondate for Palestine. P.C.I.J. Series A, No.2. p.11.

(120) lbid., p.15. 
(121) The role of diplomatic negotiations in the determination of the subject matter of a dispute was invoked by India in its third preliminary objection. It argued that "Article36(2) of the Statute by referring to legal disputes, establishes as a condition of the jurisdiction of, the Court a requisite definition of the dispute through negotiations". The Court found no need to settle the question because "assuming that there is a substance" in that argument, the condition was complied with the Court observed. Right of passage over the Indian Territory case(1957), cited supra note 121, p. 149. Commenting on the Court's acceptance of that objection Rosenne says that the prior recourse to negotiation "is inherent in the concept of dispute " and hence in Art.36(2), the law and practice ..., supra note 5, p.513. Comp.l.f. Shihata, supra note 19, p.241.

(122) P.C.I.J. Series A. No.13, p.10-11.

(123) Ibid., In fact this interpretation is recognized by some partisans of the reservation of previous recourse to diplomatic negotiations. Thus N. Kaasik, for instance, observes that the Court did not consider the priority of negotiation as a principle of general international law but as a principle of particular international law that could be abandoned tacitly, i.e. it cannot be taken into account except where there exists an express stipulation to that effect. By this attitude the Court had, in his view, annulled practically or destroyed a condition so important, supra note 88, pp.78-81 and 90-92.

(124) See J. Soubeyrol, supra note 88, p.334-5.

(125) J.G. Merrills, International Dispute Settlement, 1984, p.18.

(126) I.C.J. Reports 1980, cited supra note 37, p.23, para.43 (emphasis added).

(127) I.C.J. Reports 1978, cited supra note 38, p.12, para. 29.

(128) I.C.J. Reports 1984, cited supra note 11, p. 440, para.106.

(129) lbid., p.438, para.102.

(130) lbid., p.440, para.106.

(131) In fact, this is the view widely held view. In addition to those expressed their views in 1956 before the Institut de Droit International [46 Annuaire I.D.I.(1956), esp. pp.199-217.], see P.M. Norton, "the Nicaragua case: political Question before the International Court of Justice ", 27 Virg. J.I.L.(1987), pp.459-526, at 586 and Rosenne, the Law and Practice ...., supra note 5, p.513. J. Soubeyrol goes a step further. He thinks that the reservation is incompatible with the compulsory jurisdiction under Art.36(2) because it opens the way for withdrawing the declaration in order to prevent the other party to the dispute from referring it to the Court. Supra note 88, p.323.

(132) see e.g. Art.39 of the General Act of 1928.

(133) D.J. Ende, "Reaccepting the Compulsory Jurisdiction of the International Court of Justice: A Proposal for A New United States Declaration", 61 Wash. L.R. (1986), pp.1145-83, at 1174-76.

(134) See Chapter 3 above, pp.177-179.

(135) Ibid., pp.177-178.

(136) S. Rosenne Documents ..., supra note 24, p.308.

(137) See S. Prasasvinitchai, supra note $3, p .136$.

(138) The Declaration of 1959. I.C.J.Y.B. 1959-60, p.236. 
(139) C.H. Vignes, "Observations sur la Nouvelle Declaration Française d'Acceptation de la Jurisdiction Obligatoire de la Cour Internationale de Justice", 31 R.G.D.I.P.(1960), pp.52-74, at 68-69 and S. Prasasvinitchai, supra note 3, p.134.

(140) I.C.J.Y.B. 1985-86, p.77.

(141) The Declaration of Kenya, Malta and Mauritius. Ibid., pp.74,77 and 79.

(142) S. Rosenne, documents ..., supra note 24, p.279.

(142A) R.P. Anand,Studies In International Adjudication, 1969, pp.48-49.

(143) I.C.J.Y.B. 1985-86, p.71.

(144) lbid., p.67 and 74.

(145) J.G. Merrills, the Optional Clause ..., supra note 22, p.108. A different formula had been made in the declaration of Israel terminated in 1985. For the text of this reservation see chapter 3 supra. p. 178, and for a comment on it see T. Meron, "Israel's Acceptance of the Compulsory Jurisdiction of the International Court of Justice", 4 Isr.L.R.(1969), pp.307-332, at 330-331.

(146) J.G. Merrills, Ibid.

(147) lbid.

(148) Jurisdiction and Admissibility, cited supra note 11.

(149) Summary of Argument by Professor Louis Sohn, Verbatim Record, Public Sitting held on October 16, 1984, I.C.J.Doc.C.R 84/18, p.67.

(150) lbid. see also I.C.J. Reports 1984, p.431-38. For comments on this argument see T.M. Lieverman, "Law and Order: Some reflections on Nicaragua, the United States, and the World Court", 10 Maryl.J.I.L.T. 1986, pp.295-320, at 29899; T. Frank, Judging the World Court, supra note 91, pp.42-43 and $H$. Hohmann and P.J.I.M. De Waart, "Compulsory Jurisdiction and the Use of force as a legal Issue: The Epoch-Making Judgement of International Court of Justice in Nicaragua v. United States of America", 34 Neth.I.L.R.(1987), pp.162-191.

(151) I.C.J.Reports 1984, p.442. Commenting on this holding T. Frank says that " What else could 16 jurists of the ostensible pinnacle of the international legal system have been expected to say?", "Icy day at the I.C.J", 79 A.J.I.L.(1985), pp.379-84, at 383. However, in the second phase of the case [Merits]. Judge Oda observed that the U.S., in accepting the Court's jurisdiction over"legal disputes" could have accepted it over Nicaragua's claims. He said that" it has throughout this century been considered that... disputes such as the present one, at least where it concerns allegations of threat or use of force and intervention, have not been deemed to fall into [the category of legal disputes]". Military and Paramilitary Activities in and Against Nicaragua, Merits, Judgement, I.C.J.Reports 1986, p.14, at 238, para.55.

(152) lbid., p.289, para.56.

(153) lbid., para.58.

(154) See Judge Oda's view, supra note 151; D.J. Ende, supra note 133, at 1173 P.M. Norton, supra note 131, pp.373-4 and the references cited therein.

(155) "the United States Should Accept, by a new Declaration, the General Compulsory Jurisdiction of the World Court", 80 A.J.I.L.(1986), pp.331-36, at 334-5.

(156) lbid., p.335 (emphasis original). 
(157) Ibid.

(158) There seem to be no doubt that the Court's decision" is meant to have "binding force" in a sense that it must be complied with. Otherwise Art.94 of the Charter will lose its raison d'etre. Consequently, it is very likely that the Court would declare the incompatibility such a proviso with the Charter and the Statute provisions as did its predecessor in Free Zones of Upper Savoy and District of Gex case, where it refused to comply to demand, contrary to fundamental procedural rules, made by both parties with a view of receiving its private and confidential opinion on fundamental issue in their dispute. P.C.I.J. Series A, No.22, p.5.

(159) See pp. 330-331,334-335 above.

(160) the United States should accept..., supra note 155, p.334.

(161) Ibid.

(162) Modifying U.S. Acceptance ..., supra note 45, pp.397-98.

(163) Ibid., p.397. To fill in this gap Gardner proposed the addition of the proviso "provided, however, that this reservation shall not be deemed to cover actions not justified by military necessity against ships and aircraft, diplomatic and governmental agents and government property, or private citizens and their property...", "U.S. Termination of the Compulsory Jurisdiction of the International Court of Justice", 24 Column.J.T.L.(1986), pp.421-427, at 426-27. Criticizing Gardner's proviso D.J. Ende points out that "it would be wiser to err on the side of over inclusion and preclude some offensive litigation than to weaken the defensive effectiveness of the reservation" by the insertion of such a clause which if interpreted broadly by the Court could defeat the reservation's purpose. Thus such a proviso presents more problems than it solves. supra note 133, p.1175.

(164) A. D'Amato, modifying U.S. Acceptance ..., supra note 45, p.397. D.J. Ende observes that this criticism is based on a wholly unrealistic assumption. It is unlikely that a State will escalate peaceful disputes into hostilities. Rather, a State will not appear as a respondent or will ignore the Court's decision. As far as the U.S. is concerned "it is inconceivable that any State would risk the United States in order to avoid adverse I.C.J. decision". Supra note 133, p.1176. But how could it be sure that the U.S. being a great power will not use the reservation in such a way?

(165) A.D'Amato, ibid., p.398.

(166) See D.J. Ende, supra note 133, p.1174-75.

(167) J.G. Merrills, the Optional Clause ..., supra note 22, p.108.

(168) For example ratione temporis reservation. See chapter 3 infra, pp. 159160.

(169) This was due to the fact that the reservations of vital interests, honour and independence were broad enough to cover territorial disputes. E. Hambro observes the reservation concerning territorial Status is in the same class as those reservations which have generally not survived the First World War but the reservation of territorial status consists one exception. Some observations ....," supra note 3, pp150-151. For a list of arbitration treaties which 
contained the latter reservation see $\mathrm{P}$. Chapal, L'Arbitrabilité des differends Internationaux,1967, p.109. It is worth noting that the U.S. Senate seems to have considered territorial disputes as not amongst those affecting national security or the vital interest. In its "Resolutions on the International Court of Justice " the Senate stated in the preamble of resolution No.74 concerning territorial disputes that adjudication is limited to disputes which affect neither the national security nor the vital interest of the parties concerned. Then it requested the submission of territorial disputes to the Court. For the text of this resolution see 69 A.J.I.L. 1975, pp.246-49, at 47, and for a comment on this resolution see $5 \mathrm{Ga}$. J.I.L (1975). "international Court of JusticeJurisdiction-resolutions to expand the Jurisdiction of the international Court of Justice and to improve the Court's Image as a Viable Alternative to Achieve Pacific Settlement of International Disputes, pp.314-25, at 31.

(170) P.C.I.J.,Series D, No.6, p.44.

(171) Hudson's Treatise, supra note 49, p.471 and "Obligatory Jurisdiction Under Article 36 of the Statute of the Permanent Court of International Justice", 19 lowa L.R.(1934), pp. 190-217, at 209.

(172) See the declarations of Romania and Iraq, P.C.I.J., Series D, No.6, p.53 and Series E, No. 15, p.215. The Iranian declaration substituted Islands for ways of communications, ibid., Series D, No.6, p.53.

(173) The declaration of Albania, ibid., p.52.

(174) See the unratified Egyptian declaration of 1939, ibid., Series E, No. 15, p.216.

(175) I.C.J.Y.B., 1985-86, p.85.

(176) Ibid., pp.67 and 72.

(177) Ibid., p.79.

(178) Ibid., p.71.

(179) See the pleadings of the Greek Government in the Aegean Sea Continental Shelf, p.251 and I.C.J. Reports 1978, p.3, at 30-32.

(180) I.C.J. Reports 1978, cited supra note 38, p.25. The reservation was suggested by Politis in a letter addressed to the Greek Foreign Minister on September 9, 1928. Ibid., p.26.

(181) For these disputes see P.C. Jessup, the price of International Justice, 1971, pp.33-35.

(182) This dispute is now under the consideration of the Court. See I.C.J.Y.B. 19861987, pp.145-146.

(183) I.C.J. Reports 1978, p.30.

(184) lbid.

(185) Ibid., p.32.

(186) Ibid., p.33.

(187) Ibid., pp.33-34. Judge De Castro disagreed with such interpretation. He thought that "the evolution of law cannot modify the meaning which the words had for the authors of the declaration. The evolution of the law can, by establishing new legal rules, confer or withdraw rights, and can even change an entire legal regime, but it cannot change the meaning of the declaration : it cannot make the 
declarant say what he did not wish to say or even what he could not have wished to say.", ibid., p.68.

(188) Ibid., p.35. See also I.C.J. Pleadings, supra note 179, p.254.

(189) I.C.J. Reports 1978, p.35.

(190) Ibid.

(191) Ibid., p.36. Judge De Castro and Stassinopoulos(Judge ad hoc) dissented on this point. They thought that the expression "territorial disputes did not include the status of the continental shelf, still less its delimitation. Ibid., pp.79 and 62-66 respectively.

(192) The declarations of El Salvador and India, I.C.I.J.Y.B. , 1985-86,pp.67 and 72.

(193) The declaration of Honduras, ibid., p.71.

(194) The reservation appears in the declarations of Malta, the Philippines, EI Salvador, India and Honduras.

(195) In fact the most recent years have shown that the Court is the most sufficient means for the settlement of such disputes. It has decided case concerning the Continental Shelf between Tunisia and Libya [Continental Shelf (Tunisia/ Libyan Arab Jamahiria), Judgment , I.C.J. Reports 1982, p.18] ; the Delimitation of the Maritime Boundary in the Gulf of Maine Area, [Judgment , I.C.J. Reports 1984, p.246 ], and the Frontier Dispute between Borkina Faso and the Republic of Mali[ Judgement, I.C.J. Reports 1986, p.554]. Furthermore, amongst the disputes which are still under the consideration of the Court there are some which have been referred even by a State making the reservation of territorial disputes, but on the basis of a compromis. Thus Honduras and El Salvador have concluded a special agreement by virtue of which they have referred to the Court on December 11, 1986 their dispute concerning Land, Island and Maritime Frontier(see I.C.J.Y.B., 1986-87, pp.128-192). For some important examples of disputes concerning boundaries which had been settled judicially before 1971 see, P.C. Jessup, the Price ..., supra note 181, pp.2-21.

Is is worth noting that the U.S. Senate requested the President of the U. S. in the Resolution No. 74 (cited supra note 169), "to direct the Secretary of State forthwith to seek to submit to the International Court of Justice for binding decisions as many as possible of those outstanding territorial disputes involving the United States where such disputes cannot be settled by negotiation".

(196) 1 U.N.T.S., p.49.

(197) I.C.J.Y.B., 1956-57, p.207.

(198) Ibid., 1984-85, p.69.

(199) Ibid., 1985-86, p.62. Comp. the declarations of New Zealand and the Philippines, ibid., pp.81 and 85 .

(200) See p.357 above.

(201) I.C.J.Y.B., 1985-86, p.79. Comp. the declaration of honduras of 1986, ibid., p.71.

(202) Ibid., p.72.

(203) See p. 357 above.

(204) See H.W. Briggs, Reservations ..., supra note 51, pp.304-305 ; B. Maus, supra note 3, pp.179-181, and R. Taoka, "Japan and the Optional Clause", 3 
Jap. A.I.L.(1959), pp.1-11, at 8-9.

(205) See Chapter 4 above p. 291.

(206) See J.G. Merrills, the Optional Clause ..., supra note 22, p.109 ; R.M. M'Gonigle and M.W. Zacher, "Canadian Foreign Policy and the Control of Marine Pollution", in B. Johnson and M.W. Zacher, Canada Foreign Policy and the Law of the Sea, 1977, pp.100-157, at 118-119 ; L.C. Green, "Canada and Arctic Sovereignty", 48 Can.B .R. (1970), pp.740-755, at 740-741, and R.St. Macdonald, the New Canadian ..., supra note 59, at 34-35.

(207) I.C.J.Y.B., 1985-1986, p.83.

(208) See Chapter 4 above p.291:

(209) A statement made by the Secretary of State for the external Affairs, H. C. Debates (Can.), 1970, April 16, at 5951. See also "Canadian Prime Minister's Remarks on the Proposed Legislation", 9 I.L.M.(1970), pp.600-604. This could be the main reason behind the Philippines reservations. Otherwise their insertion would contradict the Philippines previous insistence during the general debate in the U. N. General Assembly in 1968 and 1969 on the submission of its dispute with Malaysia over Sabah or North Borneo to the I.C.J. See P.C. Jessup, the Price ..., supra note181, pp.35-36.

(210) J.G. Merrills describes the Indian reservation as "the broadest reservation ratione materiae yet devised.", the Optional Clause ..., supra note 22, p.110.

(211) See pp.359-362 above.

(212) A. D' Amato, Modifying ..., supra note 45, p.397.

(213) Canada has withdrawn those reservations from its current declaration deposited on Sep. 10, 1985, see I.C.J.Y.B.,1985-86, p.64. It is to be observed that the reservations of Malta and Honduras, being made in 1983 and 1986, do not appear to have been inserted as a result of these uncertainties but as a result of the conclusion of the new treaty on the law of the sea. Ibid., pp.79 and 71.

(214) Those reservations figure in the declarations of Barbados, El Salvador, Honduras, India, Malta, New Zealand and the philippines, ibid., pp.62, 67, 71, $72,79,81$ and 85 .

(215) $\mathrm{H}$. Lauterpacht described the Court's Judgment in the Anglo- Norwegian Fisheries case of 1951 as a "daring pieces of judicial legislation", the Times (newspaper), Jan. 8, 1952, p.7. C.H.M. Waldock discussed in detail why that judgment may be thought to have been taken leave of what had previously thought to be the existing law, see his article "the Anglo- Norwegian Fisheries case " , 28 i.(1951), pp.114-171. For the Court's contribution to the development of the law of the sea see P. Mengozzi, "the International Court of Justice, the United Nations Conference on the Law of the Sea", 3 Ita.Y.B.I.L.(1977), pp.92-111 ; C.H.M. Waldock, the International Court of justice and the Law of the Sea, 1979 ; S. Oda, "the Role of the International Court of Justice", 19 Indian J.I.L.(1979), pp.157-165, at 162-163, and W. Friedmann, the International Court of Justice and the Evolution of International Law", 14 Archiv V. (196970), pp.305-322, at 316-317.

(216) Corfu Channel, Merits, Judgment, I.C.J. Reports 1949, p.4. See C.H.M. Waldock, the I.C.J. and the Law of the sea, supra note $215, \mathrm{pp} .4-6$ and S. Oda, the 
Role ..., supra note 215, p.162.

(217) Fisheries, Judgment, I.C.J. Reports 1951, p.116.

(218) See C.H.M. Waldock, the I.C.J. and the Law of the Sea, supra note 215, pp.8-. 10 ; S. Oda, the Role ..., supra note 215 , pp.162-163, and W. Friedmann, supra note 215, p.317.

(219) North Sea Continental Shelf, Judgment, I.C.J. Reports 1969, p.3.

(220) See W. Fiedmann, supra note 215, p.317.

(221) S. Oda, the Role ..., supra note 215, p.163. But Comp. D.G. Partan, "Increasing the Effectiveness of the International Court", 18 Harv.I.L.J.(1977), pp.559-575, at 568.

(222) Fisheries Jurisdiction(united Kingdom v. Iceland), Merits, Judgment, I.C.J. Reports, 1974, p.3 and Fisheries(Federal Republic of Germany v. Iceland), Merits, I.C.J. Reports 1974, p.175.

(223) S. Oda, the Role ..., supra note 215, p.163. Comp. D.G. Patran, supra note 221, p.568-569.

(224) See p.361 above.

(225) See C.H.M. Waldock, the I.C.J. and the Law of the Sea, supra note 215, p.16.

(226) See note 195 above .

(227) E.g. the Philippines(see note 209 above), El Salvador and Honduras, being parties to the dispute concerning Land, Island and Maritime Frontier which is under the consideration of the Court. See I.C.J.Y.B.1986-87, p.145-146.

This is also why the Canadian reservation had been subjected to a severe criticism. L.C. Green, for instance, has regretted that "a country which, in its Prime Minister's words, does not believe in double standards nor seek to pick and choose the rules of the law which it finds convenient to obey, shows such lack of faith in its own position and in the integrity of the international bench...", supra note 206, p.768. Consequently Green observes that by inserting this reservation "Canada has achieved nothing - other than to find herself the recipient of unnecessary international criticism and accusations of hypocrisy and double standards.", ibid., p.770 (emphasis original). See also A. D' Amato, Modifying ..., supra note 45, p.397.

(228)J.G. Merrills, the Optional Clause ..., supra note 22, pp.109-110.

(229) P.C.I.J. Series D, No.6, p.52.

(230) I.C.J.Y.B., 1985-86, p.67.

(231) See Chapter 1 above, p.31.

(232) It was made in the declarations of Argentina of 1935(P.C.I.J. Series E, No. 12, p.335) and Brazil of 1937 (ibid., No.13, p.277).

(233) See B. Maus, supra note 3,pp.171-173 and A.N. Farmanfarma, supra note 61, pp:146-148.

(234) A.N. Farmanfarma, ibid, p.147. See also S. Prasasvinitchai, supra note 3, pp.149-159.

(235) Treatment of Polish Nationals and Other Persons of Polish Origin or Speech in Danzig Territory, Advisory Opinion, 1932, P.C.I.J. Series A/B, No. 44, at 24.

(236) B. Maus, supra note 3, p.173. 
(237) See C.H.M. Waldock, "Decline of the Optional Clause", 32 B.Y.B.I.L. (195556), pp.244-287, at 276 ; B. Maus, supra note $3, p .173$, and $S$. Prasasvinicthai, supra note 3, p.150.

(238) See B. Maus, ibid., p.174 ; A.N. Farmanfarma, supra note 61, p.148 and S. Prasasvinitchai, supra note $3, \mathrm{pp} .150-151$.

(239) B. Maus, ibid., p.175.

(240) Ibid.

(241) See Section 2 Chapter 1 above .

(242) Ibid., p.59 seq.

(243) I.C.J.Y.B., 1985-86, p.72.

(244) J.G. See Merrills, the Optional Clause..., supra note 22, pp.93-94.

(245) Trial of pakistani prisoners of war, Interim Protection, Order of July 1973, I.C.J. Reports 1973, p.328.

(246) I.C.J. Reports 1978, p.16(Aegean Sea Continental Shelf case)

(247) Article 37 provides :

"Whenever a treaty or convention in force provides for reference of a matter to a tribunal to have been instituted by the League of Nations, or to the Permanent Court of International Justice, the matter shall, as between the parties to the present Statute, be referred to the International Court of Justice."

(249) I.C.J.Y.B., 1950-51, p.193.

(250) Ibid., 1984-85, p.79.

(251) Ibid., 1985-86, p.60.

(252) For further details see T. Meron, Israel's Acceptance ..., supra note 145, pp.328-330. See also B. Maus, supra note 3, pp.177-178, and J. G. Merrills, the Optional Clause ..., supra note 22, pp.108-109. 


\section{CHAPTER VI \\ SUBJECTIVE RESERVATIONS RATIONE MATERIAE}

This classification is based mainly on the power conferred by the reservation on the interested state for the determination of the scope of the reservation and hence its applicability. It covers thus cases in which the decision of whether a matter does come within the scope of the reservation is vested explicitly in the interested state, as well as cases in which such a decision is maintained implicitly owing to the fact that the interested State's assessment is the major, if not the sole criterion for assessing the content of the reservation. It extends also to the case in which the most important category of legal disputes is excluded, but the Court's jurisdiction could be established provided that the declarant State "specially agrees" or third states act in a certain way. In other words, the establishment of the Court's jurisdiction depends on the will of either the declarant state or of third states.

\section{SECTION 1; DOMESTIC JURISDICTION AS DETERMINED BY THE DECLARANT STATE}

Under the P. C. I. J. it would hardly have been conceived that a state would ever accept the Court's jurisdiction under the Optional Clause while withholding for itself the decision whether or not a future dispute would be adjudicated. Yet this happened shortly after the establishment of the present Court when the United States deviated from the established practice by recognising the Court's jurisdiction with the proviso that the declaration shall not apply to:

\footnotetext{
"(b) Disputes with regerd to metters which are esentieily uithin the domestic jurisdiction of the Unite States of AmeriLA AS DETERHIHED BY THE WHITE STATES OF AHERTCA."
}

Thus unlike the objective formula of domestic jurisdiction, 2 this new formula is - at least according to the 
apparent meaning of its terms - unblushingly "subjective". For its scope cannot be pre-determined according to the words of the reservation but is left for subsequent determination after the seisin of the court at the discretion of the interested state.

The circumstances in which the United States reservation was devised have been described. 4 These circumstances have, however, lost their significance since the withdrawal of the United States declaration in 1985. It may suffice here to recall that apprehensions of judicial encroachment upon certain areas which were deemed of vital interests, such as the navigation of the Panama Canal, immigration into the United States, and tariffs, had led to the insertion of the reservation. $b$

However, the last eight words in the United States reservation, namely, "as determined by the United States of America" have spawned countless of words of polemic and years of controversy. 7 Focus has been made on two points: the undesirability of similar reservations and their validity. Whilst it has ben generally admitted that such reservations are undesirable, $B$ the question of their validity is still unsettled. The validity issue has been approached in different ways, to the extent that almost every conceivable course, whether legal or of opportunity, has been followed. The court itself has treated such reservations in a different manner as compared to other reservations. This has deepened the doctrinal views as regards these reservations. It is to be observed that the significance of these reservations lies in the fact that they provide a precedent for testing the limits of the freedom of making reservations, more than in the question of their validity as such.

However, owing to the importance of state practice and its relevance as an element of interpretation, the position of the subjective reservation of domestic jurisdiction in the declarations of acceptance should be 
clarified first before proceeding to the consideration of the Court's attitude towards the reservation and the different approaches adopted by jurists.

\section{A - The Reservation in the Declarations of Acceptance}

In arguing against the insertion of the Connally Amendment in 1946 Senator Pepper of Florida warned that other nations would wish to modify their adherence to the compulsory jurisdiction of the court in the same way. 9 It did not take long to see his prediction realised. In less than one year the reservation appeared in a new version in the French declaration of February 18, 1947. This declaration excluded from the Court's jurisdiction "differences relating to matters which are essentially within the national jurisdiction $A S$ UNDERSTOOD BY THE GOUERNHENT OF THE FRENCH REPUBLIC. 10 The terms of the French declaration appeared to judge Read as requiring a "genuine understanding". In other words the Court's jurisdiction could not be ousted, he argued, by a mere pretention by the invoking state that it understands or by a declaration that it understands. 11 However, both models seem to raise a problem of interpretation. Thus $J$ $B$ Elkind thinks that exactly the opposite view of the two models is possible. "An 'understanding' would seem to relate to a subjective view of the matter which cannot be questioned. A 'determination' is a more objective, almost a judicial process, which might well be opened to review". 12 A third model was introduced by Mexico. Its declaration excluded "disputes arising from matters that, IH THE OPIHION OF THE HEXICAN GOUERHHENT are within the domestic jurisdiction of the United States of Mexico". 13 A fourth model is adopted by Liberia and the Philippines. They both exclude from the scope of their declarations any dispute "which [they] consider essentially within [their] domestic jurisdiction". 14 In due course the United States' model was included in the declarations of : India of 1956, ${ }^{15}$ Malawi, ${ }^{16}$ Sweden, ${ }^{17}$ Pakistan (of 1948 and 1957), 18 and South Africa ${ }^{19}$ with the difference 
that the last two declarations excluded matters which were essentially within the domestic jurisdiction of the "GOUERHHEHT" of the reserving State, and that the adjective "domestic" was omitted from the declaration of South Africa. The latter simply excluded disputes falling within "the jurisdiction of the Government of the Union of South Africa". It could, thus, have been considered broader than the other models. 20 All these models have generally been considered as producing the same effects.

Today, the subjective reservation of domestic jurisdiction appears only in the declarations of Liberia. Malawi, the Philippines and Sweden. This is due to the termination of the declarations of South Africa ${ }^{22}$ and the United States, 23 and the substitution of this reservation by the objective formula in the declarations of India and Pakistan. 24

In conclusion it is to be noted firstly that the reservation has appeared in two declarations (Malawi and the Philippines) since the end of the fifties when the trend to abandon the reservation was marked. Secondly. all the declarations containing the reservation, except that of the Philippines, have not been subjected to change since they were made for the first time. The Government of the Philippines terminated its previous declaration (of 1947) in 1972 and deposited a fresh one containing four other reservations in addition to the subjective reservation of domestic jurisdiction. 25

\section{B - THE COURT'S POSITION VIS-A-VIS THE RESERVATION}

The Court had the following opportunities to put an end to the controversy on the validity of the subjective reservation of domestic jurisdiction. 
(I) The U. S. Nationals in Morocco Case ${ }^{26}$

This was the first case brought under an instrument containing the subjective reservation of domestic jurisdiction. The declarations of both parties (France and the United States) contained such a reservation. The reservation was not invoked. However the United States stated in its counter-memorial that "its abstaining from raising the issue does not affect its legal right to rely in any future case on its reservation contained in its acceptance of the compulsory jurisdiction of the Court". 27 The responsibility of raising the issue of the consistency of these reservations with the statute was thus left to the court. Yet, the court declined to do so and contented itself with recording the parties reliance on their declarations accepting the "compulsory jurisdiction of the Court" in accordance with the statute. 29

Whether such an attitude by the Court could be considered as a tacit recognition of the validity of the declarations, despite the reservations, as the court could not have exercised its jurisdiction based on a void instrument, has been overridden. It is argued that the Court exercised its jurisdiction on the basis of the principle of FORUM PROROGATIUH, in spite of the fact that the application was based on Article 36 (2) of the Statute, since the movement of the United States withdrawal of its preliminary objection, which was based on account of insufficient clarification of the identity of the parties. 29

\section{(II) Certain Norwegian Loans Case}

France instituted proceedings against Norway by an application relying on the declarations of the parties made under Article 36 (2) of the Statute. France asked the Court to adjudge and declare that the bonds sold to its nationals were international loans which only could be discharged by repayment or redemption in gold value at 
the date of the repayment or redemption. Norway lodged four preliminary objections to the jurisdiction of the Court, but only the first is relevant here. The Norwegian argument on this point was in two parts. In the first part the Norwegian Government maintained that the subject mater of the dispute did not fall within any of the categories enumerated in Article 36 (2). The dispute was thus "beyond any possible doubt" within its jurisdiction, the Norwegian Government argued. In the second part it invoked the French subjective reservation of domestic jurisdiction. It argued that if any doubt remained as to the first point, it "would rely upon the reservation made by the French Government". 31 It is worth noting that the Norwegian Government raised the issue of interpretation of the reservation. It emphasised that "such a reservation must be interpreted in good faith and should a Government seek to rely upon it with a view to denying the jurisdiction of the court in a case which manifestly did not involve a matter which is essentially within the national jurisdiction, it would be committing an $A R U S D E$ DROIT which would not prevent the Court from acting". $\$ 2$

The Court declined to examine "whether the French reservation is consistent with the undertaking of a legal obligation and is compatible with Article 36, paragraph 6 , of the statute". $\$$ It accepted Norway's reliance on the French reservation on the ground that the validity of the reservation had not been questioned by the parties and therefore recognised Norway's right to refuse to accept the Court's jurisdiction on the ground of reciprocity. In so holding, the court said:

"[I]t has before it provision which both parties to the dispute regard as constituting an expression of their common will relating.: to the acceptance of the court. The court does not therefore consider that it is called upon to enter into an examination of the reservation in the light of considerations which are not presented by the issues in the proceedings. The Court, without prejudging the question, gives effect to the reservation as it stands and as the Farties recognise it." $\$ 4$ 
This holding has been criticised - as will be seen - by both some judges of the Court as well as by commentators and different conclusions have been drawn from it. It may suffice here to observe that the Court was criticised for basing its jurisdiction on the sole ground of the invocation of the reservation while it had many other alternatives. It could have based its decision on the interpretation adopted by Norway concerning the use of the reservation in good faith, 35 or discussed its jurisdiction on the first part of the objection as did judges Moreno Quintana and Badawi, 36 or could have ignored the declarations completely and based its jurisdiction on the treaties referred to by the parties in the course of the proceedings. 37

\section{(III) Interhande l Case}

This case offered two occasions for the consideration of the question of validity of the subjective reservation of domestic jurisdiction and its effect on the instrument to which it was attached.

\section{(i) Interim measures of protection phase}

The Swiss Government asked the Court to indicateINTER ALIA - that the Government of the United States was requested not to sell the shares of the General Aniline and Film Corporation (G.A.F.C.). The United States Government filed a preliminary objection based on its subjective reservation of domestic jurisdiction. It stated that it had determined that the matter of sale or disposition of the stock of the G.A.F.C. was a matter essentially within its jurisdiction. "This determination ... is not subject to review or approval by the tribunal, It operates to remove definitively from the jurisdiction of the court the matter which it determines", $38 \mathrm{Mr}$ Loftus Backer, the United States Government Agent stated. The terms of the reservation rendered the subject matter of the determination non-justiciable. For, that deter- 
mination destroyed the PRIMA FACIE jurisdiction as a legal basis for indicating provisional measures, Mr Backer argued. 39

On the other hand, professor Guggenheim - Co-agent of the Swiss Government - contested the above interpretation. He doubted that that reservation could have such an absolute character. Otherwise it would have the effect of rendering inoperative a provision essential for the exercise of the Court's jurisdiction [i.e. Article 36 (6) of the Statute]. " ${ }^{40}$ Although he challenged the validity of the reservation, professor Guggenheim stated that he could not imagine that the Court should wish to adjudicate at that stage "upon so complex and delicate a question as the validity of the American reservation". 41

Despite these arguments by both parties, the Court took jurisdiction to consider the indication of interim measures pursuant to its statute, but it rejected, for lack of urgency, the Swiss request.

Five of the sixteen members of the Court expressed their disagreement with the Court's reasoning. They all agreed, though in different ways, that since PPIHA FACIE the Court would have no jurisdiction on the merits, it manifestly has no right to exercise jurisdiction in this stage of the proceedings. ${ }^{43}$.

The clear implication of this holding of the Court is that a declaration containing a subjective reservation of domestic jurisdiction could be relied upon as a basis of a valid seisin, and hence for the conferment of the incidental jurisdiction to indicate provisional measures, and that the invocation of the reservation cannot preclude the court from exercising that jurisdiction. 44

It is to be noted, finally, that the Court made a formal finding at this stage. It stated that "whereas [the parties] have, by Declarations made on their behalf. 
ACCEPTED THE COHPULSORY TURISDICTION ON THE BASIS OF ARTICLE 36, PARAGRAPH 2, of the statute", and continued: "whereas by its subject-matter the present dispute falls within the preview of that paragraph".

\section{(ii) Preliminary objections phase}

The United States Government maintained its previous objection which had become part (a) of the fourth preliminary objection. The reservation was invoked in regard to the "sale and disposition" of the shares only. The United States Government was thus willing to allow the court to decide whether the seisure and retention of shares fell within domestic jurisdiction. ${ }^{46}$ The Swiss government also maintained its previous position that the Unites states reservation was invalid. Relying on the opinions of judges Guerrero and Lauterpacht in the NoRHEGIAN LOANS case, professor Guggenheim based the invalidity on the inconsistency of the reservation with both paragraphs 2 and 6 of Article 36 of the Statute. 47 Professor Guggenheim argued also that the reservation must be interpreted in good faith and that the court would not accept an allegation that a matter was within domestic jurisdiction when in fact it was manifestly not. Such a determination would be an abuse of right, he maintained.

The Agent of the United States Government (Mr Backer), on the other hand, argued that the reservation was valid and that it was not used arbitrarily in that case by the United States Government. He exposed the details of the facts to which the reservation was applied, but only for "the information of the Court". Mr Backer emphasised that the submission of these facts "does not in any way modify the conclusion that the determination of the United States is not subject to review or approval by this Court". "49 He also seemed to argue that the court was not entitled to judge whether the reservation was invoked in good faith. He said that 
"the Court has never examined and we assume will not examine into the motives which lead nations to exercise the automatic reservation". However he stated that "any examination would nevertheless reveal the reasonableness of the United States position despite the extravagant charges of arbitrariness which have been made here". 50

Also, Mr Backer maintained that since the local remedies were available, and that the shares could not be sold before a final decision of the courts of the United States, the objection based on the subjective reservation of domestic jurisdiction had lost practical significance and had become "somewhat moot" and "somewhat academic". 51

Thus, unlike the situation in the NORHEGIAN LOANS case, the reservation was invoked here and maintained by the respondent State; challenged by the applicant state, and was of immediate relevance. The parties to the present case, unlike in the NORHEGIAN LOANS case or in the first phase of this case, did not handle - to use judge Sir Percy Spender's words - "the objection tenderly" or walked "discretely around the issue involved". 52 The Court's approach had therefore to differ from that adopted in the NORHEGIAN LOANS case.

This approach by the Court seemed to give the impression that the court cannot consistently consider the issue of admissibility unless its jurisdiction was established. Thus it examined the first and second objections and part (b) of the fourth objection before the third objection, namely, non-exhaustion of local remedies. Yet, it turned to the third objection without disposing of whether its jurisdiction covered the issue in regard to which the United States Government invoked the reservation.. Having upheld the third objection, the Court decided by 10 votes to 5 that part (a) of the fourth preliminary objection was "without object". 53

The clear implication of this approach is that the 
Court tried to find ground on which it might have been possible to decline its jurisdiction without pronouncing on the question of validity. Failing to find such a basis, the admissibility issue was the only escape route to avoid the problem of adjudication on the validity of the reservation. Thus, the court left itself open to criticism from the Bench as well as commentators.

\section{(IV) The Aerial Incident of July 27th, 1955 Case (United States of America $v$ Bulgaria)}

Although the Court was not here in a position to decide the validity of the subjective reservation of domestic jurisdiction, the case has significance in throwing light on how the United states Government had interpreted its reservation. In its application instituting proceedings against Bulgaria, the United States Government claimed that the acts committed on July 27 . 1955 by the Bulgarian Air force in the Bulgarian Airspace against American Nationals on board a civil airplane fell within the categories of legal disputes listed in Article 36 (2). 55 Bulgaria filed four preliminary objections to the jurisdiction of the court, the second of which was based on the United States reservation of domestic jurisdiction. The Bulgarian Government maintained that the defence of its territory, the security of the airspace above the south western frontier region, and the disposition of its anti-aircraft defence fell under its domestic jurisdiction.

Inconsistently with the United States argument in the INTERHANDEL case, Mr Eric H Hager, the United States Agent, declared that "the United States reservation (b) [i.e. domestic jurisdiction reservation] does not permit the United States or any other state to make an arbitrary determination in bad faith". 57 He denied that this reservation empowered a state "to make an arbitrary determination that a particular matter is domestic when it is evidently one of international concern and has been so 
treated by the parties".

58

At this stage the United States Government appeared to adopt judge Read's view - that the reservation left to the court a residuum of decision-making power as will be seen. 5 However, being aware of the Court's view in the ISRAEL $\because$ BULGARIA case that the Bulgarian declaration had been discontinued since the dissolution of the P. C. I. $J$. the United States Government withdrew its argument to and returned to the interpretation made in the IHTERHAN$D E L$ case. This change of view was based on a "further study and consideration of the history and background of [the] reservation ...". 61 The result of the study had thus led to the qualification of the interpretation made in this case as "not valid", and that a "determination under reservation (b) that a matter is essentially domestic constitutes an absolute bar to jurisdiction irrespective of the propriety or arbitrariness of the determination". 62 Consequently the United States Government admitted that "Bulgaria is accorded the same rights and powers with respect to reservation (b) as the United States". 63 By this recognition the United States Government established - as Rosenne observed - the first precedent in which an applicant accepted a respondent's preliminary objection as justified. 64

\section{(V) Military and Paramilitary Activities in and Against Nicaragua Case}

The jurisdiction of the Court was based in this case on - IHTER ALIA - the declarations of the United States and Nicaragua made under Article 36 (2) of the Statute. The United States objected to the jurisdiction of the court and the admissibility of the claim on many grounds. 65 However it did not invoke its domestic jurisdiction reservation. Yet it informed the court that this decision was "without prejudice to the rights of the United states under that proviso [i.e. proviso (b) containing the reservation] in relation to any subsequent 
pleadings, proceedings, or case before this Court". bo The Court was not thus in a position to pronounce on the question of validity of the subjective reservation of domestic jurisdiction except by raising the issue PROPRIO HATU, a course which it refused to follow in the UHITED STATES NATIONALS IN MOROCCO and CERTAIH NOPHEGIAN LOANS cases as has ben seen. However, the Court had to satisfy itself that it had jurisdiction under Article 36 (2) of the statute. For this purpose, the Court observed, first, that "Nicaragua has to show that it was a "State accepting the same obligation "within the meaning of Article 36, paragraph 2, of the Statute". 67 Secondly, the Court raised the question whether the United States declaration of 1946 "constitutes the necessary consent of the United States to the jurisdiction of the court, in the present case, taking into account the reservations which were attached to the declaration". 69 On the first point the Court found that the parties to the case had accepted "THE SAHE OBLIGATION" within the meaning of Article 36 (2). 69 As to the second point, the Court noted that reservation (a) in the United States declaration, referring to disputes, the solution of which is entrusted to other tribunals, had no relevance whatsoever to the present case; referred to the United States decision not to invoke domestic jurisdiction reservation while reserving its right to do so in future cases, and proceeded to the examination of the multilateral treaty reservation which was invoked. ${ }^{70}$ Consequently the court found, by eleven votes to five, that it had jurisdiction to entertain the application filed by Nicaragua on the basis of Article 36 (2) and (5) of the statute.

\section{C - VALIDITY OR NULLITY - DIFFERENT DOCTRINAL APPROACHES}

The cautious attitude adopted by the court has contributed to a large extent to the emergence and development of different views, especially from the Bench, in respect of the question of validity of the subjective reservation of domestic jurisdiction. These views might 
be grouped into four different approaches.

\section{(I) Invalid Reservations Nullifying the Entire Instrument of Acceptance}

As has been said earlier, it was difficult under the the P. C. I. J. to conceive an acceptance of the Court's jurisdiction with such a reservation. However, the few earlier writers who had conceived it did not hesitate to declare it contrary to the very purpose of the Optional Clause, devoid of a legal obligation and contrary to the proviso of Article 36 (2) of the Statute. and therefore invalid. ${ }^{72}$ This approach has been developed by L Preuss 73 and Waldock, 74 and fully exhausted by the late judge $\operatorname{Sir} \mathrm{H}$ Lauterpacht in the HofHEGIAN LaAHS 75 and the IHTERHANDEL 76 cases. In these cases, judge Lauterpacht based his view on the understanding that the reservation has an "automatic" effect. By this he meant that the invocation of the reservation rendered the court function an automatic one limited to "registering" that invocation without examining its merits. The court, therefore, "is bound to hold ... that it is without jurisdiction". 77 This understanding leads to the conclusion that the reservation is invalid, and its invalidity nullifies the entire instrument containing it.

\section{(i) Invalidity of the reservation}

In arguing for the invalidity of the subjective reservation of domestic jurisdiction two basic grounds are usually relied on, each of which is said to be capable of nullifying such a reservation: the inconsistency of the reservation with the statute of the court and the Charter of the United Nations, and the lack of the element of legal obligation in it. 


\section{(a) Inconsistency of the reservation with the statute and the Charter}

The court is obliged to function according to its Statute. This obligation is provided for expressly in both Article 1 of the statute and Article 92 of the Charter. Article 36 (6) of the Statute provides:

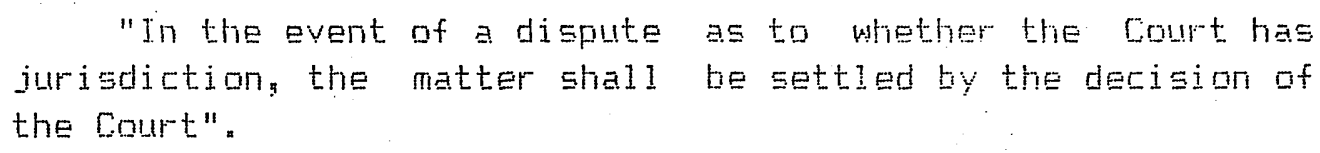

Thus, it is argued that this text does not only confer a right on the court, but also obliges it, and not the interested party, to decide on its own jurisdiction.

The Court's jurisprudence indicates that neither the Court nor the parties to a case before it can depart from the provision of the statute. In the FREE ZaNES OF UPPEP SANOY AND DISTRICT OF GEX the P. C. I. J. refused to comply with demands made by both parties to the case that it should communicate to them unofficially the result of its deliberations. It refused to do so because it found that the request was in conflict with "the spirit and letter of its statute". Consequently the P. C. I. J. said that it "cannot, on the proposal of the parties, depart from the terms of the statute". 79

The present Court has also confirmed this principle. In its Advisory Opinion of July 7, 1955 concerning the UOTING PROCEDURE OF THE GEHERAL ASGEHBIY IH THE HATTER OF PETITIONS FPOH SOUTH HEST AFRICA the Court held that the General Assembly cannot act except in accordance with the Charter. 80

It is argued that if the court refused to depart from the statute at a request made by both parties, it would be still less able to do so at the request of one party alone. 81 This argument is further supported by the insertion of the new provision in Article 1 of the Statute and Article 92 of the Charter requiring the Court to 
function in accordance with the statute.

82

Accordingly a reservation depriving the Court of its right to decide on its own jurisdiction and preventing it from performing the duty imposed upon it by the statute by keeping that decision in the hands of the interested state runs against general provisions of the Statute and the Charter as well as against a specific provision of the latter.

To add even further force to this argument, it is said that the subjective reservation also runs against "one of the most fundamental principles of international - and - national - jurisprudence according to which it is within the inherent power of a tribunal to interpret the text establishing its jurisdiction". 85 Both the present Court and its predecessor, the P. C. I. J.. have recognised this principle even in the absence of any provision to that effect. 84 The most extensive treatment of this principle was in the NOTTEROHH case where the Court said:

"Faragraph o of Article 36 merely adopted, in respect of the court, a rule consistently accepted by general international $l$ aw in the matter of international arbitration. Since the ALABAMA. case, it has been generally recognised following the earlier precedents, that in the absence of any agreement to the contrary an international tribunal has the right to decide es to its own jurisdiction and has the power to interpret for this purpose the instruments which govern thet jurisdiction".

The importance of Article 36 (2), being inserted deliberately into the statute as an indispensable safeguard for the operation of the system of compulsory jurisdiction, refutes, it is submitted, the attempt which contemplates bringing the reservation within the four corners of conformity with Article 36 (6) 86 by arguing that it is still for the court to decide upon the jurisdiction conferred upon it by a declaration containing such a reservation "although it will have to say that no jurisdiction exists when [the invoking state] has deter- 
mined that a matter is within domestic jurisdiction". 87 This argument has been criticised as a formal examination of Article 36 (6) ignoring its substance 88 and transforming the Court's power to determine its jurisdiction to one of a "verbal character" or "dialectical character", ${ }^{89}$ or a ministerial one confined to registering the determination made by the interested state.

\section{(b) Inconsistency of the reservation with the requirement of a legal obligation}

An instrument containing this reservation cannot, it is argued, be considered as a declaration in the sense meant in Article 36 (2) of the Statute. This Article contemplates an acceptance of "obligation" of "compulsory jurisdiction". A state making such a reservation has undertaken an obligation to the extent that it, and it alone. considers that it has done so. What does this mean? Judge Lauterpacht answered:

"This means that it hes undertalen no obligation. An instrument in which a party is entitled to determine the existence of its obligation is not a valid and enforceable legal instrumegt. It is a declaration of a political principle and purpose".

Consequently the reservation is in conflict with the purpose and object of the system of compulsory jurisdiction. For, whereas this system purports to ensure the adjudication of disputes upon the application of a single party, the reservation conditions the obligation to adjudicate "upon a further expression of consent after the specific dispute has arisen". 71

The natural conclusion of the above arguments is that the subjective reservation of domestic jurisdiction is void. It is a reservation of the same kind as the request made to the P. C. I. J. in the FREE ZOHES case. It does not differ from a proviso stipulating that the Court's decision would not be binding unless given by 
unanimity, or one excluding certain judges of certain nationality. 92 This conclusion cannot, it is argued, be affected by the argument that the statute is interpreted in practice to permit reservations to the Court's jurisdiction, and that since states are free to accept or not to accept the jurisdiction they can limit their consent by whatever reservations they think fit. No doubt, it is true, that Article 36 (2) has been interpreted to permit reservation and that the jurisdiction depends on the consensus of the agreement of the parties. Yet the freedom to insert reservations is limited and the Court's jurisdiction depends on a further condition, namely. whether such consensus is compatible with the statute. Reservations to the functioning and organization of the Court are not permitted. They cannot limit the duties and rights conferred upon the court by the statute. The FREE ZONES case is illustrative. 73

The inequality between the reserving state and a non-reserving one, where the latter is the respondent, is also put forward as another reason for the nullity of the reservation. It is said that the reservation may put the reserving state in an advantageous position. For it can force any other state to come before the Court unless the other party is prepared to resort to a "distasteful and impolite determination". In such a case, it throws on the respondent state the difficulty and embarrassing responsibility of relying on a reservation that it might consider odious, in cases where it might find it wiser not to make a determination that may be quoted against it on another occasion. In such a case only the invalidity of the reservation would remove the inequality.

\section{(ii) Invalidity of the entire declaration}

According to this approach, the criterion upon which the effect of an invalid reservation on the whole declaration is to be determined is the importance of the reservation for the acceptance of the Court's jurisdic- 
tion. The reservation can be severed from the declaration only if it does not constitute an essential part of the instrument. Having found that the subjective reservation of domestic jurisdiction was the crucial part of the declaration, judges Sir $\mathrm{H}$ Lauterpacht 75 and Sir Percy spender 96 agreed that it could not be ignored, or otherwise the decision would run against the will of the reserving state and the fundamental principle of international judicial settlement confirmed by the established practice of the court, that the court cannot uphold its jurisdiction unless the intention to confer it has been proved beyond reasonable doubt. Consequently, a declaration containing such a reservation is incapable of conferring any jurisdiction on the court. However the grounds on which this conclusion was reached were different. While judge Sir P Spender relied exclusively on the terms of the reservation, which appeared to him clear enough to the extent of precluding any reference to the preparatory works, 97 judge Sir $H$ Lauterpacht relied on both the terms of the reservations and their preparatory works, or the circumstances in which they were made.

This approach has been adopted by most authorities including Charles De Visscher, 99 L Preuss, 100 Dubisson, 101
R Y Jennings, 102 and R P Anand. $10 \mathrm{~S}$

\section{(II) Valid Acceptances Containing Invalid Reservations}

The difference between this approach and the previous one lies in the effect of the invalidity of the subjective reservation of domestic jurisdiction. Unlike the first, this approach holds the severability of the reservation, or the offending words in it, namely, "as determined by the declarant state". 104 Different arguments have been advanced in support of this view. While judge Guerrero did not indicate the reason for which he favoured the separation of the reservation from the declaration, 105 the intention of the reserving state appeared to judges Klaestad and Armand-Ugon in the INTER- 
HANDEL case to be the determinant factor. This is in spite of the fact that the former thought that the invalidity of the offending words precludes the court from acting upon them 106 and the latter believed that the Court may, in performing its duty to safeguard its statute. "appraise the legality of the different parts of the declaration in order to determine whether the relevant clauses of the statute have been correctly applied". 107 However, they both agreed that an interpretation invalidating the whole declaration as a result of the nullity of the reservation would lead to results contrary to the intention of the declarant state. The consequences of the invalidity of the declaration would be that the reserving states could neither sue nor be sued under Article 36 (2). In other words, the reserving state could find itself in the same position as States which have not submitted to the compulsory jurisdiction. Both judges had no doubt that the reserving state - at least in this case - intended to make a real and effective declaration. though with far reaching reservations. 108

Judge Armand-Ugon advanced another argument. A declaration accepting the Court's jurisdiction under Article 36 (2) consists, in his view, of two elements: acceptance, and reservations. They are distinct elements of a single judicial act. Nothing justifies treating them as an indivisible whole. He considered the offending words in the reservation as "an accessory stipulation".

The implication of these arguments is that it might lead to the same result as the first approach, i.e. the invalidity of the whole declaration. This would be the case where evidence is to the effect that there would have been no acceptance without this reservation being attached to it.

Professor Briggs adds two other arguments for the severability of the reservation. The first is based on the rule of interpretation adopted by the court in the 
RIGHT OF PASSAGE case, according to which "a text emanating from a government must, in principle, be interpreted as producing and intended to produce effects in accordance with existing law and not in violation of it". 110 The second is based on the rule in the HOTTEBOHN case, which prevents a unilateral attempt to withdraw jurisdiction in a case already pending before the Court from depriving the Court of jurisdiction already established.

In order to release the court from the invidious task of pronouncing the validity of the reservation while at the same time holding its jurisdiction in a case referred to it under a declaration containing such a reservation. Professor Leo Gross advances the rule governing the conflict between the obligation undertaken and the Charter of the United Nations and other obligations. Since the Statute "forms an integral part of the Charter" (Article 92 of the Charter) an obligation leaving the determination of jurisdiction to the parties concerned cannot, by virtue of Article 103 of the Charter, prevail over the obligation resulting from Article 36 (6): of the Statute, the court can ignore the reservation without having to declare on its validity. In other words, by invoking Article 103 of the Charter, the Court would need only to find whether there exists a conflict between two obligations. ${ }^{112}$ Professor Gross argues that the application of the charter would be in line with the practice of the Court in showing respect for the sovereignty of a State and at the same time allows the Court to perform its duty as a guardian of the system of compulsory jurisdiction.

\section{(II) Reasonableness and Good Faith Tests: "Amelioration by Interpretation"}

During the debates over the United States reservation of domestic jurisdiction many senators, among whom Senator Connally himself - the author of the reservation - expressed the view that the United States would never 
use its reservation unreasonably and in bad faith. Many writers have also shared the same view without indication, to what would happen if the reservation is used arbitrarily. Nor did they indicate the criterion to be applied for the determination of reasonableness or good faith. 115 The invocation of these tests besides that of $A B U S D E$ DROIT in some cases before the court - as has been seen ${ }^{116}$ - has given new life to this approach. 117 The basic understanding of this approach is the rejection of a rigid and literal interpretation of the words of the reservation. 118 It is argued that the view that the words of the reservation are clear and therefore do not require an interpretation begs the decisive questions. namely, which interpretation should prevail, the literal or equitable? Moreover, the maxim UT RES HAGIS UALEAT QUAH PEREAT comes into play as long as the absolute interpretation - i.e. that giving to the reservation a peremptory effect - might lead to doubts as to whether the reservation, and hence the whole declaration is valid. 119

Two other principles have also been advanced against the absolute interpretation. The first is that cited above, which was pronounced by the court in the RIGHT OF PASSAGE case requiring the interpretation of any text emanating from a government "as producing or intended to produce effects in accordance with the existing $l$ aw and not in violation of it." 120 The second is that laid down by the P. C. I. J. in the POLISH POSTAL SERUICES IH DANZIG 121 case and confirmed by the present Court in its advisory opinion on COMPETEHCE OF ASSEHBLY REGARDING ADHISSION TO THE UNITED NATIONS 122 that:

"It is a cardinal principle of interpretation that words must be interpreted in the sense they would normally have in their context, unless such interpretation would lead to something unreasonable or absurd".

An interpretation leading to the nullification of the acceptance must thus be rejected. 
However, this interpretation was canvassed particularly by the supporters of the first and second approaches, but has been rejected. The application of good faith, reasonableness and abuse of rights tests have been criticised on many grounds. Firstly, it is argued that the Court has no power to exercise control over the determination made by a state. If the Court attempts to do so, it would arrogate to itself a power which has been expressly denied to it and kept by the reserving state for itself. 124 For instance, it was observed that the requirement of good faith would add the proviso "provided it is so determined by [the declaring state] in good faith". 125 Secondly, it is difficult for the court to attribute bad faith; unreasonableness, or ABUS DE DROIT to a sovereign state. The Court must be guided with great caution in this respect. ${ }^{126}$ Furthermore, the comprehensiveness of the scope of the reserved domain makes it very difficult to conceive situations where a state uses so extravagantly and arbitrarily its reservation. 127 Finally, it is said that the practice of the court excludes the application of these tests. Thus it did not apply them in the NORHEGIAN LOANS case. 128

In reply to this criticism, it is argued that this approach had been adopted by states, though inconsistently by some, before the court. 129 The cases in which the reservation was invoked show that the reservation was not invoked in a way putting an end to the proceedings. Rather, it was invoked as a preliminary objection in the same manner as other reservations are invoked. 130 It is also observed that if the intention of the reserving State was to exclude any control over a determination made by itself, the reservation would have been phrased as follows: "Provided, that this declaration shall not apply to any dispute which this government decides to withdraw from the jurisdiction of the Court", instead of using the reservation in question as a subterfuge. 131 Even if there is still some doubt as to the intention of the reserving state, it might be argued that that inten- 
tion is respected. For the determination of the nature of the dispute is to be made by the interested state, but such a determination is subject to the Court's control. 132

The difficulties of attributing bad faith, unreasonableness, abuse of right, and those inherent in arriving at a classification of "domestic" or "international" jurisdiction are generally admitted. However it is argued that such difficulties scarcely warrant the conclusion that the reservation confers on the reserving state an absolute power to defeat the Court's jurisdiction. ${ }^{135}$ They should not prevent the Court from applying these tests. On the contrary, the Court must apply - at least the principle of good faithpursuant to Article 38 (c) of its Statute, since it is a general principle of $1 \mathrm{aw}$. 154 The Court's jurisprudence, it is submitted, is clear on this point. In the NUCLEAP TESTS case, second phase, the Court said:

"One of the basic principles governing the creation and performance of legal obligationsag whatever their sources, is the principle of good faith".

This holding was confirmed by the Court in the MILITARY AND PARAHILITARY ACTIUITIES IN AND AGAINST HICARAGUA CaSE (jurisdiction and admissibility). 136

As to the non-exercise of control over the determination made by Norway in the HOPHEGIAN LOANS case, it is maintained that the court did not adopt the absolute interpretation, although it declined jurisdiction because of Norway's reliance on the reservation. The Court had no occasion to consider the question of reasonableness or good faith raised by Norway because France did not contend whether Norway's determination was made in bad faith or unreasonableness. 137

Although the supporters of this approach agree that the absolute interpretation should be avoided, they do not agree as to how the reasonableness and good faith tests are to be applied. While judge Read had limited his 
view to the reasonableness test according to the specific circumstances of every case, ${ }^{138}$ others seem to generalise on the application of these tests. 13? However, there is a general agreement among the supporters of this approach that the court examines its control over the truth or falsity of a declaration or whether it was made in good faith or bad faith according to an objective criterion, namely, international law. 140

Thus, the net result of this approach seems to be similar to that of the second approach. They both lead to the conclusion that only matters which are according to international law within domestic jurisdiction are covered by the reservation in question. 141 . In other words, the reservation is not subjective but it is another variant of the objective formula of the reservation of domestic jurisdiction. The only difference between them is that according to the latter the Court decides whether a matter is DOHESTIC as a matter of law, regardless of the determination alleged by the parties concerned, or whether it is reasonable and made in good faith. 142

\section{(IV) Valid Reservation}

Unlike the previous approach which holds the validity of the reservation as long as the intention of the reserving state is not clear that it intended to give the reservation an absolute effect, this approach is based on the understanding that the meaning of the reservation is clear. It has an automatic effect depriving the court of jurisdiction if it is invoked. Yet it is not incompatible with the statute. The difficult task of this approach is, thus, to counter the arguments of invalidity put forward by the proponents of approaches 1 and 2 .

\section{(i) Consistency with Article 36 (6) of the Statute}

To prove the consistency of the reservation in question with Article 36 (6), reliance has been made on 
the interpretation limiting the Court's power under Article 36 (6) to what the proponents of the first and second approaches described as a "verbal" or "dialectal" power confined to "registering" the determination made by the interested state. 143 There is nothing wrong, it is observed, in limiting the Court's power to determine its jurisdiction to a ministerial one. The Court's function is sometimes confined to registering a course of action taken by the parties and suspend or terminate proceedings. 144 This is so where the parties, for example, pursuant to a common reservation "agree to have recourse to another means of peaceful settlement". 145 In support of this argument the attention is drawn to the circumstances in which the reservation might leave a residuum of decision-making power. This would be the case where the reservation is not invoked in the first responsive pleading. In such a case the court, and the Court alone, would be empowered to decide its jurisdiction. 14t However. assuming the correctness of this argument, no explanation is given to the case where the reservation is not invoked at that stage, but the right to do so later is reserved.

\section{(ii) Consistency with Article 36 (2)}

Although it is conceded that it is hard to see exactly what obligation is accepted by a declaration containing the subjective reservation of domestic jurisdiction, it is maintained that the reservation is not inconsistent with Article 36 (2) of the Statute. This is because, firstly. Article 36 (2) does not require implicitly that a substantive obligation is assumed. Such a requirement is not clear in spite of the reference to the terms "obligation" and "compulsory". For, the former "is more descriptive of what is recognised than a requirement of what should be" and the latter "is certainly stronger, but an automatic declaration does constitute saHETHIHG, even if only a procedure". 147 Secondly, it is pointed out that the argument depriving the declaration the character of a legal obligation because of its inconsis- 
tence with the requirement of a "legal obligation" is based on private law standard the application of which would invalidate a large number of declarations made under Article 36 (2). This is so because declarations terminable at any time without notice, would also fall down. "It should be evident that these acceptances and these containing the automatic reservation stand in PARI DELICTO, and attempts to denounce the one while justifying the other can only be idle folly". 148

State practice has also been relied on as a proof of consistency of the reservation with the statute. It is argued that the reservation has come to be accepted in practice as a permissible reservation to Article 36 (2). This is because it has been accepted by a number of States and its validity has never been contested through diplomatic channels even by those which have shown themselves assiduous in protecting the compulsory jurisdiction. Thus they are, prepared, at least tacitly, to acquiesce in it. This practice constitutes therefore a subsequent interpretation of Article 36 (2). 149

Two further grounds for the validity of this reservation have been added recently by James Crawford: the "applicable principles of law" and the consideration of "automatic declarations" as another way of access to the Court. 150 under the first, he argues that declarations of acceptance, being not multilateral treaties, are not governed by treaty reservation rules. If these rules, viz. Article 20 of the Vienna Convention on the Law of Treaties (V.C.L.T.) are extended to declarations by analogy, being customary international law, they would prohibit reservations altogether on two distinct grounds. Firstly, Article 36 (3) of the statute allows declarations to be made unconditionally or on condition of reciprocity for a certain time only [Article 19 (6) of V.C.L.T.]. Secondly, the Court has not expressly accepted particular reservations to its "constituent instrument". [Article 20 (3) of V.C.L.T.]. 151 As he thinks that the 
reservation in question is not inconsistent with Article 36 (6) of the statute and therefore not "prohibited" by that Article, Crawford emphasises that the relevant issue must be whether the reservation is "inconsistent with the object and purpose" of the Optional Clause [Article 19 (c) of V.C.L.T.J. He argues that this test is not applicable to the declarations of acceptance, because it can entail different interpretations. 152 The Court should be reluctant to substitute its own view for a consistent State practice either in accepting a particular view of the object and purpose of a treaty or in not objecting to the reservation in question on that ground, Crawford argues. He concludes that :

"the application of treaty reservation rules could well entail that automatic reservations have been accepted; under the customary analogue to the treaty reservation rules in the Vienna Convention, as not inconsictent with the object and purpose of the Optional Clause".

In the light of state practice as mentioned above, Crawford argues also that the application of ordinary principles of vires leads to the same result, namely, the validity of the reservation. This is so because states, on a bilateral basis, so long as no underlying issue of 7US COGENS, or basic element of the Court's structure is involved, can accept states making the subjective reservation of domestic jurisdiction as parties vis-a-vis themselves.

Under the second ground, namely, "automatic declarations" as another way of access to the Court, which is the most convincing approach in his view, Crawford argues that even if the instrument containing the automatic reservation is incapable of generating legal consequences or entails no immediate legal obligation, it does not follow automatically that such instrument is void. A conclusion drawn on the existence of general principle invalidating that instrument "fails to distinguish the voidness of an instrument, for example where an overrid- 
ing legal rule deprives it absolutely of legal effect, and the presence of obligation or legal content of an instrument which is capable of generating legal consequences, for instance by a subsequent course of conduct". The reservation in question falls in Crawford's view in the latter category. Explaining this point, Crawford points out that an instrument is void where it fails to comply with the requirements of the procedure set forth for the achievement of the results for which the instrument was made only where there exists no other procedure. However, if that object can be achieved by another procedure fulfilling the required conditions, the instrument will not be invalid. "An act ULRA UIRES under the intended head of power may turn out to be valid under another". 156

Thus Crawford cannot see anything that could prevent a state accepting the Court's jurisdiction under Article 36 (2) of the Statute; from considering a state which has made a declaration to similar effect, but under Article 36 (1) as if the latter was party to the compulsory jurisdiction system under Article 36 (2). This is so inasmuch as the difference between acceptance of the Court's jurisdiction under paragraphs 1 and 2 , of Article 36 is that, under the former, the obligation is assumed vis-a-vis other declarants and not just any state which has accepted the Court's jurisdiction $A D$ HOC or by treaty. Thus he likens a declaration containing subjective reservation to one made by a non-member of the United Nations according to Security Council Resolution 9 (1).

Accordingly Crawford concludes that:

"an automatic reservation is not voidz it is in law an Article 36 paragraph I procedure which is intended to have effect vis-a-vis parties to the optional clause but which requires the latter's consent or acceptance to operate as such". 


\section{D - A LIMITED CHOICE}

Since the likelihood is remote, if not impossible, that a state would contest the validity of its own reservation, the question of validity might be raised by a non-reserving state in two hypotheses: as a respondent or applicant. In the first hypothesis. It may argue that the reservation is invalid and its validity entails the nullity of the whole declaration. Although this hypothesis is not excluded especially if the defendant state finds it wiser - as already mentioned ${ }^{15}$ - not to make a determination that may be quoted against it on another occasion, it may find it easier to invoke the reservation being sure that the applicant state cannot contest its validity. The most likely hypothesis in which the question of validity of the reservation would be raised is thus where the respondent state relies on its own reservation claiming that the dispute concerns matters falling within its domestic jurisdiction. In such hypothesis the applicant may argue that the reservation is invalid - as happened in the INTERHANDEL case 160 - but such invalidity does not entail the nullity of the whole declaration.

The sensitive question, however, is what approach amongst those discussed above would be adopted by the Court if it finds itself obliged to take a position on the point? 161

\section{(I) The First Approach is Rejected by the Court}

The conclusion drawn from the invalidity of the reservation, namely, the invalidity of the whole declaration, is in contradiction to the Court's jurisprudence. This has been admitted even by the most protagonist of this approach. Thus judge Sir $\mathrm{H}$ Lauterpacht admitted in the INTEPHANDEL case that the court had decided, at least provisionally, that a declaration containing such a reservation was "a valid legal instrument cognizable by the court". 162 Also in the first phase of the same case 
the Court - as already pointed out - made a formal finding that the parties had accepted its jurisdiction "on the basis of Article 36 (2)". In the NOPHEGIAN LOANS case the Court also made a statement implying the validity of the declaration. It said:

"[T]he French Declaration ACCEPTS the Court's jurisdiction within narrower limits than the Norwegian Declaration; consequently: THE cominon HILL of the parties, which is the basis of the Court"s jurisdiction, exists within these narrower limits indicated by the French reservations".

The Court's judgment in the MILITARY AND PARAHILITARY ACTIUITIES IN AND AGAINST HICARAGUA Case seems, however, to remove all doubt on the question. Although the United States reserved its right to invoke its reservation in future - i.e. did not abandon it - the court found that the United States had "ASSUMED AS INESCAPABLE ORLIGATION TOHARDS OTHER STATES ACCEPTING THE OPTIOHAL CLAUSE". 165 In another passage the Court said also that the 1984 notification excluding some disputes from the United States declaration of 1946 with immediate effect "cannot override THE ORLIGATION OF THE UHITED STATES TO SUBHIT TO THE COHPULSORY JURISDICTION OF THE COURT UIS-AUIS NICARAGUA, A STATE ACCEPTIHG THE SAHE ORLIGATIOH". 16G

Moreover, since the view of the inseverability of the reservation from declarations is based almost completely on the intention of the reserving state, in other words on the understanding that the reservation is an essential part of the acceptance, the argument seems more theoretical so long as that intention is unknown. 167 However, what appears to be certain is that the intention of one state cannot be substituted by that of another state. Thus, it is hard to understand Lauterpacht's reliance on the intention of the United States and those of South Africa and India while he was considering the French reservation. 168 In fact, it is not inconceivable. so long as the intention of states making the reservation is unknown, that a reserving state may argue that the 
reservation was not a crucial part of its acceptance, and therefore it is severable. If confirmation of this hypothesis is needed, it is provided by the Portuguese argument in the RIGHT OF PASSAGE OUER INDIAN TERRITORY case.

\section{(II) The Fourth Approach - Insufficient Grounds for Invalidity}

The grounds on which the fourth approach stand do not seem strong enough to justify the adaptation of an important system as the compulsory jurisdiction to the reservation of a question instead of attempting, at least, to adapt the latter to the former. However, before discussing these grounds it might be better to return to the Court's position towards the reservation and reflect a little on the reasons which prevented the court from pronouncing on the question of validity.

In spite of the rare self revelations in the judges individual opinions on this question in the HOPHEGIAH LOANS and INTERHAHDEL case, a careful reading of some opinions indicates that the court avoided taking a position on the question for reasons of a non-legal nature. The majority preferred to "postpone a decision on the subject" 170 because of, firstly, the "political implications" of such a decision on other declarations containing similar reservations. ${ }^{171}$ This cause seems to have found strong support in the fact that most of the states which have made such reservation were the client of the Court or to use Lauterpacht's words "traditionally wedded to the cause of international judicial settlement". 172 The second reason, which is almost a corollary of the first. was the moral value of the declarations containing such reservations as a support to the principle of compulsory jurisdiction. ${ }^{175}$ Thirdly, the idea that a decision invalidating a reservation could be considered as an "offensive to the dignity of a sovereign State" seems to have found a place in the deliberations of the court. 174 These reasons were described by judge Lauterpacht as 
obvious that there is no dispute as to jurisdiction in case the parties agree to settle their dispute by another means of settlement. Furthermore, the parties' action in such a case is exercised according to the statute (Article 88 of the Rules of the Court), which enables them to ask the court to remove the case from the list. 179

\section{(ii) Inconsistency with Article 36 (2)}

1. If the object of the argument that Article 36 (2) does not require the assumption of a substantive obligation is to adapt the compulsory jurisdiction system to the reservation, its result seems to exceed that object. For such an argument denies the very existence of something that can be called "compulsory jurisdiction". However, it is perhaps not expected that such an important document as the Statute should explain in detail that the obligation undertaken under it "must be substantive".

2. There exists a basic difference which could justify the nullity of the subjective reservation of domestic jurisdiction and sustain the validity of the reservation of the right to terminate the acceptance without a previous notice. While the former seeks to defeat the Court's jurisdiction even after the application has been filed in the case, the NoTTEBOHM rule prevents the latter from having such an effect. 179

3. As to the argument that the reservation has come to be accepted in practice as a permissible reservation, the following remarks may be made. In considering state practice in regard to domestic jurisdiction reservation it must not be forgotten that the declarations of 41 states out of the 46 currently in force do not contain such a reservation, and that 14 out of the 41 have included in their declaration the reservation in its objective 
form. 180 Furthermore, Article 36 (6) of the Statute has also been interpreted in this manner, i.e. as empowering the court, and the court alone, to decide on its own jurisdiction even by some states making the reservation in the subjective form. Thus the United States had argued before the Court in the case concerning the IHTEPPRETATION OF PEACE TREATIES HITH BULGARIA, HUNGARY AND FUHAHIA that "it has long been recognised in international law and PPACIICE" that an international tribunal has an authority to determine its own jurisdiction. ${ }^{181}$ It also argued that:

\begin{abstract}
"Even if the Feace Treaties expresely provide that their provisions should not be construed to affect matters which are solely or esentially within the domestic juriediction of any Stete. these states could not by unilateral declarations determine for themselves what matterco yere solely within their domestic jurisdiction".
\end{abstract}

It is true that non-reserving states have not protested against the reservation through diplomatic channels. Yet it cannot be taken for granted that they have accepted this as a valid reservation. They do not feel obliged to do so, as long as they have the opportunity to raise the question of invalidity whenever they deem it necessary before the court. Thus Switzerland had not been prevented from contesting the validity of the reservation. Nor had India or Australia been prevented from doing so in regard to the Portuguese third condition $18 \mathrm{~S}$ and the national security ${ }^{184}$ reservations. Also, it should not be forgotten that some States abandoned the practice of making such a reservation in a period during which hopes had been expressed not only in standard writings but also by legal institutions ${ }^{185}$ as well as some governments 186 that such practice should be abandoned because of its inconsistency with the statute. 197 Another fact that must be kept in mind is that the reserva- 
tion represents a practice of only 5 States amongst not the 46 states which accept the jurisdiction of the Court under Article 36 (2), but amongst the 159 States 188 members of the United Nations. For although 116 states are still outside the system of compulsory jurisdiction they are very much concerned with any attempt to modify the statute, a modification which requires a majority of two thirds of the states members of the statute.

The permissibility of the subjective reservation of domestic jurisdiction seems thus far from established.

\section{(iii) The invalidity of the reservation according to} the "applicable principles of law"

1. It is doubtful that the application of treaty reservation rules, by analogy to declarations, would lead to the prohibition of reservations altogether because of the argument advanced by Crawford. For, firstly, it was made clear in 1945 that paragraph 3 of Article 36 of the statute had been interpreted to allow reservation and therefore there was noneed to amend it in order to clarify this point. 189 Secondly, the Court has in practice accepted reservations and it has recently expressed clearly the view that reservations other than those mentioned in Article 36 (3) are permissible. 190

2. As to the argument that the Court should be very hesitant in applying the "object and purpose" rule because it might entail different interpretations, it might be said that there seems to be no doubt that the object of compulsory jurisdiction is at least to ensure the adjudication of disputes upon an application of a single party without need for a further expression of consent after the dispute has arisen. 171 More to the point, the court has applied this rule- 
as has been seen - in the RIGHT OF PASSAGE OUER INDIAN TERRITORY case. ${ }^{192}$

\section{(iv) The "automatic declarations" as another way of access to the Court - approach}

The difficulty with this approach is that the declarations containing subjective reservations of domestic jurisdiction are made expressly pursuant to Article 36, paragraph 2, and not paragraph 3. This distinction is not theoretical but has a practical effect. As Crawford observes, a State making a declaration under paragraph 2 of Article 36 intends to accept the Court's jurisdiction - vis-a-vis - other declarant states. The question thus is whether such a "result" can be achieved by considering a declaration containing such a reservation as made according to the "procedure" set forth in paragraph I of Article 36? To condition the effect of such declarations on the consent of other states parties to the compulsory jurisdiction of the Court is to put these states in a privileged position. For, in such a case any of these States can sue a reserving State at any time. Whereas the latter can only sue those which have accepted that State as a party vis-a-vis themselves. It is doubtful whether States making the reservation in question intended to put themselves in such a position or they will accept such interpretation. If such inequality is established by Security Council Resolution 9 (1946), it is justified by the desire to open the Court to States NOT PARTIES TO THE STATUTE. There seems to be no justification for generalising such inequality between States PARTIES TO THE STATU$T E$. Moreover, this approach leaves the main question unanswered, namely, whether this reservation can be made even in a declaration made under Article 36 (1)? 198

From the above considerations it appears that all the ways conceived for preserving subjective reservations of domestic jurisdiction lead to their nullity. 


\section{(III) Choice Between the Second and Third Approaches}

The choice left to the court is thus the adoption of either the second or third approach. It is difficult to state categorically in abstract terms what course of action would be followed by the court if the issue of validity were raised before it and it did not find another way of disposing of the case. without pronouncing on the validity of the reservation. The intention of the reserving state has been given much weight by every approach. Yet, the intention of the five states making the reservation is unknown ${ }^{194}$ The circumstances in which the reservation might be invoked would be of great importance for determining the course of action to be followed. An argument by the reserving state that the reservation was not an essential part of its acceptance, or that it did not intend to deprive the Court of the power to control a determination made by itself, or its attempt to prove that the matter in dispute fell within its domestic jurisdiction according to international law in spite of its invocation of the reservation may facilitate the Court's task and affect its decision.

HOwever, the HILITARY AND PARAHILITARY ACTIUITIES case has provided two new grounds in support of Approach 3. The non-invocation of the reservation by the United States, despite its attempt not to leave any stone unturned, proves that there are cases in which the reserving State cannot, in good faith, assert that the dispute concerned matters of domestic jurisdiction. 175 This precedent cannot, however, be generalised and there is no guarantee that other states will use the reservation in such a way. The second, and the most important, is the clear statement made by the court that the declaration of acceptance, and the reservations and conditions embodied therein are governed by the principle of good faith. After indicating that the declaration of acceptance, as a unilateral act, establishes a series of bilateral engagements "in which the conditions, reservations and time- 
limits clauses are taken into consideration", the Court said:

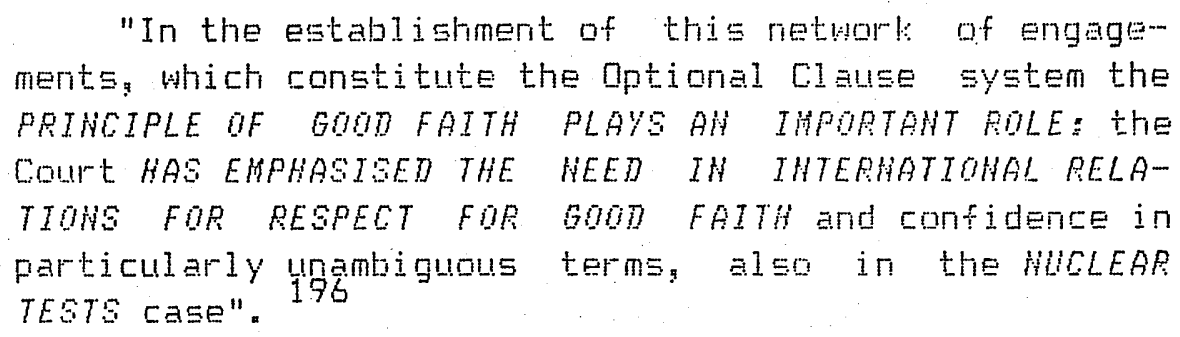

Then it quoted its statement in the latter case that the creation and performance of legal obligations. regardless of their sources, are governed by the basic principle of good faith. 197 Consequently, the Court applied this principle in this case. It refused to take the view that declarations of indefinite duration can be terminated immediately. It said that "the requirements of good faith" justified the treatment, by analogy, of such declarations according to the law of treaties, which requires a reasonable time for the termination of treaties of indefinite duration.

The court can thus rely on this principle and exercise its power provided for in Article 36 (6) of the Statute. It might also consider it wiser not to rely on this principle for the reasons advanced especially by the supporters of the first approach against its application and choose to declare the invalidity of the reservation or ignore it and proceed to the examination of the merits of the case, i.e. adopt the second approach. This might be the case especially where the circumstances of the case were in favour of such approach; if, for instance, the reserving state took the same position taken by Portugal in the RIGHT OF PASSAEE DUER IHDIAH TERPITORY case. 197 The disappearance of one of the reasons which had prevented the Court from pronouncing on the validity of the issue, namely, the abandonment of the reservation by client states, may encourage the Court to follow the second approach. Furthermore, it might be argued that the Court is fully justified in following this approach. It 
is true that the basic principle which governs the Court's jurisdiction is the consent of states. However in exercising its jurisdiction in spite of the invocation of the reservation the court might not be considered as disregarding that principle. For, States have expressed their consent to the Court's jurisdiction and, to use Schwarzenberger's words "dares the Court to annul" 200 the reservation in question. The court would thus exercise its function to "imbue parties to the statute with due respect for the Court's 7 LS cogIHS and manifest the Court's credibility". 201 There is no doubt that reserving states were fully aware that the Court rejected demands contrary to the statute. The possibility of a decision invalidating the reservation had also been expressed - as has been seen - by seven judges of the Court. What are those states thus expecting the Court to do if it were forced to take position on the question? They have been offered the opportunity to revise their acceptances, either to renounce the reservation in question or to annul their declarations completely, but they chose not to do so. The court therèfore seems fully justified in adopting the second approach.

\section{E - Conclusions}

From what has been said the following conclusions ought to be drawn.

In spite of the fact that the Court had been offered many opportunities to pronounce on the validity of subjective reservations of domestic jurisdiction, it cautiously stepped aside for reasons of a non-legal character.

The Court will not raise the issue of validity $E X$ PROPRIO HATU, but will exercise its jurisdiction on the basis of the parties' declarations if the validity issue is not raised. 
If the invalidity of the reservations is invoked the Court will not decide the question of validity except when all other grounds have failed to dispose of the case.

The weight of arguments seems to be in favour of the nullity of these reservations, being contrary to both constitutional provisions governing the Court's functioning and the object and purpose of the Optional Clause.

The Court cannot hold the invalidity of the whole declaration without revising its previous jurisprudence.

The Court might thus ignore or declare the invalidity of these reservations and proceed to the examination of the merits of the case. The intention of the reserving states and the circumstances of the case would be of much significance in the Court's choice of what approach should be followed.

These reservations proved to be not in the interest of states making them. The application of the principle of reciprocity renders them a defence that backfires. 202 In fact reciprocity is, perhaps, the most efficace legal sanction of the reservation. 203 Thus, it is not difficult to understand why the reservation had ben dropped from many declarations. 204

Although these reservations were initiated by developing countries, they do not find a place now except in the declarations of developing countries. They are still kept by States which have never appeared before the Court either as a respondent or applicant on the basis of Article 36 (2). They did not, therefore, pay the price of making them though they should have learned the lessons of the others. 


\section{SECTION 2 : NATIONAL SECURITY AND NATIONAL DEFENCE RESERVATIONS}

Two kinds of reservations concerning national security and defence were made. The first was made by the United Kingdom and the second by France.

\section{A - THE BRITISH NATIONAL SECURITY RESERVATION}

In 1957 the United Kingdom amended its previous declaration of 1955 for the purpose of excluding. INTER $A L I A$, disputes "relating to any question which, in the opinion of the Government of the United Kingdom, affects the national security of the United Kingdom or of any of its dependent territories". 205 The reservation was said to have been inserted with the object of precluding any challenge to British right to conduct nuclear testing. 206 The form of this reservation was subject to very strong criticism. Thus during its declaration before the House of Commons Mr P Noel Baker accused the British Government of a "smashing blow at British interests" and observed that "if the action of the Government stood long uncorrected, it would be a grave setback to the cause of establishing justice in international affairs." 207 Also in the literature, the reservation was considered as "more unfortunate", than the subjective reservation of domestic jurisdiction. This was because, while international law provides a criterion for determining whether a matter falls within domestic or international jurisdiction, there are no applicable rules of international. law which can determine whether a question affects the national security. 208 It was observed also that such a reservation was not able to stand alongside the statute of the Court "for a double reason: not only is the category of "national security" potentially comprehensive, but it is not a category capable of any kind of judicial assessment". 209 However, since the reservation is aimed at depriving the court of the decision of the applicability of the reservation, its 
validity is treated in the same manner as the subjective reservation of domestic jurisdiction. 210

Although the British Government stated in 1958 that it had decided to withdraw this reservation, 211 it was maintained in the declaration of 1958 by the proviso, which included disputes which "had they been the subject of proceedings brought before the International Court of Justice previous to that date, would have been excluded from the Court's compulsory jurisdiction". 212 The reservation was not thus dropped completely until 1963 . 213

\section{B - THE FRENCH NATIONAL SECURITY AND NATIONAL DEFENCE RESERVATION}

\section{(I) National Security}

In its declaration of acceptance of 1959 France excluded from the scope of the Court's compulsory jurisdiction disputes "arising out of a crisis affecting the national security or out of any measures or action relating thereto". 214 Thus France, unlike the United Kingdom, did not reserve for itself the decision to determine whether a matter affected its national security. In fact by that very declaration France, having learned a lesson from the HOPHEGIAN LoHS Case, had substituted its subjective reservation of domestic jurisdiction included in its 1947 declaration by an objective one.

The object of the new reservation of national security was well known. It was designed - as already mentioned - to exclude disputes arising from events in Algeria. 215 However the reservation, having been couched in general terms, was able to deprive the Court's jurisdiction in regard to other disputes concerning other regions. 216 Also; the terms of the reservation appeared to suggest that the security of a nation could be taken into consideration only when there was a "crisis" 
affecting it. Although the existence of such a requirement was capable of excluding any dispute relating to such a crisis.

Whereas this reservation did not affect the Court's power under Article 36 (6) to determine its jurisdiction. it is submitted that the comprehensiveness and character of the area covered by the reservation could render the invoking state's assessment, the major, if not the sole criterion for assessing its content. The necessary elements of a determination whether the national security of a state has been affected are possessed only by that state. The Court's control over such a determination might therefore be confined to the elements produced by that state. Thus, in spit of its consistency with Article 36 (6) of the statute, this reservation has been considered "implicitly self-judging" compared with the explicit self-judging reservation of domestic jurisdiction. 218

\section{(I I) National Defence}

In its last declaration made in 1966 France added to its reservation of hostilities and national security the proviso excluding "disputes concerning activities connected with national defence". 217 Although this reservation was introduced without being accompanied with any public statement, the contemporary circumstances appeared to leave no doubt that it was inserted in anticipation of the French nuclear tests in the Pacific and therefore with the obvious intention of barring in advance any legal debate concerning the French responsibility vis-a-vis states parties to the compulsory jurisdiction system, 220 and as a result of the revision of the French position towards the North Atlantic treaty Organization (N.A.T.O.). ${ }^{221}$ The reservation was made six weeks before the scheduled date of the French first nuclear explosion in the atmosphere and coincided with the continuing debate about the re-organization of 
N.A.T.O. ${ }^{222}$ The scope and validity of this reservation had been argued at length before the Court in the MUCLEAP TESTS cases. Here the applicants (Australia and New Zealand) based their applications on both the General Act of 1928 and their declarations of acceptance and the French declaration of 1966. 223 France invoked its reservation of national defence in very short and direct terms. In its letter dated 16 May 1973 addressed to the Registrar of the Court, France stated that the Court was manifestly without jurisdiction because its nuclear tests in the Pacific were incontestably covered by the reservation of national defence. They formed part of a programme of nuclear weapon development and therefore constituted one of those activities connected with national defence. ${ }^{224}$ Accordingly France did not appoint an agent, and requested the court to remove the case from its list. 225

The provision on which the applications instituting proceedings were based appeared to the court "PRIMA FACIE, to afford a basis on which the jurisdiction of the court might be based". 226 Therefore, the reservation had been deemed not to create an impediment to the exercise of the Court's power to indicate interim measures of protection. 227

In its memorial on jurisdiction and admissibility, the Australian Government submitted that there were only two ways of approaching this reservation. Either it could be given a broad or narrow meaning and hence it could be regarded as a "subjective" and "automatic" reservation, or as an "objective" one. 228 It argued that although the reservation was apparently drafted in an objective form, it was subjective in substance. Thus, while France intended to leave the decision on the applicability of the reservation to the Court, its conduct in this case rendered the reservation subjective. For, France did not produce the facts which were necessary for the court to decide whether the French nuclear tests were really 
connected with national defence. 227 on the other hand, the reservation could be regarded as a subjective one in the sense that its content could not be determined by reference to an objective criterion, but must be left to be settled in accordance with the view of the interested State. ${ }^{230}$ The terms of the reservation appeared to the Australian government to support this approach. For they could be interpreted in the widest sense as to cover not only events actually occurring but also a "consideration of contingencies and circumstances in future, conceived by, or known only to the particular Government concerned". 231 In such a case, the reservation was invalid for the same reasons advanced for the invalidity of the subjective reservations of domestic jurisdiction. 232 However the reservation was severable from the declaration which remained effective without it. This was so, it was agreed, because, firstly, France dropped its subjective reservation of domestic jurisdiction from its declaration of 1959 in order to remove any future doubts as to the effectiveness of its new declaration. 233 Secondly, the reservation of national defence did not constitute an essential part of the French acceptance. It was not made "jointly and simultaneously" with the acceptance of the Court's jurisdiction. It "was only an addition made to a reservation formulated in 1959, which existed for seven years without the addition being considered necessary, or what is more, 'essential', by the French Government". 234 The reservation could be saved from nullity only if its meaning was confined to activities which were "intrinsically" or "essentially" connected with national defence. 235

The Government of New Zealand was of the view that the reservation in question had to be interpreted as consistent with the statute by limiting the meaning of its terms in a way which enables the court to exercise its control over the applicability of the reservation. For instance, to require the measures of national defence be ultimately related to the right of self-defence. 236 
Having found that the claims of the applicants were without object, the Court did not discuss the scope and validity of the national defence reservation. 237 However, by the termination of the French declaration in 1974 as a result of the NUCLEAR TESTS cases, and because they were not, fortunately, copied by other states, the reservations of national security and national defence have disappeared. 


\section{SECTION (3) : MULTILATERAL TREATY RESERVATIONS}

The exclusion of disputes arising out of multilateral treaties, except within certain conditions, from the Court's compulsory jurisdiction is one of the reservations newly created since 1946 . It has been adopted in two versions:

\section{A - THE VANDENBERG TYPE}

The multilateral treaty reservation was introduced for the first time by the United States in its declaration of 1946. Proviso (c) of that declaration upheld from the scope of the accepted jurisdiction:

\footnotetext{
"disputes arising under a multileteral treaty: unlese (1) all Farties to the treaty effected by the decieion are also Farties to the case before the Court, or (2) the lnited states of America specially agrees to jurisdiction".
}

This proviso is known as "the Vandenberg Amendment" 239 because it was adopted by the United States on a motion of Senator Vandenberg. However, the proviso had its origins in a memorandum submitted by $\mathrm{Mr}$ John Foster Dulles to a sub-committee of the Senate Foreign Relations Committee when the Senate was considering the United States acceptance of the Court's jurisdiction. 240 Noting that disputes under multilateral treaties often give rise to the same issue as against more than one other nation, and that since Article 36 (2) of the statute used the singular "any other state" in referring to the principle of reciprocity, whereas jurisdiction should be compulsory only when all the other parties to the dispute have previously accepted that jurisdiction. Mr Dulles thought that it was desirable to make perfectly clear that:

\footnotetext{
"there is no compul sory obligetion to submit to the Court merely because one of the several perties to such a dispute is sinilarly bound, the others not heving bound themselves to become perties before the court and, consequently, not being
} 
subject to the Charter provision (Article 74) requiring mem-

bers to comply with ${ }_{41}$ decisions of the court in ceses in which they are a party".

To meet Mr Dulles' concern, the Committee proposed the text of the reservation as quoted above, which was adopted by the senate without debate or objection. 242

Thus neither the TRAUAUX PREPARATOIRES nor the language of the reservation could help ascertain the purpose for which the multilateral treaty reservation was inserted. On the contrary, they have deepened the views as regard both the meaning of the reservation and its effect. The difficulty of wresting any intelligible meaning from the language which $\mathrm{Mr}$ Dulles employed in suggesting it, 243 and the failure of the Committee which drafted the reservation, in formulating in legal terms whatever purpose they may have had, were observed. It is said that the reservation was formulated without reference to the provisions of the statute which amply met Vandenberg's concerns. Article 59 confines the binding force of the RES IUDICATA to the parties to the case. Article 62 allows a state to apply for leave to intervene when it considers that it has an interest of a legal nature which may be affected by the decision in the case. Article 63 allows a state to intervene in a case whenever the construction of a multilateral treaty to which it is a party is in question. 245

On the other hand, the language of the reservation betrayed much confusion. The main difficulty of this type of reservation is the qualifying words "all Parties to the treaty affected by the decision". Scholars discussing the reservation disagreed about whether the word "affected" qualified the "Parties" to the treaty, or the "treaty" itself and hence required the presence of all parties to such a treaty before the Court. They disagreed also about the meaning of that word. It has been argued that the interpretation requiring the presence of all parties to a treaty invoked before the court goes beyond 
the intent" of the senate, It renders the reservation unworkable. In many instances it would be impossible to secure the pursuance of all parties to a treaty since many of them would have no real interest in the dispute. Accordingly, the word "affected" qualified the :Parties" to the treaty invoked and must be interpreted narrowly as to mean "directly affected" or "legally affected". 246

On the other hand, some scholars took the view that whether the phrase "affected by the decision" qualified the parties to the treaty or the treaty itself, the court would lack jurisdiction under this type of reservation unless every party to the treaty was a party to the proceedings before the court. This view is based on the interpretation of Article 62 of the Statute, read in conjunction with Article 63 as laying down that, when the meaning of any multilateral treaty is in issue in a case. every party to it has a general interest of a legal nature, which may be affected by the decision of the Court. 247

The question of, how can the Court determine who is "affected" until the final discussion of the case is reached has also been raised. 248 Moreover, it is pointed out that the reservation requires all parties to the multilateral treaty to be parties to the case; but the reserving state "itself would not be" party to the case before the court UNLESS THE COURT ALREADY HAD NUPISDICTION OUER [the reserving state] HITH RESPECT TO THE CASE.

All these questions had been raised before the Court in the MILITARY AND PARAMILITARY ACTIUITIES IN AND AGAINST NICARAGUA case. In its application instituting proceedings against the United States, Nicaragua relied on four multilateral treaties: the Charter of the United Nations; the Charter of the Organization of American States; the Montevideo Convention on rights and Duties of States of 26 December 1933, and the Havana Convention on the Rights and Duties of States in the Event of Civil 
Strife of 20 February 1928. 250 Relying on its multilateral treaty reservation, the United States claimed that since the dispute was one which arose under these treaties, and since it did not specially agree to jurisdiction, the court could take cognisance of the case only if all treaty parties affected by the prospective judgment of the court were also parties to the case. The United States explained the rational of its multilateral treaty reservation, in the words of the court "as being that it protects the United States and third states from the inherently prejudicial effects of partial adjudication of complex multiparty disputes". 251 It spelled out the reasons which inspired the reservation as follows:

$"$ ".. (1) the United States does not wish to leave its legal rights and obligations under multilateral treaties adjudicated with respect to a multilateral dispute unless the rights and obligations of fll the treaty parties involed in that dispute uill also be adjudicated: $(2)$ adjudication of bilateral aspects of a multilateral dispute is potentially unjust in so far as absent states may have possession of facts and documents directly relevant to the rights of the perties to the adjudication INTEP SE; and (S) adjudication of tilateral asperts of a multilateral dispute will inevitably affect the legal rights and practical intereste of the absent state".

As to the meaning of the phrase "affected by the decision", the United States emphasised that the phrase referred only to states affected by a decision in a legal and practical sense by adjudication of claims submitted to the court and not to those which had a legal right or interest in the proceedings. Consequently, three states (Costa Rica, El Salvador and Honduras) were identified as States likely to be "affected". $25 \mathrm{~s}$

Nicaragua, on the other hand, alleged that the reservation should be interpreted according to the TRAUAUX PREPARATOIRES to the insertion of the reservation. It contended that the record demonstrated that the reservation was redundant. It was not capable of divesting the Court of jurisdiction in any case. This was so inasmuch 
as the reservation was intended to exclude "a multiparty suit against the United States that included parties that had not accepted the Court's compulsory jurisdiction". 254 The United States interpretation did not find support, Nicaragua argued, in the TRAUAUX PREPARATOIRES, "and it would be necessary to ascertain in what circumstances a State not party to a case should be deemed affected by the decision which is yet to be taken by the court". 255

Furthermore, Nicaragua contended that its application was not based exclusively on multilateral treaties. but also on proposals of customary and general law. Consequently, Nicaragua submitted that the reservation in question, even if it was relevant or valid, had no application to its claims based upon customary international law.

The Court treated the reservation in a curious way. Although it noted that the reservation contained some obscure aspects, particularly as to whether the term "affected" applied to the "treaty" itself, or to the parties to it, the court accepted, without recorded analysis, the view expressed by counsel for the United States that the reservation was referring to "States affected". Accordingly, the Court released itself from the task of considering the second interpretation whereby it is the treaty which is "affected", so that all parties to the treaty would have to be before the Court, as an $\theta$ FORTIORI case. 257 The Court observed that, in so far as the interests of third states identified as likely to be "affected" by the Court decision were concerned, the reservation was unnecessary. These states were able to initiate separate proceedings against the applicant State, or to avail themselves of the incidental procedures of intervention under Articles 62 and 63 of the Statute, for the protection of their interests, in so far as these were not already protected by Article 59 of the Statute. 258 
Besides the interpretation of the reservation, the case was important for another reason. It provided the Court with the opportunity to apply, for the first time. the new procedural technique first provided for in the 1972 Rules and maintained in the present Rules, namely, to "declare that the objection does not possess in the circumstances of the case, an exhaustivly preliminary character". 259 Having found that the objection based on the multilateral treaty reservation did not raise a jurisdictional problem but one concerning matters of substance relating to the merits of the case, and because of the elimination of the joinder of a preliminary objection to the merits, the court had no choice but to avail itself of the new procedural technique. The objection was deemed to raise matters of substance relating to merits because. firstly, the applicant state had not based its claims - as already mentioned - exclusively on breaches of multilateral treaties but had also invoked a number of principles of general and customary international law, in addition to the bilateral Treaty of Friendship, Commerce and Navigation of 1956 . These principles remained binding as such, the court said, although they were enshrined in treaty law provision. 260 Consequently, and so $f a r$ as the jurisdictional problem was concerned, the court found that "the claim ... would not in any event be barred by the multilateral treaty reservation". 261 Secondly, it was thought that a decision on the scope of the reservation would have meant giving a definitive interpretation of the term "affected" in the reservation. This had to be avoided since the term "affected" was deemed to apply to the parties to multilateral treaties and not to those treaties, and because it was not possible to name with any precision the states affected. They could be identified "only when the general lines of the judgment to be given become clear". ${ }^{262}$ A decision, for example, rejecting the application on the facts would have excluded any possibility of third states' claims to be affected, the Court observed. However, the Court emphasised that "the determination of the States 'affected' could not be left 
to the parties but must be made by the court". 263

The adoption of the new procedure was criticised by judge schwebel. He thought that this approach was not acceptable so long as the multilateral treaty reservation was intended to be a jurisdictional bar. Such a purpose could not be served if the identification of states "affected" was to be made only at the stage of the merits. 264 Advocating that the court could determine the States which would be affected by the decision prior to going to the merits, judge Schwebel put forward two arguments. Firstly, he noted that Article 62 of the Statute used the same term - namely, "affected", but it had never been suggested by either the P. C. I. J. or the present Court that that Article could not be applied because the determination of whether a state has any interests that may be affected by the judgment could only be made after the general lines of the judgment to be given have become clear. 265 Secondly, both parties named in their pleadings Costa Rica, El Salvador and Honduras as the States whose interests were likely to be affected by the Court's judgment on the merits. The Court's approach was, therefore, inconsistent with the parties' pleadings. 266 The dissent further noted that the Court's holding that the reservation was incapable of depriving the Court of jurisdiction at the jurisdictional stage was equivalent to saying that the reservation was invalid. This was so, judge Schwebel believed, so long as the invalidity was no more than an inherent incapacity to produce legal results. He carried the argument further by saying that the result of such holding was that the United States declaration could not be invoked because it was invalid as a result of the invalidity of a reservation inseverable from it. 267

Judge Ruda interpreted the phrase "Parties... affected by the decision" in a different way from that adopted by the majority. The history of the United States multilateral treaty reservation seemed to him to indicate 
that the reservation was inserted in order to protect the United states interests and not the interests of the third states. Nor did it appear to him logical that a State accepting the Court's jurisdiction with. a reservation protecting its own interests could act on behalf of third States. Each state was the sole judge of its own interests. It could intervene under the provision of the Statute if it deemed that its interests were in jeopardy. The case involved, in Ruda's view, two distinct disputes. The first was between the United States and Nicaragua, and the second was between Nicaragua and the States named by the United States as likely to be affected. A judgment in the first dispute would not affect the rights, duties and obligations of the latter states. "Whatever conduct if any, that the Court would impose on the United States, such a decision would not debar the rights of lthose States] vis-a-vis Nicaragua". 269 For this reason judge Ruda thought that the situation was different from that which was foreseen, in which the United States would be obliged to follow a course of action and the other parties to the dispute would remain free. The non-existence of other parties to the dispute between Nicaragua and the United states excluded any possibility of other states being affected whatsoever the obligations that might have been imposed upon the United States. Accordingly, judge Ruda thought that the multilateral treaty reservation was not applicable in that case, and, therefore, should have ben rejected. 270

In the merits phase 271 the court found itself obliged to continue the examination of the multilateral treaty reservation. It had to decide on the scope of the reservation and rule upon the points related to it since its jurisdiction was based on the consent of States as expressed in their declarations of acceptance. The challenge to jurisdiction on the ground of the reservation remained and could not have been ignored or overridden by the acceptance of jurisdiction on grounds other than the multilateral treaties invoked. Otherwise the question of 
whether or not the objection based on the reservation was well founded would have been left unanswered. $272 \mathrm{~A}$ decision on the objection based on the reservation was also necessary for the determination of the effect of the reservation. Such a decision was thus important for both the jurisdiction of the court and for the determination of what rules of law were to be applied as two aspects which were ultimately linked. 273

In explaining the scope of the reservation, the Court did not rely on the intention of the invoking state when it inserted the reservation. Rather, it explained the reservation according to its own text. 274 Thus the court pointed out that there were two possibilities where the reservation could not bar the court's jurisdiction, even if there were third states not parties to the proceedings and who were likely to be affected by the Court's decision. The first was the case in which the reserving state specially agreed to the Court's jurisdiction and the second was that in which that state waived its right to object to the Court's jurisdiction on the Basis of the reservation in question. Since the United States did not specially agree to jurisdiction, the court had to consider whether the right to object had been waived, at least indirectly by the conduct of that state: The Court observed that the waiver must be unequivocally expressed. Therefore, it refused to consider the non-appearance of the respondent state as tantamount to a waiver of that right. 275 It declined also to regard the inconsistent attitude of the United States, by relying on multilateral treaty law as the applicable law and at the same time invoking its multilateral treaty reservation, as a waiver of the reservation. 276

As to the meaning of the word "Affected", the court did not explain what does it mean in the light of Article 59 of the statute. 277 However, the Court interpreted it broadly. It said that the application of the reservation did not require that the "right" of the state be af- 
fected, but that the state itself be affected - a broader criterion. A decision affecting the right of a state is affecting the State itself and thus is excluded by the reservation. 278 In line with this broad criterion the Court also pointed out the fact that a decision which would affect a third state party to the multilateral treaty was sufficient for depriving the Court of jurisdiction regardiess of whether that State would be affected unfavorably or otherwise. 279

The Court found that a decision on Nicaragua's claims that the United States had violated Article 2 (4) of the Charter of the United Nations and Articles 18, 20 and 21 of the Organization of American States would affect El Salvador. Consequently, it decided that the reservation was applicable so as to exclude the treaty law of the Charter of the United Nations and the organization of American States from its adjudication. However the reservation had no further impact on other treaties or other sources of international law enumerated in Article 38 of the Statute. ${ }^{280}$ The reservation did not thus preclude the court from determining the claims of Nicaragua based upon customary international law. In so holding the court seems to have considered the dispute between Nicaragua and the United States as "APISING UNDER" customary international law.

Four judges disagreed with the Court's decision applying the reservation. 281 Judges Elias and SetteCamera thought that the reservation was not relevant in the merits phase. The states named as likely to be affected were free to intervene under Articles 62 and 63 of the statute, but they chose not to intervene. 282 Judge $\mathrm{Ni}$ was of the view that the United States had waived its reservation by its conflicting stand in the case. 283 Also judge Ruda agreed with the majority that the reservation was applicable, but he disagreed on the manner in which it was applied. He thought that the court failed to understand the effect of the reservation. ${ }^{204}$ This misun- 
derstanding was due, in his view, to the substitution of the term "reservations" for the term "exception clauses" attached by states to their declarations of acceptance. The misconception of the term "reservation". had helped the Court to imagine that the multilateral treaty reservation would be fully applied if the case was disposed of on other grounds, namely, principles of customary and general international law. There was no justification for such a view, judge Ruda observed, if the dispute was one "arising under" a multilateral treaty. 285 A reservation would be respected only if the circumstances described in it were met. Applied to the reservation in question, this meant either the presence of all parties affected, or a special waiver of the reservation. 286

The way in which the multilateral treaty reservation was applied by the Court was considered by the United States as one of the reasons which required the withdrawal of its acceptance of the Court's jurisdiction.

Fortunately, the Vandenberg type has not been copied except by Pakistan. ${ }^{288}$ The Court's acceptance, without any discussion, of the United States view that the word "affected" referred to the "Parties" to the multilateral treaty may complicate the Court's task should a case be brought before it in which Pakistan might argue that it inserted the word "affected" as a qualification to the "treaty" itself and not to the Parties to it.

\section{B - THE SIMPLE FORMULA OF THE MULTILATERAL TREATY RESERVATIONS}

The United States Reservation had served as a paradigm for another formula adopted first by Malta in 1966, 289 then copied by the Philippines 290 and India. 291 They uphold from the scope of their acceptance disputes "arising under a multilateral treaty, unless (1) all parties to the treaty are also parties to the case before 
the Court, or (2) [they] specially agree ( ). to jurisdiction". 292 Having omitted the qualification "affected by the decision" in the Vandenberg type, this formula is simpler, but by the same token wider in its effect. Its application requires the presence of all states parties to the multilateral treaty invoked before the court together with the original parties to the case. ${ }^{293}$ An objection based on the reservation maintains its preliminary character and therefore must be decided at the jurisdictional stage. The absence of only one party to a multilateral treaty will deprive the Court of jurisdiction at the very start.

In view of the fact that one of the important functions of the court has been the interpretation of treaties, and that most of present day international law is contained in multilateral treaties, 295 the effect of this formula may be bizarre. Its practical effect could be no jurisdiction in the absence of special agreement. 296 especially in cases involving universal treaties, or even treaties of regional ambit such as the charter of the Organization of American states. The reservation is therefore a subjective one. It leaves the establishment of the Court's jurisdiction dependant on either the will of the invoking state or - especially in treaties between a small number of states - of third states. 277

For these reasons the reservation has been widely criticised 298 and, even the question of its validity has been raised. Thus, professor Briggs regrets that the Court dismissed the objection based on the multilateral treaty reservation in the MILITAPY AND FARAMILITAPY ACTIUITIES case. He points out that the Court should have dismissed it on another ground, "for example, that it is not the function of the court to make sense out of a reservation that by its terms is nonsensical". Such a reservation is "destructive of international judicial process", and inconsistent with the statute. 279 
The Court, however, released itself - as already mentioned 300 - from considering the validity of this formula in the MILITARY AND PARAMILITARY ACTIUITIES case. However the question had received the attention of judges Jennings 301 and Ago. 302 Although they recognised the draconic effect of the multilateral treaty reservation, they did not have any doubt that "a state may, if it so desires, reserve against any case whatsoever invoking a treaty to which it is a party". 30.5 If an unqualified reservation is permissible, there would be no doubt that it may be made subject to a qualification, even a vague one such as that included in the vandenberg type.

Whatever the portion of international legal disputes excluded by this reservation might be, the reservation does not exclude the first category of disputes enumerated in Article 36 (2) of the Statute as a whole. namely, "the interpretation of a treaty". It has no effect on bilateral treaties. 305 Nor can it affect the other three categories of disputes enumerated in that Article so long as multilateral treaties are not involved. Likewise it cannot - as the court said 30 - $_{-}$ affect the application of the sources of international law other than multilateral treaty law. Moreover, the reservation does not seem to contradict any provision of the statute. It seems therefore a valid reservation.

Nevertheless this does not alleviate the undesirability of the reservation. No doubt the reservation should be dropped not only because of its conspicuous effect on compulsory jurisdiction, but mainly because there seems to be no justification for its insertion. $307^{\circ}$ It does not afford protection for the reserving state more than that afforded by the provisions of the statute (Articles 59, 62 and 63). Thus it does not serve any purpose but that of being used as a means of escaping the obligation assumed under Article 36 (2) of the Statute. 300 
However, this reservation provides another example of the reservations which had been initiated by a developed country but imitated, developed and maintained only by developing countries. 


\section{NOTES}

(1) U.N.T.S. ,p.9(emphasis added).

(2) See Chapter 4, Section 2 supra.

(3) The term"subjective" has been used by many writers. See e.g C.H.M. Waldock, "Decline of the Optional Clause ", 32 B.Y.B.I.L.(1955-56), pp.244287, at 271 and S. Rosenne, the Law and Practice of the International Court, 2nd. Revised ed., 1985, p.395. This formula has also bee described as 'selfjudging"(see e.g. A. Larson, "the Self-Judging Clause and Self Interests", 46 A.B.A.J.(1960, pp.729-731, at 729) ; "automatic"[this term was used for the first time by Judge $H$. Lauterpacht in his Separate Opinion in Certain Norwegian Loans case (Judgment, I.C.J. Reports 1957, p.9, at 34) then it has been widely adopted. See e.g.R.Y. Jennins, "Recent Cases on 'Automatic' Reservations to the Optional Clause", 7 I.C.L.Q.(1958), pp.349-366 and F. Gerber, le Consentement de l' Etat a la Juridiction de la Cour Internationale de Justice, thesis (Université d' Orléans, Faculté de Droit et des Sciences Economiques), 1980, pp.177-180)] ; "peremptory"[this term was also used by judge Lauterpacht in his Separate Opinion in the Interhandel case (Interim Measure of Protection, Order of October 24th, 1957 : I.C.J. Reports, 1957, p.105, at 119). It has also been adopted by many writers : see e.g. H.W. Briggs, "the United States and the International Court of Justice : A Re-examination ", 53 A.J.I.L.(1959), pp.301-318, at 307] ; "Connally Amendment" (this is the most popular in the U.S. See e.g. J. Dixon, Jr, "the Connally Amendment - the Conflict between Nationalism and an Effective World Court", 53 Ky.L.J.(1964), pp.164-175). G.Schwarzenberger critcises these terms and prefers the term "daring reservations", International Law -as Applied by International Courts and Tribunals, vol.IV(international Judicial Law), 1986, p.499. For criticism of these different terms see also J.H. Crabb, "On Judging the Connally Amendment", 50 Jeorgt.L.J.(1962), pp.529-545, at 529-530 and J.B. Elkind, Non- Appearance before the International Court of Justice, 1984, p.121.

(4) For the history of this reservation see the following documents ; Compulsory Jurisdiction, International Court of Justice, Hearings before a Subcommittee of the committee on Foreign Relations, U.S. Senate, 79 th Congress, 2nd Session on S. Res.196, 1946 (hereinafter Hearings), Report of the Foreign Relations Committee No.1835, 79th congress, 2nd Session, and Congressional Records, 79th Congress, 2nd Session, July 31, August 1, 2, 1946. See also F.O. Wilcox, "the United States Accept Compulsory Jurisdiction", 40 A.J.I.L.(1946), suppt., pp.699-719 ; L. Preuss, "the International Court of Justice, the Senate, and Matters of Domestic Jurisdiction", ibid., pp.720-736 ; H.W. Briggs, "Reservations to the Acceptance of Compulsory Jurisdiction of the International Court of Justice", 93 R.C.A.D.I.(1958), pp.230-363, at 328-335 ; J.B. Elkind, supra note 3, pp.124-139, and D. Kitchel, Too Grave a Risk- the Connally Amendment Issue, 1963, pp.13-18.

(5) I.C.J.Y.B., 1985-86, p.60. 
(6) See 92 Cong. Rec. No.153, August1, 1946, pp.10691-10694, 10736-10764 and No. 154, Aug. 2, 1946, pp.10839-10840. For discussion of these subjects see A. Larson, "the Facts, the Law, and the Connally Amendment", 74 D.L.J.(1961), pp. 74-119, at 103-105. Fear of the alleged vague and unwritten international law had also been maintained. See the State Bar Committee on World Peace through Law, "Pro and Con of the Connally Amendment : Should it Be Maintained, Repealed, or Modified", 35 J.S.B.C.(1960), pp.334341 , at 336 and R. Layton, "the Dilemma of the World Court : the United States Reconsiders Compulsory Jurisdiction", 12 Stanford L.R.(1960), pp.323-354, at 327.

(7) A.E.D. Howard observes that "it is hard to find eight words in Shakespeare or the Bible which have occasioned so much dispute", "the Connally Amendment", 2 J.J.B.M.S.(1961), pp.1-8, at 1.

(8) See e.g. J. Crawford, "the Legal Effect of Automatic Reservations to the Jurisdiction of the International Court of Justice", 50 B.Y.B.I.L.(1979), pp.63-86, at 63-64.

The undesirability of the reservation is confirmed by the result of a poll conducted in 1961 on whether the U. S. reservation should be repealed. Only 5 out of $\mathbf{3 1 0}$ law school deans, law schools professors and professors of international law, who expressed an opinion, were against repeal. See R.B. Schlesinger, "the Connally Amendment - Amelioration by Interpretation?", 48 Virg.L.R.(1962),pp.685-697.

(9) 92 Con. Rec. Aug. 1, 1946, p.10694.

(10) 26 U.N.T.S., p.91(emphasis added).

(11) See his Dis. Op. in Certain Norwegian Loans case, cited supra note 3, p.94.

(12) Supra note 3, p.153.

(13) I.C.J.Y.B., 1986-87, p.79(emphasis added). See B. Maus, les Reserves dans les Declarations d'Acceptation de la Juridiction Obligatoire de la Cour Internationale de Justice, thesis(Université de Genève, Faculté de Droit),1959, p.161.

(14) I.C.J.Y.B., 1986-87,pp.74, 84.

(15) 226 U.N.T.S., p.235.

(16) I.C.J.Y.B., 1986-87, p.76.

(17) Ibid., p.87.

(18) 16 U.N.T.S., p.197 and 257 ibid., p.360.

(19) 216 ibid., p.115.

(20) See S. Prasasvinitchai, la Clause Facultative de Juridiction Obligatoire de la Cour Internationale de Justice, thesis(Université de Paris , Faculté de Droit et des Sciences Economiques), 1962, p.105.

(21) See e.g. G. Schwarzenberger, supra note 3, at 500 ; H.W. Briggs, Reservations ..., supra note 4, p.335, and H. Lauterpacht's Dis. Op. in the Interhandel case, Judgment, I.C.J. Reports 1959, p.6, at 117-118.

(22) 595 U.N.T.S., p.363.

(23) See note 1 above.

(24) France also had substituted the objective formula for the subjective one in its 
declarations of 1959 and that of 1966 which was terminated in 1974.

(25) I.C.J.Y.B., 1986-87, p.84.

(26) Rights of Nationals of the United States of America in Morocco, Judgment, I.C.J. Reports 1952, p.176.

(27) Case Concerning Rights of Nationals of the United States of America in Morocco, I.C.J. Pleadings, pp. 257, 262.

(28) I.C.J. Reports 1952, p.178.

(29) See e.g. the Sep. Op. of Judge Lauterpacht in the Norwegian Loans case , I.C.J. Reports 1957, p.60 ; S. Rosenne, the Law ..., supra note 3, p.397, and I.F.I. Shihata, the Power of the International Court to Determine its Own Jurisdiction - Competence de la competence, 1965, p.276.

(31) I.C.J. Pleadings, case of Certain Norwegian Loans, vol.1, pp.121-129.

(32) Ibid., p.131 (English translation quoted from the Sep. Op. of Judge Lauterpacht and the Dis. Op. of Judge Basdevant in this case, I.C.J. reports 1957, pp. 53 and 73.

(33) Certain Norwegian Loans Case, cited supra note 3, p.26.

(34) Ibid., p.27.

(35) See the Diss. Op. of Judges Basdevant and Read Ibid., pp.76 and 94.

(36) Ibid., pp.28, 29-33.

(37) See I.F.I. Shihata, supra note 29, p.278.

(38) I.C.J. Pleadings, Interhandel case (Switzerland v. United States of America), pp.452-453.

(39) Ibid., p.460.

(40) Ibid., p.461.

(41) Ibid., pp.462-463. Translation quoted from the Court's Order of October 24th, 1957, Interhandel case(Interim Measures of Protection), cited supra note 3 , at 111 .

(42) Ibid., p.112.

(43) Judges Wellington Koo, ibid., pp.113-114; Klaestad, with whom the President Hackworth and judge Read agreed, ibid., pp.115-116, and Lauterpacht, ibid., pp.117-120. Note the line of reasoning adopted by Lauterpacht here as compared to that followed in the Norwegian Loans case , I.C.J. Reports 1957, pp.34-66.

(44) See I.F.I. Shihata, supra note 29, p.279 and H.W. Briggs, Reservations ..., supra note 4, p.359. For this reason $S$. Rosenne observes that the subjective reservation of domestic jurisdiction is not "automatic", the Law ..., supra note 3 , p.399.

(45) I.C.J. Reports 1957, p.110.

(46) I.C.J. Pleadings, supra note 38, pp.319-320. See also Section 2, Chapter 4, above, pp.271-273.

(47) I.C.J. Pleadings, Ibid., pp. 408-409, 575.

(48) Ibid., p. 579.

(49) Ibid., pp.601, 610.

(50) Ibid., p.610.

(51) lbid. Judge H. Lauterpacht thought that such an argument could not deprive the 
Court of jurisdiction. A government could not maintain an objection and at the same time invite the Court to consider it as being of no importance. I.C.J. Reports 1959 , p.98.

(52) Ibid., p.55.

(53) Ibid., p.26.

(54) See e.g. the Diss. Op. of Judges H. Lauterpacht, Klaestad and Armand-Ugon ibid., pp.98, 75-76, and 91 respectively and the Sep. Op. of Judge Spender ibid., p.54. See also J.B. Elkind, supra note 3, p.151. Comp. M. Dubisson, la Cour International de Justice, 1964, p.188 and J.H.W. Verzijl, "the System of the Optional Clause", 1 Int'l. Rel.(1959), pp.585-610, at 601-602. For this case in general see H.W. Briggs, "the Interhandel : the Court's Judgment of March 21, 1959, on the Preliminary Objections of the United States ", 53 A.J.I.L.(1959), pp.547-563 ; C. De Visscher, "I' Affaire de I'Interhandel devant la Cour International de Justice", 30 R.G.D.I.P.(1959), pp.413-433, and G. Perrin, "l' Affaire de I' Interhandel- Phase des Exceptions Preliminaires", 16 An.S.D.I.(1959), p.73.

(55) I.C.J. Pleadings, Aerial Incident of July 27, 1955(Israel v. Bulgaria; United States of America v. Bulgaria, United Kingdom v. Bulgaria), p.22 seq.

(56) Ibid., p.271

(57) Ibid., p 323

(58) Ibid.

(59) See pp 33, 35 . below.

(60) See I. F. Shihata, supra note 29, p. 283.

(61) I.C.J. Pleadings, supra note 55, pp.676,677. L. Gross, observes that "it is always possible, of course, to rake over the inentical debate in the Senate and come up with different results, although one should have assumed that the history of the Connally Amendment and the position of the United States in the Interhandel case were well known to all cocerned in the Department of State", "Bulgaria Invokes the Connally Amendment", in his book Essays on International Law and. Organization, vol. 2, 1984, pp.727-751, at 741(reprinted From 56 . A.J.I.L.(1962), pp.357-382).

(62) I.C.J. Pleadings, ibid., p.677.

(63) Ibid.

(64) "la Cour Internationale de Justice en 1960", 65 R.G.D.I.P.(1961), pp.473526 , at 475.

(65) Military and Paramilitary Activities in and against Nicaragua(Nicaragua v. United States of America), Jurisdiction and Admissibility, I.C.J. Reports 1984, p.392, at 396-397.

(66) Ibid., p.422, para.67. R.N. Gardner observes that the U.S. did not invoke the Connally reservation because it was "ashamed to argue that mining another country's harbors and supporting insurgents seeking to overthrow its government were within the U.S. domestic jurisdiction", "U. S. Termination of the Compulsory Jurisdiction of the International Court of Justice", 24 Columb.J.I.L.(1986), pp.421-427, at 423.

(67) I.C.J. Reports 1984, p.398, para.14.

(68) Ibid., p.421, para.67. 
(69) Ibid., pp. 420-421, paras.64-65.

(70) Ibid., p.422 seq., paras. 67 seq. For the multilateral treaty reservation see Section 3 below.

(71) Ibid., p.442, para.113.

(72) See H. Lauterpacht, "the British Reservations to the Optional Clause", 10 Economica (1930), pp. 137-172, at 154, 169, and M.O. Hudson, the Permanent Court of International Justice 1920-1942. A treatise, 1943, p.397 and "Obligatory Jurisdiction Under Article 36 of the Statute of the Permanent Court of International Justice", 19 lowa L.R.(1934), pp.190-217, at 208-209.

(73) "Questions Resulting from the Connally Amendment", 32 A.B.A.J.(1946)pp.660-662, 721.

(74) "The Plea of Domestic Jurisdiction Before International Legal Tribunals", 31 B.Y.B.I.L.(1954), pp. 96-142, at $131-137$ and Decline of the Optional Clause", 32 ibid., (1955-56), pp.244-287, at 271-273.

(75) Cited supra note 3 , pp.34-66.

(76) Cited supra note 21, pp.95-125. It is to be observed that the Senate Foreign Relations Committee rejected a reservation similar to the Connally reservation proposed by Senator Austin on the same grounds. The Report of the Committee stated:

"The Committee ... decided that a reservation of the right of decision as to what are matters essentially within domestic jurisdiction tend to defeat the purposes which it is hoped to achieve by means of the proposed delegation as well as the purposes of Article 36, paragraphs 2 and 6 of the Statute of the Court.", Senate Report No.1835, supra note 4, pp.4-5. Senator Papper relied also on these grounds in his argument that the reservation was invalid. 92 Cong. Rec., No.154, August 2, 1946, p.10837.

(77) I.C.J. Reports 1957, p.34 and 1959, p.59.

(78) Lauterpacht's Sep. Op. in the Norwegian Loans case , I.C.J. Reports 1957, p.43. See also C.H.M. Waldock, the Plea ..., supra note 74, p.133, R.P. Anand, compulsory Jurisdiction of the International Court of Justice, 1961, p.204. Comp.B. Maus, supra note 13, pp.156-157.

(79) Free Zones of Upper Savoy and District of Gex, Order of 19 August 1929, P.C.I.J., Series A, No.22, p.12.

(80) Voting Procedure on Questions Relating to Reports and Petitions Concerning the South West Africa, Advisory Opinion, I.C.J. Reports 1955, p.67, at 76

(81) C.H.M. Waldock, the Plea ..., supra note 74, p.133 and Lauterpacht's Sep. Op. in the Norwegian Loans case, I.C.J. Reports 1957, p.45. See also Armand-Ugon's Dis. Op. in the Intehandel case, idid., 1959, p.93.

(82) See C.H.M. Waldock, ibid. and R.P. Anand, supra note, 78, p. 204.

(83) Lauterpacht's Sep. Op. in the Norwegian Loans case, I.C.J. Reports 1957, p.44. See also J.B. Elkind, supra note 3, p.119 and H.W. Briggs, Reservations ..., supra note 4, pp.356-357. For Article $36(6)$ in general see esp. I.F.I. Shihata, supra note 29 and $\mathrm{G}$. Berlia, "la Jurisprudence des Tribunaux Internationaux en ce qui Concerne leur Competence",88 R.C.A.D.I.(1955), 
pp.112-160.

(84) For an examination of this principle in the jurisprudence of both Courts see I.F.I. Shihata, ibid., pp.34-38.

(85) Nottebohm, Preliminary Objection, Judgement, I.C.J. Reports 1953, p.111, at 119.

(86) See Lauterpacht's Sep .Op. in the Norwegian Loans case, I.C.J. Reports 1957, pp.47-48.

(87) M.O. Hudson, "World Court - America's Declaration Accepting Jurisdiction", 32 A.B.A.J.(1946), pp.832-836, 895-897, at 835. See also H. Kelsen, the Law of the United Nations, 1950, p.529. But Comp.his view in Principles of International Law, 2nd. Revised ed.(R.W. Tucker ed.), 1966, pp.538-539.

(88) C.H.M. Waldock, Decline ..., supra note 74, p.272.

(89) Lauterpacht's Sep. Op. in the Norwegian Loans case, I.C.J. Reports 1957, pp.47-48.

(90) Ibid., p.48. See also A. Yancov, "les Réserves dans les Declarations d' Acceptation de la Juridiction Obligatoire de la Cour International de Justice", 52 A.U.S.F.D.(1961), pp.586-597, at 594 ; C. Vulcan, "la Clause Facultative", 18 Acta S.J.G.(1947-48), pp.30-55, at 51, and C.H.M. Waldock, Decline supra note 74, p.272.

(91) L. Preuss, Questions ..., supra note 73. See also C.H.M. Waldock, the Plea ..., supra note 74, p.131; $M$. Rague, "the reservation Power and the Connally Amendment", 11 N.U.J.I.L.P.(1978), pp. 323-358, at 343, and J.D. Arndt, "International Court of Justice- Legal Effect, Constitutional and International, of Connally Amendment", 28 U.Kans.C.L.R. (1959-60), pp.1-34, at 17.

(92) See the Sep. Op. of Judge Lauterpacht in the Norwegian Loans case I.C.J. Reports 1957, pp.44-45.

(93) See the Sep. Op. of Judge Spender in the Interhandel case, I.C.J. Reports 1959, p.55; the Diss. Op. of Judge Armand-Ugon, Ibid., p.92 ; the Diss. Op. of Judge Lauterpacht, ibid., p.103 and his Sep. Op. in the Norwegian Loans case, I.C.J. Reports 1957, p.45, and the Diss. Op. of Judge Guerrero, ibid., p.68. The Above arguments for the invalidity of the reservation had been expressly shared by six Judges ; Guerrero and Lauterpacht in the Norwegian Loans case [I.C.J. Reports 1957, pp.68-69 and 34-66 respectively.], Lauterpacht, Spender, klaestad, Judge ad hoc Carry who declared that he agreed with Klaestad, and Armand- Ugon in the Interhandel case [ I.C.J. Reports 1959, pp.95-118; 54-59; 75-78; 32; 91-94 respectively. Judge Read also shared the same view in case the reservation were to be given an automatic effect.

(94) C.H.M. Waldock, the Plea ..., supra note 74, pp. 135-136 and the Sep. Op. of Judge Lauterpacht in the Nonwegian Loans case , I.C.J. Reports 1957, p.65. In fact, Judge Lauterpacht had fully agreed with Waldock except on the value of the declaration containing such a reservation. Whereas it appeared to Waldock of certain value as a basis for the operation of jurisdiction forum prorogatums, Lauterpacht considered it of no value of whatsoever. Ibid., pp.133-134 and 64 respectively.

(95) I.C.J. Reports 1957, pp.55-60, and 1959, p.101. 
(96) I.C.J. Reports 1959, pp.57-58.

(97) Ibid., p.57. Judge Spender thought that the reference to the preparatory works was not permissible. "Nor, were it permissible, would be necessary or profitable".

(98) I.C.J. Reports 1957, pp. 57-58, and 1959, pp.103, 106-111.

(99) Supra note 54, pp. 416-421.

(100) Questions ..., supra note 73, pp.661-662.

(101) Supra note 54, p.189

(102) Supra note 3, pp.361-362.

(103) Supra note 78, p.203. This is, of course, in addition to those mentioned before such as C.H.M. Waldock, the Plea ..., supra note 74. pp.131-137 and Decline ..., supra note 3 , pp.371-273 ; G. Berlia, supra note 83, pp.115-118 ; B. Maus, supra note 13, p.157, and M.A. Rague, supra note 91 . See also K. Holloway, Modern trends in treaty Law, 1967, pp. 687-688. Comp. the cautious attitude adopted by S. Rosenne, the Law ..., supra note 3, pp.398-399 and J.P. Kelly, the International Court of Justice: Crisis and reformation", 12 N.Y.J.I.L.(1987), pp. 342-374, at 359. Many other writes hold the view that the reservation is invalid but without indicating the effect of such invalidity on the declaration as a whole. See e.g. D.H. Ott, Public International Law in the Modern World, 1987, p.343 and C. Vulcan, supra note 90, p.51.

(104) While Judge Gerrero did not raise the issue (Diss. Op. in the Norwegian Loans case, I.C.J. Reports 1957, pp.67-70), Judges Lauterpacht (ibid., pp.55-56), Klaestad and Armand- Ugon(Diss. Ops. in the Interhandel case, I.C.J. Reports 1959, pp. 76 and 93) referred to the severance of the offending words. In fact,Judge Lauterpacht rejected the possibility of severing the whole reservation - Ibid. However this seems to be a theoretical question if it is admitted that the objective reservation of domestic jurisdiction is unnecessary. See Section 2, Chapter4 above

(105) Ibid. Comp. his view in "la Qualification unilateral de la Competence Nationale", in Constantopoulos et al (eds.), Grundprobleme des Internationalen Rechts, 1957, pp.207-212.

(106) I.C.J. Reports 1959, p.76.

(107) Ibid., p.91. However, Judge armand- Ugon had come to the conclusion that the Court should regard the offending words in the reservation as "unwritten and inoperative. They should be declared without effect vis-a-vis the Court." Ibid.

Comp. G. Schwarzenberger, supra note 3, pp.502-503.

(108) Ibid., pp.77-93.

(109) Ibid., p.91.

(110) Right of Passage over Indian Territory, Preliminary Objections, Judgement, I.C.J. Reports 1957, 125, at 142. See H.W. Briggs, Reservations ..., supra note 4, p.361.

(111) H.W. Briggs, Ibid. For this rule see Section 1, Chapter 2 above p. 101. Shihata describes this argument as a "weak" one , supra note 29, p.289. Comp. J.B. Elkind, supra note 3, p.160. There is a difference between the "unilateral attempt " referred in the Nottebohm case and the subjective reservation of domestic jurisdiction. While the letter is "an intrinsic fact build into and forms 
an integral part of the declaration", the former was an extrinsic fact of the termination of the declaration after the seisin. See L. Gross, Bulgaria Invokes ..., supra note 61, p.748 and I.F.I. Shihata ,ibid.

(112) L Gross, ibid., pp.749-750.

(113) Ibid., p.750.

(114) See e.g. Senator Connally's statement on August 2, 1946, 92 Cong. Rec. No.154, p.10833. See also Senator Morse's view, ibid., p.10831.

(115) See e.g. A.J. Schweppe, "the Connally Reservation Should not be Withdrawn", 46 A.B.A.J.(1960), pp. 732-736, at 736 ; O.J. Lissitzyn, the International Court of Justice, : Its Role in Maintenance of International Peace and Security, 1951, p.65 ; L Henkin, "the Connally Reservation Revisited and, Hopefully, Maintained", 65 A.J.I.L.(1971), pp.374-377, at 376, and F.O. Wilcox, supra note $4, .712$.

(116) See the Norwegian Loans; Interhandel, and Aerial Incident cases, p.392 seq,above.

(117) L. Gross has attributed this approach to Professors Guggenheim and Bourqui in their arguments in the Norwegian Loans case as Co- Agent and Advocate of the Swiss Government. See Bulgaria Invokes ..., supra note 61, p.745.

(118) See e. g. the Diss. Op. of Judge Read in the Norwegian Loans case, I.C.J. Reports 1957, p.92, but see his interpretation of the words of the French reservation , p 390 above. See also R.B. Schlesinger, supra note 8, pp.689690.

(119) R.B. Schlesinger, ibid.

(120) See note 110 above.

(121) Polish Postal Service in Danzig, Advisory Opinion, 1925, P.C.I.J. Series B, No.11, p.39.

(122) Competence of the General Assembly for the Admission of a State to the United Nations, Advisory Opinion, I.C.J. Reports 1950, p.4, at 8.

(123) See the Diss. Op. of Judge Read, I.C.J. Reports 1957, pp.94-95 and J.B. Elkind, supra note 3, pp. 163-164.

(124) The Sep. Op. of Judge Lauterpacht in the Norwegian Loans case, I.C.J. Reports 1957, pp. 52_53, and his Dis. Op. Interhandel case,ibid.,1959, p.112, see also J.Crawford, supra note 8, p.67.

(125) The Sep. Op. of Judge Spender's in the Norwegian Loans case, I.C.J. Reports 1957, p.59.

(126) The Diss. Op. of Judge Lauterpacht in the Interhandel case, I.C.J. Reports 1959, p.112.

(127) Ibid., and the Sep. Op. in the Norwegian Loans case, I.C.J. Reports 1957, p.53. See also $\mathrm{Ch}$. de Visscher, supra note 54, pp.418-419 and S. Prasasvinitchai, supra note 20, pp.108-109. G Schwarzenberger, considers Lauterpacht's argument on the non-applicability of the good faith principle as one "gratuitously attested" to the protagonists of the subjective reservations, supra note 3, p.504.

(128) The Diss. Op. of Judge Lauterpacht , ibid., p.111.

(129) See the Norwegian, Swiss and American arguments in the Norwegian loans; 
Interhandel, and Aerial Incident cases, p.392 seq above.

(130) J.H. Crabb, supra note 3, pp.534-535.

(131) Ibid., p.537.

(132) D.W. Greig, International Law, 2nd ed.,1976, pp.655-656.

(133) See J.B. Elkind, supra note 3, p.163 and J.H. Crabb, supra note 3, p.541.

(134) J.B. Elkind, ibid., pp.162-163.

(135) Nuclear Tests (Australia v. France), Judgment, I.C.J. Reports 1974, p.253, at 473.

(136) Cited supra note 65, p.418, para.60.

(137) R.B. Schlesinger, supra note 8, pp.687-688 and J. H. Crabb, supra note 3, p.539.

(138) See his Diss. Op. in the Norwegian Loans case, I.C.J. Reports 1957, p.94. Judge Read was disclined to apply the test of good faith or abus de droit because the Court could not examine a dispute between two sovereign States on the basis of these principles. However he found in the Norwegian argument of the international question in 134 pages an indication that Norway intended to leave the determination of the character of the matter to the Court. Ibid., p.93.

(139) See e.g. J.B. Elkind, supra note 3, pp.157-164 ; R.B. Schlesinger, supra note 8, pp.685-697, and J.H. Crabb, supra note 3, pp.531-543.

(140) See D.W. Greig, supra note 132, pp.655-656 and R.B. Schlesinger, supra note 8, p.687 note 6 . See also I.F.I. Shihata, supra note 29, p.290.

(141) See I.F.I. Shihata, ibid., p.291.

(142) See J.H. Crabb, supra note 3, p.539.

(143) See pp.403-404 above.

(144) See J. Crawford, supra note 8, p.72. Professor E.J. Macdonald is of the same view. In spite his admission of the merits of the inconsistency argument, he points out that if paragraph 6 of Article 36 "can be interpreted as consistent with the automatic reservation, then presumably it is the duty of the Court to so interpret. it.", "Automatic Reservations and the World Court", 47 Georgt.L.J.(1958), pp.106-123, at 117.

(145) J. Crawford, ibid.

(146) E.J. Macdonald, supra note 144, p.119. It is argued also that Art. 36(6) does not empower the Court to invalidate an acceptance or to interpret reservations included therein. See E.J. Macdonald, ibid., pp.112-115 and G. Cottereau, la Position de la France a l' Egard de la Juridiction Internationale, thesis (Univesité de Paris V), 1980, pp.388-390. For counter arguments see R. Layton supra note 6, pp.323-354. Comp. M.J. Glennon, "Protecting the Court's Institutional Interests : Why not the Marbury Approach?", 81 A.J.I.L.(1987), pp.121-129, at 124-125.

(147) J. Crawford, supra note 8, p.75(emphasis added).

(148) E.J. Macdonald, supra note 144, p.122.

(149) See J. Crawford, supra note 8, pp.81, 82, 85 and D.W. Greig, supra note 132, pp. 652-654. Comp. S. Rosenne, the Law ..., supra note 3, pp. 397-399. For this argument see also M.A. Rague, supra note 91 , pp.341-342.

(150) Ibid., pp.75-85. 
(151) Ibid.; p.79.

(152) Ibid., p.81. Thus he adopts Kelsen's view that " if almost any reservation has the effect of restricting the purposes and objects of Article 36, it is not easy to determine at what point the cumulative effect of such reservation, or the quality of a particular reservation, may prove incompatible with such purposes and objects.", Principles of International Law , supra note 87, pp.538-539 note 114.

(153) J. Crawford, ibid., pp.81-82.

(154) lbid., p.82.

(155) lbid., p.83.

(156) Ibid.

(157) See the text in I.C.J.Y.B., 1986-87, p.47.

(158) J. Crawford, supra note 8, p.85.

(159) See p.394 seq. above.

(160) See D.W. Greig, supra note 132, p.653 ; I.F.I. Shihata, supra note 29, pp. 295-296, and E.J. Macdonald, supra note 144, p.110.

(161) I.C.J. Reports 1959, p.119. In agreement with Lauterpacht , H.W. Briggs, the U. S. and the I.C.J. ..., supra note 3, p.559 ; L. Gross, Bulgaria Invokes ..., supra note 61, p.745, and J. Crawford, supra note 8 , p.66 note 8.

(163) See p. 395 above.

(164) I.C.J. Reports 1957, p.23 (emphasis added). See H.W. Briggs, Reservations ..., supra note 4, p.343. Comp. L. Gross, Bulgaria Invokes ..., supra note 61, .745 .

(165) Cited supra note 65, p.419, para. 61 (emphasis added).

(166) lbid., p.421, para. 65 (emphasis added).

(167) This is because, unlike the case in the U. S. A., the acceptance of the Court's jurisdiction in the other States making the reservation seems to be a governmental act which does not require the intervention of the legislative branch. See B. Maus, supra note 13, p.151.

(168) Sep. Op. in the Norwegian Loans case, I.C.J. Reports 1957, p.57.

(169) See I.C.J. Pleading, case concerning Right of Passage over Indian Territory (Portugal v. India), vol.IV, p.145. See also Section 2, Chapter 2 below.

(170) Diss. Op. of Judge Lauterpacht in the Interhandel case, I.C.J. Reports 1959, pp.98, 102, 117, 118.

(171) lbid., pp.104-105.

(172) Sep. Op. in the Norwegian Loans case, I.C.J. Reports 1957, p.63.

(173) Dis. Op. in the Interhandel case, I.C.J. Reports 1959, pp.104-105.

(174) Ibid.

(175) Ibid., p.98.

(176) Sep. Op., ibid., p.54 (emphasis added). See G Schwarzenberger, supra note 3, pp.503-504; Ch. de Visscher, supra note 54, p.420 ; F. Gerber, supra note 3, p.180; H.W. Briggs, the U. S. and the I.C.J. ..., supra note $3, .558$, and R. Layton, supra note 6, p.335.

(177) This of course in addition to the arguments of invalidity advanced by the proponents of the first and the second approaches whose weight has been recognized even by the supporters of this approach. See e.g. D.W. Greig, supra 
note 132, pp.51, 54 and J. Crawford, supra note 8, p.64. Crawford points out that the object of his Article is "to examine what seems almost the settled viewat least among commentators- of the legal effect of the "automatic reservation"., ibid.

(178) See Section 1, Chapter 5 supra, at 339 seq.

(179) Ibid., p.34. See also C.H.M. Waldock, Decline ..., supra note 74, p.273 and R.P. Anand, Compulsory ..., supra note 78, p.215.

(180) See Section 2, Chapter 4 above pp.278-279.

(181) I.C.J. Pleadings, Interpretation of Peace Treaties with Bulgaria, Hungary and Romania, pp.277-278(emphasis added).

(182) Ibid., p.278.

(183) See Section 2, Chapter 2 Supra.

(184) See Section 2 Below.

(185) See e.g. the Resolution adopted by the Institut de Droit International in 1959, 48(II) Annuaire I.D.I.(1959), pp.358-361 and the American Bar Association, "Association's Assembly Deplores Connally Amendment", 32 A.B.A.J.(1946), p.873, at 874 .

(186) The executive branch of the U.S.A. had regularly expressed its doubts over the consistency of this reservation with the Statute of the Court. See S. Rosenne, the Law..., supra note 3, p.391 note 1 and the references cited therein. It is to be noted that the Senate Resolution 94, which intended to repeal the Connally Amendment, was introduced by Senator Herbert Humphrey with the support of the American Bar Association, the White House and the Departments of State and Justice. For this resolution see, Compulsory Jurisdiction, International Court of Justice, Hearings before the Committee on Foreign Relations, United States Senate, 86 Congress, 2nd. Session on S. Res. 94, a resolution to Amend S. Res. 196, 1960.

(187) The reservation was abandoned by France (337 U.N.T.S., p.375) ; India(260 ibid., p.459), and Pakistan(374 ibid., p.127). The United Kingdom also abandoned one reservation belonging to the same category, see Section2 below. However it is to be observed that the reservation was not abandoned for this reason only but basically, perhaps, because of the effect of reciprocity.

(188) See I.C.J.Y.B., 1986-87, p.41. It may be worth noting that in a survey conducted by Judge Lauterpacht in 1957 of more than 200 treaties he found no more than six treaties containing the reservation in question most of which were concluded by States making this reservation in their declarations of acceptance of the Court's compulsory jurisdiction. See his Sep. Op. in the Norwegian Loans case, I.C.J. Reports 1957, pp.62-63.

(189) See Section 3, Chapter 1 above, p.??

(190) See Military and Paramilitary Activities case, cited supra note 65, p.418, para.59.

(191) L. Preuss, Questions ..., supra note 73, p.661.

(192) See Section 2, Chapter 2 above, p??

(193) See C.H.M. Waldock, the Plea ..., supra note 74, p.132 and I.F.I. Shihata supra note 29, pp.47-52. Comp. S. Rosenne, the Law ..., supra note 3, pp.438-441 
and B. Maus, supra note 13, p.156.

(194) It is difficult to prove that the Philippines, for example, terminated its declaration of 1947 in order to introduce this reservation because the new. declaration (1972) includes 4 other reservations of no less importance especially the multilateral treaty reservation and that concerning the law of the sea. See I.C.J.Y.B. , 1986-87, p.84.

(195) See D.E. Ende, "Reaccepting the Compulsory Jurisdiction of the International Court of Justice. A Proposal for New United States Declaration ", 61 Wash.L.R.(1986), pp. 1145-1165, at 1166. This precedent seems to contradict Crawford's argument that the term "domestic jurisdiction " is not used as a term of art in the reservation but as an escape clause, supra note 8, p.70. It might be argued also that the very existence of other reservations alongside with the subjective reservation of domestic jurisdiction indicates that it is not intended to play the role of an absolute escape clause as that played by the reservations of vital interests and honour.

(196) Military and Paramilitary Activities case, cited supra note 65, p.418, para.60 (emphasis added).

(197) See p.35 above.

(198) I.C.J. Reports 1984, p.420, para.63.

(199) See p.45 below.

(200) Supra note 3, p.499

(201) Ibid.

(202) For the effect of reciprocity on the reserving State see A.E. Howard, supra note 7, p.12 ; A. Larson, the facts, the Law ..., supra note 6. pp.79-85 ; A D 'Amato, "Modifying U.S. acceptance of the Compulsory Jurisdiction of the World Court", 79 A.J.I.L.(1985), pp.385-405, at 392-394, and F.L. Grieves, Supranationalism and International Adjudication, 1969, pp.98-100.

(203) See the Diss. Op. of Judge Lauterpacht in the Interhandel case, I.C.J. Reports 1959, p.116. Professor Briggs observes that the Court might have found it more appropriate to leave it for the reserving State "to worry whether the Connally reservation is not more dangerous to [the reserving State] interests than protective thereof", Interhandel ..., supra note 54, p.559.

(204) See J.B. Elkind, supra note 3, p.147 and M. Dubisson, supra note 54, p.186.

(205) 265 U.N.T.S., p.221.

(206) See R.P. Anand, Compulsory ..., supra note 78, p.219 ; J.G. Merrills, the Optional Clause Today", 50 B.Y.B.I.L.(1979), pp. 87-116, at 94 ; S. Prasasvinitchai, supra note 20, p.106, and B. Maus, supra note13, p.162 note 135.

(207) Parliamentary Debates, House of Commons, vol.577 (Nov. 8, 1957), cols.492, 494. It was also observed that the reservation constituted of a retrograde step and direct blow to the Court's prestige and influence, ibid., p.514.

(208) H.W. Briggs, Reservations ..., supra note 4, pp.302-303.

(209) R.Y. Jennings, supra note 3, p.362. See also I.F.I. Shihata, supra note 29, p.273. 
(210) See ibid ; G Schwarzenberger, supra note 3, p.500 ; B. Maus, supra note 13, p.162 ; Judge Lauterpacht's Sep. Op. in the Norwegian Loans case, I.C.J. Reports 1957, p.63 ; S. Rosenne, the Law ..., supra note 3, pp.395-396, and F. Hoging, "the Diminishing role of the World Court", 34 I.A. (1958), pp.184-194, at 192.

(211) See the statement made in the House of Commons on Nov. 26, 1958, Parliamentary Debates, House of Commons, vol.596 (Nov. 26, 1958), Written Answers, Col.38.

(212) 316 U.N.T.S., p.59. For discussion on the problems of interpretation of this proviso see E. Lauterpacht, "the Contemporary Practice of the United Kingdom in the Field of International Law - Survey and Comment, VII (Settlement of Disputes. Jurisdiction of the International Court of Justice. United Kingdom Declaration of November 26, 1958),8 I.C.L.Q. (1959), pp.197-201, at 199201. See also M.O. Hudson, "the thirty-Seventh Year of the World Court", 53 A.J.I.L.(1959), pp.319_323.

(213) For the text of the 1963 declaration see 482 U.N.T.S., p.187.

(214) 337 ibid., p.65.

(215) See Section 2, Chapter 5 above p.349. See also C.H. Vignes, "Observations sur la Nouvelle Déclaration Française d' Acceptation de la Juridiction Obligatoire de la Cour Internationale de Justice", 31 R.G.D.I.P.(1960), pp.52-74, at 69 and J. Feydy, "la Nouvelle Declaration Française d' Acceptation de la Juridiction Obligatoire de la Cour Internationale de Justice", 12 .A.F.D.I.(1966), pp. 155161 , at 159.

(216) C.H. Vignes, ibid.

(217) Ibid., pp.69-70.

(218) See J.B. Elkind, supra note 3, p.123 ; C.H. Vignes, supra note 215, p.70, and J. Feydy, supra note 215, p.159.

(219) 565 U.N.T.S., p.21.

(220) See Ch. Rousseau, "Cronique des Faits Internationaux [Experieces Nuclaires dans le Pacifique (2 Juiller-5 Octobre 1966)]", 37 R.G.D.I.P.(1966), pp.1032-1040, at 1040 ; A. Cocatre-Zilgien, "Justice Internationale Facultative et Justice Internationale Obligatoire", 80 R.S. (1976), pp. 689737, at 716, and the Diss. Op. of Judge DE Castro in the Nuclear Tests case (Australia v. France), Judgment, I.C.J. Reports 1974, p.253, at 376.

(221) See J Feydy, supra note 215, p.159. See also I.C.J. Pleadings, Nuclear Tests (New Zealand v. France), vol. 2, pp. 196, 284 seq.

(222) I.C.J. Pleadings, ibid., p.288 and Ch. Rousseau, supra note 220, p.1040.

(223) Nuclear Tests (Australia v. France), cited supra note 220, and (New Zealand v. France), Judgement, I.C.J. Reports 1974, p.457.

(224) Nuclear Tests (Australia v. France), Interim Protection, Order of 22 June 1973, I.C.J. Reports 1973, p.99, at 102, and (New Zealand v. France), ibid., p.135, at 137 .

(225) Ibid.

(226) Ibid., p.102.

(227) Judges Foster and Petren disagreed with this reasoning. They thought that the

Court should have considered at greater length the problem of jurisdiction, ibid., 
pp.112 and 124 respectively. Judge Foster pointed out that he was very much afraid that the Court's Order "may have in minds of many the impression that the International Court of Justice henceforth considered the French reservation concerning its national defence, hence its security, the vital interests of the nation to be null and void.

(228) I.C.J. Pleadings(Australia v. France) Vol.1,pp.306-316. See also the arguments of Mr. E. Lauterpacht as a Counsel for the Government of Australia, ibid., pp.441-470.

(229) Ibid., pp.311-316, 443.

(230) lbid., pp.306-307.

(231) lbid., p.308.

(232) Ibid., pp.308-311, 445-450.

(233) Ibid., p.451.

(234) Ibid., p.311.

(235) Ibid., p.314. The arguments advanced by the Australian Government appeared to Judge De Castro sofisticated. In his view the reason behind the insertion of the French reservation was clear and conclusive. It was made to cover nuclear tests. I.C.J. Reports, 1974, p.376. G. de Lachariere describes these arguments as odd and astonishing , "Commentaires sur la Position de la France a l' Egard de la Licéité Juridique de ses Experiences Nucleaires", 19 A.F.D.I.(1973),pp.235251, at 237-238.

(236) I.C.J. Pleadings, ibid., vol.II, pp.197-198.

(237) I.C.J. Reports 1974, pp.272, 478. For these cases see B. Bollecker- Stern, "I' Affaire des Essais Nucleaires Français devant la Cour Internationale de Justice", 20 A.F.D.I.(1974), pp.299-333 ; G. de Lacharière, supra note 235, and J. Dhommaux, "Quand la France Contest les Decisions de la Cour de la Haye", R.P.P.(1975), pp.35-42.

(238) 1 U.N.T.S., p.9.

(239) See e.g. F.O. Wilcox, supra note 4, pp. 714-716 and L. Preuss, the I.C.J., the Senate ..., supra note 4, p.720.

(240) For the history of this proviso see esp. F. O. Wilcox, ibid.; H.W. Briggs, Reservations ..., supra note 4, pp.306-308 and the U. S. and the I.C.J. ..., supra note 3, pp.314-316 ; B. Maus, supra note 13, pp.164-165, and the Sep. Op. of Judge Ruda in Military and Paramilitaty Activities case (Jurisdiction and Admissibility ), cited supra note 65, pp.455-456.

(241) "Memorandum of John Foster Dulles Concerning Acceptance of the United States of the Compulsory Jurisdiction of the International Court of Justice, July 10, 1946, in Hearings ..., supra note 4, p.44.

(242) Cong. Rec. supra note 4, pp. 10618, 10621(Aug. 1, 1946).

(243) Hudson characterized Dulles' objection as "a jumble of ideas.", World Court ..., supra note 87, p.836.

(244) See L. Preuss, the I.C.J., the Senate ..., supra note 4, p.720.

(245) See ibid.; A. D' Amato, "the United States Should Accept, by a new Declaration, the General Compulsory Jurisdiction of the World Court ", 80 A.J.I.L.(1986), pp. 331-336, at 333 ; J.G. Merrills, the Optional ..., supra note 206, p.107 ; C. 
Vulcan, supra note 90, p.52, and S. Prasasvinitchai, supra note 20, pp. 146147.

Q. Wright argues that the reservation was intended to clarify Article 62 and 63 of the Statute. It was made with the view to guarding against an arbitrary exercise by the Court of its discretion under these Articles to refuse intervention by a third State which considers itself to have an interest of a legal nature affected by the decision. See "the international Court of Justice and the Interpretation of Multilateral Treaties", 41 A.J.I.L.(1947), suppt, pp.445-452, at 449-452. For criticism of this view see M.O. Hudson, "the Twenty-Sixth Year of the World Court", 42 ibid., suppt., pp.1-19, at 13 and C.H.M. Waldock, Decline ..., supra note 3, p.274 note 4 .

(246) Q. Wright, ibid., p.449 and F.O. Wilcox, supra note 4, p.715.

(247) M.O. Hudson, World Court ..., supra note 87, pp.836, 895 and "the TwentyFifth Year of the World Court", 41 A.J.I.L.(1947), suppt., pp. 1-19, at 12; H. Lauterpacht in Openheim's International Law, 7th ed., vol.2, 1952, p.63 ; B. Maus, supra note 13, p.167 ; S. Prasasvinitchai, supra note 20 , p.145 ; R.P. Anand, Compulsory ..., supra note 78, pp.223, 227, and H. Kelsen, Principles of International Law, supra note 87, p.538 note 114.

(248) A. D' Amato, supra note 202, p.394. H. Kelsen observed that"the question as to which parties are affected by the decision of the Court can be answered only after the Court has assumed and exercised jurisdiction in the dispute concerned.", the Law of the U. N., supra note 87,p.530.

(249) C.H.M. Waldock, Decline ..., supra note 3, p.274 note 2(emphasis added).

(250) Military and Paramilitary Activities case (Jurisdiction and Admissibility), cited supra note $65, \mathrm{p} .422$, para. 68.

(251) Ibid.

(252) Quoted from the Sep. Op. of Judge Sette_Camara in Military and Paramilitary Activities in and against Nicaragua case(nicaragua v. United States of America), Merits, Judgment, I.C.J. Reports 1986, p.14, at 193 (emphasis Original). For criticism of these reasons see ibid., p.194.

(253) I.C.J. Reports 1984, p.422, para.68.

(254) Ibid., p.423, para.70.

(255) Ibid.

(256) Ibid., p.424, para.71. The United States described Nicaragua reliance on fundamental rules of general and customary international law as a mere restatement or paraphrases of claims and obligations based expressly on multilateral treaties, especially the Charters of the U. N. and O. A. S. Ibid., p.423, para.69.

(257) Ibid., para.72. See H.W Briggs, "the International Court Lives up to its Name", 81 A.J.I.L. (1987), pp.78-86, at 80.

(258) I.C.J. Reports 1984, p.425, paras.74-75.

(259) Article 79 (7) of the 1978 Rules.

(260) I.C.J. Reports, p.425, para.73.

(261) Ibid.

(262) Ibid., para75. 
(263) Ibid. Judge Nagenda- Singh added another reason which required the adoption of the new procedure. He said that it was not possible at that stage to know which multilateral treaties would have to be invoked by the Court's decision. Ibid., p.450. For a summary on the examination of the reservation in the first phase of this case see T.J. Pax, "Nicaragua v. United States in the International Court of Justice : Compulsory Jurisdiction or Just Compulsory", 8 B.C.I.C.L.R.(1985), pp.471-515, at 502-505.

(264) I.C.J. Reports 1984, p. 604, para.71. In agreement : L. Kirgis, Jr, " Nicaragua v. United States as a Precedent", 79 A.J.I.L.(1985), pp.652-664, at 655.

(265) I.C.J. Reports 1984, p.605, para.72.

(266) Ibid., p.607, para.73.

(267) lbid., p.611, para.78.

(268) Ibid., pp.456-457, para.22.

(269) Ibid., pp.457-458, para.25.

(270) Ibid., p.458, para.27.

(271) Cited supra note 252.

(272) Ibid., p.32.

(273) See the Sep. Op. of Judge Ni, ibid., pp.203-204, 209.

(274) Ibid., p.33, para.45. Judge Ago observed in his Sep. Op. that "it can never be sufficiently emphasized that acceptance of the Court's compulsory jurisdiction on the basis of Article 36, paragraph 2, of its Statute is a sovereign, voluntary act the effects of which are strictly confined to the limits within which it was conceived and intended." Ibid., p.183, para.5.

(275) Ibid., p.33, para.45.

(276) Ibid., pp.33-34, para.46. Judge $\mathrm{Ni}$ expressed the view that the court should have considered this conduct by the $U$. S. as a waiver of its objection based on the multilateral treaty reservation and, therefore, rejected the objection. Ibid., pp.209-211.

(277) See H.W. Briggs, the I.C.J. Lives up to its Name, supra note 257, p.81.

(278) I.C.J. Reports 1986, p.36, para.52.

(279) Ibid., p.37, para.53.

(280) Ibid., pp.38, 92 seq, paras.56, 172 seq.

(281) Judge Elias, Sette- Camara, Ni, and Ruda, ibid., pp.178,198, 211, and 217219 respectively.

(282) Ibid., pp.178, 198. Judge Sette -Camara said that the reservation was relevant to the extent that it made it concumbent upon the Court to take into consideration that these States were free to come before it to defend their rights and interests if they wished to do so. He pointed out also that it should not be forgotten that Art. 59 of the Statute confined the binding force of the res judicata to the parties in the case . Ibid., p.198.

(283) See note 276 above.

(284) I.C.J. Reports 1986, p.219, para.14.

(285) Ibid., p.217, para.11. Explaining the difference between the terms

"reservations" and "exceptions" Judge Ruda said:

$[T]$ he fact that exception clauses may frequently be useful as a means of delineation 
do not justify any presumption that a State employing them has retracted, various parts of a priory wholesale acceptance of the Court's jurisdiction ; on the contrary, the instrument remains a positive indication that the State has unreservedly accepted that jurisdiction within a certain area which those exceptions have merely helped to define. Outside that area, there is simply no acceptance subject to a "reservation", and to reason as if there were is to yield to a kind of optical illusion." lbid., p.218, para.12.

Thus in Ruda's view , "reservations" are based on the conception that a State's submission under Article 36 (2) of the Statute is total unless limited, and exception clauses are based on the understanding that the submission is limited unless otherwise extended. However the Court jurisprudence seems to contradict this distinction. In interpreting the reservation ratione temporis (an exception clause according to the above criterion) the Court appeared to have taken the view that the submission is total unless limited. See Section 1, Chapter 3 above, pp.169-170. Nevertheless, the phrase "disputes arising under...", being part of the a clause embodied in the declaration must be taken into consideration whether such a clause is considered as a reservation or exception.

(286) Ibid., p.219, para.14. Judge Jennings arrived at the same conclusion but on different ground $\mathrm{He}$ argued that since Nicaragua had pleaded its case in the duplex form of a dispute under multilateral treaties, or alternatively, a dispute under customary law; that the respondent relied firmly on Art. 51 of the Charter of the $U$. N. , and since"one party cannot in effect redefine the response of the other party", the dispute clearly arose under a multilateral treaty. Ibid., p.533.

(287) A. D. Sofear stated that the United States was considering an amendment to its declaration, but the decision of the Court led to the U.S.' withdrawal from compulsory jurisdiction because in whatever language the declaration were drafted, it could not have prevented the Court from asserting jurisdiction if it wanted to take a case as it did in Military and Paramilitary Activities case. A.D. Sofear Statement is quoted by Judge Schwebel., ibid., p. 297.

Judge Schwebel referred indirectly to Israel as another State which did the same, perhaps, as a result of an apprehension that the Court may not apply its reservations should occasion for their application arise. Ibid.

(288) I.C.J.Y.B., 1986-87, p.82.

(289) lbid., p.76.

(290) lbid., p.84.

(291) Ibid., p.71.

(292) The wording of the Indian reservation is clearer. It uses the words disputes "concerning the interpretation or application of a multilateral treaty" instead of disputes "arising under".

(293) See the Sep. Op. of Judge Sette - Camara, in Military and Paramilitary Activities case (Merits), I.C.J. Reports 1986, p.192.

(294) See the Sep. Op. of Judge Nagenda Singh, ibid., (Jurisdiction and Admissibility), I.C.J. Reports 1984, p.449.

(295) See C. H.M. Waldock, Decline ..., supra note 3, p.275 and R.P. Anand, Compulsory ..., supra note 78, p.227. 
(296) See the Sep. Op. of Judge Jennings, I.C.J. Reports 1984, p.554.

(297) See C.H.M. Waldock, Decline ..., supra note 3, p.275.

(298) See e.g. Ibid.; R.P. Anand, Compulsory ..., supra note 78, p.227; H.W. Briggs, Reservations ..., supra note 4, p.307, and the Sep. Op. of Judge Sette- Camara, I.C.J. Reports 1986, p.193.

(299) "Nicaragua v. United States : Jurisdiction and Admissibility ", 79 A.J.I.L. (1985), pp. 373-378, at 378 .

(300) See p.75 above.

(301) I.C.J. Reports 1984, pp. 554-555 and ibid., 1986, p.529.

(302) Ibid., 1986, p.186.

(303) Ibid., 1984, p.554. A similar statement was made by Judge Ago, ibid., 1986, p.183.

(304) Ibid., 1984, p.554.

(305) It is to be observed that the reservation has no effect on the scope of the jurisdiction accepted under compromissory clauses, even in regard to disputes arising under multilateral treaties. See M.O. Hudson, World Court ..., supra note 87 , p.895 ; S. Rosenne, the Law ..., supra note 3, p.404, and R.P. Anand, Compulsory ..., supra note 78, p.227.

(306) See p.444 above.

(307) Professor 'D' Amato ascribes the insertion of the reservation into the $U$. S. declaration, partly to "a sense of excess caution by a nation not familiar with the jurisprudence of the World Court.", Modifying ..., supra note 202, p.394. In denying any solid reason for the insertion of this reservation, the eminent authority, the late Judge Sir C.H.M. Waldock said that it "seems only to have been inspired by vague fears and misconceptions as to the working of the Optional Clause in a case arising under a multilateral treaty.", Decline ..., supra note 3 , p. 275.

(308) See H.W. Briggs, the U. S. and the I.C.J. ..., supra note 3, p.316. 


\section{GENERAI CONCLUSI ONS \\ AND SUGGESTI ONS}

Having examined individually the different problems concerning reservations and conditions inserted in the declarations of acceptance of the Court's compulsory jurisdiction it might be now possible to draw the following general conclusions: there has been a general decline in the Optional Clause; the effect of reservations proved to be limited, and there seem to be some grounds for optimism that the existing situation can be improved.

\section{A - DECLINE OF THE COMPULSORY JURISDICTION SYSTEM}

It has been shown that the Optional Clause of the P. C. I. J. had constituted a major breakthrough in the development of compulsory adjudication. The widespread acceptance of the Clause and the abandonment of the vague and comprehensive reservations of vital interests, honour, independence, etc. for new reservations limited in number and scope had increased the hopes and expectations that the optional clause went a long way towards the achievement of the goal anticipated in 1920 that it would constitute a first step towards general compulsory jurisdiction. These hopes and expectations were further increased, especially in 1934 when adherence to the Optional Clause reached its high-water mark. In October that year, 42 out of 63 states 1 were bound by the Optional Clause. However since then there has been a general decline in the Optional Clause both PATIONE PEPSOHAE and RATIOHE HATERIAE.

\section{I - Decline Ratione Personae}

Table 4 on page 468 graphically illustrates the decline of the membership to the compulsory jurisdiction of the Court both quantitatively and qualitatively. By adding the eleven declarations which have expired, been withdrawn or been terminated without being subsequently replaced since 1951 . ' the total number of states which 
have been bound by Article 36 (2) of the Statute of the I. C. J. will be 57. Taking into account the Huge increase of the "clientele" of the court, this number compares very unfavourably with the 47 acceptances which had been at one time or another effective under the Statute of the P. C. I. J. in addition to 9 other signatures of the Optional Clause which had not been ratified.

\section{TABLE 4}

YEAR State bound Members of the $L$ of $N$ Permanent members Percentage under Article or $U N$ and other parties of the Sec. Council 36 (2) entitled to appear

$\begin{array}{lllll}\text { (June) } 1934 & 42 & 63 & 3 & 66 \\ 1938 & 39 & 62(2) & 3 & 63 \\ \text { (July) } 1953 & 36 & 62 & 4 & 58 \\ 1963 & 40 & 115 & 4 & 34 \\ 1973 & 46 & 135 & 3 & 34 \\ 1987 & 46 & 162 & 1 & 29\end{array}$

These figures do not, however, reflect the actual decline. The most significant deterioration has been in the scope of the objection assumed, its duration and variation.

\section{I - Decline Ratione Materiae}

Whereas the declaration made under the Optional Clause of the P. C. I. J. reflected a considerable confidence in the court, some of the declarations made under the present Statute reflect a total lack of confidence in the $-I$. C. J. New types of reservations capable of turning the compulsory jurisdiction system into one in which States decide on a case-by-case basis whether to subject themselves to the Court's jurisdiction have appeared. Thus the subjective reservation of domestic jurisdiction was introduced just one year after the establishment of the I. C. J. Other major reservations have been added since 1955, and the scope of some of the previous reservations has been widened considerably. Fhus another reservation appeared excluding disputes Concerning na- 
tional security or national defence both as determined by the declarant state or without qualification. Another reservation capable of reviving old treaties of arbitration containing the famous reservations of vital interests, honour, etc. has also been made. It is the reservation excluding disputes excluded from the judicial settlement or arbitration by treaty, convention or any other instrument to which the declarant State is a party.

New subject-matter reservations such as those concerning the exclusion of disputes relating to some parts of the sea or pollution, have also appeared. Furthermore, the scope of some earlier post-war reservations has been extended dramatically. Thus, for example another variant of the multilateral treaty reservation has been initiated. According to this formula, the court cannot take cognisance of a case in which a multilateral treaty is invoked, unless all the parties to such treaty are also parties to the case before the Court, or the declarant State specially agrees to jurisdiction.

An undesirable development concerning the reservations RATIONE TEMPORIS has also occurred. By using the date of the declaration as the exclusion date the period subject to the Court's jurisdiction has been reduced dramatically in some declarations. Thus, El Salvador's declaration of 1978, for example, reduced that period by 57 years. The hope that the effect of RATIOHE TEHPORIS reservations would diminish with time has not therefore been completely achieved.

The trend of creating new reservations has also affected the reservation RATIONE PERSONAE. Thus, a new reservation was created as a solution for the "single shot" problem. Accordingly a large number of states parties to the Court's compulsory jurisdiction exclude disputes with new adhering states during the first 12 months of their adherence. Although this reservation can be defended as a means of preventing the unscrupulous use 
of the Court, it is not a perfect solution. On the contrary, being made along with the reservation of the right to terminate or vary the acceptance at any time, this reservation can be used as an escape clause for achieving the same result against which it was originally designed. This could be so if the state making such a reservation sues the other party just after the expiry of the 12 months period and then terminates its acceptance or modifies it in order to prevent being sued by the new adherent.

However, the most dramatic development has affected time limits and variation conditions. A comparison between the declarations made under the statutes of the two courts (the P. C. I. J. and the I. C. J.) shows this drastic change. Whereas 33 out of the 56 (i.e. 58\%) declarationsor instruments of ratification made under the P. C. I. J. were for a fixed period, only 10 out of the 57 (i.e. 17\%) declarationsmade under the statute of the present Court had been at one time or another made in this form. Seven declarations which were originally made for a fixed period, and thereafter were terminable by a simple notification to the Secretary-General, are now terminable at any time. By adding this number to the 15 declarations which have been made terminable immediately by a simple notice to the secretary-General, the total number of declarations in this form will be 22 out of the 46 declarations currently in force (i.e. almost $50 \%$ ). There has been a remarkable shift, not only from a long to a short period, but also from a fixed period to escape devices. The pretence by which states purport to accept the compulsory jurisdiction while running very little risk has created a glaring inequality between the parties to the compulsory jurisdiction system and consists of a throwback to the era before the League of Nations, in which elastic reservations were inserted. In fact, this new form of termination serves the same purposes as the reservations of vital interests and honour with the difference that, unlike these reservations, the rule in 
the NOTTEROHM case is applicable to termination by a simple notice.

The second aspect of this regrettable development is the creation of the condition conferring on the declarant state the right to vary its declaration by adding or withdrawing reservations or conditions inserted therein. If the number of states making this condition is added to those making their declarations terminable immediately, the result will be that 25 out of 46 (54\%) contain these escape clauses. 5 This number would be 26 if all declarations containing the most sweeping reservations are discounted. Table 5 below illustrates how these reservations and conditions are made.

TABLE 5

States Inmediate Inmediate Multilateral Dom. Juris. Disputes excluded Termination Variation Treaty res. (Subjective) from compulsory arbitration

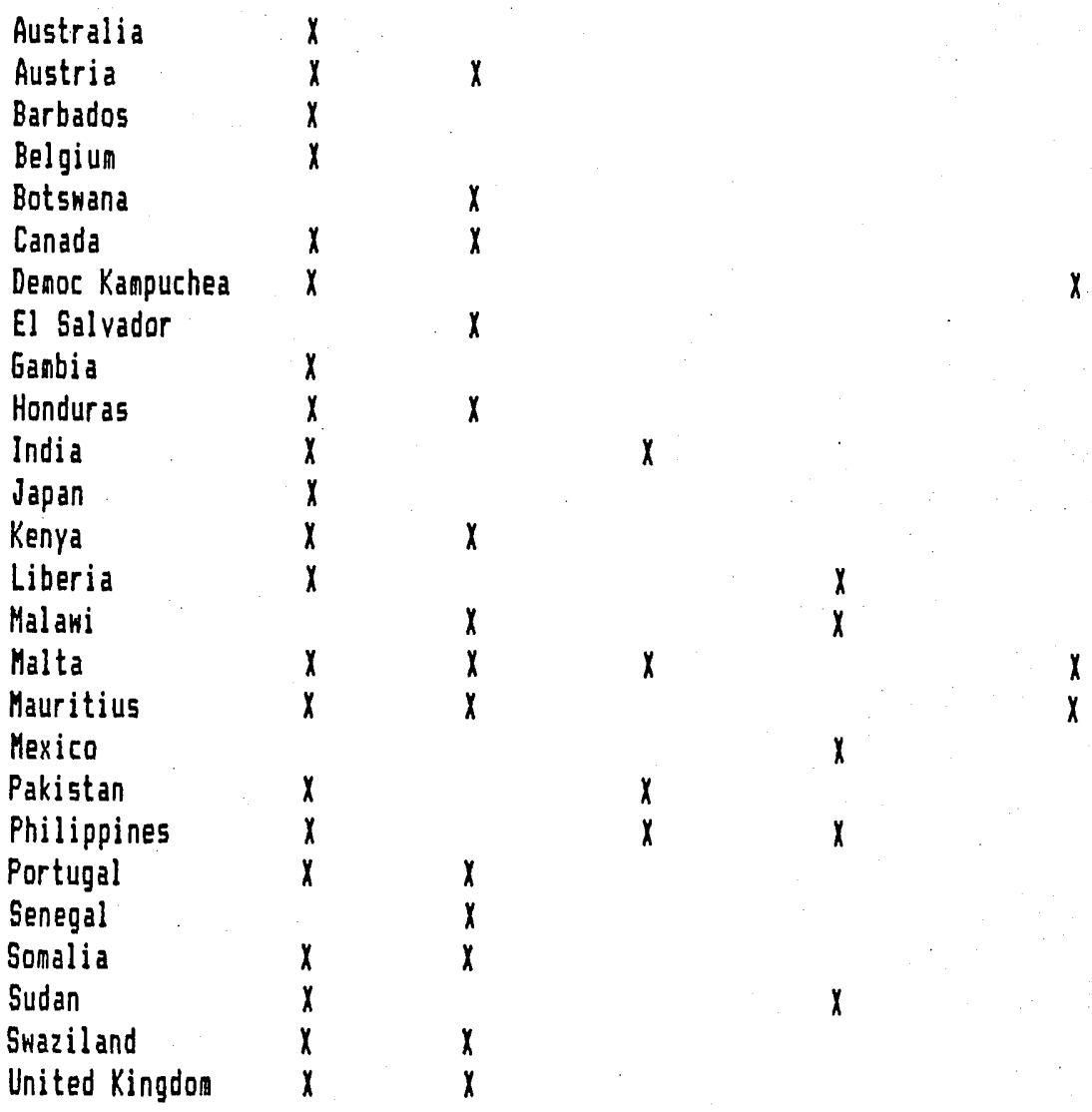


The number of reservations and conditions in a single declaration may also illustrate the decline. This number has reached its high-water mark only since the end of the fifties. Thus, the British declaration of 1958 contained 12 reservations and conditions, without counting that of reciprocity. The same number figures now in the Indian declaration: one of those reservations contains 5 paragraphs excluding a wide area of disputes.

Table 6 below which contains the number of the most extravagant reservations and conditions only, illustrates the general decline of compulsory jurisdiction.

TABLE 6

$\begin{array}{llll}\text { Year Domestic National Multilateral Immediate Immediate Compulsary } \\ \text { Jurisdiction Security } & \text { Treaty Termination Variation Arbitration } \\ \text { (Subjectivel or Defence } & & \text { or Judicial } \\ & & \text { Settlement }\end{array}$

$\begin{array}{lllllll}1953 & 05 & -- & 01 & 10 & -- & -- \\ 1963 & 04 & 02 & 02 & 16 & 03 & 01 \\ 1973 & 05 & 01 & 05 & 19 & 10 & 03 \\ 1987 & 05 & -- & 04 & 21 & 14 & 03\end{array}$

\section{III - Reasons for the Decline}

\section{(i) General reasons}

In their discussions in the Sixth Committee of the General Assembly of the United Nations concerning the "review of the role of the International Court of Justice" during the period from 1970 to 1974, 's government representatives voiced the general reasons for their reluctance to have their disputes settled judicially and hence not to accept the compulsory jurisdiction unconditionally. 7 They had confirmed the reasons usually articulated in the literature of international law. The debates indicate that the principld cause behind the different reasons for states reluctance is the present state of the international community being a heterogeneous one. ${ }^{8}$ Thus while the relatively homogeneous nature 
of the international community of the League of Nations had facilitated recourse to compulsory jurisdiction the nearly universal society representing a mosaic of forms of civilization, legal systems and levels of economic development has caused States' unwillingness to use the Court, or to reduce the scope of their declarations accepting its jurisdiction. 9 The radical change in the structure of the post war international community caused by the spread of socialism in Eastern Europe and the emergence of a large number of new States has widened the divergence of conceptions concerning both the court itself and the applicable law.

\section{a) Attitude of Socialist Countries}

In their views, expressed before the Sixth Committee, the Socialist Countries maintained their well-known. complex and unyielding opposition to compulsory jurisdiction. They opposed any attempt to enhance the role of the Court or even the inclusion of the item on the agenda of the General Assembly. 10 This attitude is due mainly to distrust and disbelief in the possibility of judicial impartiality in cases affecting Communist states in a world with a non-communist majority. The delegates of these countries had thus echoed Lifinov's axiom that "only an angel could be unbiased in judging Russian affairs". 11 This attitude was wel1-summarised by ELVAREZ TABIO, the Cuban delegate in his statement that the idea of judicial organs capable of rendering equitable judgments is "little more than utopian". 12

The second reason advanced by the Socialist Countries for their refusal to submit to the Court compulsory jurisdiction, was the law to be applied by the court. They regard traditional international law as an instrument designed to serve the interests of capitalist imperialist powers. They consider themselves bound by such rules as they have recognised explicitly or implicitly. They refuse therefore a settlement according to the 
"doctrines of the bourgeois, imperialist legal systems." 13

As a third reason, Socialist Countries pointed out that compulsory jurisdiction runs against the fundamental principle of a State's sovereignty.

However, in spite of their hostile attitude regarding the court, they could not deny its contribution to the codification and progressive development of international law. 15

\section{b) Attitude of developing Countries}

Developing Countries, unlike Socialist Countries, do not share the same view. However, there is no doubt that developing countries in general, and new states in particular have no comparable background or history or ideology directly related to the question of compulsory jurisdiction as such. In fact, some of the reasons advance by these states had been shared even by the Western States. However, although developing countries had generally supported the idea of enhancing the Court's role. they had articulated some reasons behind their cautious attitude $/ I S-A-1 / I S$ the Court's compulsory jurisdiction. Two reasons had been shared by a large number of states in this group: the law to be applied by the court, and its composition.

As regards the former, it was pointed out that the present international $\mathrm{law}$ is too conservative. This point of view was taken even by certain Western Countries such as Finland, Australia and Spain. ${ }^{16}$ Many States, particularly the newly-independent ones, questioned some aspects of most of the current sources of international law as a body in whose making they played no role, and whose output is still largely determined by Westerndominated conceptions. Thus, it was said for example, that the customary rules which are the fruit of practices of a few states imposed in the past through a policy of 
force, can no longer be claimed to be LEX LATA, ${ }^{17}$ and that some treaties have been imposed on the weak and the rule PACTA SUNT SERUANDA has been invoked to sanctify them. ${ }^{18}$ On the other hand, it was suggested that Article 38 of the statute should be amended so as to insert binding decisions issued by international organizations as a source of international law, and non-binding resolutions and declarations in paragraph $I$ (d) of the said Article as subsidiary means for the determination of law.

The above views should not be interpreted as a rejection of [the] present international law as a whole, but as an indication of dissatisfaction with some of the rules. Thus, some satisfaction with the progress achieved through codification was expressed. 20 These views reflect therefore the fear of developing countries that the rules which they question could be applied by the court. and their emphasis that the court should continue to assist the evolution of the work undertaken by the United Nations, with regard to the codification and progressive development of international law.

The apprehension concerning the applicable law is reflected by the declaration of Guatemala of 1947 which excepted from the Court's compulsory jurisdiction the dispute with the United Kingdom concerning the restoration of the territory of Belize. Yet Guatemala agreed to have the dispute decided EX AEgllo ET BoHo. Canada also attributed the insertion of the reservations concerning living resources and pollution into the declaration of 1970 to the apprehension that the court might affect the rapid development of the law in those areas. In other words. Canada intended not to give the Court an opportunity to decide on its declaration concerning these areas and hence to stop Canada's engagement on making a new law through customary law. The Truman Proclamation contribution to the development of the rules concerning the continental shelf and its fate, had it been tested by the Court shortly after its making, might have been 
present in the minds of those who advised the insertion of these reservations.

Dissatisfaction with the composition of the Court was the second major reason invoked by developing countries. It was pointed out that the Court's composition did not reflect the changes which had occurred in the international community. This dissatisfaction found grounds in the fact that only one judge from Africa and one from Asia had been members of the P. C. I. J. during the whole life of that Court and that until 1963, only one judge from Africa and two from Asia had been elected to the present Court. 21 Consequently, it has been stressed that all legal systems must be adequately represented. 22 Furthermore, the view has been expressed that a criterion should be found whereby seats would be allocated not only according to the principlé lé legal or cultural legal systems, but also on geographical or regional bases.

It is true that these two factors have influenced the attitude of developing countries $1 / S-A-1 / S$ compulsory adjudication, but they proved not to be the real obstacle. Thus, the improvement of the composition of the Court (there are six judges from developing countries, including the President and Vice-President, 3 of whom are from Africa) had a little effect on their attitude. Also their reluctance is till reflected even by codified conventions which contain rules they themselves have helped to shape.

However, as a corollary of the above reasons, the experience of newly independent states before the seventies has increased their reluctance. the RIGHT OF PASSAGE OUER INDIAN TERRITORY, the NORTHERN CAHEROON cases; and, particularly the SOUTH HEST AFRICA case of 1966 have shaken their confidence in the court. The first was brought before the court as a result of India's attempt to remove an old burden which it did not accept but inherited from the past colonial age. 25 In the second and the third, which concerned the status of the former 
British colony and a territory under international mandate respectively, the court avoided adjudicating the merits. 26 Thus, new states did not hesitate to mention the last case as an evidence of the necessity of progressive development of international law and attribution of new seats to judges from these states.

As a fourth reason many states attribute their reluctance to resort to the court to the excessive attachment to the principles of sovereignty. 28 This appears to be a natural attitude on the part of states that had acquired their independencies recently. It is not surprising, therefore, to find the objective reservation of domestic jurisdiction limited to declarations made by developing countries - with the exception of Canada - in spite of the fact that it has no more than the psychological effect of reassuring these states that their sovereignty would thereby be preserved.

Non-familiarity with compulsory adjudication seems to be one of the foremost reasons behind new states' reluctance to accept compulsory jurisdiction. This is illustrated by the fact that Latin American States, which had played a leading role in the development of compulsory arbitration, especially during the period between the end of the last century and the advent of the $P . C$. I. J.. accept compulsory jurisdiction generally without reservations. While the majority of new states are reluctant to accept it, or they accept it with a large number of reservations.

\section{c) The attitude of developed Countries}

The reluctance of developed countries might also be attributed to the uncertainty of international law and the composition of the court. As the new States fear that they might be subjected to traditional international law, developed countries are beginning to hesitate to resort to judicial settlement through the fear of being sub- 
jected to over-progressive rules. 29 Thus, any decision that increases the confidence of new States will decrease that of developed countries and UICE UERSA. Codification seems to be the effective remedy, if not the only one, for this dilemma.

The increase of the number of judges from new States, though basically at the expense of Latin America. had affected Western attitudes UIS-A-UIS the Court. Thus, as a result of the Court's judgment in the HORTH SEA CONTINEHTAL SHELF case in 1969, concerns were expressed, SOTTO VOCE, in several Western foreign ministries about "strangers" who had expressed their opinions. 30 The existence of "so many judges" from states which did not accept the Court's jurisdiction was one of the reasons advanced by the French Minister of Foreign Affairs before the French National Assembly as a justification for withdrawing the French declaration accepting the Court's jurisdiction. 31 The same reason figures among the justifications advanced by the United States for withdrawing from the MILITARY AND PARANILITARY ACTIUITIES IN AHD AGAINST NICARAGUA case. 32 Furthermore, the United States strongly questioned the impartiality of certain judges of the court. In fact its statement concerning those judges is tantamount to considering them as spies for their own countries. The statement reads:

\footnotetext{
" .. . much of the evidence that would establish Nicaragua"s aggression against its neighbours is of a highly sensitive intelligence character. We will not rist: $U_{\text {. }} \Xi$. nationel security by presenting such sensitive materiel in putilc or before a court that includes tup judges from the Warsaw Fact na-
}

However, doubts of the impartiality of the Court as a cause for reluctance does not seem very convincing. In fact, studies devoted to the voting behaviour of the judges of the court and their independence and impartiality refute such a conception. Thus, in his recent in depth study of those questions, professor Weiss has 
reached the conclusions that, "there is a high degree of consensus among the judges on most decisions"; that "there have not been persistent voting alignments which have significantly affected the decisions of the judge", and that the "review of the voting behaviour of the judges of the Court does not support charges that the Court systematically votes in a pre-determined manner to the detriment of particular states". 34

In addition to these divergent reasons, and perhaps, as a corollary of them, the different groups of States had expressed their preference of other means of settlement. Thus, even states which have been parties to the compulsory jurisdiction of both the present court and its predecessor - such as Great Britain and Australiamade it clear that the improvement of the Court's role does not mean the downgrading of other means of settlement. 35 As has been shown, the reservation excluding disputes in regard to which the parties have agreed or shall agree to resort to other means of settlement other than the Court is the most popular reservation. However it is not the case meant by States' preference of other means. They prefer political means - especially negotiations - for the settlement of their disputes. They prefer to keep open as far as possible the choice of resorting to manoeuvres such as lobbying, propaganda, bargaining, exerting pressure and manipulation of votes offered by political means.

The special character of adjudication, being a zero-sum game in which one party wins and the other loses, has also a negative effect on States' attitude toward the Court's compulsory jurisdiction. The effect of the fear of losing a case on states' attitudes can easily be proved by states' behaviour after being sued before the court. A large number of declarations of acceptance had been terminated as a result of the institution of proceedings. The most recent examples are the withdrawal of the United States from compulsory 
jurisdiction as a result of the institution of proceedings in the HILITARY AND PARAMILITARY ACTIUITIES IH AND AGAINST NICARAGUA case, and that of France as a result of the NUCLEAR TESTS case. This cause of termination seems to reflect the conflict between the desire for appearing as a law-abiding nation, suing others, and at the same time to be immune to other parties applications.

The psychological obstacle, that recourse to the Court might be considered as an unfriendly act, has been widely deplored. 37 It is perhaps surprising that this conception is still persistent, although it was emphasised as early as the First Hague Peace Conference of 1899 that recourse to the Permanent Court of Arbitration "can only be regarded as a friendly action ()" (Articles 3 and 37). A similar view was also embodied in the Resolution of the Institute of International Law of 1959. $3 \mathrm{~B}$ Thus the General Assembly Resolution 3232 of 1974 reaffirmed that recourse to judicial settlement "should not be considered an unfriendly act between states". 37 However, the reservations excluding disputes between certain groups of States the relations between which have a special character, such as the exclusion of disputes between the Commonwealth states, seems to have been inspired by this factor.

Finally, it may be worth noting that reservations had been generally deplored by States' responses to the Secretary-General, and in their debates in the Sixth Committee. Socialist Countries pointed out that they were in the same position as those which hedged their declarations with so many reservations. 40 states which accepted compulsory jurisdiction without reservations, 41 or even those which had abandoned certain subjective reservations were proud of their attitude. Some States among those whose declarations contained certain reservations pointed out that they were reviewing their declarations with a view to abolishing or restricting their reservations; 43 and the proposal that acceptance of the Court's compul- 
sory jurisdiction should be without reservations was made by certain states, some of which do not accept it even with reservations. 44 It is not surprising thus that the General Assembly Resolution 3232 urged States to study the "possibility of accepting, with as few reservations as possible, the compulsory jurisdiction of the International Court of Justice." 45

\section{(ii) Special reasons}

In addition to the main reasons for the decline of compulsory jurisdiction there are special reasons that have caused States to append new reservations and conditions to their acceptances. The following are the major ones:

a) The desire not to have a determined dispute decided by the court

It has been shown that almost all reservations even general ones, were inserted with a view to precluding another party to a specific dispute from resorting to the court. Thus, for example, the complex double formula of the reservation RATIONE TEHPORIS - as one of he first reservations to appear - was included by Belgium in order to prevent the Netherlands from referring the dispute concerning Wielingen to the P. C. I. J.

b) The Court's handling of some cases

As a result of the Court's interpretation of some provisions of the statute, new reservations have appeared. Thus the reservation excluding disputes with new adhering parties to the compulsory jurisdiction system during the first 12 months of their adherence, was created as a result of the Court's statement in the RIGHT OF PASSAGE OUER INDIAN TERRITORY case, that a State accepting the 
compulsory jurisdiction must expect that an application may be filed against it before the Court by a new declarant state on the same day on which that state deposits with the Secretary-General its declaration of acceptance. The Court's recognition of the validity of the Portuguese third condition in the same case is the cause of the wide spread of this condition.

\section{c) Causes inherent in the Statute itself}

As the Court admitted explicitly, the uncertainty inherent in the compulsory jurisdiction system by extending the Court's jurisdiction as to cover "any question of international law", and at the same time allowing the possibility of using the compulsory jurisdiction system as a means for "hitand-run" or "single shot", and hence creating inequality between the parties to the system, and between these parties on the one hand, and those opting out on the other, has no doubt contributed to the increase of reservations. However, this cause must not be over-emphasised because the provision regulating compulsory jurisdiction i.e., Article 36 ( 2 - 5) has been almost the same since 1920, but it had not been misused during the period of the P. C. I. J.

\section{d) Imitation}

By inserting reservation in their declarations, old and experienced states have not only limited the scope of compulsory jurisdiction but have also provided patterns to be adopted particularly by new states which are already oversensitive about their hard-won independence. Thus, many of the reservations that have been abandoned by old states, including those which backfire such as the subjective reservations of domestic juris- 
diction, are still maintained by the new states. The adoption of certain reservations which were designed to exclude specific disputes of special characteristics is another example. Thus, the Buraimi reservation, which was designed to prevent any attempt by Saudi Arabia to refer the dispute concerning the Buraimi Arbitration, has been copied by other states.

\section{e) Psychological factors}

The insertion of some reservations excluding disputes already excluded by the statute of the Court or by virtue of another reservation in the same declaration seems to have no explanation except that they are inserted for psychological reasons. The reserving states wanted to emphasise the importance of those disputes. Examples of these reservations are to be found in the objective reservation of domestic jurisdiction, legal disputes, and the reservations of hostilities PATIONE TEMPORIS included in the declaration of the United Kingdom of June 2, 1955 and in the 1956 Israeli declaration.

The conclusion to be drawn from the above analysis of the different causes of the decline of the compulsory jurisdiction is that reservations are not so much the causes but the symptoms of the disease. Whatever their real causes, reservations reflect states' belief that broad commitment would produce few practical gains in terms of immediate national interests, while it might pose significant risk in an unforeseen future.

\section{B - EFFECT OF RESERVATIONS}

The difficulty, if not the impossibility, of determining the exact effect of reservations must be admitted. It is not possible to know the number of disputes which 
have not been brought before the Court because of the conviction that they fell within the scope of some reservations. It is difficult to imagine a state wasting so much money in bringing disputes which are clearly excluded by virtue of a reservation either in the declaration of that state or in the declaration of the other party to the dispute. However, State practice under the Article 36 (2) of the statute provides many examples in which acceptances were terminated, and replaced by new ones containing new reservations designed to prevent the submission of certain disputes. Thus, the United Kingdom had used its declarations for this purpose 4 times during the period between June 6, 1955 and November 261958. Australia and Canada had also used this method successfully for preventing the submission of their disputes with Japan and the United States of America respectively concerning Pearl Fisheries, and Arctic Waters Pollution Prevention Act of 1970

However, if the number of cases in which objections based on reservations succeeded in divesting the court of jurisdiction, is used as a criterion for the evolution of the effect of reservations, the conclusions will be that reservations proved to have little effect on the operation of the compulsory jurisdiction system. Thus, although in two cases only of the eleven contentious cases, which were filed before the P. C. I.J. on the basis of the Optional Clause during the 18 years if its existence, a final judgment was rendered and the Court's jurisdiction went unchallenged, objections based on reservations succeeded in depriving the court of jurisdiction in one case only.

Table 7 on page 485 indicates the effect. of reservations on all the cases filed before the both the $P$. C. I. J. and the I. C. J. on the basis of Article 36 (2) of the statute. 
+4
0
0
4
4
$w$

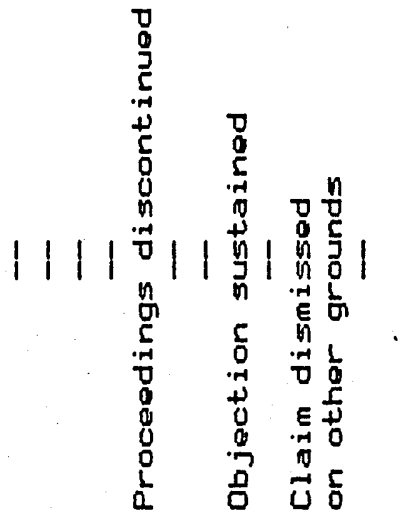

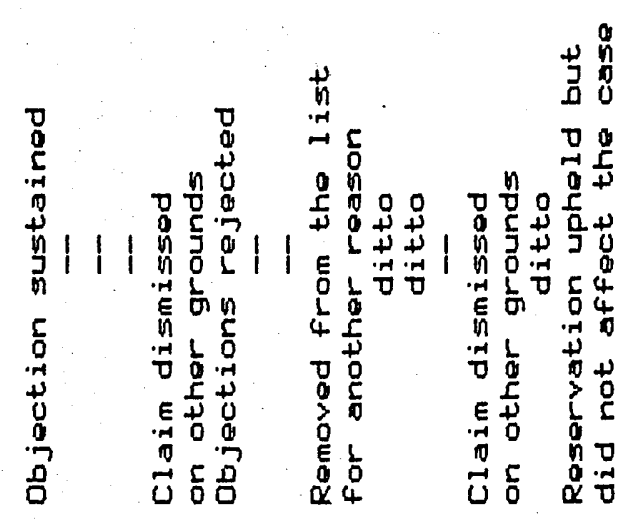

$\frac{n}{0}$

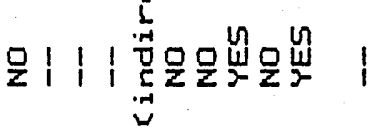

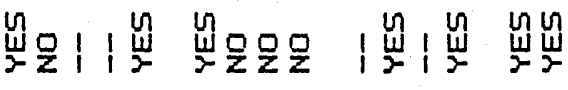

빅

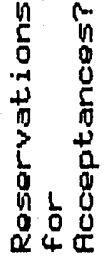

n

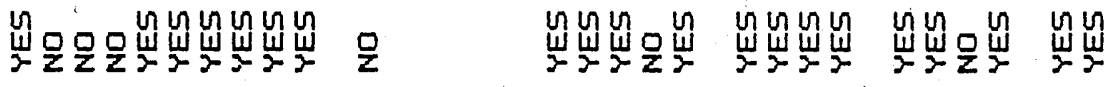

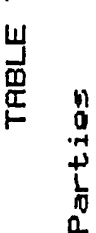

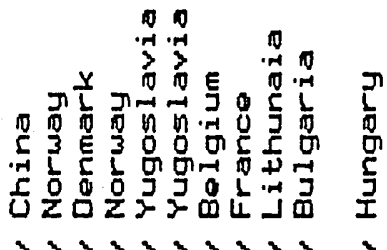

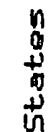

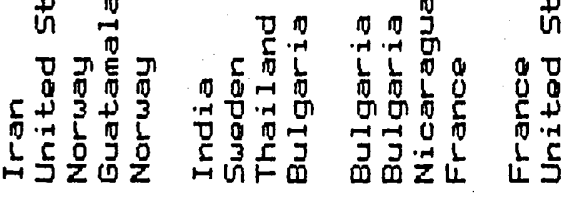

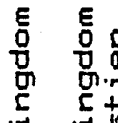

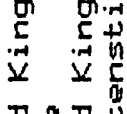

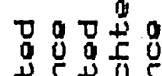

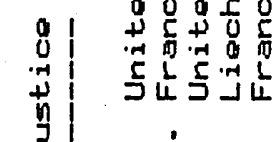

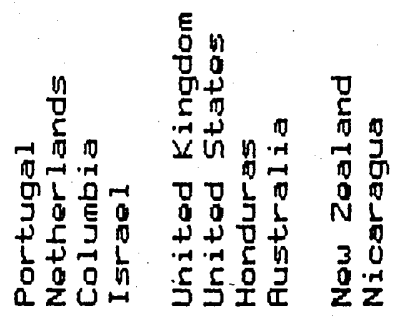

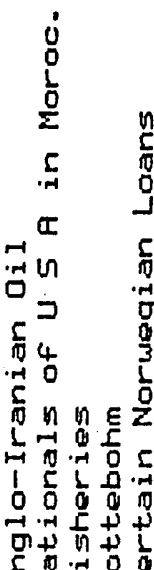

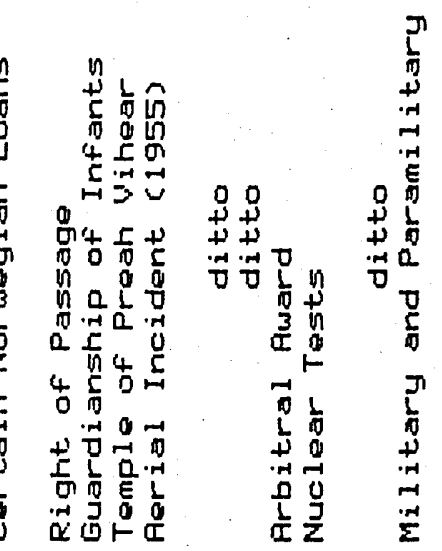


It is obvious that the Court can play a major role in controlling the effect of reservations while exercising its function of interpretation. It can therefore alleviate their deleterious effect. In practice, however. this role has not been fully played. The Court has taken a cautions attitude in respect of certain reservations. Thus, although it has been offered many opportunities to pronounce on the validity of the subjective reservation of domestic jurisdiction, it cautiously stepped aside for reasons of a non-legal character. Yet the positive role played by the court in this respect cannot be denied. In fact it has played a significant role through the interpretation of some reservations. It has, for example, limited the scope of the reservations RATIONE TEHPORIS by applying the criterion of the "real cause", which means that a situation or fact in regard to which a dispute is said to have arisen, cannot be taken into account unless it is the real cause of the dispute. The court has also interpreted this reservation in a positive manner as indicating the disputes which are covered by a declaration accepting its compulsory jurisdiction rather than proceeding on the principle of excluding from that acceptance any given dispute. This approach, combined with the "real cause" criterion, constitutes a major element in limiting the scope of this reservation and hence enhancing the scope of the compulsory jurisdiction.

\section{C - GROUNDS FOR OPTIMISM}

Balancing the signs of decline cited above there are, fortunately some grounds for optimism. The most important sign perhaps is that states' confidence in the Court seems to have been increased during the last two decades. The Court's docket has been fuller in the last few years than it had been during the previous two decades. Thus in 1986 - 1987 the Court docket contained 6 contentious cases and one request for advisory opinion. 46 It is true that only one case has been brought before the Court on the basis of Article 36 (2) since 1973. However 
what seems important is the removal of the psychological factor concerning the impartiality of the court and the overcoming of the real obstacle, which is the political willingness of states not to resort to the court. It is worth noting that developing countries - especially new States - have shown an increasing tendency to resort to the Court during the last few years. Four of the six cases referred to above are between developing countries and the fifth is brought also by a developing country (Nicaragua). Recourse to the Court by some African States, such as Tunisia, Libya, Burkina Faso and Malawi, is a sign of improvement. New States seem thus to have started the application of the idea, usually articulated by themselves, that judicial settlement is to their benefit. At least it does not involve, as the other means of ten do, "a compromise in which the physical or economic pressures exerted by one of the parties might dominate".

The court is a forum in which these states are to be offered a virtual equality. In fact, if the SOUTH HEST AFRICA case of 1966 had shaken up the confidence of new States and the HAMIEIA case had restored it, the MILITARY AND PARAHILITARY ACTIUITIES IN AND AGAINST NICARAGUA case, having refuted their apprehensions discussed above, should leave no doubt that the Court constitutes perhaps the best means for the settlement of their disputes. However, there seems to be no doubt that the number of cases referred to the Court since 1980 constitutes a positive sign, especially if it is borne in mind that there are not thousands of millions of potential litigants before the Court - as judge Schwebel observes - but only 162.48

Another sign of the increase of confidence on the part of new states is that 12 new declarations have been made since 1963. It is true that this number constitutes a small portion of the total number of these states, but it must not be forgotten that most of them have emerged recently and might have had no time to think about accepting the compulsory jurisdiction. 
Other grounds for optimism can be found in the following facts:

Since 1963 the average number of reservations in every individual declaration has decreased. Thus, while 4 of the declarations ${ }^{49}$ which have been made since 1963 constitute a drawback, 9 declarations ${ }^{50}$ contain a small number of reservations, usually otiose reservations, but with the condition of variation or termination with immediate effect. Only 3 new declarations are encumbered with a large number of reservations. 51 On balance, 5 declarations are made without reservations or with unnecessary reservations. 52 Thus, 20 of the 46 declarations currently in force are positive acceptance of compulsory jurisdiction and constitute a genuine commitment to the court.

Four States [Australia, Canada, New Zealand and the United Kingdom] have replaced their previous declarations with new ones which are much better and disclose a greater commitment. The United Kingdom, for example, has dropped 6 of the reservations made during the fifties.

Reservations concerning national security or national defence have disappeared without being imitated.

A new time-limit formula has been introduced by. Switzerland and Liechtenstein. Their declarations are for an unlimited period, revocable after ONE YEAR'S NOTICE.

The Netherlands modified the exclusion date in its RATIONE TEMPORIS reservation from 1946 to 1921.

The conclusion to be drawn from these signs is that although thesystem of compulsory jurisdiction is ill, it is far from dead. 


\section{D - SUGGESTIONS}

The number of States accepting the Court's compulsory jurisdiction, their practice under Article 36 ( 2 and 3 ) of the Statute and their debates in the Sixth Committee concerning the review of the Court's role, leave no doubt that there are no prospects at the present time nor in the near future that the automatic compulsory jurisdiction via the Optional Clause will be introduced. Socialist States, especially the U. S. S. R. have made it clear that they would oppose any amendment to the statute aiming at that object. A proposal to accept the compulsory jurisdiction without reservations appears to be a premature move and likely to fall - as in fact it didon deaf ears. Any suggestion must thus be realistic. Certainly reservations are not a good thing for international law and justice, but it should not be forgotten that the majority of the members of the League of $\mathrm{Na}-$ tions, including great powers, did not adhere to the Optional Clause except after the Assembly's recommendation that reservations might be included in the declarations of acceptance. Any suggestions for improvement must, thus, be made within the framework of maintaining reservations. The "all-or-nothing" approach should be abandoned. It would be more realistic and wiser to "elevate our sights a little lower" perhaps "much lower" as professor Sohn points out. 5.3 However, the existing situation could be improved, it is believed, even within this framework. For, if the insertion of reservations reflects a state's desire not to overlook any of the diverse and often complex elements that have to be taken into consideration before deciding to accept compulsory jurisdiction, some reservations indicate a misplaced ingenuity or excessive caution on the part of legal advisors while calculating the balance of benefits and risks of their acceptance. Such misplaced ingenuity or excessive caution has led to the insertion of reservations which operate against the interests of the declarant state itself. In this respect the following sugges- 
tions might be made.

Subjective reservations must be abandoned, not only because they are intolerable in any effective system of compulsory jurisdiction, but also because they proved to be in practice inimicable to the interests of States making them. Their inclusion proved that a major element in the balance of benefits and risks of accepting the Court's compulsory jurisdiction, namely, the operation of the principle of reciprocity, had been neglected. Lessons learned from the NORHEGIAN LOANS case must not be forgotten. The United States statement justifying withdrawal from the Court's compulsory jurisdiction provides another proof that these reservations must be eliminated. In that statement, the United States admitted explicitly that it had "never been able to use [its] acceptance of compulsory jurisdiction to bring other states before the Court". 54 Consequently, it is greatly hoped that the proposed reservation excluding any dispute brought before the Court under Article 36 (2) of the Statute unless it is decided by a chamber of the court composed in accordance with Article 26 of the Statute, will not be adopted. This reservation must be ruled out for the same reasons advanced against the subjective reservation of domestic jurisdiction. It is incompatible with the Rules of the court, and might be used as an escape device by the respondent state by declining to accept any combination of judges acceptable to the other party. 55 It is vital - as a great authority observes - "to overcome the hesitation endemic in approaches to a Court composed of persons from different cultures and traditions". 56

The reservation of the right to terminate or vary an acceptance at any time proved to be more harmful than any other reservation, because - as shown in practiceit enables states parties to the compulsory jurisdiction system to escape their obligation when and as they wish, and the new comers to take the benefit, on their own conditions and according to their convenience. Thus, many 
suggestions have been made, such as the proposal to apply reciprocity to time-limits, to insert the "single-shot" solution reservation and the suggestion that Article 36 (4) of the statute should be amended so as to include a provision providing that declarations, shall not enter into force until a month or so after their deposit. However it has been shown that the first might complicate the problem instead of being a cure, and the court rejected it. The second and third could only provide a partial solution, because while they might solve the "singleshot" problem, they leave a state party to the system free to "hit another party and run". The simple and. perhaps. complete solution for these problems seems to be the insertion in Article 36 (2) of the Statute the proviso:

"Frovided that the acceptance shall have effect as
long as it has not been revoled subject to one year"s notice".

It is true that the debates before the Sixth Committee concerning the review of the Court's role indicate that many States were against the idea of amending the Statute, but their opposition concerned attempts to introduce the system of AUTOMATIG AND GENERAL COMPULSORY 7URISDICTION. There is, therefore, a good chance of having this minor amendment to the existing system adopted. However, if the time is not yet ripe for the adoption of such an amendment it might be considered in the future when the circumstances allow.

It is to be observed that the importance of this proviso is not limited to preventing a state from accepting the Court's jurisdiction for the purpose of referring a single dispute to the court, or from escaping being sued in respect of a determined dispute, but, it might also adduce States unfamiliar with the system of compulsory jurisdiction to accept it, since they are not required to make long term declarations. 
Reservations excluding disputes already excluded by the statute should have no place in States' declarations of acceptance. For, while they do not provide any further protection to the declarant states, they might be developed into undesirable ones. The substitution of the subjective reservation of domestic jurisdiction for the objective one is an example.

In making subject-matter reservations, States are advised to refer EO NOMINE to the dispute or category of disputes they wish to exclude instead of the general GENUS PROXIMUH. This proposal could serve both the interests of the declarant state as well as the system of compulsory jurisdiction. State practice provides examples on how general reservations can backfire. Thus, the Greek reservation of territorial disputes, which was designed to exclude a dispute with Bulgaria, prevented Greece from having its dispute with Turkey, concerning the Aegean sea Continental Shelf, decided by the court.

As a corollary, States are also advised to eliminate reservations which have achieved their purpose. If the existence of these reservations is unnecessary, they might be imitated by other states. Thus, if the reservations of the Law of the sea were inserted as a result of the uncertainty of that law during the past decade, their retention by developing countries could prevent the Court from a further contribution to the development of that law, in which they played a great role in shaping. Law needs application as several representatives to the General Assembly from those countries pointed out.

In replacing their previous declarations or renewing them, states are urged to pay attention to the fact that the retention of the proviso excluding "disputes arising after the present declaration" diminishes the period subject to the Court's jurisdiction by excluding the period during which the Court's jurisdiction had been accepted by the previous declarations. 
New States might be recommended to insert a reservation excluding disputes arising prior to the date of their independence or subsequent date if they feel that they might be bound by treaties forced upon them and rights acquired during the period of colonization

Efforts should be made to prevent a further deterioration of the present situation. Jurists should play a leading role in this respect. They must - as professor Humbro points out 58 - remember that they are not exclusively servants of governments and institutions, but they are also servants of the international community.

Jurists should also exploit every opportunity to emphasise again and again that recourse to the court is a normal way of settling international disputes. Every effort should be made to eliminate this psychological factor which encourages states to settle their disputes outside the Court.

The adoption of these suggestions might enhance the role of the system of the optional compulsory jurisdiction as a reconcilable means with the principle of sovereignty in the prevailing circumstances and as the only available means for a progressive and general acceptance of compulsory jurisdiction.

On the following page is a model of a declaration which might be recommended for states to adopt as a means which serves their own interests as well as that of the system of compulsory jurisdiction. 
"UNDER PARAGRAPH 2 OF ARTICLE 36 OF THE STATUTE OF THE INTERNATIONAL COURT OF JUSTICE, I DECLARE ON BEHALF OF [THE GOVERNMENT OF STATE X] THAT [STATE X] RECOGNISES THE COURT'S JURISDICTION AS COMPULSORY IPSO FACTO AND WITHOUT SPECIAL AGREEMENT AS PROVIDED FOR IN THE SAID PARAGRAPH.

PROVIDED, THAT THIS DECLARATION DOES NOT EXTEND TO:

(List of clearly defined and objectively determined subject-matter disputes)

THIS DECLARATION SHALL REMAIN IN FORCE AS LONG AS IT HAS NOT BEEN REVOKED SUBJECT TO ONE YEAR'S NOTICE." 


\section{NOTES}

(1) This number covers only States which were parties to the L. N. (57 States) and those mentioned in the Annex to the Covenant (4 States). It does not therefore include other States which were entitled to appear before the P.C.I.J. (10 States), See P.C.I.J. , Series E, No.10, pp.47 seq.

(2) 55 members of the U.N., mentioned in the Annex to the Covenant and one (Monaco) of the 8 other States which were entitled to appear before the P.C.I.J., ibid., No. 14, pp.59 seq.

(3) For the list of these States see I.C.J.Y.B., 1986-87, p.59.

(4) These declarations were made by Argentina, Costa Rica, Czechoslovakia, Guatemala, Egypt, Iraq, Liberia, Poland and Turkey. See table 2, Chapter 2, above pp. 54-55.

(5) the Declarations of New Zealand and Norway are omitted because the right to vary them is limited to the special question of dispute settlement in the law of the sea.

(6) See 25, 26, 27, 28 and 29 Official Records of the General Assembly (O.R.G.A.), Sixth Committee, Annexes, Agenda Items 96, 90, 90, 97 and 93 respectively.

(7) It is to be noted that not all the reasons which cause States' reluctance to resort to the Court can be considered as causes behind the insertion of reservations. Thus, foe example, the conception that adjudication is expensive or a timeconsuming procedure may discourage States to resort to the Court but not to accept the Court's jurisdiction with reservations.

(8) See e.g. the views expressed by Japan, France and Australia in "Views Expressed by Member States and States Parties to the Statute of the International Court of Justice in their Replies to the Questionnaire Prepared by the SecretaryGeneral", U. N. Doc. A/8382, paras.49, 51 and 53 respectively. See also the views of the Ukranian S.S.R. [26 O.R.G.A., p.195, para.50 (U. N. Doc. A/C.6/SR.1280)] and Bulgaria [ibid, p.201, para. 52(U.N. Doc. A/C. 6/S.R. 1281)]. But comp. the view expressed by Cyprus, ibid., para. 25 (U.N. Doc. A/C. 6/ S.R. 1280).

(9) 29 ibid., para.12(U.N. Doc.A/C. 6/S.R.1467).

(10) See e.g. the view expressed by Poland [26 O.R.G.A., p.178, para.44 (U.N. Doc. A/C. 6/S.R. 1277)] and the Ukranian S.S.R., U.N. Doc. A/8382, para.385.

(11) Quoted by O. J. Lissitzyn, the International Court of Justice, 1953, p.63.

(12) 25 O.R.G.A., p.230, para.26 (U.N. Doc. A/C/. 6/S.R. 1217).

(13) See the U.S.S.R. statement, ibid., p.200, para.11 (U.N. Doc. A/C. 6/S.R. 1212). See also the statements of Cuba [29 ibid., p.18, para.3 (U.N. Doc. A/C. 6/S.R. 1467)] ; Byelorussian S.S.R. [ ibid., p.22, para.43] and Romania [ ibid., p.27para.21 (U.N. Doc. A/C. 6/S.R. 1468)].

(14) See e.g. the statements made by the delegates of Byelorussian [Ibid., p.33, para.44] and U.S.S.R. [ibid., p.37, para.4 (U.N. Doc. A/C. 6/S.R. 1470)].

(15) See e.g. the views expressed by the delegates of Cuba [29 ibid., p.18, para.4 
(U.N. Doc. A/C. 6/S.R. 1467)]; Hungary [ibid., p.21, para.34], and Poland [25 ibid., p.191, para.17 (U.N. Doc.A/C. 6/S.R. 1210).

(16) See U.N. Doc. A/8382, paras. 62,66 and26 O.R.G.A., p.206, para. 21(U.N. Doc. A/C. 6/S.R. 1283) respectively.

(17) See e.g. the statemens of the delegates of Ecuador[26 O.R.G.A., p.220, para.10 (U.N. Doc.A/C. 6/S.R.1283)] and Afghanistan [25 ibid., p.214, para.45 (U.N. Doc. A/C. 6/S.R. 1283)].

(18) See e.g. Mr.Alcivar's (Ecuador) statement 25 ibid., p.233, para.3 (U.N. Doc. A/C. 6/S.R. 1218).

(19) See e.g. the Australian proposal in U.N. Doc. A/8382, para.66 and the statements of the delegates of Mexico [29 O.R.G.A., p.38, para.16 (U.N. Doc. A/C. 6/S.R. 1470)], Ethiopia [26 ibid., p.215, para.55 (U.N. Doc. A/C. 6/S.R. 1283)] and Ecuador 25 ibid., p.233, para.3 (U.N. Doc. A/C. 6/S.R. 1218).

(20) See e.g. the statement of the Egyptian delegate, 25 ibid., p.209, para.5 (U.N. Doc. AV. 6/S.R. 1214.

(21) See T.O. Elias, "does the International Court of Justice, as it is Presently, Shaped Correspond to the Requirements which Follow from its Functions as the Central Judicial Body of the International Community" in $\mathrm{H}$. Mosler and R. Bernhardt (eds.), Judicial Settlement of International Disputes, 1974, pp.1923 , at 23.

(22) See e.g. the responses of Laos, Argentina, Mexico, Iraq and Yugoslavia to the Secretary-General Questionnaire, U.N. Doc. A/8382, paras.97, 101, 104, 110 and 112 respectively.

(23) See e.g. the responses of Laos and Yugoslavia, ibid., and the statements of the representatives of Ghana [25 O.R.G.A., p.230, para.32(U.N. Doc.A/C. 6/S.R. 1217)] and Ecuador [ibid., p.234, para.5 (U.N. Doc. A/C. 6/S.R. 1218)].

(24) See Zemanec in H. Mosler and R. Bernhardt(eds.), supra note 21, p.61.

(25) For the effect of this case on the attitude of those States see Q.I. Natchaba, les Etats Africains et la Cour Internationale de Justice, thesis (Université de Poitiers, Faculté de Droit et des Sciences Sociales), 1978, vol. 1, pp.126-128.

(26) For the effect of the Court's Judgments in the South West Africa cases see ibid., p.145 seq and R. Falk, Reviving the World Court, 1986, pp.25-137.

(27) See e.g. the views expressed by the delegates of Ethiopia [26 O.R.G.A., p.173, para.6(U.N. Doc. A/C. 6/S.R. 1277)] and United Republic of Tanzania [25 ibid., p.228, para.7 (U.N. Doc. A/C. 6/S R 1217)].

(28) See the View of U.R. of Tanzania [ibid., para.11] ; Ghana \{lbid., p.231, para.32] and Madagascar [29 ibid., p.27, para.23 (U.N. Doc. A/C. 6/S.R. 1668)]. Comp. Kenya's view 25 ibid., p.205, para.30 (U.N. Doc. A/C. 6/S.R. 1213).

(29) See e.g. U.S.A. response to the Secretary-General Questionnaire, supra note 8, U.N. Doc. A/8382, para.60.

(30) See E. MacWhinney, "Acceptance, and Withdrawal or Denial of World Court Jurisdiction : Some Recent Trends as to Jurisdiction", 20 Isr.L.R. (1985), pp.184-166, at 151 .

(31) Journal Official de la republique Française, 9 March 1974, pp.1086-1087. 
(32) " Statement on the U. S. Withdrawal from the Proceedings Initiated by Nicaragua in the International Court of Justice ", 24 I.L.M. (1985), p.246, at 247.

(33) Ibid., p.248.

(34) E.B. Weiss, "Judicial Independence and Impartiality : A Preliminary Inquiry", in L.F. Damrosch (ed.), the International Court of Justice at a Crossroads, 1987, pp.123-154, at 132 .

(35) See 25 O.R.G.A., p.217, para.1 (U.N. Doc A/C. 6/S.R. 1216) and 29 ibid., p.16, para.3 (U.N. Doc. AVC. 6/S.R. 1466).

(36) See e.g. the view expressed by the delegate of Guyana, 26 ibid., p.220, para.17 (U.N.Doc. A/C. 6/S.R.1284).

(37) See the statements of the delegates of Australia [29 ibid., p.16, para.9 (U.N. Doc. A/C. 6/ S.R. 1465)], Italy [ibid., p.20, para.20 (U.N. Doc. A/C. 6/S.R. 1467)] and the British response to the Secretary-General Questionnaire, U.N. Doc. A/8382/Add.1, para.51.

(38) 48 (II) Annuaire I.D.I.(1959), p.359.

(39) Resolution 3232(XXIX), "Review of the Role of the International Court of Justice", 2280th plenary meeting , 12 November 1974.

(40) See the statement of Poland [25 O.R.G.A., P.191, para.18 (U.N. Doc.A/C. 6/S.R. 1384)].

(41) See e.g. the Swedish view [lbid., p.218, para.9 (U.N. Doc. AVC. 6/S.R. 1216)] and the Nigerian one[ Ibid., p.223, para.55].

(42) E.g. India, 25 ibid., p.214, para. 11(U.N. Doc. A/C. 6/S.R. 1215).

(43) E.g. New Zealand (U.N. Doc. A/8382/ Add. 4) and U.S.A. [27 O.R.G.A., p.435, para.24 (U.N. Doc. A/C. 6/S.R. 1384)].

(44) E.g. Turkey, 26 ibid., p.216, para. 67 (U.N. Doc.A/C. 6/S.R. 1283).

(45) Supra note 39.

(46) See I.C.J.Y.B., 1986-87, p.127.

(47) See the statement made by Faruk, the delegate of Pakistan to the General Assembly, 26 O.R.G.A., p.200, para.44 (U.N. Doc. A/C. 6/S.R. 1279).

(48) "Reflections on the Role of the International Court of Justice", 61 Wash.L.R.(1986), pp.1061-1071, at 1068.

(49) The declarations of El Salvador, India , Honduras and the Philippines.

(50) The Declarations of Austria, Barbados, Botswana, Canada, Gambia, Kenya, Senegal, Somalia and Swaziland.

(51) Malawi, Malta and Mauritius.

(52) Costa Rica, New Zealand, Nigeria, Togo and Norway.

(53) L. B. Sohn, "Step- by-Step Acceptance of the Jurisdiction of the International Court of Justice", 58 A.S.I.L. (1964), pp.131-136, at 131.

(54) "Statement Concerning Termination of Acceptance Of I.C.J. Compulsory Jurisdiction , October7, 1985 (Press Statement), 24 I.L.M. (1985), p.1743, at 1744.

(55) This reservation is suggested by R. N. Gardner, " U. S. Termination of the Compulsory Jurisdiction of the International Court of Justice", 24 Colum.J.T.L. (1986), pp.421-427, at 425, 427, and M. Leigh and S.D. Ramsey, "Confidence in the Court : It Need not be a 'Hollow Chamber", in L. F. Damrosch (ed.), supra 
note 34, pp.106-122, at 119-122.

(56) Judge M. Lachs, " A Few Thoughts on the Independence of Judges of the International Court of Justice", 25 Colum.J.T.L. (1987), pp.593-600, at 594.

(57) See e.g. the views expressed by the delegates of Uruguay, 29 O.R.G.A., p.24, para.61(U.N. Doc. A/C. 6/S.R. 1467) and Turkey, Ibid., p.30, para.45 (U.N. Doc. A/C. 6/S.R. 1468).

(58) In H. Mosler and R. Bernhardt (eds.), supra note 21, p.173. 


\section{Bibliography}

\section{(1) Documentary Sources:}

\section{A. Publications of the Court:}

The International Court of Justice, Reports of Judgments, Advisory Opinions and Orders, 1947_1987.

Pleadings, Oral Arguments and Documents. , Yearbooks, 1947-1987.

The Permanent Court of International Justice, Advisory Committee of Jurists, Documents Presented to to the Committee Relating to Existing Plans for the Establishment of a Permanent Court of International Justice, 1920.

, Procès Verbaux of the Proceedings of the Committee, June 16 th- July 24 th 1920 with Annexes, 1920.

The Permanent Court of Intemational Justice, Series A, Judgments and Orders . , Series B, Advisory Opinions.

, Series AVB, Judgments, Orders and Advisory Opinions.

— Series C, Acts and Documents Relating to Judgments and Advisory Opinions. Series D, Acts and Documents Conceming the Organization of the Court .

, Series E, Annual Reports.

B Bublications of the Leaque of Nations:

League of Nations, Documents Concerning the Action Taken by the Council of the League of Nations and the Adoption by the Assembly of the Statute of the Permanent Court of International Justice, 1921.

_ Documents Concerning the Action Taken by the Assembly on the Statute of the Permanent Court of Inetrnational Justice, 1921.

_. Official Journal.

, Treaty Series.

$c$ Publications of the United Nations:

United Nations Conference on International Organization, San Francisco 1945, Documents. 16 vols. 1945.

_United Nations Document AV8382 and Add. 1-4, "Views Expressed by Member States and States Parties to the Statute of the International Court of justice in their Replies to the Questionnaire Prepared by the Secretary -General", Sep.1971.

United Nations Official Records of the General Assembly, " Review of the Role of the International Court of justice ", Sixth Committee, Annexes , Agenda Items: 96(1970), 90(1971), 90 (1972), 97(1973), 93(1974).

United Nations, General Assembly Resolutions Nos. 171(II) (14 Nov. 1947), 2625(XXV) (24 Oct. 1970) and 3232 (XXIX) (12 Nov. 1974).

\section{Other Sources:}

British and Foreign State Paper.

British Parliamentary Papers, Memorandum on the Signature by his Majesty's Government in the United Kingdom of the Optional Clause of the Statute of the Permanent Court of International Justice Presented by the secretary of State for 
foreign Affairs to Parliament by Command of His Majesty . Misc. No.12 (1929), Cmd. 3452.

_ A Commentary on the charter of the United Nations Signed at San Francisco on 26th June 1945, Misc. No.9 (1945), Cmd. 6666.

British Parliamentary Debates, House of Commons, Vols.577 and 596.

Canada - House of Commons Debates, 1970.

Hudson, Manley O, World Court Reports, A collection of the Judgments, Orders and Opinions of the Permanent Court of International Justice.

Hansard's Parliamentary Debates.

International Legal Materials, "Canadian Prime Minister's Remarks on the proposed Legislation ", Vol.9. 1970.

_ Statement on the U.S. Withdrawal from the Proceedings Initiated by Nicaragua in the International Court of Justice ", January 18, 1985, Vol. 24 (1985).

_ Statement Concerning Termination of Acceptance of I.C.J. Compulsory Jurisdiction, Oct. 7, 1985, Vol. 24 (1985).

Journal Officiel de la Republique Francaise, 9 March 1974.

Manning W.R. Arbitration Treaties Among the American Nations to the Close of the Year 1910,1924.

Martens, Fr. de, Nouveau Recueil Général de Traités.

Rosenne,Shabtai, Documents on the Intemational Court of Justice, 1974.

, Documents on the Intemational Court of Justice, 2nd. ed. 1979.

Scott, James Brown (ed.), The International Conferences of American States 18991928, 1931.

_. Instructions to the American Delegates to the Hague Conferences and their Official Reports, 1916.

— The Proceeding of the Hague Peace Conferences, the Conference of 1899, 1920.

T The Proceedings of the Hague Conferences, the Conference of 1907, 1920.

Traités Généraux d' Arbitrage Communiques au Bureaux International de la Cour Permanente d' Arbitrage, Première Serie, 1911.

United States Congressional Record.

Charter of the United Nations : Report to the President on the results of the San Francisco Conference by the Chairman of the United States Delegation, the Secretary of State, June 26, 1945, Department of State Publication 2349, Conference Series 71, 1945.

United States, Compulsory Jurisdiction, International Court of Justice, Hearing before a Subcommittee of the Committee on Foreign Relations, U.S. Senate, 79th Congress 2nd Session on S.Res. 196,1946.

_ Hearings before the Committee on Foreign Relations , U.S. Senate, 87 th Congress 2nd. session on S.Res. 94, 1960.

\section{(II) Books \& Articles}

Acevedo, Domingo E, " Disputes Under Considerations by the U.N Security Council or 
Regional Bodies ", In Damrosch, L.F.(ed) ,The International Court of Justice at a crossroads, 1987, pp.242-263.

Ahi, Mahdi Madjid , les Négociations Diplomatiques Préalables a la Soumission d' un Differend a une Instance Intemationale, 1957.

Allot, P.J., " the International Court of Justice ", in Waldock, C. H. M. (ed.), Intemational Disputes : the Legal Aspects , 1972, pp.128-158.

Almond,Jr, Harry.H., " the Military Activities Case : New Perspectives on the International Court of Justice and Global Order", 21 I.L. (1987), pp. 195209.

Anand, R. P. , Compulsory Jurisdiction of the Intemational Court of Justice, 1961. , Studies in Intemational Adjudication, 1969. International Courts and Contemporary Conflicts, 1974.

_. "Role of International Adjudication", in Gross, Leo (ed.), the Future of the International Court of Justice, vol.1, 1976, pp.1-21.

" Attitude of 'New' Asian-African Countries Toward the International Court of Justice", in Snyde, F. E. and Sathirathai, S. (eds.), Third World Attitudes Toward International Law : An Introduction, 1987, pp-162-177.

Arend, Anthony Clark, " the Obligation to Pursue Peaceful Settlement of Intemational Disputes During Hostilities", 24 Virg. J. I. L. (1983), pp. 97-123.

Arndt, John D. , " International Court of Justice - Legal Effect , Constitutional and International, of Connally Amendment", 28 U. Kans. C. L. R. (1959-60), pp. 1-34

Atkinson, Nolan N. , " Justiciability and the Statute of the International Court of Justice", 15 Howard L. J. (1969), pp. 519-589.

Bains, J. S. , " Domestic Jurisdiction and the World Court ", 5 Indian J. I. L. (1965), pp. 464-492.

Baker, P. J. N. , " Obligatory Jurisdiction of the Permanent Court of International Justice ", 6 B. Y. B. I. L. (1925), pp. 69-102.

Baldwin, Rignal W. , " An Alternative to the Connally Amendment as a Practical and Realistic Step Toward World Peace Trough Law ", 13 S. C. L. Q. (1961), pp. 516-527.

Barclay, Sir Thomas, " the Hague and Vital Interests ", 21 L. Q. R. (1905), p.109. , Problems of Intemational Practice and Diplomacy, 1907.

- New Methods of Adjusting International Disputes and the Future, 1917.

Barries, George N. , " the United States' Walkout at the I. C. J. :Seeing the Writing on the Wall and Getting Out Before Getting Hurt", A. R. (1985), pp. 10-13.

Bentwich, Norman, "the Limits of the Domestic Jurisdiction of the State", A. S. I. L. (1945), pp. 59-89.

Berlia, Georges, " la Jurispnudence des Tribunaux Intemationaux en ce qui Concerne leur Compétence", 88 R. D. A. D. I. (1955), pp.112-160.

Bilder, Richard B. , " Some Limitations of Adjudication as an International Dispute Settlement Technique ", 23 Virg. J. I. L. (1982), pp. 1-12.

, " International Dispute Settlement and the Role of Adjudication ", in Damrosch, L. F.(ed.), the International Court of Justice at a Crossroads, 1987, pp. 155182.

Bleicher, Smuel A. , " I. C. J. Jurisdiction : Some New Considerations and Proposed 
American Declaration", 60 Colum. J. T. L. (1967), pp. 61-89.

Bollecker-Stern, Brigitte, " I' Affaire des Essais Nucleaires Français devant la Cour Internationale de Justice ", 20 A. F. D. I. (1974), pp. 299-333.

Borel, Eugène, " l' Acte Général de Genève ", 27 (II) R. C. A. D. I. (1929), pp. 501-595.

, and Politis, N. , "l' Extension de l' Arbitrage Obligatoire et la Competence de la P. C. I. J. ", 33(II) Annuaire I. D. I. (1927), pp. 669-761.

Boyle, Howard H. , "Proposed Repeal of Connally Reservation - A Matter of Concern ", 43 M. L. R. (1959-60), pp. 317-324.

Bramson, A., " Problèmes de Competence dans le Statut et la Jurisprudence de la Cour Internationale de Justice ", 8 Annales U. M. C. S. (1961), pp. 101-136.

Brierly, J. L. , " Matters of Domestic Jurisdiction ", 6 B. Y. B. I. L. (1925), pp. 819.

" British Reservations to the General Act ", 12 B. Y. B. I. L. (1931), pp. 132135.

" Vital Interests and the Law ". 21 B. Y. B. I. L. (1944), pp. 51-59.

Briggs, Herbert W. , " Reservations to the Acceptance of Compulsory Jurisdiction of the International Court of Justice ", 93(I) R. C. A. D. I. (1958), pp. 229-363. , Interhandel : the Court's Judgment of March 21, 1959 on the Preliminary Objections of the United States ", 53 A. J. I. L. (1959), pp. 547-563.

, " the United States and the International Court of Justice : A Re-Examination ", 53 A. J. I. L. (1959), pp. 301-318.

_, " Nicaragua v. United States : Jurisdiction and Admissibility ", 79 A. J. I. L. (1985), pp. 373-378.

, "the International Court of Justice Lives up to its Name ", 81 A. J. I. L. (1987), pp. 78-86.

Brown M. and Politis N. , " la Classification des Conflicts Comportant un Reglement Judiciaire", 29 Annuaire I. D. I. (1922), pp. 23-59.

Brownlie, Ian, Principles of Public International Law, 3rd. ed., 1983. , "the Justiciability of Disputes and Issues in International Relations", 42 B. Y. B. I. L. (1969), pp. 123-143.

Buigues, J. L. I. , " les Declarations d' Acceptation de la Juridiction Obligatoire de la Cour Internationale de Justice : leur Nature et leur Interpretation", Ö. Z. Ö.R. (1972), pp. 254-288.

Cassese, Antonio, "the Concept of ' Legal Dispute 'in the Jurisprudence of the International Court", Comunicazioni e Studi, 14 Instituto di Diritto Internazionale e Struniero della Universita di Milano (1975)pp. 173-200.

Cavalcanti, Amaro, Restrictive Clauses in International Arbitration Treaties", 8 A. J. I. L. (1914), pp. 723-737.

Chapel, Philippe, Lanbitrabilité des Differends Internationaux, 1967.

Charpentier, J. , " l' Arrêt de la C. I. J. dans l' Affaire de Barcelona Traction", 10 A. F. D. I. (1964), pp.327-352.

Chayes, Abram, "Nicaragua, the United States, and the World Court", 85 Colum. L. R. (1985), pp. 1445-1482.

Claude, Jr., Inis L. , " States and the World Court : the Politics of Neglet ", 13 Virg. J. I. L. (1971), pp. 344-355. 
Cocatre - Zilgien, Andre, " Justice Internationale Facultative et Justice Internationale Obligatoire", 80 R. S. (1976), pp. 689-737.

Coory, E. J. , " A Commonwealth Court ", 43 J. P. C. (1962), pp. 347-353.

Coquia, George R. "the Problem of Jurisdiction of the International Court of Justice ", 52 Phili. L. J. (1977), pp. 154-164.

Cory, Helen May, Compulsory Arbitration of International Disputes , 1932.

Cottereau, Gilles, Positions de la France a l'Egard de la Juridiction Internationale, thesis(Université de Paris V), 1980.

Crabb, John N. , " On Judging the Connally Amendment " , 50 Gergt. L. R. ( 1962), pp.529- 545.

Crawford, James, "The Effect Of Automatic Reservations to the Jurisdiction of the International Court ", 50 B. Y. B. I. L. (1979) , PP. 63- 86.

D'Amato, Anthony, " Modifying U. S. Acceptance Of The Compulsory Jurisdiction of The World Court ", 79 A. J. I. L. (1985) , pp. 385- 405.

ـ the United States Should Accept, by a New Declaration, the General Compulsory Jurisdiction of the World Court ", 80 A. J. I. L. (1986), pp. 331- 36.

Dalfen , C. M. , " The World Court in Idle Splendor : The Basis of States' Attitudes " 23 I. J. (1967 - 68 ), pp. 124 - 139.

Daly , Joseph L. , " Is The International Court of Justice Worth the Effort ? " , 20 A. K. L. R. (1987) , PP. 391 - 407.

Danwin , H. G. , " General Introduction in Waldock , C. H. M. (ed. ), International Disputes : The Legal Aspects, 1972 , pp. 57 - 76.

Davies , D. J. L. , " Domestic Jurisdiction : A Limitation of International Law " , 32 G. S. (1947) , pp. $60-67$.

Debbasch, Charles, " La Compétence ' Ratione Temporis' de la Cour Internationale de Justice dans le Systeme de la Clause Facultative de la Juridiction Obligatoire " , 31 R. G. D. I. P. , ( 1960 ), PP. $230-259$.

Decaux , Emmanuel , La Reciprocité en Droit Intemational \& 1980.

De Paw , Frans , " La Belgique et la Compétence Obligatoire de la Cour Intemationale " , 1 R. B. D. I. ( 1965 ) , pp. $49-87$.

, "La Declaration de la Cour Internationale de Justice " , 2. R. B. D. I. ( 1966 ), pp. 94 - 124.

Delbez , Louis , Les Principes Généraux du Contentieux Intemational, 1962.

Deutsch, Eberliard P. , " The International Court of Justice . " 5 Cor. I. L. J. ( 1972 ) , pp. $35-41$.

Dhommeaux , Jean , "Quand la France Contest les Decisions de la Cour de La Haye ? " , 77 R. P. P. ( 1975 ) , pp. 35 - 42.

Dillard , H. C. , " The World Court : Reflections of a Professor Tumed Judge " , 2 Am. U. L. R. ( 1978 ) , pp. $205-250$.

Dixon , John , Jr . , " The Connally Amendment - the Conflict between Nationalism and Effective World Court " , 53 Ky. L. J. ( 1964 ) pp. 164 - 175.

Dreyfus , Simone, " Les Declarations Souscrites par la France aux Termes de l'Article 36 du Statut de la Cour Internationale de Justice " , 5 A. F. D. I. ( 1959 ), pp. $258-275$.

Dubisson, Michel , La Cour Intemationale de Justice , 1964. 
Elias , Taslim Olawale, " Does the International Court of Justice, as it is Presently Shaped, Correspond to the Requirements which Follow from its Functions as the Central Judicial Body of International Community ? " , in Moster H . and Bernhardt , R . ( eds ) , Judicial Settlement of International Disputes , 1974 , pp. 19 - 34.

Elkin , Jerome B ., Non-Appearance Before the International Court of Justice ", 1984.

Ende , Douglas J. " Reaccepting the Compulsory Jurisdiction of the International Court of Justice : A Proposal for a new United States Declaration " , 61 Wash. L. R. ( 1986 ) , pp. $1145-1183$.

Engel, Salo, " the Compulsory Jurisdiction of the International Court of Justice " , 40 Gergt. L. J . ( 1951 ) , pp. $41-66$.

Enriques, Giuliano , " I'Acceptation, sans reciprocite, de la Juridiction Obligatoire de la Cour Permanente de Justice Internationale ", 13 R. D. I. L. C. (1932), pp. $834-860$.

Fachiri Alexander P ., the Permanent Court of International Justice, 1925. " Repudiation of the Optional Clause " , 20 B. Y. I. L. ( 1939 ) , pp. 52 - 58.

Falk Richard, Reviving the World Court, 1986.

Farmanfarma, Ali Naghi, the Declarations of the Members Accepting the Compulsory Jurisdiction of the International Court of Justice , 1952.

Faucet , J. E. S. the British Commonwealth in Intemational Law, 1963.

Fenwick, Charles G. " National Security and International Arbitration ", 18 A. J. I. L. ( 1924 ) , pp. $777-781$.

, "Elimination of the Loopholes in the Arbitration Treaties " , 21 A. J. I. L. ( 1927 ) , p. $499-503$.

Feydi , Julien, " la Nouvelle Declaration Francaise d'Acceptation de la Juridiction Obligatoire de la Cour Internationale de Justice " , 12 A. F. D. I. ( 1966 ) , pp. $155-161$.

Fitzmaurice , Sir Gerald , "the Law and Procedure of the International Court of Justice : International Organizations and Tribunals ", 29 B. Y. B. I. L. ( 1952 ) , pp. $1-62$.

. " the Law and Procedure of the International Court of Justice " , 1951 - 54 : General Principles and Sources of Law " , 30 B. Y. B. I. L. ( 1953 ) , PP. 1 70.

" the Law and Procedure of the International Court of Justice : General Principles and Sources of International Law ", 35 B. Y. B. I. L. (1959) , pp. $183-231$

the Future of Public International Law and the International Legal System in the Circumstances of Today " , in Livre du Centenaire - 1873 - 1973 (Institut de Droit International) , 1973 , pp.196 - 328

" Enlargement of the Contentious Jurisdiction of the Court ", in Gross , Leo (ed ), the Future of the International Court of Justice ", Vol. 2 , 1976 , pp. 461 498.

Foda, Ezzeldine, the Projected Arab Court of Justice, 1957.

Frank , Thomas M . , the structure of Impartiality, 1968. 
, " Icy Day at the I. C. J." 79 A. J. I. L. ( 1985 ) , pp. 379 - 384.

—, " Judging the World Court, 1986.

Friedman, Wolfgang, " the International Court of Justice and the Evolution of International law ", 14 Archiv. V . (1969-1970) , pp. $305-320$.

Gardner, Richard N ., " U. S. Termination of the Compulsory Jurisdiction of the International Court of Justice " , 24 Colum . J. T. L. (1986) , pp. 421 - 427.

Geamanu , G . , " theorie et Pratique des Negociations en Droit International " , 166 ( I) R. C. A. D. I. (1980), pp. $373-448$.

_, " les Négociations Moyen Principal du Reglement Pacifique des Differends Internationaux ", in Makarczyk , J . (ed ), Essays in International Law in Honour of Judge Manfred Lachs, 1984 , pp. 375 - 388.

Gerber , Frederic , " le Consentement de l'Etat a la Juridiction de la Cour Internationale de Justice " , thesis , Universite d'Orleans , Faculte de Droit et des Sciences Economiques, 1980.

Giobanu, Dan, " Litispendence Between the International Court of Justice and the Political Organs of the United Nations", in Gross, Leo (ed), the Future of the International Court of Justice, vol.1, 1976, pp. 209-275.

Giustini , Anthony, " Compulsory Adjudication in International Law : the Past, the Present and Prospects for the Future ", 9 For. I. L. J. (1985 - 86 ) , pp. 213 - 256.

Glennon, Michael J ., " Nicaragua V. United States : Constitutionality of the U. S. Modification of the I. C. J. Jurisdiction ", 74 A. J. I. L. ( 1985 ) , pp. 682 689.

" Protecting the Court's Institutional Interests ... Why not the Marbury Approach ? ", 81 A. J. I. L. (1987), pp. 121-129.

Glichitch Stevan , la juridiction Obligatoire de la Permanente Cour of Intemationale Justice, 1940.

Goldie , L. F. E. " the Critical Date " , 12 I. C. L. G. ( 1963 ) , pp. 1251 - 1284

Gorden , Edward , "Changing Attitudes towards Courts and their Possession of Social Decisin Prerogatives " , in Gross, Leo ( ed ), the Future of the International Court of Justice, Vol. 1 , 1976 , pp. $336-364$.

Green, L. C., " Canada and Arctic Souvereignty ", 48 Can. B. R. (1970), pp. 740755.

" ' Legal Disputes ' Under Article 36 ( 2 ) of the Statute " , in Damrosch L. F. ( ed ) , the Intemational Court of Justice at a Crossroads , 1987 , pp. 183 - 222.

Greig , D. W. , International Law, 2nd . ed. 1976.

Grieves , Forest . L. , Supranationalism and Intemational Adjudication, 1969.

Grisel , Etienne, les exceptions d'Incompétence et d'Irrecevabilité dans la Procedure de la Cour Internationale de Justice, 1968.

Gross , Leo , _ " the Charter of the United Nations and the Lodge Reservations " 41 A. J. I. L. ( 1947 ) , pp. 531 - 554.

" some Observations on the International Court of Justice " , 56 A. J. I. L. ( 1962 ) , pp. $33-62$.

" Bulgaria Invokes the Connally Amendment " , 56 A. J. I. L. ( 1962 ) , pp. 357

- 382 
, " the International Court of Justice and the United Nations ", 121 ( I ) R. C. A.

D. I. ( 1967 ) , pp. $319-440$

" the International Court of Justice : Consideration of Requirements for

Enhancing its Role in the International Legal Order " , 65 A. J. I. L. ( 1971), pp. 253 - 326

( ed ) the Future of the Intemational Court of Justice, 1976.

, Essays on Intemational Law and Organization , 1984.

, " Underutilization of the International Court of Justice " , 27 Harv. I. L. J. ( 1986 ) , pp. 571 - 597.

, "Compulsory Jurisdiction Under the Optional Clause : History and Practice " , in Damrosch , L. F. ( ed ), the International Court of Justice at a Crossroads, 1987 , pp. $19-57$.

Guerrero , J. G. , " La Qualification Unilaterale de la Compétence Nationale " , in Constantopoulos et al ( ed . ) , Gundprobleme des Intemational Rechts , 1957 , pp. $207-212$.

Hambro, Edward , "Some Observations on the Compulsory Jurisdiction of the International Court of Jurisdiction " , 25 B.Y. B. I. L. ( 1948 ) , pp. 133 157.

_, " the Jurisdiction of the International Court of Justice ", 76 (I) R. C. A. D. I. ( 1950 ) ,pp. $123-215$.

_ " will the Revised Rules Lead to Greates Willingness on the Part of Prospective Clients ? " , in Gross , Leo ( ed ) , the Future of Intemational Court of Justice, Vol. 1 , 1976 , pp. $370-372$.

Hassan , Farooq , " A Legal Analysis of the United States Attempted Withdrawal from the Jurisdiction of the World Court in the Proceedings Initiated by Nicaragua " , 10 U. D. L. R. ( 1985 ) , pp. $295-318$.

Henkin , Louis " the Connally Reservation Revisited and , Hopefully , Maintained " , 65 A. J. I. L. ( 1971 ) , pp. 374 - 377.

Hershey , A. S. , " Convention for the Peaceful Adjustment of International Differences " , 2 A. J. I. L. ( 1908 ) , pp. 29 - 49.

Higgins , A . P. , the Hague Peace Conferences, 1909.

, British Acceptance of Compulsory Arbitration Under the 'Optional Clause' , and its Implication , 1929.

Higgings , Rosalyn , " Policy Consideration and the International Judicial Process " , 17 I. C. L. Q. ( 1968 ), pp. 58 - 84.

Highet , Keith , "' You Can Run But You Can't Hide ' - Reflections on the U. S. Position in the Nicaragua case " , 27 Virg . J. I. L. 1987 , pp. $551-572$.

Hohmann , H. and De Waart , P. J. I. M. , " Compulsory Jurisdiction and the Use of Force as a Legal Issue : the Epoch - Making Judgment of the Intemational Court in Nicaragua v. United States of America " , 34 Neth. I. L. R. (1987) , pp.162 191.

Holloway , Kaye , les Reserves dans les Traités Intemationaux , 1958. Modern Trends in Treaty Law, 1967.

Honig , F." the Diminishing Role of the World Court " , 34 I.A. (1958 ) , pp.184 194

Howard , A. E. Dick, " the Connally Amendment ", 2 J. J. B. M. S. ( 1961 ) , pp. 1 
- 18.

Howell , J. M. , " Domestic Jurisdiction" , in Wilson. R. R. ( ed. ), International law Standard and Commonwealth Development, 1966 , pp. 138 - 146. the Commonwealth and the Concept of Domestic Jurisdiction ", 5 Can. Y. B. I. L. ( 1967 ) , pp. $14-44$.

Hudson, Manley O. " Obligatory Jurisdiction Under Article 36 of the Statute of the Permanent court of International Justice ", 19 lowa L. R. ( 1934 ), pp. 190 $-217$.

, the Permanent Court of International Justice - 1920 - 1942 : A Treatise, 1943.

" the World Court : America's Declaration Accepting Jurisdiction " , 32 A. B. A. J. ( 1946 ) , pp. $832-836,895-897$.

—, " the Twenty - Fourth Year of the World Court ", 40 A. J. I. L. ( 1946 ) , pp. 1 $-52$.

, " the Twenty - Fifth Year of the World Court " , 41 A. J. I. L. (1947 ), pp. 119 .

, " the Twenty - Sixth Year of the World Court " , 42 A. J. I. L. ( 1948 ) , pp. 1 - 19.

" the Thirtieth Year of the World Court " , 46 A. J. I. L. ( 1956 ) , pp. 1-39.

_," the Thirty- Fourth Year ofthe World Court ", 50 A. J. I. L. (1956), pp. 1-17. " the Thirty-Seventh Year of the World Court " , 53 A. J. I. L. ( 1959 ) , pp. $319-323$.

Hull , W. J. , " Obligatory Arbitration and the Hague Conferences " , 2 A. J. I. L. ( 1908 ) , pp. $731-742$.

Ioannou , Krateros. M. , " Reservations to the Acceptance of the Compulsory Jurisdiction of the I. C. J. - A Tabular Analysis of their procedural Treatment ", I Hellinic R. I. R. ( 1980 ), pp. 415 - 437.

Janis , Mark Weston, "Somber Reflexions on the Compulsory Jurisdiction of the International Court of justice " , 81 A. J. I. L. ( 1987 ) , pp. $144-146$.

Jenks , C. W. , the Prospects of Intemational Adjudication, 1964.

Jennings , Robert Yewdall , " Does the International Court of Justice, as it is Presently Shaped, Correspond to the Requirements which Follow from its Functions as the Central Judicial Body of the International Community ? " , in Mosler , H. and Bernhardt , R. ( eds. ), Judicial settlement of International Disputes , 1974 , pp. 35 - 48.

, the Commonwealth and International Law " 30 B. Y. B. I. L. ( 1953 ) , pp. 326 - 330.

, Recent cases on Automatic Resenvations to the Optional Clause " , 7 I. C. L. Q. ( 1958 ) , pp. $349-366$.

Jessup , Philip C. the Price of Intemational Justice, 1971.

Jiménéz de Aréchaga , "the Amendments to the Rules of Procedure of the International Court of Justice ", 67 A. J. I. L. ( 1973 ) , pp. 1 - 22.

Jones , Georges F." Termination of Declarations Under the Optional Clause: Military and Pramilitary Activities in and against Nicaragua ", 20 T. I. L. J. ( 1985 ), 
pp. $557-581$.

Kaasik, N. " la Clause des Negociations Diplomatiques dans le Droit Positif et dans la Jurisprudence de la Cour Permanente de Justice Internationale ", 14 R. D. I. L. C. (1933), pp. $62-95$.

Kahn , Paul W. From Nuremberg to the Hague : the United States Position in Nicaragua $v$. United States and the Development of Intemational Law ", 12 Y. L. J. I. L. ( 1987 ) , pp. 1 - 87.

Kearney , Richard D . , " Amid the Encircling Gloom ", in Gross , Leo (ed. ), the Future of the International Court of Justice, Vol.1 , 1976 , pp. $105-130$.

Kelly , J. Patrick , " the International Court of Justice : Crisis and Reformation " , 12 Y. L. J. I. L. ( 1987 ) , pp. 342 - 374.

Kelsen, Hans, " Compulsory Adjudication of International Disputes " , 37 A. J. I. L. ( 1943 ) , suppl. pp. 397 - 406.

, "Limitations on the Function of the United Nations ",55 Y. L. J. ( $1945-46$ ) ,pp. $997-1015$.

, the Law of the United Nations, 1950

_, Principles of International Law, 2nd . ed. Revised and ed. by Tucker , R. W. , 1966.

Kirgis ( Jr ) , Frederic L. " Nicaragua v. United States as a Precedent " , 79 A. J. I. L. ( 1986 ) , pp. $652-657$.

Kitchel , Denison, Too Grave a Risk, 1963.

Lacharrière , Guy de , " Commentaires sur la Position Juridique de la France a l'egard de la Liecite de ses experiences Nucleaires ", 19 A. F. D. I. ( 1973 ), pp. 235 - 251.

Lachs Manfred , " la Cour Internationale de Justice dans le Monde d'Aujourd'hui " , II B. R. I. L. ( 1975 ) , pp. $548-561$.

, the Revised Procedure of the International Court of Justice " , in Kuyper , P. J. and Lammers , J. G. ( eds. ), Essays on the Development of the International Legal Orders , 1980 , pp. $21-52$.

, " A Few Thoughts on the Independence of Judges of the International Court of Justice " , 25 Colum. J. T. L. ( 1987 ) , pp. $593-600$.

Lalonde, Philippe V. " the Death of the Eastern Carelia Doctrine : Has Compulsory Jurisdiction Arrived in the World Court ? " 37 , F. L. R. U. T. (1979), pp. 80 - 100.

Lammasch, Heinrich, " Compulsory Arbitration at the Second Hague Conference " , 4 A. J. I. L. ( 1910 ) , pp. 83 -95.

Larson, Arthure , " the Self - Judging Clause and Self Interest " , 46 A. B. A. J. ( 1960 ), pp. $724-731$.

, " the Facts, the Law and Connally Amendment ", 74 D. L. R. ( 1961 ), pp. 74 $-119$.

Lauterpacht, E. " the Contemporary Practice of the United Kingdom in the Field of International Law - Survey and Comments, VII, Settlement of International Disputes, Jurisdiction of the International Court of Justice, United Kingdom Declaration of November 26,1958 ", 8 I. C. L. C. (1959), pp. 197-201. 
Lauterpacht, Sir Hersch, " the British Reservations to the Optional Clause ", 10 Economica , ( 1930 ), pp. 137 - 172. the Function of Law in the Intemational Community, 1933. the International Protection of Human Rights ", 70 ( I) R. C. A. D. I. ( 1947 ) , pp. 5 - 101.

the Development of International Law by the International Court , 1958.

Lavalle ,Roberto, " the Notion of International Legal Dispute and the Assumption of Juridiction by the International Court of Justice in Hostage case" , 35 - $36 R$. H. D. I. ( $1982-83)$, pp. $97-110$.

Layton, Robert , " the Dilemma of the World Court : the United States Reconsiders Jurisdiction , 12 Stanford L. R. ( 1960) , pp. 323 - 354.

Leigh, Monroe and Ramsey , Stephen D ., " Confidence in the Court : It Need not be a' Hollow Chambers ' " , in Damrosch , L. F. ( ed. ) , ' the International Court of Justice at a Crossroads , 1987 , pp. $106-122$.

Lloyd , Lorna , "' A Spring board for the Future' : A Historical Examination of Britain's Role in shaping the Optional Clause of the Permanent Court of International justice " , 79 A. J. I. L. ( 1985 ) , pp. 28 - 51.

Loder , B. C. J. , " Permanent Court of International Justice and Compulsory Jurisdiction " , 2 B. Y. B. I. L. (1921-1922) , pp. 6 - 27.

Lieverman, Theodor M. , " Law and Power : some Reflections on Nicaragua, the United States, and the World Court ", 10 Maryl. J. I. L. T. ( 1986 ) , pp. 295 - 320.

Lissitzyn , Oliver J. the International Court of Justice, 1951.

Macdonald , R. St. J. , " the New canadian Declaration of Acceptance of Compulsory Jurisdiction " , 8 Can. Y. B. I. L. ( 1970 ) , pp. 3 - 38.

Makowski , Julian , " l'Organisation Actuelle de l'Arbitrage International " , 36 ( II ) R. C. A. D. I. ( 1931 ) , pp. 267 - 380.

Mani , V. S. , " A Review of the Function of the International Court of Justice " , II Indian J. I. L. ( 1971 ) , pp. 27 -38.

Maus, Bertrand, les Reserves dans les Declarations d'Acceptation de la Juridiction Obligatoire de la Cour Internationale de Justice, thesis (Université de Genève ), 1959.

Mengozzi, Paolo, " the International Court of Justice, the United Nations Conference on the Law of the Sea ", 3 Ita. Y. I. L. (1977), pp. 92-114.

McDonald , Eugene J. " Automatic Resenvations and the World Court " , 47 Georgt. L. J. ( 1958 ) , pp. $106-123$.

McWinney , Edward , " Acceptance and Withdrawal or Denial , of World Court Jurisdiction : some Recent Trends as to Jurisdiction ", 20 Isr. L. R. ( 1985 ), pp. 148 - 166.

Merignhac . A. , Traite Theorique et Pratique de l'Arbitrage Intemational, 1895.

, la Conference de la Paix, 1900.

Meron, Theodor, " Israsel's Acceptance of Compulsory Jurisdiction of the International Court of Justice", 4 Isr.L. R. (1969), pp. 307-332.

Merrills, J. G. , " the Justiciability of International Disputes", 47 Can. B. $R$. (1969), pp. 241-269.

" Sir Gerald Fitzmaurice's Contribution to to the Jurisprudence of the International Court of Justice", 48 B. Y. B. I. L. (1976-77), pp. 183-240. 
" the Optional Clause Today ", 50 B. Y. B. I. L. (1979), pp. 87-116.

Intemational Dispute Settlement, 1984.

Minagawa, Takeshi, " Operation of Reciprocity Under the Optional Clause ", Jap. A. I. L. (1960), pp. 32-41.

" "the Principle of Domestic Jurisdiction and the International Court of Justice ", 8 Hito. J. L. P. (1979), pp. 9-27.

Morgenthau, H. J. , Politics Among Nations, 3rd. Ed., 1963.

Mosler, Hermann, "the International Court of Justice at its Present Stage of Development ", 5 Dalh. L. J. (1979), pp. 545-567.

ـ " the Area of Justiciability : Some Cases of Agreed Delimitation in Submissions of Disputes to the International Court of Justice ", in Makarczyk, J. (ed.), Essays in Intemational Law in Honour of Judge Manfred Lachs, 1984, pp. 409-422.

, " Political and Justiciable Legal Disputes : Revival of an Old Controversy? ", in Cheng, Bin ans Brown, E. D. (eds.), Contemporary Problems of International Law : Essays in Honour of George Schwarzenberger on His Eightieth Birthday, 1988, pp. 216-229.

and Berhardt, R. (eds), Judicial Settlement of International Disputes, 1974.

Murphy (Jr), Cornelius F. , " the World court and the Peaceful Settlement of Disputes ", 7 Ga. J. L. C. L. (1977), pp. 551-578.

Natchaba, Quattara Famberé, les Etats Africains et la Cour Internationale de Justice, thesis (Université de Poitiers, Faculté de Droit et des Sciences Sociales), 1978.

Norton, Patrick M. , " the Nicaragua Case : Political Questions before the International Court of Justice ", 27 Virg. J. I. L. (1987), pp. 459-526.

Oppenheim, L. F. , Intemational Law, Vol. 2, 7th ed., Lauterpacht, 1952.

Ott, David H., Public Intemational Law in the Modern World, 1987.

Owen, Harold J. , "Compulsory Jurisdiction of the International Court of Justice : A Study of its Acceptance by Nations ", 3 Ga. L. R. (1969), pp. 704-726.

Partan, Danial G. , " Increasing the Effectiveness of the International Court ", 18 Harv. I. L. J. (1977), pp. 559-575.

Pax, Thomas J. , " Nicaragua v. United States in the International Court of Justice : Compulsory Jurisdiction or Just Compulsory? ", 2 B. C. I. C. L. R. (1985), pp. 471-515.

Perrin, G. , " I' Affaire de l' Interhandel - Phase des Exceptions Préliminaires ", 16 An. S. D. I. (1959), p73-208.

Petrén, B. A. S. , "Some Thoughts on the Future of the Intemational Court of Justice ", 6 Neth. Y. B. I. L. (1975), pp. 59-76.

Politis, N. , la Justice Internationale, 1924.

Pollux, " Domestic Jurisdiction ", 17 Act. S. J. G. (1947), pp. 13-35.

Prasasvinitchai, Sudhee, la Clause Facultative de Juridction Obligatoire de la Cour Internationale de Justice, thesis (Université de Paris, Faculté de Droit et des Sciences Economiques), 1962.

Preuss, Lawrence, " the International Court of Justice, the Senate and Matters of 
Domestic Jurisdiction ", 40 A. J. I. L. (1946), pp. 720-736.

, "Questions Resulting from the Connally Amendment ", 32 A. B. A. J. (1946), pp. 660-662, 721.

, "Article 2, Paragraph 7, of the Charter of the United Nations and Matters of Domestic Jurisdiction ", 74(II) R. C. A. D. I. (1949), pp. 553-653.

_, Quadeer, Anwar-i-., " the International Court of Justice : A Proposal to Amend its Statute ", in Snyder, F. E. and Sathirathai, S. (eds.), Third World Attitudes Toward International Law : An Introduction, 1987, pp. 179-195.

Quéneudec, Jean-Pierre, " les Etats Africains et la Competence de la C. I. J. ", An. A. (1967), pp. 27-50.

Rague, M. A. , " the Reservation Power and the Connally Amendment ", 11 N. Y.U. J. I. L. P. (1978), pp. 323-358.

Rajan, M. S. , " the Question of Defining ' Domestic Jurisdiction ", 1 Indian S. I. S. (1960), pp. 248-279.

Ralston, J. H. , " Some Suggestions as to the Permanent Court of Arbitration ", 1 A. J. I. L. (1907), pp. 321-329.

Rao, H. S. G. , " the Nature of Declarations under the Optional Clause ", 8 Justitia (Hydrabad), (1962), pp. 49-61.

Rao, Roma T. S. , " Review of the Functioning of the International Court of Justice Some Considerations Relating to the Amendment of its Statute ", 11 Indian J. I. L. (1971), pp. 20-26.

Reisman, W. Michea, " Has the International Court of Justice Exceeded its Jurisdiction? ", 80 A. J. I. L. (1986), pp. 128-134.

, the Other Shoe Falls : the Future of Article $36(1)$, Jurisdiction in the Light of Nicaragua", 81 A. J. I. L.(1987), pp. 166-173.

Roberts, B. K. " the World Court and the Connally Amendment ", 35 Fl. B. J. (1961), pp. 430-434.

Rogers, W. P. , " United States ' Automatic' Reservation to the Optional Clause Jurisdiction of the International Court of Justice ", 7 I. C. L.Q. (1958), pp. 758-762.

Rolin , Henri, " the International Court of Justice and Domestic Jurisdiction ", 8 Int'l. O. (1954), pp. 36-44.

Rosenne, Shabtai, the Intemational Court of Justice, 1957. , the Time Factor in the Jurisdiction of the Intemational Court of Justice, 1960.

_. " la Cour Internationale de Justice en 1960 ", 56 R. G. D. I. P. (1961), pp.473-526.

_. Procedure in the Intemational Court : A Commentary on the 1978 Rules of the International Court of Justice, 1983.

, the Law and Practice of the Intemational Court , 2nd . Revised ed., 1985.

Rostow, Eugene V. , " Disputes Involving the Inherent Right of Self - Defence ", in Damrosch, L. F. , the International Court of Justice at a Crossroads, 1987, pp. 264-287.

Rousseau, Charles, " la determination des Affaires qui Relèvent Essentiellement de la Competence Nationale des Etats ", 44(I) Annuaire I. D. I. (1952), pp. 137176. 
_, Experiences Nucleaires dans le Pacifique ", 37 R. G. D. I. P. (1966), pp. $1032-1040$.

, Droit International Public, vol. 5, 1983.

Rovine, A. W. , " the National Interest and the World Court", in Gross, Leo, the Future of the International Court of Justice, vol. 1, 1976, pp. 313-335.

Rubin, Alfred P. , " the Intemational Effects of Unilateral Declarations ", 71 A. J. I. L. (1977), pp. 1-30.

Rucz, Claude, " l' Indications de mesures Conservatoires par la Cour Internationale de Justice dans l' Affaire des Activités Militaires et Paramilitaires au Nicaragua et contre celui-ci ", 89 R. G. D. I. P. (1985), pp. 83-111.

Rudzinski, Alexander Witold, " Domestic Jurisdiction in the United Nations Practice ", 9 India Q. (1953), pp. 313-352.

Sauveplane, J. G., " les Limitations Ratione Temporis dans I' Acceptation de la Clause Facultative", Neth.Y. B. I. L. (1956), pp. 342-354.

Schachter, Oscar, " Disputes Involving the Use of Force ", in Damrosch, L. F.(ed.), the International Court of Justice at a Crossroads, 1987, pp. 223-241.

Schindler, Dietrich, " Les Progrés de L'Arbitrage Obligatoire Depuis la Creation de la Societé des Nations ", 25 (V) R. C. A. D. I. ( 1928 ), pp. 237-361.

Schlesinger, Rudolf B. , " The connally Amendement - Amelioration by Interpretation ", 48 Virg. L. R. (1962), pp. 685 - 697.

Schwarzenberger, George, Intemational Law as Applied by International Courts and Tribunals, Vol. 4 (International Juridical Law), 1986.

Schwebel, Stephen M. , " Reflections on the Role of the International Court of Justice " , 61 Wash. L. R. (1986), pp.1061-1070.

Schweppe, Alfred J. , " The Connally Amendement Should not Withdrawn " 46 A. B. A. J. (1960) pp. 732.

Scott, James Brown, " the Work of the Second Hague Conference", 2 A. J. I. L. (1908), pp. 1-28.

Shihata, Ibrahim F. I. , The Power of the International Court to Determine its Own Jurisdiction, Competence de la Competence, 1965.

_ , " The Attitude of New States Towards the International Court of Justice " 19 Int'l O. (1965), pp. 203-222.

Sohn, Louis B. " Exclusion of Political Disputes From Judicial Settlement ", 38 A. J. I. L. (1944), Suppt. pp. 694-700.

_ , "Step by Step Acceptance of the Jurisdiction of the International Court of Justice ", 58 A. S. I. L. ( 1964 ), pp. 131-136.

Sørensen,Max, "The international Court of Justice : Its Role in Contemporary International Relations ", 14 Int'. O. ( 1960 ), pp. 260-276.

Soubeyrol, Jacques, " Validité dans le Temps de la Declaration D'Acceptation de la Juridiction Obligatoire ", 5 A. F. D. I. ( 1959 ), pp. 232- 357.

Steinberger, Heimut, " Judicial Settlement of International Disputes " in Bernhardt, R. ( ed.), Encyclopedia of Public International Law, 1980 (1), pp. 120-133.

Stone, J. Legal Controls of Intemational Conflicts, 1959.

_ , " The International Court and World Crisis ", International conciliation, No 536 ( 1962 ). 
Suy, E., Les Actes Unilateraux en Droit Intemational Public, 1962.

Taoka, Ryoichini, Japan and the Optional Clause ", 3 Jap. A. I. L. (1959), pp. 1-11.

Ténékides, C. G. , " Les Actes Compromissoires Concurents ", 17 R. D. I. L. C. ( 1936), pp.719-740.

Thirlway, H. W. A., " Reciprocity in the Jurisdiction of the International Court of Justice ", 15 Neth. Y. B. I. L. (1984), pp. 97-138.

Trindade, Cançado A. A. , " The Domestic Jurisdiction of States in the Practice of the United Nations and Regional Organisations ", 25 I. C. L. Q. (1976 ), pp. 715765.

Vallat, Francis, " Forward ", in waldock, C. H. M., International Disputes : The Legal Aspects, 1972.

_ , "The Functions of International Court of Justice in the World Community " 2 Ga. J. I. C. L. ( 1972 ), pp. 55-58.

Verdross, Alfred, " La Compétence Nationale dans le Cadre de L'Organisation des Nations Unies et L'Independence des Etats ", 36 R. G. D. I. P. ( 1968 ), pp. 314325.

, "The Plea of Domestic Jurisdiction Before International Tribunal and Political Organ of the united Nations ", 28 Z. A. Ö. R. ( 1968 ), pp. 33-40.

Verzijl, J. H. W. " The competence of The International Court of justice ", 2 Int'l. Rel. ( 1954 ), pp. 39-49.

_ , " Cour Internationale de Justice: Affaire Relative a Certains Emprunts Norvégiens ", 4 Ned. T. I. R. ( 1957 ), pp.373-406.

, "The System of the Optional Clause ", 1 Int'l. Rel. ( 1959), pp. 585-610.

Vignes, Claude-Henri, " Observations Sur la Nouvelle Déclaration Française D'Acceptation de la Juridiction Obligatoire de la Cour internationale de la Justice ", 31 R.G. D. I. P. (1959), pp. 52-74.

Visscher, Charles de, "L'Affaire de L'Interhandel devant la Cour Internationale de Justice ", 30 R. G. D. I. P. ( 1959 ), pp. 413-33.

, Theory and Reality in Public international Law, 1968.

Vulcan, C. " La Clause Facultative " 18 Acta. S. J. G. ( 1947-48 ), pp. 30-55.

Wagner, W. J., " Is a Compulsory Adjudicatioin of International Legal Disputes Possible? ", 2 Northw. U. L. R. ( 1952 ), pp. 21-54.

Waldock, C. H. M. " The Plea of Domestic Jurisdiction Before International Legal Tribunals, 31 B. Y. B. I. L. (1954), pp. 96-142.

, " Decline of the Optional Clause ", 32 B. Y. B. I. L. (1955-56 ), pp. 244-287.

_. " "The Anglo - Norwegian Fisheries Case ", 28 B. Y. B. I. L. ( 1951 ), pp. 114-171.

, (ed.) Intemational Disputes : The Legal Aspects ,1972.

- The Intemational Court and the Law of the Sea, 1979.

Watson, J. S., " Autointerpretation, Competence and the Continuing Validity of Article 2(7) of the united Nations Charter ", 71 A. J. I. L. (1977), pp. 60-83.

WEhberg, Hans, Restrictive Clauses in international Arbitration Treaties ", 7 A. J. I. L. (1913), pp. 301-314.

Weiss, E. B. , " Judicial Independence and Impartiality : A Preliminary Inquiry ", in 
Damrosch, L. F. (ed.), The International Court of Justice at a Crossroads, 1987, pp. 123-154.

, "Reciprocity and the Optional Clause ", in Damrosch, L. F. (ed.), The international Court of Justice at a Crossroads, 1987, pp. 82-105.

Westlake, J. International Law, Vol. 1,1904.

Weir, Keith, " The international Court of Justice : Is it Time for Change? " 8 Houston J. I. L. ( 1985 ), pp. 175-191.

Wilcox, Francis O., " The United States Accepts Compulsory Jurisdiction ", 40 A. J. I. L. (1946) ,Suppt., pp. 699-719.

Williams, J. F. , "The Optional Clause ", 11 B. Y. B. I. L. ( 1930 ), pp. 63-84.

Wilson, Robert R., International Agreements for Obligatory Arbitration ", Thesis ( Harvard University ), 1927.

, "Reservations Clauses in Agreements for Obligatory Arbitration ", 23 A. J. I. L. (1929), pp. 68-93.

_ " Clauses Relating to Reference of Disputes in Obligatory Arbitration Treaties ", 25 A. J. I. L. (1931), pp. 469-489.

Woo, J. S. , " the World Court and Domestic Jurisdiction ", 10 K. J. I. L. (1965), pp. 49-64.

Wright, Quincy, " the International Court of Justice and the Interpretation of Multilateral Treaties ", 41 A. J. I. L. (1947), suppt., pp. 445-452.

_. "Domestic Jurisdiction as a Limit on International and Supra-National Action ", 56 Northw. U. L. R. (1961), pp. 11-40.

Wyk, J. T. , " the International Court of Justice at the Cross- Roads ", Acta Juridica (1967), pp. 201-213.

Yancov, Alexander, " les Reserves dans les Declarations d' Acceptation de la Juridiction Obligatoire de la Cour Intemationale de Justice ", 52 An. U. S. F. D. (1961), pp. 586-597.

Yocota, Kisaburo, " the Compulsony Jurisdiction of the International Court of Justice ", in International Law Association, Reports of the 51 st. Conference, Tokyo, 1964, pp. 8-18. 